Prepared for the U.S. Department of Energy

under Contract DE-AC05-76RL01830

\title{
Formulation and Characterization of Waste Glasses with Varying Processing Temperature
}

$\begin{array}{ll}\text { D Kim } & \text { JV Crum } \\ \text { MJ Schweiger } & \text { JD Vienna } \\ \text { CP Rodriguez } & \text { FC Johnson } \\ \text { WC Lepry } & \text { JC Marra } \\ \text { JB Lang } & \text { DK Peeler }\end{array}$

October 2011

Pacific Northwest

NATIONAL LABORATORY

Proudly Operated by Battelle Since 1965 


\title{
DISCLAIMER
}

This report was prepared as an account of work sponsored by an agency of the United States Government. Neither the United States Government nor any agency thereof, nor Battelle Memorial Institute, nor any of their employees, makes any warranty, express or implied, or assumes any legal liability or responsibility for the accuracy, completeness, or usefulness of any information, apparatus, product, or process disclosed, or represents that its use would not infringe privately owned rights. Reference herein to any specific commercial product, process, or service by trade name, trademark, manufacturer, or otherwise does not necessarily constitute or imply its endorsement, recommendation, or favoring by the United States Government or any agency thereof, or Battelle Memorial Institute. The views and opinions of authors expressed herein do not necessarily state or reflect those of the United States Government or any agency thereof.

\author{
PACIFIC NORTHWEST NATIONAL LABORATORY \\ operated by \\ BATTELLE \\ for the \\ UNITED STATES DEPARTMENT OF ENERGY \\ under Contract DE-AC05-76RL01830
}

Printed in the United States of America
Available to DOE and DOE contractors from the
Office of Scientific and Technical Information,
P.O. Box 62, Oak Ridge, TN 37831-0062;
ph: (865) 576-8401
fax: $(865) 5765728$
email: reports@adonis.osti.gov

\author{
Available to the public from the National Technical Information Service, \\ U.S. Department of Commerce, 5285 Port Royal Rd., Springfield, VA 22161 \\ ph: (800) 553-6847 \\ fax: (703) 605-6900 \\ email: orders@nits.fedworld.gov \\ online ordering: http://www.ntis.gov/ordering.htm
}


PNNL-20774

EMSP-RPT-009

\section{Formulation and Characterization of Waste Glasses with Varying Processing Temperature}

$\begin{array}{ll}\text { D Kim } & \text { JV Crum } \\ \text { MJ Schweiger } & \text { JD Vienna } \\ \text { CP Rodriguez } & \text { FC Johnson }^{1} \\ \text { WC Lepry } & \text { JC Marra }^{1} \\ \text { JB Lang } & \text { DK Peeler }\end{array}$

October 2011

Prepared for

the U.S. Department of Energy

under Contract DE-AC05-76RL01830

Pacific Northwest National Laboratory

Richland, Washington 99352

\footnotetext{
${ }^{1}$ Savannah River National Laboratory
} 



\section{Summary}

This report documents the preliminary results of glass formulation and characterization accomplished within the finished scope of the U.S. Department of Energy, Office of Environmental Management EM-31 technology development tasks for WP-4 and WP-5, including

- WP-4.1.2: Glass Formulation for Next Generation Melter

- WP-5.1.2.3: Systematic Glass Studies

- WP-5.1.2.4: Glass Formulation for Specific Wastes.

These tasks were prematurely closed during the early stage of the development. This report also presents the recommended studies for eventual restart of these tasks.

The initial glass formulation efforts for the cold crucible induction melter, operating at $\geq 1200^{\circ} \mathrm{C}$, with selected high-level waste (AZ-101) and low-activity waste (AN-105), successfully developed glasses with significant increase of waste loading compared to that which is likely to be achieved based on expected reference Hanford Tank Waste Treatment and Immobilization Plant formulation. Three glasses formulated for AZ-101 high-level waste (with a waste loading of $39.8 \mathrm{wt} \%$ to $45.1 \mathrm{wt} \%$ compared to $37 \mathrm{wt} \%$ for WTP) and one glass for AN-105 low-activity waste (containing $24 \mathrm{wt} \% \mathrm{Na}_{2} \mathrm{O}$ at $31.3 \mathrm{wt} \%$ waste loading) were selected for the initial cold crucible induction melter demonstration tests; however, the melter tests were not performed due to an early closure of this task. Glass formulations for the cold crucible induction melter were expanded to cover additional high-level wastes that have a high potential to successfully demonstrate the unique advantages of the cold crucible induction melter technologies, based on projected composition of Hanford wastes. However, only the preliminary scoping tests were completed with selected wastes.

Advanced glass formulations for the reference Hanford Tank Waste Treatment and Immobilization Plant melter, operating at $\sim 150^{\circ} \mathrm{C}$, were initiated with selected specific wastes to determine the estimated maximum waste loading. The preliminary results from these initial formulation efforts are summarized. In addition, a test matrix of 32 high-aluminum glasses was developed based on a new space filling methodology developed in this study to assess the potential for $\mathrm{Al}_{2} \mathrm{O}_{3}$ concentrations in glass exceeding $22 \mathrm{wt} \%$. Although the test matrix was developed, no experimental work was initiated during FY11. 



\section{Acknowledgments}

The authors are grateful to the U.S. Department of Energy's Environmental Management Office of Waste Processing (EM-31) for initial funding of the project and for the Office of River Protection and Washington River Protection Solutions for their continued support. Programmatic direction by Steve Schneider and Gary Smith at EM-31, technical support by Albert Kruger at the Office of River Protection, and technical guidance by Gene Ramsey at Washington River Protection Solutions are greatly appreciated. The authors also would like to acknowledge Catherine Veyer and Eric Tchemitcheff at AREVA Federal Services LLC, Nick Soelberg at Idaho National Laboratory, and Ian Pegg at Vitreous State Laboratory of The Catholic University of America for their helpful discussion and guidance. 



\section{Acronyms and Abbreviations}

\begin{tabular}{|c|c|}
\hline AJHM & advanced Joule-heated melter \\
\hline $\mathrm{CCC}$ & canister centerline cooling \\
\hline CCIM & cold crucible induction melter \\
\hline CUA & Catholic University of America \\
\hline DBVS & demonstration bulk vitrification system \\
\hline DOE & U.S. Department of Energy \\
\hline DWPF & Defense Waste Processing Facility \\
\hline EM & U.S. Department of Energy, Office of Environmental Management \\
\hline EM-31 & U.S. Department of Energy, Office of Waste Processing \\
\hline HBV & high-level waste blend vessel \\
\hline HLP & Hanford LAW product \\
\hline HLW & high-level waste \\
\hline HTWOS & Hanford Tank Waste Operations Simulator \\
\hline IHLW & immobilized high-level waste \\
\hline ICP-AES & inductively coupled plasma-atomic emission spectroscopy \\
\hline ICV & in-container vitrification \\
\hline INL & Idaho National Laboratory \\
\hline IWL & improved waste loading \\
\hline JHM & Joule-heated melter \\
\hline LAW & low-activity waste \\
\hline LRM & low-activity reference material \\
\hline MFPV & melter feed preparation vessel \\
\hline MT & metric ton \\
\hline NRC & National Research Council \\
\hline OB & optical basicity \\
\hline ORP & U.S. Department of Energy, Office of River Protection \\
\hline PCT & product consistency test \\
\hline PNNL & Pacific Northwest National Laboratory \\
\hline PSAL & SRNL Process Science Analytical Laboratory \\
\hline SEM & scanning electron microscope \\
\hline SRNL & Savannah River National Laboratory \\
\hline SRS & Savannah River Site \\
\hline TCLP & toxicity characteristic leach procedure \\
\hline VHT & vapor hydration test \\
\hline
\end{tabular}


VSL Vitreous State Laboratory

WP waste processing

WTP Hanford Tank Waste Treatment and Immobilization Plant

XRD $\quad$-ray diffraction 


\section{Contents}

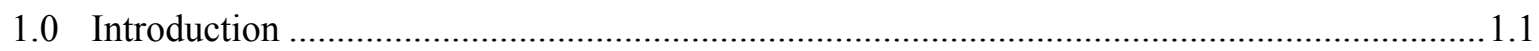

1.1 Glass Formulation for Cold Crucible Induction Melter (WP-4.1.2) ............................... 1.1

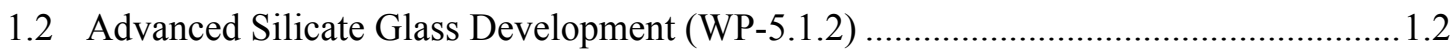

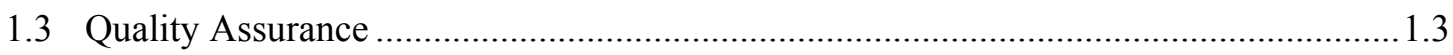

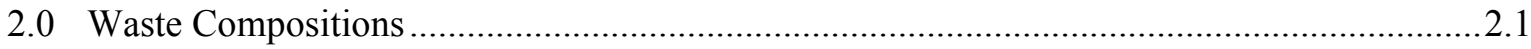

2.1 Selection of Wastes for Initial Formulation for the Cold Crucible Induction Melter .....2.1

2.2 Projected Hanford High-Level Waste Compositions ........................................................2.4

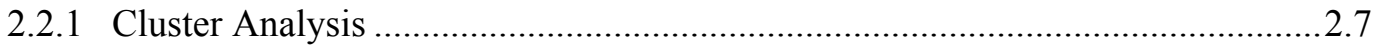

2.2.2 High-Level Waste Glass Formulation Constraints for Waste Loading

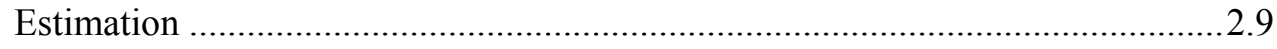

2.2.3 Waste Loading Estimates for 20 Waste Clusters .............................................2.13

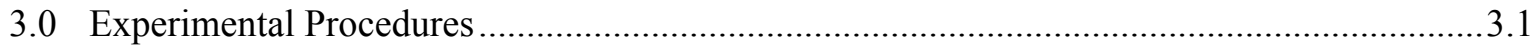

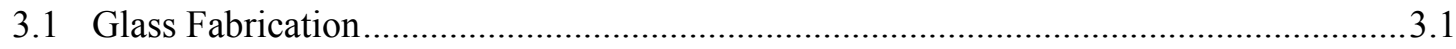

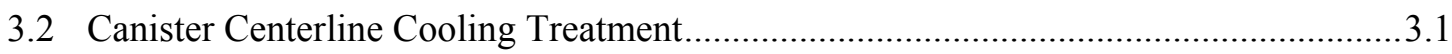

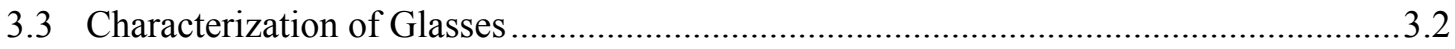

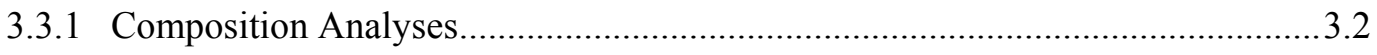

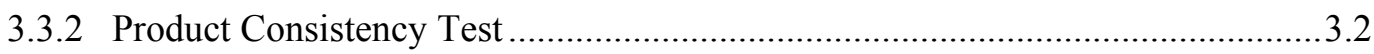

3.3.3 Toxicity Characteristic Leaching Procedure ................................................... 3.2

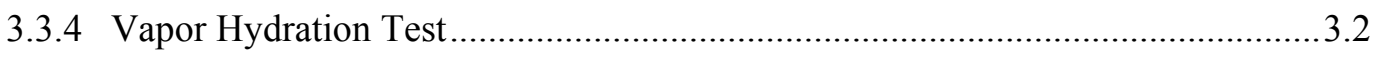

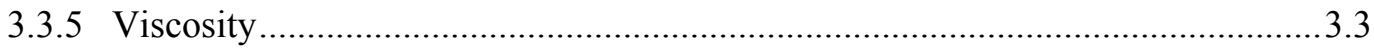

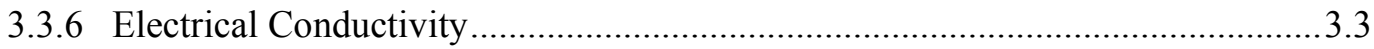

3.3.7 Equilibrium Crystal Fraction and Crystal Identification after Canister

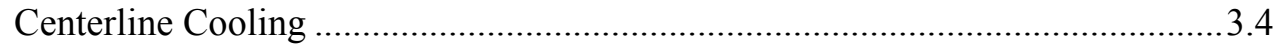

4.0 Glass Formulation for the Cold Crucible Induction Melter.................................................. 4.1

4.1 Cold Crucible Induction Melter Glass Formulation for AZ-101 HLW ...........................1

4.1.1 Formulation Approach for AZ-101 HLW Glasses for the Cold Crucible Induction Melter ......................................................................................

4.1.2 Test Results of AZ-101 HLW Glasses for Cold Crucible Induction Melter .........4.5

4.2 Cold Crucible Induction Melter Glass Formulation for AN-105 LAW ........................4.16

4.2.1 Preliminary Vapor Hydration Test Model for High Alkali Glasses...................4.16

4.2.2 Formulation Approach for AN-105 LAW Glasses for the Cold Crucible Induction Melter ...................................................................................... 4.22

4.2.3 Test Results of AZ-105 LAW Glasses for the Cold Crucible Induction

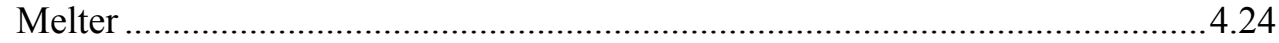

4.3 Cold Crucible Induction Melter Glass Formulation for Selected Waste Clusters.........4.33

4.3.1 Cold Crucible Induction Melter Glass Formulation for Spinel-Limited Waste Clusters. 
4.3.2 Cold Crucible Induction Melter Glass Formulation for High-Chromium Waste Clusters.

5.0 Advanced Silicate Glass Formulation ............................................................................. 5.1

5.1 Glass Formulation for Specific Wastes (WP-5.1.2.4) .................................................. 5.1

5.1.1 Advanced Silicate Glass Formulation for High-Iron Waste Clusters.....................5.1

5.1.2 Advanced Silicate Glass Formulation for Spinel-Limited Waste Clusters ...........5.3

5.1.3 Advanced Silicate Glass Formulation for High-A1 Waste Clusters .....................5.6

5.2 Systematic Glass Studies: High- $\mathrm{Al}_{2} \mathrm{O}_{3}$ Test Matrix Glasses ..........................................

5.2.1 Existing Data on High- $\mathrm{Al}_{2} \mathrm{O}_{3}$ Glasses ........................................................ 5.10

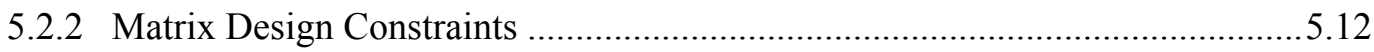

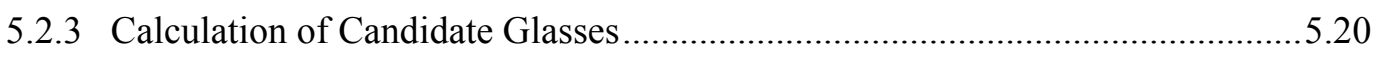

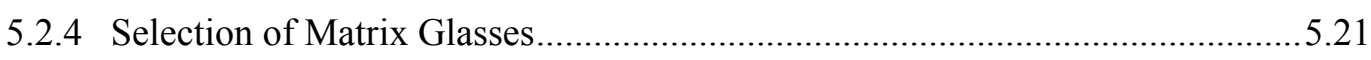

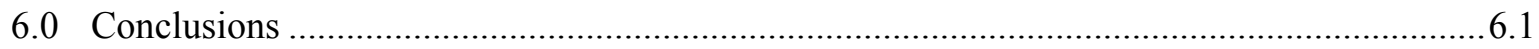

6.1 Summary of Glass Formulation for Cold Crucible Induction Melter (WP-4.1.2) .........6.1

6.2 Summary of Advanced Silicate Glass Development (WP-5.1.2)................................... 6.3

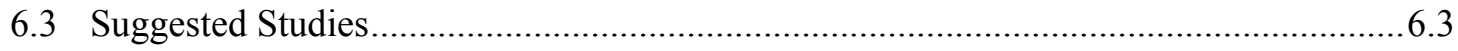

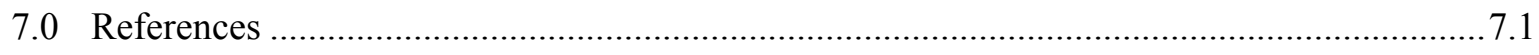

Appendix A Composition of Waste Clusters ...........................................................................

Appendix B LAW Glasses Used for Preliminary VHT Model Development ............................... B.1

Appendix C SEM Micrographs of VHT Samples of CCIM-AN Glasses....................................... 1

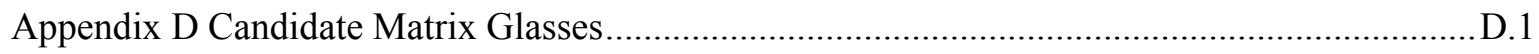




\section{Figures}

Figure 2.1. Composition of Projected Wastes for 15 Components of Interest for Glass Formulation

Figure 2.2. Composition of Projected Wastes for Three Major Components

Figure 2.3. Composition of Projected Wastes for Three Components Important for Spinel

Formation

Figure 2.4. Composition of Projected Wastes for Four Components Important for Potential Phase Separation

Figure 2.5. Average Distance versus Number of Clusters from K-Means Cluster Analysis ..........2.7

Figure 2.6. Parallel Coordinate Plots for 20 Clusters Based on 15 Components...........................2. 2.8

Figure 2.7. Projected Mass of Waste Oxides and Glass Based on Estimated Maximum Waste

Loading based on Different Constraints

Figure 4.1. Crystals Remaining Attached to the Crucible after Melting of CCIM-AZ-02

Figure 4.2. PCT Normalized Releases of CCIM-AZ Glasses (AZ-10, 17, and 18 glasses have

$17 \mathrm{wt} \% \mathrm{Fe}_{2} \mathrm{O}_{3}, \mathrm{AZ}-16$ has $16 \mathrm{wt} \% \mathrm{Fe}_{2} \mathrm{O}_{3}$, and $\mathrm{AZ}-29$ through $\mathrm{AZ}-33$ have $\left.15 \mathrm{wt} \% \mathrm{Fe}_{2} \mathrm{O}_{3}\right) . .4 .8$

Figure 4.3. TCLP Cd of CCIM-AZ Glasses (AZ-10, 17, and 18 glasses have $17 \mathrm{wt} \% \mathrm{Fe}_{2} \mathrm{O}_{3}$,

AZ-16 has $16 \mathrm{wt} \% \mathrm{Fe}_{2} \mathrm{O}_{3}$, and $\mathrm{AZ}-29$ through $\mathrm{AZ}-33$ have $15 \mathrm{wt} \% \mathrm{Fe}_{2} \mathrm{O}_{3}$ ).

Figure 4.4. Total Crystal Vol\% (a) and Spinel Vol\% (b) As a Function of Temperature

(AZ-10, 17, and 18 glasses have $17 \mathrm{wt} \% \mathrm{Fe}_{2} \mathrm{O}_{3}$, AZ-16 has $16 \mathrm{wt} \% \mathrm{Fe}_{2} \mathrm{O}_{3}$, and $\mathrm{AZ}-29$ through AZ-33 have $15 \mathrm{wt} \% \mathrm{Fe}_{2} \mathrm{O}_{3}$ ).

Figure 4.5. Estimated Spinel $T_{L}$ (a) and $T_{1 \%}$ (b) Compared with Predicted Values

Figure 4.6. Total Crystal Vol\% (a) and Spinel Vol\% (b) As a Function of Temperature for

Selected Three Glasses (AZ-10, 16, and 29 glasses have 17, 16, and $15 \mathrm{wt} \% \mathrm{Fe}_{2} \mathrm{O}_{3}$,

respectively).

Figure 4.7. Total Crystal Vol\% (a) and Spinel Vol\% (b) As a Function of Waste Loading for

Selected Three Glasses

Figure 4.8. Viscosity (a) and Electrical Conductivity (b) of Three Glasses Selected for CCIM

Tests (AZ-10, 16, and 29 glasses have 17, 16, and $15 \mathrm{wt} \% \mathrm{Fe}_{2} \mathrm{O}_{3}$, respectively) ...................15

Figure 4.9. Predicted versus Measured VHT Alteration Rate

Figure 4.10. VHT Spider Plot for the Effect of Component Mass\% Change on $\ln \left(r_{\text {alt }}\right)$

Figure 4.11. PCT Spider Plot for the Effect of Component Mass\% Change on $\ln \left(r_{N a}\right)$....

Figure 4.12. Thin Section of VHT Samples after 7-day Tests at $200^{\circ} \mathrm{C}$ for the First Set of Quenched CCIM-AN Glasses.

Figure 4.13. Thin Section of VHT Samples after 7-day Tests at $200^{\circ} \mathrm{C}$ for the First Set of CCC-Treated CCIM-AN Glasses

Figure 4.14. SEM Micrograph Showing the VHT Alteration Layer of CCIM-AN-09CCC

Sample After 7-day VHT at $200^{\circ} \mathrm{C}$ (average alteration thickness of $8 \mu \mathrm{m}$ )

Figure 4.15. PCT Normalized Releases for CCIM-AN Glasses after 7-Day Test at $90^{\circ} \mathrm{C}$. . .29

Figure 4.16. Thin Section of VHT Samples after 7-day Tests at $200{ }^{\circ} \mathrm{C}$ for the Second Set of CCC-Treated CCIM-AN Glasses 
Figure 4.17. Cross-Sections of VHT Samples After 7-day Test at $200^{\circ} \mathrm{C}$ for the CCIM-AN$27 \mathrm{CCC}$

Figure 4.18. Viscosity and Electrical Conductivity of Selected Two CCIM-AN Glasses with $24 \mathrm{wt} \% \mathrm{Na}_{2} \mathrm{O}$.

Figure 4.19. Salt Phase that Remained on Crucible Wall after Melting of Four CCIM-HCC14 Glasses 4.42

Figure 5.1. Predicted Versus Measured $T_{1 \%}$ for High- $\mathrm{Al}_{2} \mathrm{O}_{3}$ Glasses with $T_{1 \%}$ Data .................5.12

Figure 5.2. Concentration and Predicted Property Range ......................................................5.26

Figure 5.3. Scatter Plot for All Candidate Glasses (Square: selected, X: deleted) ......................5.27

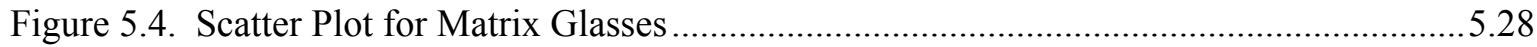

Figure 5.5. Scatter Plot for Matrix and Existing Glasses (Square: matrix, Circle: existing) ........5.29

Figure 6.1. $\mathrm{Fe}_{2} \mathrm{O}_{3}$ Concentration and Waste Loading in Three AZ-101 Glasses Selected for Initial CCIM Demonstration Testing from This Study

Figure 6.2. Total Crystal Vol\% As a Function of Waste Loading for Selected Three Glasses ......6.2 


\section{Tables}

Table 2.1. Wastes Considered for Glass Formulation for Next-Generation Melters 2.1

Table 2.2. Waste Compositions (in wt $\%$ oxides) Considered for Next-Generation Melter

Glass Formulation. 2.2

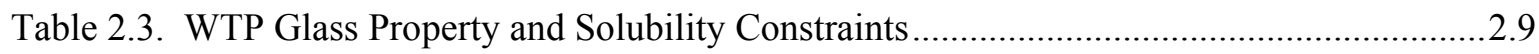

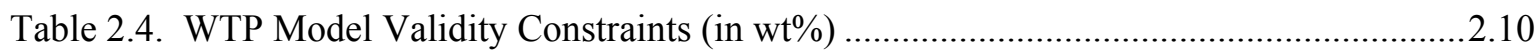

Table 2.5. WTP Model Validity Constraints for Predicted PCT Normalized Releases................2.10

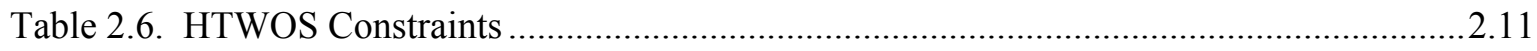

Table 2.7. Composition of Waste Clusters and Estimated Maximum Waste Loading .................2.15

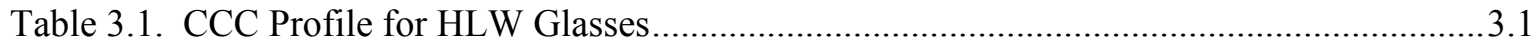

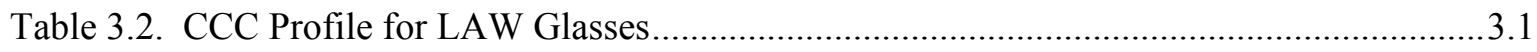

Table 4.1. Glass Property Requirements ${ }^{(a)}$ for HLW Glasses ....................................................... 4.2

Table 4.2. Target Composition and Predicted Properties of CCIM-AZ Glasses ............................4.3

Table 4.3. Comparison of Target and Analyzed Compositions of CCIM-AZ-10 through CCIM-AZ-18 Glasses and their Relative Percent Difference (RPD) ....................................... 4.5

Table 4.4. Comparison of Target and Analyzed Compositions of CCIM-AZ-29 through CCIM-AZ-33 Glasses and their Relative Percent Difference (RPD) ....................................... 4.6

Table 4.5. Measured Crystal Vol\% after CCC Treatment for CCIM-AZ Glasses.........................4.7

Table 4.6. PCT Normalized Releases and TCLP Responses of Quenched and CCC Treated

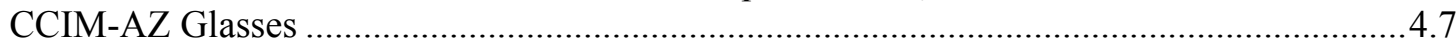

Table 4.7. Crystal Vol\% after Isothermal Heat Treatment for CCIM-AZ Glasses.......................4.9

Table 4.8. Target Compositions of Major Components in Three Selected Glasses......................4.13

Table 4.9. Measured Viscosity and Electrical Conductivity of Three Selected Glasses ..............4.16

Table 4.10. Summary of Glasses with VHT Data.....................................................................18

Table 4.11. VHT Model Coefficients ...........................................................................................19

Table 4.12. Composition of a Baseline Glass Used for Calculation of the Effect of Glass

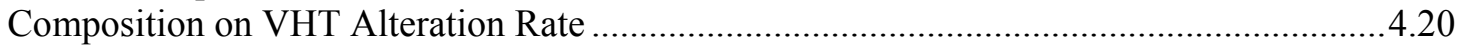

Table 4.13. Glass Property Requirements ${ }^{(a)}$ for LAW Glasses .................................................4.22

Table 4.14. Target Composition and Predicted Properties of CCIM-AN Glasses........................4.23

Table 4.15. Comparison of Target and Analyzed Compositions of First Set of CCIM-AN Glasses and their Relative Percent Difference (RPD) ..........................................................24

Table 4.16. Comparison of Target and Analyzed Compositions of Second Set of CCIM-AN Glasses and their Relative Percent Difference (RPD) ........................................................ 4.25

Table 4.17. VHT Alteration Rates for the First Set of CCIM-AN Glasses after 7-Day Test at $200^{\circ} \mathrm{C}$

Table 4.18. PCT Normalized Releases (in g/L) from Quenched and CCC Treated CCIM-AN

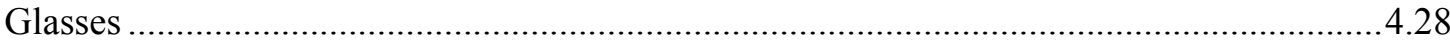

Table 4.19. Viscosity and Electrical Conductivity of Selected CCIM-AN Glasses ....................4.33

Table 4.20. Composition of Waste Clusters in Terms of 23 Oxide Components .........................4.34 
Table 4.21. Glasses Formulated for Spinel-Limited Waste Clusters and Their Predicted Properties

Table 4.22. Summary of Results for the Initial Glasses Formulated for Spinel-Limited Clusters

Table 4.23. Glasses Formulated for a High- $\mathrm{Cr}_{2} \mathrm{O}_{3}$ Waste Cluster and Their Predicted Properties

Table 5.1. Glasses Melting at $1150{ }^{\circ} \mathrm{C}$ Formulated for High-Iron Clusters and Their Predicted and Measured Properties

Table 5.2. Glasses Melting at $1150^{\circ} \mathrm{C}$ Formulated for Spinel-Limited Waste Clusters and Their Predicted and Measured Properties

Table 5.3. Glasses Melting at $1150^{\circ} \mathrm{C}$ Formulated for High-Aluminum Waste Clusters and Their Predicted and Measured Properties

Table 5.4. Existing High- $\mathrm{Al}_{2} \mathrm{O}_{3}$ Glasses with Measured $T_{1 \%}$ Data

Table 5.5. High- $\mathrm{Al}_{2} \mathrm{O}_{3}$ Glasses Processed in Scaled Melter Tests. .5 .14

Table 5.6. High- $\mathrm{Al}_{2} \mathrm{O}_{3}$ Glasses Formulated and Tested to Select the Glass for Melter Test

Table 5.7. High- $\mathrm{Al}_{2} \mathrm{O}_{3}$ Glasses Formulated Based on High-Al Clusters .5 .16

Table 5.8. Single Component Concentration Constraints Developed for Matrix Design .5 .17

Table 5.9. Multicomponent Constraints Used in Matrix Design Compared with Maximum Possible ${ }^{\mathrm{a}}$ and Maximum in High- $\mathrm{Al}_{2} \mathrm{O}_{3}$ Glasses ${ }^{\mathrm{b}}$.

Table 5.10. Property Constraints Used in Matrix Design Compared with Their Requirements...5.19

Table 5.11. Existing High- $\mathrm{Al}_{2} \mathrm{O}_{3}$ Glasses That Have Measured $T_{1 \%}$ Data and Meet Matrix Design Constraints 5.20

Table 5.12. Composition and Predicted Properties of 32 Matrix Glasses. 5.22 


\subsection{Introduction}

Resolving the nation's high-level waste (HLW) legacy requires designing, constructing, and operating large and technically complex processing facilities coupled to equally complex waste treatment and vitrification facilities. Vitrification technology was chosen to treat HLW at the Hanford Site and Savannah River Site (SRS), as well as the low-activity waste (LAW) at the Hanford Site, and it may potentially be applied to other defense waste streams, such as Idaho National Laboratory (INL) tank waste or calcine. Joule-heated melters (JHMs) are being used at the Defense Waste Processing Facility (DWPF) at SRS and will be used at the Hanford Tank Waste Treatment and Immobilization Plant (WTP) to vitrify tank waste fractions (Perez et al. 2001).

The loading of waste into glass and the glass production rates at WTP and DWPF are limited by the current melter technology. Significant reductions in glass volumes for disposal and shorter mission life are only possible with advances in melter technology and glass formulations. These were discussed in the National Research Council report (NRC 2009) “Advice on the Department of Energy's Cleanup Technology Roadmap: Gaps and Bridges," Waste Processing Gap No. 4 (WP-4): "Increased vitrification capacity may be needed to meet schedule requirements of EM's high-level waste programs" and Waste Processing Gap No. 5 (WP-5): "The baseline tank waste vitrification process significantly increases the volume of high-level waste to be disposed." Based on the National Research Council's recommendations, the U.S. Department of Energy, Office of Environmental Management (EM) launched the EM-31 technology development tasks to address the waste processing gaps including WP-4 and WP-5.

This report documents the preliminary results from the FY2011 EM-31 WP-4 and WP-5 subtasks related to the formulation and characterization of glasses with varying processing temperature. These tasks were prematurely closed during the early stage of the development, without significant progress for some subtasks. This report summarizes all the results of glass formulation and characterization achieved prior to closure. Background information and scope covered in this report are described in the following subsections.

\subsection{Glass Formulation for Cold Crucible Induction Melter (WP-4.1.2)}

The rate of glass production and loading of waste in glass is strongly dependent on glass melter design and operation. Melters with a higher throughput rate may shorten the cleanup mission. Melters that allow for higher waste loading in glass may also significantly reduce lifecycle costs. Next-generation melter technologies with a higher waste throughput rate have been developed to support accelerating the cleanup mission and reducing the lifecycle cost within the U.S. Department of Energy (DOE) complex.

Two melter technologies have been considered (Bush 2010), an advanced Joule-heated melter (AJHM) equipped with more corrosion-resistant electrodes and refractory materials and a cold crucible induction melter (CCIM). In the CCIM design, the molten glass is in contact with a frozen "skull" of glass inside a water-cooled metal crucible; therefore, there are no glass-contact materials that can corrode (Roach et al. 2009). Both melter technologies enable higher melter operating temperatures that can lead to higher loading of waste in glass and a higher processing rate of melter feeds to achieve a higher waste throughput rate. However, it should be noted that the CCIM technologies offer the opportunity for much 
higher process temperatures because of the formation of the skull layer. In addition to their capability to achieve higher operating temperatures, the bottom pouring configuration of the CCIM may make the CCIM more tolerant to crystallization within the melter and reduce some of the constraints associated with crystal formation in the JHM. However, a potential concern with higher operating temperatures of the CCIM is higher volatilization from the melter. Whereas the AJHM is significantly closer in design to currently installed/operating melters and so will have fewer challenges for retrofitting of DWPF or WTP.

Advanced glass formulations have been developed to highlight the unique benefits of the next-generation melter technologies while demonstrating reasonable estimates of increased waste loading and glass throughput rates under the WP-4.1.2: Glass Formulation for Next Generation Melter. This subtask focused on developing new glass formulations with higher waste loadings that can be successfully processed with the AJHM or advanced CCIM technologies. These glasses should possess melt properties adequate for processing and meet all product quality requirements. The glass formulations for the AJHM have been performed by the Vitreous State Laboratory (VSL) at Catholic University of America (CUA) (Kot et al. 2011). The glass formulations for the CCIM have been developed through joint efforts by the Pacific Northwest National Laboratory (PNNL) and the Savannah River National Laboratory (SRNL) and their results are presented in this report. Initial results of this subtask on CCIM formulation at PNNL and SRNL were reported in Kim et al. 2011. Detailed results achieved to date are summarized in Section 4.0.

\subsection{Advanced Silicate Glass Development (WP-5.1.2)}

Vitrification into borosilicate glass is a mature, efficient method to treat U.S. HLW and LAW. However, estimates of the quantity of glass produced by the current state-of-technology glass formulations are excessively high. Therefore, advanced silicate-based glass formulations are needed to reduce the volume of glass produced at both the Hanford and the Savannah River Sites. The possible advances are generally specific to the chemical nature of the waste being treated.

Recent developments in advanced silicate glasses suggest that step function improvements in HLW and LAW loading in glass are possible. The first of these advances include the use of crystal-tolerant glasses for HLW where sparingly insoluble components such as chromium are allowed to crystallize in the melter but are passed out of the melter before accumulating in a sludge layer (Matyas et al. 2010). Another advancement is the development of glasses with significantly higher aluminum content than what would be allowed by the current nepheline precipitation constraints, as well as a corresponding revision to those constraints (McCloy and Vienna 2010). Yet another advancement is the development of very-low silica glasses for ultra-high waste loadings (Marra et al. 2010; Matlack et al. 2010). They were planned to be further developed and demonstrated under WP-5.1.2 task.

The primary programmatic objective was to develop data to evaluate the impacts of advanced methods of silicate glass formulations and melter operations for step function increases in loading of Hanford and SRS wastes in glasses. Data were planned to be generated in this activity at the appropriate quality assurance level to allow for use in waste form qualification activities. However, qualification of these advanced silicate waste forms was not the immediate target of these studies. The WP-5.1.2 included following four subtasks initiated at PNNL: 
- WP-5.1.2.1 - Crystal Tolerant Glasses

- WP-5.1.2.2 - Nepheline Model Development

- WP-5.1.2.3 - Systematic Glass Data for Models

- WP-5.1.2.4 - Optimization for Specific Wastes.

The subtask WP-5.1.2.1 - Crystal Tolerant Glasses was completed and the results were documented in Matyas et al. (2010), and the technology was transferred to the site for further development. The recent results from subtask WP-5.1.2.2 - Nepheline Model Development were summarized in Rodriguez et al. (2011). Section 5 of this report documents the initial results, which were completed before the task close out, from two subtasks-WP-5.1.2.3 - Systematic Glass Data for Models and WP-5.1.2.4 - Optimization for Specific Wastes.

\subsection{Quality Assurance}

A graded quality assurance approach was used for the WP-4 and WP-5 tasks performed under the DOE EM-31 Technology Development and Deployment program. The following work activities performed in the WP-4.1.2 and WP-5.1.2 subtasks were considered waste form quality impacting and were performed in accordance with the quality assurance plan for the EM-31 Support Project (EM31SP-PQAP) under Quality Level 2. This work was conducted to the quality requirements of NQA-1-2008 as instituted through the PNNL Nuclear Project Quality Assurance Plan (Energy \& Environment Directorate) [PNNL-NQA-EQAM-1].

- glass fabrication to prepare glass samples for product consistency test (PCT) and toxicity characteristic leach procedure (TCLP)

- Canister centerline cooling treatment to prepare glass samples for PCT and TCLP

- PCT and TCLP.

All other activities that are not waste form quality impacting (e.g., liquidus temperature, viscosity, and electrical conductivity) were performed in accordance with the quality assurance plan for the EM-31 Support Project (EM-31SP-PQAP) under Quality Level 3. This work was conducted in accordance with best laboratory practices (NQA-1-2000 based) as implemented through PNNL's standards-based management system (HDI) work flows and subject areas.

Quality assurance (QA) activities performed by SRNL are defined in the project specific quality assurance plan, SRNL-RP-2010-00932. 



\subsection{Waste Compositions}

This section describes the waste compositions that were used in this study. Section 2.1 summarizes the selection of waste compositions used for initial glass formulation efforts for CCIM. Section 2.2 describes the projected Hanford waste compositions used for both CCIM glass formulation (Section 4.0) and advanced silicate glass formulation (Section 5.0). Section 2.2 also describes the cluster analyses of the projected Hanford wastes, glass formulation constraints used for estimation of maximum waste loading, and estimated waste loading and glass mass for each cluster.

\subsection{Selection of Wastes for Initial Formulation for the Cold Crucible Induction Melter}

Table 2.1 lists the wastes that were considered for use in initial CCIM glass formulations. The selection of wastes initially focused on Hanford waste streams because they are likely to show the highest cost benefit to implementation, considering the size and cost of the Hanford tank waste cleanup program and the timing of startup. INL treatment is likely to show a cost increase because of the low cost baseline options selected, and DWPF will be so far progressed in their program before CCIM implementation that it will have only moderate cost impacts.

Table 2.1. Wastes Considered for Glass Formulation for Next-Generation Melters

\begin{tabular}{|l|l|l|l|}
\hline \multicolumn{1}{|c|}{ Waste ID } & \multicolumn{1}{c|}{ Site } & \multicolumn{1}{c|}{ Type } & \multicolumn{1}{c|}{ Comment } \\
\hline C-104 Actual & Hanford & HLW & Zr and Th rich \\
\hline AZ-101 Actual & Hanford & HLW & Fe rich \\
\hline Alumina & INL & Calcine/HLW & Al rich \\
\hline Alumina-Na Blend & INL & Calcine/HLW & Al rich \\
\hline Zirconia & INL & Calcine/HLW & Zr rich \\
\hline Zirconia-Na Blend & INL & Calcine/HLW & Zr rich \\
\hline SBW* & INL & SBW/HAW & Na rich \\
\hline Bi Limited & Hanford & HLW & BiPO $_{4}$ waste \\
\hline Cr Limited & Hanford & HLW & Redox/BiPO \\
\hline Al Limited & Hanford & HLW & Al rich \\
\hline Al and Na Limited & Hanford & HLW & Al rich \\
\hline AN-105 & Hanford & LAW & Low S, Cl rich \\
\hline AN-102 & Hanford & LAW & S and Cl rich \\
\hline AZ-102 & Hanford & LAW & S rich \\
\hline AP-101 & Hanford & LAW & K rich \\
\hline High $\mathrm{Al}_{2} \mathrm{O}_{3}$ & DWPF & HLW & Al rich \\
\hline High Fe $\mathrm{O}_{3}$ & DWPF & HLW & Fe rich \\
\hline High $\mathrm{MnO}$ and NiO $^{*} \mathrm{SBW}$ is a sodium-bearing high-activity waste stored in INL tanks & Mn rich \\
\hline
\end{tabular}

The compositions of the Hanford related wastes are given in Table 2.2 and are expressed in terms of $\mathrm{wt} \%$ of oxides and halogens (referred to as "oxides" in this report). 
Table 2.2. Waste Compositions (in wt $\%$ oxides) Considered for Next-Generation Melter Glass Formulation

\begin{tabular}{|c|c|c|c|c|c|c|c|c|c|c|}
\hline \multirow[b]{2}{*}{ Component } & \multicolumn{6}{|c|}{ HLW } & \multicolumn{4}{|c|}{ LAW } \\
\hline & AZ-101 & C-104 & $\begin{array}{c}\mathrm{Bi}- \\
\text { Limited }\end{array}$ & $\begin{array}{c}\mathrm{Cr}- \\
\text { Limited }\end{array}$ & $\begin{array}{c}\text { Al- } \\
\text { Limited }\end{array}$ & $\begin{array}{l}\text { Al\&Na- } \\
\text { Limited }\end{array}$ & AN-105 & AN-102 & AZ-102 & AP-101 \\
\hline $\mathrm{Al}_{2} \mathrm{O}_{3}$ & 24.58 & 9.69 & 23.18 & 27.48 & 52.95 & 45.13 & 17.88 & 6.40 & 0.30 & 5.23 \\
\hline $\mathrm{B}_{2} \mathrm{O}_{3}$ & 0.00 & 0.00 & 0.60 & 0.57 & 0.42 & 0.77 & 0.08 & 0.03 & 0.00 & 0.01 \\
\hline $\mathrm{BaO}$ & 0.00 & 0.00 & 0.02 & 0.03 & 0.12 & 0.06 & 0.00 & 0.00 & 0.00 & 0.00 \\
\hline $\mathrm{Bi}_{2} \mathrm{O}_{3}$ & 0.00 & 0.00 & 13.33 & 7.85 & 2.53 & 2.45 & 0.00 & 0.00 & 0.00 & 0.00 \\
\hline $\mathrm{CaO}$ & 1.40 & 1.67 & 1.66 & 2.66 & 2.38 & 1.53 & 0.00 & 0.19 & 0.00 & 0.00 \\
\hline $\mathrm{CdO}$ & 2.16 & 0.27 & 0.00 & 0.01 & 0.05 & 0.02 & 0.00 & 0.00 & 0.00 & 0.00 \\
\hline $\mathrm{Ce}_{2} \mathrm{O}_{3}$ & 0.80 & 0.30 & 0.00 & 0.00 & 0.00 & 0.00 & 0.00 & 0.00 & 0.00 & 0.00 \\
\hline $\mathrm{Cl}$ & 0.00 & 0.00 & 0.00 & 0.00 & 0.00 & 0.00 & 2.17 & 1.33 & 0.07 & 0.79 \\
\hline $\mathrm{Cr}_{2} \mathrm{O}_{3}$ & 0.46 & 0.40 & 1.03 & 3.30 & 1.15 & 1.50 & 0.07 & 0.09 & 0.90 & 0.32 \\
\hline $\mathrm{Cs}_{2} \mathrm{O}$ & 0.50 & 0.50 & 0.50 & 0.50 & 0.50 & 0.50 & 0.50 & 0.50 & 0.50 & 0.50 \\
\hline $\mathrm{F}$ & 0.00 & 0.00 & 1.63 & 2.15 & 1.47 & 0.48 & 0.01 & 0.70 & 0.56 & 0.31 \\
\hline $\mathrm{Fe}_{2} \mathrm{O}_{3}$ & 37.67 & 17.80 & 13.83 & 14.13 & 13.03 & 5.95 & 0.00 & 0.00 & 0.00 & 0.00 \\
\hline $\mathrm{HfO}_{2}$ & 0.00 & 14.35 & 0.00 & 0.00 & 0.00 & 0.00 & 0.00 & 0.00 & 0.00 & 0.00 \\
\hline $\mathrm{K}_{2} \mathrm{O}$ & 0.00 & 0.00 & 0.92 & 0.40 & 0.31 & 1.40 & 1.72 & 0.66 & 3.32 & 19.49 \\
\hline $\mathrm{La}_{2} \mathrm{O}_{3}$ & 0.89 & 0.00 & 0.00 & 0.00 & 0.00 & 0.00 & 0.00 & 0.00 & 0.00 & 0.00 \\
\hline $\mathrm{Li}_{2} \mathrm{O}$ & 0.00 & 0.00 & 0.32 & 0.39 & 0.38 & 0.16 & 0.00 & 0.00 & 0.00 & 0.00 \\
\hline $\mathrm{MgO}$ & 0.00 & 0.00 & 0.85 & 0.17 & 0.26 & 0.46 & 0.00 & 0.00 & 0.00 & 0.00 \\
\hline $\mathrm{MnO}$ & 0.91 & 3.55 & 0.00 & 0.00 & 0.00 & 0.00 & 0.00 & 0.00 & 0.00 & 0.00 \\
\hline $\mathrm{Na}_{2} \mathrm{O}$ & 10.58 & 11.03 & 13.39 & 21.62 & 7.91 & 26.88 & 76.79 & 84.71 & 80.57 & 71.24 \\
\hline $\mathrm{Nd}_{2} \mathrm{O}_{3}$ & 0.65 & 9.97 & 0.00 & 0.00 & 0.00 & 0.00 & 0.00 & 0.00 & 0.00 & 0.00 \\
\hline $\mathrm{NiO}$ & 1.66 & 1.01 & 3.83 & 1.14 & 0.88 & 0.21 & 0.00 & 0.15 & 0.00 & 0.03 \\
\hline $\mathrm{P}_{2} \mathrm{O}_{5}$ & 1.34 & 1.37 & 9.91 & 3.59 & 2.32 & 4.27 & 0.00 & 1.15 & 0.24 & 0.49 \\
\hline $\mathrm{PbO}$ & 0.00 & 0.00 & 0.50 & 0.52 & 0.90 & 0.19 & 0.00 & 0.06 & 0.00 & 0.03 \\
\hline $\mathrm{Re}_{2} \mathrm{O}_{7}$ & 0.00 & 0.00 & 0.00 & 0.00 & 0.00 & 0.00 & 0.10 & 0.10 & 0.10 & 0.10 \\
\hline $\mathrm{RuO}_{2}$ & 0.15 & 0.10 & 0.10 & 0.10 & 0.10 & 0.10 & 0.00 & 0.00 & 0.00 & 0.00 \\
\hline $\mathrm{SiO}_{2}$ & 3.77 & 6.57 & 12.43 & 11.36 & 10.81 & 6.48 & 0.10 & 0.05 & 0.48 & 0.10 \\
\hline $\mathrm{SnO}_{2}$ & 0.66 & 0.00 & 0.00 & 0.00 & 0.00 & 0.00 & 0.00 & 0.00 & 0.00 & 0.00 \\
\hline $\mathrm{SO}_{3}$ & 0.38 & 0.19 & 0.94 & 1.64 & 0.44 & 0.46 & 0.59 & 3.89 & 12.98 & 1.38 \\
\hline $\mathrm{TiO}_{2}$ & 0.00 & 0.00 & 0.31 & 0.01 & 0.02 & 0.36 & 0.00 & 0.00 & 0.00 & 0.00 \\
\hline $\mathrm{ZnO}$ & 0.00 & 0.00 & 0.32 & 0.27 & 0.18 & 0.38 & 0.00 & 0.00 & 0.00 & 0.00 \\
\hline $\mathrm{ZrO}_{2}$ & 11.44 & 21.21 & 0.41 & 0.12 & 0.87 & 0.26 & 0.00 & 0.00 & 0.00 & 0.00 \\
\hline
\end{tabular}

Each of these wastes was adjusted slightly to ensure adequate analysis of key partially volatile radionuclides $\left(\mathrm{Cs}_{2} \mathrm{O}\right.$, and $\mathrm{Re}_{2} \mathrm{O}_{7}$ as $\mathrm{Tc}_{2} \mathrm{O}_{7}$ surrogates) and noble metals to ensure adequate crystal nucleation in HLW simulant melts. The waste compositions were evaluated for their potential to successfully demonstrate the unique advantages of the CCIM technology over current reference technologies. The comments and waste loading targets from these evaluations are given below (note that these targets are very challenging and represent the high end of the likely results of laboratory scale formulation activities):

AZ-101: This waste is relatively high in aluminum, iron, and zirconium, which suggests that using a melter technology capable of higher melting temperature and increased tolerance to spinel crystals could increase loading and potentially increase the processing rate. In addition, the composition is at the high end of potential noble metal concentrations for Hanford tank wastes. The maximum expected waste loading for the reference WTP formulation is $37 \mathrm{wt} \%$. 
C-104: This waste represents a relatively small fraction of waste in the Hanford tanks with high thorium and zirconium (being found only in cluster \#3, below). Although CCIM technology is likely to obtain significantly higher loadings of this waste than a Joule-heated melter because of higher operating temperatures, the impacts will not be as significant as for other wastes.

Bismuth-limited: This waste represents the $\mathrm{BiPO}_{4}$ waste stream, which makes up a relatively large fraction of Hanford tank wastes. The waste loading is generally limited by phosphate content, which is not expected to be significantly higher in a CCIM than the reference melter type unless the composition is changed to either a phosphate-based glass or a glass ceramic where the phosphate is precipitated from the silicate melt.

Chromium-limited: This waste represents a mix of REDOX (Reduction-Oxidation Plant) and $\mathrm{BiPO}_{4}$ wastes, which make up a large fraction of Hanford tank sludge. A melter with higher operating temperature and crystal tolerance has a potential to obtain higher loadings for this waste type. However, this waste also contains relatively high concentration of $\mathrm{SO}_{3}$, suggesting that the waste loading may be limited by salt formation. In that case the CCIM may not have an advantage.

Aluminum-limited: There is a full range wastes with very high aluminum in the Hanford sludge because aluminum was a component of the fuel cladding that was dissolved and sent to the tank farm. This waste type makes up almost half of the Hanford HLW. Higher-temperature melting can generally tolerate higher aluminum loadings; however, in the case of this particular composition, nepheline precipitation on slow cooling (and its impact on durability) is the biggest challenge. The CCIM does not appear to have a strong advantage for these waste types; however, if lower alkali can be added to the glass, the resulting, partially crystallized waste form may pass durability constraints.

Aluminum- and sodium-limited: A subset of the high-aluminum wastes described above simultaneously includes high sodium. Glasses for these wastes include minimal alkali addition and are still limited by nepheline precipitation. It is not clear how a CCIM would show significant advantages over a JHM for this waste stream. It is worth noting, however, that this type of Hanford waste is closely related to the DWPF high $\mathrm{Al}_{2} \mathrm{O}_{3}$ composition from sludge batch 19 (Chew and Hamm 2009).

AN-105: This is a low-sulfur and high-chlorine LAW stream. Its loading is limited by $\mathrm{Na}_{2} \mathrm{O}$ concentration in glass, which dictates the chemical durability of glass. The maximum expected waste loading for the reference WTP formulation is $27 \mathrm{wt} \%$ (yielding $21 \mathrm{wt} \% \mathrm{Na}_{2} \mathrm{O}$ in glass). This waste stream is also characterized by its high chlorine content, but its loading is not limited by chlorine because of its low sulfur content (the chlorine limit depends on the sulfur concentration in glass). The higher melting temperature of CCIM technologies would allow higher concentrations of refractory additive components that increase chemical durability, such as $\mathrm{ZrO}_{2}$ and $\mathrm{SnO}_{2}$, which may enable higher waste loading.

AN-102: This waste has elevated concentrations of both sulfur and chlorine. The loading in glass by CCIM is not expected be significantly higher than demonstrated in JHM because the waste loading is likely to be limited by salt formation.

AZ-102: This waste represents the highest sulfate wastes. Similar to AN-102, the CCIM is not expected to obtain significantly higher loadings for this waste in a silicate glass, although a phosphate glass is expected to achieve significant loading increases. 
AP-101: This waste represents a relatively small fraction of Hanford LAW with high potassium, which is to be processed first in the WTP. Similar to AN-105, the higher melting temperature of CCIM technologies may enable higher waste loading.

Based on these preliminary informal evaluations, the AZ-101 HLW and AN-105 LAW were selected for initial glass formulations and demonstration for CCIM. The results of glass formulation tests are described in Sections 4.1 and 4.2.

\subsection{Projected Hanford High-Level Waste Compositions}

Information on the composition of the Hanford tank wastes for the entire mission is needed to estimate the impact of CCIM technologies on the glass volume, which is used to evaluate the impact on the duration and lifecycle costs of Hanford cleanup mission. The projected compositions of Hanford tank wastes generated by the WTP Dynamic Flowsheet Model (G2) were used. The G2 model run selected (MRQ 10-0063 Scenario 6.0.1a using adjusted System Plan Rev 3 feed vector [Certa et al. 2008]) represents one of the many recent G2 runs. The compositions of HLW at a node between high-level waste blend vessel (HBV, HLP-VSL-0028) and melter feed preparation vessel (MFPV, HFP-VSL-00001 and 5) were used. The G2 model output included 378 HLW batches for the entire mission with the first batch dated May 2018 and the last dated December 2033.

The G2 output given in the masses of elements and compounds were converted to concentrations of 63 oxides used in the glass formulation (i.e., in mass fraction of oxides and halogens) and to a total mass of oxides. The total oxide mass in metric tons (MT) from this particular G2 run was 11,075 metric tons (MT) (average 29.3 MT) with each batch ranging from 7.1 to $46.7 \mathrm{MT}$.

Figure 2.1 through Figure 2.4 show the concentrations of the components of interest as a function of time: Figure 2.1 for the 15 components that were used for cluster analyses in Section 2.2.1; Figure 2.2 for three major components that are present in high concentrations in Hanford wastes and have primary impact on the waste loading in glass; Figure 2.3 for three components that are important for the formation of spinel that has strong effect on waste loading; and Figure 2.4 for four components that are of interest for glass formulation related to potential phase separation and its effect on waste loading. 


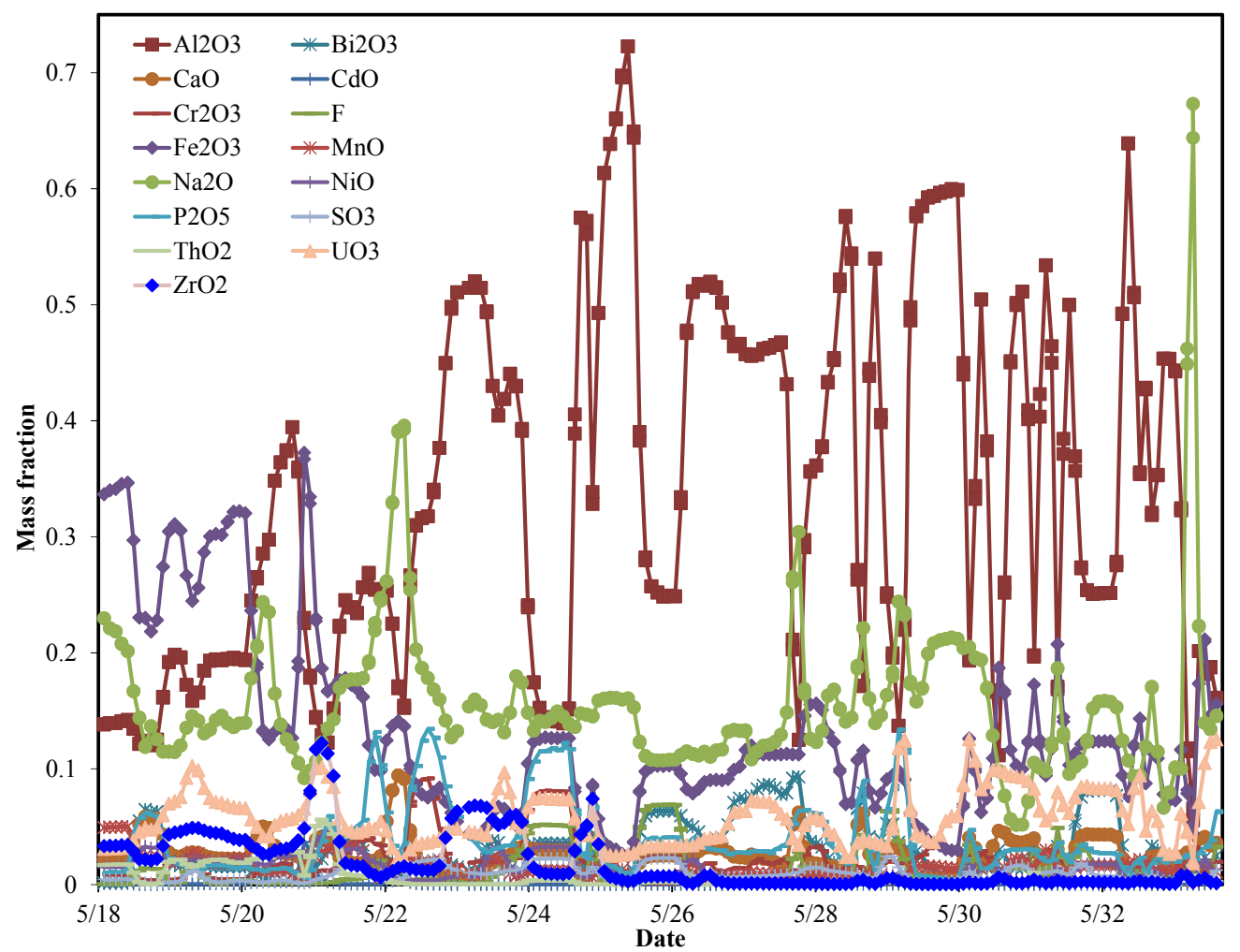

Figure 2.1. Composition of Projected Wastes for 15 Components of Interest for Glass Formulation

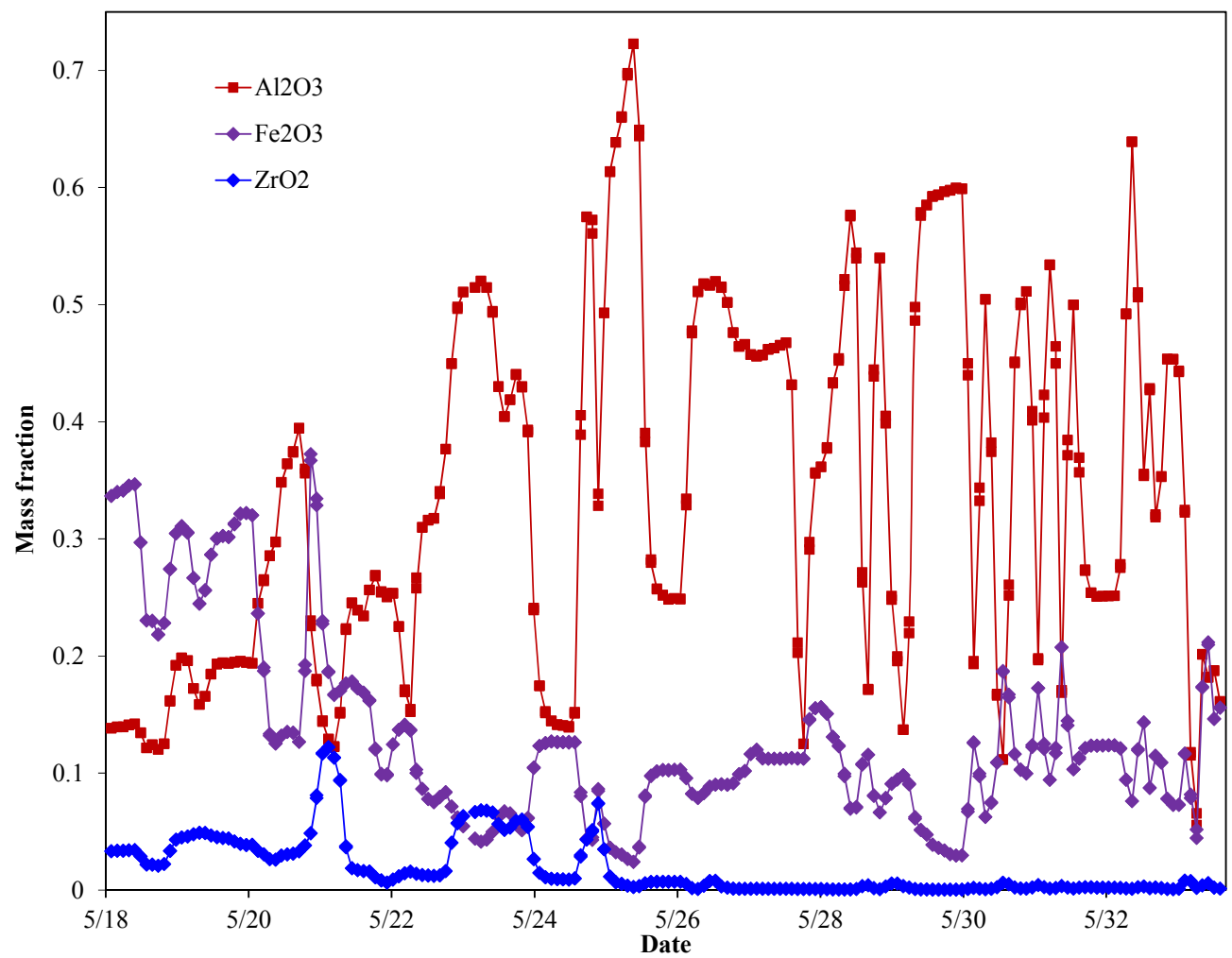

Figure 2.2. Composition of Projected Wastes for Three Major Components 


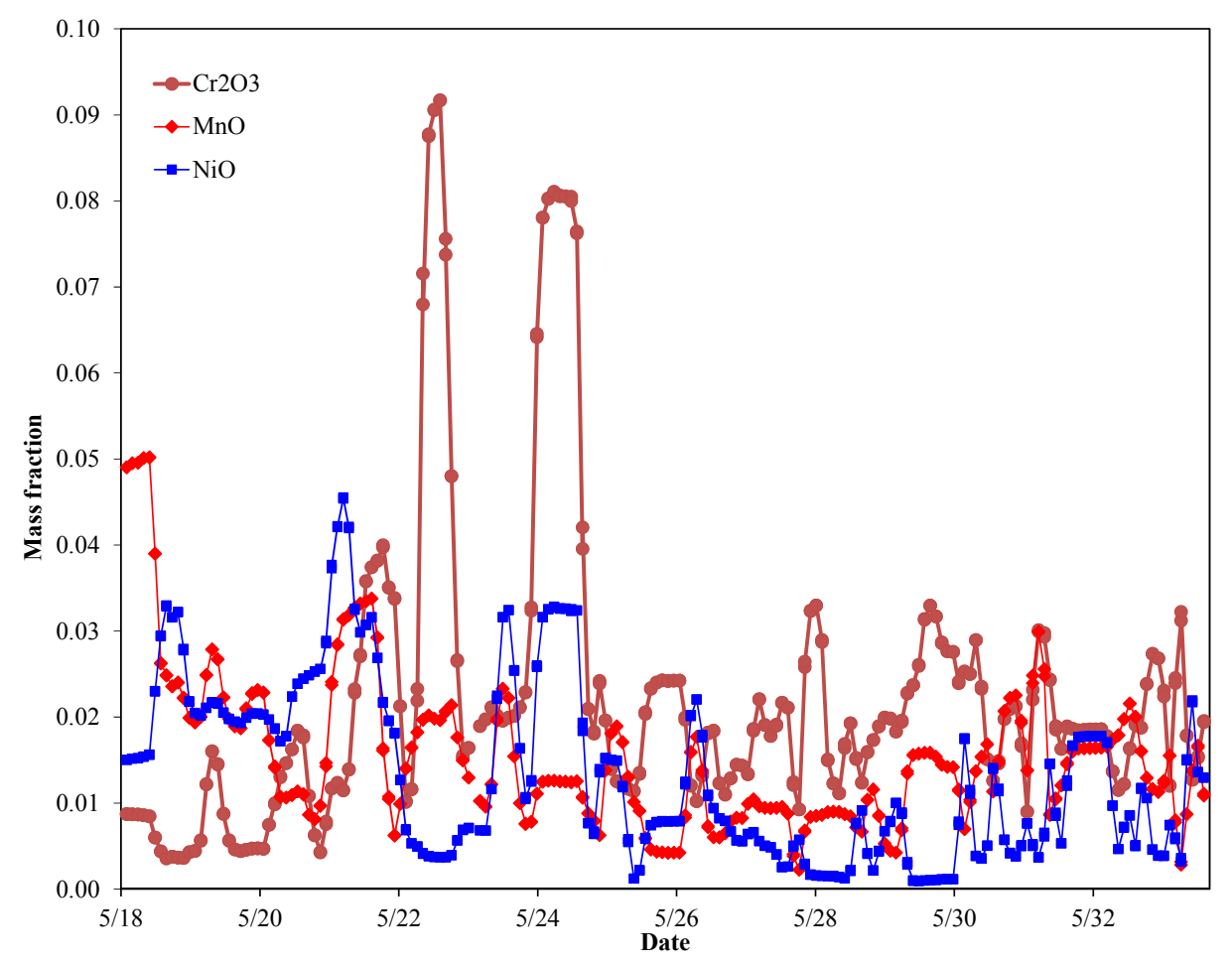

Figure 2.3. Composition of Projected Wastes for Three Components Important for Spinel Formation

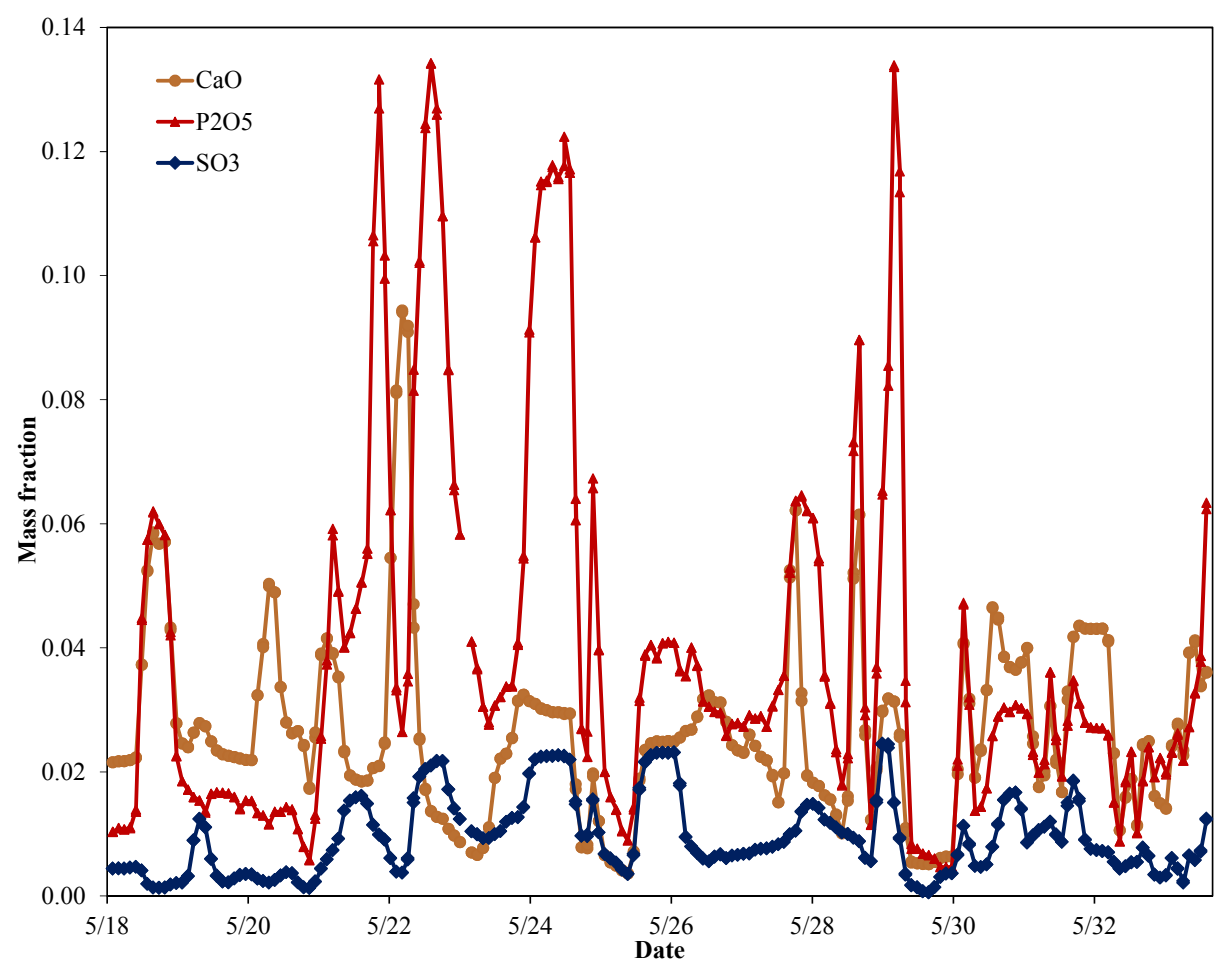

Figure 2.4. Composition of Projected Wastes for Four Components Important for Potential Phase Separation 


\subsubsection{Cluster Analysis}

To keep the required glass formulations and glass mass estimation for each set of constraints manageable, K-Means cluster analysis was performed to sort 378 waste batches into waste clusters of like compositions using JMP ${ }^{\circledR}$ statistical software (Release 6.0.0, SAS Institute, Inc., Cary, NC). Waste batches were sorted according to their composition by mass of the 15 components: $\mathrm{Al}_{2} \mathrm{O}_{3}, \mathrm{Bi}_{2} \mathrm{O}_{3}, \mathrm{CaO}$, $\mathrm{CdO}, \mathrm{Cr}_{2} \mathrm{O}_{3}, \mathrm{~F}, \mathrm{Fe}_{2} \mathrm{O}_{3}, \mathrm{MnO}, \mathrm{Na}_{2} \mathrm{O}, \mathrm{NiO}, \mathrm{P}_{2} \mathrm{O}_{5}, \mathrm{SO}_{3}, \mathrm{ThO}_{2}, \mathrm{UO}_{3}$, and $\mathrm{ZrO}_{2}$, which represent the components that are present in large concentrations or have a strong effect on waste loading in glass.

In cluster analysis, as the number of clusters increases, the average distance (a measure of closeness of data points or waste compositions to the centroid of each cluster used by JMP ${ }^{\circ}$ software) over all clusters analyzed decreases, i.e., the higher the number of clusters, the more accurate the partitioning of composition becomes. However, it is desirable to keep the number of clusters small so that the glass formulation is manageable. Figure 2.5 shows the decrease of the average distance as the number of clusters increases from 10 to 40 . Figure 2.5 indicates that the decrease of average distance slows down after the number of clusters reaches about 20 . The 20 clusters match reasonably well with the number used in previous studies of 17 clusters (Perez et al. 2001; Kim and Vienna 2002) and were chosen for the present study.

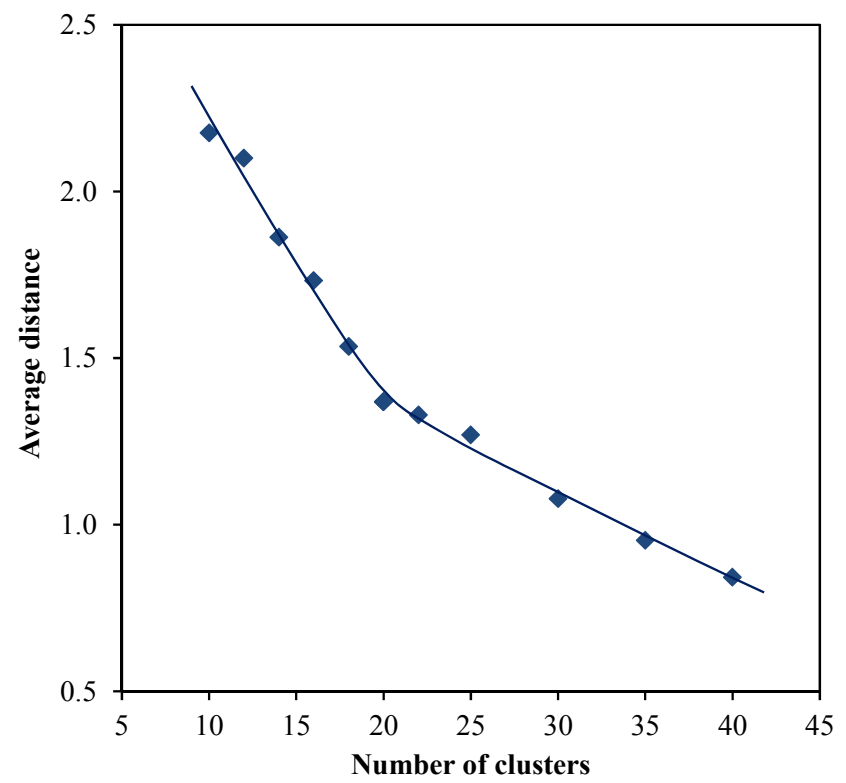

Figure 2.5. Average Distance versus Number of Clusters from K-Means Cluster Analysis

Figure 2.6 shows the parallel coordinate plots for the 20 clusters, generated by JMP® software. In Appendix A, Table A.1 lists the composition of 20 clusters in terms of 63 oxide components that are tracked in the G2 model. The glass formulation spreadsheet developed at PNNL uses 41 oxide components excluding the 22 minor components that are present in the wastes at very low concentrations. Table A.2 lists the composition of 20 clusters in terms of 41 oxide components (normalized mass fraction). Tables A.1 and A.2 also include the total oxide mass for each cluster, which is a sum of oxide masses for all batches that belong to each cluster. 

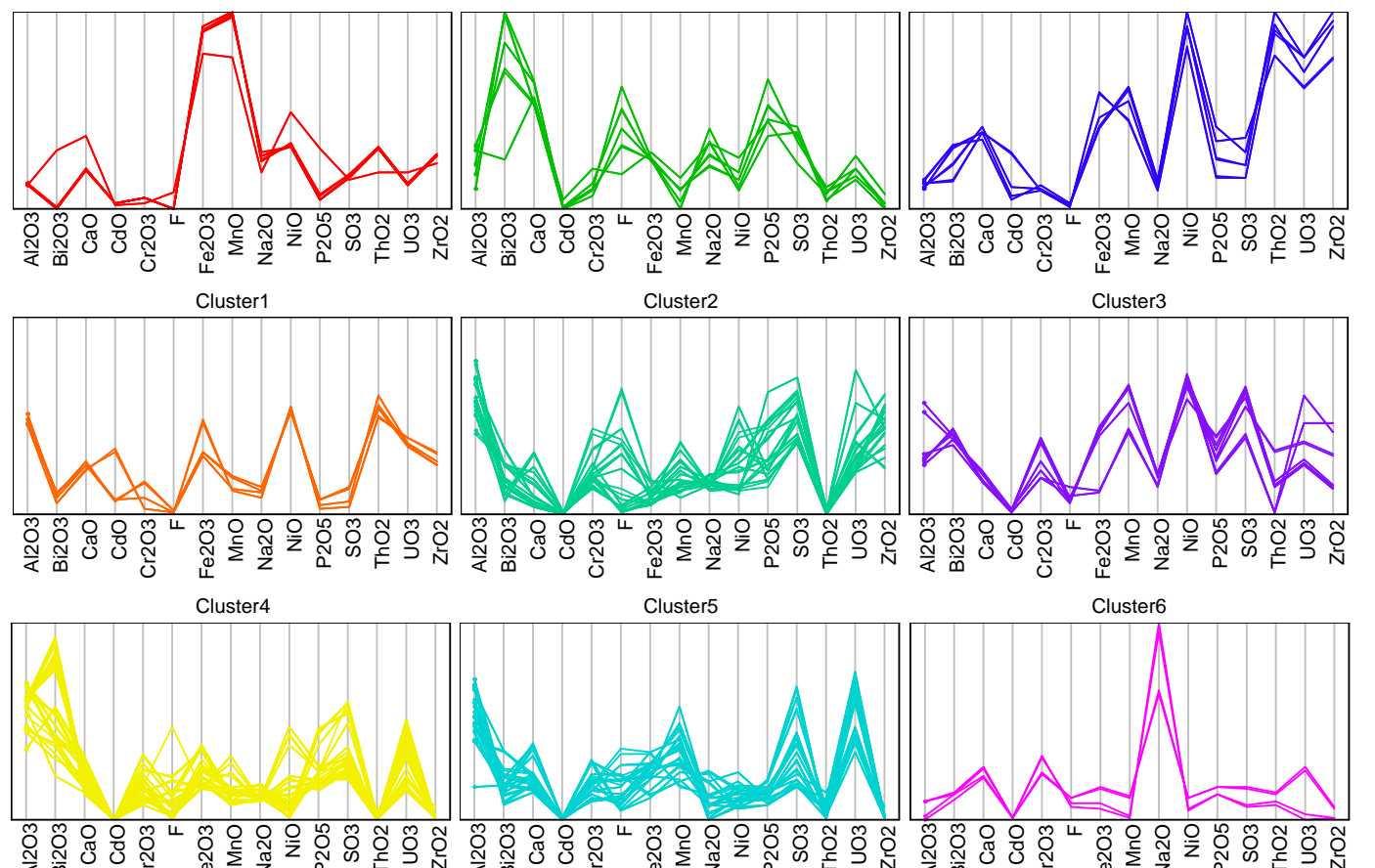

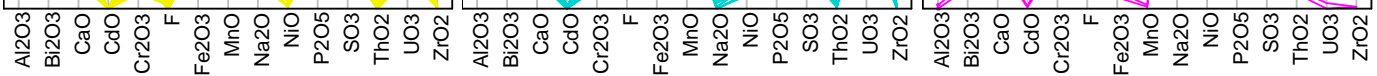
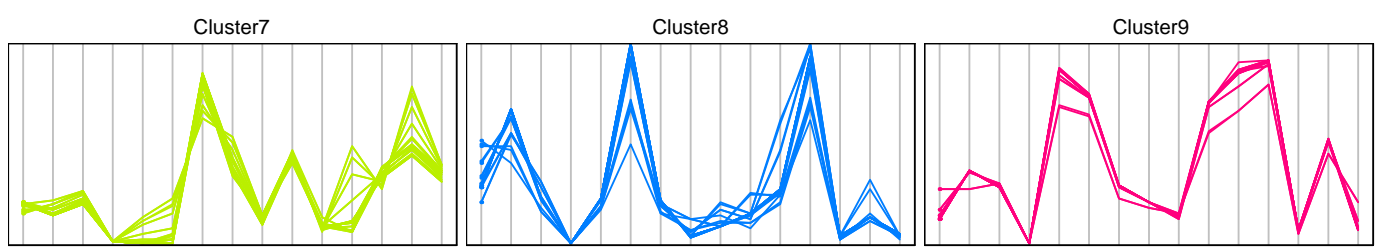

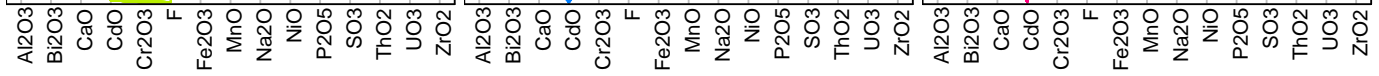
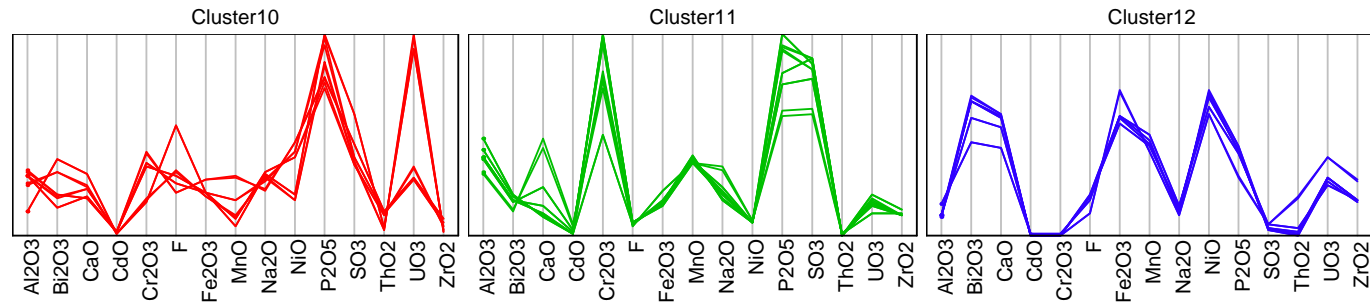

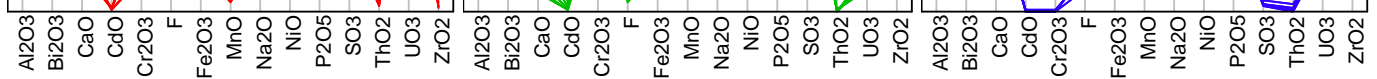
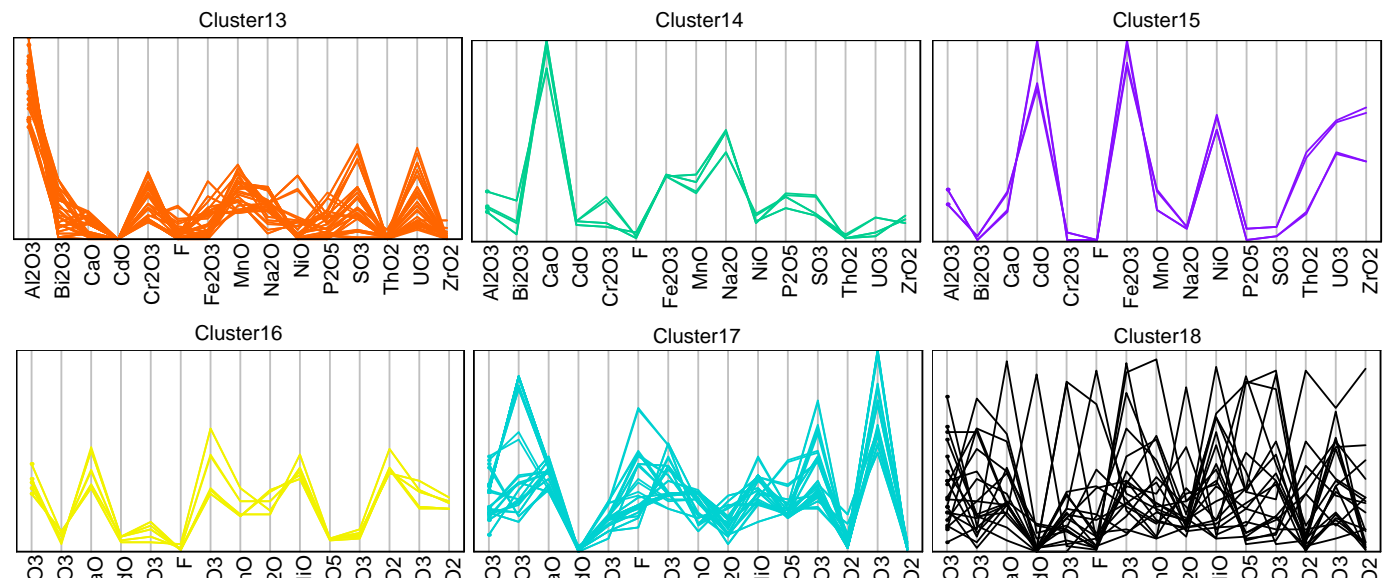

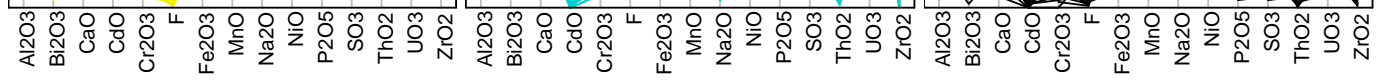
Cluster19

Cluster20

Cluster Means

Figure 2.6. Parallel Coordinate Plots for 20 Clusters Based on 15 Components 


\subsubsection{High-Level Waste Glass Formulation Constraints for Waste Loading Estimation}

Using the compositions of 20 waste clusters expressed in 41 oxide components (Table A.2), the maximum waste loading for each waste cluster was calculated by applying the constraints and glass property models developed for the WTP and those for the Hanford Tank Waste Operations Simulator (HTWOS). Table 2.3 through 2.5 summarize the preliminary constraints being developed for WTP, and Table 2.6 summarizes the HTWOS constraints. A detailed description of the preliminary glass formulation methods and constraints being developed for the operation of the WTP is in Vienna and Kim (2008). The HTWOS 2009 baseline constraints are summarized in Belsher and Meinert (2009) derived from Vienna et al. (2009) and the models used for the HTWOS are given in Vienna et al. (2009). Selected constraints for the HTWOS were revised and described in McCloy and Vienna (2010).

Table 2.3. WTP Glass Property and Solubility Constraints

\begin{tabular}{|c|c|c|}
\hline $\begin{array}{r}\text { Constraint Description } \\
\end{array}$ & Lower limit & Upper limi \\
\hline $\begin{array}{l}\text { PCT normalized B release, } r_{\mathrm{B}}(\mathrm{g} / \mathrm{L}) \\
\text { PCT normalized Li release, } r_{\mathrm{Li}}(\mathrm{g} / \mathrm{L}) \\
\text { PCT normalized Na release, } r_{\mathrm{Na}}(\mathrm{g} / \mathrm{L})\end{array}$ & & $\begin{array}{c}16.70 \\
9.57 \\
13.35 \\
\end{array}$ \\
\hline Nepheline rule, $N_{\mathrm{Si}}=g_{\mathrm{SiO} 2} /\left(g_{\mathrm{Al} 2 \mathrm{O} 3}+g_{\mathrm{Na} 2 \mathrm{O}}+g_{\mathrm{SiO} 2}\right)$ & 0.62 & \\
\hline $\begin{array}{l}\text { CdO concentration in glass, } g_{\mathrm{CdO}}(\mathrm{wt} \%) \text { or } \\
\text { TCLP Cd concentration, } c_{\mathrm{Cd}}(\mathrm{mg} / \mathrm{L})\end{array}$ & & $\begin{array}{c}0.1 \\
0.48\end{array}$ \\
\hline $\mathrm{Tl}_{2} \mathrm{O}$ concentration in glass, $g_{\mathrm{TL} 2 \mathrm{O}}(\mathrm{wt} \%)$ & & 0.465 \\
\hline Temperature at $1 \mathrm{vol} \%$ spinel crystal, $T_{1 \%}\left({ }^{\circ} \mathrm{C}\right)$ & & 950 \\
\hline $\begin{array}{l}\text { Non spinel phase rule, } g_{\mathrm{Al} 2 \mathrm{O} 3}+g_{\mathrm{ThO} 2}+g_{\mathrm{ZrO} 2}(\mathrm{wt} \%) \\
\text { Non spinel phase rule, } g_{\mathrm{ThO} 2}+g_{\mathrm{ZrO} 2}(\mathrm{wt} \%) \\
\text { Non spinel phase rule, } g_{\mathrm{ZrO} 2}(\mathrm{wt} \%)\end{array}$ & & $\begin{array}{l}18 \\
13 \\
9.5\end{array}$ \\
\hline $\begin{array}{l}\text { Viscosity at } 1150^{\circ} \mathrm{C}, \eta_{1150}(\mathrm{~Pa} \cdot \mathrm{s}) \\
\text { Viscosity at } 1100^{\circ} \mathrm{C}, \eta_{1100}(\mathrm{~Pa} \cdot \mathrm{s})\end{array}$ & 2 & $\begin{array}{c}8 \\
15\end{array}$ \\
\hline $\begin{array}{l}\text { Electrical conductivity at } 1100^{\circ} \mathrm{C}, \varepsilon_{1100}(\mathrm{~S} / \mathrm{m}) \\
\text { Electrical conductivity at } 1200^{\circ} \mathrm{C}, \varepsilon_{1200}(\mathrm{~S} / \mathrm{m})\end{array}$ & 10 & 70 \\
\hline $\mathrm{SO}_{3}$ concentration in glass, $g_{\mathrm{SO} 3}(\mathrm{wt} \%)$ & & 0.44 \\
\hline $\begin{array}{l}\text { Phosphate phase rule, } g_{\mathrm{P} 205}(\mathrm{wt} \%) \\
\text { Phosphate phase rule, } g_{\mathrm{P} 205} \times g_{\mathrm{CaO}}\left(\mathrm{wt} \%{ }^{2}\right) \\
\text { Phosphate phase rule, } g_{\mathrm{L} \text { L2O }}(\mathrm{wt} \%)\end{array}$ & & $\begin{array}{l}4.5 \\
6.5 \\
6.0 \\
\end{array}$ \\
\hline
\end{tabular}

There are two groups of constraints, based on glass properties and concentrations, that are used when formulating glasses: acceptability constraints and processing constraints. Acceptability constraints are concerned with the acceptability of the final product, related to the resistance against corrosion to prevent the spread of the radioactive and toxic elements into the environment. The current regulation for immobilized HLW (IHLW) product uses two standard test methods - product consistency test (PCT) (ASTM 2008) and toxicity characteristic leach procedure (TCLP) (EPA 1997). The PCT normalized releases should be less than environmental assessment glass (Jantzen et al. 1993). See Table 2.3 for limiting values. As Hanford tank waste is a listed hazardous waste, a delisting action is required. A draft petition for delisting (see Vienna and Kim 2008) specifies that the CdO concentration in glass is below $0.1 \mathrm{wt} \%$ or the TCLP cadmium concentration is below $0.48 \mathrm{mg} / \mathrm{L}$ and the $\mathrm{Tl}_{2} \mathrm{O}$ concentration in glass is 
below $0.465 \mathrm{wt} \%$ (Table 2.3). However, the PCT and TCLP requirements are easily met for most Hanford HLW glasses, and therefore are sometimes not used as constraints (e.g., see Table 2.6).

Table 2.4. WTP Model Validity Constraints (in wt\%)

\begin{tabular}{|c|c|c|c|c|}
\hline \multirow{2}{*}{ Component } & \multicolumn{2}{|c|}{ If $g_{\mathrm{CdO}} \leq 0.1 \mathrm{wt} \%$} & \multicolumn{2}{|c|}{ If $g_{\mathrm{CdO}}>0.1 \mathrm{wt} \%$} \\
\hline & Lower limit & Upper limit & Lower limit & Upper limit \\
\hline $\mathrm{Al}_{2} \mathrm{O}_{3}$ & 1.8 & 13.0 & 1.9 & 8.5 \\
\hline $\mathrm{B}_{2} \mathrm{O}_{3}$ & 4.5 & 15.0 & 4.8 & 14.0 \\
\hline $\mathrm{CaO}$ & 0 & 1.0 & 0 & 1.0 \\
\hline $\mathrm{CdO}$ & 0 & 1.6 & 0 & 1.6 \\
\hline $\mathrm{Cr}_{2} \mathrm{O}_{3}$ & 0 & 0.6 & 0 & 0.5 \\
\hline $\mathrm{F}$ & 0 & 0.44 & 0 & 0.44 \\
\hline $\mathrm{Fe}_{2} \mathrm{O}_{3}$ & 1.4 & 15.0 & 1.9 & 14.0 \\
\hline $\mathrm{K}_{2} \mathrm{O}$ & 0 & 1.6 & 0 & 1.6 \\
\hline $\mathrm{Li}_{2} \mathrm{O}$ & 0 & 6.0 & 1.9 & 6.0 \\
\hline $\mathrm{MgO}$ & 0 & 1.2 & 0 & 1.2 \\
\hline $\mathrm{MnO}$ & 0 & 8.0 & 0 & 7.0 \\
\hline $\mathrm{Na}_{2} \mathrm{O}$ & 3.9 & 20.0 & 3.9 & 15.0 \\
\hline $\mathrm{NiO}$ & 0 & 1.0 & 0 & 1.0 \\
\hline $\mathrm{PbO}$ & 0 & 1.0 & 0 & 1.0 \\
\hline $\mathrm{SiO}_{2}$ & 35.0 & 53.0 & 35.0 & 53.0 \\
\hline $\mathrm{SrO}$ & 0 & 10.0 & 0 & 10.0 \\
\hline $\mathrm{ThO}_{2}$ & 0 & 6.0 & 0 & 6.0 \\
\hline $\mathrm{TiO}_{2}$ & 0 & 1.0 & 0 & 1.0 \\
\hline $\mathrm{UO}_{3}$ & 0 & 6.5 & 0 & 6.3 \\
\hline $\mathrm{ZnO}$ & 0 & 4.0 & 0 & 4.0 \\
\hline $\mathrm{ZrO}_{2}$ & 0 & 9.6 & 0 & 9.1 \\
\hline Sum of Minors $^{(a)}$ & 0 & 5.19 & 0 & 4.29 \\
\hline
\end{tabular}

Table 2.5. WTP Model Validity Constraints for Predicted PCT Normalized Releases

\begin{tabular}{|c|c|}
\hline Component(s) & Upper limit, g/L \\
\hline PCT $r_{\mathrm{B}}$ & 6.61 \\
\hline $\mathrm{PCT} r_{\mathrm{Li}}$ & 4.27 \\
\hline $\mathrm{PCT} r_{\mathrm{Na}}$ & 5.53 \\
\hline
\end{tabular}


Table 2.6. HTWOS Constraints

\begin{tabular}{|c|c|c|c|c|c|}
\hline \multirow[b]{2}{*}{ Constraint } & \multirow[b]{2}{*}{ Constraint Description } & \multicolumn{2}{|c|}{ Baseline } & \multicolumn{2}{|c|}{ Revised } \\
\hline & & $\begin{array}{c}\text { Lower } \\
\text { limit }\end{array}$ & $\begin{array}{c}\text { Upper } \\
\text { limit }\end{array}$ & $\begin{array}{c}\text { Lower } \\
\text { limit }\end{array}$ & $\begin{array}{c}\text { Upper } \\
\text { limit }\end{array}$ \\
\hline \multirow{4}{*}{$\begin{array}{l}\text { Property } \\
\text { Constraints }\end{array}$} & Viscosity at $1150^{\circ} \mathrm{C}, \eta_{1150}(\mathrm{~Pa} \cdot \mathrm{s})$ & 4 & 6 & & \\
\hline & Temperature at 1 vol $\%$ spinel crystal, $T_{1 \%}\left({ }^{\circ} \mathrm{C}\right)$ & & 950 & & \\
\hline & Liquidus temperature of $\mathrm{Zr}$-phase, $T_{L}$-Zrs $\left({ }^{\circ} \mathrm{C}\right)$ & & 1050 & & \\
\hline & $\begin{array}{l}\text { Nepheline rule, } N_{\mathrm{Si}}=g_{\mathrm{SiO} 2} /\left(g_{\mathrm{Al} 2 \mathrm{O} 3}+g_{\mathrm{Na} 2 \mathrm{O}}+g_{\mathrm{SiO} 2}\right) \text { or } \\
\text { Nepheline rule, OB }\end{array}$ & 0.62 & & & $0.575^{(\mathrm{a})}$ \\
\hline \multirow{5}{*}{$\begin{array}{l}\text { Solubility } \\
\text { Constraints }\end{array}$} & $\mathrm{Cr}_{2} \mathrm{O}_{3}$ concentration in glass, $g_{\mathrm{Cr} 2 \mathrm{O} 3}(\mathrm{wt} \%)$ & & 1.2 & & \\
\hline & $\mathrm{SO}_{3}$ concentration in glass, $g_{\mathrm{SO} 3}(\mathrm{wt} \%)$ & & 0.5 & & 0.6 \\
\hline & Noble metal oxides in glass, $g_{\mathrm{PdO}}+g_{\mathrm{Rh} 2 \mathrm{O} 3}+g_{\mathrm{RuO} 2}(\mathrm{wt} \%)$ & & 0.25 & & \\
\hline & F concentration in glass, $g_{\mathrm{F}}(\mathrm{wt} \%)$ & & 2 & & \\
\hline & $\begin{array}{l}\text { Phosphate phase rule, } g_{\mathrm{P} 205}(\mathrm{wt} \%) \\
\text { Phosphate phase rule, } g_{\mathrm{P} 205} \times g_{\mathrm{CaO}}\left(\mathrm{wt} \%^{2}\right) \\
\text { Phosphate phase rule, } g_{\mathrm{L} \text { L2O }}(\mathrm{wt} \%)\end{array}$ & & $\begin{array}{l}2.5 \\
6.5 \\
6.0\end{array}$ & & 4.5 \\
\hline \multirow{20}{*}{$\begin{array}{l}\text { Model } \\
\text { Validity } \\
\text { Constraints }\end{array}$} & $\mathrm{Al}_{2} \mathrm{O}_{3}$ & 1.9 & 20.0 & & \\
\hline & $\mathrm{B}_{2} \mathrm{O}_{3}$ & 4.0 & 20.0 & & \\
\hline & $\mathrm{BaO}$ & & 4.7 & & \\
\hline & $\mathrm{Bi}_{2} \mathrm{O}_{3}$ & & 3.2 & & 7 \\
\hline & $\mathrm{CaO}$ & & 7.0 & & \\
\hline & $\mathrm{CdO}$ & & 1.5 & & \\
\hline & $\mathrm{Fe}_{2} \mathrm{O}_{3}$ & 4.0 & 17.4 & & \\
\hline & $\mathrm{K}_{2} \mathrm{O}$ & & 6.0 & & \\
\hline & $\mathrm{MgO}$ & & 6.0 & & \\
\hline & $\mathrm{MnO}$ & & 7.0 & & \\
\hline & $\mathrm{Na}_{2} \mathrm{O}$ & 4.1 & 21.4 & & \\
\hline & $\mathrm{Nd}_{2} \mathrm{O}_{3}$ & & 5.9 & & \\
\hline & $\mathrm{NiO}$ & & 3.0 & & \\
\hline & $\mathrm{SiO}_{2}$ & 30.3 & 53.0 & & \\
\hline & $\mathrm{SrO}$ & & 10.1 & & \\
\hline & $\mathrm{ThO}_{2}$ & & 6.0 & & \\
\hline & $\mathrm{TiO}_{2}$ & & 3.1 & & \\
\hline & $\mathrm{UO}_{3}$ & & 6.3 & & \\
\hline & $\mathrm{ZnO}$ & & 4.0 & & \\
\hline & $\mathrm{ZrO}_{2}$ & & 13.5 & & \\
\hline
\end{tabular}

The glass properties may strongly depend on the temperature history of the glass product. Slowly cooled glasses are more susceptible to amorphous phase separation or crystallization. Crystallization of the slowly cooled glass near the center of the canister, simulated by the canister centerline cooling (CCC) treatment, can result in a severe deterioration of glass chemical durability as determined by PCT, especially if nepheline $\left(\mathrm{NaAlSiO}_{4}\right)$ is formed (Kim et al. 1995; Li et al. 1997). It has been known that the 
formation of spinel crystals in many HLW glasses does not affect the PCT durability (Bickford and Jantzen 1984). To formulate glasses without nepheline precipitation, empirical rules based on nepheline discriminator $\left(N_{S i}\right)$ (Li et al. 2003) and optical basicity (OB) have been developed (see McCloy and Vienna 2010, for how to calculate OB from glass composition)

$$
\begin{gathered}
N_{S i}=\frac{g_{\mathrm{SiO}_{2}}}{g_{\mathrm{SiO}_{2}}+g_{\mathrm{Na}_{2} \mathrm{O}}+g_{\mathrm{Al}_{2} \mathrm{O}_{3}}} \geq 0.62 \\
\text { OB (Optical Basicity) } \leq 0.575
\end{gathered}
$$

where $g_{i}$ is the mass fraction of the $i^{\text {th }}$ oxide in glass. The WTP and Baseline HTWOS constraints use only the $N_{S i}$ rule as a nepheline rule (Table 2.3 and Table 2.6), whereas the revised HTWOS constraints specify that the nepheline rule is met when either the $N_{S i}$ or OB rule is satisfied (Table 2.6).

The processing constraints are used to make sure of adequate processability of glass in the melter, expressed in terms of either melt properties (viscosity and electrical conductivity, liquidus temperature, temperature at $1 \mathrm{vol} \%$ spinel) or component concentrations. The required ranges for melt properties differ for different melter types and operating strategies. The required ranges can also depend on the purpose of the constraints, e.g., for plant operation (WTP) or for glass mass estimation (HTWOS). The viscosity and electrical conductivity of the glass melt should be maintained within a certain range for acceptable processing (see Table 2.3). The permitted range for electrical conductivity of molten glass is wide and its requirement is met usually when the viscosity requirement is met and therefore often not used, especially when the narrow viscosity range is specified as in HTWOS constraints (Table 2.6).

An often limiting property of HLW glass is its liquidus temperature $\left(T_{L}\right)$, the highest temperature at which a crystalline phase can exist in the melt at equilibrium. The glass with a $T_{L}$ above a certain limit can precipitate the crystalline phase in the melter and may interfere with melter operation. To prevent a potential problem in the melter, the $T_{L}$ is historically constrained to be $100^{\circ} \mathrm{C}$ lower than the nominal melter processing temperature. The WTP has developed a constraint to limit the equilibrium volume percent of spinel crystal at $950^{\circ} \mathrm{C}$ to less than $1 \%$, i.e. $T_{1 \%} \leq 950{ }^{\circ} \mathrm{C}$ (Vienna and Kim 2008). HTWOS constraints use the $T_{1 \%} \leq 950{ }^{\circ} \mathrm{C}$ and $T_{L}$-Zrs $\leq 1050{ }^{\circ} \mathrm{C}$ where $T_{L}$-Zrs is the liquidus temperature of the zirconium-containing crystalline phases. The current WTP constraints use the $T_{1 \%} \leq 950{ }^{\circ} \mathrm{C}$ requirement but apply a set of non-spinel phase rules (Table 2.3) instead of the $T_{L}$-Zrs constraint. Table 2.4.

In addition, the single or multiple component constraints are used to limit the concentrations of the potential troublesome components and thereby reduce the risk of their deleterious effects on glass processing. For WTP, the $\mathrm{SO}_{3}$ concentration and a set of phosphate phase rules are applied (Table 2.3). Five sets of single or multiple component constraints are used for HTWOS, which are grouped as solubility constraints in Table 2.6. The constraints for both WTP and HTWOS also include constraints on concentration of individual components that are used to ensure that formulated glasses are within the composition region where the property models are valid (Table 2.4 and Table 2.6). The WTP constraints also apply the model validity upper bounds on predicted PCT normalized releases (see Table 2.5). 


\subsubsection{Waste Loading Estimates for 20 Waste Clusters}

Table 2.7 shows the composition of waste clusters (same composition as in Appendix A, Table A.2 that lists all 41 components, but Table 2.7 lists only the 15 components used in cluster analysis) and estimated maximum waste loadings along with the constraints that limit the waste loading and resulting glass mass. The maximum waste loading calculations were performed separately for WTP, HTWOS baseline, and HTWOS revised constraints. Table 2.7 also shows the composition of waste clusters in six different waste groups discussed below.

The model validity composition ranges were the only constraints that limited the loading for all clusters in WTP formulation. This resulted in relatively low overall waste loadings and therefore large glass mass. The model validity constraints are somewhat artificial and are not real limits driven by processing or product requirements. There are three primary reasons for WTP's model validity constraints to be so constrictive. First, the current WTP models were developed for the first four tanks that were planned to be vitrified during the initial WTP contract, which represent a very small fraction of entire Hanford HLWs. Second, the current WTP models were developed based on the waste composition estimates made in early 2000, but the composition estimates have evolved significantly. Third, the WTP contract is focused on design, construction, and commissioning of the plant not on overall process optimization, so, maximizing waste loading was never a formal driver. Expansion of the valid composition region is needed to allow the waste loadings to be limited by constraints driven by the actual process and quality requirements.

When the waste loading is limited by glass properties or nepheline constraints, not limited by model validity or solubility constraints, the calculations for glass optimization continue until other property requirements are met and maximize the waste loading, i.e., there are always multiple constraints that limit the waste loading as shown in Table 2.7 for HTWOS.

Based on waste cluster composition and the constraints that limit waste loading for HTWOS baseline and revised constraints, the waste clusters were further grouped into six different waste groups described as follows. Note that these groupings are somewhat arbitrary and are used to picture the overall waste compositions trend.

High- $\mathrm{Al}_{2} \mathbf{O}_{3}$. These clusters contain $41.8 \mathrm{wt} \% \mathrm{Al}_{2} \mathrm{O}_{3}$ or higher. The waste loading for these clusters is expected to be primarily limited by nepheline formation. At the same time, because of the strong effect of $\mathrm{Al}_{2} \mathrm{O}_{3}$ on increasing the $T_{1 \%}$ and $T_{L}$-Zrs, glass needs to be formulated to avoid the crystallization. For the glasses formulated based on HTWOS baseline constraints, all four waste clusters were limited by three constraints, $T_{L}$-Zrs, $N_{S i}$, and VisU (VisU: viscosity upper limit, see the footnotes to Table 2.7 for abbreviations used for constraints). It should be noted that the prediction of waste loading limited by the $T_{L}$-Zrs constraint is not realistic considering that the $\mathrm{ZrO}_{2}$ concentration in glass is very low (the highest was $1.8 \mathrm{wt} \% \mathrm{ZrO}_{2}$ for glasses formulated for Cluster 5, the rest less than $0.1 \mathrm{wt} \%$ ). For the revised HTWOS constraints, the waste loading becomes limited by the constraints involving OB instead of $N_{S i}$ and model validity for $\mathrm{Al}_{2} \mathrm{O}_{3}$. The primary factor for the increased waste loading going from baseline to revised constraint is the introduction of OB: for Clusters 5 and 8 the $N_{S i}$ changes to OB and for Clusters 7 and 16 the waste loading become limited by model validity.

High- $\mathrm{Fe}_{2} \mathrm{O}_{3}$. These clusters contain $30 \mathrm{wt} \% \mathrm{Fe}_{2} \mathrm{O}_{3}$ or higher and are similar to the $\mathrm{AZ}-101$ composition given in Table 2.2, which was used for initial glass formulation for CCIM. The waste 
loading is primarily limited by $T_{1 \%}$. Table 2.7 shows that all three high- $\mathrm{Fe}_{2} \mathrm{O}_{3}$ clusters were limited by $T_{1 \%}, N_{S i}$, and VisL (VisL: viscosity lower limit). A brief waste loading sensitivity study for these wastes showed that dramatic increase of waste loading results when the $T_{1 \%}$ constraint is relaxed (i.e. $T_{1 \%}$ is allowed to increase over the current limit of $950^{\circ} \mathrm{C}$ ) whereas there is little change in waste loading when the other two constraints are relaxed.

Spinel-limited. These waste clusters do not have high aluminum or iron and are not limited by salt formation. They typically contain relatively high or moderate concentrations of "spinel components" $\left(\mathrm{Fe}_{2} \mathrm{O}_{3}, \mathrm{Cr}_{2} \mathrm{O}_{3}, \mathrm{NiO}\right.$, and $\left.\mathrm{MnO}\right)$ that participate in the spinel structure and have therefore strong impact on $T_{1 \%}$. The waste loading is primarily limited by spinel $T_{1 \%}$ and like high- $\mathrm{Fe}_{2} \mathrm{O}_{3}$ clusters. Relaxing the $T_{1 \%}$ constraint would increase the waste loading significantly. Table 2.7 shows that all four clusters were limited by $T_{1 \%}, N_{S i}$, and VisL similar to high- $\mathrm{Fe}_{2} \mathrm{O}_{3}$ clusters.

$\mathrm{Cr}_{2} \mathrm{O}_{3}-\mathrm{SO}_{3}$ limited. The two clusters (Clusters 12 and 14) contain highest $\mathrm{Cr}_{2} \mathrm{O}_{3}$ concentration at $7.7 \mathrm{wt} \%$ and $7.4 \mathrm{wt} \%$. These two clusters also contain high $\mathrm{SO}_{3}$ (one with highest $\mathrm{SO}_{3}$ and the other with third highest among all clusters). The two other clusters (Clusters 6 and 11) do not have highest $\mathrm{Cr}_{2} \mathrm{O}_{3}$ or highest $\mathrm{SO}_{3}$ but contain relatively high concentrations of both $\mathrm{Cr}_{2} \mathrm{O}_{3}$ and $\mathrm{SO}_{3}$. Within this group, two clusters are limited by $\mathrm{Cr}_{2} \mathrm{O}_{3}$ and two limited by $\mathrm{SO}_{3}$ based on baseline HTWOS constraints while three clusters are limited by $\mathrm{Cr}_{2} \mathrm{O}_{3}$ and one limited by $\mathrm{SO}_{3}$ based on revised HTWOS constraints. Both $\mathrm{Cr}_{2} \mathrm{O}_{3}$ and $\mathrm{SO}_{3}$ limits are related to salt formation, and formation of salt by either $\mathrm{Cr}_{2} \mathrm{O}_{3}$ or $\mathrm{SO}_{3}$ is strongly affected by each other, which is why they are grouped together.

$\mathrm{P}_{2} \mathrm{O}_{5}-\mathrm{CaO}$ limited. These clusters are characterized by the limiting constraints involving $\mathrm{P}_{2} \mathrm{O}_{5}$ with the combination of relatively high concentration of $\mathrm{CaO}$. The limiting mechanism is not well defined for this waste group, suspected to be limited either by salt formation or by crystallization of calcium phosphate phases in the cold-cap, forming a "killer-scum." More studies are needed to clearly identify the limiting mechanism for these waste clusters.

High- $\mathrm{Na}_{2} \mathrm{O}$. Only a very small fraction of wastes represents this waste cluster with $\mathrm{Na}_{2} \mathrm{O}$ at $54 \mathrm{wt} \%$. The waste loading is limited by the model validity of $\mathrm{Na}_{2} \mathrm{O}$ in glass but it would become ultimately limited by chemical durability.

In summary, the high- $\mathrm{Al}_{2} \mathrm{O}_{3}$ waste clusters are limited by nepheline and spinel crystallization, the high- $\mathrm{Fe}_{2} \mathrm{O}_{3}$ and spinel-limited clusters are limited by spinel crystallization, and the other $\mathrm{Cr}_{2} \mathrm{O}_{3}-\mathrm{SO}_{3}$ limited and $\mathrm{P}_{2} \mathrm{O}_{5}-\mathrm{CaO}$ limited clusters are primarily limited by salt formation or potentially by the formation of crystals other than spinel. For the present waste projections discussed above, it is not likely that the waste loading is limited by the crystallization of zirconium-containing phases.

The overall picture can be somewhat different if glass formulation is performed for each waste batch as in Belsher and Meinert (2009). The estimation of waste loading and glass volume based on the cluster analyses provides a very rough approximation. For more rigorous glass volume estimations and sensitivity studies, waste loading calculations for each batch should be performed like in Belsher and Meinert (2009) and Vienna and Kim (2008). 
Table 2.7. Composition of Waste Clusters and Estimated Maximum Waste Loading

\begin{tabular}{|c|c|c|c|c|c|c|c|c|c|c|c|}
\hline Cluster \# & 5 & 7 & 8 & 16 & 1 & 10 & 18 & 3 & 4 & 19 & 20 \\
\hline Group & \multicolumn{4}{|c|}{ High- $\mathrm{Al}_{2} \mathrm{O}_{3}$} & \multicolumn{3}{|c|}{ High- $\mathrm{Fe}_{2} \mathrm{O}_{3}$} & \multicolumn{4}{|c|}{ Spinel limited } \\
\hline $\mathrm{Al}_{2} \mathrm{O}_{3}$ & 47.06 & 44.94 & 41.75 & 57.34 & 13.96 & 18.94 & 20.12 & 13.73 & 37.32 & 28.51 & 23.41 \\
\hline $\mathrm{Bi}_{2} \mathrm{O}_{3}$ & 1.86 & 5.56 & 1.85 & 1.45 & 0.67 & 1.71 & 0.34 & 2.47 & 0.98 & 0.86 & 4.99 \\
\hline $\mathrm{CaO}$ & 1.56 & 2.44 & 2.47 & 0.87 & 2.47 & 2.42 & 2.22 & 3.88 & 2.62 & 4.02 & 3.96 \\
\hline $\mathrm{CdO}$ & 0.02 & 0.00 & 0.02 & 0.00 & 0.09 & 0.08 & 3.23 & 0.47 & 0.52 & 0.23 & 0.03 \\
\hline $\mathrm{Cr}_{2} \mathrm{O}_{3}$ & 2.28 & 1.85 & 2.00 & 2.03 & 0.82 & 0.67 & 0.62 & 1.24 & 1.31 & 1.18 & 1.85 \\
\hline $\mathrm{F}$ & 1.42 & 0.53 & 1.09 & 0.26 & 0.15 & 0.45 & 0.12 & 0.16 & 0.13 & 0.17 & 2.26 \\
\hline $\mathrm{Fe}_{2} \mathrm{O}_{3}$ & 5.83 & 10.89 & 10.74 & 5.49 & 33.55 & 29.96 & 34.88 & 18.84 & 14.75 & 17.02 & 14.35 \\
\hline $\mathrm{MnO}$ & 1.19 & 0.95 & 1.83 & 1.38 & 4.80 & 2.17 & 1.24 & 2.89 & 0.97 & 1.32 & 1.35 \\
\hline $\mathrm{Na}_{2} \mathrm{O}$ & 14.84 & 12.83 & 11.86 & 16.27 & 20.61 & 13.39 & 9.57 & 12.68 & 12.14 & 20.22 & 15.08 \\
\hline $\mathrm{NiO}$ & 1.29 & 0.69 & 0.64 & 0.36 & 1.67 & 2.04 & 2.74 & 4.18 & 2.47 & 1.93 & 1.54 \\
\hline $\mathrm{P}_{2} \mathrm{O}_{5}$ & 4.53 & 3.58 & 2.16 & 1.40 & 1.74 & 1.66 & 0.97 & 4.28 & 1.16 & 1.30 & 3.30 \\
\hline $\mathrm{SO}_{3}$ & 1.22 & 0.86 & 0.86 & 0.50 & 0.44 & 0.44 & 0.18 & 0.67 & 0.27 & 0.26 & 0.98 \\
\hline $\mathrm{ThO}_{2}$ & 0.06 & 0.03 & 0.26 & 0.05 & 1.60 & 1.98 & 1.71 & 5.06 & 3.06 & 2.37 & 0.29 \\
\hline $\mathrm{UO}_{3}$ & 5.34 & 5.32 & 7.88 & 3.90 & 3.28 & 7.61 & 7.49 & 9.49 & 5.72 & 4.92 & 9.29 \\
\hline $\mathrm{ZrO}_{2}$ & 5.29 & 0.19 & 0.21 & 0.18 & 3.30 & 4.41 & 6.60 & 11.15 & 3.34 & 2.97 & 0.28 \\
\hline SUM & 93.77 & 90.66 & 85.63 & 91.47 & 89.13 & 87.92 & 92.01 & 91.19 & 86.76 & 87.28 & 82.95 \\
\hline \multirow{2}{*}{$\begin{array}{c}\text { Oxide } \\
\text { mass (MT) }\end{array}$} & 719 & 1,840 & 1,183 & 1,454 & 405 & 734 & 124 & 266 & 221 & 249 & 1,351 \\
\hline & \multicolumn{4}{|c|}{5,196} & \multicolumn{3}{|c|}{1,263} & \multicolumn{4}{|c|}{2,087} \\
\hline \multicolumn{12}{|c|}{ Estimated maximum WL and glass mass based on WTP constraints } \\
\hline Max WL & 26.34 & 28.93 & 30.02 & 22.67 & 40.55 & 41.37 & 36.54 & 23.90 & 22.77 & 24.90 & 19.45 \\
\hline Limited by & $\begin{array}{c}\mathrm{MV} \\
\left(\mathrm{Cr}_{2} \mathrm{O}_{3}\right)\end{array}$ & $\begin{array}{c}\mathrm{MV} \\
\left(\mathrm{Al}_{2} \mathrm{O}_{3}\right)\end{array}$ & $\begin{array}{c}\mathrm{MV} \\
\left(\mathrm{Cr}_{2} \mathrm{O}_{3}\right)\end{array}$ & $\begin{array}{c}\mathrm{MV} \\
\left(\mathrm{Al}_{2} \mathrm{O}_{3}\right)\end{array}$ & $\begin{array}{c}\mathrm{MV} \\
(\mathrm{CaO}) \\
\end{array}$ & $\begin{array}{c}\mathrm{MV} \\
(\mathrm{CaO}) \\
\end{array}$ & $\begin{array}{c}\mathrm{MV} \\
(\mathrm{NiO}) \\
\end{array}$ & $\begin{array}{c}\mathrm{MV} \\
(\mathrm{NiO})\end{array}$ & $\begin{array}{c}\mathrm{MV} \\
\left(\mathrm{Al}_{2} \mathrm{O}_{3}\right)\end{array}$ & $\begin{array}{c}\mathrm{MV} \\
(\mathrm{CaO}) \\
\end{array}$ & $\begin{array}{l}\text { MV } \\
\text { (F) }\end{array}$ \\
\hline \multirow{2}{*}{$\begin{array}{l}\text { Glass mass } \\
\text { (MT) }\end{array}$} & 2,730 & 6,359 & 3,941 & 6,412 & 999 & 1,774 & 339 & 1,114 & 970 & 1,001 & 6,945 \\
\hline & \multicolumn{4}{|c|}{19,442} & \multicolumn{3}{|c|}{3,112} & \multicolumn{4}{|c|}{10,030} \\
\hline \multicolumn{12}{|c|}{ Estimated maximum WL and glass mass based on HTWOS baseline constraints } \\
\hline Max WL & 33.69 & 37.86 & 40.36 & 30.82 & 43.70 & 42.20 & 38.25 & 42.81 & 40.99 & 45.94 & 50.42 \\
\hline Limited by & $\begin{array}{c}T_{L} \text {-Zrs, } \\
N_{S i}, \\
\text { VisU }\end{array}$ & $\begin{array}{c}T_{L} \text {-Zrs, } \\
N_{S i} \\
\text { VisU }\end{array}$ & $\begin{array}{c}T_{L} \text {-Zrs, } \\
N_{S i}, \\
\text { VisU }\end{array}$ & $\begin{array}{c}T_{L}-\mathrm{Zrs}, \\
N_{S i}, \\
\mathrm{VisU}\end{array}$ & $\begin{array}{c}T_{l \%}, \\
N_{S i}, \\
\text { VisL }\end{array}$ & $\begin{array}{c}T_{l \%}, \\
N_{S i}, \\
\text { VisL }\end{array}$ & $\begin{array}{c}T_{l^{\circ},}, \\
N_{S i}, \\
\text { VisL }\end{array}$ & $\begin{array}{c}T_{l^{\circ},}, \\
N_{S i}, \\
\text { VisL }\end{array}$ & $\begin{array}{c}T_{1 \%}, \\
T_{L} \text {-Zrs, } \\
N_{S i}, \\
\text { VisL } \\
\end{array}$ & $\begin{array}{c}T_{l \%}, \\
N_{S i}, \\
\text { VisL }\end{array}$ & $\begin{array}{c}T_{l^{\circ},}, \\
N_{S i}, \\
\text { VisL }\end{array}$ \\
\hline \multirow{2}{*}{$\begin{array}{l}\text { Glass mass } \\
\text { (MT) }\end{array}$} & 2,134 & 4,859 & 2,932 & 4,717 & 927 & 1,739 & 324 & 622 & 539 & 542 & 2,679 \\
\hline & \multicolumn{4}{|c|}{14,642} & \multicolumn{3}{|c|}{2,990} & \multicolumn{4}{|c|}{4,382} \\
\hline \multicolumn{12}{|c|}{ Estimated maximum WL and glass mass based on HTWOS revised constraints } \\
\hline Max WL & 41.33 & 44.50 & 47.19 & 34.88 & \multirow[b]{2}{*}{$\begin{array}{l}\text { No } \\
\text { change }\end{array}$} & 42.27 & 38.29 & \multirow[b]{2}{*}{$\begin{array}{l}\text { No } \\
\text { change }\end{array}$} & 43.86 & 47.76 & 52.15 \\
\hline Limited by & $\begin{array}{l}T_{L}-\mathrm{Zrs}, \\
\mathrm{OB}, \\
\text { VisU }\end{array}$ & $\begin{array}{c}\mathrm{MV} \\
\left(\mathrm{Al}_{2} \mathrm{O}_{3}\right)\end{array}$ & $\begin{array}{l}T_{1 \%}, \\
\text { OB, } \\
\text { VisL }\end{array}$ & $\begin{array}{c}\mathrm{MV} \\
\left(\mathrm{Al}_{2} \mathrm{O}_{3}\right)\end{array}$ & & $\begin{array}{l}T_{1 \%,} \\
\mathrm{OB}, \\
\text { VisL }\end{array}$ & $\begin{array}{l}T_{1 \%}, \\
\text { OB, } \\
\text { VisL }\end{array}$ & & $\begin{array}{l}T_{1 \%}, \\
\text { OB, } \\
\text { VisL }\end{array}$ & $\begin{array}{c}T_{L} \text {-Zrs, } \\
\text { OB, } \\
\text { VisL }\end{array}$ & $\begin{array}{l}T_{1 \%}, \\
\text { OB, } \\
\text { VisL }\end{array}$ \\
\hline \multirow{2}{*}{$\begin{array}{l}\text { Glass mass } \\
\text { (MT) }\end{array}$} & 1,740 & 4,134 & 2,507 & 4,168 & 927 & & 324 & 622 & 504 & 522 & 2,589 \\
\hline & \multicolumn{4}{|c|}{12,548} & \multicolumn{3}{|c|}{2,987} & \multicolumn{4}{|c|}{4,237} \\
\hline
\end{tabular}


Table 2.7. (Continued)

\begin{tabular}{|c|c|c|c|c|c|c|c|c|c|c|}
\hline Cluster \# & 12 & 14 & 6 & 11 & 2 & 13 & 15 & 17 & \multirow{2}{*}{$\begin{array}{c}9 \\
\text { High-Na }\end{array}$} & \multirow[b]{2}{*}{ Total } \\
\hline Group & \multicolumn{4}{|c|}{$\mathrm{Cr}_{2} \mathrm{O}_{3}-\mathrm{SO}_{3}$ limited } & \multicolumn{4}{|c|}{$\mathrm{P}_{2} \mathrm{O}_{5}-\mathrm{CaO}$ limited } & & \\
\hline $\mathrm{Al}_{2} \mathrm{O}_{3}$ & 16.40 & 32.32 & 27.92 & 28.37 & 20.47 & 22.68 & 13.05 & 18.40 & 9.35 & - \\
\hline $\mathrm{Bi}_{2} \mathrm{O}_{3}$ & 3.41 & 1.77 & 3.81 & 5.73 & 7.26 & 2.47 & 5.77 & 1.23 & 1.31 & - \\
\hline $\mathrm{CaO}$ & 3.01 & 2.17 & 2.00 & 2.49 & 5.63 & 2.49 & 5.36 & 8.91 & 2.58 & - \\
\hline $\mathrm{CdO}$ & 0.02 & 0.08 & 0.06 & 0.03 & 0.05 & 0.05 & 0.02 & 0.36 & 0.04 & - \\
\hline $\mathrm{Cr}_{2} \mathrm{O}_{3}$ & 7.71 & 7.42 & 2.95 & 2.22 & 1.38 & 2.91 & 0.38 & 1.46 & 2.74 & - \\
\hline $\mathrm{F}$ & 5.01 & 0.44 & 0.55 & 6.08 & 2.83 & 2.29 & 1.23 & 0.26 & 0.70 & - \\
\hline $\mathrm{Fe}_{2} \mathrm{O}_{3}$ & 12.25 & 8.52 & 14.86 & 9.57 & 11.41 & 10.15 & 23.62 & 13.86 & 6.70 & - \\
\hline $\mathrm{MnO}$ & 1.23 & 2.04 & 3.04 & 0.53 & 0.58 & 0.88 & 2.42 & 1.62 & 0.59 & - \\
\hline $\mathrm{Na}_{2} \mathrm{O}$ & 14.27 & 19.37 & 16.83 & 12.36 & 24.81 & 22.81 & 12.86 & 37.18 & 54.16 & - \\
\hline $\mathrm{NiO}$ & 3.14 & 0.39 & 3.08 & 0.78 & 0.78 & 1.55 & 3.08 & 0.57 & 0.49 & - \\
\hline $\mathrm{P}_{2} \mathrm{O}_{5}$ & 11.14 & 11.18 & 4.36 & 4.43 & 6.75 & 11.67 & 5.60 & 3.17 & 2.44 & - \\
\hline $\mathrm{SO}_{3}$ & 2.20 & 1.99 & 1.41 & 2.14 & 0.91 & 1.10 & 0.15 & 0.45 & 0.35 & - \\
\hline $\mathrm{ThO}_{2}$ & 0.38 & 0.03 & 0.81 & 0.22 & 0.38 & 0.44 & 0.29 & 0.14 & 0.63 & - \\
\hline $\mathrm{UO}_{3}$ & 7.31 & 3.59 & 5.50 & 3.47 & 3.93 & 8.05 & 5.02 & 2.57 & 3.52 & - \\
\hline $\mathrm{ZrO}_{2}$ & 1.30 & 1.37 & 2.83 & 0.63 & 0.34 & 0.61 & 2.40 & 1.39 & 0.52 & - \\
\hline SUM & 88.79 & 92.67 & 90.02 & 79.05 & 87.50 & 90.15 & 81.26 & 91.58 & 86.13 & - \\
\hline \multirow{2}{*}{$\begin{array}{l}\text { Oxide mass } \\
\text { (MT) }\end{array}$} & 275 & 173 & 364 & 533 & 339 & 209 & 327 & 165 & 144 & 11,075 \\
\hline & \multicolumn{4}{|c|}{1,346} & \multicolumn{4}{|c|}{1,040} & 144 & 11,075 \\
\hline \multicolumn{11}{|c|}{ Estimated maximum WL and glass mass based on WTP constraints } \\
\hline Max WL & 7.78 & 8.09 & 20.34 & 7.23 & 15.55 & 19.21 & 18.67 & 11.22 & 21.88 & - \\
\hline Limited by & $\begin{array}{c}\mathrm{MV} \\
\left(\mathrm{Cr}_{2} \mathrm{O}_{3}\right)\end{array}$ & $\begin{array}{c}\mathrm{MV} \\
\left(\mathrm{Cr}_{2} \mathrm{O}_{3}\right)\end{array}$ & $\begin{array}{c}\mathrm{MV} \\
\left(\mathrm{Cr}_{2} \mathrm{O}_{3}\right)\end{array}$ & $\begin{array}{l}\text { MV } \\
(\mathrm{F})\end{array}$ & $\begin{array}{l}\text { MV } \\
(\mathrm{F})\end{array}$ & $\begin{array}{l}\text { MV } \\
(\mathrm{F})\end{array}$ & $\begin{array}{c}\mathrm{MV} \\
(\mathrm{CaO})\end{array}$ & $\begin{array}{c}\mathrm{MV} \\
(\mathrm{CaO}) \\
\end{array}$ & $\begin{array}{c}\mathrm{MV} \\
\left(\mathrm{Cr}_{2} \mathrm{O}_{3}\right)\end{array}$ & - \\
\hline \multirow{2}{*}{$\begin{array}{l}\text { Glass mass } \\
\text { (MT) }\end{array}$} & 3,538 & 2,143 & 1,790 & 7,369 & 2,179 & 1,090 & 1,752 & 1,468 & 657 & 54,572 \\
\hline & \multicolumn{4}{|c|}{14,840} & \multicolumn{4}{|c|}{6,489} & 657 & 54,572 \\
\hline \multicolumn{11}{|c|}{ Estimated maximum WL and glass mass based on HTWOS baseline constraints } \\
\hline Max WL & 15.56 & 16.17 & 35.44 & 23.31 & 37.02 & 21.41 & 44.61 & 47.99 & 39.51 & - \\
\hline Limited by & $\begin{array}{c}\mathrm{Sol} \\
\left(\mathrm{Cr}_{2} \mathrm{O}_{3}\right)\end{array}$ & $\begin{array}{c}\text { Sol } \\
\left(\mathrm{Cr}_{2} \mathrm{O}_{3}\right)\end{array}$ & $\begin{array}{c}\mathrm{Sol} \\
\left(\mathrm{SO}_{3}\right)\end{array}$ & $\begin{array}{c}\mathrm{Sol} \\
\left(\mathrm{SO}_{3}\right)\end{array}$ & $\begin{array}{c}\mathrm{Sol} \\
\left(\mathrm{P}_{2} \mathrm{O}_{5}\right)\end{array}$ & $\begin{array}{c}\mathrm{Sol} \\
\left(\mathrm{P}_{2} \mathrm{O}_{5}\right)\end{array}$ & $\begin{array}{c}\text { Sol } \\
\left(\mathrm{P}_{2} \mathrm{O}_{5}\right)\end{array}$ & $\begin{array}{c}\mathrm{Sol} \\
\left(\mathrm{CaO}^{*}\right. \\
\left.\mathrm{P}_{2} \mathrm{O}_{5}\right)\end{array}$ & $\begin{array}{c}\mathrm{MV} \\
\left(\mathrm{Na}_{2} \mathrm{O}\right)\end{array}$ & - \\
\hline \multirow{2}{*}{$\begin{array}{l}\text { Glass mass } \\
\text { (MT) }\end{array}$} & 1,769 & 1,072 & 1,028 & 2,286 & 916 & 978 & 734 & 343 & 364 & 31,503 \\
\hline & \multicolumn{4}{|c|}{6,154} & \multicolumn{4}{|c|}{2,970} & 364 & 31,503 \\
\hline \multicolumn{11}{|c|}{ Estimated maximum WL and glass mass based on HTWOS revised constraints } \\
\hline Max WL & \multirow[b]{2}{*}{$\begin{array}{c}\text { No } \\
\text { change }\end{array}$} & \multirow[b]{2}{*}{$\begin{array}{c}\text { No } \\
\text { change }\end{array}$} & 40.68 & 27.98 & 41.36 & 38.54 & 46.53 & & & - \\
\hline Limited by & & & $\begin{array}{c}\mathrm{Sol} \\
\left(\mathrm{Cr}_{2} \mathrm{O}_{3}\right)\end{array}$ & $\begin{array}{c}\mathrm{Sol} \\
\left(\mathrm{SO}_{3}\right)\end{array}$ & $\begin{array}{c}\mathrm{Sol} \\
\left(\mathrm{CaO}^{*}\right. \\
\left.\mathrm{P}_{2} \mathrm{O}_{5}\right)\end{array}$ & $\begin{array}{c}\mathrm{Sol} \\
\left(\mathrm{P}_{2} \mathrm{O}_{5}\right)\end{array}$ & $\begin{array}{c}\mathrm{Sol} \\
(\mathrm{CaO} * \\
\left.\mathrm{P}_{2} \mathrm{O}_{5}\right)\end{array}$ & $\begin{array}{l}\text { No } \\
\text { change }\end{array}$ & $\begin{array}{c}\text { No } \\
\text { change }\end{array}$ & - \\
\hline \multirow{2}{*}{$\begin{array}{l}\text { Glass mass } \\
\text { (MT) }\end{array}$} & 1,769 & 1,072 & 895 & 1,905 & 819 & 543 & 703 & 343 & 364 & 28,186 \\
\hline & \multicolumn{4}{|c|}{5,641} & \multicolumn{4}{|c|}{2,409} & 364 & 28,186 \\
\hline \multicolumn{11}{|c|}{$\begin{array}{l}\text { “_“ empty cell } \\
\text { Max WL: maximum waste loading given in wt } \% \\
\text { MV(“comp”) or Sol(“comp”): model validity or solubility constraint for a given component } \\
T_{L} \text {-Zrs: liquidus temperature for zirconium-containing phase; } T_{1 \%}: \text { temperature at } 1 \mathrm{vol} \% \text { spinel; } N_{S i}: \text { nepheline discriminator; } \\
\text { OB: optical basicity; VisL: viscosity lower limit; VisU: viscosity upper limit } \\
\text { No change: no change from the baseline constraints }\end{array}$} \\
\hline
\end{tabular}


Figure 2.7 shows a pie chart of the relative fraction of each waste group for the projected waste oxide mass, projected glass masses based on WTP, HTWOS baseline, and HTWOS revised constraints. The total mass of oxides and glass masses are also included in Figure 2.7.
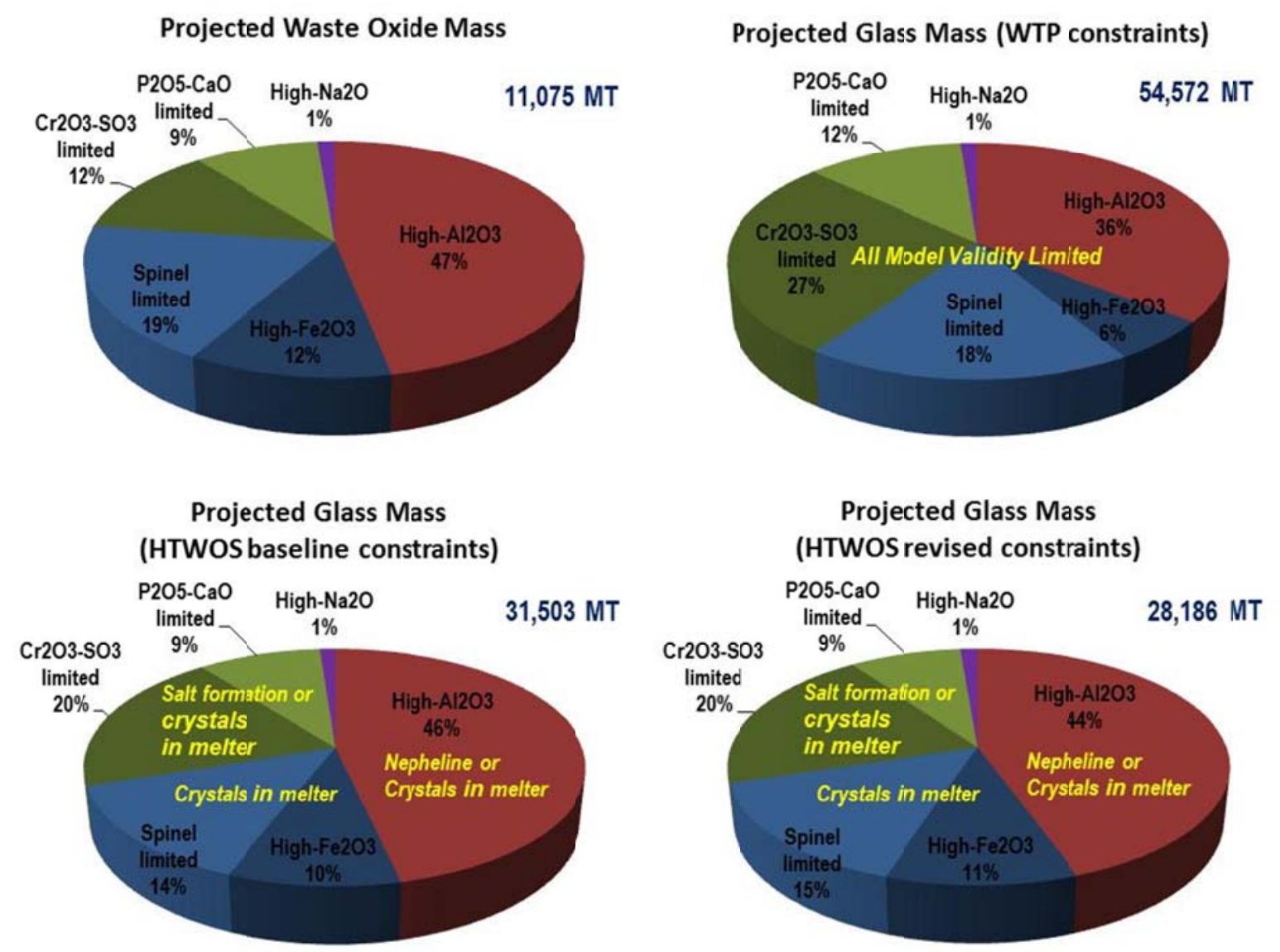

Figure 2.7. Projected Mass of Waste Oxides and Glass Based on Estimated Maximum Waste Loading based on Different Constraints 



\subsection{Experimental Procedures}

\subsection{Glass Fabrication}

Glasses for property measurements were prepared in platinum-alloy crucibles with a lid following a two-step melting process while a quick meltability evaluation for some glasses was obtained from the first melt only. The first melt was of raw materials after mechanically mixing them in an agate milling chamber. Melting was performed nominally for 1 or 2 hours at a recommended melting temperature that was estimated based on model predicted viscosity (recommended melting temperature is given for all glasses formulated in this study in Sections 4.0 and 5.0). A second melt of the glass was performed after the quenched glass was ground to a fine powder in a tungsten carbide mill. Generally, the temperature of second melt was adjusted, based on the fluidity of the melt estimated during pouring of the first melt.

\subsection{Canister Centerline Cooling Treatment}

Selected glass melts were cooled according to the CCC profile for WTP HLW or LAW glasses as given in Table 3.1 and Table 3.2, respectively. This cooling is intended to simulate the center line temperature/time profile of melts prepared at $1150^{\circ} \mathrm{C}$. For HLW glasses with recommended melting temperature between $1200^{\circ} \mathrm{C}$ and $1300^{\circ} \mathrm{C}$, the melt was brought to $1150^{\circ} \mathrm{C}$, cooled to $1050^{\circ} \mathrm{C}$ at $-2^{\circ} \mathrm{C} / \mathrm{min}$, and then cooled following the profile given in Table 3.1. No adjustment was made to the CCC profile for LAW glasses as it starts at a relatively high temperature of $1114^{\circ} \mathrm{C}$.

Table 3.1. CCC Profile for HLW Glasses

\begin{tabular}{|c|c|c|c|}
\hline Segment & Time (min) & Start Temp $\left({ }^{\circ} \mathbf{C}\right)$ & Rate $\left({ }^{\circ} \mathbf{C} / \mathbf{m i n}\right)$ \\
\hline 1 & $0-45$ & 1050 & -1.556 \\
\hline 2 & $45-107$ & 980 & -0.806 \\
\hline 3 & $107-200$ & 930 & -0.591 \\
\hline 4 & $200-329$ & 875 & -0.388 \\
\hline 5 & $329-527$ & 825 & -0.253 \\
\hline 6 & $527-707$ & 775 & -0.278 \\
\hline 7 & $707-1776$ & 725 & -0.304 \\
\hline
\end{tabular}

Table 3.2. CCC Profile for LAW Glasses

\begin{tabular}{|c|c|c|c|}
\hline Segment & Time (min) & Start Temp $\left({ }^{\circ} \mathbf{C}\right)$ & Rate $\left({ }^{\circ} \mathbf{C} / \mathbf{m i n}\right)$ \\
\hline 1 & $0-16$ & 1114 & -7.125 \\
\hline 2 & $16-73$ & 1000 & -1.754 \\
\hline 3 & $73-195$ & 900 & -0.615 \\
\hline 4 & $195-355$ & 825 & -0.312 \\
\hline 5 & $355-640$ & 775 & -0.175 \\
\hline 6 & $640-1600$ & 725 & -0.130 \\
\hline 7 & $1600-3710$ & 600 & -0.095 \\
\hline
\end{tabular}




\subsection{Characterization of Glasses}

\subsubsection{Composition Analyses}

To confirm that the "as-fabricated" glasses correspond to the defined target compositions, a representative sample of each glass was chemically analyzed at the SRNL Process Science Analytical Laboratory (PSAL). Two preparation methods were used in measuring these chemical compositions: lithium metaborate fusion followed by $\mathrm{HNO}_{3}$ dissolution or $\mathrm{HNO}_{3}$ dissolution. For each glass, measurements were obtained from samples prepared in duplicate. All of the prepared samples were analyzed (twice for each element of interest) by inductively coupled plasma-atomic emission spectroscopy (ICP-AES).

\subsubsection{Product Consistency Test}

PCT responses were measured in triplicate on each of the glasses, including quenched or CCC samples using Method A of the procedure (ASTM 2008). Also included in the experimental test matrix and tested in triplicate was the environmental assessment (Jantzen et al. 1993) glass, the Approved Reference Material (Mellinger and Daniel 1984) glass, and blanks from the sample cleaning batch. Glass samples were ground, washed, and prepared according to the standard PCT procedure. The resulting solutions were sampled (filtered and acidified) and analyzed. Normalized release rates were calculated based on target compositions using the average of the logs of the leachate concentrations.

The normalized elemental mass loss, $r_{i}$, is calculated from:

$$
r_{i}(\mathrm{~g} / \mathrm{L})=\frac{c_{i}}{f_{i}}
$$

where $c_{i}$ is the concentration of the $i^{\text {th }}$ element in the leachate $\left(\mathrm{g} / \mathrm{m}^{3}=\mathrm{ppm}=\mu \mathrm{g} / \mathrm{ml}=\mathrm{mg} / \mathrm{L}\right.$ assuming a solution density of $1 \mathrm{~g} / \mathrm{mL}$ ) and is the mass fraction of the $i^{\text {th }}$ element in glass (unitless), which is calculated from target glass composition.

\subsubsection{Toxicity Characteristic Leaching Procedure}

The TCLP was performed on quenched or CCC glass samples at Davis \& Floyd ${ }^{1}$ under an SRNL subcontract. The extraction and analyses were performed according to SW 846 Method 1311 (EPA 1997). Crushed glass pieces that passed through a $9.5-\mathrm{mm}$ (0.4-inch) sieve and $\geq 100 \mathrm{~g}$ in mass, are placed in dilute acetic acid ( $\mathrm{pH}$ value of $4.98 \pm 0.05)$ and agitated at $30 \pm 2 \mathrm{rpm}$ for $18 \pm 2$ hours at room temperature. The concentrations of hazardous metals in solution were then measured by ICP-AES.

\subsubsection{Vapor Hydration Test}

The standard vapor hydration test (VHT) method (ASTM 2011) was employed to assess the durability of LAW glass products. Specimens were cut from rectangular glass bars with a diamond saw

\footnotetext{
${ }^{1}$ Davis \& Floyd, Inc., 816 E. Durst Avenue, Greenwood, SC.
} 
and all sides were polished with 600 grit $\mathrm{SiC}$ paper. The specimens (approximately $10 \times 10 \times 1.5 \mathrm{~mm}^{3}$ ) were rinsed successively with acetone and deionized water, after which the dimensions and weight were measured to an accuracy of $\pm 0.002 \mathrm{~mm}$ and $\pm 0.01 \mathrm{mg}$, respectively. VHT specimens were suspended by a Teflon thread connected to a stainless steel support. The support along with the specimens was placed inside a Parr $22 \mathrm{ml} \mathrm{T304} \mathrm{stainless} \mathrm{steel} \mathrm{vessel} \mathrm{together} \mathrm{with} 0.25 \mathrm{ml}$ of deionized water. The sealed vessel containing the sample was heated at $200 \pm 2{ }^{\circ} \mathrm{C}$ in an automated temperature-controlled oven for a specified time. After removing the sample from the vessel, the sample was cross-sectioned and polished. The cross-section of each sample was examined and the thickness of the uncorroded part of the sample was measured with an accuracy of $\pm 0.002 \mathrm{~mm}$ by an optical microscope.

The VHT alteration rate, $r_{a l t}\left(\mathrm{~g} / \mathrm{m}^{2} / \mathrm{d}\right)$, of the specimen is calculated from the equation:

$$
r_{a l t}\left(\mathrm{~g} / \mathrm{m}^{2} / \mathrm{d}\right)=\frac{d_{i} \rho}{2 t}\left(1-\frac{d_{r}}{d_{i}}\right)=\frac{m_{i}}{2 w_{i} l_{i} t}\left(1-\frac{d_{r}}{d_{i}}\right)
$$

where $d_{i}, w_{i}$, and $l_{i}$ are the initial thickness, width, and length of the specimen, respectively, $d_{r}$ is the average thickness of the remaining glass, $m_{i}$ is the initial specimen mass, $t$ is the duration of test, and $\rho$ is the density of glass. The average density of $2.7 \mathrm{~g} / \mathrm{cc}$ was used for all LAW glasses used in this study.

\subsubsection{Viscosity}

The viscosity of glass was measured as a function of temperature following PNNL procedure GDL-VIS using a Brookfield rotating spindle digital viscometer (DV-III) staged above a high-temperature Deltech ${ }^{\circledR}$ furnace and equipped with a $\mathrm{Pt} / \mathrm{Rh}$ spindle which fit through a hole in the top of the furnace. A $50 \mathrm{~mL}$ glass sample, measured by liquid displacement, was added into a $\mathrm{Pt} / \mathrm{Rh}$ crucible and placed into the furnace set at $1150{ }^{\circ} \mathrm{C}$. The spindle was immersed into the molten glass in the center of the crucible with its lower end of the rod at $5.1 \mathrm{~mm}$ above the bottom. A thermocouple was located directly under the bottom center of the crucible. The furnace was set to the required ramp/soak schedule and digital data collection of spindle torque and temperature commenced. The temperature sequence was $1150^{\circ} \mathrm{C}, 1100^{\circ} \mathrm{C}, 1050^{\circ} \mathrm{C}, 1000^{\circ} \mathrm{C}, 950^{\circ} \mathrm{C}, 1050^{\circ} \mathrm{C}, 1150^{\circ} \mathrm{C}, 1200^{\circ} \mathrm{C}$, and then $1150^{\circ} \mathrm{C}$. The soak time was $30 \mathrm{~min}$. at each temperature, except the second soak at $1150^{\circ} \mathrm{C}$ was for $45 \mathrm{~min}$. The hysteresis approach allows for the potential impacts of crystallization (at lower temperatures) to be assessed (via reproducibility) with duplicate measurements being taken in the range at which the melter is anticipated to be operating. Volatilization (at higher temperatures) is minimized by measuring viscosity at temperatures above $1150^{\circ} \mathrm{C}$ as the final viscosity measurement. The viscometer was calibrated with a standard glass (DWPF start-up frit) at specified intervals following PNNL procedure GDL-VSC.

\subsubsection{Electrical Conductivity}

The electrical conductivities of molten glasses were measured as a function of temperature using a probe with two platinum- $10 \%$ rhodium blades according to the PNNL procedures GDL-ELC (for measurement) and GDL-ECC (for calibration). The $50 \mathrm{~mL}$ of glass used for viscosity measurements was added back into a platinum/rhodium crucible and placed into the furnace at $1100^{\circ} \mathrm{C}$. The probe was then lowered through a hole in the top of the furnace and into the melt, making sure that the probe was in the center of the crucible. Using the automated Solartron Analytical 1455 Cell Test System which was 
connected to the probe, the probe was lowered into the glass precisely $1.27 \mathrm{~cm}$. The glass soaked at temperatures of $1200^{\circ} \mathrm{C}, 1100^{\circ} \mathrm{C}, 1000^{\circ} \mathrm{C}$, and $900^{\circ} \mathrm{C}$ for 45 minutes at each temperature, allowing the program to collect impedance data at frequencies of $10000 \mathrm{~Hz}, 1000 \mathrm{~Hz}, 100 \mathrm{~Hz}$, and $63 \mathrm{~Hz} 5 \mathrm{~min}$. apart at the end of each temperature setting when the sample was at thermal equilibrium. Only the $1000 \mathrm{~Hz}$ frequency data were used in the conductivity calculation since these were the closest values to real impedance. Measured data were exported into Excel ${ }^{\circledR}$, where the impedance data were converted into conductance.

The electrical conductivity system was checked at specified intervals in 0.1 and $1 \mathrm{M}$ solutions of $\mathrm{KCl}$ at room temperature to determine a cell constant. Two measurements were taken at intervals of approximately $5 \mathrm{~min}$. for each solution. The cell constant was then used to calculate the conductivity of each glass melt.

\subsubsection{Equilibrium Crystal Fraction and Crystal Identification after Canister Centerline Cooling}

The equilibrium crystal fraction as a function of temperature were measured in Pt-alloy crucibles and boats with tight fitting lids (to minimize volatility) according the PNNL procedure GDL-LQT. The heat treatment time was $24 \pm 2$ hours for $900-1250^{\circ} \mathrm{C}$ to ensure equilibrium was achieved without excessive volatility. Selected glasses were subjected to simulated CCC treatments (roughly $150 \mathrm{~g}$ glass sample in Pt-alloy boats) according to the profiles described in Section 3.2. Samples were analyzed by x-ray diffraction (XRD) to determine the type and quantity of crystal fractions (quantitative analyses) according to the PNNL procedure GDL-XRD. 


\subsection{Glass Formulation for the Cold Crucible Induction Melter}

This section deals with the EM-31 program WP-4.1.2 task on the formulation of glasses for CCIM with a processing temperature higher than $1150{ }^{\circ} \mathrm{C}$. The primary objective of glass formulation effort for CCIM was to estimate the potential benefit in waste loading that can be achieved by CCIM compared to the baseline WTP technology using the $1150^{\circ} \mathrm{C}$ JHM. For initial glass formulation efforts, two wastes, AZ-101 HLW and AN-105 LAW, were selected as described in Section 2.1. The initial formulation tests with these two wastes based on crucible melts were completed, glass compositions for melter tests were selected, and the recipes for melter feed were developed. However, the actual melter tests were not performed before this task was closed. The results of formulating the glasses for these two wastes are described in Sections 4.1 and 4.2.

The next step of glass formulation efforts was to use the projected Hanford waste compositions that were described in Section 2.2 to estimate the potential benefit of CCIM focusing only on HLWs. Only part of the formulation tests for selected waste clusters was completed before this task was closed. The glass formulations and some limited test results are in Section 4.3.

\subsection{Cold Crucible Induction Melter Glass Formulation for AZ-101 HLW}

The composition of AZ-101 HLW was presented in Table 2.1. As discussed in Section 2.1, AZ-101 was selected based on its potential to successfully demonstrate the unique advantages of the CCIM technology over current reference technologies. This waste is relatively high in aluminum, iron, and zirconium, which suggests that higher melting temperature and tolerance to spinel crystals for the CCIM technology could increase loading and potentially increase the processing rate.

\subsubsection{Formulation Approach for AZ-101 HLW Glasses for the Cold Crucible Induction Melter}

Various constraints that are being applied for WTP and HTWOS were discussed in Section 2.2.2. The glass formulations for specific waste compositions use the selected constraints that are critical for the specific waste and melter technology to screen the candidate glasses with maximum waste loading. The selection of glass for a melter demonstration test involves confirming that the selected glass will pass all the acceptance and processing requirements discussed in Section 2.2.2.

Table 4.1 summarizes the glass property requirements applied when designing the AZ-101 HLW glasses for testing for the CCIM. The requirements for crystal fraction versus temperature, CCC crystallinity, viscosity, and electrical conductivity were self-imposed for the glass development purpose. Available glass property models (Vienna et al 2002; Vienna et al. 2009) were used to predict these properties whenever possible. However, the predicted values were used primarily as guidelines for glass formulation because the high waste loaded glasses that are considered in this study are well outside the model validity composition range of these models or, any models that the authors are aware of. 
Table 4.1. Glass Property Requirements ${ }^{(\mathrm{a})}$ for HLW Glasses

\begin{tabular}{|l|c|}
\hline \multicolumn{1}{|c|}{ Property } & Requirements \\
\hline Crystal fraction vs. temperature & As low as possible \\
\hline CCC crystallinity & No nepheline formation after CCC \\
\hline PCT normalized release for Q and CCC samples & $\mathrm{B}<16.70, \mathrm{Li}<9.57, \mathrm{Na}<13.35 \mathrm{~g} / \mathrm{L}$ \\
\hline TCLP Cd response for Q and CCC samples & $<0.48 \mathrm{mg} / \mathrm{L}$ \\
\hline Viscosity & 4 Pa.s at a nominal melting temperature $\left(T_{m}\right)$ \\
\hline Electrical conductivity & $10-100 \mathrm{~S} / \mathrm{m}$ at $T_{m}$ \\
\hline $\begin{array}{l}\text { (a) } \text { Self-imposed for the glass development purpose except for PCT and TCLP requirements } \\
\text { Q stands for quenched and CCC canister centerline cooling }\end{array}$ \\
\hline
\end{tabular}

Main difference for the CCIM formulation compared to that for WTP baseline melter is the potential increased melting temperature and tolerance to crystallization. For AZ-101 HLW, the most critical information for formulating glasses with maximum possible waste loading is the crystal fraction versus temperature because the waste loading is likely limited by the crystal content within the glass melts. However, currently the limit for crystal inclusions is not known. DoQuang et al. (2004) cite a 3 wt\% limit on noble metals in the CCIM to be installed in LaHague for the production of R7/T7 glass.

Currently, there is no practical model to predict the crystal fraction as a function of temperature except one by Hrma and Vienna (2003) that has very limited applicability. Instead, spinel

$\left[\left(\mathrm{Fe}^{2+}, \mathrm{Ni}\right)\left(\mathrm{Fe}^{3+}, \mathrm{Cr}, \mathrm{Al}\right)_{2} \mathrm{O}_{4}\right]$ liquidus temperature $\left(T_{L}\right)$ and temperature at which $1 \mathrm{vol} \%$ spinel crystal exists $\left(T_{1 \%}\right)$ have been used as conservative constraints to prevent the potential accumulation of crystals in the melter. Models to predict the $T_{L}$ and $T_{1 \%}$ have been developed (Vienna et al 2002; Vienna et al. 2009); however, they have poor predictability, especially for the glasses outside the valid composition range. Therefore, these models were used only as qualitative guidelines in selecting glasses for testing. The models for PCT normalized releases and TCLP Cd response (Vienna et al 2009) were used to confirm that these requirements will be met. The PCT and TCLP models also suffer poor predictability outside the valid composition range. However, the performance of PCT and TCLP models is not of concern because PCT and TCLP rarely limit the waste loading of HLW glasses as long as nepheline doesn't precipitate on slow cooling. To estimate the potential for nepheline precipitation after CCC treatment, the nepheline rules based on both $N_{S i}$ (see Eq. 2.1) and OB (see Eq. 2.2) were calculated. Whenever possible the glass formulation was performed to satisfy the nepheline constraint, but this constraint was not used to limit the waste loading as this constraint is known to be conservative (McCloy and Vienna 2010).

The model for viscosity (Vienna et al. 2009) was used to predict the nominal melting temperature at a predicted viscosity of $4 \mathrm{~Pa} \cdot \mathrm{s}$. The model for electrical conductivity (Vienna et al. 2009) was used to confirm that the glasses have predicted electrical conductivity within the desired range of 10 to $100 \mathrm{~S} / \mathrm{m}$ for CCIM (Marra et al. 2008) at a predicted nominal melting temperature.

Table 4.2 shows the target compositions and predicted properties for AZ-101 HLW (CCIM-AZ-xx ${ }^{1}$ ) glasses. Some initial compositions formulated with high waste loading did not result in homogeneous glasses because of severe crystallization during melting. The crystals formed did not dissolve into glass, even with increased temperature and time, as shown for CCIM-AZ-02 glass in Figure 4.1. The first seven glasses (CCIM-AZ-02 through 20) in Table 4.2 were melted but resulted in severe crystallization and therefore were not used for further property testing. The predicted nominal melting temperature $\left(T_{m}\right)$ at a

\footnotetext{
${ }^{1}$ All glasses that were formulated and considered in this study were given unique ID numbers. However, only partial selected glasses were prepared, and the missing ID numbers represent the glasses that were considered but were not prepared for testing.
} 
predicted viscosity of $4 \mathrm{~Pa} \cdot \mathrm{s}$ ranged from $1150{ }^{\circ} \mathrm{C}$ to $1300^{\circ} \mathrm{C}$. The predicted electrical conductivity was within the desired range of $10 \mathrm{~S} / \mathrm{m}$ to $100 \mathrm{~S} / \mathrm{m}$ at $T_{m}$ for all CCIM-AZ glasses. The predicted normalized PCT releases and TCLP Cd response were all below the regulatory limits. The predicted $T_{L}$ and $T_{1 \%}$ were all higher than the traditional constraints (see footnotes in Table 4.2) that have been imposed to avoid crystal accumulation in the melter. The nepheline constraint was met for all CCIM-AZ glasses, primarily by satisfying the $N_{S i}$ rule, except the CCIM-AZ-18 glass that failed both $N_{S i}$ and OB rules.

Table 4.2. Target Composition and Predicted Properties of CCIM-AZ Glasses

\begin{tabular}{|c|c|c|c|c|c|c|c|c|}
\hline \multirow[b]{2}{*}{ Oxide } & \multicolumn{7}{|c|}{ Glasses that were prepared but NOT tested for properties } & \multirow[b]{2}{*}{ Limits $^{(a)}$} \\
\hline & $\begin{array}{l}\text { CCIM- } \\
\text { AZ-02 }\end{array}$ & $\begin{array}{l}\text { CCIM- } \\
\text { AZ-03 }\end{array}$ & $\begin{array}{l}\text { CCIM- } \\
\text { AZ-05 }\end{array}$ & $\begin{array}{c}\text { CCIM- } \\
\text { AZ-06 }\end{array}$ & $\begin{array}{l}\text { CCIM- } \\
\text { AZ-08 }\end{array}$ & $\begin{array}{l}\text { CCIM- } \\
\text { AZ-19 }\end{array}$ & $\begin{array}{c}\text { CCIM- } \\
\text { AZ-20 }\end{array}$ & \\
\hline $\mathrm{Al}_{2} \mathrm{O}_{3}$ & 0.12650 & 0.12650 & 0.11826 & 0.13050 & 0.11093 & 0.10440 & 0.10440 & - \\
\hline $\mathrm{B}_{2} \mathrm{O}_{3}$ & 0.16599 & 0.10000 & 0.15682 & 0.08000 & 0.08000 & 0.11000 & 0.11000 & - \\
\hline $\mathrm{CaO}$ & 0.00720 & 0.00720 & 0.00674 & 0.02000 & 0.00632 & 0.00595 & 0.00595 & - \\
\hline $\mathrm{CdO}$ & 0.01112 & 0.01112 & 0.01039 & 0.01147 & 0.00975 & 0.00917 & 0.00917 & - \\
\hline $\mathrm{Ce}_{2} \mathrm{O}_{3}$ & 0.00412 & 0.00412 & 0.00385 & 0.00425 & 0.00361 & 0.00340 & 0.00340 & - \\
\hline $\mathrm{Cr}_{2} \mathrm{O}_{3}$ & 0.00237 & 0.00237 & 0.00221 & 0.00244 & 0.00208 & 0.00195 & 0.00195 & - \\
\hline $\mathrm{Cs}_{2} \mathrm{O}$ & 0.00257 & 0.00257 & 0.00241 & 0.00265 & 0.00226 & 0.00212 & 0.00212 & - \\
\hline $\mathrm{Fe}_{2} \mathrm{O}_{3}$ & 0.19387 & 0.19387 & 0.18124 & 0.20000 & 0.17000 & 0.16000 & 0.16000 & - \\
\hline $\mathrm{K}_{2} \mathrm{O}$ & 0.00000 & 0.00000 & 0.00000 & 0.00000 & 0.00000 & 0.00000 & 0.04000 & - \\
\hline $\mathrm{La}_{2} \mathrm{O}_{3}$ & 0.00453 & 0.00453 & 0.00423 & 0.00467 & 0.00397 & 0.00374 & 0.00374 & - \\
\hline $\mathrm{Li}_{2} \mathrm{O}$ & 0.00979 & 0.03000 & 0.02517 & 0.02000 & 0.03500 & 0.05000 & 0.03000 & - \\
\hline $\mathrm{MnO}$ & 0.00463 & 0.00463 & 0.00433 & 0.00478 & 0.00406 & 0.00382 & 0.00382 & - \\
\hline $\mathrm{Na}_{2} \mathrm{O}$ & 0.08337 & 0.07876 & 0.08104 & 0.08153 & 0.12117 & 0.06872 & 0.09037 & - \\
\hline $\mathrm{Nd}_{2} \mathrm{O}_{3}$ & 0.00335 & 0.00335 & 0.00313 & 0.00345 & 0.00293 & 0.00276 & 0.00276 & - \\
\hline $\mathrm{NiO}$ & 0.00849 & 0.00849 & 0.00794 & 0.00876 & 0.00745 & 0.00701 & 0.00701 & - \\
\hline $\mathrm{P}_{2} \mathrm{O}_{5}$ & 0.00684 & 0.00684 & 0.00640 & 0.00706 & 0.00600 & 0.00565 & 0.00565 & - \\
\hline $\mathrm{RuO}_{2}$ & 0.00077 & 0.00077 & 0.00072 & 0.00080 & 0.00068 & 0.00064 & 0.00064 & - \\
\hline $\mathrm{SiO}_{2}$ & 0.30037 & 0.35076 & 0.32518 & 0.35149 & 0.37757 & 0.40775 & 0.36610 & - \\
\hline $\mathrm{SO}_{3}$ & 0.00190 & 0.00190 & 0.00178 & 0.00196 & 0.00167 & 0.00157 & 0.00157 & - \\
\hline $\mathrm{SnO}_{2}$ & 0.00340 & 0.00340 & 0.00318 & 0.00350 & 0.00298 & 0.00280 & 0.00280 & - \\
\hline $\mathrm{ZrO}_{2}$ & 0.05882 & 0.05882 & 0.05499 & 0.06068 & 0.05158 & 0.04855 & 0.04855 & - \\
\hline Total & 1.00000 & 1.00000 & 1.00000 & 1.00000 & 1.00000 & 1.00000 & 1.00000 & - \\
\hline Waste loading & 0.515 & 0.515 & 0.481 & 0.531 & 0.451 & 0.425 & 0.425 & - \\
\hline$T_{m}$ at $4 \mathrm{~Pa} \cdot \mathrm{s},{ }^{\circ} \mathrm{C}$ & 1250 & 1250 & 1200 & 1300 & 1200 & 1200 & 1200 & - \\
\hline EC at $T_{m}, \mathrm{~S} / \mathrm{m}$ & 24.2 & 29.3 & 26.6 & 26.9 & 38.8 & 34.4 & 29.6 & $10-100$ \\
\hline Spinel $T_{L},{ }^{\circ} \mathrm{C}$ & 1405 & 1457 & 1319 & 1555 & 1274 & 1255 & 1192 & $<T_{m}-100^{(\mathrm{b})}$ \\
\hline Spinel $T_{1 \%},{ }^{\circ} \mathrm{C}$ & 1332 & 1355 & 1250 & 1416 & 1176 & 1142 & 1107 & $<T_{m}-200^{(\mathrm{c})}$ \\
\hline PCT-B, g/L & 0.317 & 0.179 & 0.405 & 0.102 & 0.327 & 0.305 & 0.451 & $<16.7$ \\
\hline PCT-Li, g/L & 0.325 & 0.193 & 0.385 & 0.138 & 0.330 & 0.309 & 0.399 & $<9.57$ \\
\hline PCT-Na, g/L & 0.232 & 0.134 & 0.273 & 0.103 & 0.307 & 0.206 & 0.333 & $<13.35$ \\
\hline TCLP Cd, mg/L & 0.218 & 0.127 & 0.227 & 0.101 & 0.170 & 0.131 & 0.190 & $<0.48$ \\
\hline$N_{S i}$ & 0.589 & 0.631 & 0.620 & 0.624 & 0.619 & 0.702 & 0.653 & $\geq 0.62$ \\
\hline OB & 0.575 & 0.593 & 0.576 & 0.601 & 0.604 & 0.578 & 0.594 & $\leq 0.575$ \\
\hline
\end{tabular}


Table 4.2. Target Composition and Predicted Properties of CCIM-AZ Glasses (continued)

\begin{tabular}{|c|c|c|c|c|c|c|c|c|c|c|}
\hline \multirow[b]{2}{*}{ Oxide } & \multicolumn{9}{|c|}{ Glasses that were tested for properties } & \multirow[b]{2}{*}{ Limits $^{(a)}$} \\
\hline & $\begin{array}{l}\text { CCIM- } \\
\text { AZ-10 }\end{array}$ & $\begin{array}{l}\text { CCIM- } \\
\text { AZ-17 }\end{array}$ & $\begin{array}{l}\text { CCIM- } \\
\text { AZ-18 }\end{array}$ & $\begin{array}{l}\text { CCIM- } \\
\text { AZ-16 }\end{array}$ & $\begin{array}{l}\text { CCIM- } \\
\text { AZ-29 }\end{array}$ & $\begin{array}{l}\text { CCIM- } \\
\text { AZ-30 }\end{array}$ & $\begin{array}{l}\text { CCIM- } \\
\text { AZ-31 }\end{array}$ & $\begin{array}{l}\text { CCIM- } \\
\text { AZ-32 }\end{array}$ & $\begin{array}{l}\text { CCIM- } \\
\text { AZ-33 }\end{array}$ & \\
\hline $\mathrm{Al}_{2} \mathrm{O}_{3}$ & 0.11093 & 0.11093 & 0.11093 & 0.10440 & 0.09788 & 0.09788 & 0.09788 & 0.09788 & 0.09788 & - \\
\hline $\mathrm{B}_{2} \mathrm{O}_{3}$ & 0.11000 & 0.14000 & 0.14000 & 0.11000 & 0.11000 & 0.11000 & 0.07000 & 0.15000 & 0.11000 & - \\
\hline $\mathrm{CaO}$ & 0.00632 & 0.00632 & 0.00632 & 0.00595 & 0.00557 & 0.00557 & 0.00557 & 0.00557 & 0.04000 & - \\
\hline $\mathrm{CdO}$ & 0.00975 & 0.00975 & 0.00975 & 0.00917 & 0.00860 & 0.00860 & 0.00860 & 0.00860 & 0.00860 & - \\
\hline $\mathrm{Ce}_{2} \mathrm{O}_{3}$ & 0.00361 & 0.00361 & 0.00361 & 0.00340 & 0.00319 & 0.00319 & 0.00319 & 0.00319 & 0.00319 & - \\
\hline $\mathrm{Cr}_{2} \mathrm{O}_{3}$ & 0.00208 & 0.00208 & 0.00208 & 0.00195 & 0.00183 & 0.00183 & 0.00183 & 0.00183 & 0.00183 & - \\
\hline $\mathrm{Cs}_{2} \mathrm{O}$ & 0.00226 & 0.00226 & 0.00226 & 0.00212 & 0.00199 & 0.00199 & 0.00199 & 0.00199 & 0.00199 & - \\
\hline $\mathrm{Fe}_{2} \mathrm{O}_{3}$ & 0.17000 & 0.17000 & 0.17000 & 0.16000 & 0.15000 & 0.15000 & 0.15000 & 0.15000 & 0.15000 & - \\
\hline $\mathrm{K}_{2} \mathrm{O}$ & 0.00000 & 0.00000 & 0.00000 & 0.00000 & 0.00000 & 0.00000 & 0.00000 & 0.00000 & 0.00000 & - \\
\hline $\mathrm{La}_{2} \mathrm{O}_{3}$ & 0.00397 & 0.00397 & 0.00397 & 0.00374 & 0.00350 & 0.00350 & 0.00350 & 0.00350 & 0.00350 & - \\
\hline $\mathrm{Li}_{2} \mathrm{O}$ & 0.03000 & 0.03000 & 0.03000 & 0.03000 & 0.03000 & 0.05000 & 0.04500 & 0.03000 & 0.03000 & - \\
\hline $\mathrm{MnO}$ & 0.00406 & 0.00406 & 0.00406 & 0.00382 & 0.00358 & 0.00358 & 0.00358 & 0.00358 & 0.00358 & - \\
\hline $\mathrm{Na}_{2} \mathrm{O}$ & 0.10781 & 0.08642 & 0.10781 & 0.11382 & 0.11991 & 0.07499 & 0.11992 & 0.09253 & 0.09122 & - \\
\hline $\mathrm{Nd}_{2} \mathrm{O}_{3}$ & 0.00293 & 0.00293 & 0.00293 & 0.00276 & 0.00259 & 0.00259 & 0.00259 & 0.00259 & 0.00259 & - \\
\hline $\mathrm{NiO}$ & 0.00745 & 0.00745 & 0.00745 & 0.00701 & 0.00657 & 0.00657 & 0.00657 & 0.00657 & 0.00657 & - \\
\hline $\mathrm{P}_{2} \mathrm{O}_{5}$ & 0.00600 & 0.00600 & 0.00600 & 0.00565 & 0.00530 & 0.00530 & 0.00530 & 0.00530 & 0.00530 & - \\
\hline $\mathrm{RuO}_{2}$ & 0.00068 & 0.00068 & 0.00068 & 0.00064 & 0.00060 & 0.00060 & 0.00060 & 0.00060 & 0.00060 & - \\
\hline $\mathrm{SiO}_{2}$ & 0.36593 & 0.35732 & 0.33593 & 0.38264 & 0.39928 & 0.42419 & 0.42426 & 0.38665 & 0.39354 & - \\
\hline $\mathrm{SO}_{3}$ & 0.00167 & 0.00167 & 0.00167 & 0.00157 & 0.00147 & 0.00147 & 0.00147 & 0.00147 & 0.00147 & - \\
\hline $\mathrm{SnO}_{2}$ & 0.00298 & 0.00298 & 0.00298 & 0.00280 & 0.00263 & 0.00263 & 0.00263 & 0.00263 & 0.00263 & - \\
\hline $\mathrm{ZrO}_{2}$ & 0.05158 & 0.05158 & 0.05158 & 0.04855 & 0.04551 & 0.04551 & 0.04551 & 0.04551 & 0.04551 & - \\
\hline Total & 1.00000 & 1.00000 & 1.00000 & 1.00000 & 1.00000 & 1.00000 & 1.00000 & 1.00000 & 1.00000 & - \\
\hline Waste loading & 0.451 & 0.451 & 0.451 & 0.425 & 0.398 & 0.398 & 0.398 & 0.398 & 0.398 & - \\
\hline$T_{m}$ at $4 \mathrm{~Pa} \cdot \mathrm{s},{ }^{\circ} \mathrm{C}$ & 1200 & 1200 & 1150 & 1200 & 1200 & 1200 & 1200 & 1200 & 1200 & - \\
\hline $\mathrm{EC}$ at $T_{m}, \mathrm{~S} / \mathrm{m}$ & 33.1 & 28.9 & 36.6 & 34.3 & 35.7 & 35.5 & 43.6 & 30.2 & 27.1 & $10-100$ \\
\hline Spinel $T_{L},{ }^{\circ} \mathrm{C}$ & 1272 & 1272 & 1226 & 1218 & 1165 & 1202 & 1182 & 1163 & 1232 & $<T_{m}-100^{(\mathrm{b})}$ \\
\hline Spinel $T_{1 \%},{ }^{\circ} \mathrm{C}$ & 1178 & 1184 & 1160 & 1114 & 1049 & 1077 & 1057 & 1055 & 1093 & $<T_{m}-200^{(\mathrm{c})}$ \\
\hline PCT-B, g/L & 0.358 & 0.389 & 0.583 & 0.399 & 0.448 & 0.344 & 0.363 & 0.512 & 0.259 & $<16.7$ \\
\hline PCT-Li, g/L & 0.330 & 0.360 & 0.516 & 0.364 & 0.405 & 0.345 & 0.400 & 0.488 & 0.276 & $<9.57$ \\
\hline PCT-Na, g/L & 0.261 & 0.257 & 0.386 & 0.296 & 0.338 & 0.235 & 0.382 & 0.350 & 0.230 & $<13.35$ \\
\hline $\begin{array}{c}\text { TCLP Cd, } \\
\text { mg/L }\end{array}$ & 0.184 & 0.193 & 0.280 & 0.181 & 0.178 & 0.129 & 0.143 & 0.194 & 0.170 & $<0.48$ \\
\hline$N_{S i}$ & 0.626 & 0.644 & 0.606 & 0.637 & 0.647 & 0.710 & 0.661 & 0.670 & 0.675 & $\geq 0.62$ \\
\hline $\mathrm{OB}$ & 0.591 & 0.577 & 0.586 & 0.588 & 0.586 & 0.575 & 0.598 & 0.568 & 0.587 & $\leq 0.575$ \\
\hline \multicolumn{11}{|c|}{$\begin{array}{l}\text { (a) Used as guidelines for formulating the glasses. } \\
\text { (b) Based on a traditional constraint used in Perez et al. (2001). } \\
\text { (c) Based on a constraint of } T_{1 \%}<950^{\circ} \mathrm{C} \text { for glasses with } T_{m}=1150^{\circ} \mathrm{C} \text { (Vienna et al. 2009). } \\
\text { Shaded cells indicate that the predicted or calculated value is not within the limits. }\end{array}$} \\
\hline
\end{tabular}




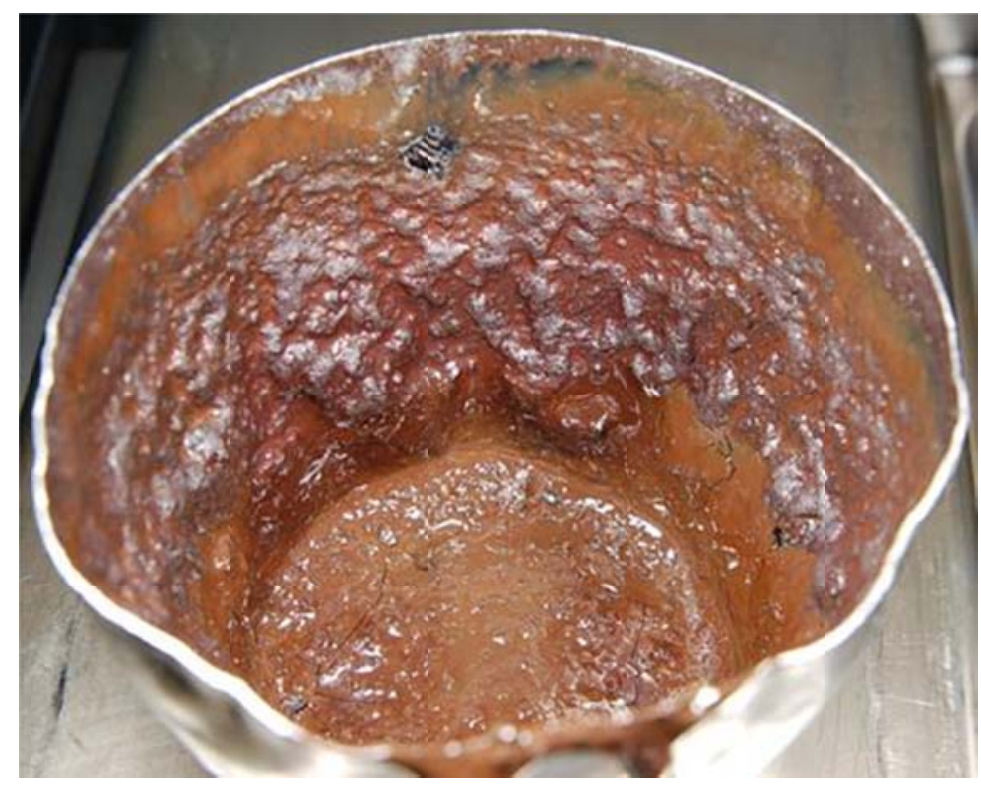

Figure 4.1. Crystals Remaining Attached to the Crucible after Melting of CCIM-AZ-02

\subsubsection{Test Results of AZ-101 HLW Glasses for Cold Crucible Induction Melter}

Chemical analyses of glasses were performed for CCIM-AZ glasses primarily to confirm glass batching and melting preparation. Table 4.3 and Table 4.4 compare the target and analyzed compositions and provide their relative percent difference (RPD) values. The RPD values were calculated for components with concentration higher than $1 \mathrm{wt} \%$. The analytical results matched well with the target concentrations for all eight CCIM-AZ glasses without any specific glasses that are suspected for any batching error.

Table 4.3. Comparison of Target and Analyzed Compositions of CCIM-AZ-10 through CCIM-AZ-18 Glasses and their Relative Percent Difference (RPD)

\begin{tabular}{|c|c|c|c|c|c|c|c|c|c|c|c|c|}
\hline \multirow[b]{2}{*}{ Glass } & \multicolumn{4}{|c|}{ Target (wt\%) } & \multicolumn{4}{|c|}{ Analyzed $(\mathrm{wt} \%)^{(1)}$} & \multicolumn{4}{|c|}{$\mathbf{R P D}^{(2)}$} \\
\hline & AZ-10 & AZ-16 & AZ-17 & AZ-18 & AZ-10 & AZ-16 & AZ-17 & AZ-18 & AZ-10 & AZ-16 & AZ-17 & AZ-18 \\
\hline $\mathrm{Al}_{2} \mathrm{O}_{3}$ & 11.09 & 10.44 & 11.09 & 11.09 & 11.10 & 10.43 & 11.04 & 11.16 & $0.1 \%$ & $-0.1 \%$ & $-0.4 \%$ & $0.6 \%$ \\
\hline $\mathrm{B}_{2} \mathrm{O}_{3}$ & 11.00 & 11.00 & 14.00 & 14.00 & 11.93 & 11.54 & 14.41 & 14.44 & $8.5 \%$ & $4.9 \%$ & $2.9 \%$ & $3.2 \%$ \\
\hline $\mathrm{CaO}$ & 0.63 & 0.59 & 0.63 & 0.63 & 0.75 & 0.71 & 0.74 & 0.77 & & & & \\
\hline $\mathrm{CdO}$ & 0.97 & 0.92 & 0.97 & 0.97 & 0.66 & 0.61 & 0.59 & 0.64 & & & & \\
\hline $\mathrm{Ce}_{2} \mathrm{O}_{3}$ & 0.36 & 0.34 & 0.36 & 0.36 & 0.33 & 0.31 & 0.32 & 0.33 & & & & \\
\hline $\mathrm{Cr}_{2} \mathrm{O}_{3}$ & 0.21 & 0.20 & 0.21 & 0.21 & 0.20 & 0.16 & 0.17 & 0.16 & & & & \\
\hline $\mathrm{Cs}_{2} \mathrm{O}$ & 0.23 & 0.21 & 0.23 & 0.23 & & & & & & & & \\
\hline $\mathrm{Fe}_{2} \mathrm{O}_{3}$ & 17.00 & 16.00 & 17.00 & 17.00 & 17.37 & 15.94 & 16.59 & 16.80 & $2.2 \%$ & $-0.3 \%$ & $-2.4 \%$ & $-1.2 \%$ \\
\hline $\mathrm{La}_{2} \mathrm{O}_{3}$ & 0.40 & 0.37 & 0.40 & 0.40 & 0.31 & 0.29 & 0.30 & 0.31 & & & & \\
\hline $\mathrm{Li}_{2} \mathrm{O}$ & 3.00 & 3.00 & 3.00 & 3.00 & 2.95 & 2.91 & 2.90 & 2.93 & $-1.8 \%$ & $-2.9 \%$ & $-3.2 \%$ & $-2.2 \%$ \\
\hline $\mathrm{MnO}$ & 0.41 & 0.38 & 0.41 & 0.41 & 0.33 & 0.31 & 0.31 & 0.33 & & & & \\
\hline $\mathrm{Na}_{2} \mathrm{O}$ & 10.78 & 11.38 & 8.64 & 10.78 & 11.11 & 11.63 & 8.71 & 11.25 & $3.1 \%$ & $2.2 \%$ & $0.8 \%$ & $4.3 \%$ \\
\hline $\mathrm{Nd}_{2} \mathrm{O}_{3}$ & 0.29 & 0.28 & 0.29 & 0.29 & 0.32 & 0.30 & 0.31 & 0.34 & & & & \\
\hline $\mathrm{NiO}$ & 0.74 & 0.70 & 0.74 & 0.74 & 0.72 & 0.65 & 0.66 & 0.69 & & & & \\
\hline $\mathrm{P}_{2} \mathrm{O}_{5}$ & 0.60 & 0.56 & 0.60 & 0.60 & 0.51 & 0.49 & 0.48 & 0.50 & & & & \\
\hline $\mathrm{RuO}_{2}$ & 0.07 & 0.06 & 0.07 & 0.07 & & & & & & & & \\
\hline
\end{tabular}




\begin{tabular}{|c|c|c|c|c|c|c|c|c|c|c|c|c|}
\hline \multirow[b]{2}{*}{ Glass } & \multicolumn{4}{|c|}{ Target (wt\%) } & \multicolumn{4}{|c|}{ Analyzed (wt\%) ${ }^{(1)}$} & \multicolumn{4}{|c|}{ RPD $^{(2)}$} \\
\hline & AZ-10 & AZ-16 & AZ-17 & AZ-18 & AZ-10 & AZ-16 & AZ-17 & AZ-18 & AZ-10 & AZ-16 & AZ-17 & AZ-18 \\
\hline $\mathrm{SiO}_{2}$ & 36.59 & 38.26 & 35.73 & 33.59 & 36.49 & 37.77 & 35.10 & 33.17 & $-0.3 \%$ & $-1.3 \%$ & $-1.8 \%$ & $-1.3 \%$ \\
\hline $\mathrm{SO}_{3}$ & 0.17 & 0.16 & 0.17 & 0.17 & 0.16 & 0.14 & 0.12 & 0.15 & & & & \\
\hline $\mathrm{SnO}_{2}$ & 0.30 & 0.28 & 0.30 & 0.30 & 0.27 & 0.25 & 0.25 & 0.27 & & & & \\
\hline $\mathrm{ZrO}_{2}$ & 5.16 & 4.85 & 5.16 & 5.16 & 4.88 & 4.62 & 4.61 & 4.98 & $-5.4 \%$ & $-4.9 \%$ & $-10.6 \%$ & $-3.4 \%$ \\
\hline Total & 100.00 & 100.00 & 100.00 & 100.00 & 100.40 & 99.07 & 97.62 & 99.21 & & & & \\
\hline
\end{tabular}

Table 4.4. Comparison of Target and Analyzed Compositions of CCIM-AZ-29 through CCIM-AZ-33 Glasses and their Relative Percent Difference (RPD)

\begin{tabular}{|c|c|c|c|c|c|c|c|c|c|c|c|c|}
\hline \multirow[b]{2}{*}{ Glass } & \multicolumn{4}{|c|}{ Target (wt\%) } & \multicolumn{4}{|c|}{ Analyzed (wt\%) ${ }^{(1)}$} & \multicolumn{4}{|c|}{$\mathbf{R P D}^{(2)}$} \\
\hline & AZ-29 & AZ-30 & AZ-31 & AZ-33 & AZ-29 & AZ-30 & AZ-31 & AZ-33 & AZ-29 & AZ-30 & AZ-31 & AZ-33 \\
\hline $\mathrm{Al}_{2} \mathrm{O}_{3}$ & 9.79 & 9.79 & 9.79 & 9.79 & 9.98 & 9.89 & 9.90 & 9.88 & $2.0 \%$ & $1.1 \%$ & $1.2 \%$ & $1.0 \%$ \\
\hline $\mathrm{B}_{2} \mathrm{O}_{3}$ & 11.00 & 11.00 & 7.00 & 11.00 & 10.82 & 11.08 & 7.02 & 11.04 & $-1.6 \%$ & $0.7 \%$ & $0.3 \%$ & $0.4 \%$ \\
\hline $\mathrm{CaO}$ & 0.56 & 0.56 & 0.56 & 4.00 & 0.52 & 0.50 & 0.50 & 4.28 & & & & $7.1 \%$ \\
\hline $\mathrm{CdO}$ & 0.86 & 0.86 & 0.86 & 0.86 & 0.75 & 0.74 & 0.73 & 0.75 & & & & \\
\hline $\mathrm{Ce}_{2} \mathrm{O}_{3}$ & 0.32 & 0.32 & 0.32 & 0.32 & 0.31 & 0.30 & 0.30 & 0.30 & & & & \\
\hline $\mathrm{Cr}_{2} \mathrm{O}_{3}$ & 0.18 & 0.18 & 0.18 & 0.18 & 0.16 & 0.14 & 0.17 & 0.14 & & & & \\
\hline $\mathrm{Cs}_{2} \mathrm{O}$ & 0.20 & 0.20 & 0.20 & 0.20 & & & & & & & & \\
\hline $\mathrm{Fe}_{2} \mathrm{O}_{3}$ & 15.00 & 15.00 & 15.00 & 15.00 & 14.87 & 14.94 & 14.73 & 14.80 & $-0.9 \%$ & $-0.4 \%$ & $-1.8 \%$ & $-1.3 \%$ \\
\hline $\mathrm{La}_{2} \mathrm{O}_{3}$ & 0.35 & 0.35 & 0.35 & 0.35 & 0.28 & 0.28 & 0.28 & 0.28 & & & & \\
\hline $\mathrm{Li}_{2} \mathrm{O}$ & 3.00 & 5.00 & 4.50 & 3.00 & 2.97 & 4.91 & 4.42 & 2.99 & $-1.1 \%$ & $-1.7 \%$ & $-1.8 \%$ & $-0.4 \%$ \\
\hline $\mathrm{MnO}$ & 0.36 & 0.36 & 0.36 & 0.36 & 0.32 & 0.31 & 0.31 & 0.31 & & & & \\
\hline $\mathrm{Na}_{2} \mathrm{O}$ & 11.99 & 7.50 & 11.99 & 9.12 & 12.82 & 8.13 & 12.97 & 9.65 & $6.9 \%$ & $8.4 \%$ & $8.2 \%$ & $5.8 \%$ \\
\hline $\mathrm{Nd}_{2} \mathrm{O}_{3}$ & 0.26 & 0.26 & 0.26 & 0.26 & 0.27 & 0.27 & 0.27 & 0.26 & & & & \\
\hline $\mathrm{NiO}$ & 0.66 & 0.66 & 0.66 & 0.66 & 0.45 & 0.45 & 0.46 & 0.44 & & & & \\
\hline $\mathrm{P}_{2} \mathrm{O}_{5}$ & 0.53 & 0.53 & 0.53 & 0.53 & 0.44 & 0.49 & 0.48 & 0.39 & & & & \\
\hline $\mathrm{RuO}_{2}$ & 0.06 & 0.06 & 0.06 & 0.06 & & & & & & & & \\
\hline $\mathrm{SiO}_{2}$ & 39.93 & 42.42 & 42.43 & 39.35 & 40.45 & 42.59 & 42.80 & 39.48 & $1.3 \%$ & $0.4 \%$ & $0.9 \%$ & $0.3 \%$ \\
\hline $\mathrm{SO}_{3}$ & 0.15 & 0.15 & 0.15 & 0.15 & & & & & & & & \\
\hline $\mathrm{SnO}_{2}$ & 0.26 & 0.26 & 0.26 & 0.26 & 0.33 & 0.32 & 0.32 & 0.31 & & & & \\
\hline $\mathrm{ZrO}_{2}$ & 4.55 & 4.55 & 4.55 & 4.55 & 4.28 & 4.39 & 4.32 & 4.42 & $-6.0 \%$ & $-3.5 \%$ & $-5.1 \%$ & $-2.9 \%$ \\
\hline Total & 100.00 & 100.00 & 100.00 & 100.00 & 100.00 & 99.74 & 99.98 & 99.75 & & & & \\
\hline
\end{tabular}

Table 4.5 summarizes the results of XRD analyses of CCC-treated samples of CCIM-AZ glasses. Crystals identified after CCC treatment included spinel $\left[\left(\mathrm{Fe}^{2+}, \mathrm{Ni}\right)\left(\mathrm{Fe}^{3+}, \mathrm{Cr}, \mathrm{Al}\right)_{2} \mathrm{O}_{4}\right]$ as the major phase with a smaller fraction of baddeleyite $\left(\mathrm{ZrO}_{2}\right)$ only in glasses with $16 \mathrm{wt} \%$ or $17 \mathrm{wt} \% \mathrm{Fe}_{2} \mathrm{O}_{3}$ (CCIM-AZ-10, 17, 18, and 16). As mentioned earlier, spinel crystals are known to have little impact on the PCT normalized releases (Bickford and Jantzen 1984). Nepheline $\left(\mathrm{NaAlSiO}_{4}\right)$ was not detected in any glasses, including the CCIM-AZ-18 glass that failed the nepheline constraint (i.e., failed both $N_{S i}$ and OB rules, see Table 4.2. In summary, it is expected that the PCT releases of CCIM-AZ glasses are not likely to be affected by CCC treatment. 
Table 4.5. Measured Crystal Vol\% after CCC Treatment for CCIM-AZ Glasses

\begin{tabular}{|c|c|c|c|c|c|c|c|c|c|}
\hline Crystal & AZ-10 & AZ-17 & AZ-18 & AZ-16 & AZ-29 & AZ-30 & AZ-31 & AZ-32 & AZ-33 \\
\hline Spinel & 4.9 & 5.0 & 4.8 & 4.6 & 5.1 & 6.1 & 4.9 & N/A & 5.0 \\
\hline Baddeleyite & 1.0 & 1.3 & 0.8 & 0.5 & 0 & 0 & 0 & N/A & 0 \\
\hline
\end{tabular}

Table 4.6 summarizes the PCT normalized releases and TCLP responses of quenched and CCC treated CCIM-AZ Glasses. Figure 4.2 displays the PCT normalized releases for boron, lithium and sodium (Figure 4.2) and Figure 4.3 shows the TCLP cadmium response for CCIM-AZ glasses. The PCT normalized releases of all the quenched and CCC-treated glasses were well below the limits of the Environmental Assessment glass (Jantzen et al. 2003). All quenched and CCC glasses passed the TCLP cadmium requirement of $0.48 \mathrm{mg} / \mathrm{L}$. Note that the AZ-101 waste is one of the small number of Hanford waste streams with high cadmium content. For all PCT-normalized boron, lithium, and sodium releases and TCLP cadmium response, the measured values (for quenched samples) were equal to or slightly higher than the predicted. The CCC treatment had mixed effects on PCT normalized releases and the TCLP Cd response, but did not show a significant difference from quenched samples as expected from CCC crystallinity results.

Table 4.6. PCT Normalized Releases and TCLP Responses of Quenched and CCC Treated CCIM-AZ Glasses

\begin{tabular}{|r|c|c|c|c|c|c|c|c|}
\hline Glass & AZ-10 & AZ-17 & AZ-18 & AZ-16 & AZ-29 & AZ-30 & AZ-31 & AZ-33 \\
\hline PCT Normalized releases, g/L \\
\hline PCT-B, Q & 0.4755 & 0.5728 & 0.7502 & 0.4810 & 0.4865 & 0.5362 & 0.4840 & 0.4810 \\
\hline PCT-Li, Q & 0.6348 & 0.7960 & 0.8098 & 0.6515 & 0.6181 & 0.6896 & 0.5994 & 0.6495 \\
\hline PCT-Na, Q & 0.3991 & 0.3500 & 0.5507 & 0.4307 & 0.3902 & 0.2571 & 0.4837 & 0.4119 \\
\hline PCT-B, CCC & 0.4455 & 0.7318 & 1.0884 & 0.4404 & 0.4264 & 0.4401 & 0.4746 & 0.3288 \\
\hline PCT-Li, CCC & 0.5615 & 0.9063 & 0.9668 & 0.5419 & 0.5311 & 0.5964 & 0.5496 & 0.4668 \\
\hline PCT-Na, CCC & 0.3880 & 0.4240 & 0.6999 & 0.3936 & 0.3669 & 0.2139 & 0.4624 & 0.3038 \\
\hline TCLP responses, mg/L $/$ (L) \\
\hline TCLP B, Q & 1.4000 & 1.2900 & 1.8700 & 1.0500 & 1.4300 & 1.2100 & $<1$ & 1.2500 \\
\hline TCLP Cd, Q & 0.2760 & 0.2080 & 0.3040 & 0.1850 & 0.2490 & 0.2190 & 0.2240 & 0.2530 \\
\hline TCLP B,CCC & 1.6800 & 2.0000 & 2.5400 & 1.6600 & 1.5700 & 1.1200 & $<1$ & 1.3500 \\
\hline TCLP Cd, CCC & 0.3330 & 0.3130 & 0.4170 & 0.3220 & 0.2940 & 0.1960 & 0.2240 & 0.2610 \\
\hline
\end{tabular}




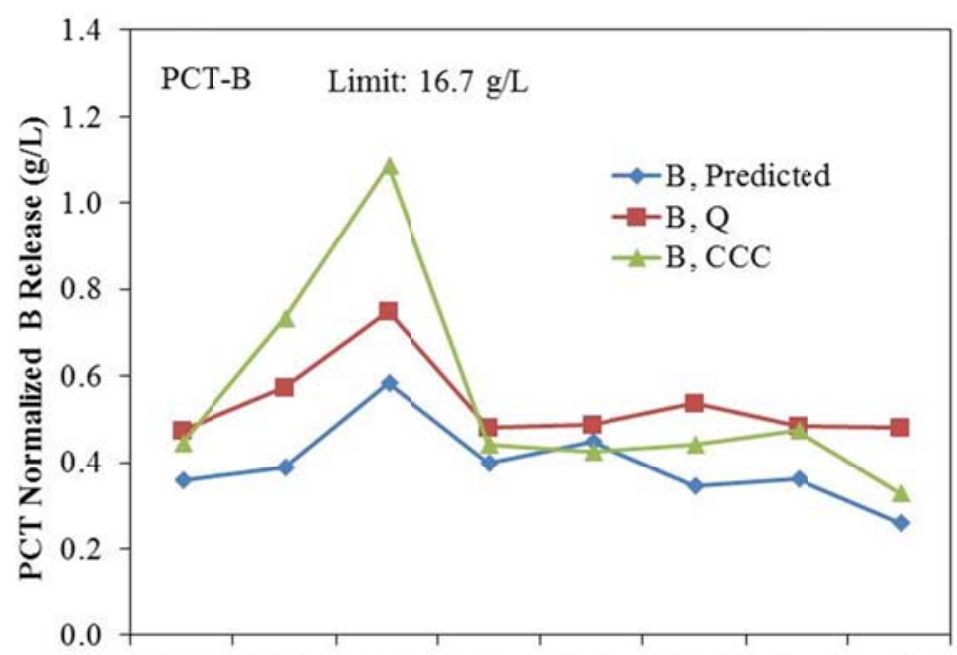

AZ-10 AZ-17 AZ-18 AZ-16 AZ-29 AZ-30 AZ-31 AZ-33
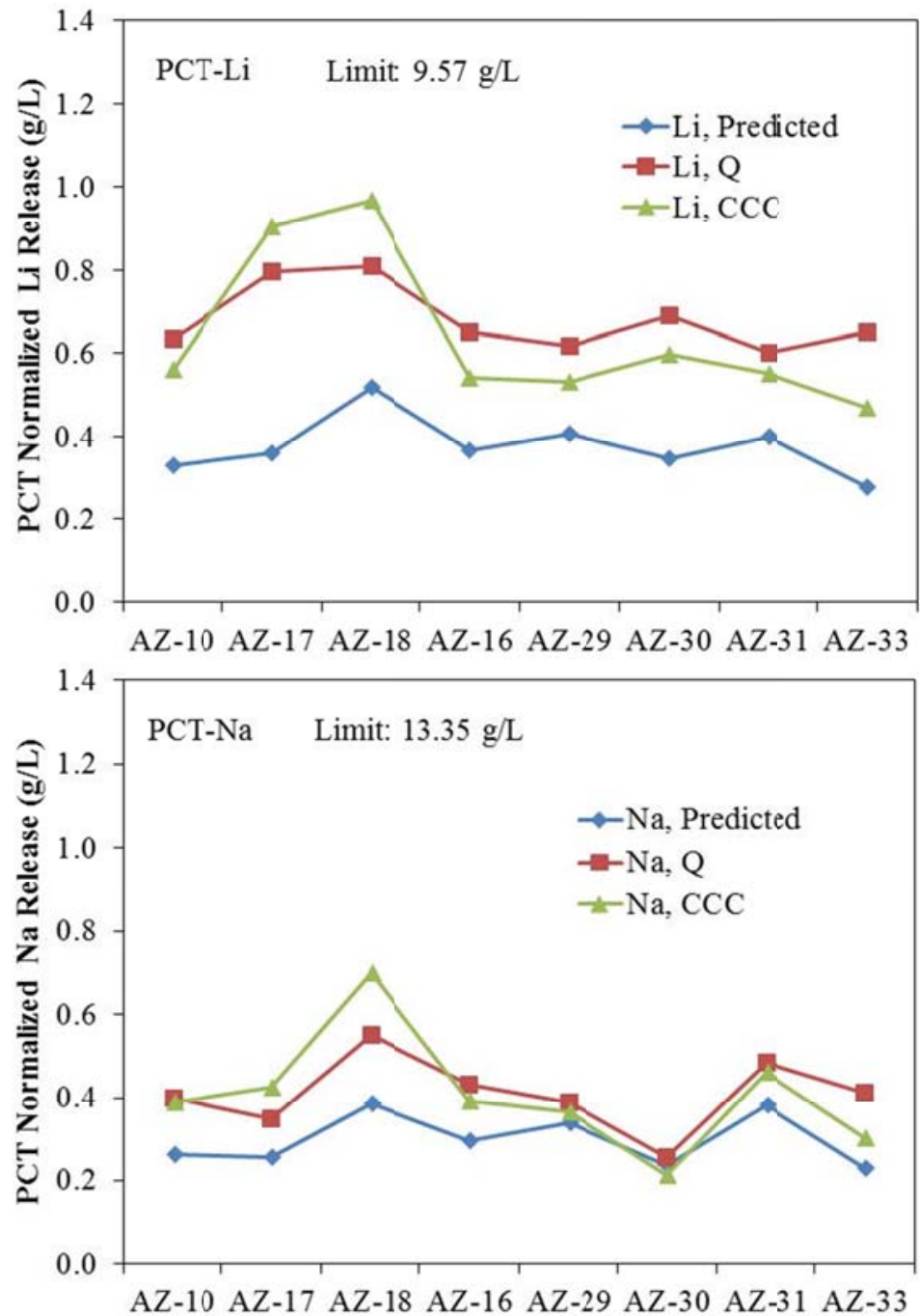

Figure 4.2. PCT Normalized Releases of CCIM-AZ Glasses (AZ-10, 17, and 18 glasses have $17 \mathrm{wt} \% \mathrm{Fe}_{2} \mathrm{O}_{3}$, AZ-16 has $16 \mathrm{wt} \% \mathrm{Fe}_{2} \mathrm{O}_{3}$, and AZ-29 through AZ-33 have $15 \mathrm{wt} \% \mathrm{Fe}_{2} \mathrm{O}_{3}$ ) 


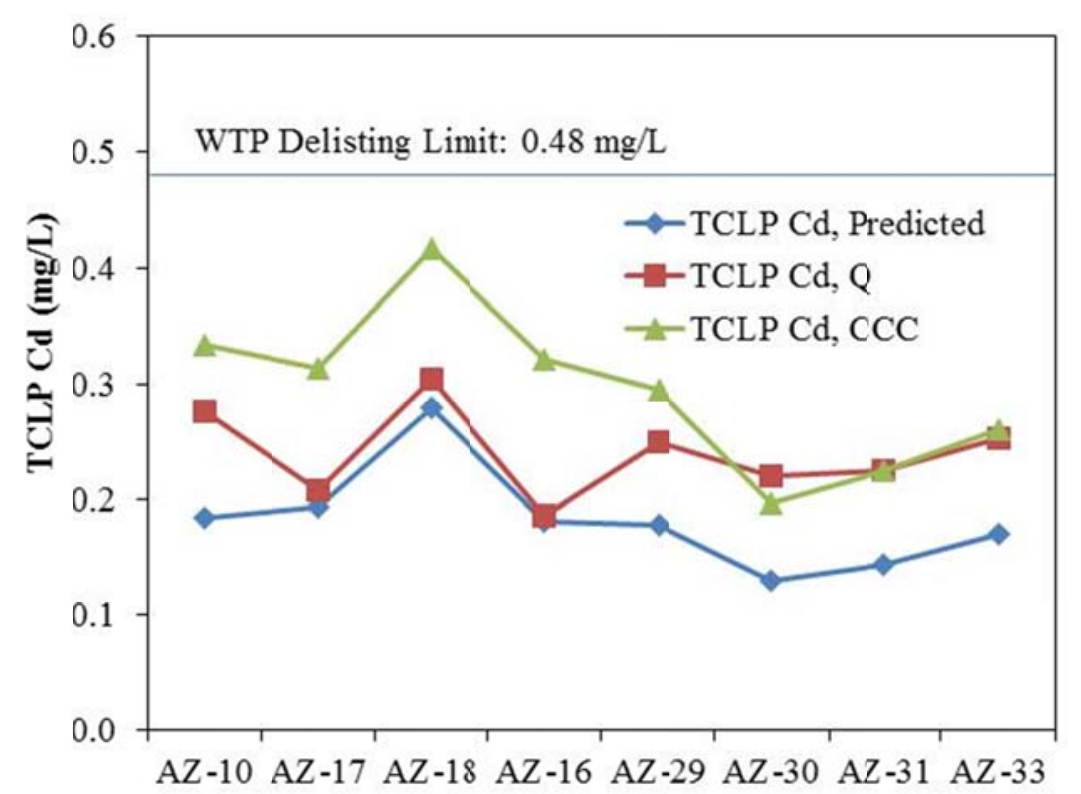

Figure 4.3. TCLP Cd of CCIM-AZ Glasses (AZ-10, 17, and 18 glasses have $17 \mathrm{wt} \% \mathrm{Fe}_{2} \mathrm{O}_{3}$, AZ-16 has 16 wt $\% \mathrm{Fe}_{2} \mathrm{O}_{3}$, and $\mathrm{AZ}-29$ through $\mathrm{AZ}-33$ have $15 \mathrm{wt} \% \mathrm{Fe}_{2} \mathrm{O}_{3}$ )

Table 4.7 summarizes the results of XRD analyses of isothermal heat-treated samples at temperatures from $900^{\circ} \mathrm{C}$ to $1250^{\circ} \mathrm{C}$ of CCIM-AZ glasses. Four crystalline phases were identified for isothermal heat-treated AZ-101 glasses: spinel and hematite $\left(\mathrm{Fe}_{2} \mathrm{O}_{3}\right)$ that contain $\mathrm{Fe}_{2} \mathrm{O}_{3}$ as a main constituent and baddeleyite and zircon $\left(\mathrm{ZrSiO}_{4}\right)$ that contain $\mathrm{ZrO}_{2}$. Spinel was a primary phase for all nine CCIM-AZ glasses.

Table 4.7. Crystal Vol\% after Isothermal Heat Treatment for CCIM-AZ Glasses

\begin{tabular}{|c|c|c|c|c|c|c|c|c|c|c|}
\hline $\mathbf{T},{ }^{\circ} \mathbf{C}$ & Crystal & AZ-10 & AZ-17 & AZ-18 & AZ-16 & AZ-29 & AZ-30 & AZ-31 & AZ-32 & AZ-33 \\
\hline \multirow{4}{*}{900} & Spinel & 3.2 & 2.6 & 2.6 & 2.5 & 2.9 & 3.5 & 3.1 & 2.0 & 2.0 \\
\hline & Hematite & 1.7 & 2.8 & 2.0 & 1.0 & - & 0.2 & - & 1.6 & 1.1 \\
\hline & Baddeleyite & 0.9 & 0.3 & 0.9 & 0.5 & - & - & - & - & - \\
\hline & Zircon & - & 1.6 & - & - & - & 0.3 & - & 0.3 & 0.1 \\
\hline \multirow{4}{*}{1000} & Spinel & 2.7 & 1.7 & 2.1 & 2.2 & 1.3 & 1.8 & 1.4 & 1.5 & 1.5 \\
\hline & Hematite & 1.0 & 2.1 & 1.1 & - & - & - & - & 0.2 & - \\
\hline & Baddeleyite & 0.8 & 0.5 & 0.9 & 0.5 & - & - & - & & - \\
\hline & Zircon & - & 1.0 & - & & - & 0.3 & - & 0.8 & - \\
\hline \multirow{3}{*}{1100} & Spinel & 1.6 & 1.5 & 1.8 & 1.3 & 0.9 & 1.1 & 0.7 & 1.0 & 0.9 \\
\hline & Hematite & - & 1.0 & - & - & - & - & - & - & - \\
\hline & Baddeleyite & 0.6 & 0.8 & 0.7 & 0.2 & - & - & - & - & - \\
\hline \multirow{3}{*}{1200} & Spinel & 1.5 & 1.9 & 1.5 & 0.8 & - & - & - & 0.8 & - \\
\hline & Hematite & - & 0.3 & - & - & - & - & - & - & - \\
\hline & Baddeleyite & 0.4 & 0.5 & 0.3 & - & - & - & - & - & - \\
\hline \multirow[t]{2}{*}{1250} & Spinel & 2.3 & 1.7 & 3.2 & 1.1 & - & - & - & 3.3 & - \\
\hline & Hematite & - & 1.0 & - & - & - & - & - & - & - \\
\hline
\end{tabular}


Figure 4.4 shows the effects of the heat-treating temperature on the total crystal vol\% (a) and spinel vol\% (b). The crystal content in general increased as the waste loading increased and decreased as the temperature increased. However, all glasses with $17 \mathrm{wt} \%$ and $16 \mathrm{wt} \% \mathrm{Fe}_{2} \mathrm{O}_{3}$ (CCIM-AZ-10 through 18) and one glass with $15 \mathrm{wt} \% \mathrm{Fe}_{2} \mathrm{O}_{3}$ (CCIM-AZ-32) exhibited the crystal content that increased as the temperature increased at higher temperatures. This unusual behavior is caused by formation of small crystals that occurred during "quenching" of the heat treated melts, but were not present at the higher heat-treatment temperature. The precipitation of these small spinel crystals makes it difficult to measure the $T_{L}$ and $T_{1 \%}$ values. Therefore, the $T_{L}$ and $T_{1 \%}$ values were estimated by extrapolating the crystal content data at lower temperatures.
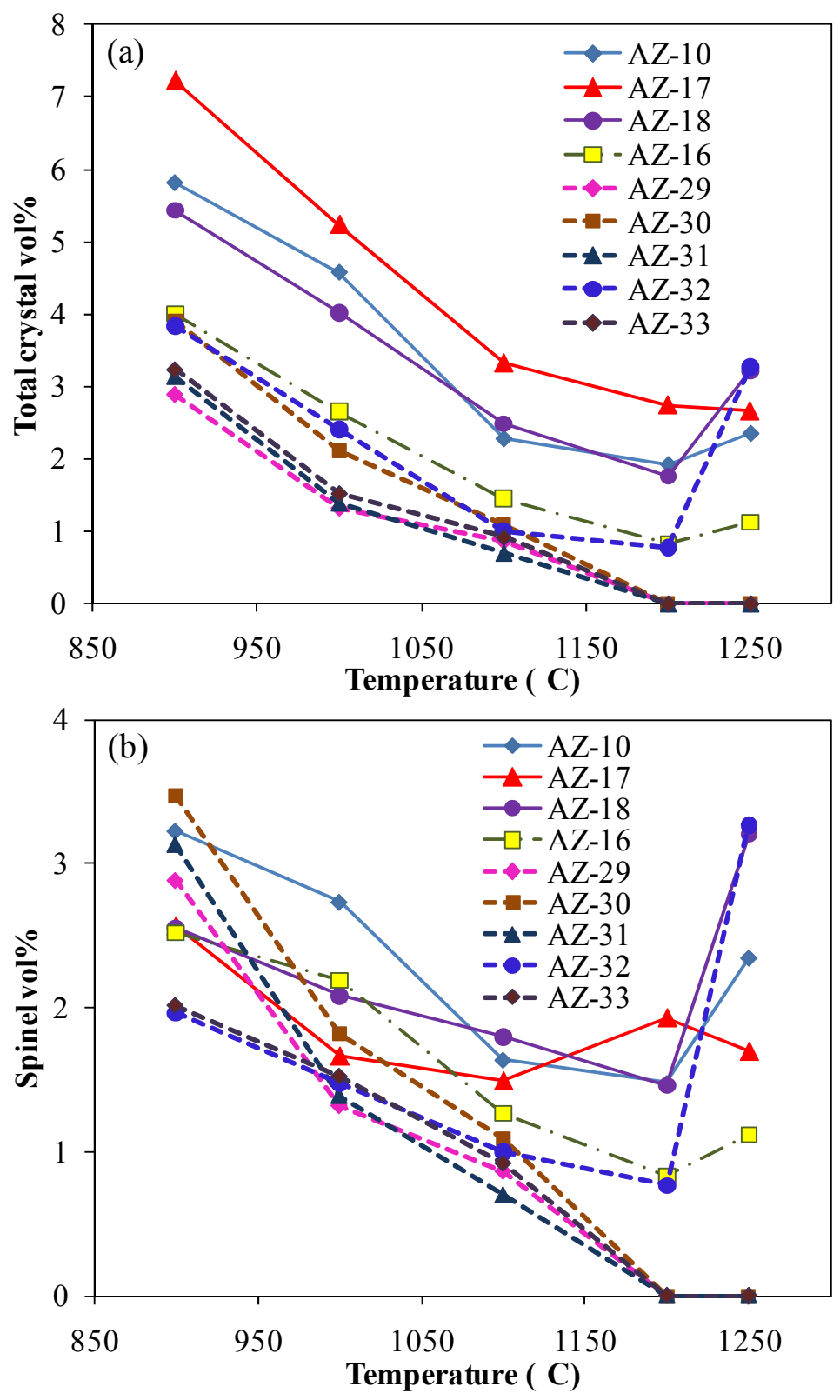

Figure 4.4. Total Crystal Vol\% (a) and Spinel Vol\% (b) As a Function of Temperature (AZ-10, 17, and 18 glasses have $17 \mathrm{wt} \% \mathrm{Fe}_{2} \mathrm{O}_{3}, \mathrm{AZ}-16$ has $16 \mathrm{wt} \% \mathrm{Fe}_{2} \mathrm{O}_{3}$, and $\mathrm{AZ}-29$ through $\mathrm{AZ}-33$ have $15 \mathrm{wt} \% \mathrm{Fe}_{2} \mathrm{O}_{3}$ ) 
Figure 4.5 displays the estimated spinel $T_{L}$ (a) and $T_{1 \%}$ (b) for all CCIM-AZ glasses tested. The estimated spinel $T_{L}$ and $T_{1 \%}$ showed a similar general trend, except for three glasses marked in as high- $\mathrm{B}_{2} \mathrm{O}_{3}$ glasses. Both the estimated spinel $T_{L}$ and $T_{1 \%}$ were higher than the predicted values for $17 \mathrm{wt} \% \mathrm{Fe}_{2} \mathrm{O}_{3}$ and $16 \mathrm{wt} \% \mathrm{Fe}_{2} \mathrm{O}_{3}$ glasses but agreed reasonably well with the predicted for $15 \mathrm{wt} \% \mathrm{Fe}_{2} \mathrm{O}_{3}$ glasses. It is likely that the outlying results for the three glasses with high $\mathrm{B}_{2} \mathrm{O}_{3}$ concentrations marked in Figure 4.5 were caused by the precipitation of small spinel crystals that interfered with the estimation of $T_{L}$ and $T_{1 \%}$. However, the reason for the high- $\mathrm{B}_{2} \mathrm{O}_{3}$ glasses to be more susceptible for these small spinel crystals is not clear.
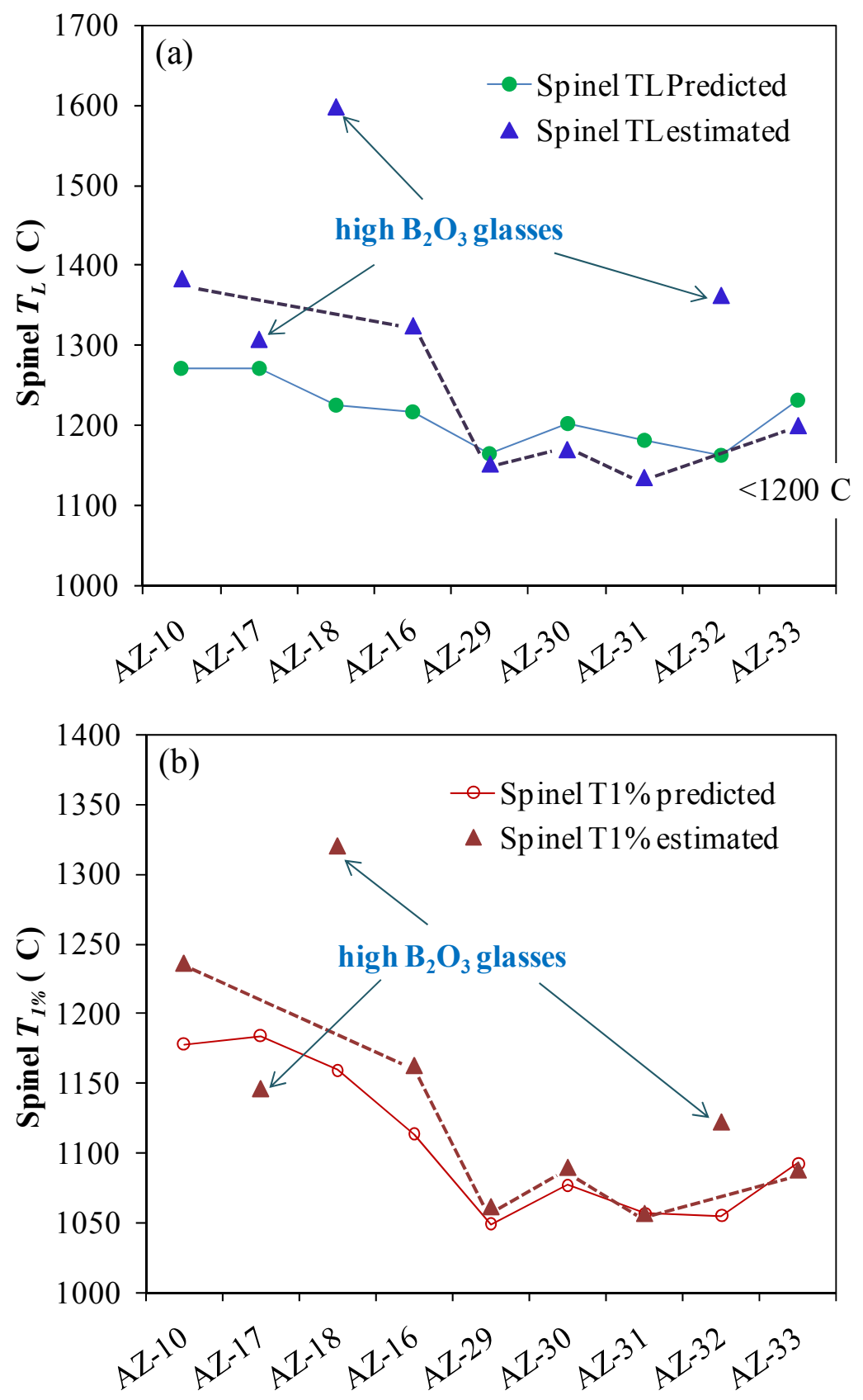

Figure 4.5. Estimated Spinel $T_{L}$ (a) and $T_{1 \%}$ (b) Compared with Predicted Values 
Based on total crystal vol\% and spinel vol\% versus temperature data in Figure 4.4 and the estimated spinel $T_{L}$ and $T_{1 \%}$ in Figure 4.5, the three glasses with $17 \mathrm{wt} \%, 16 \mathrm{wt} \%$, and $15 \mathrm{wt} \% \mathrm{Fe}_{2} \mathrm{O}_{3}, \mathrm{CCIM}-\mathrm{AZ}-10$, 16 , and 29, respectively, were selected for initial CCIM demonstration tests. The estimated spinel $T_{L}$ and $T_{1 \%}$ increase as waste loading increases in these three glasses (Figure 4.5). Figure 4.6 displays the total crystal vol\% (a) and spinel vol\% (b) as a function of temperature for the selected three glasses.
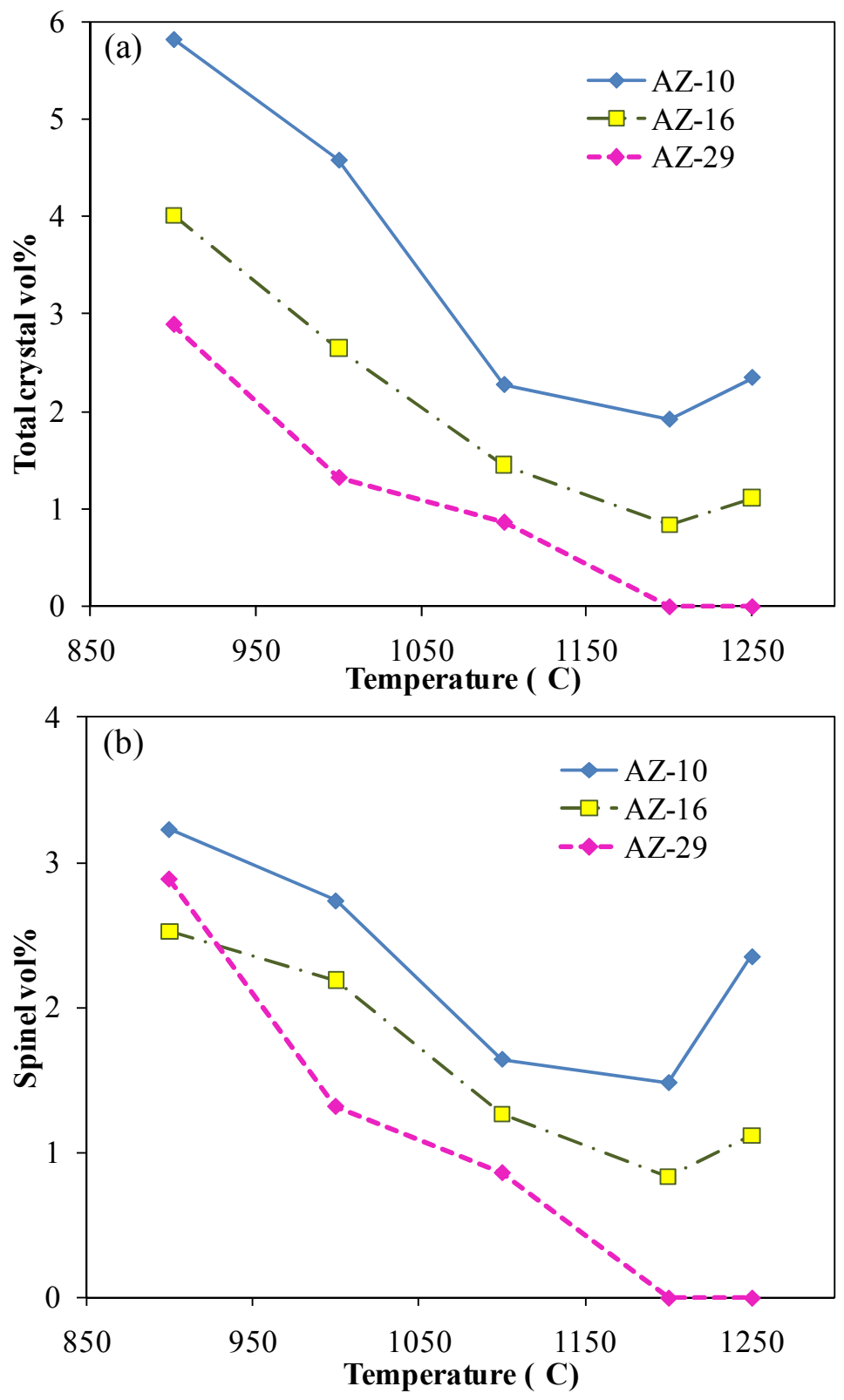

Figure 4.6. Total Crystal Vol\% (a) and Spinel Vol\% (b) As a Function of Temperature for Selected Three Glasses (AZ-10, 16, and 29 glasses have 17, 16, and $15 \mathrm{wt} \% \mathrm{Fe}_{2} \mathrm{O}_{3}$, respectively)

Table 4.8 summarizes the composition of three selected glasses. They all have the same $\mathrm{B}_{2} \mathrm{O}_{3}$ and $\mathrm{Li}_{2} \mathrm{O}$ concentrations. As the waste loading increases, the concentrations of major waste components $\left(\mathrm{Al}_{2} \mathrm{O}_{3}, \mathrm{Fe}_{2} \mathrm{O}_{3}\right.$, and $\left.\mathrm{ZrO}_{2}\right)$ increase, and the concentration of $\mathrm{Na}_{2} \mathrm{O}$, which was adjusted to keep the predicted viscosity constant, gradually decreases. Table 4.8 also includes estimated values for spinel $T_{L}$, 
$T_{1 \%}$, and total crystal and spinel vol\% at $950{ }^{\circ} \mathrm{C}$ and $1150{ }^{\circ} \mathrm{C}$. Figure 4.7 displays the total crystal vol $\%$ (a) and spinel vol\% (b) as a function of waste loading for the selected three glasses, which shows that the crystal content increases as waste loading increases. The CCIM technologies possess the potential for higher tolerance to crystals in the melt. By processing these glasses during the CCIM demonstration tests starting at $39.8 \mathrm{wt} \%$ waste loading $\left(15 \mathrm{wt} \% \mathrm{Fe}_{2} \mathrm{O}_{3}\right)$ and increasing to $42.5 \mathrm{wt} \%\left(16 \mathrm{wt} \% \mathrm{Fe}_{2} \mathrm{O}_{3}\right)$ and to $45.1 \mathrm{wt} \%\left(17 \mathrm{wt} \% \mathrm{Fe}_{2} \mathrm{O}_{3}\right)$, it would be possible to evaluate the CCIM's tolerance to crystals in the melt within the range of crystal contents summarized in Figure 4.7.

Table 4.8. Target Compositions of Major Components in Three Selected Glasses

\begin{tabular}{|c|c|c|c|}
\hline Glass & AZ-29 & AZ-16 & AZ-10 \\
\hline $\mathrm{Al}_{2} \mathrm{O}_{3}$ & 9.79 & 10.44 & 11.09 \\
\hline $\mathrm{B}_{2} \mathrm{O}_{3}$ & 11.00 & 11.00 & 11.00 \\
\hline $\mathrm{Fe}_{2} \mathrm{O}_{3}$ & 15.00 & 16.00 & 17.00 \\
\hline $\mathrm{Li}_{2} \mathrm{O}$ & 3.00 & 3.00 & 3.00 \\
\hline $\mathrm{Na}_{2} \mathrm{O}$ & 11.99 & 11.38 & 10.78 \\
\hline $\mathrm{SiO}_{2}$ & 39.93 & 38.26 & 36.59 \\
\hline $\mathrm{ZrO}_{2}$ & 4.55 & 4.85 & 5.16 \\
\hline Subtotal $^{(\mathrm{a})}$ & 95.26 & 94.94 & 94.63 \\
\hline Waste loading, wt $\%$ & 39.8 & 42.5 & 45.1 \\
\hline $\mathrm{Al}_{2} \mathrm{O}_{3}+\mathrm{Fe}_{2} \mathrm{O}_{3}+\mathrm{ZrO}_{2}$ & 29.3 & 31.3 & 33.3 \\
\hline$T_{m}$ at $4 \mathrm{~Pa} \cdot \mathrm{s},{ }^{\circ} \mathrm{C}$ & 1200 & 1200 & 1200 \\
\hline Estimated $T_{L}$ & 1152 & 1325 & 1384 \\
\hline Estimated $T_{1 \%}$ & 1062 & 1163 & 1237 \\
\hline Estimated total crystal vol\% at $950{ }^{\circ} \mathrm{C}^{(\mathrm{b})}$ & 2.2 & 3.3 & 5.1 \\
\hline Estimated total crystal vol\% at $1050^{\circ} \mathrm{C}^{(\mathrm{b})}$ & 0.2 & 0.8 & 1.6 \\
\hline Estimated spinel vol $\%$ at $950{ }^{\circ} \mathrm{C}^{(b)}$ & 2.2 & 2.3 & 3.0 \\
\hline Estimated spinel vol\% at $1050{ }^{\circ} \mathrm{C}^{(\mathrm{b})}$ & 0.2 & 1.0 & 1.4 \\
\hline \multicolumn{4}{|c|}{$\begin{array}{l}\text { (a) Balance is remaining waste components. } \\
\text { (b) Obtained from linear fit of total crystal or spinel vol } \% \text { versus temperature } \\
\text { data up to } 1100^{\circ} \mathrm{C} \text {. }\end{array}$} \\
\hline
\end{tabular}



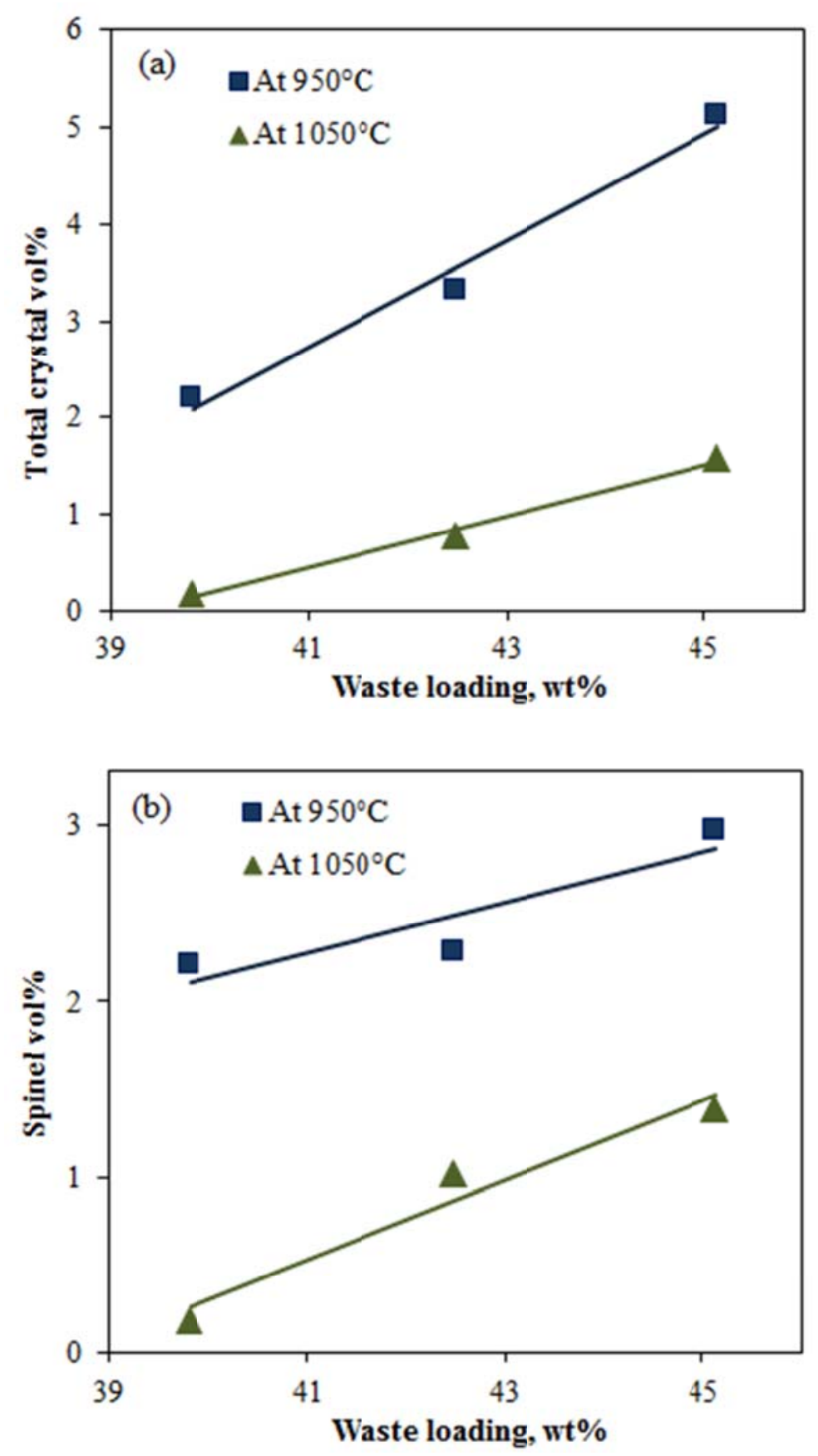

Figure 4.7. Total Crystal Vol\% (a) and Spinel Vol\% (b) As a Function of Waste Loading for Selected Three Glasses

Table 4.9 summarizes the viscosity and electrical conductivity of three glasses selected for the CCIM demonstration tests. Figure 4.8 displays the results of viscosity (a) and electrical conductivity (b) as a function of temperature for these three glasses. All three glasses had almost the same predicted viscosity (average predicted value is included in Figure 4.8a). The measured viscosities were reasonably well predicted for all three glasses at temperatures equal to or higher than $1150^{\circ} \mathrm{C}$. The viscosities at lower temperatures were likely to be affected by the crystal contents given in Figure 4.6, i.e., the measured viscosities were higher than predicted, and the low-temperature viscosity increased as the waste loading 
increased. The measured viscosity was $\sim 4 \mathrm{~Pa} \cdot \mathrm{s}$ at $1200^{\circ} \mathrm{C}$; i.e., the recommended melting temperature is $1200{ }^{\circ} \mathrm{C}$ for all three glasses. For electrical conductivity, three glasses had different predicted values as shown in Figure 4.8b. Figure 4.8b shows that the measured electrical conductivities were lower than predicted, and the measured differences between glasses were greater than predicted. However, the measured electrical conductivities for all three glasses were within the desired range of $10 \mathrm{~S} / \mathrm{m}$ to $100 \mathrm{~S} / \mathrm{m}$ at a recommended melting temperature of $1200^{\circ} \mathrm{C}$ (Marra et al. 2008).
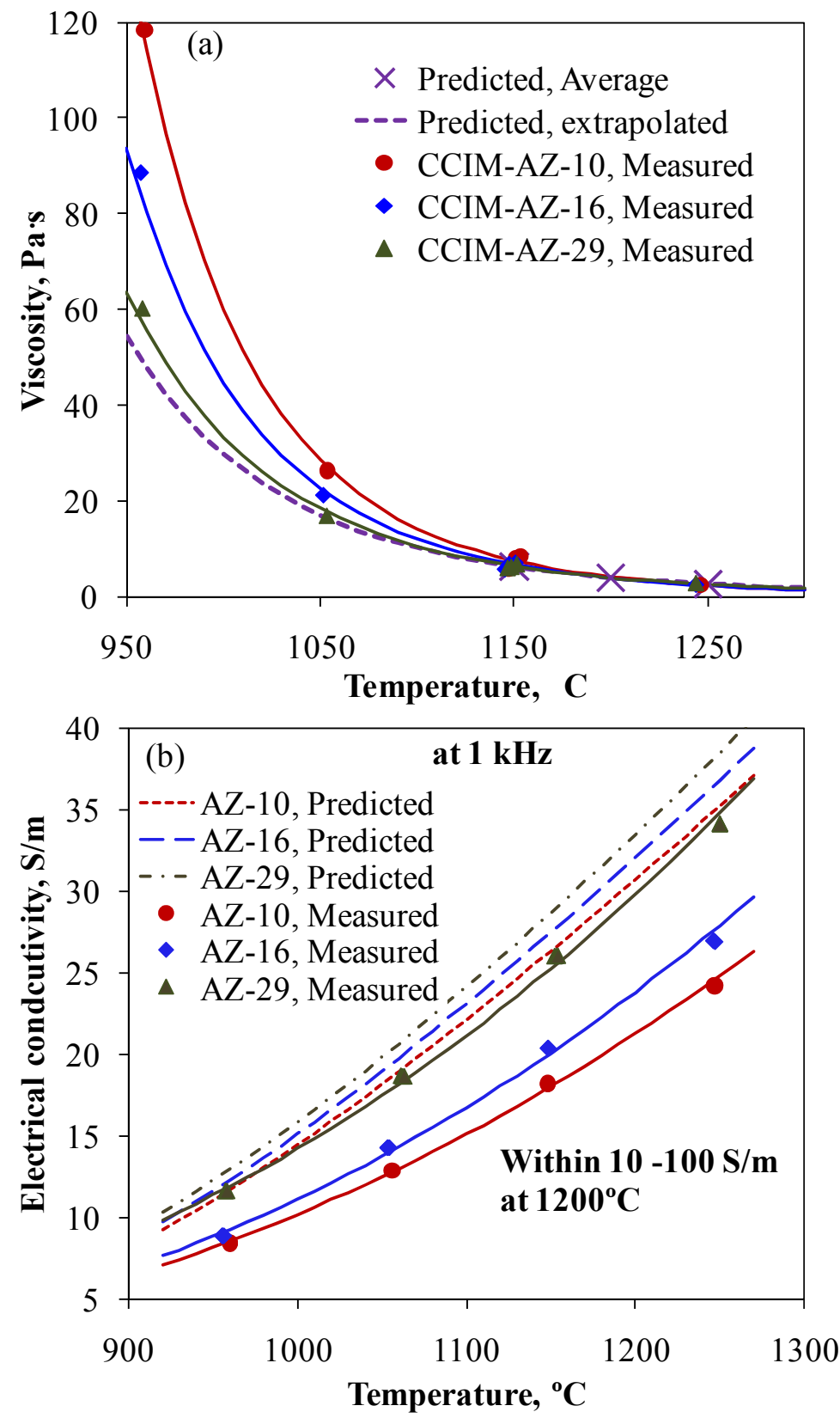

Figure 4.8. Viscosity (a) and Electrical Conductivity (b) of Three Glasses Selected for CCIM Tests (AZ-10, 16, and 29 glasses have 17, 16, and $15 \mathrm{wt} \% \mathrm{Fe}_{2} \mathrm{O}_{3}$, respectively) 
Table 4.9. Measured Viscosity and Electrical Conductivity of Three Selected Glasses

\begin{tabular}{|c|c|c|c|c|c|}
\hline \multicolumn{2}{|c|}{ CCIM-AZ-10 } & \multicolumn{2}{|c|}{ CCIM-AZ-16 } & \multicolumn{2}{|c|}{ CCIM-AZ-29 } \\
\hline \multicolumn{6}{|c|}{ Viscosity $(n)$ at a given temperature } \\
\hline T, $\mathbf{C}$ & $\eta, \mathbf{P a} \cdot \mathbf{s}$ & $\mathbf{T}, \mathbf{C}$ & $\eta, \mathbf{P a} \cdot \mathbf{s}$ & $\mathbf{T}, \mathrm{C}$ & $\eta, \mathbf{P a} \cdot \mathbf{s}$ \\
\hline 1151 & 8.14 & 1147 & 6.91 & 1148 & 6.20 \\
\hline 1053 & 26.30 & 1051 & 21.34 & 1053 & 16.87 \\
\hline 959 & 118.47 & 957 & 88.73 & 958 & 60.19 \\
\hline 1153 & 8.36 & 1151 & 7.20 & 1151 & 6.75 \\
\hline 1246 & 2.49 & 1244 & 2.63 & 1243 & 2.82 \\
\hline 1147 & 5.89 & 1145 & 5.86 & 1146 & 5.97 \\
\hline \multicolumn{6}{|c|}{ Electrical conductivity (q) at a given temperature $(1 \mathrm{kHz})$} \\
\hline $\mathbf{T}, \mathbf{C}$ & $\varepsilon, \mathbf{S} / \mathbf{m}$ & $\mathbf{T}, \mathbf{C}$ & $\varepsilon, \mathbf{S} / \mathbf{m}$ & $\mathbf{T}, \mathbf{C}$ & $\varepsilon, \mathbf{S} / \mathbf{m}$ \\
\hline 960 & 8.47 & 955 & 8.90 & 957 & 11.59 \\
\hline 1056 & 12.90 & 1053 & 14.29 & 1062 & 18.63 \\
\hline 1148 & 18.20 & 1148 & 20.38 & 1153 & 26.00 \\
\hline 1247 & 24.25 & 1246 & 26.93 & 1250 & 34.09 \\
\hline
\end{tabular}

\subsection{Cold Crucible Induction Melter Glass Formulation for AN-105 LAW}

The composition of AN-105 LAW was given in Table 2.1. As discussed in Section 2.1, the loading of $\mathrm{AN}-105$ is limited by $\mathrm{Na}_{2} \mathrm{O}$ concentration in glass that dictates the chemical durability of glass. The higher melting temperature of CCIM technologies would allow higher concentrations of refractory additive components that increase chemical durability, such as $\mathrm{ZrO}_{2}$ and $\mathrm{SnO}_{2}$, which may enable higher waste loading.

\subsubsection{Preliminary Vapor Hydration Test Model for High Alkali Glasses}

For AN-105 LAW, the key properties that limit waste loading are the PCT normalized releases and the VHT alteration rate. Existing PCT normalized release models (Vienna et al. 2009) were used because the PCT models provide reasonable predictability for the present purpose. Although the recent models reported in Vienna et al. (2009) were developed primarily for estimating HLW glass volumes, they are considered global models and can be used for LAW glasses. They were developed from the compiled database that covers a large fraction of the region of waste glass compositions considered potentially of interest for Hanford including LAW glasses.

However, the performance of the VHT alteration rate model is in general poor compared to the PCT models. In addition, the recent models report (Vienna et al. 2009) does not include the model for VHT alteration rate. Therefore, existing data on the VHT response in glasses with high alkali oxides were collected and used to develop a preliminary VHT model suited for the high-waste-loaded AN-105 based glasses in this study.

The VHT alteration rate data were collected from a glass database that has been compiled at PNNL, which was also used for the development of the glass property models reported in Vienna et al. (2009). The VHT data reported in four data sets were considered:

- WTP glasses. This data set includes the glasses tested at VSL to develop the LAW glass property models for WTP. The data collection and model development are reported in Piepel et al. (2007). 
The VHT alteration rate was based on 24-day tests at $200^{\circ} \mathrm{C}$. One hundred eighty-one glasses had VHT alteration rate data.

- ORP glasses. This data set includes the glasses resulting from the glass formulation developments performed at VSL for ORP to increase the waste loading in LAW glasses, reported in Matlack et al. (2006, 2007b, and 2009). The VHT alteration rate was based on 24-day tests at $200^{\circ} \mathrm{C}$. One hundred seventeen glasses had VHT alteration rate data.

- Hanford LAW product (HLP) acceptance glasses. This data set includes the HLP glasses developed and tested at PNNL to help determine the composition range of LAW glasses that will meet performance expectations of the Hanford site burial facility (Vienna et al 2001). The VHT alteration rate after 24 days was obtained from the plots of VHT alteration mass versus time. For some glasses, extrapolation was needed. Only the glasses with reasonable extrapolation were considered, i.e., the glasses with too much scatter or with test periods too far away from 24 days were excluded. Seventy-two glasses had the VHT data converted to 24-day rate.

- in-container vitrification (ICV) glasses: This data set includes the ICV glasses tested at PNNL under the demonstration bulk vitrification system (DBVS) to evaluate the bulk vitrification as a candidate technology for LAW supplement treatment (Kim et al. 2003). The VHT alteration rate was based on 14-day tests at $200^{\circ} \mathrm{C}$. Ninety-three glasses had VHT alteration rate data.

As mentioned above, the VHT alteration rate was based on the 24-day tests except for the data set for ICV glasses. These 463 glasses were further sorted to collect the high-alkali borosilicate glasses, i.e., only the glasses that satisfy the following conditions were collected:

- $g_{\mathrm{B} 2 \mathrm{O} 3} \geq 4 \mathrm{wt} \%$

- $g_{\mathrm{Na} 2 \mathrm{O}}+0.66 g_{\mathrm{K} 2 \mathrm{O}}+2.07 g_{\mathrm{Li} 2 \mathrm{O}} \geq 16 \mathrm{wt} \%$

Additional glasses were excluded as they were not adequate for the model:

- CCC treated glasses

- glasses that completely corroded before the end of test duration (24 days or 14 days)

- glasses with no corrosion after the end of test duration (24 days or 14 days)

- glasses that formed a significant fraction of crystals during melting (applicable to HLP glasses only).

Table 4.10 summarizes the glasses collected for VHT model development, including the number of glasses with VHT alteration data and those used for model development after excluding the glasses for the reasons described above. Table 4.10 also shows the range of concentrations for the components of interest including $g_{\mathrm{Na} 2 \mathrm{O}}+0.66 g_{\mathrm{K} 2 \mathrm{O}}+2.07 g_{\mathrm{Li} 2 \mathrm{O}}$ and the range of VHT alteration rates. Appendix B, Table B. 1 lists the composition and VHT alteration rate for 257 glasses used for VHT model development. 
Table 4.10. Summary of Glasses with VHT Data

\begin{tabular}{|c|c|c|c|c|c|c|c|c|c|c|}
\hline Data Set & \multicolumn{2}{|c|}{ ORP Glasses } & \multicolumn{2}{|c|}{ WTP Glasses } & \multicolumn{2}{|c|}{ HLP Glasses } & \multicolumn{2}{|c|}{ ICV Glasses } & \multicolumn{2}{|c|}{ All Glasses } \\
\hline \# of glasses with VHT data & \multicolumn{2}{|c|}{117} & \multicolumn{2}{|c|}{181} & \multicolumn{2}{|c|}{72} & \multicolumn{2}{|c|}{93} & \multicolumn{2}{|c|}{463} \\
\hline \# of glasses used for model & \multicolumn{2}{|c|}{83} & \multicolumn{2}{|c|}{86} & \multicolumn{2}{|c|}{51} & \multicolumn{2}{|c|}{37} & \multicolumn{2}{|c|}{257} \\
\hline \multicolumn{11}{|c|}{ Component concentration range (in mass fraction) of the glasses used for model } \\
\hline Component & Min & Max & Min & Max & Min & Max & Min & Max & Min & Max \\
\hline $\mathrm{Al}_{2} \mathrm{O}_{3}$ & 0.058 & 0.136 & 0.050 & 0.090 & 0.040 & 0.120 & 0.080 & 0.168 & 0.040 & 0.168 \\
\hline $\mathrm{B}_{2} \mathrm{O}_{3}$ & 0.061 & 0.128 & 0.061 & 0.130 & 0.060 & 0.126 & 0.040 & 0.060 & 0.040 & 0.130 \\
\hline $\mathrm{CaO}$ & 0.000 & 0.105 & 0.000 & 0.100 & 0.000 & 0.050 & 0.025 & 0.055 & 0.000 & 0.105 \\
\hline $\mathrm{Fe}_{2} \mathrm{O}_{3}$ & 0.000 & 0.030 & 0.000 & 0.100 & 0.000 & 0.158 & 0.040 & 0.110 & 0.000 & 0.158 \\
\hline $\mathrm{K}_{2} \mathrm{O}$ & 0.001 & 0.059 & 0.000 & 0.054 & 0.003 & 0.03 & 0.000 & 0.025 & 0.000 & 0.059 \\
\hline $\mathrm{Li}_{2} \mathrm{O}$ & 0.000 & 0.036 & 0.000 & 0.045 & 0.000 & 0.001 & 0.000 & 0.000 & 0.000 & 0.045 \\
\hline $\mathrm{MgO}$ & 0.000 & 0.034 & 0.000 & 0.037 & 0.000 & 0.043 & 0.000 & 0.030 & 0.000 & 0.043 \\
\hline $\mathrm{Na}_{2} \mathrm{O}$ & 0.130 & 0.260 & 0.131 & 0.240 & 0.160 & 0.236 & 0.170 & 0.240 & 0.130 & 0.260 \\
\hline $\mathrm{SiO}_{2}$ & 0.343 & 0.433 & 0.383 & 0.491 & 0.360 & 0.598 & 0.390 & 0.501 & 0.343 & 0.598 \\
\hline $\mathrm{SnO}_{2}$ & 0.000 & 0.050 & 0.000 & 0.000 & 0.000 & 0.000 & 0.000 & 0.000 & 0.000 & 0.050 \\
\hline $\mathrm{SO}_{3}$ & 0.002 & 0.021 & 0.001 & 0.024 & 0.001 & 0.003 & 0.000 & 0.010 & 0.000 & 0.024 \\
\hline $\mathrm{TiO}_{2}$ & 0.000 & 0.016 & 0.004 & 0.030 & 0.000 & 0.086 & 0.000 & 0.020 & 0.000 & 0.086 \\
\hline $\mathrm{ZnO}$ & 0.010 & 0.037 & 0.010 & 0.050 & 0.000 & 0.043 & 0.000 & 0.000 & 0.000 & 0.050 \\
\hline $\mathrm{ZrO}_{2}$ & 0.030 & 0.061 & 0.000 & 0.050 & 0.000 & 0.060 & 0.020 & 0.080 & 0.000 & 0.080 \\
\hline $\mathrm{Na}_{2} \mathrm{O}+0.66 \mathrm{~K}_{2} \mathrm{O}+2.07 \mathrm{Li}_{2} \mathrm{O}$ & 0.205 & 0.264 & 0.171 & 0.245 & 0.162 & 0.239 & 0.170 & 0.251 & 0.162 & 0.264 \\
\hline \multicolumn{11}{|c|}{ VHT alteration rate range for the glasses used for model } \\
\hline$r_{a l t}\left(\mathrm{~g} / \mathrm{m}^{2} / \mathrm{d}\right)$ & 2.0 & 130.0 & 0.2 & 108.2 & 0.4 & 87.8 & 0.3 & 147.1 & 0.2 & 147.1 \\
\hline $\ln \left(r_{a l t}\right), \ln \left(\mathrm{g} / \mathrm{m}^{2} / \mathrm{d}\right)$ & 0.69 & 4.87 & -1.61 & 4.68 & -1.00 & 4.47 & -1.15 & 4.99 & -1.61 & 4.99 \\
\hline
\end{tabular}

A simple linear model form was applied for the 257 model glasses:

$$
\ln \left(r_{\text {alt }}\right)=\sum_{n=1}^{14} g_{i} b_{i}
$$

where $r_{\text {alt }}$ is the VHT alteration rate $\left(\mathrm{g} / \mathrm{m}^{2} / \mathrm{d}\right), g_{i}$ is the mass fraction of the $i^{\text {th }}$ component in glass, and $b_{i}$ is the model coefficient for the $i^{\text {th }}$ component. Table 4.11 lists the model coefficients and $R^{2}$ value for the 14 component model (13 oxide components plus "Others" component that represents the sum of all components not specifically listed in the 13). The poor predictability of this model is evident from the low $R^{2}$ value of 0.593 , which suggests that the output of this model should be used with caution. The $2^{\text {nd }}$ order model or any other model forms to improve the predictability were not explored for the present study as they are notorious for poor performance when extrapolated. Figure 4.9 shows the predicted versus measured VHT alteration rate for each data set. Except for the ORP glasses that had high alkali glasses only and therefore had overall high VHT alteration rates, the three data sets had similar range of the measured VHT rates. 
Table 4.11. VHT Model Coefficients

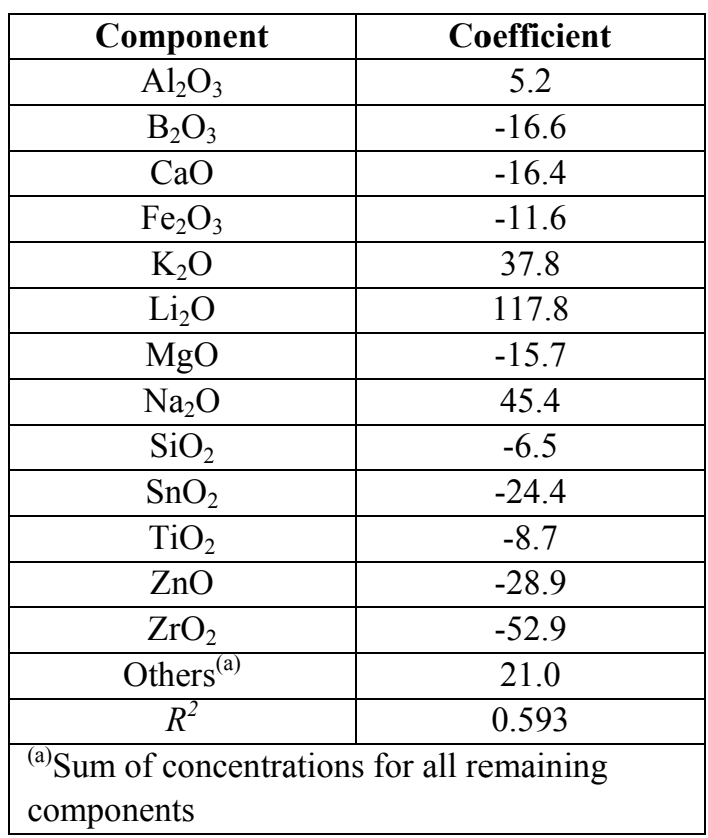

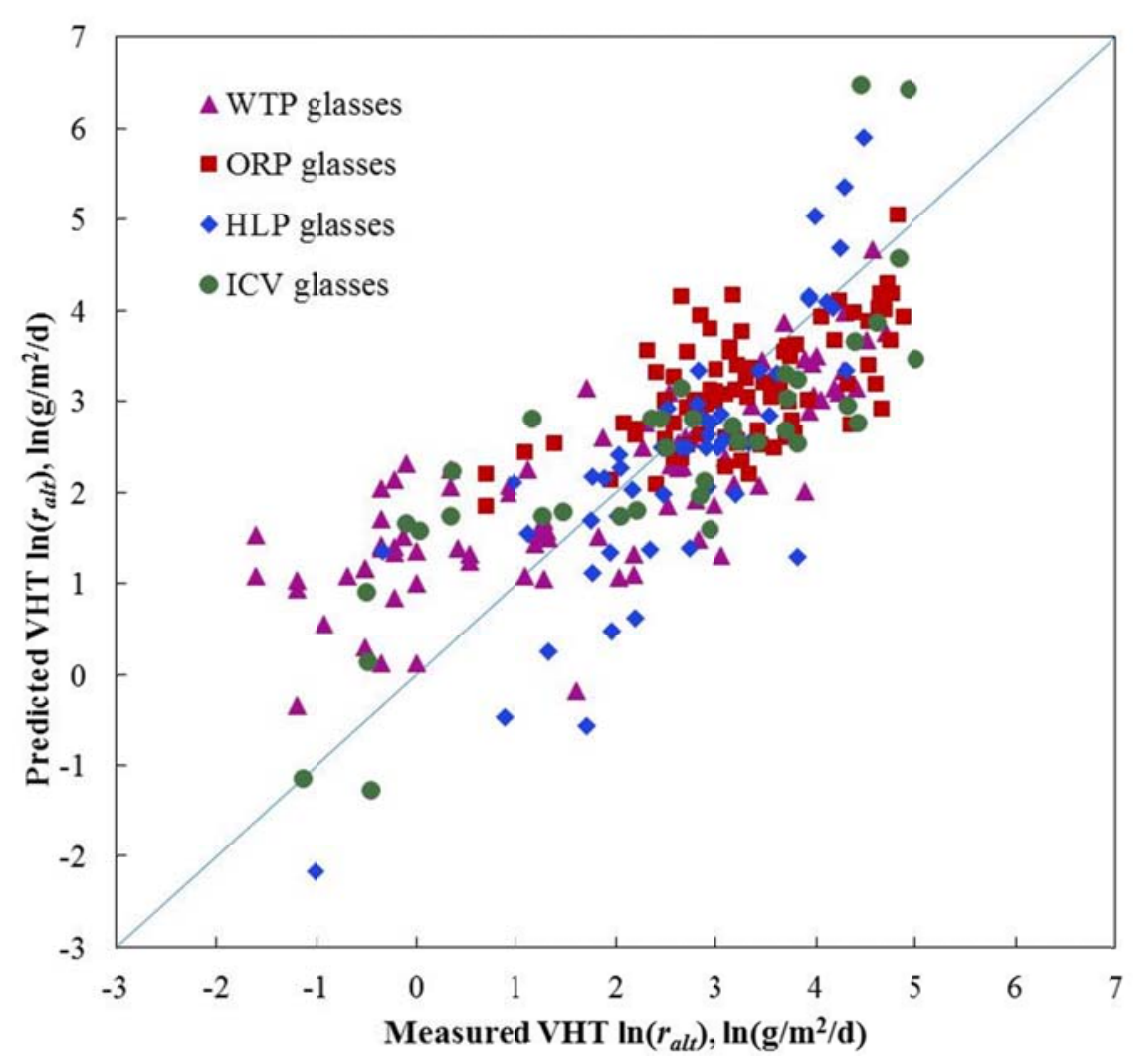

Figure 4.9. Predicted versus Measured VHT Alteration Rate

The preliminary model was used to plot the effect of glass composition on the VHT alteration rate in $\ln \left(\mathrm{g} / \mathrm{m}^{2} / \mathrm{d}\right)$. The baseline glass was selected as a typical WTP glass containing:

- $20 \mathrm{wt} \% \mathrm{Na}_{2} \mathrm{O}$ 
- fixed concentrations for $\mathrm{Al}_{2} \mathrm{O}_{3}, \mathrm{~B}_{2} \mathrm{O}_{3}, \mathrm{Fe}_{2} \mathrm{O}_{3}, \mathrm{TiO}_{2}, \mathrm{ZnO}$, and $\mathrm{ZrO}_{2}$ according to the WTP glass formulation rules (Vienna 2005)

- arbitrarily chosen concentration at $3 \mathrm{wt} \%$ for components with variable concentrations according to the WTP glass formulation rules (Vienna 2005), which include $\mathrm{Li}_{2} \mathrm{O}, \mathrm{K}_{2} \mathrm{O}, \mathrm{CaO}$, and $\mathrm{MgO}$

- $\mathrm{SiO}_{2}$ concentration as a balance.

Table 4.12 shows the composition of the baseline glass.

Table 4.12. Composition of a Baseline Glass Used for Calculation of the Effect of Glass Composition on VHT Alteration Rate

\begin{tabular}{|c|c|}
\hline Oxide & Mass fraction \\
\hline $\mathrm{Al}_{2} \mathrm{O}_{3}$ & 0.061 \\
\hline $\mathrm{B}_{2} \mathrm{O}_{3}$ & 0.100 \\
\hline $\mathrm{CaO}$ & 0.030 \\
\hline $\mathrm{Fe}_{2} \mathrm{O}_{3}$ & 0.055 \\
\hline $\mathrm{K}_{2} \mathrm{O}$ & 0.030 \\
\hline $\mathrm{Li}_{2} \mathrm{O}$ & 0.010 \\
\hline $\mathrm{MgO}$ & 0.030 \\
\hline $\mathrm{Na}_{2} \mathrm{O}$ & 0.200 \\
\hline $\mathrm{SiO}_{2}$ & 0.405 \\
\hline $\mathrm{TiO}_{2}$ & 0.014 \\
\hline $\mathrm{ZnO}$ & 0.035 \\
\hline $\mathrm{ZrO}$ & 0.030 \\
\hline $\mathrm{SUM}$ & 1.000 \\
\hline
\end{tabular}

Figure 4.10 shows the change of predicted VHT alteration rate (in $\ln \left[\mathrm{g} / \mathrm{m}^{2} / \mathrm{d}\right]$ ) as a function of mass $\%$ change of a glass component from the baseline glass calculated using the model given in Table 4.11. Figure 4.10 shows that alkali oxides strongly increase the VHT alteration rate while most other major LAW glass components, except for $\mathrm{Al}_{2} \mathrm{O}_{3}$, decrease the alteration rate. The addition of $\mathrm{Al}_{2} \mathrm{O}_{3}$ is predicted to slightly increase the alteration rate.

To compare the compositional effect for VHT with that for PCT, the PCT-Na model given in Vienna et al. (2009) was used to perform similar calculations. The results are shown in Figure 4.11 for PCT normalized sodium release. The PCT-Na models in Vienna et al. 2009 used the second order model form, with the second order terms for $\mathrm{Al}_{2} \mathrm{O}_{3}$ and $\mathrm{B}_{2} \mathrm{O}_{3}$. As shown in Figure 4.11, the $\mathrm{B}_{2} \mathrm{O}_{3}$ addition decreases the PCT release initially at low concentrations but increases the PCT release with further increase in $\mathrm{B}_{2} \mathrm{O}_{3}$ concentration after a minimum. The effect of $\mathrm{Al}_{2} \mathrm{O}_{3}$ is very strong at lower concentrations and becomes smaller as concentration of $\mathrm{Al}_{2} \mathrm{O}_{3}$ increases. There is similarity between VHT and PCT in that alkali oxides increase the glass corrosion while $\mathrm{ZnO}, \mathrm{SiO}_{2}, \mathrm{Fe}_{2} \mathrm{O}_{3}$, and $\mathrm{ZrO}_{2}$ all decrease the glass corrosion. The major difference lies in the effect of $\mathrm{Al}_{2} \mathrm{O}_{3}$ and $\mathrm{B}_{2} \mathrm{O}_{3}$ : $\mathrm{Al}_{2} \mathrm{O}_{3}$ has a strong positive effect on PCT with a slight negative effect on VHT, but $\mathrm{B}_{2} \mathrm{O}_{3}$ has a positive effect on VHT with relatively strong negative effect on PCT at higher $\mathrm{B}_{2} \mathrm{O}_{3}$ concentration range. Another difference to note is that both $\mathrm{CaO}$ and $\mathrm{SnO}_{2}$ have positive effect on VHT but no effect on PCT. Glass formulation applies this information on the effect of the glass composition on PCT and VHT while keeping the viscosity and melting temperature within desired range. 


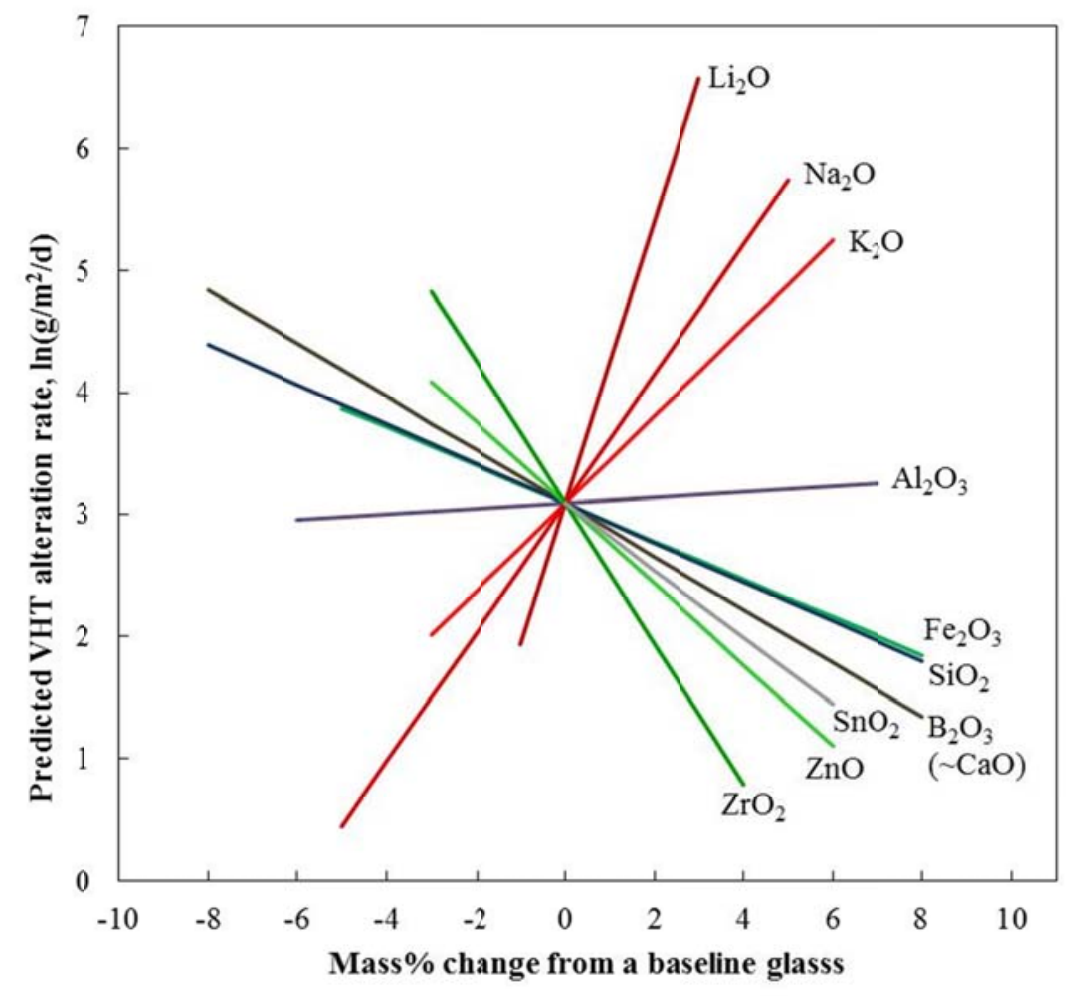

Figure 4.10. VHT Spider Plot for the Effect of Component Mass\% Change on $\ln \left(r_{\text {alt }}\right)$

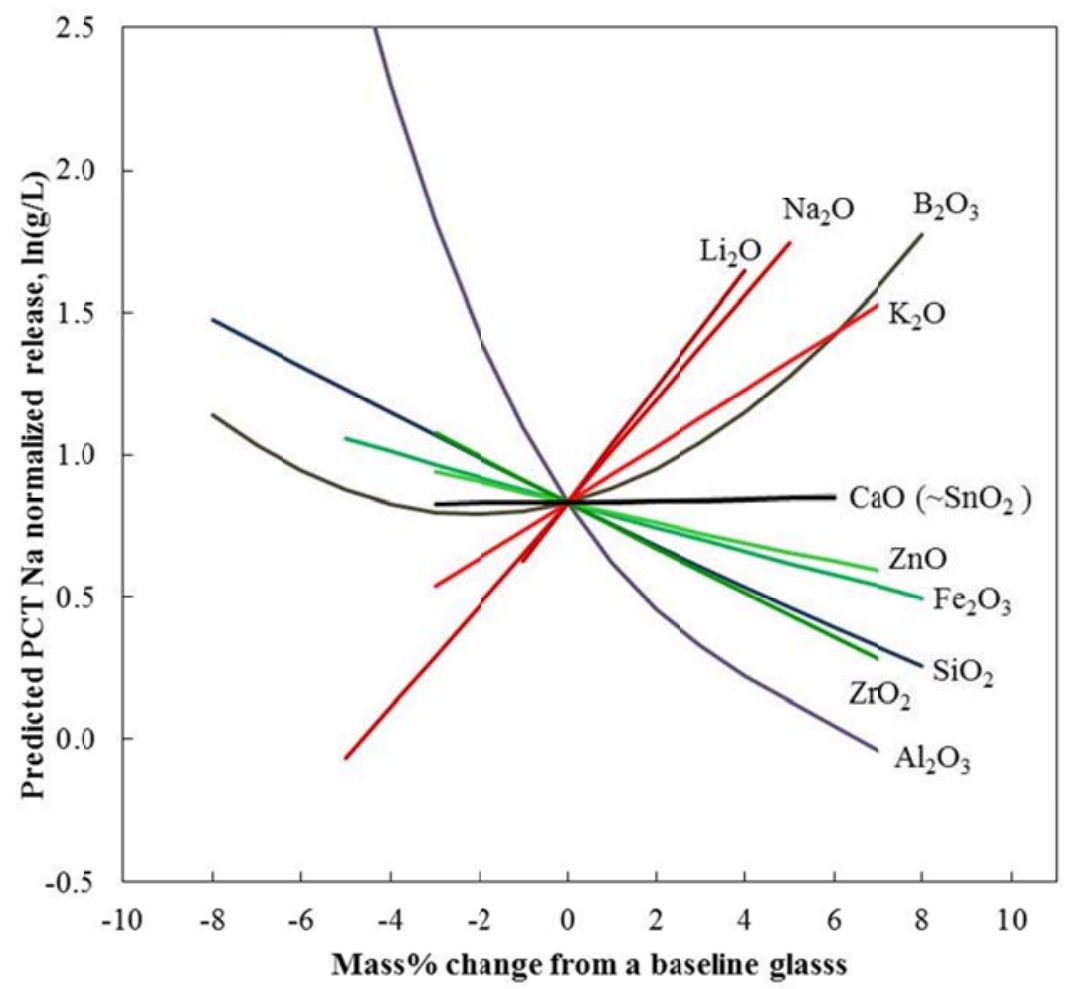

Figure 4.11. PCT Spider Plot for the Effect of Component Mass\% Change on $\ln \left(r_{N a}\right)$ 


\subsubsection{Formulation Approach for AN-105 LAW Glasses for the Cold Crucible Induction Melter}

Table 4.13 summarizes the glass property requirements applied when designing the LAW glasses for CCIM testing. The requirements for CCC crystallinity, viscosity, and electrical conductivity were self-imposed for the glass development purpose. Available glass property models (Vienna et al. 2002; Vienna et al. 2009) were used to predict these properties whenever possible. However, the predicted values were used primarily as guidelines for glass formulation because the high waste loaded glasses that are considered in this study are outside the model validity composition range of these models.

Table 4.13. Glass Property Requirements ${ }^{(a)}$ for LAW Glasses

\begin{tabular}{|l|c|}
\hline \multicolumn{1}{|c|}{ Property } & Requirements \\
\hline CCC crystallinity & No nepheline formation after CCC \\
\hline PCT normalized release of Q and CCC samples & B and $\mathrm{Na}<4 \mathrm{~g} / \mathrm{L}$ \\
\hline VHT alteration rate of Q and CCC samples & $<50 \mathrm{~g} / \mathrm{m}^{2} / \mathrm{d}$ \\
\hline Viscosity & $4 \mathrm{~Pa} \cdot \mathrm{s}$ at a nominal melting temperature $\left(T_{m}\right)$ \\
\hline Electrical conductivity & $10-100 \mathrm{~S} / \mathrm{m}$ at $T_{m}$ \\
\hline $\begin{array}{l}\text { (a) Self-imposed for the glass development purpose except for PCT and VHT requirements } \\
\text { Q stands for quenched and CCC canister centerline cooling. }\end{array}$ \\
\hline
\end{tabular}

Table 4.14 shows the target compositions and predicted properties for AN-105 LAW (CCIM-AN-xx) glasses. The glass formulation was performed in two steps. The second set of glasses was formulated after completing the testing and evaluation of the first set of glasses. The first set of glasses had $23 \mathrm{wt} \%$ to $25 \mathrm{wt} \% \mathrm{Na}_{2} \mathrm{O}$ in glass ( $30 \mathrm{wt} \%$ to $32.6 \mathrm{wt} \%$ waste loading) while the second set had $25 \mathrm{wt} \%$ and $26 \mathrm{wt} \% \mathrm{Na}_{2} \mathrm{O}$ (32.6 wt $\%$ and $33.9 \mathrm{wt} \%$ waste loading). The testing for the second set of glasses was not fully completed before the task close out.

The predicted nominal melting temperature $\left(T_{m}\right)$ at a predicted viscosity of $4 \mathrm{~Pa} \cdot \mathrm{s}$ was from $1200^{\circ} \mathrm{C}$ to $1300^{\circ} \mathrm{C}$. The predicted electrical conductivity was within the desired range of $10 \mathrm{~S} / \mathrm{m}$ to $100 \mathrm{~S} / \mathrm{m}$ at $T_{m}$ for all CCIM-AN glasses. The predicted normalized PCT releases (Vienna et al. 2009) and predicted VHT alteration rate (by Table 4.11) are all below the waste acceptance criteria although the glasses with high $\mathrm{Na}_{2} \mathrm{O}$ concentration (CCIM-AN-27, 28, 31) approach the limits especially for VHT. The nepheline constraint was met for two CCIM-AN glasses only, CCIM-AN-02 and 09, by satisfying the $N_{S i}$ rule; all other glasses failed both the $N_{S i}$ and OB rules. 
Table 4.14. Target Composition and Predicted Properties of CCIM-AN Glasses

\begin{tabular}{|c|c|c|c|c|c|c|c|}
\hline \multirow[b]{2}{*}{ Oxide } & \multicolumn{6}{|c|}{ 1st set of glasses } & \multirow[b]{2}{*}{ Limits $^{(a)}$} \\
\hline & $\begin{array}{l}\text { CCIM- } \\
\text { AN-02 }\end{array}$ & $\begin{array}{l}\text { CCIM- } \\
\text { AN-04 }\end{array}$ & $\begin{array}{l}\text { CCIM- } \\
\text { AN-09 }\end{array}$ & $\begin{array}{l}\text { CCIM- } \\
\text { AN-11 }\end{array}$ & $\begin{array}{l}\text { CCIM- } \\
\text { AN-18 }\end{array}$ & $\begin{array}{l}\text { CCIM- } \\
\text { AN-20 }\end{array}$ & \\
\hline $\mathrm{Al}_{2} \mathrm{O}_{3}$ & 0.06000 & 0.06000 & 0.05589 & 0.05589 & 0.06000 & 0.05822 & - \\
\hline $\mathrm{B}_{2} \mathrm{O}_{3}$ & 0.10375 & 0.10032 & 0.09124 & 0.11582 & 0.07730 & 0.08053 & - \\
\hline $\mathrm{CaO}$ & 0.00000 & 0.03000 & 0.00000 & 0.00000 & 0.02000 & 0.00000 & - \\
\hline $\mathrm{Cl}$ & 0.00649 & 0.00649 & 0.00677 & 0.00677 & 0.00677 & 0.00706 & - \\
\hline $\mathrm{Cr}_{2} \mathrm{O}_{3}$ & 0.00021 & 0.00021 & 0.00022 & 0.00022 & 0.00022 & 0.00023 & - \\
\hline $\mathrm{Cs}_{2} \mathrm{O}$ & 0.00150 & 0.00150 & 0.00156 & 0.00156 & 0.00156 & 0.00163 & - \\
\hline $\mathrm{F}$ & 0.00003 & 0.00003 & 0.00003 & 0.00003 & 0.00003 & 0.00003 & - \\
\hline $\mathrm{K}_{2} \mathrm{O}$ & 0.00515 & 0.00515 & 0.00537 & 0.00537 & 0.00537 & 0.00560 & - \\
\hline $\mathrm{Na}_{2} \mathrm{O}$ & 0.23000 & 0.23000 & 0.24000 & 0.24000 & 0.24000 & 0.25000 & - \\
\hline $\mathrm{Re}_{2} \mathrm{O}_{7}$ & 0.00030 & 0.00030 & 0.00031 & 0.00031 & 0.00031 & 0.00033 & - \\
\hline $\mathrm{SiO}_{2}$ & 0.48082 & 0.45425 & 0.48676 & 0.45218 & 0.47659 & 0.48447 & - \\
\hline $\mathrm{SO}_{3}$ & 0.00176 & 0.00176 & 0.00183 & 0.00183 & 0.00183 & 0.00191 & - \\
\hline $\mathrm{SnO}_{2}$ & 0.02500 & 0.02500 & 0.02500 & 0.02500 & 0.02000 & 0.02500 & - \\
\hline $\mathrm{ZnO}$ & 0.02500 & 0.02500 & 0.02500 & 0.02500 & 0.02000 & 0.02500 & - \\
\hline $\mathrm{ZrO}_{2}$ & 0.06000 & 0.06000 & 0.06000 & 0.07000 & 0.07000 & 0.06000 & - \\
\hline Total & 1.00000 & 1.00000 & 1.00000 & 1.00000 & 1.00000 & 1.00000 & - \\
\hline Waste loading & 0.300 & 0.300 & 0.313 & 0.313 & 0.313 & 0.326 & - \\
\hline$T_{m}$ at $4 \mathrm{~Pa} \cdot \mathrm{s},{ }^{\circ} \mathrm{C}$ & 1250 & 1200 & 1250 & 1200 & 1250 & 1250 & - \\
\hline EC at $T_{m}, \mathrm{~S} / \mathrm{m}$ & 54.3 & 52.5 & 59.8 & 56.9 & 61.0 & 66.3 & $10-100$ \\
\hline PCT-B, g/L & 1.83 & 1.73 & 2.00 & 2.89 & 1.35 & 1.93 & $<4$ \\
\hline PCT-Na, g/L & 1.78 & 1.99 & 2.13 & 2.56 & 1.89 & 2.33 & $<4$ \\
\hline VHT $r_{a l t}, \mathrm{~g} / \mathrm{m}^{2} / \mathrm{d}$ & 6.1 & 4.7 & 11.3 & 5.6 & 8.6 & 22.3 & $<50$ \\
\hline$N_{S i}$ & 0.624 & 0.610 & 0.622 & 0.604 & 0.614 & 0.611 & $\geq 0.62$ \\
\hline $\mathrm{OB}$ & 0.582 & 0.595 & 0.588 & 0.587 & 0.600 & 0.595 & $\leq 0.575$ \\
\hline
\end{tabular}

\begin{tabular}{|c|c|c|c|c|c|}
\hline \multirow[b]{2}{*}{ Oxide } & \multicolumn{4}{|c|}{ 2nd set of glasses } & \multirow[b]{2}{*}{ Limits $^{(a)}$} \\
\hline & $\begin{array}{l}\text { CCIM- } \\
\text { AN-23 }\end{array}$ & $\begin{array}{l}\text { CCIM- } \\
\text { AN-27 }\end{array}$ & $\begin{array}{l}\text { CCIM- } \\
\text { AN-28 }\end{array}$ & $\begin{array}{l}\text { CCIM- } \\
\text { AN-31 }\end{array}$ & \\
\hline $\mathrm{Al}_{2} \mathrm{O}_{3}$ & 0.05822 & 0.06055 & 0.06055 & 0.07500 & - \\
\hline $\mathrm{B}_{2} \mathrm{O}_{3}$ & 0.06674 & 0.07046 & 0.05746 & 0.05519 & - \\
\hline $\mathrm{CaO}$ & 0.02000 & 0.00000 & 0.02000 & 0.00000 & - \\
\hline $\mathrm{Cl}$ & 0.00706 & 0.00734 & 0.00734 & 0.00734 & - \\
\hline $\mathrm{Cr}_{2} \mathrm{O}_{3}$ & 0.00023 & 0.00024 & 0.00024 & 0.00024 & - \\
\hline $\mathrm{Cs}_{2} \mathrm{O}$ & 0.00163 & 0.00169 & 0.00169 & 0.00169 & - \\
\hline $\mathrm{F}$ & 0.00003 & 0.00003 & 0.00003 & 0.00003 & - \\
\hline $\mathrm{K}_{2} \mathrm{O}$ & 0.00560 & 0.00582 & 0.00582 & 0.00582 & - \\
\hline $\mathrm{Na}_{2} \mathrm{O}$ & 0.25000 & 0.26000 & 0.26000 & 0.26000 & - \\
\hline $\mathrm{Re}_{2} \mathrm{O}_{7}$ & 0.00033 & 0.00034 & 0.00034 & 0.00034 & - \\
\hline $\mathrm{SiO}_{2}$ & 0.47827 & 0.48155 & 0.47454 & 0.48236 & - \\
\hline $\mathrm{SO}_{3}$ & 0.00191 & 0.00199 & 0.00199 & 0.00199 & - \\
\hline $\mathrm{SnO}_{2}$ & 0.02000 & 0.02500 & 0.02000 & 0.02000 & - \\
\hline $\mathrm{ZnO}$ & 0.02000 & 0.02500 & 0.02000 & 0.02000 & - \\
\hline $\mathrm{ZrO}_{2}$ & 0.07000 & 0.06000 & 0.07000 & 0.07000 & - \\
\hline Total & 1.00000 & 1.00000 & 1.00000 & 1.00000 & - \\
\hline Waste loading & 0.326 & 0.339 & 0.339 & 0.339 & - \\
\hline$T_{m}$ at $4 \mathrm{~Pa} \cdot \mathrm{s},{ }^{\circ} \mathrm{C}$ & 1250 & 1250 & 1250 & 1300 & - \\
\hline EC at $T_{m}, \mathrm{~S} / \mathrm{m}$ & 67.8 & 73.7 & 75.7 & 77.4 & $10-100$ \\
\hline PCT-B, g/L & 1.44 & 1.89 & 1.43 & 1.09 & $<4$ \\
\hline PCT-Na, g/L & 2.31 & 2.63 & 2.68 & 1.99 & $<4$ \\
\hline VHT $r_{\text {alt }}, \mathrm{g} / \mathrm{m}^{2} / \mathrm{d}$ & 16.1 & 43.5 & 31.3 & 46.3 & $<50$ \\
\hline$N_{S i}$ & 0.608 & 0.600 & 0.597 & 0.590 & $\geq 0.62$ \\
\hline OB & 0.606 & 0.602 & 0.613 & 0.607 & $\leq 0.575$ \\
\hline
\end{tabular}




\subsubsection{Test Results of AZ-105 LAW Glasses for the Cold Crucible Induction Melter}

Chemical analyses of glasses were performed for all CCIM-AN glasses primarily to confirm glass batching and melting preparation. Table 4.15 and Table 4.16 compare the target and analyzed compositions and provide their relative percent difference (RPD) values for the first and second set of glasses. For the first set of glasses, the analytical results matched well with the target concentrations for all glasses except for CCIM-AN-20, which had the analyzed $\mathrm{Na}_{2} \mathrm{O}$ concentration 7.7 RPD lower than the target (23.09 $\mathrm{wt} \%$ compared to $25 \mathrm{wt} \% \mathrm{Na}_{2} \mathrm{O}$ in glass). It was not clear whether the difference was caused by glass batching/preparation or analytical error. The second set of glasses showed relatively larger differences between target and analyzed concentrations for most components in general compared to the first set. However, there was no specific glass that showed major difference from other glasses and the $\mathrm{Na}_{2} \mathrm{O}$ results were consistent and matched the target values very well.

Table 4.15. Comparison of Target and Analyzed Compositions of First Set of CCIM-AN Glasses and their Relative Percent Difference (RPD)

\begin{tabular}{|c|c|c|c|c|c|c|c|c|c|c|c|c|}
\hline & \multicolumn{6}{|c|}{ Target (wt\%) } & \multicolumn{6}{|c|}{ Analyzed (wt\%) ${ }^{(1)}$} \\
\hline Comp. & AN-02 & AN-04 & AN-09 & AN-11 & AN-18 & AN-20 & AN-02 & AN-04 & AN-09 & AN-11 & AN-18 & AN-20 \\
\hline $\mathrm{Al}_{2} \mathrm{O}_{3}$ & 6.00 & 6.00 & 5.59 & 5.59 & 6.00 & 5.82 & 6.14 & 6.14 & 5.76 & 5.77 & 6.25 & 6.27 \\
\hline $\mathrm{B}_{2} \mathrm{O}_{3}$ & 10.37 & 10.03 & 9.12 & 11.58 & 7.73 & 8.05 & 10.01 & 9.93 & 9.55 & 11.74 & 8.00 & 8.15 \\
\hline $\mathrm{CaO}$ & 0.00 & 3.00 & 0.00 & 0.00 & 2.00 & 0.00 & 0.00 & 3.21 & 0.00 & 0.00 & 2.12 & 0.00 \\
\hline $\mathrm{Cl}$ & 0.65 & 0.65 & 0.68 & 0.68 & 0.68 & 0.71 & & & & & & \\
\hline $\mathrm{Cr}_{2} \mathrm{O}_{3}$ & 0.02 & 0.02 & 0.02 & 0.02 & 0.02 & 0.02 & 0.04 & 0.03 & 0.03 & 0.03 & 0.03 & 0.02 \\
\hline $\mathrm{Cs}_{2} \mathrm{O}$ & 0.15 & 0.15 & 0.16 & 0.16 & 0.16 & 0.16 & & & & & & \\
\hline $\mathrm{F}$ & 0.003 & 0.003 & 0.003 & 0.003 & 0.003 & 0.003 & & & & & & \\
\hline $\mathrm{K}_{2} \mathrm{O}$ & 0.52 & 0.52 & 0.54 & 0.54 & 0.54 & 0.56 & 0.53 & 0.57 & 0.57 & 0.55 & 0.58 & 0.60 \\
\hline $\mathrm{Na}_{2} \mathrm{O}$ & 23.00 & 23.00 & 24.00 & 24.00 & 24.00 & 25.00 & 22.28 & 22.61 & 23.29 & 23.83 & 23.29 & 23.09 \\
\hline $\mathrm{Re}_{2} \mathrm{O}_{7}$ & 0.03 & 0.03 & 0.03 & 0.03 & 0.03 & 0.03 & & & & & & \\
\hline $\mathrm{SiO}_{2}$ & 48.08 & 45.42 & 48.68 & 45.22 & 47.66 & 48.45 & 48.26 & 45.69 & 48.79 & 45.58 & 47.83 & 49.65 \\
\hline $\mathrm{SO}_{3}$ & 0.18 & 0.18 & 0.18 & 0.18 & 0.18 & 0.19 & & & & & & \\
\hline $\mathrm{SnO}_{2}$ & 2.50 & 2.50 & 2.50 & 2.50 & 2.00 & 2.50 & 2.71 & 2.76 & 2.67 & 2.72 & 2.13 & 2.72 \\
\hline $\mathrm{ZnO}$ & 2.50 & 2.50 & 2.50 & 2.50 & 2.00 & 2.50 & 2.42 & 2.40 & 2.40 & 2.42 & 1.90 & 2.47 \\
\hline $\mathrm{ZrO}_{2}$ & 6.00 & 6.00 & 6.00 & 7.00 & 7.00 & 6.00 & 5.60 & 5.68 & 5.64 & 6.59 & 6.66 & 5.78 \\
\hline \multirow[t]{2}{*}{ Total } & 100.0 & 100.0 & 100.0 & 100.0 & 100.0 & 100.0 & 97.98 & 99.03 & 98.69 & 99.23 & 98.78 & 98.74 \\
\hline & \multicolumn{6}{|c|}{ RPD $^{(2)}$} & \multirow{17}{*}{\multicolumn{6}{|c|}{$\begin{array}{l}{ }^{(1)} \text { Empty cells represent the components that were } \\
\text { not analyzed or below detection limit } \\
{ }^{(2)} \text { Calculated for components with target concentration } \\
>0.5 \mathrm{wt} \%\end{array}$}} \\
\hline Comp. & \multicolumn{6}{|c|}{\begin{tabular}{|l|l|}
\multicolumn{2}{|c|}{ AN-11 } \\
AN-09 & AN- \\
\end{tabular}} & & & & & & \\
\hline $\mathrm{Al}_{2} \mathrm{O}_{3}$ & $2.4 \%$ & $2.4 \%$ & $3.0 \%$ & $3.3 \%$ & $4.1 \%$ & $7.6 \%$ & & & & & & \\
\hline $\mathrm{B}_{2} \mathrm{O}_{3}$ & $-3.5 \%$ & $-1.0 \%$ & $4.6 \%$ & $1.3 \%$ & $3.5 \%$ & $1.2 \%$ & & & & & & \\
\hline $\mathrm{CaO}$ & & $7.1 \%$ & & & $6.0 \%$ & & & & & & & \\
\hline \multicolumn{7}{|l|}{$\mathrm{Cl}$} & & & & & & \\
\hline \multicolumn{7}{|l|}{$\mathrm{Cr}_{2} \mathrm{O}_{3}$} & & & & & & \\
\hline \multicolumn{7}{|l|}{$\mathrm{Cs}_{2} \mathrm{O}$} & & & & & & \\
\hline \multicolumn{7}{|l|}{$\mathrm{F}$} & & & & & & \\
\hline $\mathrm{K}_{2} \mathrm{O}$ & $1.9 \%$ & $9.8 \%$ & $6.3 \%$ & $2.0 \%$ & $7.5 \%$ & $6.7 \%$ & & & & & & \\
\hline $\mathrm{Na}_{2} \mathrm{O}$ & $-3.2 \%$ & $-1.7 \%$ & $-3.0 \%$ & $-0.7 \%$ & $-3.0 \%$ & $-7.7 \%$ & & & & & & \\
\hline \multicolumn{7}{|l|}{$\mathrm{Re}_{2} \mathrm{O}_{7}$} & & & & & & \\
\hline $\mathrm{SiO}_{2}$ & $0.4 \%$ & $0.6 \%$ & $0.2 \%$ & $0.8 \%$ & $0.4 \%$ & $2.5 \%$ & & & & & & \\
\hline \multicolumn{7}{|l|}{$\mathrm{SO}_{3}$} & & & & & & \\
\hline $\mathrm{SnO}_{2}$ & $8.2 \%$ & $10.5 \%$ & $6.9 \%$ & $8.7 \%$ & $6.4 \%$ & $9.0 \%$ & & & & & & \\
\hline $\mathrm{ZnO}$ & $-3.0 \%$ & $-4.0 \%$ & $-4.0 \%$ & $-3.3 \%$ & $-4.8 \%$ & $-1.0 \%$ & & & & & & \\
\hline $\mathrm{ZrO}_{2}$ & $-6.6 \%$ & $-5.3 \%$ & $-6.1 \%$ & $-5.8 \%$ & $-4.8 \%$ & $-3.7 \%$ & & & & & & \\
\hline
\end{tabular}


Table 4.16. Comparison of Target and Analyzed Compositions of Second Set of CCIM-AN Glasses and their Relative Percent Difference (RPD)

\begin{tabular}{|c|c|c|c|c|c|c|c|c|c|c|c|c|}
\hline & \multicolumn{4}{|c|}{ Target (wt $\%)$} & \multicolumn{4}{|c|}{ Analyzed $(w t \%)^{(1)}$} & \multicolumn{4}{|c|}{$\mathbf{R P D}^{(2)}$} \\
\hline Comp. & AN-23 & AN-27 & AN-28 & AN-31 & AN-23 & AN-27 & AN-28 & AN-31 & AN-23 & AN-27 & AN-28 & AN-31 \\
\hline $\mathrm{Al}_{2} \mathrm{O}_{3}$ & 5.82 & 6.05 & 6.05 & 7.50 & 6.07 & 6.23 & 6.42 & 7.61 & $4.3 \%$ & $2.9 \%$ & $6.0 \%$ & $1.5 \%$ \\
\hline $\mathrm{B}_{2} \mathrm{O}_{3}$ & 6.67 & 7.05 & 5.75 & 5.52 & 6.57 & 6.30 & 5.23 & 4.73 & $-1.6 \%$ & $-10.7 \%$ & $-8.9 \%$ & $-14.2 \%$ \\
\hline $\mathrm{CaO}$ & 2.00 & 0.00 & 2.00 & 0.00 & 2.13 & 0.05 & 2.20 & 0.05 & $6.6 \%$ & & $10.1 \%$ & \\
\hline $\mathrm{Cl}$ & 0.71 & 0.73 & 0.73 & 0.73 & & & & & & & & \\
\hline $\mathrm{Cr}_{2} \mathrm{O}_{3}$ & 0.023 & 0.024 & 0.024 & 0.024 & 0.034 & 0.037 & 0.035 & 0.035 & & & & \\
\hline $\mathrm{Cs}_{2} \mathrm{O}$ & 0.16 & 0.17 & 0.17 & 0.17 & & & & & & & & \\
\hline $\mathrm{F}$ & 0.003 & 0.003 & 0.003 & 0.003 & & & & & & & & \\
\hline $\mathrm{K}_{2} \mathrm{O}$ & 0.56 & 0.58 & 0.58 & 0.58 & 0.55 & 0.55 & 0.60 & 0.59 & $-2.5 \%$ & $-6.3 \%$ & $3.6 \%$ & $1.4 \%$ \\
\hline $\mathrm{Na}_{2} \mathrm{O}$ & 25.00 & 26.00 & 26.00 & 26.00 & 25.87 & 26.57 & 26.64 & 26.53 & $3.5 \%$ & $2.2 \%$ & $2.4 \%$ & $2.0 \%$ \\
\hline $\mathrm{Re}_{2} \mathrm{O}_{7}$ & 0.033 & 0.034 & 0.034 & 0.034 & & & & & & & & \\
\hline $\mathrm{SiO}_{2}$ & 47.83 & 48.15 & 47.45 & 48.24 & 48.26 & 49.54 & 48.79 & 49.33 & $0.9 \%$ & $2.9 \%$ & $2.8 \%$ & $2.3 \%$ \\
\hline $\mathrm{SO}_{3}$ & 0.19 & 0.20 & 0.20 & 0.20 & 0.14 & 0.18 & 0.15 & 0.18 & & & & \\
\hline $\mathrm{SnO}_{2}$ & 2.00 & 2.50 & 2.00 & 2.00 & 1.63 & 2.00 & 1.62 & 1.63 & $-18.6 \%$ & $-19.9 \%$ & $-18.8 \%$ & $-18.7 \%$ \\
\hline $\mathrm{ZnO}$ & 2.00 & 2.50 & 2.00 & 2.00 & 2.02 & 2.46 & 1.99 & 1.96 & $0.8 \%$ & $-1.4 \%$ & $-0.7 \%$ & $-2.0 \%$ \\
\hline $\mathrm{ZrO}_{2}$ & 7.00 & 6.00 & 7.00 & 7.00 & 6.60 & 5.70 & 6.54 & 6.55 & $-5.7 \%$ & $-5.1 \%$ & $-6.6 \%$ & $-6.5 \%$ \\
\hline Total & 100.0 & 100.0 & 100.0 & 100.0 & 99.86 & 99.61 & 100.21 & 99.19 & & & & \\
\hline
\end{tabular}

All CCIM-AN glasses from both first and second sets were crystal-free after CCC treatment, although only two glasses, CCIM-AN-02 and 09, satisfied the nepheline constraint (i.e., met either $N_{S i}$ or OB rule, see Table 4.14). This lack of nepheline crystallization in these glasses that are predicted to crystallize the nepheline indicates the conservativeness of the current constraint. As a result, $\mathrm{CCC}$ treatment is not likely to have a significant impact on PCT normalized releases and VHT responses.

Negligible corrosion was observed after 7-day and 24-day VHTs at $200^{\circ} \mathrm{C}$ for the first set of glasses for all quenched and CCC-treated samples based on optical microscopic examination. All 7-day VHT samples were observed by scanning electron microscopy (SEM) to confirm the negligible corrosion by optical microscopy. Figure 4.12 and Figure 4.13 show thin-section VHT samples after 7-day tests at $200{ }^{\circ} \mathrm{C}$ for the first set of quenched (Figure 4.12) and CCC-treated (Figure 4.13) glasses prepared for the optical microscopy and SEM examination.

Table 4.17 summarizes the results of VHT alteration rates measured by SEM after 7-day tests at $200{ }^{\circ} \mathrm{C}$ for the first set of glasses. The alteration rate was more than an order of magnitude smaller than the limit of $50 \mathrm{~g} / \mathrm{m}^{2} / \mathrm{d}$ and significantly lower than predicted by the model (Table 4.11) for all quenched and CCC glasses. Figure 4.14 is an example SEM micrograph showing the VHT alteration layer formed on the CCIM-AN-09 CCC glass after the 7-day VHT at $200^{\circ} \mathrm{C}$. SEM micrographs of the VHT alteration for the first set of glasses for all quenched and CCC-treated samples are given in Appendix C. Because of negligible corrosion by VHT for the first set of glasses, the second set of glasses were formulated based on the PCT normalized releases, discussed below. 

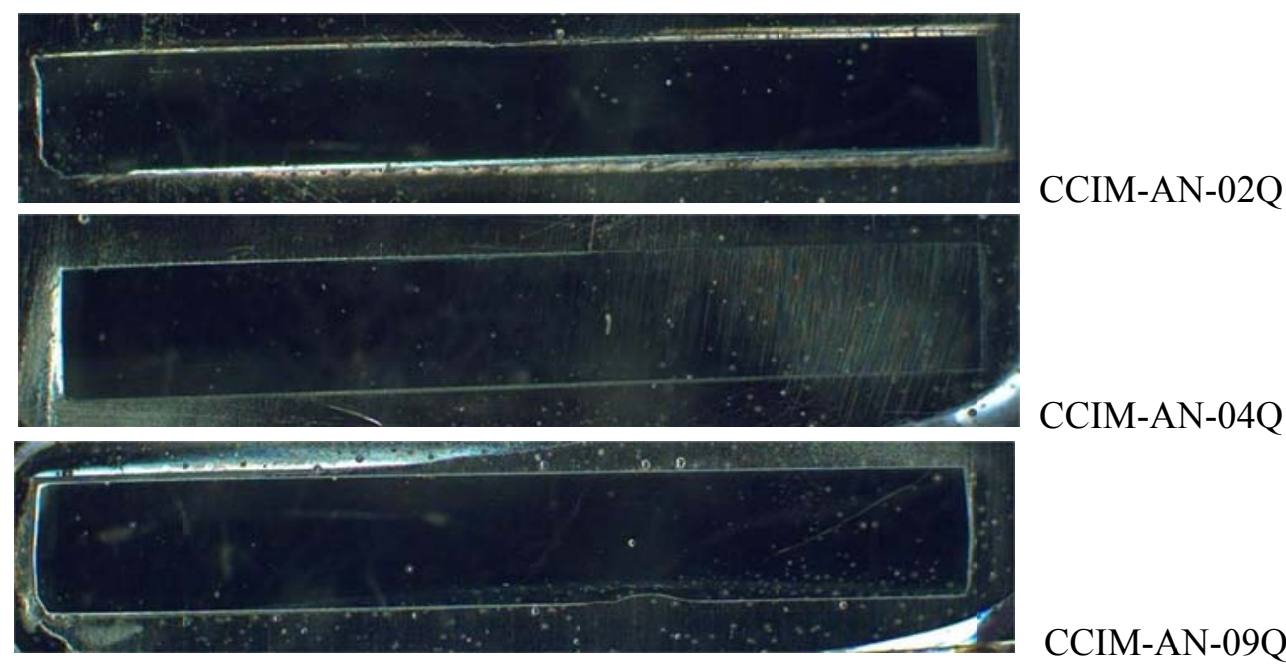

CCIM-AN-09Q
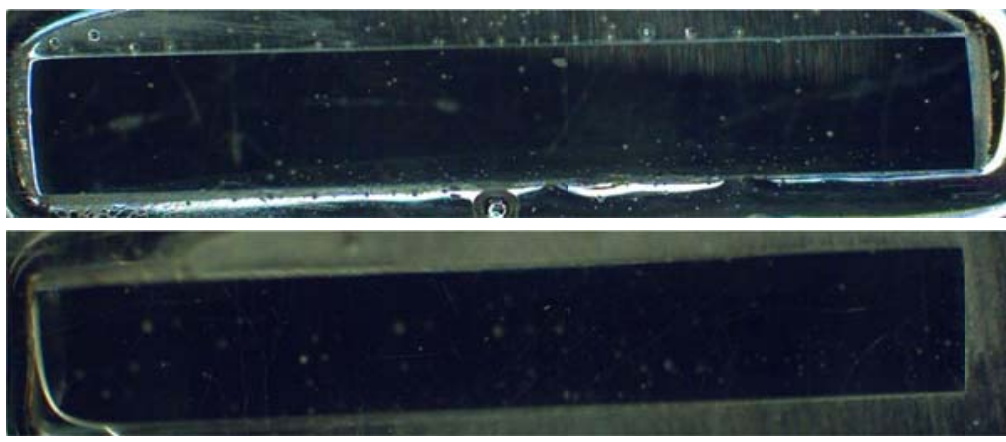

CCIM-AN-11Q

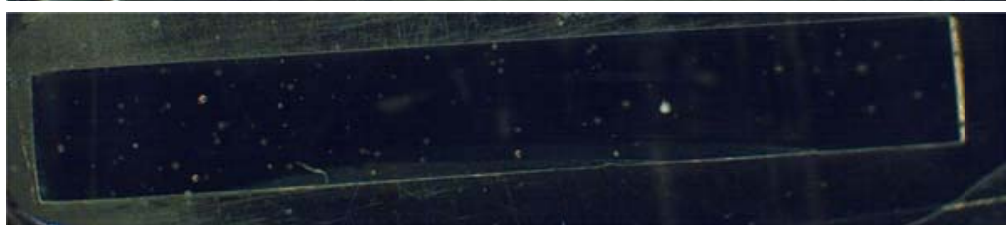

CCIM-AN-18Q

CCIM-AN-20Q

Figure 4.12. Thin Section of VHT Samples after 7-day Tests at $200^{\circ} \mathrm{C}$ for the First Set of Quenched CCIM-AN Glasses 


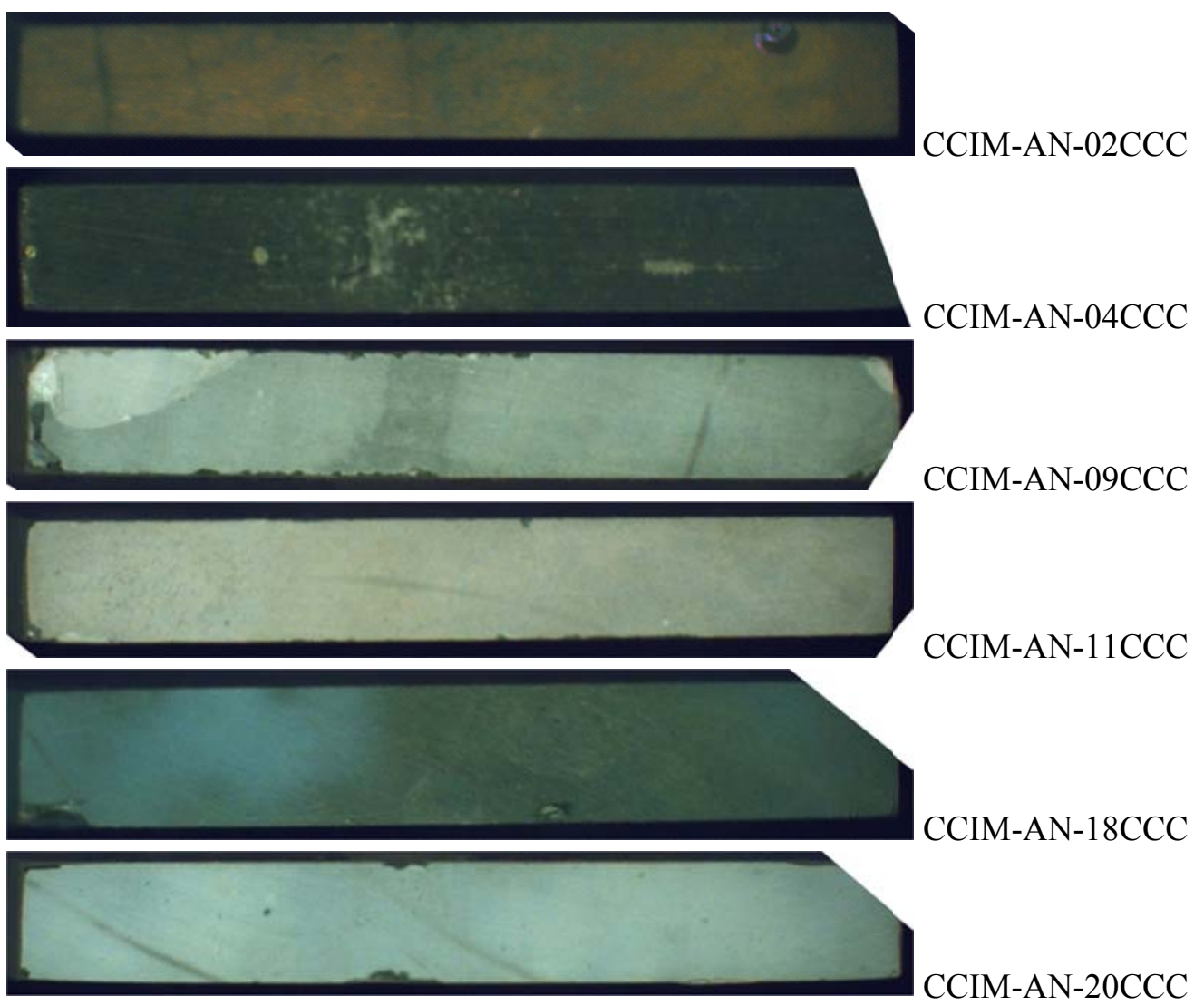

Figure 4.13. Thin Section of VHT Samples after 7-day Tests at $200^{\circ} \mathrm{C}$ for the First Set of CCC-Treated CCIM-AN Glasses

Table 4.17. VHT Alteration Rates for the First Set of CCIM-AN Glasses after 7-Day Test at $200^{\circ} \mathrm{C}$

\begin{tabular}{|r|c|c|c|c|c|c|}
\hline Glass & $\begin{array}{c}\text { CCIM- } \\
\text { AN-02 }\end{array}$ & $\begin{array}{c}\text { CCIM- } \\
\text { AN-04 }\end{array}$ & $\begin{array}{c}\text { CCIM- } \\
\text { AN-09 }\end{array}$ & $\begin{array}{c}\text { CCIM- } \\
\text { AN-11 }\end{array}$ & $\begin{array}{c}\text { CCIM- } \\
\text { AN-18 }\end{array}$ & $\begin{array}{c}\text { CCIM- } \\
\text { AN-20 }\end{array}$ \\
\hline Quenched, g/m $/ \mathrm{d}$ & 0.7 & 0.4 & 2.9 & 2.3 & 0.6 & 2.4 \\
\hline $\mathrm{CCC}, \mathrm{g} / \mathrm{m}^{2} / \mathrm{d}$ & 1.0 & $<0.4$ & 3.0 & 1.9 & 2.6 & 1.0 \\
\hline $\mathrm{AN}-02$ and 04 glasses have $23 \mathrm{wt} \% \mathrm{Na}_{2} \mathrm{O}, \mathrm{AN}-09,11,18$ have $24 \mathrm{wt} \% \mathrm{Na}_{2} \mathrm{O}$, and $\mathrm{AN}-20$ has $25 \mathrm{wt} \% \mathrm{Na}_{2} \mathrm{O}$. \\
\hline
\end{tabular}




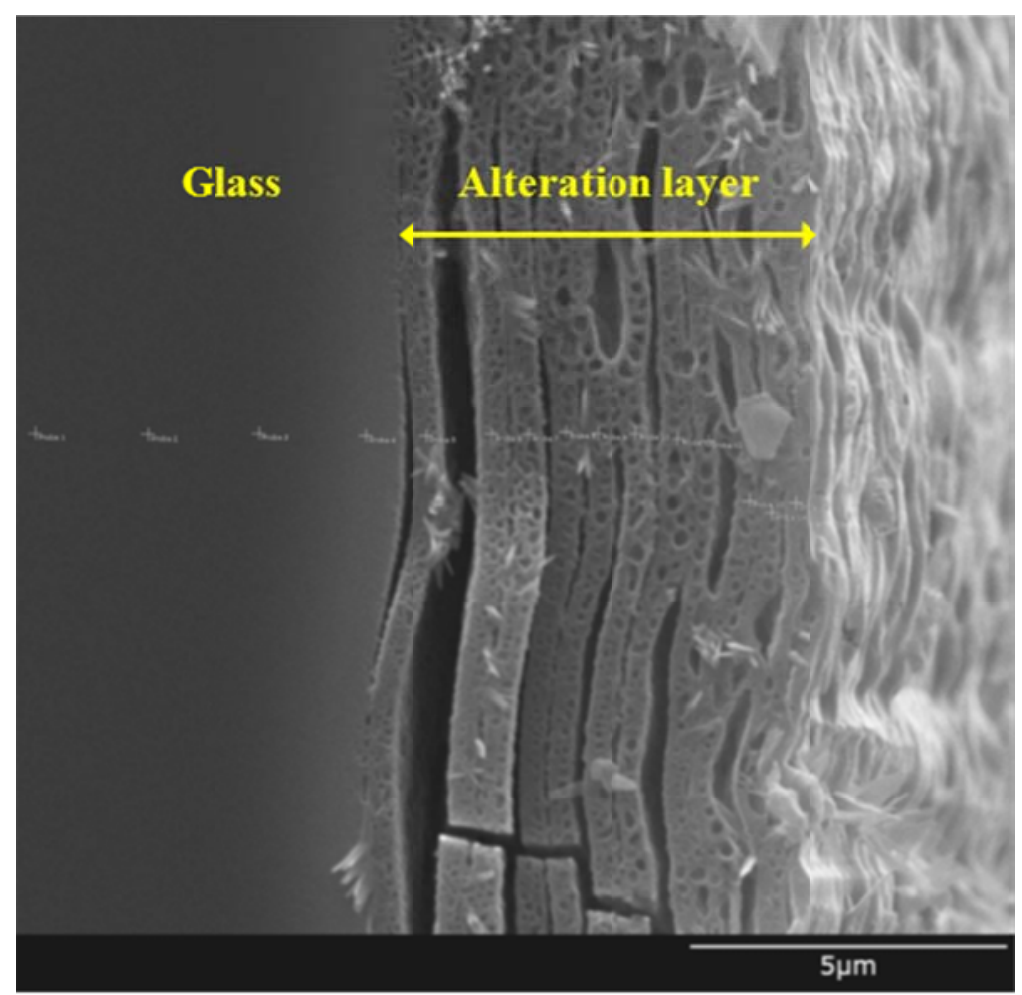

Figure 4.14. SEM Micrograph Showing the VHT Alteration Layer of CCIM-AN-09CCC Sample After 7-day VHT at $200^{\circ} \mathrm{C}$ (average alteration thickness of $8 \mu \mathrm{m}$ )

Figure 4.15 shows the results of PCT normalized boron (Figure 4.15a) and sodium (Figure 4.15b) releases from both the first and second set of quenched and CCC-treated CCIM-AN glasses. All glasses but one (CCIM-AN-11 quenched) passed the PCT requirements for normalized boron and sodium releases. The information on the effect of glass composition on PCT for the first set of glasses (up to CCIM-AN-20) was used to formulate second set of four glasses at $25 \mathrm{wt} \%$ and $26 \mathrm{wt} \% \mathrm{Na}_{2} \mathrm{O}$.

Table 4.18. PCT Normalized Releases (in $\mathrm{g} / \mathrm{L}$ ) from Quenched and CCC Treated CCIM-AN Glasses

\begin{tabular}{|c|c|c|c|c|c|c|c|c|c|c|}
\hline Glass & $\begin{array}{c}\text { CCIM- } \\
\text { AN-02 }\end{array}$ & $\begin{array}{c}\text { CCIM- } \\
\text { AN-04 }\end{array}$ & $\begin{array}{c}\text { CCIM- } \\
\text { AN-09 }\end{array}$ & $\begin{array}{c}\text { CCIM- } \\
\text { AN-11 }\end{array}$ & $\begin{array}{c}\text { CCIM- } \\
\text { AN-18 }\end{array}$ & $\begin{array}{c}\text { CCIM- } \\
\text { AN-20 }\end{array}$ & $\begin{array}{c}\text { CCIM- } \\
\text { AN-23 }\end{array}$ & $\begin{array}{c}\text { CCIM- } \\
\text { AN-27 }\end{array}$ & $\begin{array}{c}\text { CCIM- } \\
\text { AN-28 }\end{array}$ & $\begin{array}{c}\text { CCIM- } \\
\text { AN-31 }\end{array}$ \\
\hline PCT-B, Q & 2.124 & 0.915 & 1.787 & 4.176 & 0.804 & 1.046 & 0.855 & 1.538 & 0.947 & 0.691 \\
\hline PCT-Na, Q & 1.467 & 1.048 & 1.413 & 2.865 & 1.073 & 1.043 & 1.575 & 1.854 & 1.913 & 1.596 \\
\hline PCT-Si, Q & 0.379 & 0.366 & 0.460 & 0.479 & 0.378 & 0.405 & 0.445 & 0.530 & 0.501 & 0.425 \\
\hline PCT-B, CCC & 1.342 & 0.744 & 1.138 & 3.017 & 0.680 & 0.698 & 0.498 & 0.389 & 0.360 & $<0.01$ \\
\hline PCT-Na, CCC & 1.032 & 0.910 & 1.052 & 2.064 & 0.998 & 0.880 & 1.568 & 1.618 & 1.867 & 1.593 \\
\hline PCT-Si, CCC & 0.336 & 0.329 & 0.412 & 0.418 & 0.363 & 0.358 & 0.488 & 0.500 & 0.547 & 0.456 \\
\hline
\end{tabular}



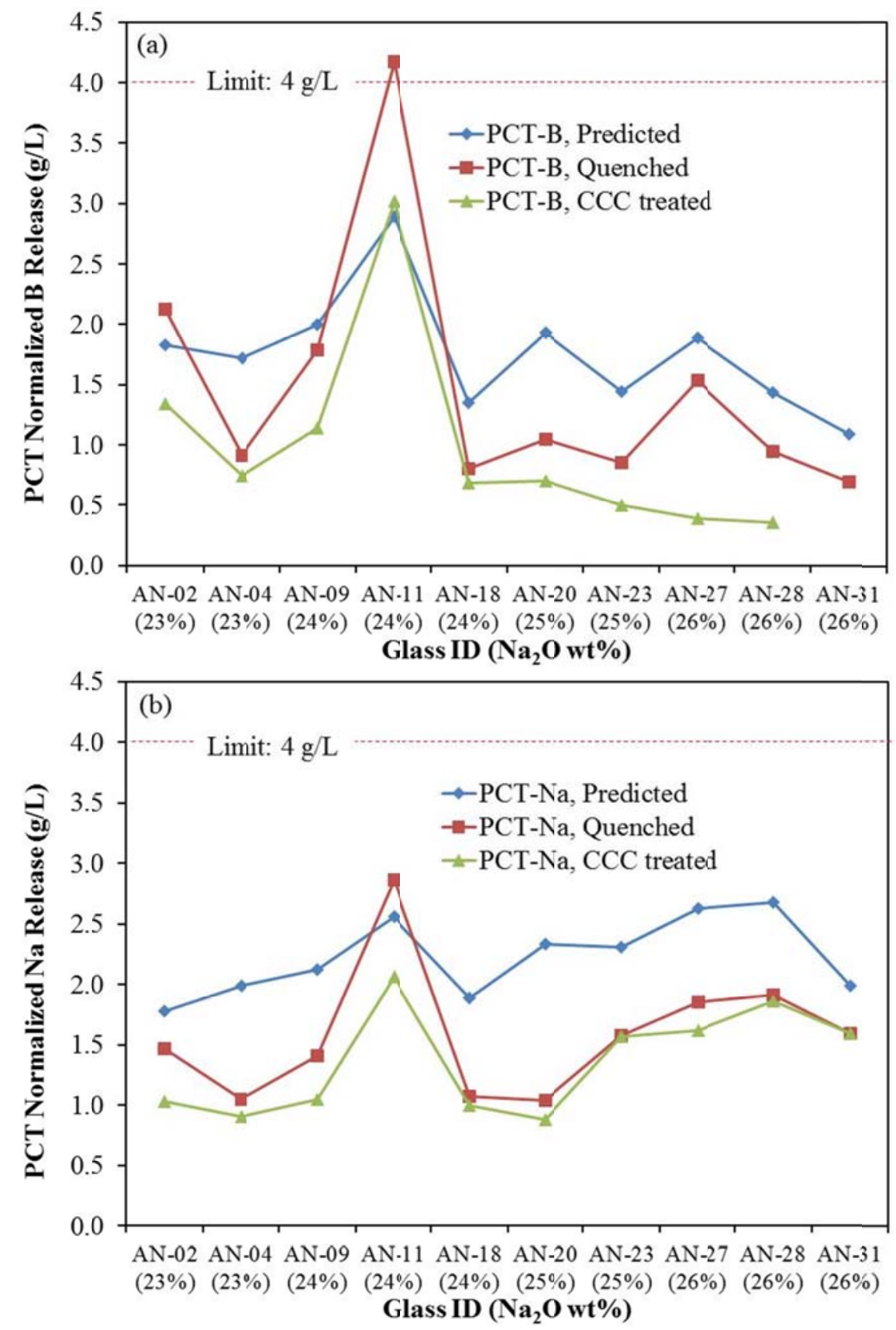

Figure 4.15. PCT Normalized Releases for CCIM-AN Glasses after 7-Day Test at $90^{\circ} \mathrm{C}$

The PCT boron and sodium releases from the second set of glasses with $25 \mathrm{wt} \%$ and $26 \mathrm{wt} \% \mathrm{Na}_{2} \mathrm{O}$ were comparable to those from the first set of glasses with $23 \mathrm{wt} \%$ and $24 \mathrm{wt} \% \mathrm{Na}_{2} \mathrm{O}$ as shown in Figure 4.15. The measured PCT normalized releases showed reasonable agreement with the predicted values, and there were no undesirable effects on PCT by CCC treatment, i.e., the CCC-treated samples showed equal to or slightly lower PCT boron and sodium releases than quenched samples for all glasses.

The VHT results for the second set of glasses were similar to those for the first set of glasses in that negligible corrosion was observed after 7-day VHTs at $200{ }^{\circ} \mathrm{C}$ except for one sample, CCIM-AN-27CCC. Figure 4.16 shows the pictures of thin section VHT samples after 7 -day tests at $200^{\circ} \mathrm{C}$ for the second set 
of CCC treated glasses prepared for the optical microscopy and SEM examination. The negligible corrosion in seven out of eight 7-day VHT samples from the second set of quenched and CCC glasses by optical microscopy were confirmed by SEM examination. Further evaluation of VHT samples to determine the exact VHT alteration rate (similar to Table 4.17 for the first set of glasses) was not performed for the second set of CCIM-AN glasses.

As shown in Figure 4.16, CCIM-AN-27CCC had severe and irregular corrosion. Additional cross-section samples were prepared and Figure 4.17 displays these samples and confirms the severe and irregular corrosion. The cause of this dramatic difference in VHT corrosion of the CCIM-AN-27CCC compared to all other CCIM-AN VHT samples is not clear. The comparison between target and analyzed composition for the second set of glasses given in Table 4.16 does not show any potential indication for this irregular behavior, i.e., there was no unusual feature on the analytical result of the CCIM-AN-27 glass. Investigation to understand the erratic VHT behavior in CCIM-AN-27CCC sample, such as a potential for amorphous phase separation that cannot not be detected by XRD, OM, and SEM observations, was not performed in this study.

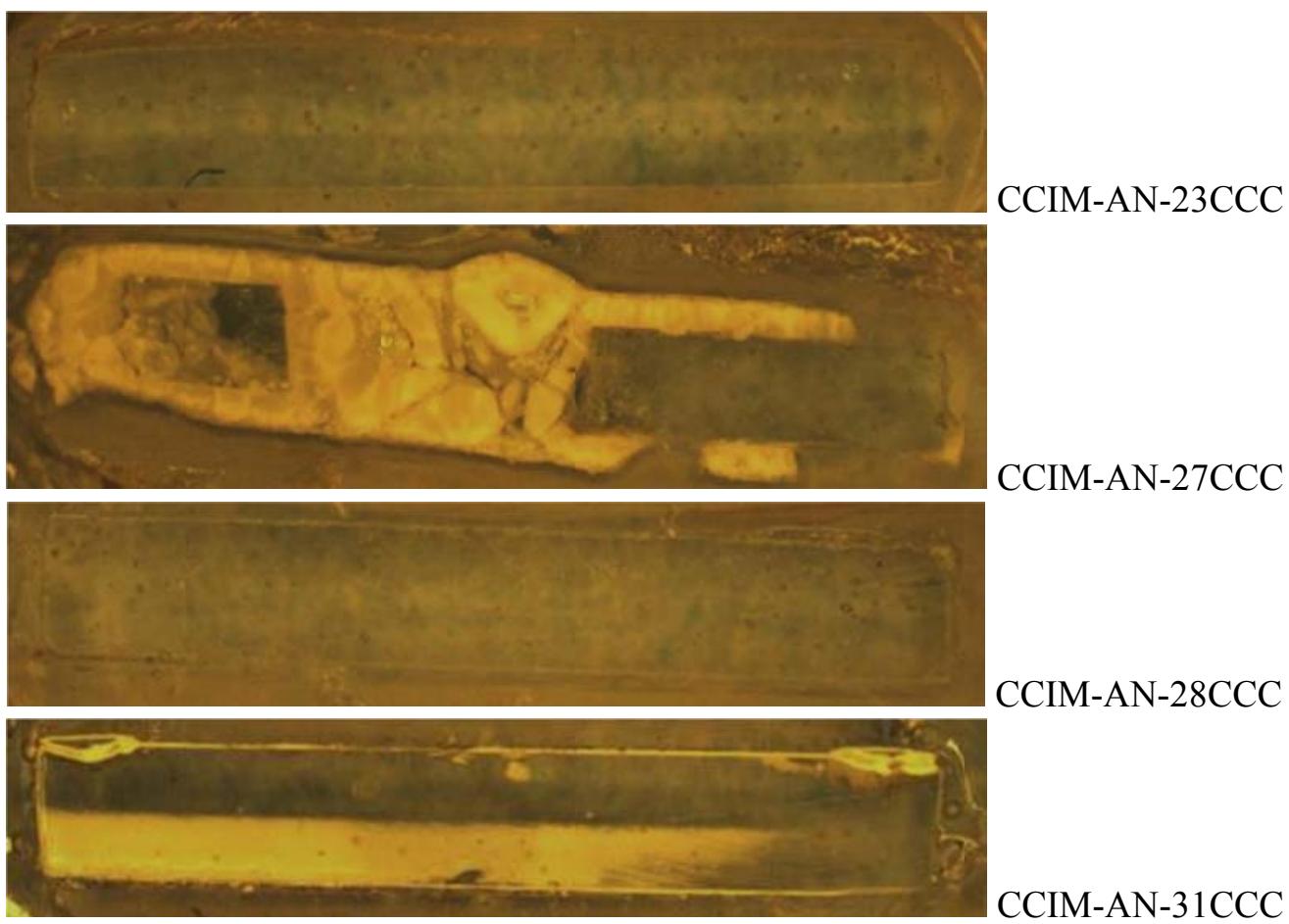

Figure 4.16. Thin Section of VHT Samples after 7-day Tests at $200{ }^{\circ} \mathrm{C}$ for the Second Set of CCC-Treated CCIM-AN Glasses 


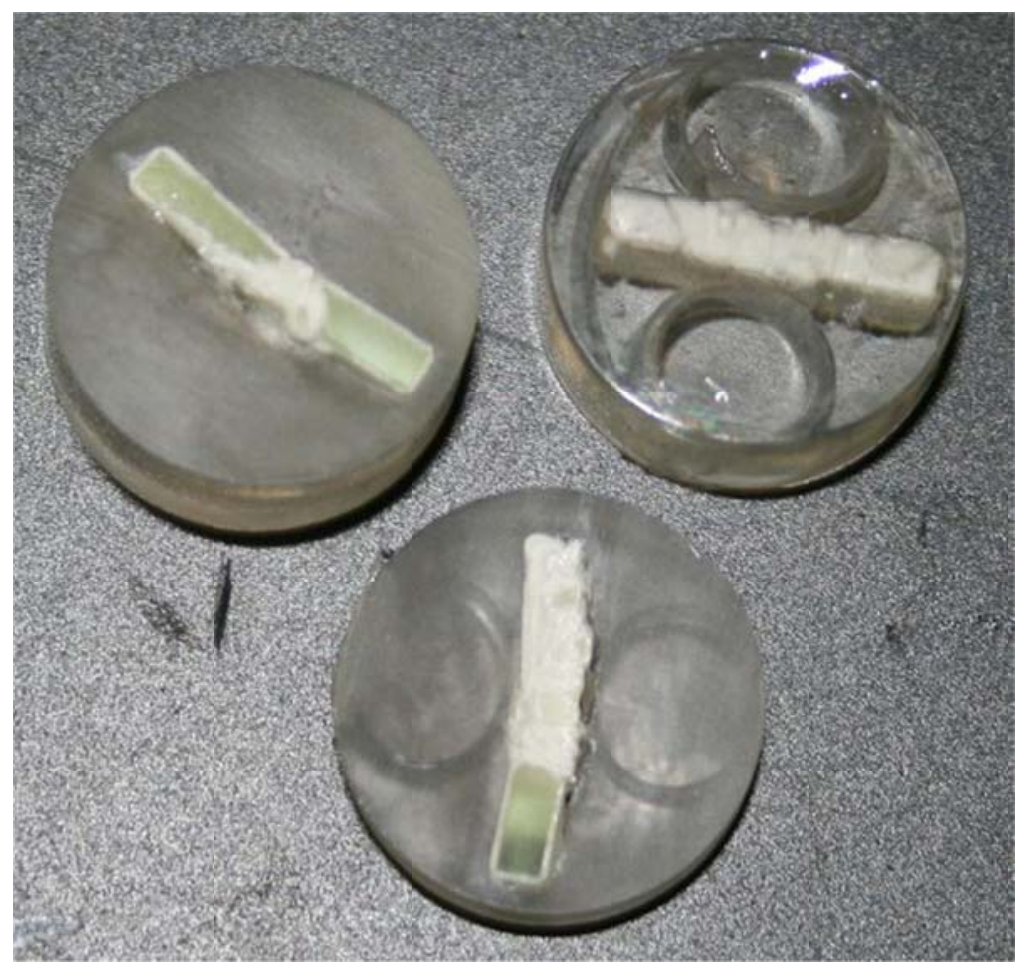

Figure 4.17. Cross-Sections of VHT Samples After 7-day Test at $200^{\circ} \mathrm{C}$ for the CCIM-AN-27CCC

Based on PCT results from the first set of glasses, two glasses, CCIM-AN-09 and 18, were selected for further testing for viscosity and electrical conductivity. The CCIM-AN-20 glass with $25 \mathrm{wt} \% \mathrm{Na}_{2} \mathrm{O}$ passed all requirements, but its analyzed composition significantly deviated from the target composition (see Table 4.15) and was not selected for further testing. Additional tests to identify the source of composition discrepancy were not performed.

Table 4.19 summarizes the viscosity and electrical conductivity of two selected glasses. Figure 4.18 displays the results of viscosity (Figure 4.18a) and electrical conductivity (Figure 4.18b) as a function of temperature for two selected glasses compared with the predicted values. Both glasses had almost the same predicted viscosity (average predicted value is included in Figure 4.18a). The measured viscosities agree reasonably well with the predicted value for both glasses within the temperatures tested. The measured viscosity was $\sim 4 \mathrm{~Pa} \cdot \mathrm{s}$ at $1250^{\circ} \mathrm{C}$; i.e., the recommended melting temperature was $1250^{\circ} \mathrm{C}$ for both glasses. 

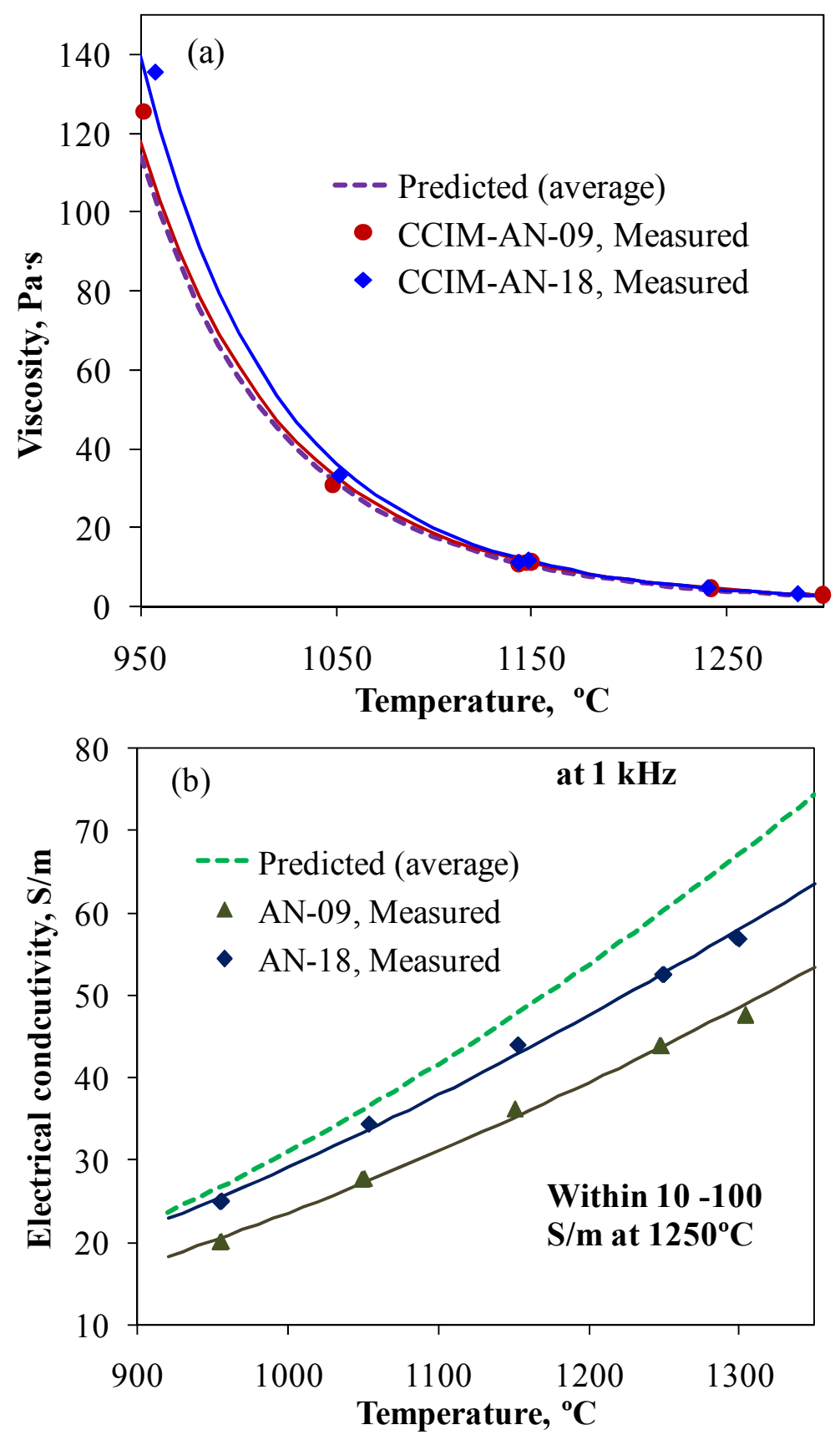

Figure 4.18. Viscosity and Electrical Conductivity of Selected Two CCIM-AN Glasses with $24 \mathrm{wt} \%$ $\mathrm{Na}_{2} \mathrm{O}$ 
Table 4.19. Viscosity and Electrical Conductivity of Selected CCIM-AN Glasses

\begin{tabular}{|c|c|c|c|}
\hline \multicolumn{2}{|c|}{ CCIM-AN-09 } & \multicolumn{2}{|c|}{ CCIM-AN-18 } \\
\hline \multicolumn{4}{|c|}{ Viscosity $(\eta)$ at a given temperature } \\
\hline $\mathbf{T}, \mathbf{C}$ & $\eta, \mathbf{P a} \cdot \mathbf{s}$ & $\mathbf{T}, \mathbf{C}$ & $\eta, \mathbf{P a} \cdot \mathbf{s}$ \\
\hline 1147 & 11.09 & 1148 & 11.63 \\
\hline 1048 & 30.82 & 1052 & 33.25 \\
\hline 952 & 125.64 & 957 & 135.73 \\
\hline 1150 & 11.29 & 1148 & 11.77 \\
\hline 1242 & 4.65 & 1240 & 4.71 \\
\hline 1299 & 2.94 & 1286 & 3.19 \\
\hline 1143 & 10.92 & 1143 & 11.18 \\
\hline \multicolumn{4}{|c|}{ Electrical conductivity $(\varepsilon)$ at a given temperature $(1 \mathrm{kHz})$} \\
\hline $\mathbf{T}, \mathbf{C}$ & $\varepsilon, \mathbf{S} / \mathbf{m}$ & $\mathbf{T}, \mathbf{C}$ & $\varepsilon, \mathbf{S} / \mathbf{m}$ \\
\hline 955 & 20.07 & 956 & 25.03 \\
\hline 1050 & 27.69 & 1054 & 34.39 \\
\hline 1151 & 36.20 & 1153 & 43.95 \\
\hline 1248 & 43.89 & 1250 & 52.47 \\
\hline 1304 & 47.62 & 1299 & 56.88 \\
\hline
\end{tabular}

Both glasses also had very similar predicted electrical conductivities (average predicted value is included in Figure 4.18b). Figure 4.18b shows that measured electrical conductivities were lower than the predicted value for both glasses with a significant measured difference between these two glasses. However, the measured electrical conductivities for both glasses were well within the desired range of $10 \mathrm{~S} / \mathrm{m}$ to $100 \mathrm{~S} / \mathrm{m}$ (Marra et al. 2008) at a recommended melting temperature of $1250^{\circ} \mathrm{C}$.

Since there was no preference between these two glasses based on viscosity or electrical conductivity, the CCIM-AN-18 glass that had slightly better performance for PCT than CCIM-AN-09 was selected for the CCIM demonstration test. The melter feed recipe was prepared for the demonstration CCIM tests but they were not performed before the closure of the project.

The results of PCT and VHT on the second set of CCIM-AN glasses discussed above suggest that it is likely possible to formulate the acceptable glasses containing even higher than $26 \mathrm{wt} \% \mathrm{Na}_{2} \mathrm{O}$. Testing glasses with $27 \mathrm{wt} \% \mathrm{Na}_{2} \mathrm{O}$ or higher would have been the next step of this study if the project had continued.

\subsection{Cold Crucible Induction Melter Glass Formulation for Selected Waste Clusters}

One of the objectives of glass formulation testing for the CCIM is to estimate the potential benefit of CCIM compared to the WTP baseline formulation. As mentioned in Section 2.1, AZ-101 HLW was selected for initial demonstration testing, based on potential for significant increase of waste loading by CCIM. The results presented in Section 4.1 clearly suggest that significant increase of waste loading is expected from CCIM for AZ-101 compared to the WTP baseline formulation for the JHM. To estimate the potential benefit for the entire Hanford mission, expected increase of waste loading needs to be estimated. Since it is not practical to estimate the waste loading for each waste batch, waste loading estimation was performed based on cluster compositions discussed in Section 2.2. 
Out of six groups of wastes discussed in Section 2.2.3, the high-iron waste clusters have similar composition as AZ-101, so the AZ-101 formulation results can be applied to estimate the expected increase of waste loading for high-iron clusters. The high-aluminum wastes, though the most dominant wastes at Hanford site, were not selected in the initial stages because the nepheline precipitation after $\mathrm{CCC}$ has a strong effect on waste loading for high-aluminum wastes, which suggest that the CCIM may not have significant benefit. The next waste groups following AZ-101 most likely to be limited by spinel or similar crystal formation, and therefore are likely to be benefitted by CCIM, were chosen:

spinel-limited and $\mathrm{Cr}_{2} \mathrm{O}_{3}-\mathrm{SO}_{3}$ limited wastes. Among $\mathrm{Cr}_{2} \mathrm{O}_{3}-\mathrm{SO}_{3}$ limited wastes, the initial focus was for high $\mathrm{Cr}_{2} \mathrm{O}_{3}$ waste cluster that has a potential to be limited by spinel crystallization rather than salt formation. The $\mathrm{P}_{2} \mathrm{O}_{5}-\mathrm{CaO}$ limited and salt-limited high $\mathrm{Cr}_{2} \mathrm{O}_{3}-\mathrm{SO}_{3}$ wastes require laboratory experimental setup designed for evaluation of salt phase formation during cold cap melting. The initial results of glass formulation for spinel-limited and high $\mathrm{Cr}_{2} \mathrm{O}_{3}$ wastes obtained before the project discontinuation are summarized in the following subsections.

The compositions of waste clusters in terms of 41 oxide components given in Table A.2 (a simplified version sorted by waste group is presented in Table 2.7) were modified as follows for use in glass formulation and testing in this section and in Section 5.1. The two radioactive components $\left(\mathrm{ThO}_{2}\right.$ and $\left.\mathrm{UO}_{3}\right)$ and minor components that are present in low concentrations $(<0.4 \mathrm{wt} \%$ in all 20 clusters $)$ and are not important for glass formulation were deleted. For noble metal oxides, $\mathrm{PdO}$ and $\mathrm{Rh}_{2} \mathrm{O}_{3}$ were replaced by the same mass fraction of $\mathrm{RuO}_{2}$. For the same reason discussed in Section 2.1, the concentration of $\mathrm{Cs}_{2} \mathrm{O}$ was fixed at $0.5 \mathrm{wt} \%$ for all clusters. The resulting normalized composition of 20 clusters in terms of 23 oxide components is given in Table 4.20.

Table 4.20. Composition of Waste Clusters in Terms of 23 Oxide Components

\begin{tabular}{|c|c|c|c|c|c|c|c|c|c|c|c|}
\hline Cluster \# & 5 & 7 & 8 & 16 & 1 & 10 & 18 & 3 & 4 & 19 & 20 \\
\hline Group & \multicolumn{4}{|c|}{ High- $\mathrm{Al}_{2} \mathrm{O}_{3}$} & \multicolumn{3}{|c|}{ High- $\mathrm{Fe}_{2} \mathrm{O}_{3}$} & \multicolumn{4}{|c|}{ Spinel limited } \\
\hline $\mathrm{Al}_{2} \mathrm{O}_{3}$ & 0.49789 & 0.47450 & 0.45532 & 0.59632 & 0.14764 & 0.21142 & 0.22312 & 0.16139 & 0.40988 & 0.30812 & 0.25944 \\
\hline $\mathrm{B}_{2} \mathrm{O}_{3}$ & 0.00250 & 0.00146 & 0.00695 & 0.00219 & 0.00259 & 0.00348 & 0.00297 & 0.00979 & 0.00144 & 0.00121 & 0.00409 \\
\hline $\mathrm{Bi}_{2} \mathrm{O}_{3}$ & 0.01967 & 0.05866 & 0.02020 & 0.01507 & 0.00706 & 0.01906 & 0.00373 & 0.02909 & 0.01073 & 0.00925 & 0.05524 \\
\hline $\mathrm{CaO}$ & 0.01650 & 0.02579 & 0.02696 & 0.00900 & 0.02608 & 0.02698 & 0.02458 & 0.04556 & 0.02882 & 0.04341 & 0.04390 \\
\hline $\mathrm{CdO}$ & 0.00018 & 0.00005 & 0.00025 & 0.00004 & 0.00091 & 0.00086 & 0.03580 & 0.00556 & 0.00569 & 0.00248 & 0.00030 \\
\hline $\mathrm{Cr}_{2} \mathrm{O}_{3}$ & 0.02410 & 0.01955 & 0.02180 & 0.02110 & 0.00864 & 0.00746 & 0.00685 & 0.01457 & 0.01439 & 0.01277 & 0.02051 \\
\hline $\mathrm{Cs}_{2} \mathrm{O}$ & 0.00500 & 0.00500 & 0.00500 & 0.00500 & 0.00500 & 0.00500 & 0.00500 & 0.00500 & 0.00500 & 0.00500 & 0.00500 \\
\hline $\mathrm{F}$ & 0.01507 & 0.00562 & 0.01184 & 0.00268 & 0.00160 & 0.00501 & 0.00131 & 0.00190 & 0.00137 & 0.00179 & 0.02507 \\
\hline $\mathrm{Fe}_{2} \mathrm{O}_{3}$ & 0.06164 & 0.11502 & 0.11712 & 0.05709 & 0.35484 & 0.33449 & 0.38683 & 0.22156 & 0.16195 & 0.18398 & 0.15896 \\
\hline $\mathrm{K}_{2} \mathrm{O}$ & 0.00620 & 0.00479 & 0.00398 & 0.00226 & 0.00841 & 0.00723 & 0.01066 & 0.01220 & 0.00594 & 0.00520 & 0.00471 \\
\hline $\mathrm{La}_{2} \mathrm{O}_{3}$ & 0.00224 & 0.00105 & 0.00073 & 0.00099 & 0.00196 & 0.00279 & 0.00935 & 0.00792 & 0.00295 & 0.00197 & 0.00355 \\
\hline $\mathrm{MgO}$ & 0.00194 & 0.00109 & 0.00367 & 0.00201 & 0.00366 & 0.00892 & 0.00287 & 0.00480 & 0.00147 & 0.00253 & 0.00622 \\
\hline $\mathrm{MnO}$ & 0.01257 & 0.01001 & 0.01991 & 0.01440 & 0.05076 & 0.02426 & 0.01370 & 0.03403 & 0.01069 & 0.01426 & 0.01498 \\
\hline $\mathrm{Na}_{2} \mathrm{O}$ & 0.15696 & 0.13542 & 0.12938 & 0.16917 & 0.21797 & 0.14952 & 0.10610 & 0.14910 & 0.13336 & 0.21849 & 0.16704 \\
\hline $\mathrm{Nd}_{2} \mathrm{O}_{3}$ & 0.00037 & 0.00030 & 0.00107 & 0.00078 & 0.00335 & 0.00228 & 0.00712 & 0.00127 & 0.00211 & 0.00209 & 0.00067 \\
\hline $\mathrm{NiO}$ & 0.01365 & 0.00730 & 0.00697 & 0.00373 & 0.01768 & 0.02283 & 0.03035 & 0.04920 & 0.02710 & 0.02084 & 0.01712 \\
\hline $\mathrm{P}_{2} \mathrm{O}_{5}$ & 0.04791 & 0.03781 & 0.02356 & 0.01453 & 0.01838 & 0.01854 & 0.01074 & 0.05033 & 0.01277 & 0.01410 & 0.03651 \\
\hline $\mathrm{PbO}$ & 0.00262 & 0.00444 & 0.00873 & 0.00271 & 0.01388 & 0.01764 & 0.00753 & 0.00741 & 0.00635 & 0.00752 & 0.00910 \\
\hline
\end{tabular}




\begin{tabular}{|c|c|c|c|c|c|c|c|c|c|c|c|c|}
\hline Cluster \# & $\mathbf{5}$ & $\mathbf{7}$ & $\mathbf{8}$ & $\mathbf{1 6}$ & $\mathbf{1}$ & $\mathbf{1 0}$ & $\mathbf{1 8}$ & $\mathbf{3}$ & $\mathbf{4}$ & $\mathbf{1 9}$ & $\mathbf{2 0}$ \\
\hline $\mathbf{G r o u p}$ & \multicolumn{3}{|c|}{ High- $\mathbf{A l}_{\mathbf{2}} \mathbf{O}_{\mathbf{3}}$} & \multicolumn{3}{|c|}{ High-Fe $_{2} \mathbf{O}_{3}$} & \multicolumn{5}{c|}{ Spinel limited } \\
\hline $\mathrm{RuO}_{2}$ & 0.00003 & 0.00000 & 0.00000 & 0.00000 & 0.00170 & 0.00193 & 0.00026 & 0.00031 & 0.00105 & 0.00138 & 0.00000 \\
\hline $\mathrm{SiO}_{2}$ & 0.03629 & 0.07915 & 0.12087 & 0.07212 & 0.06749 & 0.07482 & 0.03509 & 0.04851 & 0.11486 & 0.08729 & 0.14241 \\
\hline $\mathrm{SO}_{3}$ & 0.01291 & 0.00912 & 0.00941 & 0.00520 & 0.00469 & 0.00490 & 0.00204 & 0.00792 & 0.00296 & 0.00284 & 0.01084 \\
\hline $\mathrm{SrO}$ & 0.00778 & 0.00188 & 0.00397 & 0.00172 & 0.00080 & 0.00133 & 0.00076 & 0.00152 & 0.00244 & 0.02140 & 0.01130 \\
\hline $\mathrm{ZrO}_{2}$ & 0.05597 & 0.00198 & 0.00232 & 0.00189 & 0.03491 & 0.04924 & 0.07322 & 0.13105 & 0.03667 & 0.03212 & 0.00305 \\
\hline $\mathrm{SUM}$ & 1.00000 & 1.00000 & 1.00000 & 1.00000 & 1.00000 & 1.00000 & 1.00000 & 1.00000 & 1.00000 & 1.00000 & 1.00000 \\
\hline $\begin{array}{c}\text { Oxide mass } \\
\text { (MT) }\end{array}$ & 719.0 & $1,839.6$ & $1,183.1$ & $1,453.8$ & 405.2 & 734.0 & 123.9 & 266.3 & 220.9 & 249.2 & $1,350.5$ \\
\hline
\end{tabular}

Table 4.20. (Continued)

\begin{tabular}{|c|c|c|c|c|c|c|c|c|c|}
\hline \multirow{2}{*}{$\begin{array}{c}\text { Cluster \# } \\
\text { Group }\end{array}$} & 12 & 14 & 6 & 11 & 2 & 13 & 15 & 17 & \multirow{2}{*}{$\frac{9}{\text { High-Na }}$} \\
\hline & \multicolumn{4}{|c|}{$\mathrm{Cr}_{2} \mathrm{O}_{3}-\mathrm{SO}_{3}$ limited } & \multicolumn{4}{|c|}{$\mathrm{P}_{2} \mathrm{O}_{5}-\mathrm{CaO}$ limited } & \\
\hline $\mathrm{Al}_{2} \mathrm{O}_{3}$ & 0.17779 & 0.33611 & 0.29919 & 0.29532 & 0.21406 & 0.24823 & 0.13806 & 0.18983 & 0.09786 \\
\hline $\mathrm{B}_{2} \mathrm{O}_{3}$ & 0.00232 & 0.00328 & 0.00459 & 0.00224 & 0.00223 & 0.00259 & 0.00210 & 0.00147 & 0.00562 \\
\hline $\mathrm{Bi}_{2} \mathrm{O}_{3}$ & 0.03701 & 0.01838 & 0.04084 & 0.05967 & 0.07589 & 0.02704 & 0.06107 & 0.01267 & 0.01372 \\
\hline $\mathrm{CaO}$ & 0.03268 & 0.02253 & 0.02146 & 0.02588 & 0.05881 & 0.02723 & 0.05667 & 0.09194 & 0.02703 \\
\hline $\mathrm{CdO}$ & 0.00026 & 0.00083 & 0.00062 & 0.00033 & 0.00050 & 0.00050 & 0.00018 & 0.00372 & 0.00043 \\
\hline $\mathrm{Cr}_{2} \mathrm{O}_{3}$ & 0.08364 & 0.07716 & 0.03161 & 0.02311 & 0.01448 & 0.03181 & 0.00404 & 0.01508 & 0.02871 \\
\hline $\mathrm{Cs}_{2} \mathrm{O}$ & 0.00500 & 0.00500 & 0.00500 & 0.00500 & 0.00500 & 0.00500 & 0.00500 & 0.00500 & 0.00500 \\
\hline $\mathrm{F}$ & 0.05431 & 0.00458 & 0.00593 & 0.06331 & 0.02958 & 0.02507 & 0.01303 & 0.00263 & 0.00734 \\
\hline $\mathrm{Fe}_{2} \mathrm{O}_{3}$ & 0.13276 & 0.08857 & 0.15918 & 0.09960 & 0.11931 & 0.11112 & 0.24999 & 0.14292 & 0.07010 \\
\hline $\mathrm{K}_{2} \mathrm{O}$ & 0.01138 & 0.00757 & 0.00805 & 0.00581 & 0.00513 & 0.00507 & 0.02261 & 0.01025 & 0.02653 \\
\hline $\mathrm{La}_{2} \mathrm{O}_{3}$ & 0.00522 & 0.00079 & 0.01041 & 0.00036 & 0.00046 & 0.00202 & 0.00035 & 0.00224 & 0.00019 \\
\hline $\mathrm{MgO}$ & 0.00222 & 0.00123 & 0.00659 & 0.00149 & 0.00172 & 0.00260 & 0.00207 & 0.00116 & 0.00411 \\
\hline $\mathrm{MnO}$ & 0.01333 & 0.02118 & 0.03259 & 0.00552 & 0.00605 & 0.00963 & 0.02565 & 0.01672 & 0.00614 \\
\hline $\mathrm{Na}_{2} \mathrm{O}$ & 0.15475 & 0.20147 & 0.18036 & 0.12861 & 0.25938 & 0.24975 & 0.13604 & 0.38352 & 0.56687 \\
\hline $\mathrm{Nd}_{2} \mathrm{O}_{3}$ & 0.00022 & 0.00111 & 0.00125 & 0.00030 & 0.00079 & 0.00051 & 0.00040 & 0.00342 & 0.00083 \\
\hline $\mathrm{NiO}$ & 0.03403 & 0.00403 & 0.03301 & 0.00810 & 0.00815 & 0.01693 & 0.03257 & 0.00593 & 0.00510 \\
\hline $\mathrm{P}_{2} \mathrm{O}_{5}$ & 0.12081 & 0.11627 & 0.04671 & 0.04609 & 0.07061 & 0.12780 & 0.05931 & 0.03266 & 0.02554 \\
\hline $\mathrm{PbO}$ & 0.00429 & 0.00437 & 0.00797 & 0.00291 & 0.00657 & 0.00453 & 0.01299 & 0.00323 & 0.00612 \\
\hline $\mathrm{RuO}_{2}$ & 0.00003 & 0.00021 & 0.00055 & 0.00001 & 0.00013 & 0.00024 & 0.00039 & 0.00088 & 0.00001 \\
\hline $\mathrm{SiO}_{2}$ & 0.06362 & 0.04502 & 0.05449 & 0.19198 & 0.09788 & 0.06740 & 0.14883 & 0.02488 & 0.08925 \\
\hline $\mathrm{SO}_{3}$ & 0.02380 & 0.02069 & 0.01512 & 0.02232 & 0.00948 & 0.01202 & 0.00163 & 0.00464 & 0.00367 \\
\hline $\mathrm{SrO}$ & 0.02641 & 0.00543 & 0.00412 & 0.00552 & 0.01024 & 0.01619 & 0.00165 & 0.03083 & 0.00432 \\
\hline $\mathrm{ZrO}_{2}$ & 0.01411 & 0.01420 & 0.03038 & 0.00651 & 0.00354 & 0.00671 & 0.02539 & 0.01438 & 0.00549 \\
\hline SUM & 1.00000 & 1.00000 & 1.00000 & 1.00000 & 1.00000 & 1.00000 & 1.00000 & 1.00000 & 1.00000 \\
\hline Oxide mass (MT) & 275.2 & 173.3 & 364.1 & 533.0 & 338.9 & 209.4 & 327.2 & 164.7 & 143.8 \\
\hline
\end{tabular}




\subsubsection{Cold Crucible Induction Melter Glass Formulation for Spinel-Limited Waste Clusters}

There were four waste clusters (Clusters 3, 4, 19, and 20) grouped as spinel-limited as shown in Table 2.7. The primary property constraint to watch for in these wastes is the $T_{1 \%}$, however, some clusters (Clusters 19 and 20) also contain relatively high concentration of $\mathrm{Al}_{2} \mathrm{O}_{3}$ and therefore the nepheline precipitation may become a limiting constraint.

Table 4.21 summarizes the composition and predicted properties of the glasses formulated for spinel-limited clusters. The first step of glass development was to prepare small batches of glass and examine melting characteristics visually to sort out the glasses that form severe crystallization during melting, which will prevent preparing reasonable glasses for property characterization. Initial glass calculations showed that there is similarity between Clusters 4 and 19 in terms of maximum achievable waste loading. Therefore, it was decided that the glass formulations to determine maximum waste loading that make reasonable glass for property measurements will be performed for three clusters (Clusters 3, 4, and 20) and that of Cluster 19 can be estimated from the glass formulation results for Cluster 4.

At high waste loadings the additives are limited to $\mathrm{B}_{2} \mathrm{O}_{3}, \mathrm{Li}_{2} \mathrm{O}$, and $\mathrm{Na}_{2} \mathrm{O}$ with the $\mathrm{SiO}_{2}$ as a balance. The starting composition for each cluster was formulated at:

- $\mathrm{Al}_{2} \mathrm{O}_{3}+\mathrm{Fe}_{2} \mathrm{O}_{3}+\mathrm{ZrO}_{2}$ content estimated to be close to maximum based on formulation experience with AZ-101 HLW in Section 4.1

- fixed target concentrations of $11 \mathrm{wt} \% \mathrm{~B}_{2} \mathrm{O}_{3}$ and $3 \mathrm{wt} \% \mathrm{Li}_{2} \mathrm{O}$ in glass (the same as used in $\mathrm{AZ}-101$ glasses selected for melter demonstration tests)

- predicted viscosity of $4 \mathrm{~Pa} \cdot \mathrm{s}$ at a target melting temperature of $1200^{\circ} \mathrm{C}$.

For Cluster 3, the first glass (CCIM-SLC3-3) tested had $27 \mathrm{wt} \%$ of $\mathrm{Al}_{2} \mathrm{O}_{3}+\mathrm{Fe}_{2} \mathrm{O}_{3}+\mathrm{ZrO}_{2}(52.5 \mathrm{wt} \%$ WL) with $11 \mathrm{wt} \% \mathrm{~B}_{2} \mathrm{O}_{3}$. The maximum $\mathrm{Li}_{2} \mathrm{O}$ that can be used was $2.6 \mathrm{wt} \%$ to keep the melting temperature at $1200{ }^{\circ} \mathrm{C}$. This melt made a reasonable glass that can be used for property testing although it appeared that the waste loading limit was reached based on relatively high crystallinity. The next glass (CCIM-SLC3-4) was modified without increasing waste loading to have lower $\mathrm{B}_{2} \mathrm{O}_{3}$ at $8 \mathrm{wt} \%$ and higher $\mathrm{Li}_{2} \mathrm{O}$ at $3 \mathrm{wt} \%$ than CCIM-SLC3-3 glass. Then, the concentration of $\mathrm{Na}_{2} \mathrm{O}$ was adjusted to keep the melting temperature at $1200^{\circ} \mathrm{C}$. This melt resulted in much higher crystallinity than CCIM-SLC3-3, to the extent not adequate for property characterization, and therefore, the CCIM-SLC3-3 composition was selected as a glass for further characterization.

For Cluster 4, the first glass tested (CCIM-SLC4-4) had $33 \mathrm{wt} \%$ of $\mathrm{Al}_{2} \mathrm{O}_{3}+\mathrm{Fe}_{2} \mathrm{O}_{3}+\mathrm{ZrO}_{2}(54.2 \mathrm{wt} \%$ waste loading) with $11 \mathrm{wt} \% \mathrm{~B}_{2} \mathrm{O}_{3}$ and $3 \mathrm{wt} \% \mathrm{Li}_{2} \mathrm{O}$. The concentration of $\mathrm{Na}_{2} \mathrm{O}$ was adjusted to keep the melting temperature at $1200^{\circ} \mathrm{C}$. This melt had only small fraction of crystals. The next three glasses tested (CCIM-SLC4-7, 8, and 9) had $35 \mathrm{wt} \%$ of $\mathrm{Al}_{2} \mathrm{O}_{3}+\mathrm{Fe}_{2} \mathrm{O}_{3}+\mathrm{ZrO}_{2}(57.5 \mathrm{wt} \%$ WL) with varying concentrations of $\mathrm{B}_{2} \mathrm{O}_{3}$ and $\mathrm{Li}_{2} \mathrm{O}$ in glass:

- CCIM-SLC4-7 had $11 \mathrm{wt} \% \mathrm{~B}_{2} \mathrm{O}_{3}$ and $3 \mathrm{wt} \% \mathrm{Li}_{2} \mathrm{O}$

- CCIM-SLC4-8 had $14 \mathrm{wt} \% \mathrm{~B}_{2} \mathrm{O}_{3}$ and $3 \mathrm{wt} \% \mathrm{Li}_{2} \mathrm{O}$

- CCIM-SLC4-9 had $14 \mathrm{wt} \% \mathrm{~B}_{2} \mathrm{O}_{3}$ and $4.5 \mathrm{wt} \% \mathrm{Li}_{2} \mathrm{O}$, while $\mathrm{Na}_{2} \mathrm{O}$ addition was adjusted to keep the $1200^{\circ} \mathrm{C}$ melting temperature. 
Table 4.21. Glasses Formulated for Spinel-Limited Waste Clusters and Their Predicted Properties

\begin{tabular}{|c|c|c|c|c|c|c|c|c|}
\hline \multirow[b]{2}{*}{ Glass ID } & \multicolumn{2}{|c|}{ Cluster 3} & \multicolumn{5}{|c|}{ Cluster 4} & \multirow[b]{2}{*}{ Limits $^{\mathrm{a}}$} \\
\hline & $\begin{array}{l}\text { CCIM- } \\
\text { SLC3-3 }\end{array}$ & $\begin{array}{l}\text { CCIM- } \\
\text { SLC3-4 }\end{array}$ & $\begin{array}{l}\text { CCIM- } \\
\text { SLC4-4 }\end{array}$ & $\begin{array}{l}\text { CCIM- } \\
\text { SLC4-7 }\end{array}$ & $\begin{array}{l}\text { CCIM- } \\
\text { SLC4-8 }\end{array}$ & $\begin{array}{l}\text { CCIM- } \\
\text { SLC4-9 }\end{array}$ & $\begin{array}{c}\text { CCIM- } \\
\text { SLC4-10 }\end{array}$ & \\
\hline & Selected & $\mathrm{Bad}$ & Good & Selected & Selected & $\mathrm{Bad}$ & $\mathrm{Bad}$ & \\
\hline $\mathrm{Al}_{2} \mathrm{O}_{3}$ & 0.08478 & 0.08478 & 0.22228 & 0.23575 & 0.23575 & 0.23575 & 0.24923 & - \\
\hline $\mathrm{B}_{2} \mathrm{O}_{3}$ & 0.11000 & 0.08000 & 0.11000 & 0.11000 & 0.14000 & 0.14000 & 0.11000 & - \\
\hline $\mathrm{Bi}_{2} \mathrm{O}_{3}$ & 0.01528 & 0.01528 & 0.00582 & 0.00617 & 0.00617 & 0.00617 & 0.00652 & - \\
\hline $\mathrm{CaO}$ & 0.02393 & 0.02393 & 0.01563 & 0.01658 & 0.01658 & 0.01658 & 0.01752 & - \\
\hline $\mathrm{CdO}$ & 0.00292 & 0.00292 & 0.00309 & 0.00327 & 0.00327 & 0.00327 & 0.00346 & - \\
\hline $\mathrm{Cr}_{2} \mathrm{O}_{3}$ & 0.00766 & 0.00766 & 0.00780 & 0.00827 & 0.00827 & 0.00827 & 0.00875 & - \\
\hline $\mathrm{Cs}_{2} \mathrm{O}$ & 0.00263 & 0.00263 & 0.00271 & 0.00288 & 0.00288 & 0.00288 & 0.00304 & - \\
\hline$F$ & 0.00100 & 0.00100 & 0.00075 & 0.00079 & 0.00079 & 0.00079 & 0.00084 & - \\
\hline $\mathrm{Fe}_{2} \mathrm{O}_{3}$ & 0.11638 & 0.11638 & 0.08783 & 0.09315 & 0.09315 & 0.09315 & 0.09848 & - \\
\hline $\mathrm{K}_{2} \mathrm{O}$ & 0.00641 & 0.00641 & 0.00322 & 0.00342 & 0.00342 & 0.00342 & 0.00361 & - \\
\hline $\mathrm{La}_{2} \mathrm{O}_{3}$ & 0.00416 & 0.00416 & 0.00160 & 0.00169 & 0.00169 & 0.00169 & 0.00179 & - \\
\hline $\mathrm{Li}_{2} \mathrm{O}$ & 0.02644 & 0.03000 & 0.03000 & 0.03000 & 0.03000 & 0.04500 & 0.03000 & - \\
\hline $\mathrm{MgO}$ & 0.00252 & 0.00252 & 0.00080 & 0.00084 & 0.00084 & 0.00084 & 0.00089 & - \\
\hline $\mathrm{MnO}$ & 0.01787 & 0.01787 & 0.00580 & 0.00615 & 0.00615 & 0.00615 & 0.00650 & - \\
\hline $\mathrm{Na}_{2} \mathrm{O}$ & 0.07832 & 0.09464 & 0.15705 & 0.15355 & 0.12646 & 0.09022 & 0.14996 & - \\
\hline $\mathrm{Nd}_{2} \mathrm{O}_{3}$ & 0.00067 & 0.00067 & 0.00115 & 0.00121 & 0.00121 & 0.00121 & 0.00128 & - \\
\hline $\mathrm{NiO}$ & 0.02584 & 0.02584 & 0.01470 & 0.01559 & 0.01559 & 0.01559 & 0.01648 & - \\
\hline $\mathrm{P}_{2} \mathrm{O}_{5}$ & 0.02644 & 0.02644 & 0.00693 & 0.00734 & 0.00734 & 0.00734 & 0.00776 & - \\
\hline $\mathrm{PbO}$ & 0.00389 & 0.00389 & 0.00344 & 0.00365 & 0.00365 & 0.00365 & 0.00386 & - \\
\hline $\mathrm{RuO}_{2}$ & 0.00016 & 0.00016 & 0.00057 & 0.00061 & 0.00061 & 0.00061 & 0.00064 & - \\
\hline $\mathrm{SiO}_{2}$ & 0.36889 & 0.37901 & 0.29604 & 0.27487 & 0.27196 & 0.29320 & 0.25379 & - \\
\hline $\mathrm{SO}_{3}$ & 0.00416 & 0.00416 & 0.00161 & 0.00170 & 0.00170 & 0.00170 & 0.00180 & - \\
\hline $\mathrm{SrO}$ & 0.00080 & 0.00080 & 0.00132 & 0.00140 & 0.00140 & 0.00140 & 0.00148 & - \\
\hline $\mathrm{ZrO}_{2}$ & 0.06884 & 0.06884 & 0.01989 & 0.02109 & 0.02109 & 0.02109 & 0.02230 & - \\
\hline Total & 1 & 1 & 1 & 1 & 1 & 1 & 1 & - \\
\hline Waste loading & 0.525 & 0.525 & 0.542 & 0.575 & 0.575 & 0.575 & 0.608 & - \\
\hline $\mathrm{Al}_{2} \mathrm{O}_{3}+\mathrm{Fe}_{2} \mathrm{O}_{3}+\mathrm{ZrO}_{2}$ & 0.270 & 0.270 & 0.330 & 0.350 & 0.350 & 0.350 & 0.370 & - \\
\hline$T_{m}$ at $4 \mathrm{~Pa} \cdot \mathrm{s},{ }^{\circ} \mathrm{C}$ & 1200 & 1200 & 1200 & 1200 & 1200 & 1200 & 1200 & - \\
\hline $\mathrm{EC}$ at $T_{m}, \mathrm{~S} / \mathrm{m}$ & 20.5 & 25.7 & 44.2 & 43.1 & 33.3 & 31.9 & 42.0 & $10-100$ \\
\hline Spinel $T_{L},{ }^{\circ} \mathrm{C}$ & 1450 & 1450 & 1377 & 1436 & 1449 & 1477 & 1496 & $<T_{m}-100^{\mathrm{b}}$ \\
\hline Spinel $T_{1 \%},{ }^{\circ} \mathrm{C}$ & 1343 & 1339 & 1260 & 1331 & 1344 & 1368 & 1403 & $<T_{m}-200^{\mathrm{c}}$ \\
\hline PCT-B, g/L & 0.109 & 0.101 & 0.046 & 0.017 & 0.016 & 0.013 & 0.005 & $<16.7$ \\
\hline PCT-Li, g/L & 0.155 & 0.166 & 0.059 & 0.025 & 0.027 & 0.022 & 0.009 & $<9.57$ \\
\hline PCT-Na, g/L & 0.115 & 0.138 & 0.049 & 0.020 & 0.018 & 0.013 & 0.007 & $<13.35$ \\
\hline TCLP Cd, mg/L & 0.085 & 0.080 & 0.190 & 0.206 & 0.196 & 0.148 & 0.222 & $<0.48$ \\
\hline$N_{S i}$ & 0.693 & 0.679 & 0.438 & 0.414 & 0.429 & 0.474 & 0.389 & $\geq 0.62$ \\
\hline $\mathrm{OB}$ & 0.583 & 0.597 & 0.605 & 0.609 & 0.592 & 0.583 & 0.613 & $\leq 0.575$ \\
\hline \multicolumn{9}{|c|}{$\begin{array}{l}\text { a } \text { Used as guidelines for formulating the glasses. } \\
\text { b }{ }^{\mathrm{B}} \text { Based on a traditional constraint used in Perez et al. (2001). } \\
\mathrm{c} \text { Based on a constraint of } T_{1 \%}<950^{\circ} \mathrm{C} \text { for glasses with } T_{m}=1150^{\circ} \mathrm{C} \text { (Vienna et al. 2009). } \\
\text { Shaded cells indicate that the predicted or calculated value is not within the limits. }\end{array}$} \\
\hline
\end{tabular}


Table 4.21. (Continued)

\begin{tabular}{|c|c|c|c|c|c|c|}
\hline \multirow[b]{2}{*}{ Glass ID } & \multicolumn{5}{|c|}{ Cluster 20} & \multirow[b]{2}{*}{ Limits $^{a}$} \\
\hline & CCIM-SLC20-2 & CCIM-SLC20-4 & CCIM-SLC20-6 & CCIM-SLC20-7 & CCIM-SLC20-8 & \\
\hline & Good & Good & Selected & $\mathrm{Bad}$ & $\mathrm{Bad}$ & \\
\hline $\mathrm{Al}_{2} \mathrm{O}_{3}$ & 0.15390 & 0.16621 & 0.17852 & 0.17852 & 0.19083 & - \\
\hline $\mathrm{B}_{2} \mathrm{O}_{3}$ & 0.11000 & 0.11000 & 0.11000 & 0.08000 & 0.11000 & - \\
\hline $\mathrm{Bi}_{2} \mathrm{O}_{3}$ & 0.03277 & 0.03539 & 0.03801 & 0.03801 & 0.04063 & - \\
\hline $\mathrm{CaO}$ & 0.02604 & 0.02812 & 0.03021 & 0.03021 & 0.03229 & - \\
\hline $\mathrm{CdO}$ & 0.00018 & 0.00019 & 0.00021 & 0.00021 & 0.00022 & - \\
\hline $\mathrm{Cr}_{2} \mathrm{O}_{3}$ & 0.01217 & 0.01314 & 0.01411 & 0.01411 & 0.01509 & - \\
\hline $\mathrm{Cs}_{2} \mathrm{O}$ & 0.00297 & 0.00320 & 0.00344 & 0.00344 & 0.00368 & - \\
\hline $\mathrm{F}$ & 0.01487 & 0.01606 & 0.01725 & 0.01725 & 0.01844 & - \\
\hline $\mathrm{Fe}_{2} \mathrm{O}_{3}$ & 0.09429 & 0.10184 & 0.10938 & 0.10938 & 0.11692 & - \\
\hline $\mathrm{K}_{2} \mathrm{O}$ & 0.00279 & 0.00301 & 0.00324 & 0.00324 & 0.00346 & - \\
\hline $\mathrm{La}_{2} \mathrm{O}_{3}$ & 0.00211 & 0.00228 & 0.00244 & 0.00244 & 0.00261 & - \\
\hline $\mathrm{Li}_{2} \mathrm{O}$ & 0.02414 & 0.01646 & 0.00896 & 0.01988 & 0.00162 & - \\
\hline $\mathrm{MgO}$ & 0.00369 & 0.00398 & 0.00428 & 0.00428 & 0.00457 & - \\
\hline $\mathrm{MnO}$ & 0.00889 & 0.00960 & 0.01031 & 0.01031 & 0.01102 & - \\
\hline $\mathrm{Na}_{2} \mathrm{O}$ & 0.09909 & 0.10702 & 0.11494 & 0.11494 & 0.12287 & - \\
\hline $\mathrm{Nd}_{2} \mathrm{O}_{3}$ & 0.00040 & 0.00043 & 0.00046 & 0.00046 & 0.00050 & - \\
\hline $\mathrm{NiO}$ & 0.01015 & 0.01096 & 0.01178 & 0.01178 & 0.01259 & - \\
\hline $\mathrm{P}_{2} \mathrm{O}_{5}$ & 0.02166 & 0.02339 & 0.02512 & 0.02512 & 0.02686 & - \\
\hline $\mathrm{PbO}$ & 0.00540 & 0.00583 & 0.00626 & 0.00626 & 0.00669 & - \\
\hline $\mathrm{RuO}_{2}$ & 0.00000 & 0.00000 & 0.00000 & 0.00000 & 0.00000 & - \\
\hline $\mathrm{SiO}_{2}$ & 0.35956 & 0.32674 & 0.29373 & 0.31281 & 0.26057 & - \\
\hline $\mathrm{SO}_{3}$ & 0.00643 & 0.00695 & 0.00746 & 0.00746 & 0.00798 & - \\
\hline $\mathrm{SrO}$ & 0.00670 & 0.00724 & 0.00777 & 0.00777 & 0.00831 & - \\
\hline $\mathrm{ZrO}_{2}$ & 0.00181 & 0.00195 & 0.00210 & 0.00210 & 0.00224 & - \\
\hline Total & 1 & 1 & 1 & 1 & 1 & - \\
\hline Waste loading & 0.593 & 0.641 & 0.688 & 0.688 & 0.736 & - \\
\hline $\mathrm{Al}_{2} \mathrm{O}_{3}+\mathrm{Fe}_{2} \mathrm{O}_{3}+\mathrm{ZrO}_{2}$ & 0.250 & 0.270 & 0.290 & 0.290 & 0.310 & \\
\hline$T_{m}$ at $4 \mathrm{~Pa} \cdot \mathrm{s},{ }^{\circ} \mathrm{C}$ & 1200 & 1200 & 1200 & 1200 & 1200 & - \\
\hline $\mathrm{EC}$ at $T_{m}, \mathrm{~S} / \mathrm{m}$ & 23.9 & 22.8 & 22.0 & 26.7 & 21.6 & 10-100 \\
\hline Spinel $T_{L},{ }^{\circ} \mathrm{C}$ & 1417 & 1493 & 1570 & 1580 & 1649 & $<T_{m}-100^{\mathrm{b}}$ \\
\hline Spinel $T_{1 \%},{ }^{\circ} \mathrm{C}$ & 1191 & 1268 & 1346 & 1352 & 1424 & $<T_{m}-200^{\mathrm{c}}$ \\
\hline PCT-B, g/L & 0.230 & 0.202 & 0.164 & 0.139 & 0.120 & $<16.7$ \\
\hline PCT-Li, g/L & 0.321 & 0.289 & 0.243 & 0.235 & 0.188 & $<9.57$ \\
\hline PCT-Na, g/L & 0.223 & 0.205 & 0.176 & 0.186 & 0.139 & $<13.35$ \\
\hline TCLP Cd, mg/L & 0.008 & 0.010 & 0.012 & 0.010 & 0.015 & $<0.48$ \\
\hline$N_{S i}$ & 0.587 & 0.545 & 0.500 & 0.516 & 0.454 & $\geq 0.62$ \\
\hline $\mathrm{OB}$ & 0.578 & 0.585 & 0.592 & 0.602 & 0.599 & $\leq 0.575$ \\
\hline \multicolumn{7}{|c|}{$\begin{array}{l}{ }^{\mathrm{a}} \text { Used as guidelines for formulating the glasses. } \\
\mathrm{b} \text { based on a traditional constraint used in Perez et al. (2001). } \\
{ }^{\mathrm{c}} \text { Based on a constraint of } T_{1 \%}<950^{\circ} \mathrm{C} \text { for glasses with } T_{m}=1150^{\circ} \mathrm{C} \text { (Vienna et al. 2009). } \\
\text { Shaded cells indicate that the predicted or calculated value is not within the limits. }\end{array}$} \\
\hline
\end{tabular}

The two melts (CCIM-SLC4-7 and 8) had indication of small amount of crystals but in general made homogenous glass. However, the CCIM-SLC4-9 contained lots of crystals after the first melt. The second melt contained a little less, but still a large amount of crystals and it was difficult to pour the glass 
apparently because of the high crystal content. With two good glasses successfully prepared at $35 \mathrm{wt} \%$ $\mathrm{Al}_{2} \mathrm{O}_{3}+\mathrm{Fe}_{2} \mathrm{O}_{3}+\mathrm{ZrO}_{2}$ (57.5 wt \% waste loading), the next test melt (CCIM-SLC4-10) was prepared at $37 \mathrm{wt} \% \quad \mathrm{Al}_{2} \mathrm{O}_{3}+\mathrm{Fe}_{2} \mathrm{O}_{3}+\mathrm{ZrO}_{2}(60.8 \mathrm{wt} \%$ waste loading) with the similar composition as CCIM-SLC4-7, i.e., $11 \mathrm{wt} \% \mathrm{~B}_{2} \mathrm{O}_{3}$ and $3 \mathrm{wt} \% \mathrm{Li}_{2} \mathrm{O}$ with $\mathrm{Na}_{2} \mathrm{O}$ adjusted to make the $1200{ }^{\circ} \mathrm{C}$ melting temperature. This melt had visually very high crystallinity with severe melt inhomogeneity and not adequate for property measurements. The two reasonable glasses (CCIM-SLC4-7 and 8) with different $\mathrm{B}_{2} \mathrm{O}_{3}$ concentration at $11 \mathrm{wt} \%$ and $14 \mathrm{wt} \%$, were selected for further evaluation.

For Cluster 20, the first glass tested (CCIM-SLC20-2) had $25 \mathrm{wt} \%$ of $\mathrm{Al}_{2} \mathrm{O}_{3}+\mathrm{Fe}_{2} \mathrm{O}_{3}+\mathrm{ZrO}_{2}(59.3 \mathrm{wt} \%$ waste loading) with $11 \mathrm{wt} \% \mathrm{~B}_{2} \mathrm{O}_{3}$. The maximum $\mathrm{Li}_{2} \mathrm{O}$ that can be used to keep the melting temperature at $1200{ }^{\circ} \mathrm{C}$ was $2.4 \mathrm{wt} \%$. $\mathrm{Na}_{2} \mathrm{O}$ was not added for this glass. This melt had little crystals. The next glass was CCIM-SLC20-4 containing $27 \mathrm{wt} \%$ of $\mathrm{Al}_{2} \mathrm{O}_{3}+\mathrm{Fe}_{2} \mathrm{O}_{3}+\mathrm{ZrO}_{2}$ (64.1 wt $\%$ waste loading), $11 \mathrm{wt} \% \mathrm{~B}_{2} \mathrm{O}_{3}$, and $1.65 \mathrm{wt} \% \mathrm{Li}_{2} \mathrm{O}$ had indication of small amount of crystals but made a typical homogenous glass.

Then, two glasses (CCIM-SLC20-6 and 7) were formulated at $29 \mathrm{wt} \%$ of $\mathrm{Al}_{2} \mathrm{O}_{3}+\mathrm{Fe}_{2} \mathrm{O}_{3}+\mathrm{ZrO}_{2}(68.8 \mathrm{wt} \%$ waste loading) with $11 \mathrm{wt} \% \mathrm{~B}_{2} \mathrm{O}_{3}$ and $0.9 \mathrm{wt} \% \mathrm{Li}_{2} \mathrm{O}$ and $8 \mathrm{wt} \% \mathrm{~B}_{2} \mathrm{O}_{3}$ and $1.99 \mathrm{wt} \% \mathrm{Li}_{2} \mathrm{O}$, respectively. CCIM-SLC20-6 had relatively high crystals in the bulk of the glass but made into in general a homogeneous glass. However, the CCIM-SLC20-7 glass with lower $\mathrm{B}_{2} \mathrm{O}_{3}$ (and higher $\mathrm{Li}_{2} \mathrm{O}$ ) than CCIM-SLC20-6 had very high crystallinity with severe melt inhomogeneity not adequate for property measurements. The CCIM-SLC20-8 melt with higher waste loading at $31 \mathrm{wt} \%$ of $\mathrm{Al}_{2} \mathrm{O}_{3}+\mathrm{Fe}_{2} \mathrm{O}_{3}+\mathrm{ZrO}_{2}$ (73.6 wt $\%$ waste loading) was also prepared but was full of crystals. The CCIM-SLC20-6 was selected for further characterization.

The maximum waste loadings estimated for spinel-limited clusters to make reasonable glass for property measurements are summarized in Table 4.22. Table 4.22 also provides the estimated maximum $\mathrm{Al}_{2} \mathrm{O}_{3}+\mathrm{Fe}_{2} \mathrm{O}_{3}+\mathrm{ZrO}_{2}$ in glass and glass compositions selected for property testing. The estimated maximum waste loading for Cluster 19 was obtained by assuming that Cluster 19 has the same $\mathrm{Al}_{2} \mathrm{O}_{3}+\mathrm{Fe}_{2} \mathrm{O}_{3}+\mathrm{ZrO}_{2}$ loading in glass as Cluster 4. Note that these estimated maximum waste loadings are not those that can be processed in the CCIM, which need to be determined based on measured crystal vol $\%$ at a fixed temperature or as a function of temperature.

Table 4.22. Summary of Results for the Initial Glasses Formulated for Spinel-Limited Clusters

\begin{tabular}{|c|c|c|c|}
\hline \multirow[b]{2}{*}{ Cluster } & \multicolumn{2}{|c|}{ Estimated Maximum } & \multirow[b]{2}{*}{$\begin{array}{c}\text { Selected for property } \\
\text { testing }\end{array}$} \\
\hline & $\begin{array}{c}\text { Waste } \\
\text { loading }\end{array}$ & $\begin{array}{c}\mathrm{Al}_{2} \mathrm{O}_{3}+\mathrm{Fe}_{2} \mathrm{O}_{3}+\mathrm{ZrO}_{2} \\
\text { in glass }\end{array}$ & \\
\hline 3 & $52.5 \mathrm{wt} \%$ & $27 \mathrm{wt} \%$ & CCIM-SLC3-3 \\
\hline 4 & $57.5 \mathrm{wt} \%$ & $35 \mathrm{wt} \%$ & CCIM-SLC4-7 and 8 \\
\hline 19 & $66.8 \mathrm{wt} \%$ & $35 \mathrm{wt} \%$ & Not applicable \\
\hline 20 & $68.8 \mathrm{wt} \%$ & $29 \mathrm{wt} \%$ & CCIM-SLC20-6 \\
\hline
\end{tabular}




\subsubsection{Cold Crucible Induction Melter Glass Formulation for High-Chromium Waste Clusters}

The waste loading for the $\mathrm{Cr}_{2} \mathrm{O}_{3}-\mathrm{SO}_{3}$ limited clusters can be limited either by spinel crystallization or salt formation, depending on the concentration of $\mathrm{SO}_{3}$ compared to $\mathrm{Cr}_{2} \mathrm{O}_{3}$ and other spinel components (typically $\mathrm{Fe}_{2} \mathrm{O}_{3}, \mathrm{NiO}$, and $\mathrm{MnO}$ ). For the development of glasses for the CCIM, the wastes that are limited by salt formation are not likely benefited significantly by high melter operation temperature of CCIM. Therefore, it is preferable to select waste with a low $\mathrm{SO}_{3}$ to $\mathrm{Cr}_{2} \mathrm{O}_{3}$ ratio so that potential maximum benefit of CCIM can be evaluated. Among four $\mathrm{Cr}_{2} \mathrm{O}_{3}-\mathrm{SO}_{3}$ limited clusters (Clusters 12, 14, 6 , and 11), the two clusters (Clusters 12 and 14) are characterized by high $\mathrm{Cr}_{2} \mathrm{O}_{3}$ at $8.36 \mathrm{wt} \%$ and $7.72 \mathrm{wt} \%$ (see Table 4.20) with a slightly lower $\mathrm{SO}_{3}$ to $\mathrm{Cr}_{2} \mathrm{O}_{3}$ ratio for Cluster 14. Therefore, Cluster 14 was selected for initial formulation studies for CCIM.

Table 4.23 summarizes the composition and predicted properties formulated and melted for one of the $\mathrm{Cr}_{2} \mathrm{O}_{3}-\mathrm{SO}_{3}$ limited clusters, Cluster 14. The first set of four glasses was formulated at a fixed $\mathrm{Cr}_{2} \mathrm{O}_{3}$ concentration of $3 \mathrm{wt} \%$ (corresponding to $38.9 \mathrm{wt} \%$ waste loading) with varying concentrations of $\mathrm{B}_{2} \mathrm{O}_{3}$, $\mathrm{K}_{2} \mathrm{O}, \mathrm{Li}_{2} \mathrm{O}$, and $\mathrm{Na}_{2} \mathrm{O}$. The concentration of $\mathrm{Na}_{2} \mathrm{O}$ was adjusted last to make the predicted viscosity at $1200{ }^{\circ} \mathrm{C}$ to $5 \mathrm{~Pa} \cdot \mathrm{s}$ after choosing the concentrations for $\mathrm{B}_{2} \mathrm{O}_{3}, \mathrm{~K}_{2} \mathrm{O}$ and $\mathrm{Li}_{2} \mathrm{O}$. The main focus of melting test with these high-chromium glasses was the presence of salt phase after melting.

Figure 4.19 shows the pictures of the crucible wall of the first set of four CCIM-HCC14 glasses after melting at $1200^{\circ} \mathrm{C}$. The yellow salt layer was formed on three glasses with most significant amount observed by CCIM-HCC14-6 and much less by CCIM-HCC14-1 and CCIM-HCC14-4. The CCIM-HCC14-2 did not form any salt. The most noticeable difference in the composition of CCIMHCC14-2 glass (with no salt) was that it had higher concentration of $\mathrm{B}_{2} \mathrm{O}_{3}$ at $14 \mathrm{wt} \%$ compared to $11 \mathrm{wt} \%$ in other glasses. The CCIM-HCC14-6 glass that had most salt formation had no $\mathrm{Li}_{2} \mathrm{O}$ and consequently contained higher concentrations of $\mathrm{K}_{2} \mathrm{O}$ and $\mathrm{Na}_{2} \mathrm{O}$ to keep the viscosity the same as $4 \mathrm{~Pa} \cdot \mathrm{s}$ at $1200^{\circ} \mathrm{C}$.

Based on the information from the first set of glasses, the first glass (CCIM-HCC14-8) of the second set was formulated at increased $\mathrm{Cr}_{2} \mathrm{O}_{3}$ loading of $3.5 \mathrm{wt} \%$ (corresponding to $45.4 \mathrm{wt} \%$ waste loading) with $14 \mathrm{wt} \% \mathrm{~B}_{2} \mathrm{O}_{3}$ and $3 \mathrm{wt} \% \mathrm{Li}_{2} \mathrm{O}$. The $\mathrm{B}_{2} \mathrm{O}_{3}$ concentration was increased to $17 \mathrm{wt} \%$ for the next glass (CCIM-HCC14-10) while $\mathrm{Na}_{2} \mathrm{O}$ was decreased to keep the viscosity the same. The third glass (CCIM-HCC14-12) of the second set was formulated to have $6 \mathrm{wt} \% \mathrm{~K}_{2} \mathrm{O}$ at $14 \mathrm{wt} \% \mathrm{~B}_{2} \mathrm{O}_{3}$ and $3 \mathrm{wt} \%$ $\mathrm{Li}_{2} \mathrm{O}$ without adding $\mathrm{Na}_{2} \mathrm{O}\left(9.14 \mathrm{wt} \% \mathrm{Na}_{2} \mathrm{O}\right.$ is from waste). The last glass (CCIM-HCC14-15) was formulated with the same $\mathrm{B}_{2} \mathrm{O}_{3}, \mathrm{Li}_{2} \mathrm{O}$ and $\mathrm{K}_{2} \mathrm{O}$ as the first glass (CCIM-HCC14-8), but the predicted temperature at $4 \mathrm{~Pa} \cdot \mathrm{s}$ was increased to $1250{ }^{\circ} \mathrm{C}$ by decreasing $\mathrm{Na}_{2} \mathrm{O}$ concentration.

The melting of the second set containing $3.5 \mathrm{wt} \% \mathrm{Cr}_{2} \mathrm{O}_{3}$ with varying additive concentrations did not form any salt layer in all four glasses. In summary, the glasses without salt formation at $3 \mathrm{wt} \% \mathrm{Cr}_{2} \mathrm{O}_{3}$ and $3.5 \mathrm{wt} \% \mathrm{Cr}_{2} \mathrm{O}_{3}$ were successfully formulated so that they can be used for further characterization to determine the maximum waste loading. 
Table 4.23. Glasses Formulated for a High- $\mathrm{Cr}_{2} \mathrm{O}_{3}$ Waste Cluster and Their Predicted Properties

\begin{tabular}{|c|c|c|c|c|c|c|c|c|c|}
\hline \multirow[b]{2}{*}{ Glass ID } & \multicolumn{4}{|c|}{ First Set } & \multicolumn{4}{|c|}{ Second Set } & \multirow[b]{2}{*}{ Limits $^{\text {a }}$} \\
\hline & $\begin{array}{c}\text { CCIM- } \\
\text { HCC14- } \\
1\end{array}$ & $\begin{array}{c}\text { CCIM- } \\
\text { HCC14- } \\
2\end{array}$ & $\begin{array}{c}\text { CCIM- } \\
\text { HCC14- } \\
4\end{array}$ & $\begin{array}{c}\text { CCIM- } \\
\text { HCC14- } \\
6\end{array}$ & $\begin{array}{c}\text { CCIM- } \\
\text { HCC14- } \\
8\end{array}$ & $\begin{array}{c}\text { CCIM- } \\
\text { HCC14- } \\
10\end{array}$ & $\begin{array}{c}\text { CCIM- } \\
\text { HCC14- } \\
12\end{array}$ & $\begin{array}{c}\text { CCIM- } \\
\text { HCC14- } \\
15\end{array}$ & \\
\hline $\mathrm{Al}_{2} \mathrm{O}_{3}$ & 0.13068 & 0.13068 & 0.13068 & 0.13068 & 0.15246 & 0.15246 & 0.15246 & 0.15246 & - \\
\hline $\mathrm{B}_{2} \mathrm{O}_{3}$ & 0.11000 & 0.14000 & 0.11000 & 0.11000 & 0.14000 & 0.17000 & 0.14000 & 0.14000 & - \\
\hline $\mathrm{Bi}_{2} \mathrm{O}_{3}$ & 0.00715 & 0.00715 & 0.00715 & 0.00715 & 0.00834 & 0.00834 & 0.00834 & 0.00834 & - \\
\hline $\mathrm{CaO}$ & 0.00876 & 0.00876 & 0.00876 & 0.00876 & 0.01022 & 0.01022 & 0.01022 & 0.01022 & - \\
\hline $\mathrm{CdO}$ & 0.00032 & 0.00032 & 0.00032 & 0.00032 & 0.00037 & 0.00037 & 0.00037 & 0.00037 & - \\
\hline $\mathrm{Cr}_{2} \mathrm{O}_{3}$ & 0.03000 & 0.03000 & 0.03000 & 0.03000 & 0.03500 & 0.03500 & 0.03500 & 0.03500 & - \\
\hline $\mathrm{Cs}_{2} \mathrm{O}$ & 0.00194 & 0.00194 & 0.00194 & 0.00194 & 0.00227 & 0.00227 & 0.00227 & 0.00227 & - \\
\hline $\mathrm{F}$ & 0.00178 & 0.00178 & 0.00178 & 0.00178 & 0.00208 & 0.00208 & 0.00208 & 0.00208 & - \\
\hline $\mathrm{Fe}_{2} \mathrm{O}_{3}$ & 0.03444 & 0.03444 & 0.03444 & 0.03444 & 0.04018 & 0.04018 & 0.04018 & 0.04018 & - \\
\hline $\mathrm{K}_{2} \mathrm{O}$ & 0.00294 & 0.00294 & 0.06000 & 0.06000 & 0.00343 & 0.00343 & 0.06000 & 0.00343 & - \\
\hline $\mathrm{La}_{2} \mathrm{O}_{3}$ & 0.00031 & 0.00031 & 0.00031 & 0.00031 & 0.00036 & 0.00036 & 0.00036 & 0.00036 & - \\
\hline $\mathrm{Li}_{2} \mathrm{O}$ & 0.03000 & 0.03000 & 0.03000 & 0.00000 & 0.03000 & 0.03000 & 0.03000 & 0.03000 & - \\
\hline $\mathrm{MgO}$ & 0.00048 & 0.00048 & 0.00048 & 0.00048 & 0.00056 & 0.00056 & 0.00056 & 0.00056 & - \\
\hline $\mathrm{MnO}$ & 0.00823 & 0.00823 & 0.00823 & 0.00823 & 0.00961 & 0.00961 & 0.00961 & 0.00961 & - \\
\hline $\mathrm{Na}_{2} \mathrm{O}$ & 0.16060 & 0.13565 & 0.12300 & 0.19450 & 0.12746 & 0.10629 & 0.09139 & 0.10912 & - \\
\hline $\mathrm{Nd}_{2} \mathrm{O}_{3}$ & 0.00043 & 0.00043 & 0.00043 & 0.00043 & 0.00050 & 0.00050 & 0.00050 & 0.00050 & - \\
\hline $\mathrm{NiO}$ & 0.00157 & 0.00157 & 0.00157 & 0.00157 & 0.00183 & 0.00183 & 0.00183 & 0.00183 & - \\
\hline $\mathrm{P}_{2} \mathrm{O}_{5}$ & 0.04521 & 0.04521 & 0.04521 & 0.04521 & 0.05274 & 0.05274 & 0.05274 & 0.05274 & - \\
\hline $\mathrm{PbO}$ & 0.00170 & 0.00170 & 0.00170 & 0.00170 & 0.00198 & 0.00198 & 0.00198 & 0.00198 & - \\
\hline $\mathrm{RuO}_{2}$ & 0.00008 & 0.00008 & 0.00008 & 0.00008 & 0.00010 & 0.00010 & 0.00010 & 0.00010 & - \\
\hline $\mathrm{SiO}_{2}$ & 0.40770 & 0.40265 & 0.38824 & 0.34674 & 0.36223 & 0.35339 & 0.34173 & 0.38056 & - \\
\hline $\mathrm{SO}_{3}$ & 0.00805 & 0.00805 & 0.00805 & 0.00805 & 0.00939 & 0.00939 & 0.00939 & 0.00939 & - \\
\hline $\mathrm{SrO}$ & 0.00211 & 0.00211 & 0.00211 & 0.00211 & 0.00246 & 0.00246 & 0.00246 & 0.00246 & - \\
\hline $\mathrm{ZrO}_{2}$ & 0.00552 & 0.00552 & 0.00552 & 0.00552 & 0.00644 & 0.00644 & 0.00644 & 0.00644 & - \\
\hline Total & 1 & 1 & 1 & 1 & 1 & 1 & 1 & 1 & - \\
\hline Waste loading & 0.389 & 0.389 & 0.389 & 0.389 & 0.454 & 0.454 & 0.454 & 0.454 & - \\
\hline$T_{m}$ at $4 \mathrm{~Pa} \cdot \mathrm{s},{ }^{\circ} \mathrm{C}$ & 1200 & 1200 & 1200 & 1200 & 1200 & 1200 & 1200 & 1250 & - \\
\hline EC at $T_{m}, \mathrm{~S} / \mathrm{m}$ & 49.1 & 38.9 & 36.3 & 52.1 & 37.3 & 30.9 & 28.0 & 35.1 & $10-100$ \\
\hline Spinel $T_{L},{ }^{\circ} \mathrm{C}$ & 1320 & 1328 & 1295 & 1235 & 1479 & 1478 & 1454 & 1520 & $<T_{m}-100^{\mathrm{b}}$ \\
\hline Spinel $T_{1 \%},{ }^{\circ} \mathrm{C}$ & 982 & 992 & 978 & 931 & 1142 & 1147 & 1136 & 1163 & $<T_{m}-200^{\mathrm{c}}$ \\
\hline PCT-B, g/L & 1.083 & 1.101 & 1.194 & 1.917 & 0.924 & 1.009 & 1.041 & 0.653 & $<16.7$ \\
\hline PCT-Li, g/L & 1.359 & 1.571 & 1.455 & 1.965 & 1.409 & 1.806 & 1.417 & 1.034 & $<9.57$ \\
\hline PCT-Na, g/L & 1.027 & 0.942 & 1.120 & 2.084 & 0.783 & 0.918 & 0.873 & 0.552 & $<13.35$ \\
\hline TCLP Cd, mg/L & 0.028 & 0.028 & 0.028 & 0.048 & 0.037 & 0.039 & 0.037 & 0.027 & $<0.48$ \\
\hline$N_{S i}$ & 0.583 & 0.602 & 0.605 & 0.516 & 0.564 & 0.577 & 0.584 & 0.593 & $\geq 0.62$ \\
\hline OB & 0.569 & 0.555 & 0.575 & 0.593 & 0.558 & 0.546 & 0.565 & 0.551 & $\leq 0.575$ \\
\hline \multicolumn{10}{|c|}{$\begin{array}{l}{ }^{\mathrm{a}} \text { Used as guidelines for formulating the glasses. } \\
{ }^{\mathrm{b}} \text { Based on a traditional constraint used in Perez et al. }(2001) . \\
{ }^{\mathrm{c}} \text { Based on a constraint of } T_{1 \%}<950{ }^{\circ} \mathrm{C} \text { for glasses with } T_{m}=1150{ }^{\circ} \mathrm{C} \text { (Vienna et al. 2009). } \\
\text { Shaded cells indicate that the predicted or calculated value is not within the limits. }\end{array}$} \\
\hline
\end{tabular}




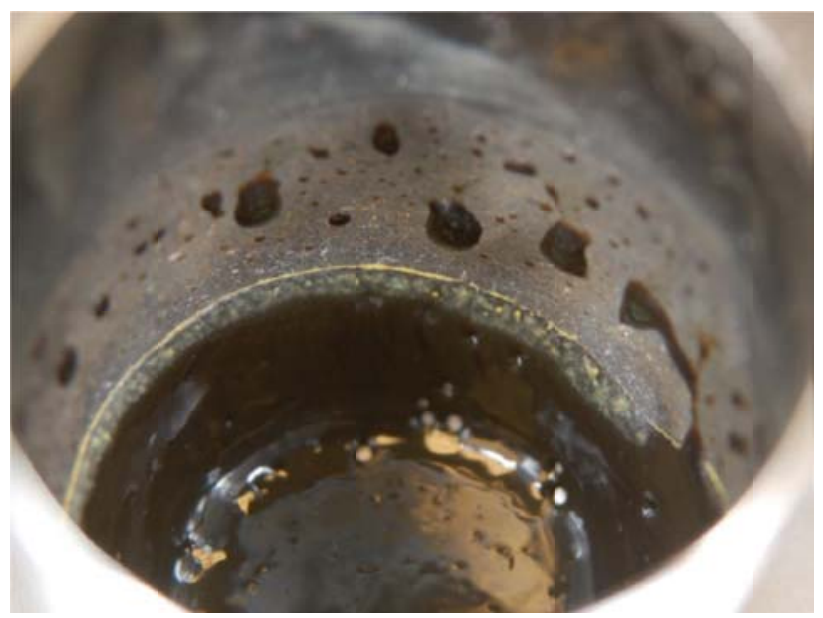

CCIM-HCC14-1

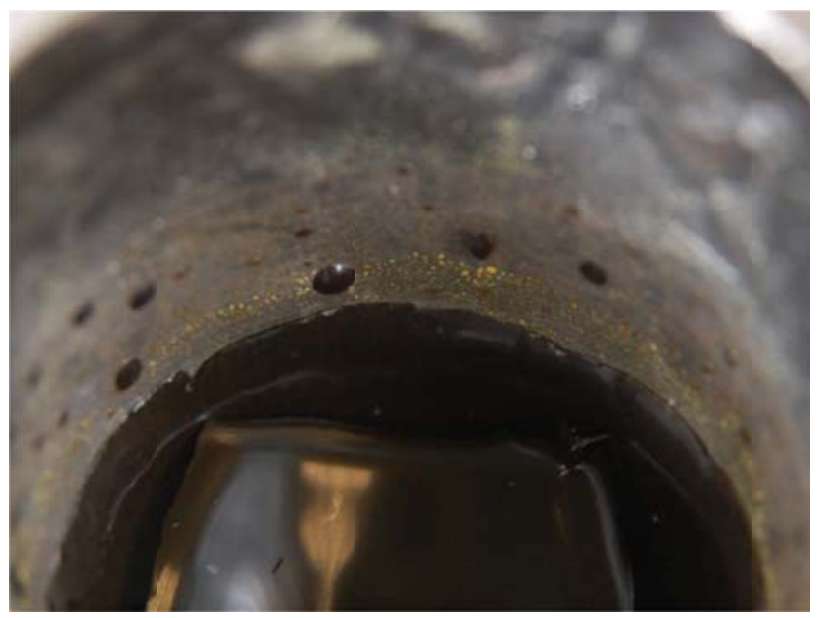

CCIM-HCC14-4

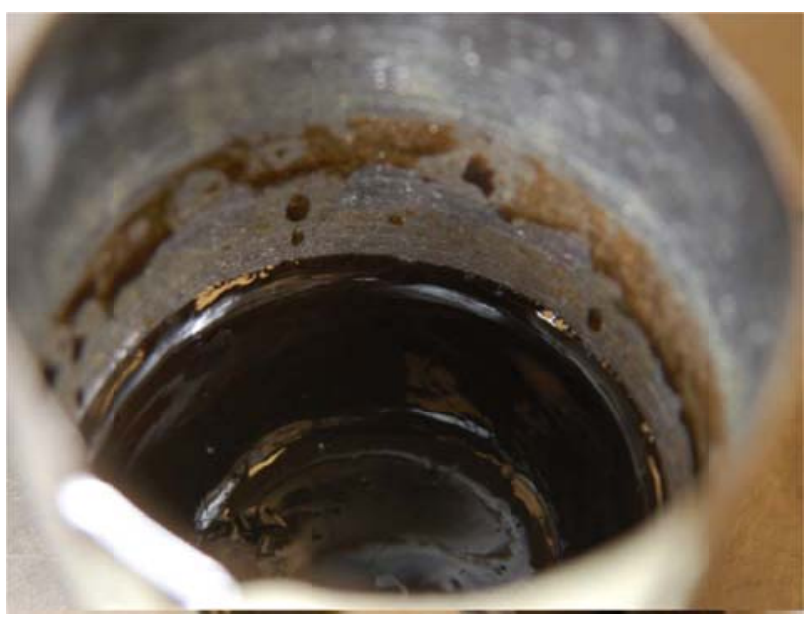

CCIM-HCC14-2

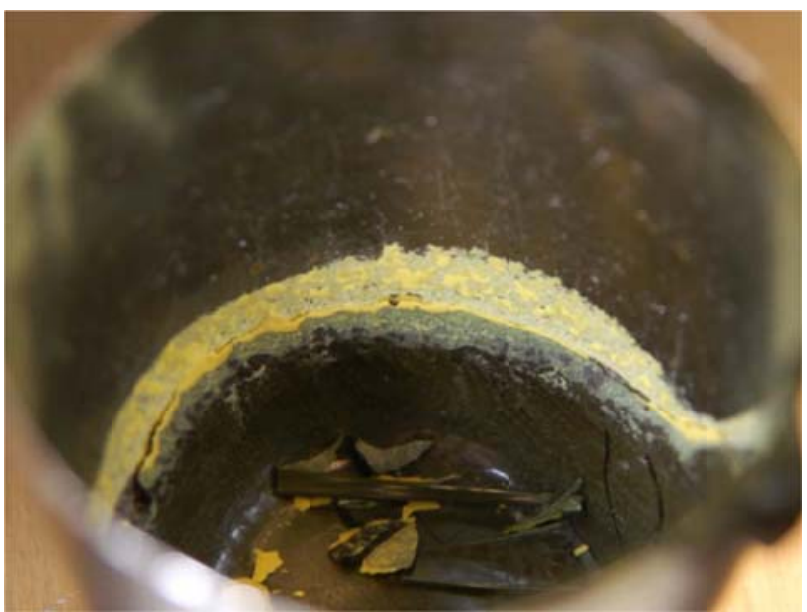

CCIM-HCC14-6

Figure 4.19. Salt Phase that Remained on Crucible Wall after Melting of Four CCIM-HCC14 Glasses 


\subsection{Advanced Silicate Glass Formulation}

This section summarizes the results of formulation and characterization of glasses with the nominal processing temperature of $1150^{\circ} \mathrm{C}$ for current WTP baseline melter. The results from two subtasks of the EM-31 Advanced Silicate Glass Development (WP-5.1.2) task, WP-5.1.2.3 - Systematic Glass Data for Models and WP-5.1.2.4 - Optimization for Specific Wastes, are presented in this section.

\subsection{Glass Formulation for Specific Wastes (WP-5.1.2.4)}

One of the objectives of this subtask WP-5.1.2.4 - Optimization for Specific Wastes was to determine the maximum achievable waste loading for each cluster and then calculate the estimated reduction of glass volume by producing waste loading optimized glasses. Candidate glasses were formulated for three waste groups that cover the majority of Hanford HLW and represent the largest resulting glass mass: high-iron, spinel-limited, and high-aluminum waste cluster groups.

Glass formulations were performed based on the cluster compositions in terms of 23 oxide components given in Table 4.20. It is expected that at least two or more iterations of glass formulation and characterization will be required to find the maximum waste loading reasonably achievable. Only the first iteration was completed before the task closure.

\subsubsection{Advanced Silicate Glass Formulation for High-Iron Waste Clusters}

The high-iron waste clusters (Clusters 1, 10, and 18) have compositions similar to AZ-101 HLW used in glass formulations for CCIM discussed in Section 4.1. The waste loading for these waste clusters is primarily limited by the spinel crystallization, i.e., the requirement for $T_{1 \%}<950^{\circ} \mathrm{C}$.

Table 5.1 shows the target compositions and predicted properties for improved waste loading-high ion cluster IWL-HICx-y glasses. The cluster number is represented by $\mathrm{x}$, and $\mathrm{y}$ is a serial number. For the first set, five glasses were formulated for Clusters 1 and 18. There is reasonable similarity between Clusters 10 and 18 so it is assumed that the maximum loading for Cluster 10 can be estimated from the glass formulation results for Cluster 18 .

For glasses formulated for Cluster 1, the IWL-HIC1-1 glass was as formulated based on HTWOS revised constraints given in Table 2.6. As shown in Table 5.1, the waste loading is limited by $T_{1 \%}$ and nepheline discriminator, $N_{S i}$. The IWL-HIC1-2 glass was also formulated to meet the revised HTWOS constraints but was forced to meet the nepheline constraint by meeting the OB requirement instead of $N_{S i}$. This resulted in slightly lower waste loading but significantly different concentrations for main additive components, $\mathrm{B}_{2} \mathrm{O}_{3}$ and alkali oxides. The IWL-HIC1-3 glass uses the same concentrations for $\mathrm{B}_{2} \mathrm{O}_{3}$ and $\mathrm{Li}_{2} \mathrm{O}$ as in the glasses selected for CCIM demonstration tests (Table 4.8) at the same waste loading as in IWL-HIC1-1. The IWL-HIC1-3 glass had $\mathrm{B}_{2} \mathrm{O}_{3}$ concentration in between the IWL-HIC1-1 and IWL-HIC1-2 glasses, and had highest $\mathrm{Li}_{2} \mathrm{O}$ and lowest $\mathrm{Na}_{2} \mathrm{O}$ concentrations among three IWL-HIC1 glasses.

For glasses formulated for Cluster 18, the IWL-HIC18-1 glass was as formulated based on HTWOS revised constraints given in Table 2.6. As shown in Table 5.1, this waste loading is limited by $T_{1 \%}$ and 
OB. This glass had similar compositional features as the IWL-HIC1-2 glass that was limited by $T_{1 \%}$ and $\mathrm{OB}$ and therefore high $\mathrm{B}_{2} \mathrm{O}_{3}$ concentration. The IWL-HIC18-3 glass uses the same concentrations for $\mathrm{B}_{2} \mathrm{O}_{3}$ and $\mathrm{Li}_{2} \mathrm{O}$ in glass as those selected for CCIM demonstration tests (Table 4.8) and so as in the IWL-HIC1-3 glass.

Table 5.1. Glasses Melting at $1150{ }^{\circ} \mathrm{C}$ Formulated for High-Iron Clusters and Their Predicted and Measured Properties

\begin{tabular}{|c|c|c|c|c|c|c|}
\hline \multirow[b]{2}{*}{ Comp. } & \multicolumn{3}{|c|}{ Cluster 1} & \multicolumn{2}{|c|}{ Cluster 18} & \multirow[b]{2}{*}{ Limits $^{(a)}$} \\
\hline & $\begin{array}{c}\text { IWL- } \\
\text { HIC1-1 }\end{array}$ & $\begin{array}{c}\text { IWL- } \\
\text { HIC1-2 }\end{array}$ & $\begin{array}{c}\text { IWL- } \\
\text { HIC1-3 }\end{array}$ & $\begin{array}{c}\text { IWL- } \\
\text { HIC18-1 }\end{array}$ & $\begin{array}{c}\text { IWL- } \\
\text { HIC18-3 }\end{array}$ & \\
\hline $\mathrm{Al}_{2} \mathrm{O}_{3}$ & 0.06229 & 0.06126 & 0.06229 & 0.07970 & 0.07970 & - \\
\hline $\mathrm{B}_{2} \mathrm{O}_{3}$ & 0.04000 & 0.14477 & 0.11000 & 0.16537 & 0.11000 & - \\
\hline $\mathrm{Bi}_{2} \mathrm{O}_{3}$ & 0.00298 & 0.00293 & 0.00298 & 0.00133 & 0.00133 & - \\
\hline $\mathrm{CaO}$ & 0.01100 & 0.01082 & 0.01100 & 0.00878 & 0.00878 & - \\
\hline $\mathrm{CdO}$ & 0.00038 & 0.00038 & 0.00038 & 0.01279 & 0.01279 & - \\
\hline $\mathrm{Cr}_{2} \mathrm{O}_{3}$ & 0.00365 & 0.00359 & 0.00365 & 0.00245 & 0.00245 & - \\
\hline $\mathrm{Cs}_{2} \mathrm{O}$ & 0.00211 & 0.00207 & 0.00211 & 0.00179 & 0.00179 & - \\
\hline $\mathrm{F}$ & 0.00068 & 0.00066 & 0.00068 & 0.00047 & 0.00047 & - \\
\hline $\mathrm{Fe}_{2} \mathrm{O}_{3}$ & 0.14971 & 0.14723 & 0.14971 & 0.13817 & 0.13817 & - \\
\hline $\mathrm{K}_{2} \mathrm{O}$ & 0.00355 & 0.00349 & 0.00355 & 0.00381 & 0.00381 & - \\
\hline $\mathrm{La}_{2} \mathrm{O}_{3}$ & 0.00083 & 0.00081 & 0.00083 & 0.00334 & 0.00334 & - \\
\hline $\mathrm{Li}_{2} \mathrm{O}$ & 0.02054 & 0.00000 & 0.03000 & 0.00000 & 0.03000 & - \\
\hline $\mathrm{MgO}$ & 0.00155 & 0.00152 & 0.00155 & 0.00102 & 0.00102 & - \\
\hline $\mathrm{MnO}$ & 0.02142 & 0.02106 & 0.02142 & 0.00489 & 0.00489 & - \\
\hline $\mathrm{Na}_{2} \mathrm{O}$ & 0.20423 & 0.15594 & 0.11443 & 0.15973 & 0.13505 & - \\
\hline $\mathrm{Nd}_{2} \mathrm{O}_{3}$ & 0.00141 & 0.00139 & 0.00141 & 0.00254 & 0.00254 & - \\
\hline $\mathrm{NiO}$ & 0.00746 & 0.00734 & 0.00746 & 0.01084 & 0.01084 & - \\
\hline $\mathrm{P}_{2} \mathrm{O}_{5}$ & 0.00775 & 0.00763 & 0.00775 & 0.00384 & 0.00384 & - \\
\hline $\mathrm{PbO}$ & 0.00586 & 0.00576 & 0.00586 & 0.00269 & 0.00269 & - \\
\hline $\mathrm{RuO}_{2}$ & 0.00072 & 0.00070 & 0.00072 & 0.00009 & 0.00009 & - \\
\hline $\mathrm{SiO}_{2}$ & 0.43485 & 0.40388 & 0.44518 & 0.36920 & 0.41925 & - \\
\hline $\mathrm{SO}_{3}$ & 0.00198 & 0.00195 & 0.00198 & 0.00073 & 0.00073 & - \\
\hline $\mathrm{SrO}$ & 0.00034 & 0.00033 & 0.00034 & 0.00027 & 0.00027 & - \\
\hline $\mathrm{ZrO}_{2}$ & 0.01473 & 0.01448 & 0.01473 & 0.02615 & 0.02615 & - \\
\hline Total & 1.00000 & 1.00000 & 1.00000 & 1.00000 & 1.00000 & - \\
\hline Waste Loading & 0.422 & 0.415 & 0.422 & 0.357 & 0.357 & - \\
\hline $\mathrm{Al}_{2} \mathrm{O}_{3}+\mathrm{Fe}_{2} \mathrm{O}_{3}+\mathrm{ZrO}_{2}$ & 0.227 & 0.223 & 0.227 & 0.244 & 0.244 & - \\
\hline$\eta_{1150}, \mathrm{~Pa} \cdot \mathrm{s}$ & 4 & 4 & 4 & 4 & 4 & $2-8$ \\
\hline$\varepsilon_{1150}, \mathrm{~S} / \mathrm{m}$ & 61.4 & 26.6 & 27.3 & 27.8 & 33.1 & $10-100$ \\
\hline Spinel $T_{1 \%},{ }^{\circ} \mathrm{C}$ & 950 & 950 & 998 & 950 & 978 & 950 \\
\hline PCT-B, g/L & 0.831 & 1.018 & 0.626 & 1.305 & 0.801 & $<16.7$ \\
\hline PCT-Li, g/L & 0.777 & 1.140 & 0.668 & 1.389 & 0.636 & $<9.57$ \\
\hline PCT-Na, g/L & 1.926 & 0.942 & 0.556 & 1.075 & 0.600 & $<13.35$ \\
\hline TCLP Cd, mg/L & 0.013 & 0.014 & 0.009 & 0.637 & 0.381 & $<0.48$ \\
\hline$N_{S i}$ & 0.620 & 0.650 & 0.716 & 0.607 & 0.661 & $\geq 0.62$ \\
\hline OB & 0.625 & 0.575 & 0.577 & 0.575 & 0.586 & $\leq 0.575$ \\
\hline \multicolumn{7}{|c|}{ Measured spinel vol\% after $24 \mathrm{~h}$ heat treatment at $950^{\circ} \mathrm{C}$} \\
\hline Spinel vol\% & 0.6 & 1.1 & 1.2 & 1.6 & 1.4 & 1 \\
\hline
\end{tabular}

None of the five IWL-HIC glasses in Table 5.1 failed the nepheline constraint. For the first iteration of glass formulation and testing for the high-iron waste clusters, the primary focus was on the spinel crystallization and the glasses were initially tested only for crystal fraction after a 24-hour heat treatment at $950^{\circ} \mathrm{C}$. 
The results of XRD measurement for the spinel vol $\%$ after the 24 -hour heat treatment at $950^{\circ} \mathrm{C}$ were included in Table 5.1. The IWL-HIC1-1 was the only glass that passed the $T_{1 \%}<950{ }^{\circ} \mathrm{C}$. This glass had low concentration of $\mathrm{B}_{2} \mathrm{O}_{3}$ at $4 \mathrm{wt} \%$ while the other four glasses had $11 \mathrm{wt} \%$ or higher. The predicted $T_{1 \%}$ did not show any correlation with the measured spinel vol\%, suggesting that the models do not work well for these glasses. No successful glass resulted from Cluster 18. Additional formulation and testing are needed for both high-iron clusters to determine the estimated maximum waste loadings.

\subsubsection{Advanced Silicate Glass Formulation for Spinel-Limited Waste Clusters}

The spinel-limited waste clusters (Clusters 3, 4, 19, and 20) have $\mathrm{Fe}_{2} \mathrm{O}_{3}$ lower than the high-iron clusters, but relatively high overall concentrations of spinel-forming components $\left(\mathrm{Fe}_{2} \mathrm{O}_{3}, \mathrm{Cr}_{2} \mathrm{O}_{3}, \mathrm{NiO}\right.$, and $\mathrm{MnO}$ ) and the waste loading for these waste clusters is primarily limited by the requirement of $T_{1 \%}<950{ }^{\circ} \mathrm{C}$.

Table 5.2 shows the target compositions and predicted properties for improved waste loading-spinel-limited cluster (IWL-SLCx-y) glasses where $\mathrm{x}$ is the cluster number, and $\mathrm{y}$ is a serial number". For the first set, 10 glasses were formulated for three clusters, Clusters 3, 4, and 20. There is reasonable similarity between Clusters 19 and 4 so it is assumed that the maximum loading for Cluster 19 can be estimated from glass formulation results for Cluster 4 .

The glasses were formulated following similar pattern used for high-iron cluster glasses. The first glasses for each cluster (IWL-SLC3-1, IWL-SLC4-1, and IWL-SLC20-1) were formulated based on HTWOS revised constraints given in Table 2.6. As shown in Table 5.2, the waste loading is limited by $T_{1 \%}$ and nepheline constraint. The glass for Cluster 3 (IWL-SLC3-1) met the nepheline constraint based on $N_{S i}$ and the (IWL-SLC4-1 and IWL-SLC 20-1) met the OB requirement. The lower loading of these major waste components in IWL-SLC3-1 glass compared to other two glasses is attributed to high overall concentrations for spinel components in Cluster 3.

The second glasses for each cluster (IWL-SLC3-2, IWL-SLC 4-2, and IWL-SLC 20-2) were also formulated to meet the HTWOS revised constraints, but were forced to meet the other nepheline constraint, i.e., IWL-SLC3-1 glass was forced to meet the OB requirement and the IWL-SLC4-1 and IWL-SLC20-1 glasses were forced to meet the $N_{S i}$ requirement. This change resulted in slightly lower waste loading for all three glasses with significantly different concentrations for main additive components, $\mathrm{B}_{2} \mathrm{O}_{3}$ and alkali oxides. The third glasses for each cluster (IWL-SLC3-3, IWL-SLC4-3, and IWL-SLC20-3) use the same concentrations for $\mathrm{B}_{2} \mathrm{O}_{3}$ and $\mathrm{Li}_{2} \mathrm{O}$ as in the glasses selected for CCIM demonstration tests (Table 4.8) at the same waste loading as in the first glasses for each cluster (IWL-SLC3-1, IWL-SLC4-1, and IWL-SLC20-1). The concentration of $\mathrm{Na}_{2} \mathrm{O}$ was adjusted to keep the viscosity at $1150^{\circ} \mathrm{C}$ at $4 \mathrm{~Pa} \cdot \mathrm{s}$. One additional (fourth) glass (IWL-SLC4-4) was formulated for Cluster 4 only. This glass had the same waste loading and $\mathrm{Li}_{2} \mathrm{O}$ concentration in glass as the IWL- SLC4-4 glass, but had increased $\mathrm{B}_{2} \mathrm{O}_{3}$ concentration of $14 \mathrm{wt} \%$. The concentration of $\mathrm{Na}_{2} \mathrm{O}$ was adjusted to keep the viscosity at $1150{ }^{\circ} \mathrm{C}$ at $4 \mathrm{~Pa} \cdot \mathrm{s}$.

All glasses for spinel limited clusters were tested for crystallinity after a 24-hour heat treatment at $950^{\circ} \mathrm{C}$. The glasses for Cluster 3 (IWL-SLC3-1, IWL-SLC3-2, and IWL-SLC3-3) contain low concentration of $\mathrm{Al}_{2} \mathrm{O}_{3}$ but the glasses for Clusters 4 and 20 contain relatively high concentration of $\mathrm{Al}_{2} \mathrm{O}_{3}$ and therefore have a potential to precipitate the nepheline. These glasses were CCC-heat treated and 
tested for crystallinity. However, the crystallinity results were not obtained in time for inclusion in this report.

Table 5.2. Glasses Melting at $1150^{\circ} \mathrm{C}$ Formulated for Spinel-Limited Waste Clusters and Their Predicted and Measured Properties

\begin{tabular}{|c|c|c|c|c|c|c|c|c|}
\hline \multirow[b]{2}{*}{ Comp. } & \multicolumn{3}{|c|}{ Cluster 3} & \multicolumn{4}{|c|}{ Cluster 4} & \multirow[b]{2}{*}{ Limits $^{(a)}$} \\
\hline & $\begin{array}{l}\text { IWL- } \\
\text { SLC3-1 }\end{array}$ & $\begin{array}{l}\text { IWL- } \\
\text { SLC3-2 }\end{array}$ & $\begin{array}{l}\text { IWL- } \\
\text { SLC3-3 }\end{array}$ & $\begin{array}{l}\text { IWL- } \\
\text { SLC4-1 }\end{array}$ & $\begin{array}{l}\text { IWL- } \\
\text { SLC4-2 }\end{array}$ & $\begin{array}{l}\text { IWL- } \\
\text { SLC4-3 }\end{array}$ & $\begin{array}{l}\text { IWL- } \\
\text { SLC4-4 }\end{array}$ & \\
\hline $\mathrm{Al}_{2} \mathrm{O}_{3}$ & 0.06220 & 0.06189 & 0.06220 & 0.17163 & 0.15812 & 0.17163 & 0.17163 & - \\
\hline $\mathrm{B}_{2} \mathrm{O}_{3}$ & 0.04000 & 0.15437 & 0.11000 & 0.19241 & 0.16484 & 0.11000 & 0.14000 & - \\
\hline $\mathrm{Bi}_{2} \mathrm{O}_{3}$ & 0.01121 & 0.01115 & 0.01121 & 0.00449 & 0.00414 & 0.00449 & 0.00449 & - \\
\hline $\mathrm{CaO}$ & 0.01756 & 0.01747 & 0.01756 & 0.01207 & 0.01112 & 0.01207 & 0.01207 & - \\
\hline $\mathrm{CdO}$ & 0.00214 & 0.00213 & 0.00214 & 0.00238 & 0.00220 & 0.00238 & 0.00238 & - \\
\hline $\mathrm{Cr}_{2} \mathrm{O}_{3}$ & 0.00562 & 0.00559 & 0.00562 & 0.00602 & 0.00555 & 0.00602 & 0.00602 & - \\
\hline $\mathrm{Cs}_{2} \mathrm{O}$ & 0.00193 & 0.00192 & 0.00193 & 0.00209 & 0.00193 & 0.00209 & 0.00209 & - \\
\hline $\mathrm{F}$ & 0.00073 & 0.00073 & 0.00073 & 0.00058 & 0.00053 & 0.00058 & 0.00058 & - \\
\hline $\mathrm{Fe}_{2} \mathrm{O}_{3}$ & 0.08539 & 0.08496 & 0.08539 & 0.06782 & 0.06248 & 0.06782 & 0.06782 & - \\
\hline $\mathrm{K}_{2} \mathrm{O}$ & 0.00470 & 0.00468 & 0.00470 & 0.00249 & 0.00229 & 0.00249 & 0.00249 & - \\
\hline $\mathrm{La}_{2} \mathrm{O}_{3}$ & 0.00305 & 0.00304 & 0.00305 & 0.00123 & 0.00114 & 0.00123 & 0.00123 & - \\
\hline $\mathrm{Li}_{2} \mathrm{O}$ & 0.03001 & 0.00000 & 0.03000 & 0.00138 & 0.05770 & 0.03000 & 0.03000 & - \\
\hline $\mathrm{MgO}$ & 0.00185 & 0.00184 & 0.00185 & 0.00061 & 0.00057 & 0.00061 & 0.00061 & - \\
\hline $\mathrm{MnO}$ & 0.01311 & 0.01305 & 0.01311 & 0.00448 & 0.00412 & 0.00448 & 0.00448 & - \\
\hline $\mathrm{Na}_{2} \mathrm{O}$ & 0.19875 & 0.16293 & 0.13032 & 0.18901 & 0.08741 & 0.18950 & 0.16264 & - \\
\hline $\mathrm{Nd}_{2} \mathrm{O}_{3}$ & 0.00049 & 0.00049 & 0.00049 & 0.00088 & 0.00081 & 0.00088 & 0.00088 & - \\
\hline $\mathrm{NiO}$ & 0.01896 & 0.01887 & 0.01896 & 0.01135 & 0.01045 & 0.01135 & 0.01135 & - \\
\hline $\mathrm{P}_{2} \mathrm{O}_{5}$ & 0.01940 & 0.01930 & 0.01940 & 0.00535 & 0.00493 & 0.00535 & 0.00535 & - \\
\hline $\mathrm{PbO}$ & 0.00286 & 0.00284 & 0.00286 & 0.00266 & 0.00245 & 0.00266 & 0.00266 & - \\
\hline $\mathrm{RuO}_{2}$ & 0.00012 & 0.00012 & 0.00012 & 0.00044 & 0.00041 & 0.00044 & 0.00044 & - \\
\hline $\mathrm{SiO}_{2}$ & 0.42576 & 0.37876 & 0.42419 & 0.30300 & 0.40060 & 0.35630 & 0.35316 & - \\
\hline $\mathrm{SO}_{3}$ & 0.00305 & 0.00304 & 0.00305 & 0.00124 & 0.00114 & 0.00124 & 0.00124 & - \\
\hline $\mathrm{SrO}$ & 0.00059 & 0.00058 & 0.00059 & 0.00102 & 0.00094 & 0.00102 & 0.00102 & - \\
\hline $\mathrm{ZrO}$ & 0.05051 & 0.05025 & 0.05051 & 0.01536 & 0.01415 & 0.01536 & 0.01536 & - \\
\hline Total & 1.00000 & 1.00000 & 1.00000 & 1.00000 & 1.00000 & 1.00000 & 1.00000 & - \\
\hline Waste Loading & 0.385 & 0.383 & 0.385 & 0.419 & 0.386 & 0.419 & 0.419 & - \\
\hline $\mathrm{Al}_{2} \mathrm{O}_{3}+\mathrm{Fe}_{2} \mathrm{O}_{3}+\mathrm{ZrO}_{2}$ & 0.198 & 0.197 & 0.198 & 0.255 & 0.235 & 0.255 & 0.255 & - \\
\hline$\eta_{1150}, \mathrm{~Pa} \cdot \mathrm{s}$ & 4 & 4 & 4 & 4 & 4 & 4 & 4 & $2-8$ \\
\hline$\varepsilon_{1150}, \mathrm{~S} / \mathrm{m}$ & 60.1 & 27.5 & 30.1 & 38.6 & 34.9 & 53.1 & 40.7 & $10-100$ \\
\hline Spinel $T_{1 \%},{ }^{\circ} \mathrm{C}$ & 950 & 950 & 984 & 950 & 950 & 968 & 980 & 950 \\
\hline PCT-B, g/L & 0.921 & 1.254 & 0.788 & 1.818 & 1.044 & 1.111 & 1.088 & $<16.7$ \\
\hline PCT-Li, g/L & 0.945 & 1.613 & 0.853 & 3.696 & 1.116 & 0.917 & 1.095 & $<9.57$ \\
\hline PCT-Na, g/L & 2.221 & 1.282 & 0.762 & 2.035 & 0.730 & 0.943 & 0.834 & $<13.35$ \\
\hline TCLP Cd, mg/L & 0.118 & 0.157 & 0.097 & 0.311 & 0.113 & 0.190 & 0.182 & $<0.48$ \\
\hline$N_{S i}$ & 0.620 & 0.628 & 0.688 & 0.457 & 0.620 & 0.497 & 0.514 & $\geq 0.62$ \\
\hline OB & 0.624 & 0.575 & 0.581 & 0.575 & 0.557 & 0.600 & 0.584 & $\leq 0.575$ \\
\hline \multicolumn{9}{|c|}{ Measured spinel vol\% after $24 \mathrm{~h}$ heat treatment at $950^{\circ} \mathrm{C}$ and Crystallinity after CCC } \\
\hline $\begin{array}{c}950^{\circ} \mathrm{C} \text { Spinel vol } \% \\
\text { (vol\% of other crystals) }\end{array}$ & 1.7 & 0.9 & 1.5 & 1.5 & 1.8 & $\begin{array}{c}1.5 \\
(1.8 \mathrm{~Np}) \\
\end{array}$ & $\begin{array}{c}1.7 \\
(3.7 \mathrm{Ap}) \\
\end{array}$ & $\begin{array}{c}1 \\
(\mathrm{NA})\end{array}$ \\
\hline CCC Crystallinity & NM & NM & NM & $2.4 \mathrm{Sp}$ & $2.7 \mathrm{Sp}$ & $\begin{array}{c}2.3 \mathrm{Sp} \\
48.7 \mathrm{~Np} \\
\end{array}$ & $2.4 \mathrm{Sp}$ & No $\mathrm{Np}$ \\
\hline \multicolumn{9}{|c|}{$\begin{array}{l}\text { (a) Used as guidelines for formulating the glasses. } \\
\text { Shaded cells indicate that the predicted or calculated value is not within the limits. } \\
\text { NM: not measured (see text). } \\
\text { Ap: apatite; Sp: spinel; Np: nepheline. } \\
\text { No Np: no nepheline formation; NA: not applicable. }\end{array}$} \\
\hline
\end{tabular}


Table 5.2. (Continued)

\begin{tabular}{|c|c|c|c|c|}
\hline \multirow[b]{2}{*}{ Comp. } & \multicolumn{3}{|c|}{ Cluster 20} & \multirow[b]{2}{*}{ Limits $^{(\mathbf{a})}$} \\
\hline & $\begin{array}{c}\text { IWL- } \\
\text { SLC20-1 }\end{array}$ & $\begin{array}{c}\text { IWL- } \\
\text { SLC20-2 }\end{array}$ & $\begin{array}{c}\text { IWL- } \\
\text { SLC20-3 }\end{array}$ & \\
\hline $\mathrm{Al}_{2} \mathrm{O}_{3}$ & 0.12767 & 0.12299 & 0.12767 & - \\
\hline $\mathrm{B}_{2} \mathrm{O}_{3}$ & 0.15220 & 0.17151 & 0.11000 & - \\
\hline $\mathrm{Bi}_{2} \mathrm{O}_{3}$ & 0.02718 & 0.02619 & 0.02718 & - \\
\hline $\mathrm{CaO}$ & 0.02160 & 0.02081 & 0.02160 & - \\
\hline $\mathrm{CdO}$ & 0.00015 & 0.00014 & 0.00015 & - \\
\hline $\mathrm{Cr}_{2} \mathrm{O}_{3}$ & 0.01009 & 0.00972 & 0.01009 & - \\
\hline $\mathrm{Cs}_{2} \mathrm{O}$ & 0.00246 & 0.00237 & 0.00246 & - \\
\hline $\mathrm{F}$ & 0.01234 & 0.01189 & 0.01234 & - \\
\hline $\mathrm{Fe}_{2} \mathrm{O}_{3}$ & 0.07822 & 0.07535 & 0.07822 & - \\
\hline $\mathrm{K}_{2} \mathrm{O}$ & 0.00232 & 0.00223 & 0.00232 & - \\
\hline $\mathrm{La}_{2} \mathrm{O}_{3}$ & 0.00175 & 0.00168 & 0.00175 & - \\
\hline $\mathrm{Li}_{2} \mathrm{O}$ & 0.00000 & 0.02194 & 0.03000 & - \\
\hline $\mathrm{MgO}$ & 0.00306 & 0.00295 & 0.00306 & - \\
\hline $\mathrm{MnO}$ & 0.00737 & 0.00710 & 0.00737 & - \\
\hline $\mathrm{Na}_{2} \mathrm{O}$ & 0.16543 & 0.10657 & 0.12985 & - \\
\hline $\mathrm{Nd}_{2} \mathrm{O}_{3}$ & 0.00033 & 0.00032 & 0.00033 & - \\
\hline $\mathrm{NiO}$ & 0.00842 & 0.00811 & 0.00842 & - \\
\hline $\mathrm{P}_{2} \mathrm{O}_{5}$ & 0.01797 & 0.01731 & 0.01797 & - \\
\hline $\mathrm{PbO}$ & 0.00448 & 0.00431 & 0.00448 & - \\
\hline $\mathrm{RuO}_{2}$ & 0.00000 & 0.00000 & 0.00000 & - \\
\hline $\mathrm{SiO}_{2}$ & 0.34456 & 0.37455 & 0.39234 & - \\
\hline $\mathrm{SO}_{3}$ & 0.00534 & 0.00514 & 0.00534 & - \\
\hline $\mathrm{SrO}$ & 0.00556 & 0.00535 & 0.00556 & - \\
\hline $\mathrm{ZrO}_{2}$ & 0.00150 & 0.00145 & 0.00150 & - \\
\hline Total & 1.00000 & 1.00000 & 1.00000 & - \\
\hline Waste Loading & 0.492 & 0.474 & 0.492 & - \\
\hline $\mathrm{Al}_{2} \mathrm{O}_{3}+\mathrm{Fe}_{2} \mathrm{O}_{3}+\mathrm{ZrO}_{2}$ & 0.207 & 0.200 & 0.207 & - \\
\hline$\eta_{1150}, \mathrm{~Pa} \cdot \mathrm{s}$ & 4 & 4 & 4 & $2-8$ \\
\hline$\varepsilon_{1150}, \mathrm{~S} / \mathrm{m}$ & 29.4 & 21.3 & 31.0 & $10-100$ \\
\hline Spinel $T_{1 \%},{ }^{\circ} \mathrm{C}$ & 950 & 950 & 982 & 950 \\
\hline PCT-B, g/L & 1.482 & 1.237 & 0.917 & $<16.7$ \\
\hline PCT-Li, g/L & 2.017 & 1.801 & 1.072 & $<9.57$ \\
\hline PCT-Na, g/L & 1.495 & 1.206 & 0.876 & $<13.35$ \\
\hline TCLP Cd, mg/L & 0.015 & 0.011 & 0.009 & $<0.48$ \\
\hline$N_{S i}$ & 0.540 & 0.620 & 0.604 & $\geq 0.62$ \\
\hline OB & 0.575 & 0.555 & 0.579 & $\leq 0.575$ \\
\hline \multicolumn{5}{|c|}{ Measured spinel vol\% after $24 \mathrm{~h}$ heat treatment at $950^{\circ} \mathrm{C}$ and Crystallinity after CCC } \\
\hline $950^{\circ} \mathrm{C}$ Spinel vol $\%, \%$ & $\begin{array}{c}1.4 \\
(2.3 \mathrm{Sp})\end{array}$ & $\begin{array}{c}1.6 \\
(1.8 \mathrm{Ap})\end{array}$ & 1.3 & $\begin{array}{c}1 \\
\text { (NA) }\end{array}$ \\
\hline CCC Crystallinity & $\begin{array}{l}2.1 \mathrm{Sp} \\
4.3 \mathrm{Ap}\end{array}$ & $\begin{array}{c}3.5 \mathrm{Sp} \\
3.7 \mathrm{Ap}\end{array}$ & $\begin{array}{l}2.5 \mathrm{Sp} \\
3.3 \mathrm{Ap}\end{array}$ & No $\mathrm{Np}$ \\
\hline \multicolumn{5}{|c|}{$\begin{array}{l}\text { (a) Used as guidelines for formulating the glasses. } \\
\text { Shaded cells indicate that the predicted or calculated value is not within the limits. } \\
\text { Ap: apatite; Sp: spinel; Np: nepheline. } \\
\text { No Np: no nepheline formation; NA: not applicable. }\end{array}$} \\
\hline
\end{tabular}

The results of XRD measurement for the spinel vol\% after a 24 -hour heat treatment at $950{ }^{\circ} \mathrm{C}$ and CCC treatment were included in Table 5.2. Among three clusters, only the formulation with Cluster 3 (IWL-SLC3-2) produced a glass that pass the $T_{1 \%}$ requirement. Out of six glasses for Clusters 4 and 20 that contain relatively high concentration of $\mathrm{Al}_{2} \mathrm{O}_{3}$, one glass (IWL-SLC4-3) formed nepheline. This 
glass had lower concentration of $\mathrm{B}_{2} \mathrm{O}_{3}$ and higher $\mathrm{Na}_{2} \mathrm{O}$ compared to IWL-SLC4-4. Additional formulation and testing are needed to determine the estimated maximum waste loading for each cluster.

\subsubsection{Advanced Silicate Glass Formulation for High-AI Waste Clusters}

Past glass formulation studies with high-aluminum wastes (Matlack et al. 2007a; Matlack et al. 2008; Matlack et al. 2010; Kim et al. 2008; Marra et al. 2010) suggest that the loading of high-alumina wastes in glass is limited by both nepheline constraint and spinel $T_{1 \%}$. Therefore the maximum loading of $\mathrm{Al}_{2} \mathrm{O}_{3}$ achievable in glass depends on the concentration of spine forming components and also $\mathrm{ZrO}_{2}$ that has strong effect on spinel formation. Among four high-aluminum waste clusters (Clusters 5, 7, 8, and 16), Cluster 5 is characterized by higher $\mathrm{ZrO}_{2}$, Clusters 7 and 8 by higher $\mathrm{Fe}_{2} \mathrm{O}_{3}$, and Cluster 16 by low zirconium and iron (see Table 4.20). The NiO was highest in Cluster 5. Based on this firsthand information it is likely that Cluster 16 will have highest $\mathrm{Al}_{2} \mathrm{O}_{3}$ loading.

Table 5.3 shows the target compositions and predicted properties for IWL-HACx-y glasses where IWL-HAC represents "improved waste loading-high-alumina cluster." For the first set, 10 glasses were formulated for Clusters 5,8, and 16. Similar to the high-iron and spinel-limited cluster glass formulations, there is reasonable similarity between Clusters 7 and 8, so it is assumed that the maximum loading of $\mathrm{Al}_{2} \mathrm{O}_{3}$ in the glasses for Cluster 7 is similar to that obtained from Cluster 8 .

The glasses were formulated following similar pattern used for high-iron cluster glasses. The first glasses for each cluster (IWL-HAC5-1, 8-1, and 16-1) were formulated based on HTWOS revised constraints given in Table 2.6. As shown in Table 5.3, the waste loading is limited by $T_{1 \%}$ and nepheline constraint. All three glasses met the nepheline constraint by satisfying the $\mathrm{OB}$ requirement. The loading of $\mathrm{Al}_{2} \mathrm{O}_{3}$ in these glasses ranged from $21.1 \mathrm{wt} \%$ to $27 \mathrm{wt} \%$, and loading of $\mathrm{Al}_{2} \mathrm{O}_{3}+\mathrm{Fe}_{2} \mathrm{O}_{3}+\mathrm{ZrO}_{2}$ ranged from $26.7 \mathrm{wt} \%$ to $29.7 \mathrm{wt} \%$. Although there is significant difference in $\mathrm{Al}_{2} \mathrm{O}_{3}$ loading between these three glasses, there is only a relatively small difference in loading of $\mathrm{Al}_{2} \mathrm{O}_{3}+\mathrm{Fe}_{2} \mathrm{O}_{3}+\mathrm{ZrO}_{2}$. These glasses are formulated without any manual adjustments and all contain high concentrations of $\mathrm{Na}_{2} \mathrm{O}$ at $19.3 \mathrm{wt} \%$ to $20.1 \mathrm{wt} \%$.

All the first glasses for each cluster (IWL-HAC5-1, 8-1, and 16-1) have the high concentrations of $\mathrm{B}_{2} \mathrm{O}_{3}(19.5 \mathrm{wt} \%$ or $20.0 \mathrm{wt} \%)$ and $\mathrm{Na}_{2} \mathrm{O}(19.3 \mathrm{wt} \%$ to $20.1 \mathrm{wt} \%)$. The high $\mathrm{B}_{2} \mathrm{O}_{3}$ concentration in high $\mathrm{Al}_{2} \mathrm{O}_{3}$ glasses was also used in past glass formulation studies with high-aluminum wastes (Kim et al. 2008; Marra et al. 2010). The next two glasses for Clusters 5 and 8 (IWL-HAC5-4, 6 and IWL-HAC8-4, 6) were formulated with increased $\mathrm{Al}_{2} \mathrm{O}_{3}$ concentration at one wt\% increment while decreasing the $\mathrm{B}_{2} \mathrm{O}_{3}$ concentration by the same $\mathrm{wt} \%$ at a fixed concentration of $\mathrm{Li}_{2} \mathrm{O}$. The $\mathrm{Na}_{2} \mathrm{O}$ was not used as additive and the viscosity changed accordingly. These changes decreased the viscosity to the range of $2.3 \mathrm{~Pa} \cdot \mathrm{s}$ to 2.5 Pa.s from $4 \mathrm{~Pa} \cdot \mathrm{s}$ and $4.5 \mathrm{~Pa} \cdot \mathrm{s}$ at $1150^{\circ} \mathrm{C}$. In next three glasses for Cluster 16 (IWL-HAC16-5, 6, and 7), the IWL-HAC16-5 glass was formulated at the same $\mathrm{Al}_{2} \mathrm{O}_{3}$ loading as the IWL-HAC16-1 glass while keeping the $\mathrm{B}_{2} \mathrm{O}_{3}$ the same at $20 \mathrm{wt} \%$ and adding $4 \mathrm{wt} \% \mathrm{Li}_{2} \mathrm{O}$. The $\mathrm{Na}_{2} \mathrm{O}$ was not used as additive and the viscosity changed accordingly. 
Table 5.3. Glasses Melting at $1150^{\circ} \mathrm{C}$ Formulated for High-Aluminum Waste Clusters and Their Predicted and Measured Properties

\begin{tabular}{|c|c|c|c|c|c|c|c|}
\hline \multirow[b]{2}{*}{ Comp. } & \multicolumn{3}{|c|}{ Cluster 5} & \multicolumn{3}{|c|}{ Cluster 8} & \multirow[b]{2}{*}{ Limits $^{(\mathrm{a}}$} \\
\hline & $\begin{array}{c}\text { IWL- } \\
\text { HAC5-1 }\end{array}$ & $\begin{array}{c}\text { IWL- } \\
\text { HAC5-4 }\end{array}$ & $\begin{array}{c}\text { IWL- } \\
\text { HAC5-6 }\end{array}$ & $\begin{array}{c}\text { IWL- } \\
\text { HAC8-1 }\end{array}$ & $\begin{array}{c}\text { IWL- } \\
\text { HAC8-4 }\end{array}$ & $\begin{array}{c}\text { IWL- } \\
\text { HAC8-6 }\end{array}$ & \\
\hline $\mathrm{Al}_{2} \mathrm{O}_{3}$ & 0.22160 & 0.23000 & 0.24000 & 0.21137 & 0.22000 & 0.23000 & - \\
\hline $\mathrm{B}_{2} \mathrm{O}_{3}$ & 0.20000 & 0.19000 & 0.18000 & 0.19536 & 0.19000 & 0.18000 & - \\
\hline $\mathrm{Bi}_{2} \mathrm{O}_{3}$ & 0.00876 & 0.00909 & 0.00948 & 0.00938 & 0.00976 & 0.01020 & - \\
\hline $\mathrm{CaO}$ & 0.00734 & 0.07000 & 0.07000 & 0.01251 & 0.07000 & 0.07000 & - \\
\hline $\mathrm{CdO}$ & 0.00008 & 0.00008 & 0.00008 & 0.00012 & 0.00012 & 0.00013 & - \\
\hline $\mathrm{Cr}_{2} \mathrm{O}_{3}$ & 0.01073 & 0.01113 & 0.01162 & 0.01012 & 0.01053 & 0.01101 & - \\
\hline $\mathrm{Cs}_{2} \mathrm{O}$ & 0.00223 & 0.00231 & 0.00241 & 0.00232 & 0.00242 & 0.00253 & - \\
\hline $\mathrm{F}$ & 0.00671 & 0.00696 & 0.00727 & 0.00550 & 0.00572 & 0.00598 & - \\
\hline $\mathrm{Fe}_{2} \mathrm{O}_{3}$ & 0.02743 & 0.02847 & 0.02971 & 0.05437 & 0.05659 & 0.05916 & - \\
\hline $\mathrm{K}_{2} \mathrm{O}$ & 0.00276 & 0.03000 & 0.03000 & 0.00185 & 0.03000 & 0.03000 & - \\
\hline $\mathrm{La}_{2} \mathrm{O}_{3}$ & 0.00100 & 0.00103 & 0.00108 & 0.00034 & 0.00035 & 0.00037 & - \\
\hline $\mathrm{Li}_{2} \mathrm{O}$ & 0.00000 & 0.04000 & 0.04000 & 0.00000 & 0.04000 & 0.04000 & - \\
\hline $\mathrm{MgO}$ & 0.00086 & 0.00089 & 0.00093 & 0.00170 & 0.00177 & 0.00185 & - \\
\hline $\mathrm{MnO}$ & 0.00559 & 0.00581 & 0.00606 & 0.00924 & 0.00962 & 0.01006 & - \\
\hline $\mathrm{Na}_{2} \mathrm{O}$ & 0.20139 & 0.07251 & 0.07566 & 0.19320 & 0.06252 & 0.06536 & - \\
\hline $\mathrm{Nd}_{2} \mathrm{O}_{3}$ & 0.00017 & 0.00017 & 0.00018 & 0.00050 & 0.00052 & 0.00054 & - \\
\hline $\mathrm{NiO}$ & 0.00608 & 0.00631 & 0.00658 & 0.00324 & 0.00337 & 0.00352 & - \\
\hline $\mathrm{P}_{2} \mathrm{O}_{5}$ & 0.02132 & 0.02213 & 0.02309 & 0.01094 & 0.01138 & 0.01190 & - \\
\hline $\mathrm{PbO}$ & 0.00116 & 0.00121 & 0.00126 & 0.00405 & 0.00422 & 0.00441 & - \\
\hline $\mathrm{RuO}_{2}$ & 0.00001 & 0.00001 & 0.00002 & 0.00000 & 0.00000 & 0.00000 & - \\
\hline $\mathrm{SiO}_{2}$ & 0.24067 & 0.23646 & 0.22761 & 0.26663 & 0.26353 & 0.25506 & - \\
\hline $\mathrm{SO}_{3}$ & 0.00575 & 0.00597 & 0.00622 & 0.00437 & 0.00455 & 0.00475 & - \\
\hline $\mathrm{SrO}$ & 0.00346 & 0.00359 & 0.00375 & 0.00184 & 0.00192 & 0.00200 & - \\
\hline $\mathrm{ZrO}_{2}$ & 0.02491 & 0.02586 & 0.02698 & 0.00108 & 0.00112 & 0.00117 & - \\
\hline Total & 1.00000 & 1.00000 & 1.00000 & 1.00000 & 1.00000 & 1.00000 & - \\
\hline Waste Loading & 0.445 & 0.462 & 0.482 & 0.464 & 0.483 & 0.505 & - \\
\hline $\mathrm{Al}_{2} \mathrm{O}_{3}+\mathrm{Fe}_{2} \mathrm{O}_{3}+\mathrm{ZrO}_{2}$ & 0.274 & 0.284 & 0.297 & 0.267 & 0.278 & 0.290 & - \\
\hline$\eta_{1150}, \mathrm{~Pa} \cdot \mathrm{s}$ & 4.53 & 2.43 & 2.49 & 4.00 & 2.29 & 2.32 & $2-8$ \\
\hline$\varepsilon_{1150}, \mathrm{~S} / \mathrm{m}$ & 46.5 & 22.9 & 23.5 & 41.9 & 21.1 & 21.6 & $10-100$ \\
\hline Spinel $T_{1 \%},{ }^{\circ} \mathrm{C}$ & 950 & 1087 & 1130 & 950 & 1086 & 1130 & 950 \\
\hline PCT-B, g/L & 0.930 & 0.186 & 0.076 & 1.347 & 0.312 & 0.145 & $<16.7$ \\
\hline PCT-Li, g/L & 3.608 & 0.442 & 0.195 & 4.091 & 0.616 & 0.303 & $<9.57$ \\
\hline PCT-Na, g/L & 1.403 & 0.302 & 0.128 & 1.853 & 0.466 & 0.220 & $<13.35$ \\
\hline TCLP Cd, mg/L & 0.019 & 0.015 & 0.015 & 0.021 & 0.016 & 0.016 & $<0.48$ \\
\hline$N_{S i}$ & 0.363 & 0.439 & 0.419 & 0.397 & 0.483 & 0.463 & $\geq 0.62$ \\
\hline OB & 0.575 & 0.576 & 0.582 & 0.575 & 0.574 & 0.579 & $\leq 0.575$ \\
\hline \multicolumn{8}{|c|}{ Measured spinel vol\% after $24 \mathrm{~h}$ heat treatment at $950^{\circ} \mathrm{C}$ and Crystallinity after CCC } \\
\hline $\begin{array}{l}950^{\circ} \mathrm{C} \text { Spinel vol } \% \\
\text { (vol } \% \text { of other } \\
\text { crystals) }\end{array}$ & $\begin{array}{l}1.7 \\
(3.6 \mathrm{Ap} \\
0.6 \mathrm{Bd})\end{array}$ & $\begin{array}{l}1.6 \\
(3.4 \mathrm{Ap} \\
0.6 \mathrm{Bd})\end{array}$ & $\begin{array}{l}2.6 \\
(3.5 \mathrm{Ap} \\
0.9 \mathrm{Bd}) \\
\end{array}$ & 1.1 & 1.9 & 1.9 & $\begin{array}{c}1 \\
(\mathrm{NA})\end{array}$ \\
\hline $\begin{array}{c}\text { CCC Crystallinity, } \\
\text { vol } \%\end{array}$ & $\begin{array}{l}5.2 \mathrm{~Np} \\
1.5 \mathrm{Ap} \\
1.6 \mathrm{Sp}\end{array}$ & $\begin{array}{l}\text { 4.0 Ap, } \\
1.8 \mathrm{Sp} \\
0.9 \mathrm{Bd}\end{array}$ & $\begin{array}{l}5.1 \mathrm{Ap} \\
2.6 \mathrm{Sp} \\
1.3 \mathrm{Bd}\end{array}$ & $\begin{array}{c}15.8 \mathrm{~Np} \\
1.9 \mathrm{Sp}\end{array}$ & $\begin{array}{l}2.8 \mathrm{Sp} \\
2.0 \mathrm{Ap}\end{array}$ & $\begin{array}{l}3.0 \mathrm{Sp} \\
2.2 \mathrm{Ap}\end{array}$ & No $\mathrm{Np}$ \\
\hline \multicolumn{8}{|c|}{$\begin{array}{l}\text { (a) Used as guidelines for formulating the glasses. } \\
\text { Shaded cells indicate that the predicted or calculated value is not within the limits. } \\
\text { Ap: apatite; Bd: baddeleyite; Sp: spinel; Np: nepheline. } \\
\text { No Np: no nepheline formation; NA: not applicable. }\end{array}$} \\
\hline
\end{tabular}


Table 5.3. (Continued)

\begin{tabular}{|c|c|c|c|c|c|}
\hline \multirow[b]{2}{*}{ Comp. } & \multicolumn{4}{|c|}{ Cluster 16} & \multirow[b]{2}{*}{ Limits $^{(\mathrm{a})}$} \\
\hline & $\begin{array}{c}\text { IWL- } \\
\text { HAC16-1 }\end{array}$ & $\begin{array}{c}\text { IWL- } \\
\text { HAC16-5 }\end{array}$ & $\begin{array}{c}\text { IWL- } \\
\text { HAC16-6 }\end{array}$ & $\begin{array}{c}\text { IWL- } \\
\text { HAC16-7 }\end{array}$ & \\
\hline $\mathrm{Al}_{2} \mathrm{O}_{3}$ & 0.27036 & 0.27036 & 0.28000 & 0.29000 & - \\
\hline $\mathrm{B}_{2} \mathrm{O}_{3}$ & 0.20000 & 0.20000 & 0.20000 & 0.20000 & - \\
\hline $\mathrm{Bi}_{2} \mathrm{O}_{3}$ & 0.00683 & 0.00683 & 0.00708 & 0.00733 & - \\
\hline $\mathrm{CaO}$ & 0.00408 & 0.07000 & 0.07000 & 0.07000 & - \\
\hline $\mathrm{CdO}$ & 0.00002 & 0.00002 & 0.00002 & 0.00002 & - \\
\hline $\mathrm{Cr}_{2} \mathrm{O}_{3}$ & 0.00957 & 0.00957 & 0.00991 & 0.01026 & - \\
\hline $\mathrm{Cs}_{2} \mathrm{O}$ & 0.00227 & 0.00227 & 0.00235 & 0.00243 & - \\
\hline $\mathrm{F}$ & 0.00122 & 0.00122 & 0.00126 & 0.00131 & - \\
\hline $\mathrm{Fe}_{2} \mathrm{O}_{3}$ & 0.02588 & 0.02588 & 0.02680 & 0.02776 & - \\
\hline $\mathrm{K}_{2} \mathrm{O}$ & 0.00103 & 0.03000 & 0.03000 & 0.03000 & - \\
\hline $\mathrm{La}_{2} \mathrm{O}_{3}$ & 0.00045 & 0.00045 & 0.00047 & 0.00048 & - \\
\hline $\mathrm{Li}_{2} \mathrm{O}$ & 0.01039 & 0.04000 & 0.04000 & 0.04000 & - \\
\hline $\mathrm{MgO}$ & 0.00091 & 0.00091 & 0.00094 & 0.00098 & - \\
\hline $\mathrm{MnO}$ & 0.00653 & 0.00653 & 0.00676 & 0.00700 & - \\
\hline $\mathrm{Na}_{2} \mathrm{O}$ & 0.19674 & 0.07670 & 0.07943 & 0.08227 & - \\
\hline $\mathrm{Nd}_{2} \mathrm{O}_{3}$ & 0.00036 & 0.00036 & 0.00037 & 0.00038 & - \\
\hline $\mathrm{NiO}$ & 0.00169 & 0.00169 & 0.00175 & 0.00181 & - \\
\hline $\mathrm{P}_{2} \mathrm{O}_{5}$ & 0.00659 & 0.00659 & 0.00682 & 0.00707 & - \\
\hline $\mathrm{PbO}$ & 0.00123 & 0.00123 & 0.00127 & 0.00132 & - \\
\hline $\mathrm{RuO}_{2}$ & 0.00000 & 0.00000 & 0.00000 & 0.00000 & - \\
\hline $\mathrm{SiO}_{2}$ & 0.24989 & 0.24542 & 0.23063 & 0.21530 & - \\
\hline $\mathrm{SO}_{3}$ & 0.00236 & 0.00236 & 0.00244 & 0.00253 & - \\
\hline $\mathrm{SrO}$ & 0.00078 & 0.00078 & 0.00081 & 0.00084 & - \\
\hline $\mathrm{ZrO}_{2}$ & 0.00085 & 0.00085 & 0.00089 & 0.00092 & - \\
\hline Total & 1.00000 & 1.00000 & 1.00000 & 1.00000 & - \\
\hline Waste Loading & 0.453 & 0.453 & 0.470 & 0.486 & - \\
\hline $\mathrm{Al}_{2} \mathrm{O}_{3}+\mathrm{Fe}_{2} \mathrm{O}_{3}+\mathrm{ZrO}_{2}$ & 0.297 & 0.297 & 0.308 & 0.319 & - \\
\hline$\eta_{1150}, \mathrm{~Pa} \cdot \mathrm{s}$ & 6.00 & 3.28 & 3.09 & 2.91 & $2-8$ \\
\hline$\varepsilon_{1150}, \mathrm{~S} / \mathrm{m}$ & 46.5 & 22.2 & 23.0 & 23.9 & $10-100$ \\
\hline Spinel $T_{1 \%},{ }^{\circ} \mathrm{C}$ & 950 & 1049 & 1078 & 1107 & 950 \\
\hline PCT-B, g/L & 0.008 & 0.003 & 0.001 & 0.000 & $<16.7$ \\
\hline PCT-Li, g/L & 0.057 & 0.014 & 0.005 & 0.001 & $<9.57$ \\
\hline PCT-Na, g/L & 0.023 & 0.010 & 0.003 & 0.001 & $<13.35$ \\
\hline TCLP Cd, mg/L & 0.004 & 0.003 & 0.004 & 0.004 & $<0.48$ \\
\hline$N_{S i}$ & 0.349 & 0.414 & 0.391 & 0.366 & $\geq 0.62$ \\
\hline OB & 0.575 & 0.574 & 0.577 & 0.580 & $\leq 0.575$ \\
\hline \multicolumn{6}{|c|}{ Measured spinel vol\% after $24 \mathrm{~h}$ heat treatment at $950^{\circ} \mathrm{C}$ and Crystallinity after CCC } \\
\hline $\begin{array}{l}950^{\circ} \mathrm{C} \text { Spinel vol } \% \\
\text { (vol } \% \text { of other } \\
\text { crystals) }\end{array}$ & 0.8 & 0.9 & $\begin{array}{l}3.0 \\
(4.2 \mathrm{Ap} \\
1.8 \mathrm{Bd}) \\
\end{array}$ & 1.2 & $\begin{array}{c}1 \\
(\mathrm{NA})\end{array}$ \\
\hline $\begin{array}{c}\text { CCC Crystallinity, } \\
\text { vo } \%\end{array}$ & $\begin{array}{l}45.2 \mathrm{~Np} \\
1.7 \mathrm{Sp} \\
0.1 \mathrm{Bd}\end{array}$ & $1.4 \mathrm{Sp}$ & $1.6 \mathrm{Sp}$ & $\begin{array}{c}1.8 \mathrm{Sp} \\
1.8\end{array}$ & No Np \\
\hline \multicolumn{6}{|c|}{$\begin{array}{l}\text { (a) Used as guidelines for formulating the glasses. } \\
\text { Shaded cells indicate that the predicted or calculated value is not within the limits. } \\
\text { Ap: apatite; Bd: baddeleyite; Sp: spinel; Np: nepheline. } \\
\text { No Np: no nepheline formation; NA: not applicable. }\end{array}$} \\
\hline
\end{tabular}

The results of XRD measurement for the spinel vol\% after a 24 -hour heat treatment at $950^{\circ} \mathrm{C}$ and CCC treatment were included in Table 5.3. Among three clusters, the formulation with Cluster 16 produced two glasses that pass the $T_{1 \%}$ requirement. All three as-formulated glasses for each cluster 
(IWL-HAC5-1, 8-1, and 16-1) based on HTWOS revised constraints precipitated nepheline after CCC treatment, which is likely to be attributed to their high $\mathrm{Na}_{2} \mathrm{O}$ concentration. These glasses passed the OB constraint at the maximum value of 0.575 . This suggests that the current OB constraint, unlike $N_{S i}$, may not be conservative for these high-aluminum glasses. All the other glasses manually adjusted by adding $\mathrm{K}_{2} \mathrm{O}$ and/or $\mathrm{Li}_{2} \mathrm{O}$ replacing $\mathrm{Na}_{2} \mathrm{O}$ did not form nepheline. Additional formulation and testing are needed to determine the estimated maximum $\mathrm{Al}_{2} \mathrm{O}_{3}$ loading for each cluster.

\subsection{Systematic Glass Studies: High- $\mathrm{Al}_{2} \mathrm{O}_{3}$ Test Matrix Glasses}

In addition to the approach of glass formulation described in Section 5.1, some test objectives may rely on defining specific glass compositions that cover a generic compositional region of interest. For example, assume that a specific process control model (e.g., $T_{1 \%}$ ) is limiting access to higher waste loadings. A review of the compositional range over which that model was either developed or validated may identify compositional gaps that need to be covered from an experimental perspective. These data can then be used to revise the existing model or develop a new model. To accomplish this through a matrix design study, the general approach is to define the glass composition region of interest. As previously mentioned, this region may be defined based on compositional gaps identified by the review of the model or validation range as compared to the glass composition region covered by higher waste loadings. Other approaches may simply set minimum and maximum limits to the glass region of interest independent of model or validation ranges. Regardless of the approach, minimum and maximum values for the major and/or minor oxides of interest are needed.

Among 20 waste clusters discussed in Section 2.2, the high-alumina clusters represent nearly a half of Hanford wastes (on a waste oxides basis or a glass basis). In addition, glasses with $\mathrm{Al}_{2} \mathrm{O}_{3}$ content of up to $27 \mathrm{wt} \%$ have been demonstrated while current models are sparsely populated with data going only to $20 \mathrm{wt} \%$. Therefore, the first glass matrix for advanced silicate glass formulation studies was developed to cover a glass composition region of high $\mathrm{Al}_{2} \mathrm{O}_{3}$.

Typically, glass composition matrices have been developed using statistical design approaches (Piepel et al. 2004). However, these approaches tend to push a majority (e.g., all) of the glasses to the boundaries of composition space. One approach to avoid this has been to define multiple sets of boundaries forming concentric circles of compositions with all glasses on one of the boundaries. This approach is not deemed appropriate for high-alumina glasses as there are specific formulation directions that do not make acceptable glasses for further characterization and the highly non-linear and unknown nature of composition effects on glass properties at their waste loading boundaries. Therefore, a new design approach is needed at least for the first high-alumina glass matrix. This approach is to evenly fill composition space with compositions that are all predicted to successfully produce glasses that can be characterized. This 'space filling' design is described below.

Design of space filling matrix for high-alumina glasses was performed according to the following steps:

1. Collect existing data on high- $\mathrm{Al}_{2} \mathrm{O}_{3}$ glasses (Section 5.2.1)

2. Define single component constraints, multicomponent constraints, and property constraints (Section 5.2.2)

3. Formulate random-generated glasses within the predetermined single component constraints (Section 5.2.3) 
4. Select matrix glasses by (Section 5.2.4):

- sorting out the glasses outside the multicomponent and property constraints

- performing distance calculations compared to existing data and sorting out the glasses that are too close to the existing glasses

- performing distance calculations between matrix glasses and sorting out the glasses that are too close each other.

\subsubsection{Existing Data on High- $\mathrm{Al}_{2} \mathrm{O}_{3}$ Glasses}

Recent efforts to increase waste loading beyond that is estimated based on WTP formulation algorithm and HTWOS constraints (Vienna et al 2009) have focused on high-aluminum wastes. The studies at VSL (Matlack et al. 2007a, 2008, 2010) and PNNL (Kim et al. 2008; Marra et al. 2010; Schweiger et al. 2011) applied iterative approach of repeating the formulation and testing of a set of few glasses to finally select glasses for scaled melter tests. In this approach, only selected properties are tested for all glasses and only selected glasses are fully characterized and tested in scaled melter runs.

The loading of wastes in high-alumina glasses is primarily limited by nepheline formation after CCC treatment and spinel $T_{1 \%}$ constraint. The other property requirements such as PCT and TCLP are easily met. Among these two critical constraints, most of the high- $\mathrm{Al}_{2} \mathrm{O}_{3}$ glasses in the studies mentioned above were tested for the nepheline formation, but limited number of glasses was tested for $T_{1 \%}$. Instead, most glasses were tested for the vol\% of spinel crystal after a $950{ }^{\circ} \mathrm{C}$ heat treatment so that the pass/fail determination of $T_{1 \%} \leq 950^{\circ} \mathrm{C}$ can be made. The limited glasses with $>21 \mathrm{wt} \% \mathrm{Al}_{2} \mathrm{O}_{3}$ and $T_{1 \%}$ data were collected and used as a set of existing data in the design of matrix glasses. Table 5.4 summarizes the glass composition, measured $T_{1 \%}$, and key predicted properties for the 14 glasses with measured $T_{1 \%}$ data. The measured $T_{1 \%}$ was obtained by interpolating or extrapolating the spinel vol\% versus temperature data for multiple temperatures given in the literature. Some glasses that had less than three data points or did not show reasonable linear fit between the spinel vol\% versus temperature were excluded.

Figure 5.1 shows the predicted versus measured $T_{1 \%}$ data for the 14 high- $\mathrm{Al}_{2} \mathrm{O}_{3}$ glasses given in Table 5.4. The $T_{1 \%}$ model developed for the glasses with lower $\mathrm{Al}_{2} \mathrm{O}_{3}$ concentration $(\leq 20 \mathrm{wt} \%)$ (Vienna et al. 2009) showed a tendency to overpredict the measured values for these high- $\mathrm{Al}_{2} \mathrm{O}_{3}$ glasses.

Three glasses out of 14 existing glasses had predicted viscosity at $1150{ }^{\circ} \mathrm{C}$ outside the WTP required range (2-8 $\mathrm{Pa} \cdot \mathrm{s})$. The predicted melting temperature ranged from $991^{\circ} \mathrm{C}$ to $1226^{\circ} \mathrm{C}$, based on predicted viscosity of $5 \mathrm{~Pa} \cdot \mathrm{s}$. All 14 glasses fail the $N_{S i}$ requirement but seven glasses pass the OB requirement and thereby passing the nepheline constraint (see Equations 2.1 and 2.2 in Section 2.2.2). 
Table 5.4. Existing High- $\mathrm{Al}_{2} \mathrm{O}_{3}$ Glasses with Measured $T_{1 \%}$ Data

\begin{tabular}{|c|c|c|c|c|c|c|c|c|c|c|c|c|c|c|}
\hline Reference & \multicolumn{7}{|c|}{ Matlack et al. (2007a) } & \multicolumn{7}{|c|}{ Matlack et al. (2008) } \\
\hline Glass ID & $\begin{array}{c}\text { HLW- } \\
\text { E-Al-12 }\end{array}$ & $\begin{array}{c}\text { HLW- } \\
\text { E-Al-27 }\end{array}$ & $\begin{array}{c}\text { HLW- } \\
\text { E-ANa- } \\
05\end{array}$ & $\begin{array}{c}\text { HLW- } \\
\text { E-ANa- } \\
06\end{array}$ & $\begin{array}{c}\text { HLW- } \\
\text { E-ANa- } \\
09\end{array}$ & $\begin{array}{c}\text { HLW- } \\
\text { E-ANa- } \\
24\end{array}$ & $\begin{array}{c}\text { HLW- } \\
\text { E-ANa- } \\
25\end{array}$ & $\begin{array}{l}\text { HWI- } \\
\text { AL-7 }\end{array}$ & $\begin{array}{l}\text { HWI- } \\
\text { AL-9 }\end{array}$ & $\begin{array}{l}\text { HWI- } \\
\text { AL-13 }\end{array}$ & $\begin{array}{l}\text { HWI- } \\
\text { AL-17 }\end{array}$ & $\begin{array}{c}\text { HWI- } \\
\text { AL- } \\
\text { 18(G) }\end{array}$ & $\begin{array}{l}\text { HWI- } \\
\text { AL-19 }\end{array}$ & $\begin{array}{l}\text { HWI- } \\
\text { AL-20 }\end{array}$ \\
\hline $\mathrm{Al}_{2} \mathrm{O}_{3}$ & 0.23971 & 0.23971 & 0.23608 & 0.25878 & 0.25878 & 0.22700 & 0.22700 & 0.23970 & 0.21310 & 0.23970 & 0.23250 & 0.22570 & 0.23970 & 0.23970 \\
\hline $\mathrm{B}_{2} \mathrm{O}_{3}$ & 0.20190 & 0.15190 & 0.14406 & 0.14445 & 0.14445 & 0.18390 & 0.19390 & 0.15190 & 0.18170 & 0.15190 & 0.14730 & 0.20130 & 0.19190 & 0.18190 \\
\hline $\mathrm{BaO}$ & 0.00054 & 0.00054 & 0.00031 & 0.00034 & 0.00034 & 0.00030 & 0.00030 & 0.00050 & 0.00050 & 0.00050 & 0.00050 & 0.00050 & 0.00050 & 0.00050 \\
\hline $\mathrm{Bi}_{2} \mathrm{O}_{3}$ & 0.01145 & 0.01145 & 0.01279 & 0.01402 & 0.01402 & 0.01230 & 0.01230 & 0.01140 & 0.01020 & 0.01140 & 0.01110 & 0.01080 & 0.01140 & 0.01140 \\
\hline $\mathrm{CaO}$ & 0.14076 & 0.06076 & 0.00801 & 0.00878 & 0.00878 & 0.00770 & 0.00770 & 0.03080 & 0.00960 & 0.06080 & 0.05890 & 0.05720 & 0.05580 & 0.01080 \\
\hline $\mathrm{CdO}$ & 0.00024 & 0.00024 & 0.00010 & 0.00011 & 0.00011 & 0.00010 & 0.00010 & 0.00020 & 0.00020 & 0.00020 & 0.00020 & 0.00020 & 0.00020 & 0.00020 \\
\hline $\mathrm{Cr}_{2} \mathrm{O}_{3}$ & 0.00521 & 0.00521 & 0.00785 & 0.00861 & 0.00861 & 0.00755 & 0.00755 & 0.00520 & 0.00460 & 0.00520 & 0.00510 & 0.00490 & 0.00520 & 0.00520 \\
\hline $\mathrm{F}$ & 0.00667 & 0.00667 & 0.00250 & 0.00274 & 0.00274 & 0.00240 & 0.00240 & 0.00670 & 0.00590 & 0.00670 & 0.00650 & 0.00630 & 0.00670 & 0.00670 \\
\hline $\mathrm{Fe}_{2} \mathrm{O}_{3}$ & 0.05899 & 0.05899 & 0.03115 & 0.03414 & 0.03414 & 0.02995 & 0.02995 & 0.05900 & 0.05240 & 0.05900 & 0.05720 & 0.05560 & 0.05900 & 0.05900 \\
\hline $\mathrm{K}_{2} \mathrm{O}$ & 0.00141 & 0.00141 & 0.00733 & 0.00804 & 0.00804 & 0.00705 & 0.00705 & 0.00140 & 0.00130 & 0.04140 & 0.03140 & 0.00130 & 0.00140 & 0.05140 \\
\hline $\mathrm{Li}_{2} \mathrm{O}$ & 0.05171 & 0.03571 & 0.03583 & 0.02811 & 0.05091 & 0.03080 & 0.03080 & 0.03570 & 0.03150 & 0.03570 & 0.03460 & 0.03360 & 0.03570 & 0.03170 \\
\hline $\mathrm{MgO}$ & 0.00117 & 0.00117 & 0.00239 & 0.00262 & 0.00262 & 0.00230 & 0.00230 & 0.03120 & 0.00100 & 0.00120 & 0.00110 & 0.00110 & 0.00120 & 0.00120 \\
\hline $\mathrm{Na}_{2} \mathrm{O}$ & 0.03580 & 0.09580 & 0.14061 & 0.15413 & 0.15413 & 0.13520 & 0.13520 & 0.09580 & 0.13180 & 0.06080 & 0.09290 & 0.09020 & 0.09580 & 0.08580 \\
\hline $\mathrm{NiO}$ & 0.00400 & 0.00400 & 0.00109 & 0.00120 & 0.00120 & 0.00105 & 0.00105 & 0.00400 & 0.00360 & 0.00400 & 0.00390 & 0.00380 & 0.00400 & 0.00400 \\
\hline $\mathrm{P}_{2} \mathrm{O}_{5}$ & 0.01052 & 0.01052 & 0.02236 & 0.02451 & 0.02451 & 0.02150 & 0.02150 & 0.01050 & 0.00940 & 0.01050 & 0.01020 & 0.00990 & 0.01050 & 0.01050 \\
\hline $\mathrm{PbO}$ & 0.00409 & 0.00409 & 0.00099 & 0.00108 & 0.00108 & 0.00095 & 0.00095 & 0.00410 & 0.00360 & 0.00410 & 0.00400 & 0.00390 & 0.00410 & 0.00410 \\
\hline $\mathrm{SiO}_{2}$ & 0.21896 & 0.30496 & 0.33890 & 0.29996 & 0.27716 & 0.32260 & 0.31260 & 0.30500 & 0.33350 & 0.30000 & 0.29580 & 0.28720 & 0.27000 & 0.28900 \\
\hline $\mathrm{SO}_{3}$ & 0.00200 & 0.00200 & 0.00239 & 0.00262 & 0.00262 & 0.00230 & 0.00230 & 0.00200 & 0.00180 & 0.00200 & 0.00190 & 0.00190 & 0.00200 & 0.00200 \\
\hline $\mathrm{TiO}_{2}$ & 0.00010 & 0.00010 & 0.00192 & 0.00211 & 0.00211 & 0.00185 & 0.00185 & 0.00010 & 0.00010 & 0.00010 & 0.00010 & 0.00010 & 0.00010 & 0.00010 \\
\hline $\mathrm{ZnO}$ & 0.00083 & 0.00083 & 0.00198 & 0.00217 & 0.00217 & 0.00190 & 0.00190 & 0.00080 & 0.00070 & 0.00080 & 0.00080 & 0.00080 & 0.00080 & 0.00080 \\
\hline $\mathrm{ZrO}_{2}$ & 0.00395 & 0.00395 & 0.00135 & 0.00148 & 0.00148 & 0.00130 & 0.00130 & 0.00390 & 0.00350 & 0.00390 & 0.00380 & 0.00370 & 0.00390 & 0.00390 \\
\hline Total & 1 & 1 & 1 & 1 & 1 & 1 & 1 & 1 & 1 & 1 & 1 & 1 & 1 & 1 \\
\hline \multicolumn{15}{|c|}{ Measured spinel $T_{1 \%}$ and Crystallinity after CCC Treatment } \\
\hline$T_{1 \%}-\mathrm{Sp},{ }^{\circ} \mathrm{C}$ & 988 & 953 & 922 & 965 & 935 & 783 & 750 & 1144 & 827 & 1066 & 960 & 968 & 969 & 1067 \\
\hline \multicolumn{15}{|c|}{ Predicted properties (Vienna et a. 2009) } \\
\hline$\eta_{1150}$, Pa.s & 1.06 & 5.17 & 8.49 & 9.20 & 3.32 & 6.72 & 5.89 & 6.13 & 5.50 & 5.91 & 4.33 & 3.76 & 3.39 & 6.56 \\
\hline$T$ at $5 \mathrm{Pas},{ }^{\circ} \mathrm{C}$ & 991 & 1154 & 1216 & 1226 & 1092 & 1187 & 1171 & 1173 & 1162 & 1171 & 1132 & 1116 & 1103 & 1183 \\
\hline$T_{1 \%}-\mathrm{Sp},{ }^{\circ} \mathrm{C}$ & 1121 & 1078 & 925 & 994 & 967 & 881 & 875 & 1173 & 909 & 1084 & 1033 & 1004 & 1051 & 1017 \\
\hline \multicolumn{15}{|c|}{ Nepheline formation criteria } \\
\hline$N_{S i}$ & 0.443 & 0.476 & 0.474 & 0.421 & 0.402 & 0.471 & 0.463 & 0.476 & 0.492 & 0.500 & 0.476 & 0.476 & 0.446 & 0.470 \\
\hline OB & 0.581 & 0.577 & 0.570 & 0.577 & 0.587 & 0.558 & 0.557 & 0.578 & 0.560 & 0.578 & 0.585 & 0.562 & 0.569 & 0.567 \\
\hline
\end{tabular}




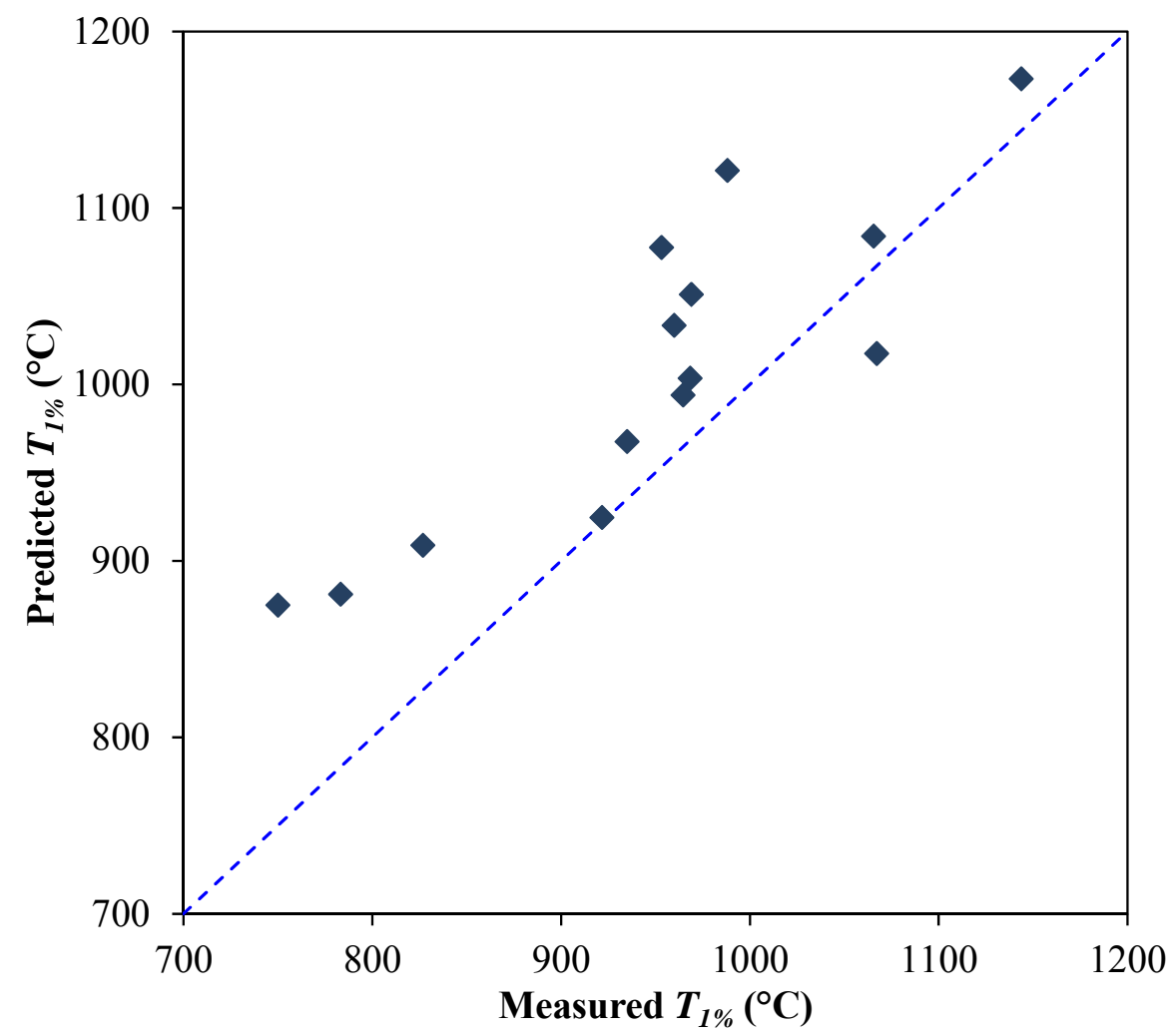

Figure 5.1. Predicted Versus Measured $T_{1 \%}$ for High- $\mathrm{Al}_{2} \mathrm{O}_{3}$ Glasses with $T_{1 \%}$ Data

\subsubsection{Matrix Design Constraints}

The glass composition constraints on single component concentrations were obtained by evaluating the compositional information on the high- $\mathrm{Al}_{2} \mathrm{O}_{3}$ glasses studied at VSL (Matlack et al. 2007a, 2008, 2010) and PNNL (Kim et al. 2008; Marra et al. 2010; Schweiger et al. 2011). Table 5.5 through Table 5.7 list the compositions and predicted properties with limited data on measured properties for the glasses evaluated for matrix design constraints. A brief discussion on these glasses is given below.

Table 5.5 list the glasses selected for and demonstrated through scaled melter tests. All glasses passed the PCT constraints for both quenched and CCC treated glasses. Theses glasses did not form nepheline after CCC treatment although three glasses, HAL-17, HAL-24, and HLW-E-Al-27, fail the nepheline constraint. All glasses met the electrical conductivity and viscosity requirements except HWI-Al-28, which had a measured viscosity of $1.6 \mathrm{~Pa} \cdot \mathrm{s}$ at $1150^{\circ} \mathrm{C}$ (compared to $\geq 2 \mathrm{~Pa} \cdot \mathrm{s}$ ). Note that the HAL-24 and HWI-Al-28 were designed to have low a viscosity to improve the melter processing rate (Marra et al. 2010, Matlack et al. 2010). The three glasses, HAL-17, HAL-24, and HLW-E-Al-27, were designed to meet the $T_{1 \%}$ requirement ( $<1 \mathrm{vol} \%$ spinel after 24 -hour heat treatment at $950{ }^{\circ} \mathrm{C}$ ). ${ }^{1}$ However, in later VSL studies (Matlack et al. 2008, 2010), the WTP crystallinity limit ( $<1$ vol\% spinel after 24-hour heat treatment at $950^{\circ} \mathrm{C}$ or $T_{1 \%} \leq 950^{\circ} \mathrm{C}$ ) was "relaxed slightly as a waste loading constraint for the crucible melts based on experience form the melter test that the melter typically can tolerate high vol\%

\footnotetext{
${ }^{1}$ The $T_{1 \%}$ requirement was not met for HAL-24, but this glass was selected for melter test as being close to meeting the requirement so as not to perform additional iteration of glass formulation and testing (Marra et al. 2010).
} 
crystals" (HWI-Al-19 and HWI-Al-28). This is in line with the approach at PNNL to develop the model that can predict crystal accumulation as a constraint for formulating crystal tolerant glasses for higher waste loading (Matyas et al. 2010).

Table 5.6 lists the glasses formulated and tested in a recent VSL study (Matlack et al. 2010) to select the high- $\mathrm{Al}_{2} \mathrm{O}_{3}$ glass for melter tests. The HWI-Al-28 was also included in Table 5.5 as it was selected for melter tests from this study. Nepheline was not detected after CCC treatment in all glasses as expected from that all glasses pass the nepheline constraint. Selected glasses tested met the electrical conductivity requirements, but the two glasses (HWI-AL-27 and HWI-AL-28) had a measured viscosity lower than $2 \mathrm{~Pa} \cdot \mathrm{s}$ at $1150^{\circ} \mathrm{C} .{ }^{2}$ All the glasses in Table 5.6 had spinel vol $\%$ larger than $1 \%$ at $950^{\circ} \mathrm{C}$ (or $T_{1 \%}$ higher than $950^{\circ} \mathrm{C}$ ) as this requirement was relaxed as mentioned above (note that all glasses had $T_{1 \%}$ even higher than $1050^{\circ} \mathrm{C}$ ).

Table 5.7 lists glasses formulated as a part of advanced silicate formulation described in Section 5.1. These glasses were not tested at the time of the matrix design. The glasses formulated solely by optimization based on HTWOS constraints without manual adjustments of compositions (IWL-HAC5-1, IWL-HAC8-1, and IWL-HAC-16-1) were excluded. The glasses in Table 5.7 represent those that have potentially maximum waste loading for each high- $\mathrm{Al}_{2} \mathrm{O}_{3}$ cluster, i.e., formulated to determine the waste loading limits. All the glasses had predicted viscosity at $1150{ }^{\circ} \mathrm{C}$ higher than $2 \mathrm{~Pa} \cdot \mathrm{s}$ and predicted $T_{1 \%}$ higher than $1049^{\circ} \mathrm{C}$. Two glasses (IWL-HAC8-4 and IWL-HAC16-5) out of seven pass the nepheline constraint.

\footnotetext{
${ }^{2}$ The report by Matlack et al. 2010 stated that these glasses "have acceptable viscosity" suggesting that lower minimum viscosity requirement than $2 \mathrm{~Pa} \cdot \mathrm{s}$ at $1150^{\circ} \mathrm{C}$ was assumed.
} 
Table 5.5. High- $\mathrm{Al}_{2} \mathrm{O}_{3}$ Glasses Processed in Scaled Melter Tests

\begin{tabular}{|c|c|c|c|c|c|}
\hline Reference & $\begin{array}{c}\text { Kim et al. } \\
(2008)\end{array}$ & $\begin{array}{l}\text { Marra et } \\
\text { al. (2010) }\end{array}$ & $\begin{array}{c}\text { Matlack et al. } \\
(2010)\end{array}$ & $\begin{array}{l}\text { Matlack et } \\
\text { al. (2008) }\end{array}$ & $\begin{array}{l}\text { Matlack et } \\
\text { al. (2010) }\end{array}$ \\
\hline Glass ID & HAL-17 & HAL-24 & HLW-E-Al-27 & HWI-Al-19 & HWI-Al-28 \\
\hline $\mathrm{Al}_{2} \mathrm{O}_{3}$ & 0.25889 & 0.25889 & 0.23971 & 0.23970 & 0.26633 \\
\hline $\mathrm{B}_{2} \mathrm{O}_{3}$ & 0.16139 & 0.20299 & 0.15190 & 0.19190 & 0.20212 \\
\hline $\mathrm{BaO}$ & 0.00058 & 0.00058 & 0.00054 & 0.00050 & 0.00060 \\
\hline $\mathrm{Bi}_{2} \mathrm{O}_{3}$ & 0.01236 & 0.01236 & 0.01145 & 0.01140 & 0.01270 \\
\hline $\mathrm{CaO}$ & 0.07331 & 0.07331 & 0.06076 & 0.05580 & 0.09201 \\
\hline $\mathrm{CdO}$ & 0.00026 & 0.00026 & 0.00024 & 0.00020 & 0.00030 \\
\hline $\mathrm{Cr}_{2} \mathrm{O}_{3}$ & 0.00563 & 0.00563 & 0.00521 & 0.00520 & 0.00580 \\
\hline $\mathrm{Cs}_{2} \mathrm{O}$ & - & - & - & - & - \\
\hline $\mathrm{F}$ & 0.00721 & 0.00721 & 0.00667 & 0.00670 & 0.00740 \\
\hline $\mathrm{Fe}_{2} \mathrm{O}_{3}$ & 0.06371 & 0.06371 & 0.05899 & 0.05900 & 0.06551 \\
\hline $\mathrm{K}_{2} \mathrm{O}$ & 0.02723 & 0.02723 & 0.00141 & 0.00140 & 0.00160 \\
\hline $\mathrm{La}_{2} \mathrm{O}_{3}$ & - & - & - & - & - \\
\hline $\mathrm{Li}_{2} \mathrm{O}$ & 0.04000 & 0.04000 & 0.03571 & 0.03570 & 0.05011 \\
\hline $\mathrm{MgO}$ & 0.00126 & 0.00126 & 0.00117 & 0.00120 & 0.00130 \\
\hline $\mathrm{MnO}$ & - & - & - & - & - \\
\hline $\mathrm{Na}_{2} \mathrm{O}$ & 0.06067 & 0.06067 & 0.09580 & 0.09580 & 0.04980 \\
\hline $\mathrm{Nd}_{2} \mathrm{O}_{3}$ & - & - & - & - & - \\
\hline $\mathrm{NiO}$ & 0.00431 & 0.00431 & 0.00400 & 0.00400 & 0.00440 \\
\hline $\mathrm{P}_{2} \mathrm{O}_{5}$ & 0.01136 & 0.01136 & 0.01052 & 0.01050 & 0.01170 \\
\hline $\mathrm{PbO}$ & 0.00442 & 0.00442 & 0.00409 & 0.00410 & 0.00450 \\
\hline $\mathrm{RuO}_{2}$ & - & - & - & - & - \\
\hline $\mathrm{SiO}_{2}$ & 0.25999 & 0.21840 & 0.30496 & 0.27000 & 0.21622 \\
\hline $\mathrm{SO}_{3}$ & 0.00216 & 0.00216 & 0.00200 & 0.00200 & 0.00220 \\
\hline $\mathrm{SrO}$ & - & - & - & - & - \\
\hline $\mathrm{TiO}_{2}$ & 0.00011 & 0.00011 & 0.00010 & 0.00010 & 0.00010 \\
\hline $\mathrm{ZnO}$ & 0.00089 & 0.00089 & 0.00083 & 0.00080 & 0.00090 \\
\hline $\mathrm{ZrO}_{2}$ & 0.00426 & 0.00426 & 0.00395 & 0.00390 & 0.00440 \\
\hline Total & 1.00000 & 1.00000 & 1.00000 & 1.00000 & 1.00000 \\
\hline \multicolumn{6}{|c|}{ Predicted properties (Vienna et al 2009) } \\
\hline$\eta_{1150,}$ Pa.s & 3.93 & 2.44 & 5.17 & 3.39 & 1.90 \\
\hline$T$ at 5 Pas, ${ }^{\circ} \mathrm{C}$ & 1121 & 1065 & 1154 & 1103 & 1040 \\
\hline$T_{1 \%}-\mathrm{Sp},{ }^{\circ} \mathrm{C}$ & 1160 & 1134 & 1078 & 1051 & 1189 \\
\hline \multicolumn{6}{|c|}{ Nepheline formation criteria } \\
\hline$N_{S i}$ & 0.449 & 0.406 & 0.476 & 0.446 & 0.406 \\
\hline $\mathrm{OB}$ & 0.582 & 0.576 & 0.577 & 0.569 & 0.574 \\
\hline \multicolumn{6}{|c|}{ Measured viscosity at $1150^{\circ} \mathrm{C}$} \\
\hline$\eta_{1150,}$, Pa.s & 5.8 & 2.1 & 4.6 & 3.3 & 1.6 \\
\hline \multicolumn{6}{|c|}{ Measured Spinel vol\% after heat treatment at each temperature } \\
\hline $800^{\circ} \mathrm{C}$ & - & - & 7.2 & 3.7 & $4.6^{\mathrm{a}}$ \\
\hline $850^{\circ} \mathrm{C}$ & - & - & 3.4 & 3.0 & - \\
\hline $900^{\circ} \mathrm{C}$ & - & - & 3.8 & 2.1 & - \\
\hline $950^{\circ} \mathrm{C}$ & 1.0 & 1.1 & 1.0 & 1.3 & $2.4^{\mathrm{b}}$ \\
\hline $1050^{\circ} \mathrm{C}$ & - & - & - & - & 2.5 \\
\hline $\begin{array}{l}\text { "“-" represents } \\
{ }^{\mathrm{a}} \text { Spinel and A } \\
\text { b Spinel, Phos }\end{array}$ & $\begin{array}{l}\text { apty cells. } \\
\text { tite. }\end{array}$ & $\ldots$ & & & \\
\hline
\end{tabular}


Table 5.6. High- $\mathrm{Al}_{2} \mathrm{O}_{3}$ Glasses Formulated and Tested to Select the Glass for Melter Test

\begin{tabular}{|c|c|c|c|c|c|c|c|c|}
\hline \multirow{2}{*}{$\begin{array}{l}\text { Reference } \\
\text { Glass ID }\end{array}$} & \multicolumn{8}{|c|}{ Matlack et al. (2010) } \\
\hline & $\begin{array}{l}\text { HWI- } \\
\text { Al-21 }\end{array}$ & $\begin{array}{l}\text { HWI- } \\
\text { Al-22 }\end{array}$ & $\begin{array}{l}\text { HWI- } \\
\text { Al-23 }\end{array}$ & $\begin{array}{l}\text { HWI- } \\
\text { Al-24 } \\
\end{array}$ & $\begin{array}{l}\text { HWI- } \\
\text { Al-25 } \\
\end{array}$ & $\begin{array}{l}\text { HWI- } \\
\text { Al-26 }\end{array}$ & $\begin{array}{l}\text { HWI- } \\
\text { Al-27 }\end{array}$ & $\begin{array}{l}\text { HWI- } \\
\text { Al-28 }\end{array}$ \\
\hline $\mathrm{Al}_{2} \mathrm{O}_{3}$ & 0.25025 & 0.25035 & 0.25035 & 0.26633 & 0.25035 & 0.25035 & 0.25035 & 0.26633 \\
\hline $\mathrm{B}_{2} \mathrm{O}_{3}$ & 0.20006 & 0.20996 & 0.21896 & 0.19192 & 0.19996 & 0.20196 & 0.20196 & 0.20212 \\
\hline $\mathrm{BaO}$ & 0.00060 & 0.00060 & 0.00060 & 0.00060 & 0.00060 & 0.00060 & 0.00060 & 0.00060 \\
\hline $\mathrm{Bi}_{2} \mathrm{O}_{3}$ & 0.01200 & 0.01200 & 0.01200 & 0.01270 & 0.01200 & 0.01200 & 0.01200 & 0.01270 \\
\hline $\mathrm{CaO}$ & 0.03019 & 0.02020 & 0.01120 & 0.02000 & 0.04019 & 0.05619 & 0.08118 & 0.09201 \\
\hline $\mathrm{CdO}$ & 0.00030 & 0.00030 & 0.00030 & 0.00030 & 0.00030 & 0.00030 & 0.00030 & 0.00030 \\
\hline $\mathrm{Cr}_{2} \mathrm{O}_{3}$ & 0.00540 & 0.00540 & 0.00540 & 0.00580 & 0.00540 & 0.00540 & 0.00540 & 0.00580 \\
\hline $\mathrm{Cs}_{2} \mathrm{O}$ & - & - & - & - & - & - & - & - \\
\hline $\mathrm{F}$ & 0.00700 & 0.00700 & 0.00700 & 0.00740 & 0.00700 & 0.00700 & 0.00700 & 0.00740 \\
\hline $\mathrm{Fe}_{2} \mathrm{O}_{3}$ & 0.06159 & 0.06159 & 0.06159 & 0.06551 & 0.06159 & 0.06159 & 0.06159 & 0.06551 \\
\hline $\mathrm{K}_{2} \mathrm{O}$ & 0.00150 & 0.00150 & 0.00150 & 0.00160 & 0.00150 & 0.00150 & 0.00150 & 0.00160 \\
\hline $\mathrm{La}_{2} \mathrm{O}_{3}$ & - & - & - & - & - & - & - & - \\
\hline $\mathrm{Li}_{2} \mathrm{O}$ & 0.03579 & 0.03579 & 0.03579 & 0.03250 & 0.03179 & 0.03579 & 0.04999 & 0.05011 \\
\hline $\mathrm{MgO}$ & 0.00120 & 0.00120 & 0.00120 & 0.00130 & 0.00120 & 0.00120 & 0.00120 & 0.00130 \\
\hline $\mathrm{MnO}$ & - & - & - & - & - & - & - & - \\
\hline $\mathrm{Na}_{2} \mathrm{O}$ & 0.09638 & 0.09638 & 0.09638 & 0.09581 & 0.09338 & 0.08738 & 0.05739 & 0.04980 \\
\hline $\mathrm{Nd}_{2} \mathrm{O}_{3}$ & - & - & - & - & - & - & - & - \\
\hline $\mathrm{NiO}$ & 0.00420 & 0.00420 & 0.00420 & 0.00440 & 0.00420 & 0.00420 & 0.00420 & 0.00440 \\
\hline $\mathrm{P}_{2} \mathrm{O}_{5}$ & 0.01100 & 0.01100 & 0.01100 & 0.01170 & 0.01100 & 0.01100 & 0.01100 & 0.01170 \\
\hline $\mathrm{PbO}$ & 0.00430 & 0.00430 & 0.00430 & 0.00450 & 0.00430 & 0.00430 & 0.00430 & 0.00450 \\
\hline $\mathrm{RuO}_{2}$ & - & - & - & - & - & - & - & - \\
\hline $\mathrm{SiO}_{2}$ & 0.27105 & 0.27105 & 0.27105 & 0.27003 & 0.26805 & 0.25205 & 0.24285 & 0.21622 \\
\hline $\mathrm{SO}_{3}$ & 0.00210 & 0.00210 & 0.00210 & 0.00220 & 0.00210 & 0.00210 & 0.00210 & 0.00220 \\
\hline $\mathrm{SrO}$ & - & - & - & - & - & - & - & - \\
\hline $\mathrm{TiO}_{2}$ & 0.00010 & 0.00010 & 0.00010 & 0.00010 & 0.00010 & 0.00010 & 0.00010 & 0.00010 \\
\hline $\mathrm{ZnO}$ & 0.00090 & 0.00090 & 0.00090 & 0.00090 & 0.00090 & 0.00090 & 0.00090 & 0.00090 \\
\hline $\mathrm{ZrO}_{2}$ & 0.00410 & 0.00410 & 0.00410 & 0.00440 & 0.00410 & 0.00410 & 0.00410 & 0.00440 \\
\hline Total & 1.00000 & 1.00000 & 1.00000 & 1.00000 & 1.00000 & 1.00000 & 1.00000 & 1.00000 \\
\hline \multicolumn{9}{|c|}{ Predicted properties (Vienna et al 2009) } \\
\hline$\eta_{1150}$, Pa.s & 4.71 & 5.06 & 5.42 & 7.13 & 5.00 & 3.43 & 2.11 & 1.90 \\
\hline$T$ at 5 Pas, ${ }^{\circ} \mathrm{C}$ & 1143 & 1152 & 1160 & 1192 & 1150 & 1105 & 1050 & 1040 \\
\hline$T_{1 \%}-\mathrm{Sp},{ }^{\circ} \mathrm{C}$ & 1076 & 1067 & 1058 & 1141 & 1087 & 1093 & 1119 & 1189 \\
\hline \multicolumn{9}{|c|}{ Nepheline formation criteria } \\
\hline$N_{S i}$ & 0.439 & 0.439 & 0.439 & 0.427 & 0.438 & 0.427 & 0.441 & 0.406 \\
\hline OB & 0.562 & 0.557 & 0.553 & 0.561 & 0.562 & 0.567 & 0.570 & 0.574 \\
\hline \multicolumn{9}{|c|}{ Measured viscosity at $1150^{\circ} \mathrm{C}$} \\
\hline$\eta_{1150,}$, Pa.s & - & - & - & 7.5 & - & - & 1.7 & 1.6 \\
\hline \multicolumn{9}{|c|}{ Measured Spinel vol $\%$ after heat treatment at each temperature } \\
\hline $800^{\circ} \mathrm{C}$ & - & - & - & - & - & $4.2^{\mathrm{a}}$ & $4.0^{\mathrm{a}}$ & $4.6^{\mathrm{a}}$ \\
\hline $850^{\circ} \mathrm{C}$ & - & - & - & - & - & - & - & - \\
\hline $900^{\circ} \mathrm{C}$ & - & - & - & - & - & - & - & - \\
\hline $950^{\circ} \mathrm{C}$ & 1.8 & 2.4 & 2.9 & 3.0 & 2.3 & 1.8 & 1.8 & $2.4^{\mathrm{b}}$ \\
\hline $1050^{\circ} \mathrm{C}$ & 1.3 & 1.4 & 1.5 & 2.3 & 1.9 & 1.1 & 1.4 & 2.5 \\
\hline
\end{tabular}


Table 5.7. High- $\mathrm{Al}_{2} \mathrm{O}_{3}$ Glasses Formulated Based on High-Al Clusters

\begin{tabular}{|c|c|c|c|c|c|c|c|}
\hline Component & $\begin{array}{c}\text { IWL- } \\
\text { HAC5-4 }\end{array}$ & $\begin{array}{c}\text { IWL- } \\
\text { HAC5-6 }\end{array}$ & $\begin{array}{c}\text { IWL- } \\
\text { HAC8-4 }\end{array}$ & $\begin{array}{c}\text { IWL- } \\
\text { HAC8-6 }\end{array}$ & $\begin{array}{c}\text { IWL- } \\
\text { HAC16-5 }\end{array}$ & $\begin{array}{c}\text { IWL- } \\
\text { HAC16-6 }\end{array}$ & $\begin{array}{c}\text { IWL- } \\
\text { HAC16-7 }\end{array}$ \\
\hline $\mathrm{Al}_{2} \mathrm{O}_{3}$ & 0.23000 & 0.24000 & 0.22000 & 0.23000 & 0.27036 & 0.28000 & 0.29000 \\
\hline $\mathrm{B}_{2} \mathrm{O}_{3}$ & 0.19000 & 0.18000 & 0.19000 & 0.18000 & 0.20000 & 0.20000 & 0.20000 \\
\hline $\mathrm{BaO}$ & - & - & - & - & - & - & - \\
\hline $\mathrm{Bi}_{2} \mathrm{O}_{3}$ & 0.00909 & 0.00948 & 0.00976 & 0.01020 & 0.00683 & 0.00708 & 0.00733 \\
\hline $\mathrm{CaO}$ & 0.07000 & 0.07000 & 0.07000 & 0.07000 & 0.07000 & 0.07000 & 0.07000 \\
\hline $\mathrm{CdO}$ & 0.00008 & 0.00008 & 0.00012 & 0.00013 & 0.00002 & 0.00002 & 0.00002 \\
\hline $\mathrm{Cr}_{2} \mathrm{O}_{3}$ & 0.01113 & 0.01162 & 0.01053 & 0.01101 & 0.00957 & 0.00991 & 0.01026 \\
\hline $\mathrm{Cs}_{2} \mathrm{O}$ & 0.00231 & 0.00241 & 0.00242 & 0.00253 & 0.00227 & 0.00235 & 0.00243 \\
\hline$F$ & 0.00696 & 0.00727 & 0.00572 & 0.00598 & 0.00122 & 0.00126 & 0.00131 \\
\hline $\mathrm{Fe}_{2} \mathrm{O}_{3}$ & 0.02847 & 0.02971 & 0.05659 & 0.05916 & 0.02588 & 0.02680 & 0.02776 \\
\hline $\mathrm{K}_{2} \mathrm{O}$ & 0.03000 & 0.03000 & 0.03000 & 0.03000 & 0.03000 & 0.03000 & 0.03000 \\
\hline $\mathrm{La}_{2} \mathrm{O}_{3}$ & 0.00103 & 0.00108 & 0.00035 & 0.00037 & 0.00045 & 0.00047 & 0.00048 \\
\hline $\mathrm{Li}_{2} \mathrm{O}$ & 0.04000 & 0.04000 & 0.04000 & 0.04000 & 0.04000 & 0.04000 & 0.04000 \\
\hline $\mathrm{MgO}$ & 0.00089 & 0.00093 & 0.00177 & 0.00185 & 0.00091 & 0.00094 & 0.00098 \\
\hline $\mathrm{MnO}$ & 0.00581 & 0.00606 & 0.00962 & 0.01006 & 0.00653 & 0.00676 & 0.00700 \\
\hline $\mathrm{Na}_{2} \mathrm{O}$ & 0.07251 & 0.07566 & 0.06252 & 0.06536 & 0.07670 & 0.07943 & 0.08227 \\
\hline $\mathrm{Nd}_{2} \mathrm{O}_{3}$ & 0.00017 & 0.00018 & 0.00052 & 0.00054 & 0.00036 & 0.00037 & 0.00038 \\
\hline $\mathrm{NiO}$ & 0.00631 & 0.00658 & 0.00337 & 0.00352 & 0.00169 & 0.00175 & 0.00181 \\
\hline $\mathrm{P}_{2} \mathrm{O}_{5}$ & 0.02213 & 0.02309 & 0.01138 & 0.01190 & 0.00659 & 0.00682 & 0.00707 \\
\hline $\mathrm{PbO}$ & 0.00121 & 0.00126 & 0.00422 & 0.00441 & 0.00123 & 0.00127 & 0.00132 \\
\hline $\mathrm{RuO}_{2}$ & $1.45 \mathrm{E}-05$ & $1.51 \mathrm{E}-05$ & $5.53 \mathrm{E}-07$ & $5.78 \mathrm{E}-07$ & $1.36 \mathrm{E}-06$ & $1.41 \mathrm{E}-06$ & $1.46 \mathrm{E}-06$ \\
\hline $\mathrm{SiO}_{2}$ & 0.23646 & 0.22761 & 0.26353 & 0.25506 & 0.24542 & 0.23063 & 0.21530 \\
\hline $\mathrm{SO}_{3}$ & 0.00597 & 0.00622 & 0.00455 & 0.00475 & 0.00236 & 0.00244 & 0.00253 \\
\hline $\mathrm{SrO}$ & 0.00359 & 0.00375 & 0.00192 & 0.00200 & 0.00078 & 0.00081 & 0.00084 \\
\hline $\mathrm{TiO}_{2}$ & - & - & - & - & - & - & - \\
\hline $\mathrm{ZnO}$ & - & - & - & - & - & - & - \\
\hline $\mathrm{ZrO}_{2}$ & 0.02586 & 0.02698 & 0.00112 & 0.00117 & 0.00085 & 0.00089 & 0.00092 \\
\hline Total & 1.00000 & 1.00000 & 1.00000 & 1.00000 & 1.00000 & 1.00000 & 1.00000 \\
\hline \multicolumn{8}{|c|}{ Predicted properties (Vienna et al 2009) } \\
\hline$\eta_{1150}$, Pa.s & 2.43 & 2.49 & 2.29 & 2.32 & 3.28 & 3.09 & 2.91 \\
\hline$T$ at 5 Pas, ${ }^{\circ} \mathrm{C}$ & 1065 & 1067 & 1056 & 1057 & 1093 & 1084 & 1076 \\
\hline$T_{1 \%}-\mathrm{Sp},{ }^{\circ} \mathrm{C}$ & 1087 & 1130 & 1086 & 1130 & 1049 & 1078 & 1107 \\
\hline \multicolumn{8}{|c|}{ Nepheline formation criteria } \\
\hline$N_{S i}$ & 0.439 & 0.419 & 0.483 & 0.463 & 0.414 & 0.391 & 0.366 \\
\hline OB & 0.576 & 0.582 & 0.574 & 0.579 & 0.574 & 0.577 & 0.580 \\
\hline
\end{tabular}

Table 5.8 summarizes the single component concentration constraints developed based on information on the composition and predicted and measured properties given in Table 5.5 through Table 5.7. For three major waste components $\left(\mathrm{Al}_{2} \mathrm{O}_{3}, \mathrm{Fe}_{2} \mathrm{O}_{3}\right.$, and $\left.\mathrm{ZrO}_{2}\right)$ and five additive components $\left(\mathrm{B}_{2} \mathrm{O}_{3}\right.$, 
$\mathrm{CaO}, \mathrm{K}_{2} \mathrm{O}, \mathrm{Li}_{2} \mathrm{O}$, and $\mathrm{Na}_{2} \mathrm{O}$ ) other than $\mathrm{SiO}_{2}$, the base approach was to set the lower and upper limits slightly outside the range from Table 5.5 through Table 5.7. See notes in Table 5.8 for additional consideration for each component. For $\mathrm{SiO}_{2}$, the lower limit was set slightly lower than the minimum from Table 5.5 through Table 5.7 like other additives but no upper limit was used as it is calculated as a balance.

For minor components (waste components other than $\mathrm{Al}_{2} \mathrm{O}_{3}, \mathrm{Fe}_{2} \mathrm{O}_{3}$, and $\mathrm{ZrO}_{2}$ ), the base approach was to set the upper limit at least 1.5 times (150\%) larger than the maximum from Table 5.5 through Table 5.7. However, smaller upper limits were used for those components that are considered troublesome and may affect the waste loading at higher concentrations, $\mathrm{Cr}_{2} \mathrm{O}_{3}, \mathrm{~F}, \mathrm{P}_{2} \mathrm{O}_{5}$, and $\mathrm{SO}_{3}$. The lower limits for these minor components would be all zero if the similar approach as the upper limits is applied, i.e., to set the lower limit smaller than the minimum from Table 5.5 through Table 5.7. However, for all minor components except $\mathrm{P}_{2} \mathrm{O}_{5}$ and $\mathrm{RuO}_{2}$, the lower limit was set at 0.001 so that the random generated concentration (see Section 5.2.3) is not too small for batching but close to zero. For $\mathrm{P}_{2} \mathrm{O}_{5}$, non-zero lower limit was used to reflect the fact that the minimum $\mathrm{P}_{2} \mathrm{O}_{5}$ from Table 5.5 through Table 5.7 was 0.007. For $\mathrm{RuO}_{2}$, which is present at very low concentrations but may have impact on crystallization of glass, the upper and lower limits were set outside the range with a non-zero lower limit. Special care needs to be taken to batch the glasses with $\mathrm{RuO}_{2}$ concentration close to the lower limit.

Table 5.8. Single Component Concentration Constraints Developed for Matrix Design

\begin{tabular}{|c|c|c|c|}
\hline Comp. & Lower Limit & Upper Limit & Notes \\
\hline $\mathrm{Al}_{2} \mathrm{O}_{3}$ & 0.18 & 0.26 & $\begin{array}{l}\text { Maximum } \mathrm{Al}_{2} \mathrm{O}_{3} \text { loading achievable in glass was estimated to be } \\
26 \mathrm{wt} \% \text {. Upper limit was set at } 26 \mathrm{wt} \% \text { based on the considerations } \\
\text { that the practical maximum loading will be lower than this if various } \\
\text { uncertainties are accounted for but the model should be valid above the } \\
\text { practical maximum. Lower limit was set at } 4 \mathrm{wt} \% \text { below the minimum } \\
\text { from Table } 5.5 \text { through Table } 5.7 \text { so that the resulting model can also } \\
\text { cover the glasses with lower waste loadings potentially constrained by } \\
\text { some other limiting components. }\end{array}$ \\
\hline $\mathrm{B}_{2} \mathrm{O}_{3}$ & 0.14 & 0.22 & $\begin{array}{l}\text { Upper limit was set at the maximum from Table } 5.5 \text { through Table } 5.7 \text {. } \\
\text { Lower limit was set at } 1 \mathrm{wt} \% \text { below the minimum from Table } 5.5 \\
\text { through Table } 5.7 \text {. }\end{array}$ \\
\hline $\mathrm{Bi}_{2} \mathrm{O}_{3}$ & 0.001 & 0.03 & $\begin{array}{l}\text { Upper limit was set at } \geq 150 \% \text { of the maximum from Table } 5.5 \text { through } \\
\text { Table 5.7. }\end{array}$ \\
\hline $\mathrm{CaO}$ & 0 & 0.1 & $\begin{array}{l}\text { Upper and lower limits were set } \sim 1 \mathrm{wt} \% \text { outside the concentration range } \\
\text { from Table } 5.5 \text { through Table } 5.7 \text {. }\end{array}$ \\
\hline $\mathrm{CdO}$ & 0.001 & 0.003 & $\begin{array}{l}\text { Upper limit was set three times higher than the WTP upper limit below } \\
\text { which the model calculation is not required }(0.1 \mathrm{wt} \% \mathrm{CdO}) \text { although the } \\
\text { maximum expected is only } 0.03 \mathrm{wt} \% \text { from glasses in Table } 5.5 \text { through } \\
\text { Table 5.7. This was to make the TCLP model, which uses } \mathrm{Cd} \text { as major } \\
\text { leach component, valid for high- } \mathrm{Al}_{2} \mathrm{O}_{3} \text { glasses. }\end{array}$ \\
\hline $\mathrm{Cr}_{2} \mathrm{O}_{3}$ & 0.001 & 0.013 & $\begin{array}{l}\text { Upper limit was set at } \sim 110 \% \text { of the maximum from Table } 5.5 \text { through } \\
\text { Table 5.7. }\end{array}$ \\
\hline $\mathrm{F}$ & 0.001 & 0.01 & $\begin{array}{l}\text { Upper limit was set at } \sim 130 \% \text { of the maximum from Table } 5.5 \text { through } \\
\text { Table 5.7. }\end{array}$ \\
\hline
\end{tabular}




\begin{tabular}{|c|c|c|c|}
\hline Comp. & Lower Limit & Upper Limit & Notes \\
\hline $\mathrm{Fe}_{2} \mathrm{O}_{3}$ & 0.01 & 0.07 & $\begin{array}{l}\text { Lower and upper limits were set slightly outside the range from Table } \\
5.5 \text { through Table 5.7. Setting the lower limit to zero was not } \\
\text { considered because it is unlikely and there is a potential sudden change } \\
\text { of glass properties with small addition of } \mathrm{Fe}_{2} \mathrm{O}_{3} \text { compared to no-Fe } \\
\text { glass. }\end{array}$ \\
\hline $\mathrm{K}_{2} \mathrm{O}$ & 0 & 0.04 & $\begin{array}{l}\text { Upper limit was set at } 1 \mathrm{wt} \% \text { higher than the maximum from Table } 5.5 \\
\text { through Table 5.7. }\end{array}$ \\
\hline $\mathrm{La}_{2} \mathrm{O}_{3}$ & 0.001 & 0.01 & $\begin{array}{l}\text { Upper limit was set at } \geq 150 \% \text { of the maximum from Table } 5.5 \text { through } \\
\text { Table 5.7. }\end{array}$ \\
\hline $\mathrm{Li}_{2} \mathrm{O}$ & 0 & 0.06 & $\begin{array}{l}\text { Upper limit was set slightly higher than the maximum from Table } 5.5 \\
\text { through Table 5.7. }\end{array}$ \\
\hline $\mathrm{MgO}$ & 0.001 & 0.01 & $\begin{array}{l}\text { Upper limit was set at } \geq 150 \% \text { of the maximum from Table } 5.5 \text { through } \\
\text { Table 5.7. }\end{array}$ \\
\hline $\mathrm{MnO}$ & 0.001 & 0.015 & $\begin{array}{l}\text { Upper limit was set at } \geq 150 \% \text { of the maximum from Table } 5.5 \text { through } \\
\text { Table 5.7. }\end{array}$ \\
\hline $\mathrm{Na}_{2} \mathrm{O}$ & 0.05 & 0.12 & $\begin{array}{l}\text { Lower and Upper limit were set slightly outside the range from Table } \\
5.5 \text { through Table } 5.7 \text { after excluding the glasses formulated for high } \\
\mathrm{Al} / \mathrm{Na} \text { waste that had higher } \mathrm{Na}_{2} \mathrm{O} \text { than the glasses formulated for any } \\
\text { high-Al wastes. }\end{array}$ \\
\hline $\mathrm{Nd}_{2} \mathrm{O}_{3}$ & 0.001 & 0.002 & $\begin{array}{l}\text { Upper limit was set at } \geq 150 \% \text { of the maximum from Table } 5.5 \text { through } \\
\text { Table 5.7. }\end{array}$ \\
\hline $\mathrm{NiO}$ & 0.001 & 0.01 & $\begin{array}{l}\text { Upper limit was set at } \geq 150 \% \text { of the maximum from Table } 5.5 \text { through } \\
\text { Table 5.7. }\end{array}$ \\
\hline $\mathrm{P}_{2} \mathrm{O}_{5}$ & 0.005 & 0.025 & $\begin{array}{l}\text { Upper limit was set at } \sim 110 \% \text { of the maximum from Table } 5.5 \text { through } \\
\text { Table 5.7. }\end{array}$ \\
\hline $\mathrm{PbO}$ & 0.001 & 0.01 & $\begin{array}{l}\text { Upper limit was set at } \geq 150 \% \text { of the maximum from Table } 5.5 \text { through } \\
\text { Table 5.7. }\end{array}$ \\
\hline $\mathrm{RuO}_{2}$ & 0.00001 & 0.00005 & $\begin{array}{l}\text { Upper limit was set at } \geq 150 \% \text { of the maximum from Table } 5.5 \text { through } \\
\text { Table 5.7. }\end{array}$ \\
\hline $\mathrm{SiO}_{2}$ & 0.2 & None & $\begin{array}{l}\mathrm{SiO}_{2} \text { is calculated as a balance. Lower limit was set slightly lower than } \\
\text { the minimum from Table } 5.5 \text { through Table } 5.7 \text { (too low a } \mathrm{SiO}_{2} \\
\text { concentration may not produce reasonable glass). No upper limit was } \\
\text { used. }\end{array}$ \\
\hline $\mathrm{SO}_{3}$ & 0.001 & 0.007 & $\begin{array}{l}\text { Upper limit was set at } \sim 110 \% \text { of the maximum from Table } 5.5 \text { through } \\
\text { Table 5.7. }\end{array}$ \\
\hline $\mathrm{SrO}$ & 0.001 & 0.01 & $\begin{array}{l}\text { Upper limit was set at } \geq 150 \% \text { of the maximum from Table } 5.5 \text { through } \\
\text { Table 5.7. }\end{array}$ \\
\hline $\mathrm{ZrO}_{2}$ & 0 & 0.04 & $\begin{array}{l}\text { Lower and Upper limit were set slightly outside the range from Table } \\
5.5 \text { through Table 5.7. }\end{array}$ \\
\hline
\end{tabular}

From past formulation studies with the wastes that contain high concentration of refractory components $\left(\mathrm{Al}_{2} \mathrm{O}_{3}, \mathrm{Fe}_{2} \mathrm{O}_{3}\right.$, and $\left.\mathrm{ZrO}_{2}\right)$ (see Sections 4.1 and 4.3), it was found that the total concentration of these components play a role in liming waste loading in glass. The glass calculation approach discussed later in Section 5.2.3 can result in an unlikely high combined concentration of these components, which will be unlikely from actual formation for each waste cluster. To avoid testing glasses that are unlikely from each waste cluster, multicomponent constraints are applied as summarized in Table 5.9. Table 5.9 lists the maximum possible from maximum concentration of each component from single component constraints in Table 5.8 and the maximum in high- $\mathrm{Al}_{2} \mathrm{O}_{3}$ glasses listed in Table 
5.5 through Table 5.7. The matrix constraint was set as the maximum in high- $\mathrm{Al}_{2} \mathrm{O}_{3}$ glasses except $\mathrm{Fe}_{2} \mathrm{O}_{3}+\mathrm{ZrO}$ constraint because the maximum in high- $\mathrm{Al}_{2} \mathrm{O}_{3}$ glasses was found to be too restrictive during preliminary formulation trials.

To avoid formulating glasses that are too far away from the glass property requirements, the property constraints are used for key properties. The viscosity at $1150{ }^{\circ} \mathrm{C}$ and $T_{1 \%}$ were selected as summarized in Table 5.10. Viscosity is a key processing property that represents the processing temperature. The upper limit for viscosity was set at two times the requirement maximum, and the lower limit was set at one fourth of the requirement minimum considering that the recent trend is to formulate the glasses at the lower end of the acceptable viscosity range to improve the melter processing rate. The upper limit for $T_{1 \%}$ was set at $1175^{\circ} \mathrm{C}$, which is $225^{\circ} \mathrm{C}$ higher than the $950^{\circ} \mathrm{C}$ requirement considering that the current model tends to over predict by roughly $60^{\circ} \mathrm{C}$ (Figure 5.1) and that the maximum measured $T_{1 \%}$ in existing glasses was $1170^{\circ} \mathrm{C}$ (Table 5.4).

Table 5.9. Multicomponent Constraints Used in Matrix Design Compared with Maximum Possible and Maximum in High- $\mathrm{Al}_{2} \mathrm{O}_{3}$ Glasses ${ }^{\mathrm{b}}$

\begin{tabular}{|c|c|c|c|}
\hline Components & $\begin{array}{l}\text { Maximum } \\
\text { Possible }^{\mathrm{a}}\end{array}$ & 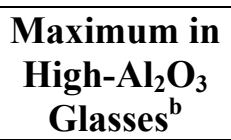 & $\begin{array}{c}\text { Matrix Upper } \\
\text { Limit }\end{array}$ \\
\hline $\mathrm{Al}_{2} \mathrm{O}_{3}+\mathrm{Fe}_{2} \mathrm{O}_{3}+\mathrm{ZrO}_{2}$ & 0.37 & 0.34 & 0.34 \\
\hline $\mathrm{Al}_{2} \mathrm{O}_{3}+\mathrm{Fe}_{2} \mathrm{O}_{3}$ & 0.33 & 0.33 & 0.33 \\
\hline $\mathrm{Al}_{2} \mathrm{O}_{3}+\mathrm{ZrO}_{2}$ & 0.30 & 0.29 & 0.29 \\
\hline $\mathrm{Fe}_{2} \mathrm{O}_{3}+\mathrm{ZrO}_{2}$ & 0.11 & 0.07 & 0.08 \\
\hline \multicolumn{4}{|c|}{$\begin{array}{l}\text { a Maximum possible from maximum concentration of each component from single } \\
\text { component constraints in Table 5.8. } \\
\text { b Maximum value in the high- } \mathrm{Al}_{2} \mathrm{O}_{3} \text { glasses listed in Table } 5.5 \text { through Table 5.7. }\end{array}$} \\
\hline
\end{tabular}

Table 5.10. Property Constraints Used in Matrix Design Compared with Their Requirements

\begin{tabular}{|c|c|c|c|c|}
\hline \multirow{2}{*}{ Property } & \multicolumn{2}{|c|}{ Requirements } & \multicolumn{2}{c|}{ Matrix Constraints } \\
\cline { 2 - 5 } & Min & Max & $\begin{array}{c}\text { Lower } \\
\text { Limit }\end{array}$ & $\begin{array}{c}\text { Upper } \\
\text { Limit }\end{array}$ \\
\hline Predicted $\eta_{1150}, \mathrm{~Pa} \cdot \mathrm{s}$ & 2 & 8 & 0.5 & 16 \\
\hline Predicted $T_{1 \%},{ }^{\circ} \mathrm{C}$ & & 950 & & 1175 \\
\hline
\end{tabular}

Comparing the matrix design constraints summarized above with the existing glasses given in Table 5.4 revealed that eight glasses are outside the matrix constraints leaving only six glasses for use in the design of a new matrix. The six glasses that meet matrix design constraints are presented in Table 5.11. 
Table 5.11. Existing High- $\mathrm{Al}_{2} \mathrm{O}_{3}$ Glasses That Have Measured $T_{1 \%}$ Data and Meet Matrix Design Constraints

\begin{tabular}{|c|c|c|c|c|c|c|}
\hline Reference & $\begin{array}{l}\text { Matlack et } \\
\text { al. (2007a) }\end{array}$ & \multicolumn{5}{|c|}{ Matlack et al. (2008) } \\
\hline Glass ID & $\begin{array}{c}\text { HLW-E-Al- } \\
27\end{array}$ & $\begin{array}{l}\text { HWI- } \\
\text { AL-7 }\end{array}$ & $\begin{array}{l}\text { HWI- } \\
\text { AL-13 }\end{array}$ & $\begin{array}{l}\text { HWI- } \\
\text { AL-17 }\end{array}$ & $\begin{array}{c}\text { HWI-AL- } \\
\text { 18(G) }\end{array}$ & $\begin{array}{l}\text { HWI- } \\
\text { AL-19 }\end{array}$ \\
\hline $\mathrm{Al}_{2} \mathrm{O}_{3}$ & 0.23971 & 0.23970 & 0.23970 & 0.23250 & 0.22570 & 0.23970 \\
\hline $\mathrm{B}_{2} \mathrm{O}_{3}$ & 0.15190 & 0.15190 & 0.15190 & 0.14730 & 0.20130 & 0.19190 \\
\hline $\mathrm{BaO}$ & 0.00054 & 0.00050 & 0.00050 & 0.00050 & 0.00050 & 0.00050 \\
\hline $\mathrm{Bi}_{2} \mathrm{O}_{3}$ & 0.01145 & 0.01140 & 0.01140 & 0.01110 & 0.01080 & 0.01140 \\
\hline $\mathrm{CaO}$ & 0.06076 & 0.03080 & 0.06080 & 0.05890 & 0.05720 & 0.05580 \\
\hline $\mathrm{CdO}$ & 0.00024 & 0.00020 & 0.00020 & 0.00020 & 0.00020 & 0.00020 \\
\hline $\mathrm{Cr}_{2} \mathrm{O}_{3}$ & 0.00521 & 0.00520 & 0.00520 & 0.00510 & 0.00490 & 0.00520 \\
\hline $\mathrm{F}$ & 0.00667 & 0.00670 & 0.00670 & 0.00650 & 0.00630 & 0.00670 \\
\hline $\mathrm{Fe}_{2} \mathrm{O}_{3}$ & 0.05899 & 0.05900 & 0.05900 & 0.05720 & 0.05560 & 0.05900 \\
\hline $\mathrm{K}_{2} \mathrm{O}$ & 0.00141 & 0.00140 & 0.04140 & 0.03140 & 0.00130 & 0.00140 \\
\hline $\mathrm{Li}_{2} \mathrm{O}$ & 0.03571 & 0.03570 & 0.03570 & 0.03460 & 0.03360 & 0.03570 \\
\hline $\mathrm{MgO}$ & 0.00117 & 0.03120 & 0.00120 & 0.00110 & 0.00110 & 0.00120 \\
\hline $\mathrm{Na}_{2} \mathrm{O}$ & 0.09580 & 0.09580 & 0.06080 & 0.09290 & 0.09020 & 0.09580 \\
\hline $\mathrm{NiO}$ & 0.00400 & 0.00400 & 0.00400 & 0.00390 & 0.00380 & 0.00400 \\
\hline $\mathrm{P}_{2} \mathrm{O}_{5}$ & 0.01052 & 0.01050 & 0.01050 & 0.01020 & 0.00990 & 0.01050 \\
\hline $\mathrm{PbO}$ & 0.00409 & 0.00410 & 0.00410 & 0.00400 & 0.00390 & 0.00410 \\
\hline $\mathrm{SiO}_{2}$ & 0.30496 & 0.30500 & 0.30000 & 0.29580 & 0.28720 & 0.27000 \\
\hline $\mathrm{SO}_{3}$ & 0.00200 & 0.00200 & 0.00200 & 0.00190 & 0.00190 & 0.00200 \\
\hline $\mathrm{TiO}_{2}$ & 0.00010 & 0.00010 & 0.00010 & 0.00010 & 0.00010 & 0.00010 \\
\hline $\mathrm{ZnO}$ & 0.00083 & 0.00080 & 0.00080 & 0.00080 & 0.00080 & 0.00080 \\
\hline $\mathrm{ZrO}_{2}$ & 0.00395 & 0.00390 & 0.00390 & 0.00380 & 0.00370 & 0.00390 \\
\hline Total & 1 & 1 & 1 & 1 & 1 & 1 \\
\hline \multicolumn{7}{|l|}{ Measured T1\% } \\
\hline$T_{1 \%}-\mathrm{Sp},{ }^{\circ} \mathrm{C}$ & 953 & 1144 & 1066 & 960 & 968 & 969 \\
\hline \multicolumn{7}{|c|}{ Predicted properties (Vienna et a. 2009) } \\
\hline$\eta_{1150}$, Pa.s & 5.17 & 6.13 & 5.91 & 4.33 & 3.76 & 3.39 \\
\hline$T$ at 5 Pas, ${ }^{\circ} \mathrm{C}$ & 1154 & 1173 & 1171 & 1132 & 1116 & 1103 \\
\hline$T_{1 \%}-\mathrm{Sp},{ }^{\circ} \mathrm{C}$ & 1078 & 1173 & 1084 & 1033 & 1004 & 1051 \\
\hline \multicolumn{7}{|c|}{ Nepheline formation criteria } \\
\hline $\mathrm{Si} /(\mathrm{Si}+\mathrm{Al}+\mathrm{Na})$ & 0.476 & 0.476 & 0.500 & 0.476 & 0.476 & 0.446 \\
\hline Optical basicity & 0.577 & 0.578 & 0.578 & 0.585 & 0.562 & 0.569 \\
\hline
\end{tabular}

\subsubsection{Calculation of Candidate Glasses}

Glass composition is calculated applying the random number

$$
\begin{gathered}
g_{i}=g_{i}^{\min }+R_{i}\left(g_{i}^{\max }-g_{i}^{\min }\right), i \neq \mathrm{SiO}_{2} \\
g_{\mathrm{SiO}_{2}}=1-\sum_{i=1}^{n-1} g_{i}
\end{gathered}
$$


where $g_{i}$ is the mass fraction of $i^{t h}$ component in the candidate glass, $R_{i}$ is the random number between 0 and 1 for $i^{\text {th }}$ component, $g_{i}^{\max }$ and $g_{i}^{\min }$ are the maximum and minimum concentrations for $i^{t h}$ component defined for matrix design (Table 5.8). From as-calculated glasses resulting from Equations 5.1 and 5.2, the glasses that satisfy the minimum $\mathrm{SiO}_{2}$ requirement, the multicomponent constraints (Table 5.9), and property constraints (Table 5.10) calculated using the glass model (Vienna et al 2009) are selected as candidate glasses for matrix design. After generating 94 as-calculated glasses, 50 candidate glasses that meet all the constraints were selected. In addition, a centroid glass was calculated as:

$$
\begin{gathered}
g_{i}^{\text {centroid }}=\frac{\left(g_{i}^{\max }+g_{i}^{\text {min }}\right)}{2}, i \neq \mathrm{SiO}_{2} \\
g_{\mathrm{SiO}_{2}}^{\text {centroid }}=1-\sum_{i=1}^{n-1} g_{i}^{\text {centroid }}
\end{gathered}
$$

where $g_{i}^{\text {centroid }}$ is the mass fraction of $i^{\text {th }}$ component in the centroid glass. In Appendix D Table D.1 lists the composition of these 51 candidate glasses and their predicted properties including the two key properties that were used for property constraints (viscosity, $T_{1 \%}$ ), electrical conductivity, temperature at $5 \mathrm{~Pa} \cdot \mathrm{s}$ that is used as reference temperature for crucible glass melting, and nepheline criteria.

\subsubsection{Selection of Matrix Glasses}

To further select matrix glasses two steps of calculating the normalized distances between the candidate glasses and existing glasses and between candidate glasses were performed. The normalized distance between two glasses was defined as:

$$
d^{x, y}=\sqrt{\sum_{i=1}^{n} \frac{\left(g_{i}^{x}-g_{i}^{y}\right)^{2}}{\sigma_{i}^{2}}}
$$

where $g_{i}^{x}$ and $g_{i}^{y}$ are the mass fraction of $i^{\text {th }}$ component in two glasses " $\mathrm{x}$ " and " $\mathrm{y}$ ", $d^{x, y}$ is the normalized distance between two glasses, $\sigma_{i}$ is the standard deviation of $i^{\text {th }}$ component mass fraction over the candidate glasses. The normalized distance was calculated based on nine major components only including three major waste components $\left(\mathrm{Al}_{2} \mathrm{O}_{3}, \mathrm{Fe}_{2} \mathrm{O}_{3}\right.$, and $\left.\mathrm{ZrO}_{2}\right)$ and six additive components $\left(\mathrm{B}_{2} \mathrm{O}_{3}\right.$, $\mathrm{CaO}, \mathrm{K}_{2} \mathrm{O}, \mathrm{Li}_{2} \mathrm{O}, \mathrm{Na}_{2} \mathrm{O}$, and $\mathrm{SiO}_{2}$ ). The selection process removed initially eight glasses that had distances $d^{x, y}<2.27$ between existing and candidate glasses and then 11 glasses that had $d^{x, y}<2.27$ between remaining candidate glasses. This resulted in 32 independent glasses as a test matrix including one centroid glass. Table 5.12 lists the composition of these 32 matrix glasses and their predicted properties. The IWL-HAM in the glass identification (ID) column represents "improved waste loadinghigh-alumina matrix." 
Table 5.12. Composition and Predicted Properties of 32 Matrix Glasses

\begin{tabular}{|c|c|c|c|c|c|c|c|c|c|}
\hline Glass ID & $\begin{array}{c}\text { IWL- } \\
\text { HAM- } \\
\text { 01 }\end{array}$ & $\begin{array}{c}\text { IWL- } \\
\text { HAM- } \\
02\end{array}$ & $\begin{array}{c}\text { IWL- } \\
\text { HAM- } \\
03\end{array}$ & $\begin{array}{c}\text { IWL- } \\
\text { HAM- } \\
04\end{array}$ & $\begin{array}{c}\text { IWL- } \\
\text { HAM- } \\
05\end{array}$ & $\begin{array}{c}\text { IWL- } \\
\text { HAM- } \\
\text { 06 }\end{array}$ & $\begin{array}{c}\text { IWL- } \\
\text { HAM- } \\
07\end{array}$ & $\begin{array}{c}\text { IWL- } \\
\text { HAM- } \\
\text { 08 }\end{array}$ & $\begin{array}{c}\text { IWL- } \\
\text { HAM- } \\
09\end{array}$ \\
\hline \# in Table D.1 & 4 & 5 & 6 & 7 & 9 & 10 & 11 & 12 & 13 \\
\hline $\mathrm{Al}_{2} \mathrm{O}_{3}$ & 0.19789 & 0.18136 & 0.19367 & 0.18392 & 0.18969 & 0.23499 & 0.19171 & 0.20149 & 0.21108 \\
\hline $\mathrm{B}_{2} \mathrm{O}_{3}$ & 0.14580 & 0.14241 & 0.21385 & 0.20329 & 0.17301 & 0.15461 & 0.14234 & 0.17230 & 0.21673 \\
\hline $\mathrm{Bi}_{2} \mathrm{O}_{3}$ & 0.01046 & 0.01932 & 0.02111 & 0.00497 & 0.00419 & 0.02037 & 0.01789 & 0.00427 & 0.00756 \\
\hline $\mathrm{CaO}$ & 0.05825 & 0.07286 & 0.01180 & 0.01083 & 0.08416 & 0.03888 & 0.08265 & 0.09341 & 0.03618 \\
\hline $\mathrm{CdO}$ & 0.00199 & 0.00242 & 0.00102 & 0.00267 & 0.00131 & 0.00228 & 0.00166 & 0.00145 & 0.00109 \\
\hline $\mathrm{Cr}_{2} \mathrm{O}_{3}$ & 0.00441 & 0.00583 & 0.01206 & 0.00461 & 0.00779 & 0.01261 & 0.01269 & 0.00899 & 0.00254 \\
\hline $\mathrm{F}$ & 0.00439 & 0.00966 & 0.00353 & 0.00724 & 0.00985 & 0.00889 & 0.00900 & 0.00777 & 0.00693 \\
\hline $\mathrm{Fe}_{2} \mathrm{O}_{3}$ & 0.02316 & 0.02644 & 0.03043 & 0.04174 & 0.04938 & 0.01012 & 0.04468 & 0.05142 & 0.06467 \\
\hline $\mathrm{K}_{2} \mathrm{O}$ & 0.02855 & 0.01360 & 0.00433 & 0.01283 & 0.02501 & 0.01394 & 0.02792 & 0.03371 & 0.01755 \\
\hline $\mathrm{La}_{2} \mathrm{O}_{3}$ & 0.00270 & 0.00543 & 0.00200 & 0.00221 & 0.00139 & 0.00454 & 0.00764 & 0.00548 & 0.00352 \\
\hline $\mathrm{Li}_{2} \mathrm{O}$ & 0.01344 & 0.04822 & 0.01322 & 0.04986 & 0.05272 & 0.03145 & 0.05455 & 0.04188 & 0.05106 \\
\hline $\mathrm{MgO}$ & 0.00955 & 0.00465 & 0.00917 & 0.00583 & 0.00900 & 0.00816 & 0.00787 & 0.00838 & 0.00428 \\
\hline $\mathrm{MnO}$ & 0.01184 & 0.00949 & 0.00589 & 0.00343 & 0.01432 & 0.00420 & 0.00541 & 0.01193 & 0.00397 \\
\hline $\mathrm{Na}_{2} \mathrm{O}$ & 0.08455 & 0.09204 & 0.11495 & 0.05159 & 0.05268 & 0.05440 & 0.06146 & 0.08187 & 0.08884 \\
\hline $\mathrm{Nd}_{2} \mathrm{O}_{3}$ & 0.00130 & 0.00151 & 0.00109 & 0.00183 & 0.00178 & 0.00154 & 0.00160 & 0.00176 & 0.00140 \\
\hline $\mathrm{NiO}$ & 0.00118 & 0.00477 & 0.00695 & 0.00393 & 0.00525 & 0.00279 & 0.00649 & 0.00572 & 0.00788 \\
\hline $\mathrm{P}_{2} \mathrm{O}_{5}$ & 0.00544 & 0.01928 & 0.02142 & 0.01828 & 0.00653 & 0.00888 & 0.01412 & 0.01120 & 0.01132 \\
\hline $\mathrm{PbO}$ & 0.00108 & 0.00839 & 0.00576 & 0.00158 & 0.00521 & 0.00934 & 0.00405 & 0.00366 & 0.00515 \\
\hline $\mathrm{RuO}_{2}$ & 0.00001 & 0.00002 & 0.00004 & 0.00005 & 0.00003 & 0.00003 & 0.00005 & 0.00002 & 0.00004 \\
\hline $\mathrm{SiO}_{2}$ & 0.35733 & 0.27966 & 0.27634 & 0.35169 & 0.27566 & 0.36647 & 0.29425 & 0.23356 & 0.24027 \\
\hline $\mathrm{SO}_{3}$ & 0.00433 & 0.00690 & 0.00516 & 0.00221 & 0.00389 & 0.00537 & 0.00578 & 0.00482 & 0.00384 \\
\hline $\mathrm{SrO}$ & 0.00291 & 0.00880 & 0.00738 & 0.00899 & 0.00358 & 0.00110 & 0.00254 & 0.00797 & 0.00743 \\
\hline $\mathrm{ZrO}_{2}$ & 0.02944 & 0.03693 & 0.03884 & 0.02641 & 0.02356 & 0.00504 & 0.00366 & 0.00692 & 0.00666 \\
\hline Total & 1 & 1 & 1 & 1 & 1 & 1 & 1 & 1 & 1 \\
\hline \multicolumn{10}{|c|}{ Multicomponent constraints } \\
\hline $\mathrm{Al}_{2} \mathrm{O}_{3}+\mathrm{Fe}_{2} \mathrm{O}_{3}+\mathrm{ZrO}_{2}$ & 0.25049 & 0.24473 & 0.26294 & 0.25208 & 0.26263 & 0.25015 & 0.24004 & 0.25983 & 0.28241 \\
\hline $\mathrm{Al}_{2} \mathrm{O}_{3}+\mathrm{Fe}_{2} \mathrm{O}_{3}$ & 0.22105 & 0.20780 & 0.22410 & 0.22566 & 0.23907 & 0.24511 & 0.23639 & 0.25291 & 0.27576 \\
\hline $\mathrm{Al}_{2} \mathrm{O}_{3}+\mathrm{ZrO}_{2}$ & 0.22733 & 0.21829 & 0.23251 & 0.21033 & 0.21325 & 0.24003 & 0.19536 & 0.20841 & 0.21774 \\
\hline $\mathrm{Fe}_{2} \mathrm{O}_{3}+\mathrm{ZrO}_{2}$ & 0.05260 & 0.06337 & 0.06926 & 0.06816 & 0.07294 & 0.01516 & 0.04834 & 0.05834 & 0.07133 \\
\hline \multicolumn{10}{|c|}{ Predicted properties (Vienna et a. 2009) } \\
\hline$\eta_{1150,}$, Pa.s & 14.06 & 1.25 & 6.38 & 6.27 & 1.22 & 13.86 & 1.37 & 0.84 & 1.13 \\
\hline$T$ at 5 Pas, ${ }^{\circ} \mathrm{C}$ & 1268.5 & 1008.1 & 1174.0 & 1175.2 & 1000.9 & 1263.7 & 1005.2 & 958.7 & 970.0 \\
\hline$T_{1 \%} \mathrm{Sp},{ }^{\circ} \mathrm{C}$ & 940.3 & 940.5 & 1047.8 & 919.7 & 1064.7 & 1074.3 & 1088.6 & 1063.4 & 989.6 \\
\hline$\varepsilon_{1150}, \mathrm{~S} / \mathrm{m}$ & 11.4 & 33.4 & 19.4 & 22.9 & 26.6 & 12.5 & 29.7 & 27.6 & 37.0 \\
\hline \multicolumn{10}{|c|}{ Nepheline formation criteria } \\
\hline$N_{S i}$ & 0.559 & 0.506 & 0.472 & 0.599 & 0.532 & 0.559 & 0.538 & 0.452 & 0.445 \\
\hline $\mathrm{OB}$ & 0.572 & 0.594 & 0.556 & 0.542 & 0.585 & 0.553 & 0.591 & 0.599 & 0.571 \\
\hline
\end{tabular}


Table 5.12. (Continued)

\begin{tabular}{|c|c|c|c|c|c|c|c|c|c|}
\hline Glass ID & $\begin{array}{c}\text { IWL- } \\
\text { HAM- } \\
10\end{array}$ & $\begin{array}{c}\text { IWL- } \\
\text { HAM- } \\
11\end{array}$ & $\begin{array}{c}\text { IWL- } \\
\text { HAM- } \\
12\end{array}$ & $\begin{array}{c}\text { IWL- } \\
\text { HAM- } \\
13\end{array}$ & $\begin{array}{c}\text { IWL- } \\
\text { HAM- } \\
14\end{array}$ & $\begin{array}{c}\text { IWL- } \\
\text { HAM- } \\
15\end{array}$ & $\begin{array}{c}\text { IWL- } \\
\text { HAM- } \\
16\end{array}$ & $\begin{array}{c}\text { IWL- } \\
\text { HAM- } \\
17\end{array}$ & $\begin{array}{c}\text { IWL- } \\
\text { HAM- } \\
18\end{array}$ \\
\hline \# in Table D.1 & 15 & 17 & 20 & 24 & 25 & 26 & 28 & 29 & 32 \\
\hline $\mathrm{Al}_{2} \mathrm{O}_{3}$ & 0.24868 & 0.23021 & 0.22837 & 0.20646 & 0.23783 & 0.21598 & 0.25920 & 0.22360 & 0.19754 \\
\hline $\mathrm{B}_{2} \mathrm{O}_{3}$ & 0.16750 & 0.14291 & 0.20640 & 0.19927 & 0.21524 & 0.17618 & 0.17329 & 0.14351 & 0.18371 \\
\hline $\mathrm{Bi}_{2} \mathrm{O}_{3}$ & 0.01494 & 0.01832 & 0.01096 & 0.00254 & 0.02269 & 0.02731 & 0.02311 & 0.01774 & 0.01686 \\
\hline $\mathrm{CaO}$ & 0.09086 & 0.03119 & 0.01669 & 0.01140 & 0.01549 & 0.02327 & 0.04830 & 0.08156 & 0.07407 \\
\hline $\mathrm{CdO}$ & 0.00250 & 0.00280 & 0.00231 & 0.00207 & 0.00150 & 0.00290 & 0.00134 & 0.00203 & 0.00190 \\
\hline $\mathrm{Cr}_{2} \mathrm{O}_{3}$ & 0.00145 & 0.00249 & 0.00279 & 0.00532 & 0.00402 & 0.00332 & 0.00250 & 0.00141 & 0.00581 \\
\hline $\mathrm{F}$ & 0.00438 & 0.00412 & 0.00622 & 0.00330 & 0.00769 & 0.00166 & 0.00483 & 0.00140 & 0.00723 \\
\hline $\mathrm{Fe}_{2} \mathrm{O}_{3}$ & 0.01824 & 0.02279 & 0.01911 & 0.01206 & 0.04794 & 0.04081 & 0.04805 & 0.05170 & 0.02006 \\
\hline $\mathrm{K}_{2} \mathrm{O}$ & 0.03933 & 0.00208 & 0.00552 & 0.03972 & 0.01975 & 0.00898 & 0.03015 & 0.01435 & 0.01799 \\
\hline $\mathrm{La}_{2} \mathrm{O}_{3}$ & 0.00946 & 0.00315 & 0.00542 & 0.00849 & 0.00871 & 0.00711 & 0.00563 & 0.00935 & 0.00599 \\
\hline $\mathrm{Li}_{2} \mathrm{O}$ & 0.01622 & 0.02545 & 0.04925 & 0.05421 & 0.01723 & 0.05977 & 0.02536 & 0.01570 & 0.03318 \\
\hline $\mathrm{MgO}$ & 0.00422 & 0.00990 & 0.00225 & 0.00885 & 0.00221 & 0.00508 & 0.00824 & 0.00517 & 0.00771 \\
\hline $\mathrm{MnO}$ & 0.00443 & 0.00704 & 0.00679 & 0.00705 & 0.00570 & 0.00517 & 0.00622 & 0.01193 & 0.00915 \\
\hline $\mathrm{Na}_{2} \mathrm{O}$ & 0.11700 & 0.11996 & 0.07708 & 0.09176 & 0.09241 & 0.05072 & 0.08094 & 0.05236 & 0.11334 \\
\hline $\mathrm{Nd}_{2} \mathrm{O}_{3}$ & 0.00107 & 0.00130 & 0.00154 & 0.00181 & 0.00168 & 0.00138 & 0.00114 & 0.00133 & 0.00135 \\
\hline $\mathrm{NiO}$ & 0.00461 & 0.00308 & 0.00203 & 0.00619 & 0.00930 & 0.00159 & 0.00635 & 0.00921 & 0.00106 \\
\hline $\mathrm{P}_{2} \mathrm{O}_{5}$ & 0.01070 & 0.01515 & 0.00888 & 0.02045 & 0.01940 & 0.00998 & 0.00867 & 0.02067 & 0.02144 \\
\hline $\mathrm{PbO}$ & 0.00852 & 0.00816 & 0.00626 & 0.00288 & 0.00489 & 0.00788 & 0.00531 & 0.00382 & 0.00371 \\
\hline $\mathrm{RuO}_{2}$ & 0.00003 & 0.00002 & 0.00005 & 0.00005 & 0.00004 & 0.00001 & 0.00002 & 0.00005 & 0.00004 \\
\hline $\mathrm{SiO}_{2}$ & 0.21230 & 0.31257 & 0.31536 & 0.28230 & 0.22645 & 0.32795 & 0.24242 & 0.30693 & 0.25504 \\
\hline $\mathrm{SO}_{3}$ & 0.00428 & 0.00556 & 0.00138 & 0.00113 & 0.00565 & 0.00142 & 0.00219 & 0.00146 & 0.00254 \\
\hline $\mathrm{SrO}$ & 0.00869 & 0.00411 & 0.00576 & 0.00330 & 0.00990 & 0.00386 & 0.00321 & 0.00659 & 0.00304 \\
\hline $\mathrm{ZrO}_{2}$ & 0.01061 & 0.02762 & 0.01958 & 0.02941 & 0.02426 & 0.01767 & 0.01353 & 0.01815 & 0.01726 \\
\hline Total & 1 & 1 & 1 & 1 & 1 & 1 & 1 & 1 & 1 \\
\hline \multicolumn{10}{|c|}{ Multicomponent constraints } \\
\hline $\mathrm{Al}_{2} \mathrm{O}_{3}+\mathrm{Fe}_{2} \mathrm{O}_{3}+\mathrm{ZrO}_{2}$ & 0.27753 & 0.28062 & 0.26705 & 0.24792 & 0.31003 & 0.27447 & 0.32077 & 0.29345 & 0.23486 \\
\hline $\mathrm{Al}_{2} \mathrm{O}_{3}+\mathrm{Fe}_{2} \mathrm{O}_{3}$ & 0.26692 & 0.25300 & 0.24748 & 0.21851 & 0.28577 & 0.25680 & 0.30724 & 0.27530 & 0.21760 \\
\hline $\mathrm{Al}_{2} \mathrm{O}_{3}+\mathrm{ZrO}_{2}$ & 0.25929 & 0.25783 & 0.24794 & 0.23586 & 0.26209 & 0.23365 & 0.27273 & 0.24175 & 0.21480 \\
\hline $\mathrm{Fe}_{2} \mathrm{O}_{3}+\mathrm{ZrO}_{2}$ & 0.02885 & 0.05041 & 0.03869 & 0.04147 & 0.07220 & 0.05848 & 0.06158 & 0.06985 & 0.03732 \\
\hline \multicolumn{10}{|c|}{ Predicted properties (Vienna et a. 2009) } \\
\hline$\eta_{1150}$, Pa.s & 2.15 & 7.94 & 4.51 & 2.11 & 5.93 & 4.07 & 5.33 & 12.05 & 1.37 \\
\hline$T$ at 5 Pas, ${ }^{\circ} \mathrm{C}$ & 1055.0 & 1197.2 & 1138.6 & 1046.2 & 1167.9 & 1128.4 & 1157.3 & 1246.3 & 1006.4 \\
\hline$T_{1 \%}-\mathrm{Sp},{ }^{\circ} \mathrm{C}$ & 943.9 & 973.5 & 880.2 & 875.2 & 1100.3 & 958.8 & 1131.1 & 1172.4 & 858.9 \\
\hline$\varepsilon_{1150}, \mathrm{~S} / \mathrm{m}$ & 20.9 & 23.1 & 27.5 & 38.1 & 16.9 & 29.9 & 16.5 & 8.5 & 29.9 \\
\hline \multicolumn{10}{|c|}{ Nepheline formation criteria } \\
\hline$N_{S i}$ & 0.367 & 0.472 & 0.508 & 0.486 & 0.407 & 0.552 & 0.416 & 0.527 & 0.451 \\
\hline OB & 0.603 & 0.577 & 0.551 & 0.569 & 0.561 & 0.560 & 0.583 & 0.575 & 0.585 \\
\hline
\end{tabular}


Table 5.12. (Continued)

\begin{tabular}{|c|c|c|c|c|c|c|c|c|c|}
\hline Glass ID & $\begin{array}{c}\text { IWL- } \\
\text { HAM- } \\
19\end{array}$ & $\begin{array}{c}\text { IWL- } \\
\text { HAM- } \\
20\end{array}$ & $\begin{array}{c}\text { IWL- } \\
\text { HAM- } \\
21\end{array}$ & $\begin{array}{c}\text { IWL- } \\
\text { HAM- } \\
22\end{array}$ & $\begin{array}{c}\text { IWL- } \\
\text { HAM- } \\
23\end{array}$ & $\begin{array}{c}\text { IWL- } \\
\text { HAM- } \\
24\end{array}$ & $\begin{array}{c}\text { IWL- } \\
\text { HAM- } \\
25\end{array}$ & $\begin{array}{c}\text { IWL- } \\
\text { HAM- } \\
26\end{array}$ & $\begin{array}{c}\text { IWL- } \\
\text { HAM- } \\
27\end{array}$ \\
\hline \# in Table D.1 & 35 & 37 & 38 & 39 & 40 & 41 & 44 & 45 & 46 \\
\hline $\mathrm{Al}_{2} \mathrm{O}_{3}$ & 0.25384 & 0.18696 & 0.24973 & 0.25923 & 0.19551 & 0.20295 & 0.22875 & 0.20433 & 0.23901 \\
\hline $\mathrm{B}_{2} \mathrm{O}_{3}$ & 0.18840 & 0.19466 & 0.21567 & 0.16126 & 0.17537 & 0.21556 & 0.18993 & 0.21262 & 0.20708 \\
\hline $\mathrm{Bi}_{2} \mathrm{O}_{3}$ & 0.02508 & 0.00888 & 0.02257 & 0.02873 & 0.01883 & 0.02486 & 0.00362 & 0.00120 & 0.01926 \\
\hline $\mathrm{CaO}$ & 0.02794 & 0.05617 & 0.03965 & 0.08985 & 0.01745 & 0.05148 & 0.09434 & 0.08060 & 0.00733 \\
\hline $\mathrm{CdO}$ & 0.00202 & 0.00251 & 0.00216 & 0.00102 & 0.00204 & 0.00286 & 0.00178 & 0.00219 & 0.00198 \\
\hline $\mathrm{Cr}_{2} \mathrm{O}_{3}$ & 0.00394 & 0.00320 & 0.00370 & 0.00897 & 0.00726 & 0.00328 & 0.00946 & 0.00279 & 0.01071 \\
\hline $\mathrm{F}$ & 0.00217 & 0.00980 & 0.00147 & 0.00188 & 0.00957 & 0.00460 & 0.00981 & 0.00315 & 0.00173 \\
\hline $\mathrm{Fe}_{2} \mathrm{O}_{3}$ & 0.03159 & 0.02524 & 0.01244 & 0.01168 & 0.06158 & 0.03107 & 0.02764 & 0.03774 & 0.06817 \\
\hline $\mathrm{K}_{2} \mathrm{O}$ & 0.01369 & 0.01467 & 0.01795 & 0.00203 & 0.03183 & 0.03983 & 0.03979 & 0.02951 & 0.02445 \\
\hline $\mathrm{La}_{2} \mathrm{O}_{3}$ & 0.00693 & 0.00549 & 0.00738 & 0.00854 & 0.00761 & 0.00164 & 0.00990 & 0.00875 & 0.00512 \\
\hline $\mathrm{Li}_{2} \mathrm{O}$ & 0.03347 & 0.02312 & 0.04004 & 0.01320 & 0.00348 & 0.04628 & 0.02464 & 0.03715 & 0.03556 \\
\hline $\mathrm{MgO}$ & 0.00242 & 0.00182 & 0.00913 & 0.00890 & 0.00275 & 0.00259 & 0.00465 & 0.00619 & 0.00158 \\
\hline $\mathrm{MnO}$ & 0.00130 & 0.01071 & 0.00605 & 0.00776 & 0.01301 & 0.00187 & 0.01484 & 0.01187 & 0.00525 \\
\hline $\mathrm{Na}_{2} \mathrm{O}$ & 0.10604 & 0.06551 & 0.11328 & 0.10069 & 0.09427 & 0.06020 & 0.05154 & 0.07742 & 0.11187 \\
\hline $\mathrm{Nd}_{2} \mathrm{O}_{3}$ & 0.00132 & 0.00170 & 0.00197 & 0.00193 & 0.00193 & 0.00146 & 0.00183 & 0.00160 & 0.00165 \\
\hline $\mathrm{NiO}$ & 0.00311 & 0.00229 & 0.00729 & 0.00297 & 0.00189 & 0.00998 & 0.00422 & 0.00800 & 0.00483 \\
\hline $\mathrm{P}_{2} \mathrm{O}_{5}$ & 0.01457 & 0.00758 & 0.01995 & 0.01314 & 0.01682 & 0.01568 & 0.00575 & 0.01459 & 0.01985 \\
\hline $\mathrm{PbO}$ & 0.00420 & 0.00484 & 0.00259 & 0.00601 & 0.00222 & 0.00825 & 0.00334 & 0.00280 & 0.00497 \\
\hline $\mathrm{RuO}_{2}$ & 0.00004 & 0.00004 & 0.00001 & 0.00002 & 0.00004 & 0.00003 & 0.00002 & 0.00005 & 0.00002 \\
\hline $\mathrm{SiO}_{2}$ & 0.24743 & 0.34072 & 0.21303 & 0.25942 & 0.31453 & 0.26192 & 0.25280 & 0.20954 & 0.21784 \\
\hline $\mathrm{SO}_{3}$ & 0.00402 & 0.00165 & 0.00604 & 0.00688 & 0.00195 & 0.00568 & 0.00126 & 0.00475 & 0.00245 \\
\hline $\mathrm{SrO}$ & 0.00125 & 0.00896 & 0.00270 & 0.00213 & 0.00506 & 0.00412 & 0.00963 & 0.00452 & 0.00921 \\
\hline $\mathrm{ZrO}_{2}$ & 0.02524 & 0.02348 & 0.00520 & 0.00377 & 0.01501 & 0.00382 & 0.01046 & 0.03866 & 0.00008 \\
\hline Total & 1 & 1 & 1 & 1 & 1 & 1 & 1 & 1 & 1 \\
\hline \multicolumn{10}{|c|}{ Multicomponent constraints } \\
\hline $\mathrm{Al}_{2} \mathrm{O}_{3}+\mathrm{Fe}_{2} \mathrm{O}_{3}+\mathrm{ZrO}_{2}$ & 0.31066 & 0.23568 & 0.26736 & 0.27468 & 0.27209 & 0.23784 & 0.26685 & 0.28073 & 0.30727 \\
\hline $\mathrm{Al}_{2} \mathrm{O}_{3}+\mathrm{Fe}_{2} \mathrm{O}_{3}$ & 0.28543 & 0.21220 & 0.26217 & 0.27091 & 0.25708 & 0.23402 & 0.25639 & 0.24207 & 0.30718 \\
\hline $\mathrm{Al}_{2} \mathrm{O}_{3}+\mathrm{ZrO}_{2}$ & 0.27907 & 0.21045 & 0.25493 & 0.26300 & 0.21052 & 0.20677 & 0.23921 & 0.24299 & 0.23909 \\
\hline $\mathrm{Fe}_{2} \mathrm{O}_{3}+\mathrm{ZrO}_{2}$ & 0.05683 & 0.04872 & 0.01763 & 0.01545 & 0.07659 & 0.03489 & 0.03810 & 0.07640 & 0.06826 \\
\hline \multicolumn{10}{|c|}{ Predicted properties (Vienna et a. 2009) } \\
\hline$\eta_{1150}$, Pa.s & 4.68 & 6.95 & 1.72 & 6.21 & 12.89 & 1.69 & 3.09 & 1.25 & 2.28 \\
\hline$T$ at 5 Pas, ${ }^{\circ} \mathrm{C}$ & 1142.5 & 1185.2 & 1016.6 & 1175.3 & 1252.2 & 1027.3 & 1092.6 & 1005.0 & 1048.8 \\
\hline$T_{1 \%}-\mathrm{Sp},{ }^{\circ} \mathrm{C}$ & 999.4 & 874.1 & 950.8 & 1095.9 & 1021.7 & 923.3 & 1085.0 & 1007.0 & 1101.7 \\
\hline$\varepsilon_{1150}, \mathrm{~S} / \mathrm{m}$ & 26.4 & 12.5 & 34.3 & 14.4 & 12.1 & 25.0 & 12.0 & 23.6 & 33.8 \\
\hline \multicolumn{10}{|c|}{ Nepheline formation criteria } \\
\hline$N_{S i}$ & 0.407 & 0.574 & 0.370 & 0.419 & 0.520 & 0.499 & 0.474 & 0.427 & 0.383 \\
\hline OB & 0.573 & 0.553 & 0.574 & 0.582 & 0.562 & 0.563 & 0.580 & 0.584 & 0.574 \\
\hline
\end{tabular}


Table 5.12. (Continued)

\begin{tabular}{|c|c|c|c|c|c|c|c|}
\hline Glass ID & $\begin{array}{c}\text { IWL-HAM- } \\
28\end{array}$ & $\begin{array}{c}\text { IWL-HAM- } \\
29\end{array}$ & $\begin{array}{c}\text { IWL-HAM- } \\
30\end{array}$ & $\begin{array}{c}\text { IWL-HAM- } \\
31\end{array}$ & $\begin{array}{c}\text { IWL-HAM- } \\
32\end{array}$ & \multirow[t]{2}{*}{ Min } & \multirow[t]{2}{*}{$\operatorname{Max}$} \\
\hline \# in Table D.1 & 47 & 48 & 49 & 50 & Centroid & & \\
\hline $\mathrm{Al}_{2} \mathrm{O}_{3}$ & 0.22314 & 0.21019 & 0.24000 & 0.23315 & 0.22000 & 0.18136 & 0.25923 \\
\hline $\mathrm{B}_{2} \mathrm{O}_{3}$ & 0.21072 & 0.20103 & 0.16638 & 0.17948 & 0.18000 & 0.14234 & 0.21673 \\
\hline $\mathrm{Bi}_{2} \mathrm{O}_{3}$ & 0.00628 & 0.00773 & 0.02974 & 0.00419 & 0.01550 & 0.00120 & 0.02974 \\
\hline $\mathrm{CaO}$ & 0.07134 & 0.04770 & 0.09639 & 0.01832 & 0.05000 & 0.00733 & 0.09639 \\
\hline $\mathrm{CdO}$ & 0.00267 & 0.00229 & 0.00127 & 0.00220 & 0.00200 & 0.00102 & 0.00290 \\
\hline $\mathrm{Cr}_{2} \mathrm{O}_{3}$ & 0.00572 & 0.01119 & 0.00144 & 0.00697 & 0.00700 & 0.00141 & 0.01269 \\
\hline $\mathrm{F}$ & 0.00272 & 0.00841 & 0.00853 & 0.00120 & 0.00550 & 0.00120 & 0.00985 \\
\hline $\mathrm{Fe}_{2} \mathrm{O}_{3}$ & 0.02998 & 0.01140 & 0.03177 & 0.01732 & 0.04000 & 0.01012 & 0.06817 \\
\hline $\mathrm{K}_{2} \mathrm{O}$ & 0.03183 & 0.01091 & 0.02879 & 0.02906 & 0.02000 & 0.00203 & 0.03983 \\
\hline $\mathrm{La}_{2} \mathrm{O}_{3}$ & 0.00227 & 0.00365 & 0.00266 & 0.00810 & 0.00550 & 0.00139 & 0.00990 \\
\hline $\mathrm{Li}_{2} \mathrm{O}$ & 0.00803 & 0.04206 & 0.04598 & 0.03927 & 0.03000 & 0.00348 & 0.05977 \\
\hline $\mathrm{MgO}$ & 0.00472 & 0.00842 & 0.00825 & 0.00781 & 0.00550 & 0.00158 & 0.00990 \\
\hline $\mathrm{MnO}$ & 0.00491 & 0.01114 & 0.00786 & 0.00992 & 0.00800 & 0.00130 & 0.01484 \\
\hline $\mathrm{Na}_{2} \mathrm{O}$ & 0.09668 & 0.10029 & 0.07741 & 0.05257 & 0.08500 & 0.05072 & 0.11996 \\
\hline $\mathrm{Nd}_{2} \mathrm{O}_{3}$ & 0.00198 & 0.00103 & 0.00167 & 0.00147 & 0.00150 & 0.00103 & 0.00198 \\
\hline $\mathrm{NiO}$ & 0.00172 & 0.00294 & 0.00905 & 0.00643 & 0.00550 & 0.00106 & 0.00998 \\
\hline $\mathrm{P}_{2} \mathrm{O}_{5}$ & 0.00902 & 0.02250 & 0.00564 & 0.01955 & 0.01500 & 0.00544 & 0.02250 \\
\hline $\mathrm{PbO}$ & 0.00183 & 0.00109 & 0.00897 & 0.00279 & 0.00550 & 0.00108 & 0.00934 \\
\hline $\mathrm{RuO}_{2}$ & 0.00004 & 0.00005 & 0.00002 & 0.00002 & 0.00003 & 0.00001 & 0.00005 \\
\hline $\mathrm{SiO}_{2}$ & 0.23658 & 0.25727 & 0.20686 & 0.31925 & 0.26897 & 0.20686 & 0.36647 \\
\hline $\mathrm{SO}_{3}$ & 0.00660 & 0.00501 & 0.00344 & 0.00499 & 0.00400 & 0.00113 & 0.00690 \\
\hline $\mathrm{SrO}$ & 0.00888 & 0.00141 & 0.00781 & 0.00608 & 0.00550 & 0.00110 & 0.00990 \\
\hline $\mathrm{ZrO}_{2}$ & 0.03235 & 0.03230 & 0.01006 & 0.02986 & 0.02000 & 0.00008 & 0.03884 \\
\hline Total & 1 & 1 & 1 & 1 & 1 & 1 & 1 \\
\hline \multicolumn{8}{|c|}{ Multicomponent constraints } \\
\hline $\mathrm{Al}_{2} \mathrm{O}_{3}+\mathrm{Fe}_{2} \mathrm{O}_{3}+\mathrm{ZrO}_{2}$ & 0.28547 & 0.25388 & 0.28183 & 0.28032 & 0.28000 & 0.23486 & 0.32077 \\
\hline $\mathrm{Al}_{2} \mathrm{O}_{3}+\mathrm{Fe}_{2} \mathrm{O}_{3}$ & 0.25312 & 0.22159 & 0.27177 & 0.25046 & 0.26000 & 0.20780 & 0.30724 \\
\hline $\mathrm{Al}_{2} \mathrm{O}_{3}+\mathrm{ZrO}_{2}$ & 0.25549 & 0.24249 & 0.25006 & 0.26301 & 0.24000 & 0.19536 & 0.27907 \\
\hline $\mathrm{Fe}_{2} \mathrm{O}_{3}+\mathrm{ZrO}_{2}$ & 0.06233 & 0.04369 & 0.04184 & 0.04717 & 0.06000 & 0.01516 & 0.07659 \\
\hline \multicolumn{8}{|c|}{ Predicted properties (Vienna et a. 2009) } \\
\hline$\eta_{1150}, \mathrm{~Pa} . \mathrm{s}$ & 5.16 & 1.99 & 0.84 & 10.68 & 3.72 & 0.84 & 14.06 \\
\hline$T$ at 5 Pas, ${ }^{\circ} \mathrm{C}$ & 1153.5 & 1043.8 & 964.7 & 1237.4 & 1117.1 & 958.7 & 1268.5 \\
\hline$T_{1 \%}-\mathrm{Sp},{ }^{\circ} \mathrm{C}$ & 969.2 & 968.8 & 1057.6 & 1066.5 & 1057.3 & 858.9 & 1172.4 \\
\hline$\varepsilon_{1150}, \mathrm{~S} / \mathrm{m}$ & 13.7 & 31.2 & 28.0 & 16.4 & 19.7 & 8.5 & 38.1 \\
\hline \multicolumn{8}{|c|}{ Nepheline formation criteria } \\
\hline$N_{S i}$ & 0.425 & 0.453 & 0.395 & 0.528 & 0.469 & 0.367 & 0.599 \\
\hline OB & 0.573 & 0.570 & 0.606 & 0.555 & 0.574 & 0.542 & 0.606 \\
\hline
\end{tabular}

Figure 5.2 show the range of concentrations for nine major components and major predicted properties. There are four set of glasses: 94 as-formulated glasses, 51 candidate glasses that meet all the matrix design constraints, six existing glasses that meet all the matrix design constraints, and 32 matrix glasses, showing the change of glass composition and property coverage with the progress of matrix design. Figure 5.3 through Figure 5.5 show the scatter plots for all as formulated glasses (Figure 5.3), matrix glasses only (Figure 5.4), and matrix and existing glasses (Figure 5.5). 

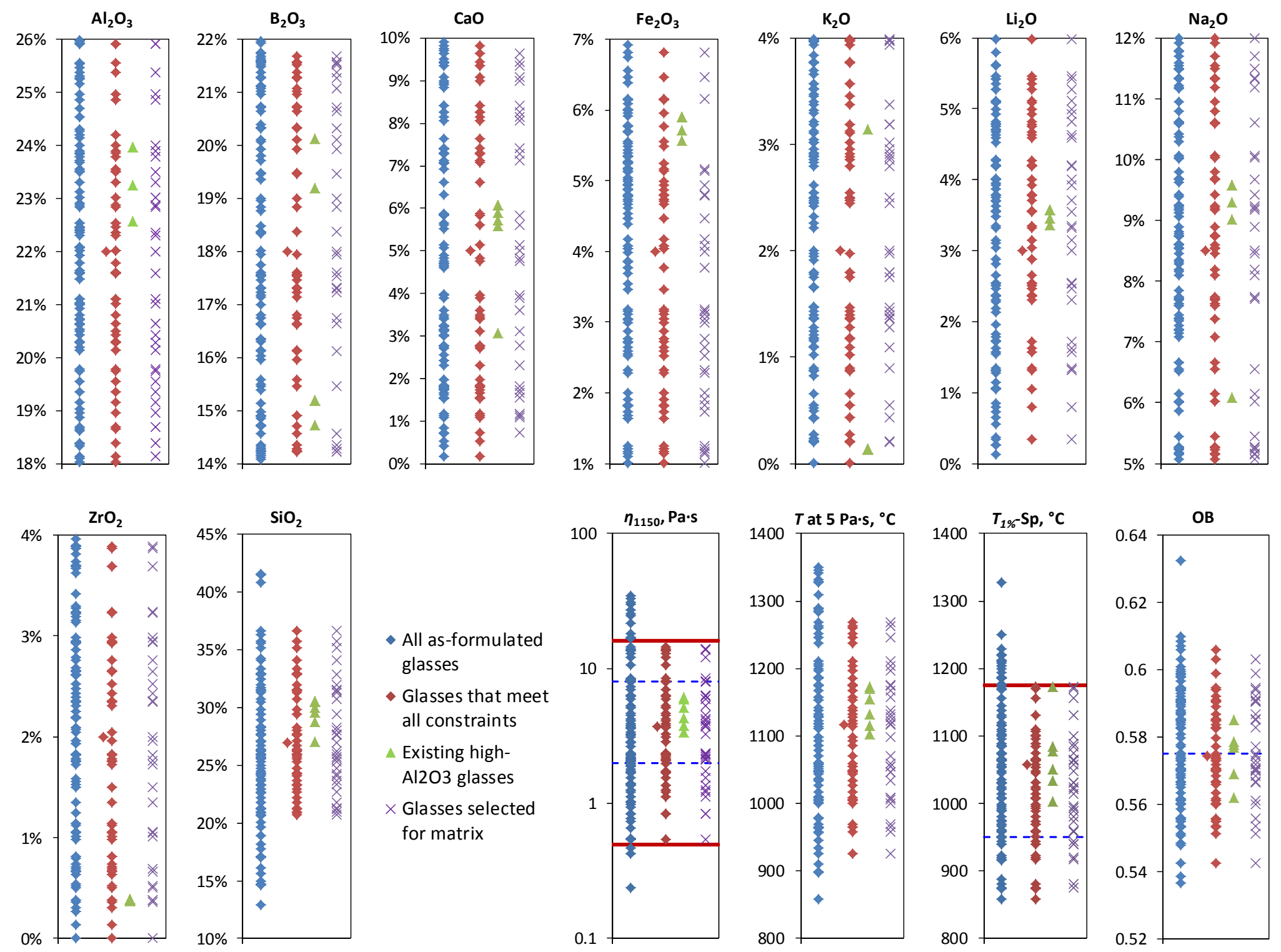

Figure 5.2. Concentration and Predicted Property Range 


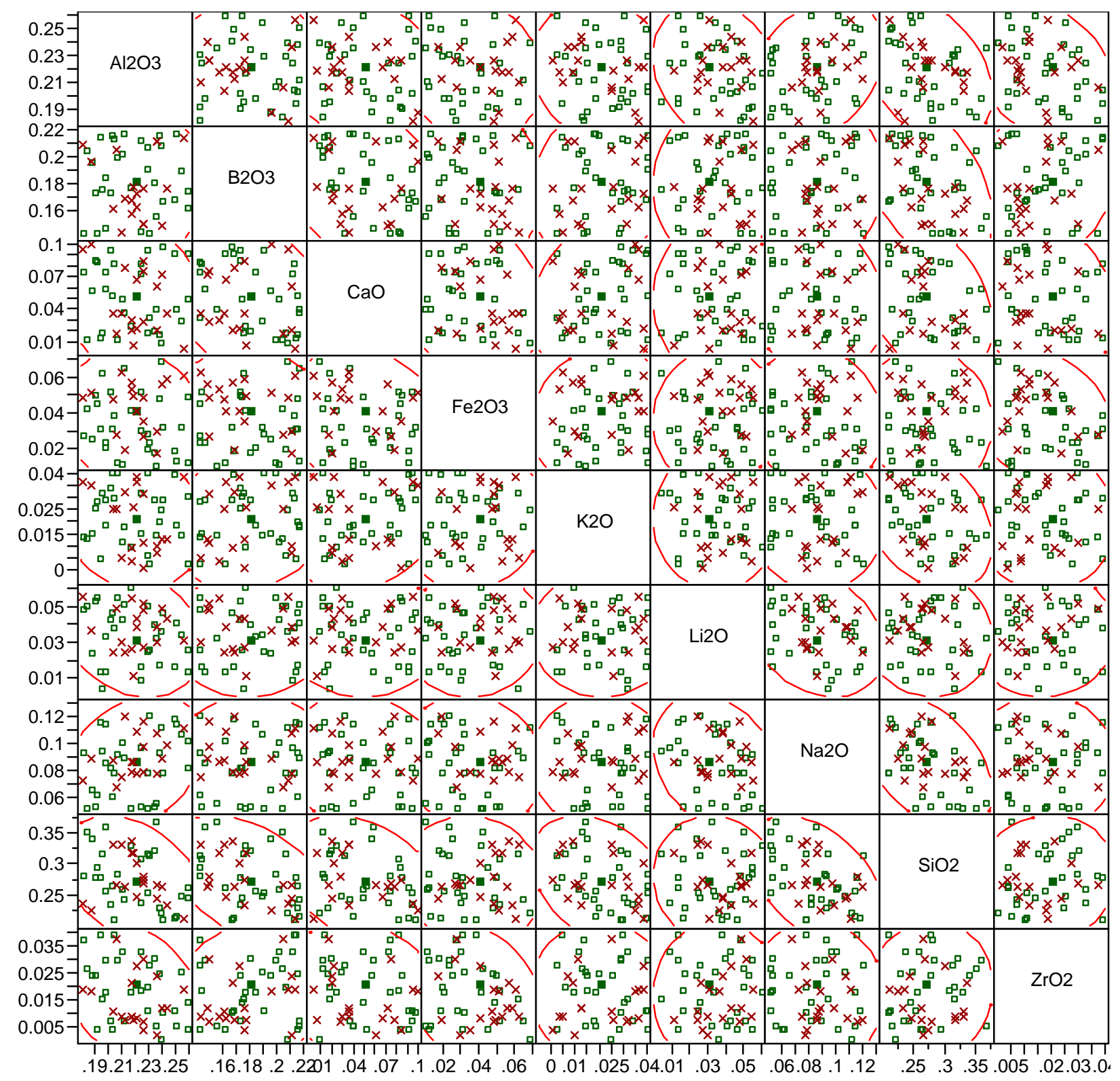

Figure 5.3. Scatter Plot for All Candidate Glasses (Square: selected, X: deleted) 


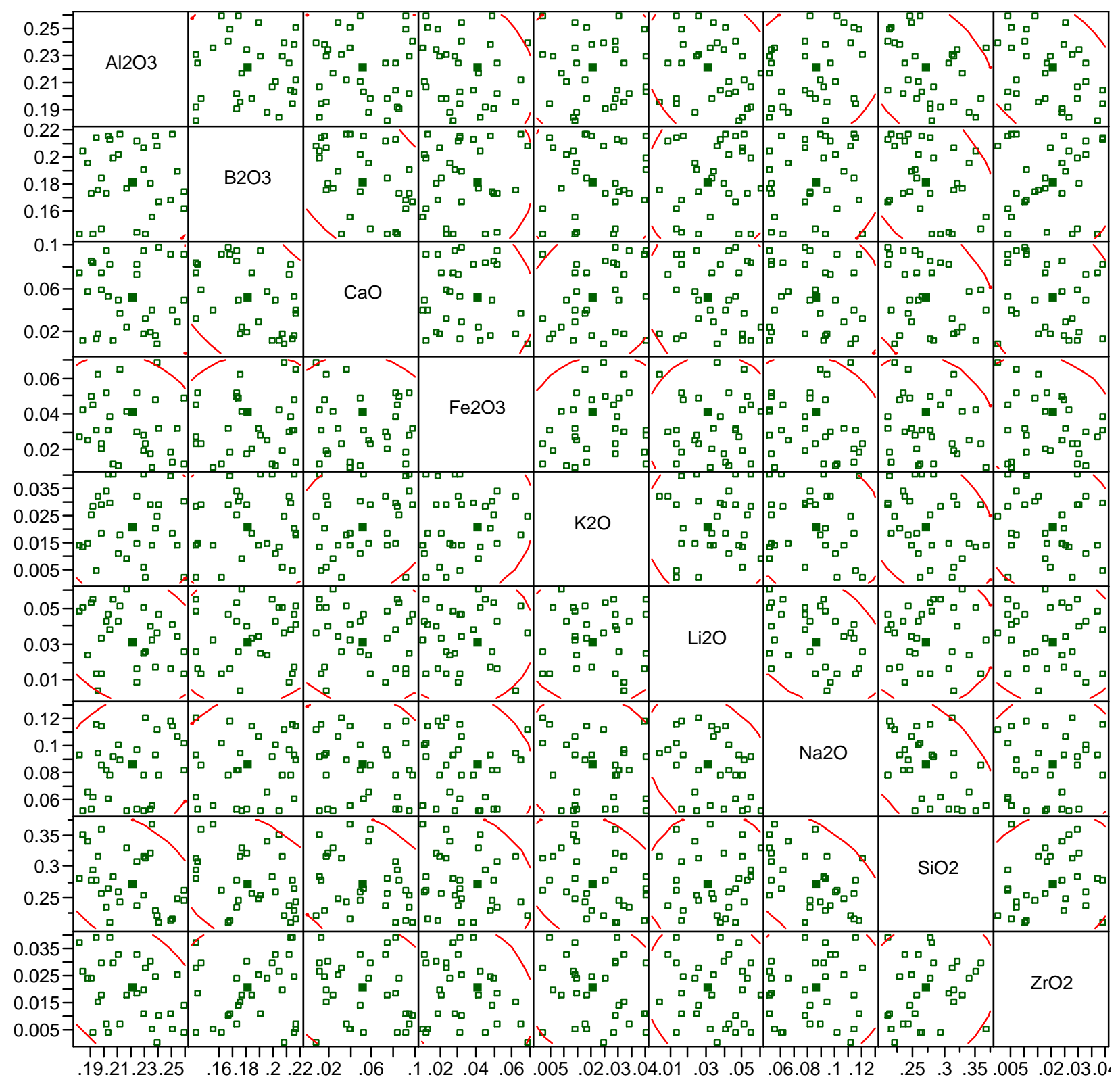

Figure 5.4. Scatter Plot for Matrix Glasses 


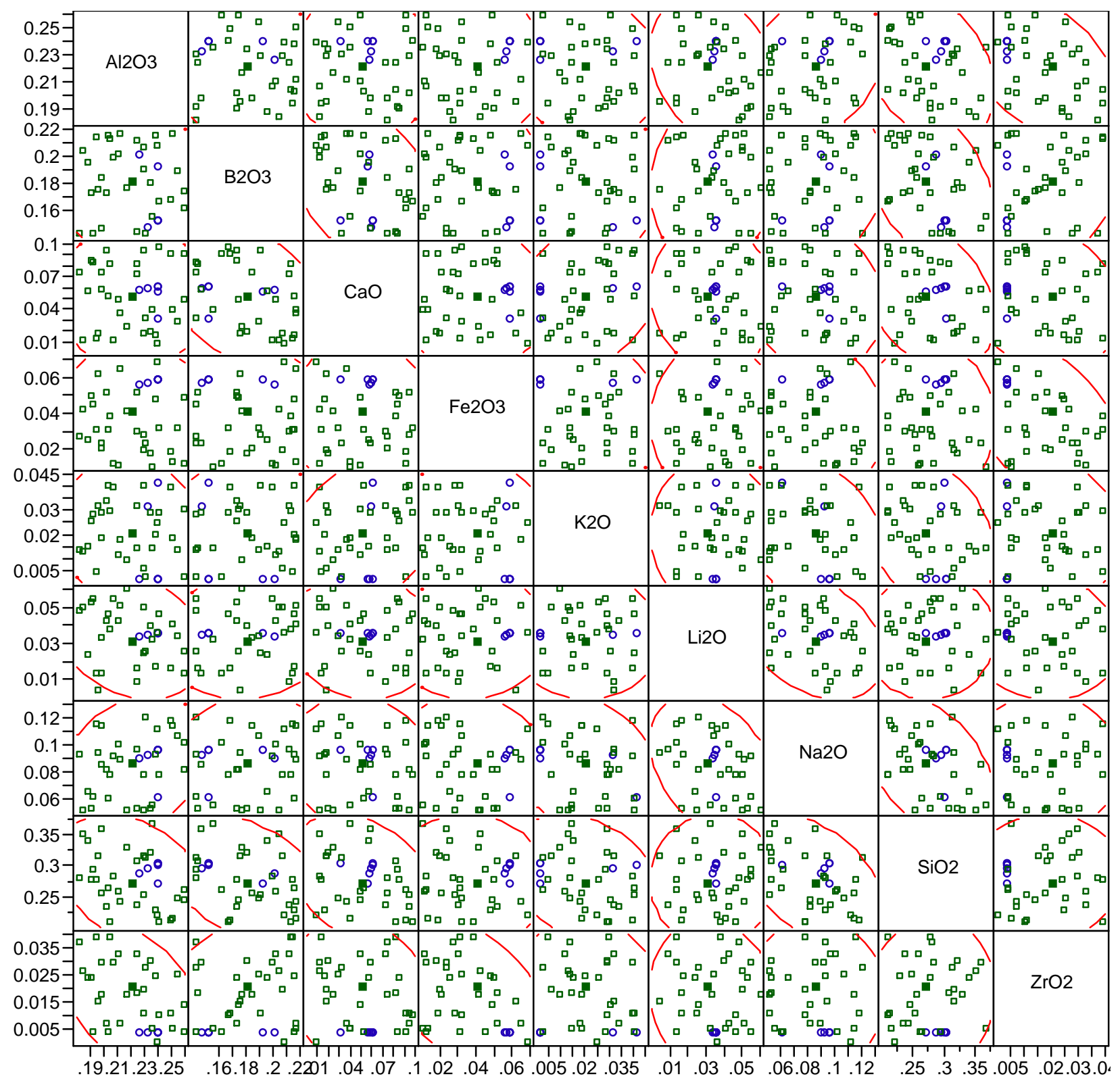

Figure 5.5. Scatter Plot for Matrix and Existing Glasses (Square: matrix, Circle: existing) 



\subsection{Conclusions}

The glass formulation and testing results achieved from the finished scope of the EM-31 technology development tasks for WP-4 and WP-5 are summarized and future work for continued glass formulation development are recommended.

\subsection{Summary of Glass Formulation for Cold Crucible Induction Melter (WP-4.1.2)}

From glass formulation and testing with AZ-101 simulated HLW, the three glasses, CCIM-AZ-29, CCIM-AZ-16, and CCIM-AZ-10, were selected for the initial CCIM demonstration. The target $\mathrm{Fe}_{2} \mathrm{O}_{3}$ concentration and waste loading of these glasses are summarized in Figure 6.1.

\section{CCIM-AZ-29}

$15 \mathrm{w} \% \mathrm{Fe}_{2} \mathrm{O}_{3}$

$39.8 \% \mathrm{WL}$
CCIM-AZ-16

$16 \mathrm{wt} \% \mathrm{Fe}_{2} \mathrm{O}_{3}$

$42.5 \% \mathrm{~W}$

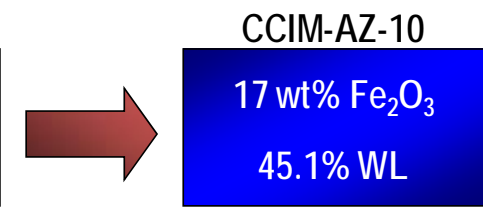

Figure 6.1. $\mathrm{Fe}_{2} \mathrm{O}_{3}$ Concentration and Waste Loading in Three AZ-101 Glasses Selected for Initial CCIM Demonstration Testing from This Study

The CCIM-AZ-10 glass at $45.1 \mathrm{wt} \%$ waste loading corresponds to a $22 \%$ increase from $37 \mathrm{wt} \%$, which is the maximum waste loading that is likely to be achieved based on expected reference WTP formulation. However, it involves the assumption that the high-waste loaded glass with more crystals can be successfully processed in the CCIM, which needs be demonstrated. The recommended nominal processing temperature for all three glasses is $1200{ }^{\circ} \mathrm{C}$ based on a measured viscosity of $4 \mathrm{~Pa} \cdot \mathrm{s}$ for all three glasses. The measured electrical conductivities at $1200{ }^{\circ} \mathrm{C}$ is $30 \mathrm{~S} / \mathrm{m}, 24 \mathrm{~S} / \mathrm{m}$, and $21 \mathrm{~S} / \mathrm{m}$ for CCIM-AZ-29, 16, and 10 glasses, respectively, which are within the desired range of 10 to $100 \mathrm{~S} / \mathrm{m}$. All three glasses meet the PCT and TCLP requirements regardless of thermal history (quenched or CCC treated glasses).

The CCIM tests with AZ-101-simulated HLW were planned to start with the CCIM-AZ-29 glass to evaluate the glass melting characteristics (e.g., processing rates, cold cap behavior, pour stability, etc.) at lower waste loading (39.8 wt\%). When successful at this waste loading $(39.8 \mathrm{wt} \%)$, it was planned to make a transition to target the higher waste loaded (42.5 wt $\%$ ) CCIM-AZ-16 glass, and then ultimately the CCIM-AZ-10 (45.1 wt\%) glass. In this approach, the capability of CCIM technologies to tolerate the crystals in the melt, which increases as the waste loading increases (summarized in Figure 6.2), can be evaluated. Preparation of melter feeds was completed but the demonstration melter run was not started before the closure of the project. 


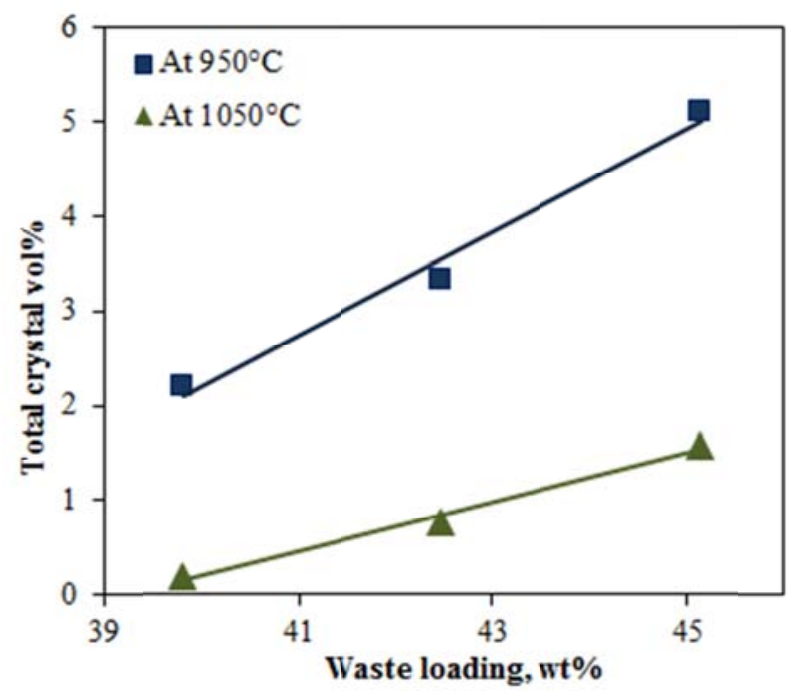

Figure 6.2. Total Crystal Vol\% As a Function of Waste Loading for Selected Three Glasses

From initial glass formulation and testing with AN-105 simulated LAW, the CCIM-AN-18 glass targeting $24 \mathrm{wt} \% \mathrm{Na}_{2} \mathrm{O}$ with a waste loading of $31.3 \mathrm{wt} \%$ was selected for the initial CCIM demonstration test. This waste loading is a $14 \%$ increase from the reference WTP formulation maximum of $21 \mathrm{wt} \%$ $\mathrm{Na}_{2} \mathrm{O}$ in glass. The $24 \mathrm{wt} \% \mathrm{Na}_{2} \mathrm{O}$ loading was also achieved by ORPLA20 glass that was developed by ORP for processing at $1150{ }^{\circ} \mathrm{C}$ and was demonstrated to have good processing characteristics. The recommended nominal processing temperature for CCIM-AN-18 glass is $1250^{\circ} \mathrm{C}$, based on a measured viscosity of $\sim 4 \mathrm{~Pa} \cdot \mathrm{s}$. The measured electrical conductivity at $1250^{\circ} \mathrm{C}$ is $53 \mathrm{~S} / \mathrm{m}$, which is within the recommended range of $10 \mathrm{~S} / \mathrm{m}$ to $100 \mathrm{~S} / \mathrm{m}$. The CCIM-AN-18 glass meets the PCT and VHT requirements for both quenched and CCC-treated glasses. This work was discontinued during the preparation for demonstration CCIM tests and melter feeds were not prepared.

Additional glass development efforts with AN-105-simulated LAW successfully formulated acceptable glasses containing up to $26 \mathrm{wt} \% \mathrm{Na}_{2} \mathrm{O}$ before the closure of this project. The present results of PCT and VHT from the glasses with $24 \mathrm{wt} \%$ to $26 \mathrm{wt} \% \mathrm{Na}_{2} \mathrm{O}$ suggest that it may be possible to formulate acceptable glasses containing even higher than $26 \mathrm{wt} \% \mathrm{Na}_{2} \mathrm{O}$. Therefore, when the project restarts, the CCIM tests will be performed with the newly developed glasses containing $\geq 26 \mathrm{wt} \% \mathrm{Na}_{2} \mathrm{O}$ rather than CCIM-AN-18.

The high waste loading (up to $26 \mathrm{wt} \% \mathrm{Na}_{2} \mathrm{O}$ ) achieved in this study with $\mathrm{AN}-105$ is attributed to two factors: (1) finding of new composition region with good VHT performance and (2) use of higher temperature. The information on the effect of glass composition on PCT and VHT gained from the present study for the AN-105 LAW glasses melting at $\geq 1200^{\circ} \mathrm{C}$ can also be used to formulate higher waste loaded glasses for the baseline WTP melter operated at $1150^{\circ} \mathrm{C}$.

After completing the initial formulations with AZ-101 HLW and AN-105 LAW, glass formulations for CCIM were expanded to cover the additional HLWs that have a high potential to successfully demonstrate the unique advantages of the CCIM technologies. The selected two waste groups were spinel-limited and high-chromium wastes. Only the preliminary scoping tests were completed with these wastes to find the maximum waste loadings at which reasonable glass can be made without severe 
crystallization (for spinel-limited wastes) or salt formation (for high-chromium waste) so that they can be used for glass property characterization.

For spinel-limited wastes, the maximum concentrations of $\mathrm{Al}_{2} \mathrm{O}_{3}+\mathrm{Fe}_{2} \mathrm{O}_{3}+\mathrm{ZrO}_{2}$ that can be in glass without severe crystallization ranged from $27 \mathrm{wt} \%$ to $35 \mathrm{wt} \%$ (corresponding to $52.5 \mathrm{wt} \%$ to $68.8 \mathrm{wt} \%$ waste loading). These $\mathrm{Al}_{2} \mathrm{O}_{3}+\mathrm{Fe}_{2} \mathrm{O}_{3}+\mathrm{ZrO}_{2}$ loading are significantly higher than those predicted as maximum based on revised HTWOS constraints, which ranged from $19.8 \mathrm{wt} \%$ to $25.5 \mathrm{wt} \%$. For high-chromium waste, the glasses without salt formation were successfully formulated at $3 \mathrm{wt} \%$ and $3.5 \mathrm{wt} \% \mathrm{Cr}_{2} \mathrm{O}_{3}$ so that they can be used for further characterization to determine the estimated maximum waste loading to be evaluated through scaled melter tests.

\subsection{Summary of Advanced Silicate Glass Development (WP-5.1.2)}

For glass formulations for specific wastes, limited testing with high-iron, spinel-limited, and high-aluminum waste clusters was completed before the closure of the project. Additional iterations of glass formulation and property testing are needed to determine the estimated maximum waste loading for these waste clusters. The incomplete results from this first initial iteration are summarized in this report for eventual restart of the task. For high-iron waste clusters, the loading of $\mathrm{Al}_{2} \mathrm{O}_{3}+\mathrm{Fe}_{2} \mathrm{O}_{3}+\mathrm{ZrO}_{2}$ in glasses for Cluster 1 will be higher than $22.7 \mathrm{wt} \%$, based on one successful glass formulated with $0.6 \mathrm{vol} \%$ spinel at $950^{\circ} \mathrm{C}$. However, no successful glass resulted from the first set of glasses formulated for Cluster 18. Among three high-aluminum clusters, one glass for Cluster 16 (IWL-HAC16-5) passed both the $T_{1 \%}$ requirement and $\mathrm{CCC}$ crystallinity requirements.

For systematic glass studies, a test matrix of 32 high-aluminum glasses was generated based on a new space filling method developed in this study. The new matrix approach involves formulating random-generated glasses within the predetermined single component constraints, and then sorting out the glasses outside the multicomponent and property constraints and the glasses that have compositions close to each other. The development of test matrix was described in detail for eventual restart of the project and for application to similar matrices for glasses with different composition regions, e.g., high-iron or spinel-limited glasses.

\subsection{Suggested Studies}

Suggested studies are briefly summarized as below.

\section{Formulation of CCIM Glasses Melting at $>1200^{\circ} \mathrm{C}$}

- Perform CCIM demonstration tests with three AZ-101 glasses selected.

- Perform additional crucible tests to determine the maximum $\mathrm{Na}_{2} \mathrm{O}$ loading in AN-105 glasses, select a new glass (with higher $\mathrm{Na}_{2} \mathrm{O}$ than CCIM-AN-18) for a CCIM test, and perform CCIM demonstration tests.

- Complete the determination of the waste loadings that would result in reasonable crystal contents that can be tolerated by CCIM for spinel-limited and high-chromium waste clusters.

- Develop an inexpensive test method to determine the tendency of salt formation during melting of HLW feeds. 
- Determine the estimated maximum waste loading for all $\mathrm{Cr}_{2} \mathrm{O}_{3}-\mathrm{SO}_{3}$ limited and $\mathrm{P}_{2} \mathrm{O}_{5}-\mathrm{CaO}$ limited waste clusters.

- Determine the potential waste loading benefit by CCIM for high-aluminum waste clusters.

- Complete pre-conceptual design for CCIM retrofit for Hanford HLW and Hanford LAW.

- Perform a cost/benefit/risk analysis on CCIM retrofit for Hanford HLW and Hanford LAW.

\section{Formulation of Advanced Silicate Glasses Melting at $1150^{\circ} \mathrm{C}$}

- Complete the determination of the maximum loadings for high-iron, spinel-limited, and high-aluminum waste clusters.

- Determine the estimated maximum waste loading for all $\mathrm{Cr}_{2} \mathrm{O}_{3}-\mathrm{SO}_{3}$ limited and $\mathrm{P}_{2} \mathrm{O}_{5}-\mathrm{CaO}$ limited waste clusters using the test method developed to determine the tendency of salt formation.

- Complete the estimation of glass volume reduction that can be achieved by applying the advanced glass formulation for improved waste loadings.

- Refine the crystal limits using the crystal tolerant glass formulation approach.

- Perform testing the high-aluminum test matrix glasses.

- Develop additional test matrices for glasses with different composition regions.

- Develop expanded glass property models to cover the entire glass composition region. 


\subsection{References}

ASTM-American Society of Testing and Materials. 2008. Standard Test Methods for Determining Chemical Durability of Nuclear, Hazardous, and Mixed Waste Glasses and Multiphase Glass Ceramics: The Product Consistency Test (PCT), ASTM C 1285-02(2008), American Society of Testing and Materials.

ASTM-American Society of Testing and Materials. 2009. Standard Test Methods for Measuring Waste Glass or Glass Ceramic Durability by Vapor Hydration Test), ASTM C 1663-09, American Society of Testing and Materials.

Belsher JD and FL Meinert. 2009. High-Level Waste Glass Formulation Model Sensitivity Study 2009 Glass Formulation Model versus 1996 Glass Formulation Model, RPP-RPT-42649, Rev. 0, Washington River Protection Solutions, Richland, Washington.

Bickford DF and CM Jantzen. 1984. Devitrification of SRL Defense Waste Glass, in Sci. Basis for Nuclear Waste Management VII, ed. GL McVay, Elsevier, New York, pp. 557-565.

Bush SR. 2010. US DOE Office of Environmental Management Technology Development Report Fiscal Year 2010, SRNS-STI-2010-00700, Savannah River National Laboratory, Aiken, South Carolina.

Certa PJ, GK Allen, TW Crawford, TM Hohl, KN Jordan, RA Kirkbride, and RL Lytle. 2008. River Protection Project System Plan - Revision 3A, ORP-11242, CH2M Hill Hanford Group, Richland, Washington.

Chew DP and BA Hamm. 2009. Liquid Waste System Plan, Revision 16, Savannah River Remediation, Aiken, South Carolina.

DoQualng R, E Pluche, C Ladirat, and A Prod'Homme. 2004. Review of the French Vitrification Program, in Waste Management 2004, WM-4320, Tucson, Arizona.

EPA-U.S. Environmental Protection Agency. 1997. Test Methods for Evaluation of Solid Waste Physical/Chemical Methods, SW-846, 3rd. ed., as amended, U. S. Environmental Protection Agency, Washington, D.C.

Hrma P, and JD Vienna. 2003. Relationship Between Liquidus Temperature and Solubility, in Ceramic Transactions, 143, pp. 159-167, American Ceramic Society, Westerville, Ohio.

Jantzen CM, NE Bibler, DC Beam, CL Crawford, and MA Pickett. 1993. Characterization of the Defense Waste Processing Facility (DWPF) Environmental Assessment (EA) Glass Standard Reference Material, WSRC-TR-92-346, Revision 1, Westinghouse Savannah River Company, Aiken, South Carolina.

Kim D, DK Peeler, and P Hrma. 1995. Effect of Crystallization on the Chemical Durability of Simulated Nuclear Waste Glasses, in Environmental Issues and Waste Management Technologies, Ceramic Transactions, Vol. 61, 177-185.

Kim D and JD Vienna. 2002. Influence of Glass Property Restrictions on Hanford HLW Glass Volume, in Environmental Issues and Waste Management Technologies VII, Ceramic Transactions, Vol. 132, 105-115. 
Kim D, JD Vienna, P Hrma, MJ Schweiger, J Matyas, JV Crum, DE Smith, WC Buchmiller, JS Tixier, Jr., JD Yeager, and KB Belew. 2003. Development and Testing of ICV Glasses for Hanford LAW, PNNL-14351, Pacific Northwest National Laboratory, Richland, Washington.

Kim D, JD Vienna, DK Peeler, KM Fox, A Aloy, AV Trofimenko, and KD Gerdes. 2008. Improved Alumina Loading in High-Level Waste Glasses, in WM'08 proceedings, HLW, TRU, LLW/ILW, Mixed, Hazardous Wastes \& Environmental Management, February 24-28, 2008, Phoenix, Arizona, WM Symposia Inc., Tucson, Arizona.

Kim D, MJ Schweiger, JD Vienna, FC Johnson, JC Marra, DK Peeler, and GL Smith. 2011. Glass Formulation for Next Generation Cold Crucible Induction Melter, in WM2011 proceedings, Global Achievements and Challenges in Waste Management, February 27 -March 3, 2011, Phoenix, Arizona., WM Symposia Inc., Tucson, Arizona (in press).

Kot WK, H Gan, M Chaudhuri, and IL Pegg. 2011. Glass Formulation for Next Generation Melters, VSL-11R2310-1, Vitreous State Laboratory, The Catholic University of America, Washington, DC.

Li H, JD Vienna, P Hrma, DE Smith, and MJ Schweiger. 1997. Nepheline Precipitation in High-Level Waste Glasses: Compositional Effects and Impact on the Waste Form Acceptability, Scientific Basis for Nuclear Waste Management, Vol. 465, 261-268.

Li H, P Hrma, JD Vienna, M Quin, Y Su, and DE Smith. 2003. "Effects of $\mathrm{Al}_{2} \mathrm{O}_{3}, \mathrm{~B}_{2} \mathrm{O}_{3}, \mathrm{Na}_{2} \mathrm{O}$, and $\mathrm{SiO}_{2}$ on Nepheline Formation in Borosilicate Glasses: Chemical and Physical Correlations." Journal of Non-Crystalline Solids. Vol. 331, 202-216.

Marra JM, A Youchak-Billings, M Stone, DK Peeler, T Edwards, C Girold, and J Dussossoy. 2008. Glass Formulation Development and Testing for Cold Crucible Induction Melter Technology Retrofit and Deployment Project, Phase II-A - Demonstrations: Lab-Scale Evaluation and Assessment Report, SRN-STI-2008-00036, Savannah River National Laboratory, Aiken, South Carolina.

Marra JC, KM Fox, GT Jannik, EB Farfan, D Kim, JD Vienna, JA Roach, AS Aloy, SV Stefanovsky, DP Lopukh, MD Bondarkov, KD Gerdes and AM Han. 2010. The DOE Office of Environmental Management International Cooperative Program: Overview of Technical Tasks and Results, in WM2010 proceedings, $H L W$, TRU, LLW/ILW, Mixed, Hazardous Wastes \& Environmental Management, March 7-11, 2010, Phoenix, Arizona, WM Symposia Inc., Tucson, Arizona.

Matlack KS, W Gong, IS Muller, I Joseph, and IL Pegg. 2006. LAW Envelope A and B Glass Formulation Testing to Increase Waste Loading, VSL-06R6900-1, Rev. 0, Vitreous State Laboratory, The Catholic University of America, Washington, DC.

Matlack KS, H Gan, W Gong, and I L Pegg. 2007a. High Level Waste Vitrification System Improvements, VSL-07R1010-1, Rev. 0, Vitreous State Laboratory, The Catholic University of America, Washington, DC.

Matlack KS, I Joseph, W Gong, IS Muller, and IL Pegg. 2007b. Enhanced LAW Glass Formulation Testing, VSL-07R1130-1, Rev. 0, Vitreous State Laboratory, The Catholic University of America, Washington, DC.

Matlack KS, H Gan, M Chaudhuri, W Kot, W Gong, T Bardakci, and IL Pegg. 2008. Melt Rate Enhancement for High Aluminum HLW Glass Formulations, VSL-08R1360-1, Vitreous State Laboratory, The Catholic University of America, Washington, DC. 
Matlack KS, I Joseph, W Gong, IS Muller, and IL Pegg. 2009. Glass Formulation Development and DM10 Melter Testing with ORP LAW Glasses, VSL-09R1510-2, Rev. 0, Vitreous State Laboratory, The Catholic University of America, Washington, DC.

Matlack KS, H Gan, M Chaudhuri, W Kot, W Gong, T Bardakci, IL Pegg, and I Joseph. 2010. DM100 and DM1200 Melter Testing with High Waste Loading Glass Formulations for Hanford High-Aluminum HLW Streams, VSL-10R1690-1, Vitreous State Laboratory, The Catholic University of America, Washington, DC.

Matyas J, JV Crum, JD Vienna, A Arrigoni, M Schaible, R Tate, and CP Rodriguez. 2010. Development of Crystal-Tolerant High-Level Waste Glasses, PNNL-20072, Pacific Northwest National Laboratory, Richland, Washington.

Mellinger GB and JL Daniel. 1984. Approved Reference and Testing Materials for Use in Nuclear Waste Management Research and Development Programs, PNL-49552, Pacific Northwest Laboratory, Richland, Washington.

McCloy JS and JD Vienna. 2010. Glass Composition Constraint Recommendations for Use in Life-Cycle Mission Modeling, PNNL-19372, Pacific Northwest National Laboratory, Richland, Washington.

NRC - National Research Council. 2009. "Advice on the Department of Energy's Cleanup Technology Roadmap: Gaps and Bridges," Committee on Development and Implementation of a Cleanup Technology Roadmap, National Academies Press, Washington, DC.

Perez Jr. JM, DF Bickford, DE Day, D Kim, SL Lambert, SL Marra, DK Peeler, DM Strachan, MB Triplett, JD Vienna, and RS Wittman. 2001. High-Level Waste Melter Study Report, PNNL-13582, Pacific Northwest National Laboratory, Richland, Washington.

Piepel GF, SK Cooley, and B Jones. 2004. Construction of a 21-Component Layered Mixture Experimental Design, PNNL-14862, Pacific Northwest National Laboratory, Richland, Washington.

Piepel GF, SK Cooley, I Muller, H Gan, I Joseph, and IL Pegg. 2007. ILAW PCT, VHT, Viscosity, and Electrical Conductivity Model Development, VSL-07R1230-1 (PNNL-16621), Vitreous State Laboratory, The Catholic University of America, Washington, DC.

Roach J, N Soelberg, M Ancho, E Tchemitcheff, and J Richardson. 2009. Cold Crucible Induction Melter Testing at the Idaho National Laboratory for the Advanced Remediation Technologies Program - 9337, in WM2009 proceedings, HLW, TRU, LLW/ILW, Mixed, Hazardous Wastes \& Environmental Management, March 1-5, 2009, Phoenix, Arizona, WM Symposia Inc., Tucson, Arizona.

Rodriguez CP, JS McCloy, MJ Schweiger, JV Crum, and A Winschell. 2011. Optical Basicity and Nepheline Crystallization in High Alumina Glasses, PNNL-20184, Pacific Northwest National Laboratory, Richland, Washington.

Schweiger MJ, BJ Riley, JV Crum, PR Hrma, CP Rodriguez, BM Arrigoni, JB Lang, D Kim, JD Vienna, FC Raszewski, DK Peeler, TB Edwards, DR Best, IA Reamer, WT Riley, PT Simmons, and RJ Workman. 2011. Expanded High-Level Waste Glass Property Data Development: Phase I, PNNL-17950, Pacific Northwest National Laboratory, Richland, Washington. 
Vienna JD, P Hrma, A Jiricka, DE Smith, TH Lorier, IA Reamer, and RL Schulz. 2001. Hanford Immobilized LAW Product Acceptance Testing: Tanks Focus Area Results, PNNL-13744, Pacific Northwest National Laboratory, Richland, Washington.

Vienna JD, D Kim, and PR Hrma. 2002. Database and Interim Glass Property Models for Hanford HLW and LAW Glasses, PNNL-14060, Pacific Northwest National Laboratory, Richland, Washington.

Vienna JD. 2005. Preliminary ILAW Formulation Algorithm Description, 24590-LAW-RPT-RT-04-0003, Rev 0, River Protection Project, Hanford Tank Waste Treatment and Immobilization Plant, Richland, Washington.

Vienna JD and D Kim. 2008. Preliminary IHLW Formulation Algorithm Description, 24590-HLW-RPT-RT-05-001, Rev. 0, River Protection Project, Hanford Tank Waste Treatment and Immobilization Plant, Richland, Washington.

Vienna JD, A Fluegel, D Kim, and P Hrma. 2009. Glass Property Data and Models for Estimating High-Level Waste Glass Volume, PNNL-18501, Pacific Northwest National Laboratory, Richland, Washington. 
Appendix A

Composition of Waste Clusters 



\section{Appendix A: Composition of Waste Clusters}

Table A.1. Composition of 20 Clusters in Terms of Full 63 "Oxide" Components that Are Tracked in the

G2 Model (components in bold represent the 15 components used in cluster analysis)

\begin{tabular}{|c|c|c|c|c|c|c|c|}
\hline Cluster \# & 1 & 2 & 3 & 4 & 5 & 6 & 7 \\
\hline $\mathrm{Ac}_{2} \mathrm{O}_{3}$ & $7.734 \mathrm{E}-12$ & $4.350 \mathrm{E}-12$ & $2.403 \mathrm{E}-11$ & $3.208 \mathrm{E}-11$ & $3.270 \mathrm{E}-12$ & $5.572 \mathrm{E}-12$ & $1.705 \mathrm{E}-12$ \\
\hline $\mathrm{Ag}_{2} \mathrm{O}$ & $1.328 \mathrm{E}-03$ & $1.438 \mathrm{E}-04$ & $1.521 \mathrm{E}-03$ & $2.011 \mathrm{E}-04$ & $2.371 \mathrm{E}-04$ & 5.591E-04 & $9.104 \mathrm{E}-05$ \\
\hline $\mathrm{Al}_{2} \mathrm{O}_{3}$ & $1.392 \mathrm{E}-01$ & $2.044 \mathrm{E}-01$ & $1.370 \mathrm{E}-01$ & $3.726 \mathrm{E}-01$ & 4.700E-01 & $2.783 \mathrm{E}-01$ & $4.489 \mathrm{E}-01$ \\
\hline $\mathrm{Am}_{2} \mathrm{O}_{3}$ & $4.828 \mathrm{E}-06$ & $1.882 \mathrm{E}-06$ & $8.150 \mathrm{E}-06$ & $1.854 \mathrm{E}-05$ & $2.386 \mathrm{E}-06$ & $6.828 \mathrm{E}-06$ & $9.615 \mathrm{E}-07$ \\
\hline $\mathrm{As}_{2} \mathrm{O}_{5}$ & $2.998 \mathrm{E}-04$ & $5.556 \mathrm{E}-04$ & $5.204 \mathrm{E}-04$ & $2.744 \mathrm{E}-04$ & $3.077 \mathrm{E}-04$ & $7.217 \mathrm{E}-04$ & $3.088 \mathrm{E}-04$ \\
\hline $\mathrm{B}_{2} \mathrm{O}_{3}$ & $2.445 \mathrm{E}-03$ & $2.128 \mathrm{E}-03$ & $8.312 \mathrm{E}-03$ & $1.310 \mathrm{E}-03$ & $2.356 \mathrm{E}-03$ & $4.273 \mathrm{E}-03$ & $1.383 \mathrm{E}-03$ \\
\hline $\mathrm{BaO}$ & $1.588 \mathrm{E}-03$ & $4.264 \mathrm{E}-04$ & $6.909 \mathrm{E}-04$ & $6.319 \mathrm{E}-04$ & $2.338 \mathrm{E}-04$ & $1.355 \mathrm{E}-03$ & $8.467 \mathrm{E}-04$ \\
\hline $\mathrm{BeO}$ & 4.914E-05 & $3.710 \mathrm{E}-04$ & $2.206 \mathrm{E}-04$ & $1.634 \mathrm{E}-04$ & $1.802 \mathrm{E}-04$ & 7.381E-04 & $7.889 \mathrm{E}-05$ \\
\hline $\mathbf{B i}_{2} \mathbf{O}_{3}$ & $6.655 \mathrm{E}-03$ & $7.246 \mathrm{E}-02$ & $2.469 \mathrm{E}-02$ & $9.754 \mathrm{E}-03$ & $1.857 \mathrm{E}-02$ & 3.799E-02 & $5.549 \mathrm{E}-02$ \\
\hline $\mathrm{CaO}$ & $2.459 \mathrm{E}-02$ & $5.615 \mathrm{E}-02$ & $3.867 \mathrm{E}-02$ & $2.620 \mathrm{E}-02$ & $1.558 \mathrm{E}-02$ & $1.996 \mathrm{E}-02$ & $2.440 \mathrm{E}-02$ \\
\hline CdO & $8.533 \mathrm{E}-04$ & $4.800 \mathrm{E}-04$ & $4.718 \mathrm{E}-03$ & $5.175 \mathrm{E}-03$ & $1.652 \mathrm{E}-04$ & $5.774 \mathrm{E}-04$ & $4.742 \mathrm{E}-05$ \\
\hline $\mathrm{Ce}_{2} \mathrm{O}_{3}$ & $2.682 \mathrm{E}-03$ & $8.378 \mathrm{E}-04$ & $6.895 \mathrm{E}-04$ & $8.690 \mathrm{E}-04$ & $2.444 \mathrm{E}-04$ & $9.507 \mathrm{E}-04$ & $2.679 \mathrm{E}-04$ \\
\hline $\mathrm{Cl}$ & $1.716 \mathrm{E}-03$ & $1.731 \mathrm{E}-03$ & $2.010 \mathrm{E}-03$ & $2.450 \mathrm{E}-03$ & $2.149 \mathrm{E}-03$ & $1.618 \mathrm{E}-03$ & $1.705 \mathrm{E}-03$ \\
\hline $\mathrm{Cm}_{2} \mathrm{O}_{3}$ & $1.033 \mathrm{E}-09$ & $6.266 \mathrm{E}-11$ & $3.164 \mathrm{E}-10$ & $5.286 \mathrm{E}-10$ & $2.471 \mathrm{E}-11$ & $1.914 \mathrm{E}-10$ & $1.745 \mathrm{E}-11$ \\
\hline $\mathrm{CoO}$ & $1.011 \mathrm{E}-04$ & $1.020 \mathrm{E}-04$ & $1.022 \mathrm{E}-04$ & $1.293 \mathrm{E}-04$ & $7.140 \mathrm{E}-05$ & $2.019 \mathrm{E}-04$ & $8.890 \mathrm{E}-05$ \\
\hline $\mathrm{Cr}_{2} \mathrm{O}_{3}$ & $8.147 \mathrm{E}-03$ & $1.382 \mathrm{E}-02$ & $1.237 \mathrm{E}-02$ & $1.308 \mathrm{E}-02$ & $2.275 \mathrm{E}-02$ & $2.940 \mathrm{E}-02$ & $1.850 \mathrm{E}-02$ \\
\hline $\mathrm{Cs}_{2} \mathrm{O}$ & $9.631 \mathrm{E}-05$ & $1.548 \mathrm{E}-04$ & $2.170 \mathrm{E}-04$ & 3.539E-04 & 3.313E-04 & $1.858 \mathrm{E}-04$ & $1.296 \mathrm{E}-04$ \\
\hline $\mathrm{CuO}$ & $7.157 \mathrm{E}-04$ & $1.668 \mathrm{E}-04$ & $3.605 \mathrm{E}-04$ & $2.303 \mathrm{E}-04$ & $1.697 \mathrm{E}-04$ & $3.538 \mathrm{E}-04$ & $6.236 \mathrm{E}-05$ \\
\hline $\mathrm{Eu}_{2} \mathrm{O}_{3}$ & $2.506 \mathrm{E}-08$ & $3.156 \mathrm{E}-09$ & $1.009 \mathrm{E}-08$ & $2.843 \mathrm{E}-08$ & $1.313 \mathrm{E}-09$ & $5.905 \mathrm{E}-09$ & $9.084 \mathrm{E}-10$ \\
\hline $\mathbf{F}$ & $1.510 \mathrm{E}-03$ & $2.824 \mathrm{E}-02$ & $1.611 \mathrm{E}-03$ & $1.250 \mathrm{E}-03$ & $1.423 \mathrm{E}-02$ & $5.520 \mathrm{E}-03$ & $5.312 \mathrm{E}-03$ \\
\hline $\mathrm{Fe}_{2} \mathrm{O}_{3}$ & $3.345 \mathrm{E}-01$ & $1.139 \mathrm{E}-01$ & $1.881 \mathrm{E}-01$ & $1.472 \mathrm{E}-01$ & $5.818 \mathrm{E}-02$ & $1.481 \mathrm{E}-01$ & $1.088 \mathrm{E}-01$ \\
\hline $\mathrm{HgO}$ & $5.291 \mathrm{E}-04$ & $1.203 \mathrm{E}-04$ & $1.397 \mathrm{E}-04$ & $3.828 \mathrm{E}-05$ & $8.747 \mathrm{E}-05$ & $1.136 \mathrm{E}-04$ & $1.576 \mathrm{E}-04$ \\
\hline I & $1.881 \mathrm{E}-06$ & 1.159E-06 & $2.830 \mathrm{E}-06$ & $3.361 \mathrm{E}-06$ & $9.455 \mathrm{E}-07$ & $1.378 \mathrm{E}-06$ & $2.137 \mathrm{E}-07$ \\
\hline $\mathrm{K}_{2} \mathrm{O}$ & $7.930 \mathrm{E}-03$ & $4.897 \mathrm{E}-03$ & $1.035 \mathrm{E}-02$ & $5.398 \mathrm{E}-03$ & 5.854E-03 & $7.485 \mathrm{E}-03$ & $4.535 \mathrm{E}-03$ \\
\hline $\mathrm{La}_{2} \mathrm{O}_{3}$ & $1.846 \mathrm{E}-03$ & $4.405 \mathrm{E}-04$ & $6.722 \mathrm{E}-03$ & $2.678 \mathrm{E}-03$ & $2.115 \mathrm{E}-03$ & $9.682 \mathrm{E}-03$ & $9.890 \mathrm{E}-04$ \\
\hline $\mathrm{Li}_{2} \mathrm{O}$ & $1.971 \mathrm{E}-04$ & $4.094 \mathrm{E}-04$ & $2.455 \mathrm{E}-04$ & $3.416 \mathrm{E}-04$ & $3.866 \mathrm{E}-04$ & $8.209 \mathrm{E}-04$ & $2.124 \mathrm{E}-04$ \\
\hline $\mathrm{MgO}$ & $3.454 \mathrm{E}-03$ & $1.647 \mathrm{E}-03$ & $4.078 \mathrm{E}-03$ & $1.335 \mathrm{E}-03$ & $1.828 \mathrm{E}-03$ & $6.126 \mathrm{E}-03$ & $1.031 \mathrm{E}-03$ \\
\hline MnO & $4.785 \mathrm{E}-02$ & $5.780 \mathrm{E}-03$ & $2.888 \mathrm{E}-02$ & $9.717 \mathrm{E}-03$ & $1.187 \mathrm{E}-02$ & $3.032 \mathrm{E}-02$ & $9.469 \mathrm{E}-03$ \\
\hline $\mathrm{MoO}_{3}$ & $1.152 \mathrm{E}-04$ & $3.733 \mathrm{E}-04$ & $3.213 \mathrm{E}-04$ & $2.235 \mathrm{E}-04$ & $2.754 \mathrm{E}-04$ & $5.377 \mathrm{E}-04$ & $2.712 \mathrm{E}-04$ \\
\hline $\mathrm{Na}_{2} \mathrm{O}$ & $2.055 \mathrm{E}-01$ & $2.477 \mathrm{E}-01$ & $1.265 \mathrm{E}-01$ & $1.212 \mathrm{E}-01$ & $1.482 \mathrm{E}-01$ & $1.678 \mathrm{E}-01$ & $1.281 \mathrm{E}-01$ \\
\hline $\mathrm{Nb}_{2} \mathrm{O}_{5}$ & $2.025 \mathrm{E}-10$ & $6.334 \mathrm{E}-10$ & $4.959 \mathrm{E}-10$ & $5.123 \mathrm{E}-10$ & $9.847 \mathrm{E}-10$ & $1.854 \mathrm{E}-09$ & $9.763 \mathrm{E}-10$ \\
\hline $\mathrm{Nd}_{2} \mathrm{O}_{3}$ & $3.161 \mathrm{E}-03$ & $7.523 \mathrm{E}-04$ & $1.076 \mathrm{E}-03$ & $1.920 \mathrm{E}-03$ & 3.529E-04 & $1.165 \mathrm{E}-03$ & $2.862 \mathrm{E}-04$ \\
\hline $\mathrm{NiO}$ & $1.667 \mathrm{E}-02$ & $7.781 \mathrm{E}-03$ & $4.176 \mathrm{E}-02$ & $2.463 \mathrm{E}-02$ & $1.289 \mathrm{E}-02$ & $3.070 \mathrm{E}-02$ & $6.909 \mathrm{E}-03$ \\
\hline $\mathrm{NpO}_{2}$ & $1.710 \mathrm{E}-05$ & $6.820 \mathrm{E}-06$ & $2.775 \mathrm{E}-05$ & $5.094 \mathrm{E}-05$ & $9.077 \mathrm{E}-06$ & $1.800 \mathrm{E}-05$ & $7.029 \mathrm{E}-06$ \\
\hline $\mathrm{P}_{2} \mathrm{O}_{5}$ & $1.733 \mathrm{E}-02$ & $6.742 \mathrm{E}-02$ & $4.272 \mathrm{E}-02$ & $1.161 \mathrm{E}-02$ & $4.523 \mathrm{E}-02$ & $4.345 \mathrm{E}-02$ & $3.577 \mathrm{E}-02$ \\
\hline $\mathrm{Pa}_{2} \mathrm{O}_{5}$ & $2.739 \mathrm{E}-09$ & $9.092 \mathrm{E}-09$ & $8.297 \mathrm{E}-09$ & $8.231 \mathrm{E}-09$ & $8.421 \mathrm{E}-09$ & $6.972 \mathrm{E}-09$ & $3.669 \mathrm{E}-09$ \\
\hline $\mathrm{PbO}$ & $1.308 \mathrm{E}-02$ & $6.277 \mathrm{E}-03$ & $6.292 \mathrm{E}-03$ & $5.774 \mathrm{E}-03$ & $2.471 \mathrm{E}-03$ & $7.410 \mathrm{E}-03$ & $4.199 \mathrm{E}-03$ \\
\hline $\mathrm{PdO}$ & $2.466 \mathrm{E}-05$ & $1.969 \mathrm{E}-05$ & $1.295 \mathrm{E}-06$ & $2.562 \mathrm{E}-04$ & $4.543 \mathrm{E}-06$ & $3.035 \mathrm{E}-06$ & $1.026 \mathrm{E}-07$ \\
\hline $\mathrm{Pr}_{2} \mathrm{O}_{3}$ & $7.926 \mathrm{E}-04$ & $4.669 \mathrm{E}-05$ & $9.009 \mathrm{E}-05$ & $2.791 \mathrm{E}-04$ & $8.270 \mathrm{E}-06$ & $1.029 \mathrm{E}-04$ & $1.199 \mathrm{E}-06$ \\
\hline $\mathrm{PuO}_{2}$ & $1.205 \mathrm{E}-04$ & $2.420 \mathrm{E}-05$ & $1.848 \mathrm{E}-04$ & $2.273 \mathrm{E}-04$ & $9.442 \mathrm{E}-05$ & $1.505 \mathrm{E}-04$ & $3.648 \mathrm{E}-05$ \\
\hline $\mathrm{RaO}$ & $6.810 \mathrm{E}-12$ & $1.951 \mathrm{E}-12$ & $2.202 \mathrm{E}-11$ & $1.427 \mathrm{E}-11$ & $9.471 \mathrm{E}-13$ & $6.725 \mathrm{E}-12$ & $5.707 \mathrm{E}-13$ \\
\hline $\mathrm{Rb}_{2} \mathrm{O}$ & 9.194E-05 & $1.320 \mathrm{E}-05$ & $2.946 \mathrm{E}-04$ & $1.385 \mathrm{E}-04$ & $4.436 \mathrm{E}-06$ & $4.902 \mathrm{E}-05$ & $2.131 \mathrm{E}-07$ \\
\hline $\mathrm{Rh}_{2} \mathrm{O}_{3}$ & $1.175 \mathrm{E}-04$ & $2.020 \mathrm{E}-05$ & $2.010 \mathrm{E}-04$ & $6.269 \mathrm{E}-05$ & $6.218 \mathrm{E}-06$ & $5.569 \mathrm{E}-05$ & $5.625 \mathrm{E}-07$ \\
\hline $\mathrm{RuO}_{2}$ & $1.457 \mathrm{E}-03$ & $8.653 \mathrm{E}-05$ & $6.312 \mathrm{E}-05$ & $6.386 \mathrm{E}-04$ & $1.882 \mathrm{E}-05$ & $4.524 \mathrm{E}-04$ & $3.058 \mathrm{E}-06$ \\
\hline $\mathrm{SO}_{3}$ & 4.422E-03 & $9.053 \mathrm{E}-03$ & $6.726 \mathrm{E}-03$ & $2.695 \mathrm{E}-03$ & $1.219 \mathrm{E}-02$ & $1.406 \mathrm{E}-02$ & $8.629 \mathrm{E}-03$ \\
\hline $\mathrm{Sb}_{2} \mathrm{O}_{3}$ & $7.350 \mathrm{E}-05$ & $2.763 \mathrm{E}-04$ & $2.540 \mathrm{E}-04$ & $9.040 \mathrm{E}-05$ & $1.664 \mathrm{E}-04$ & $2.587 \mathrm{E}-04$ & $1.451 \mathrm{E}-04$ \\
\hline $\mathrm{SeO}_{2}$ & $1.224 \mathrm{E}-05$ & $3.244 \mathrm{E}-05$ & $4.592 \mathrm{E}-05$ & $2.349 \mathrm{E}-05$ & $1.074 \mathrm{E}-05$ & $4.421 \mathrm{E}-05$ & $1.352 \mathrm{E}-05$ \\
\hline $\mathrm{SiO}_{2}$ & $6.363 \mathrm{E}-02$ & $9.346 \mathrm{E}-02$ & $4.117 \mathrm{E}-02$ & $1.044 \mathrm{E}-01$ & $3.426 \mathrm{E}-02$ & $5.068 \mathrm{E}-02$ & $7.488 \mathrm{E}-02$ \\
\hline $\mathrm{Sm}_{2} \mathrm{O}_{3}$ & $9.041 \mathrm{E}-06$ & $4.391 \mathrm{E}-06$ & $1.146 \mathrm{E}-05$ & $1.452 \mathrm{E}-05$ & $5.250 \mathrm{E}-06$ & $1.880 \mathrm{E}-05$ & $6.275 \mathrm{E}-06$ \\
\hline $\mathrm{SnO}_{2}$ & 3.369E-06 & $9.744 \mathrm{E}-07$ & $7.309 \mathrm{E}-07$ & $7.273 \mathrm{E}-07$ & $1.489 \mathrm{E}-06$ & $2.488 \mathrm{E}-06$ & $1.367 \mathrm{E}-06$ \\
\hline $\mathrm{SrO}$ & $7.576 \mathrm{E}-04$ & $9.782 \mathrm{E}-03$ & $1.293 \mathrm{E}-03$ & $2.218 \mathrm{E}-03$ & 7.342E-03 & $3.830 \mathrm{E}-03$ & $1.778 \mathrm{E}-03$ \\
\hline
\end{tabular}




\begin{tabular}{|c|c|c|c|c|c|c|c|}
\hline Cluster \# & $\mathbf{1}$ & $\mathbf{2}$ & $\mathbf{3}$ & $\mathbf{4}$ & $\mathbf{5}$ & $\mathbf{6}$ & $\mathbf{7}$ \\
\hline $\mathrm{Ta}_{2} \mathrm{O}_{5}$ & $6.268 \mathrm{E}-06$ & $6.185 \mathrm{E}-07$ & $2.207 \mathrm{E}-06$ & $2.256 \mathrm{E}-06$ & $1.955 \mathrm{E}-07$ & $1.198 \mathrm{E}-06$ & $2.170 \mathrm{E}-08$ \\
\hline $\mathrm{Tc}_{2} \mathrm{O}_{7}$ & $1.623 \mathrm{E}-05$ & $2.915 \mathrm{E}-05$ & $3.544 \mathrm{E}-05$ & $3.085 \mathrm{E}-05$ & $3.333 \mathrm{E}-05$ & $5.708 \mathrm{E}-05$ & $3.367 \mathrm{E}-05$ \\
\hline $\mathrm{TeO}_{2}$ & $2.814 \mathrm{E}-04$ & $1.727 \mathrm{E}-05$ & $3.602 \mathrm{E}-05$ & $1.345 \mathrm{E}-04$ & $2.635 \mathrm{E}-06$ & $7.729 \mathrm{E}-05$ & $4.667 \mathrm{E}-07$ \\
\hline $\mathbf{T h O}_{\mathbf{2}}$ & $1.599 \mathrm{E}-02$ & $3.749 \mathrm{E}-03$ & $5.045 \mathrm{E}-02$ & $3.054 \mathrm{E}-02$ & $5.828 \mathrm{E}-04$ & $8.115 \mathrm{E}-03$ & $2.545 \mathrm{E}-04$ \\
\hline $\mathrm{TiO}_{2}$ & $6.064 \mathrm{E}-04$ & $1.507 \mathrm{E}-04$ & $3.796 \mathrm{E}-04$ & $1.223 \mathrm{E}-04$ & $2.316 \mathrm{E}-04$ & $2.763 \mathrm{E}-04$ & $6.727 \mathrm{E}-05$ \\
\hline $\mathrm{Tl}_{2} \mathrm{O}$ & $5.974 \mathrm{E}-04$ & $2.685 \mathrm{E}-04$ & $1.861 \mathrm{E}-04$ & $1.291 \mathrm{E}-04$ & $3.530 \mathrm{E}-04$ & $5.376 \mathrm{E}-04$ & $3.568 \mathrm{E}-04$ \\
\hline $\mathbf{U O}_{3}$ & $3.267 \mathrm{E}-02$ & $3.919 \mathrm{E}-02$ & $9.467 \mathrm{E}-02$ & $5.714 \mathrm{E}-02$ & $5.331 \mathrm{E}-02$ & $5.479 \mathrm{E}-02$ & $5.310 \mathrm{E}-02$ \\
\hline $\mathrm{V}_{2} \mathrm{O}_{5}$ & $9.330 \mathrm{E}-05$ & $3.511 \mathrm{E}-04$ & $2.560 \mathrm{E}-04$ & $1.564 \mathrm{E}-04$ & $2.390 \mathrm{E}-04$ & $4.575 \mathrm{E}-04$ & $2.239 \mathrm{E}-04$ \\
\hline $\mathrm{WO}_{3}$ & $2.054 \mathrm{E}-06$ & $3.010 \mathrm{E}-05$ & $3.209 \mathrm{E}-05$ & $9.988 \mathrm{E}-05$ & $2.738 \mathrm{E}-05$ & $3.841 \mathrm{E}-04$ & $3.366 \mathrm{E}-07$ \\
\hline $\mathrm{Y}_{2} \mathrm{O}_{3}$ & $3.198 \mathrm{E}-04$ & $3.216 \mathrm{E}-05$ & $6.178 \mathrm{E}-05$ & $1.006 \mathrm{E}-04$ & $1.619 \mathrm{E}-05$ & $8.724 \mathrm{E}-05$ & $6.012 \mathrm{E}-06$ \\
\hline $\mathrm{ZnO}$ & $8.606 \mathrm{E}-04$ & $3.641 \mathrm{E}-04$ & $1.423 \mathrm{E}-03$ & $2.864 \mathrm{E}-04$ & $9.486 \mathrm{E}-04$ & $8.190 \mathrm{E}-04$ & $2.020 \mathrm{E}-04$ \\
\hline $\mathbf{Z r O} \mathbf{O}_{2}$ & $3.291 \mathrm{E}-02$ & $3.384 \mathrm{E}-03$ & $1.112 \mathrm{E}-01$ & $3.334 \mathrm{E}-02$ & $5.284 \mathrm{E}-02$ & $2.826 \mathrm{E}-02$ & $1.876 \mathrm{E}-03$ \\
\hline $\mathrm{SUM}$ & 1 & 1 & 1 & 1 & 1 & 1 & 1 \\
\hline $\begin{array}{c}\mathrm{O} \\
\text { maside }\end{array}$ & 405.155 & 338.933 & 266.291 & 220.917 & 719.021 & 364.147 & \multirow{2}{*}{$1,839.578$} \\
\hline
\end{tabular}


Table A.1. (Continued)

\begin{tabular}{|c|c|c|c|c|c|c|c|}
\hline Cluster \# & 8 & 9 & 10 & 11 & 12 & 13 & 14 \\
\hline $\mathrm{Ac}_{2} \mathrm{O}_{3}$ & $2.861 \mathrm{E}-12$ & $5.760 \mathrm{E}-12$ & $9.465 \mathrm{E}-12$ & $6.502 \mathrm{E}-12$ & $1.139 \mathrm{E}-11$ & $8.172 \mathrm{E}-12$ & $2.518 \mathrm{E}-12$ \\
\hline $\mathrm{Ag}_{2} \mathrm{O}$ & $2.826 \mathrm{E}-04$ & $4.437 \mathrm{E}-04$ & $1.190 \mathrm{E}-03$ & $1.786 \mathrm{E}-04$ & $2.609 \mathrm{E}-04$ & $1.905 \mathrm{E}-04$ & $1.896 \mathrm{E}-04$ \\
\hline $\mathbf{A l}_{2} \mathbf{O}_{3}$ & $4.167 \mathrm{E}-01$ & $9.320 \mathrm{E}-02$ & $1.889 \mathrm{E}-01$ & $2.831 \mathrm{E}-01$ & $1.638 \mathrm{E}-01$ & $2.263 \mathrm{E}-01$ & $3.221 \mathrm{E}-01$ \\
\hline $\mathrm{Am}_{2} \mathrm{O}_{3}$ & $1.995 \mathrm{E}-06$ & $1.006 \mathrm{E}-06$ & $8.212 \mathrm{E}-06$ & $6.320 \mathrm{E}-07$ & $6.970 \mathrm{E}-07$ & $2.509 \mathrm{E}-06$ & $1.095 \mathrm{E}-05$ \\
\hline $\mathrm{As}_{2} \mathrm{O}_{5}$ & $9.659 \mathrm{E}-04$ & $1.008 \mathrm{E}-03$ & $2.835 \mathrm{E}-04$ & $2.842 \mathrm{E}-04$ & $2.200 \mathrm{E}-04$ & $4.618 \mathrm{E}-04$ & $7.141 \mathrm{E}-04$ \\
\hline $\mathrm{B}_{2} \mathrm{O}_{3}$ & $6.356 \mathrm{E}-03$ & $5.349 \mathrm{E}-03$ & $3.106 \mathrm{E}-03$ & $2.148 \mathrm{E}-03$ & $2.138 \mathrm{E}-03$ & $2.364 \mathrm{E}-03$ & $3.147 \mathrm{E}-03$ \\
\hline $\mathrm{BaO}$ & $8.513 \mathrm{E}-04$ & $6.097 \mathrm{E}-04$ & $3.713 \mathrm{E}-03$ & $7.178 \mathrm{E}-04$ & 4.849E-04 & $5.198 \mathrm{E}-04$ & $3.282 \mathrm{E}-04$ \\
\hline $\mathrm{BeO}$ & $1.110 \mathrm{E}-04$ & $1.139 \mathrm{E}-04$ & $8.029 \mathrm{E}-05$ & $1.108 \mathrm{E}-03$ & $7.391 \mathrm{E}-05$ & $2.446 \mathrm{E}-04$ & $9.526 \mathrm{E}-04$ \\
\hline $\mathbf{B i}_{2} \mathbf{O}_{3}$ & $1.849 \mathrm{E}-02$ & $1.306 \mathrm{E}-02$ & $1.703 \mathrm{E}-02$ & $5.720 \mathrm{E}-02$ & $3.411 \mathrm{E}-02$ & $2.465 \mathrm{E}-02$ & $1.761 \mathrm{E}-02$ \\
\hline $\mathrm{CaO}$ & $2.467 \mathrm{E}-02$ & $2.574 \mathrm{E}-02$ & $2.411 \mathrm{E}-02$ & $2.481 \mathrm{E}-02$ & $3.012 \mathrm{E}-02$ & $2.483 \mathrm{E}-02$ & $2.159 \mathrm{E}-02$ \\
\hline $\mathrm{CdO}$ & $2.322 \mathrm{E}-04$ & $4.117 \mathrm{E}-04$ & $7.696 \mathrm{E}-04$ & $3.183 \mathrm{E}-04$ & $2.406 \mathrm{E}-04$ & 4.534E-04 & $7.921 \mathrm{E}-04$ \\
\hline $\mathrm{Ce}_{2} \mathrm{O}_{3}$ & $8.569 \mathrm{E}-04$ & $8.024 \mathrm{E}-04$ & $1.621 \mathrm{E}-03$ & $3.961 \mathrm{E}-04$ & $2.183 \mathrm{E}-04$ & $3.294 \mathrm{E}-04$ & $7.618 \mathrm{E}-04$ \\
\hline $\mathrm{Cl}$ & $1.138 \mathrm{E}-03$ & $1.728 \mathrm{E}-03$ & $2.354 \mathrm{E}-03$ & $2.315 \mathrm{E}-03$ & $2.011 \mathrm{E}-03$ & $2.534 \mathrm{E}-03$ & $2.323 \mathrm{E}-03$ \\
\hline $\mathrm{Cm}_{2} \mathrm{O}_{3}$ & $2.526 \mathrm{E}-11$ & $1.690 \mathrm{E}-11$ & $4.751 \mathrm{E}-10$ & $8.168 \mathrm{E}-12$ & $8.389 \mathrm{E}-12$ & $5.225 \mathrm{E}-11$ & $1.597 \mathrm{E}-10$ \\
\hline $\mathrm{CoO}$ & $1.871 \mathrm{E}-04$ & $1.635 \mathrm{E}-04$ & $1.117 \mathrm{E}-04$ & $2.947 \mathrm{E}-04$ & $1.198 \mathrm{E}-04$ & $1.262 \mathrm{E}-04$ & $1.447 \mathrm{E}-04$ \\
\hline $\mathrm{Cr}_{2} \mathrm{O}_{3}$ & $1.995 \mathrm{E}-02$ & $2.734 \mathrm{E}-02$ & $6.665 \mathrm{E}-03$ & $2.215 \mathrm{E}-02$ & 7.707E-02 & $2.901 \mathrm{E}-02$ & 7.395E-02 \\
\hline $\mathrm{Cs}_{2} \mathrm{O}$ & $7.785 \mathrm{E}-05$ & $1.801 \mathrm{E}-04$ & $4.815 \mathrm{E}-04$ & $1.563 \mathrm{E}-04$ & $1.583 \mathrm{E}-04$ & $2.630 \mathrm{E}-04$ & $3.100 \mathrm{E}-04$ \\
\hline $\mathrm{CuO}$ & $2.131 \mathrm{E}-04$ & $1.842 \mathrm{E}-04$ & $7.862 \mathrm{E}-04$ & $1.453 \mathrm{E}-04$ & $9.759 \mathrm{E}-05$ & $2.628 \mathrm{E}-04$ & $1.431 \mathrm{E}-04$ \\
\hline $\mathrm{Eu}_{2} \mathrm{O}_{3}$ & $1.197 \mathrm{E}-09$ & $4.184 \mathrm{E}-10$ & $1.282 \mathrm{E}-08$ & $9.064 \mathrm{E}-10$ & $1.925 \mathrm{E}-09$ & $3.323 \mathrm{E}-09$ & $7.215 \mathrm{E}-09$ \\
\hline $\mathbf{F}$ & $1.084 \mathrm{E}-02$ & $6.990 \mathrm{E}-03$ & $4.475 \mathrm{E}-03$ & $6.069 \mathrm{E}-02$ & $5.005 \mathrm{E}-02$ & $2.286 \mathrm{E}-02$ & $4.385 \mathrm{E}-03$ \\
\hline $\mathrm{Fe}_{2} \mathrm{O}_{3}$ & $1.072 \mathrm{E}-01$ & $6.675 \mathrm{E}-02$ & $2.988 \mathrm{E}-01$ & $9.548 \mathrm{E}-02$ & $1.223 \mathrm{E}-01$ & $1.013 \mathrm{E}-01$ & 8.489E-02 \\
\hline $\mathrm{HgO}$ & $1.845 \mathrm{E}-04$ & $1.027 \mathrm{E}-04$ & $1.993 \mathrm{E}-04$ & $5.042 \mathrm{E}-05$ & $1.268 \mathrm{E}-04$ & $1.140 \mathrm{E}-04$ & 4.970E-05 \\
\hline I & $7.550 \mathrm{E}-07$ & $2.819 \mathrm{E}-06$ & $1.657 \mathrm{E}-06$ & $7.672 \mathrm{E}-07$ & $1.966 \mathrm{E}-06$ & $1.516 \mathrm{E}-06$ & $1.062 \mathrm{E}-06$ \\
\hline $\mathrm{K}_{2} \mathrm{O}$ & $3.643 \mathrm{E}-03$ & $2.527 \mathrm{E}-02$ & $6.458 \mathrm{E}-03$ & $5.571 \mathrm{E}-03$ & $1.049 \mathrm{E}-02$ & $4.620 \mathrm{E}-03$ & $7.253 \mathrm{E}-03$ \\
\hline $\mathrm{La}_{2} \mathrm{O}_{3}$ & $6.655 \mathrm{E}-04$ & $1.847 \mathrm{E}-04$ & $2.491 \mathrm{E}-03$ & $3.466 \mathrm{E}-04$ & $4.813 \mathrm{E}-03$ & $1.842 \mathrm{E}-03$ & 7.602E-04 \\
\hline $\mathrm{Li}_{2} \mathrm{O}$ & $4.116 \mathrm{E}-04$ & $6.225 \mathrm{E}-04$ & $4.395 \mathrm{E}-04$ & $9.167 \mathrm{E}-04$ & $3.228 \mathrm{E}-04$ & $3.458 \mathrm{E}-04$ & $9.066 \mathrm{E}-04$ \\
\hline $\mathrm{MgO}$ & $3.358 \mathrm{E}-03$ & $3.914 \mathrm{E}-03$ & $7.970 \mathrm{E}-03$ & $1.429 \mathrm{E}-03$ & $2.048 \mathrm{E}-03$ & $2.374 \mathrm{E}-03$ & $1.176 \mathrm{E}-03$ \\
\hline MnO & $1.822 \mathrm{E}-02$ & $5.850 \mathrm{E}-03$ & $2.167 \mathrm{E}-02$ & $5.289 \mathrm{E}-03$ & $1.228 \mathrm{E}-02$ & $8.785 \mathrm{E}-03$ & $2.030 \mathrm{E}-02$ \\
\hline $\mathrm{MoO}_{3}$ & $7.838 \mathrm{E}-04$ & $1.258 \mathrm{E}-03$ & $2.630 \mathrm{E}-04$ & $5.609 \mathrm{E}-04$ & $4.163 \mathrm{E}-04$ & $3.895 \mathrm{E}-04$ & $5.524 \mathrm{E}-04$ \\
\hline $\mathrm{Na}_{2} \mathrm{O}$ & $1.184 \mathrm{E}-01$ & $5.398 \mathrm{E}-01$ & $1.336 \mathrm{E}-01$ & $1.233 \mathrm{E}-01$ & $1.426 \mathrm{E}-01$ & $2.277 \mathrm{E}-01$ & $1.931 \mathrm{E}-01$ \\
\hline $\mathrm{Nb}_{2} \mathrm{O}_{5}$ & $1.173 \mathrm{E}-09$ & $1.362 \mathrm{E}-09$ & $1.225 \mathrm{E}-09$ & $9.086 \mathrm{E}-10$ & $1.157 \mathrm{E}-09$ & $8.291 \mathrm{E}-10$ & $2.454 \mathrm{E}-09$ \\
\hline $\mathrm{Nd}_{2} \mathrm{O}_{3}$ & $9.816 \mathrm{E}-04$ & $7.868 \mathrm{E}-04$ & $2.038 \mathrm{E}-03$ & $2.879 \mathrm{E}-04$ & $2.004 \mathrm{E}-04$ & $4.689 \mathrm{E}-04$ & $1.059 \mathrm{E}-03$ \\
\hline $\mathrm{NiO}$ & $6.381 \mathrm{E}-03$ & $4.857 \mathrm{E}-03$ & $2.040 \mathrm{E}-02$ & $7.765 \mathrm{E}-03$ & $3.136 \mathrm{E}-02$ & $1.544 \mathrm{E}-02$ & $3.864 \mathrm{E}-03$ \\
\hline $\mathrm{NpO}_{2}$ & $1.039 \mathrm{E}-05$ & $7.425 \mathrm{E}-06$ & $8.707 \mathrm{E}-06$ & $5.920 \mathrm{E}-06$ & $1.111 \mathrm{E}-05$ & $9.865 \mathrm{E}-06$ & $2.726 \mathrm{E}-05$ \\
\hline $\mathbf{P}_{2} \mathbf{O}_{5}$ & $2.156 \mathrm{E}-02$ & $2.433 \mathrm{E}-02$ & $1.657 \mathrm{E}-02$ & $4.418 \mathrm{E}-02$ & $1.113 \mathrm{E}-01$ & $1.165 \mathrm{E}-01$ & $1.114 \mathrm{E}-01$ \\
\hline $\mathrm{Pa}_{2} \mathrm{O}_{5}$ & $5.746 \mathrm{E}-09$ & $1.098 \mathrm{E}-08$ & $3.726 \mathrm{E}-09$ & $1.697 \mathrm{E}-08$ & $2.906 \mathrm{E}-08$ & $1.458 \mathrm{E}-08$ & $7.220 \mathrm{E}-09$ \\
\hline $\mathrm{PbO}$ & $7.985 \mathrm{E}-03$ & $5.831 \mathrm{E}-03$ & $1.576 \mathrm{E}-02$ & $2.794 \mathrm{E}-03$ & $3.956 \mathrm{E}-03$ & $4.130 \mathrm{E}-03$ & 4.184E-03 \\
\hline $\mathrm{PdO}$ & $3.294 \mathrm{E}-08$ & $1.175 \mathrm{E}-07$ & $1.502 \mathrm{E}-07$ & $7.001 \mathrm{E}-07$ & $1.504 \mathrm{E}-06$ & $2.345 \mathrm{E}-05$ & $2.610 \mathrm{E}-05$ \\
\hline $\mathrm{Pr}_{2} \mathrm{O}_{3}$ & $3.305 \mathrm{E}-07$ & $3.907 \mathrm{E}-06$ & $2.821 \mathrm{E}-04$ & $3.054 \mathrm{E}-06$ & $7.916 \mathrm{E}-06$ & $3.895 \mathrm{E}-05$ & $4.786 \mathrm{E}-05$ \\
\hline $\mathrm{PuO}_{2}$ & 7.191E-05 & $6.146 \mathrm{E}-05$ & $1.751 \mathrm{E}-04$ & $2.235 \mathrm{E}-05$ & $3.651 \mathrm{E}-05$ & $5.096 \mathrm{E}-05$ & $2.729 \mathrm{E}-04$ \\
\hline $\mathrm{RaO}$ & $1.728 \mathrm{E}-12$ & $3.542 \mathrm{E}-12$ & $9.219 \mathrm{E}-12$ & $1.453 \mathrm{E}-12$ & $2.413 \mathrm{E}-12$ & $3.051 \mathrm{E}-12$ & $1.167 \mathrm{E}-12$ \\
\hline $\mathrm{Rb}_{2} \mathrm{O}$ & $6.925 \mathrm{E}-07$ & $9.527 \mathrm{E}-06$ & $1.110 \mathrm{E}-04$ & $6.614 \mathrm{E}-07$ & $2.260 \mathrm{E}-05$ & $1.742 \mathrm{E}-05$ & $1.692 \mathrm{E}-05$ \\
\hline $\mathrm{Rh}_{2} \mathrm{O}_{3}$ & $5.102 \mathrm{E}-07$ & $6.522 \mathrm{E}-06$ & $1.483 \mathrm{E}-04$ & $1.109 \mathrm{E}-06$ & $1.636 \mathrm{E}-05$ & $1.191 \mathrm{E}-05$ & $3.253 \mathrm{E}-05$ \\
\hline $\mathrm{RuO}_{2}$ & 5.043E-07 & $3.716 \mathrm{E}-06$ & $1.577 \mathrm{E}-03$ & $6.449 \mathrm{E}-06$ & $7.060 \mathrm{E}-06$ & $1.797 \mathrm{E}-04$ & $1.463 \mathrm{E}-04$ \\
\hline $\mathrm{SO}_{3}$ & $8.611 \mathrm{E}-03$ & $3.498 \mathrm{E}-03$ & $4.380 \mathrm{E}-03$ & $2.140 \mathrm{E}-02$ & $2.194 \mathrm{E}-02$ & $1.096 \mathrm{E}-02$ & $1.983 \mathrm{E}-02$ \\
\hline $\mathrm{Sb}_{2} \mathrm{O}_{3}$ & $3.157 \mathrm{E}-04$ & $3.856 \mathrm{E}-04$ & $1.141 \mathrm{E}-04$ & $3.669 \mathrm{E}-04$ & $2.832 \mathrm{E}-04$ & $1.682 \mathrm{E}-04$ & $2.705 \mathrm{E}-04$ \\
\hline $\mathrm{SeO}_{2}$ & $4.670 \mathrm{E}-05$ & $1.715 \mathrm{E}-04$ & $2.312 \mathrm{E}-05$ & $4.122 \mathrm{E}-05$ & $2.698 \mathrm{E}-05$ & $2.153 \mathrm{E}-05$ & $5.154 \mathrm{E}-05$ \\
\hline $\mathrm{SiO}_{2}$ & $1.106 \mathrm{E}-01$ & $8.500 \mathrm{E}-02$ & $6.684 \mathrm{E}-02$ & $1.840 \mathrm{E}-01$ & $5.862 \mathrm{E}-02$ & $6.146 \mathrm{E}-02$ & $4.315 \mathrm{E}-02$ \\
\hline $\mathrm{Sm}_{2} \mathrm{O}_{3}$ & $1.074 \mathrm{E}-05$ & $6.835 \mathrm{E}-06$ & $3.894 \mathrm{E}-05$ & $5.370 \mathrm{E}-06$ & 7.554E-06 & $6.890 \mathrm{E}-06$ & $1.289 \mathrm{E}-05$ \\
\hline $\mathrm{SnO}_{2}$ & $1.669 \mathrm{E}-06$ & $1.773 \mathrm{E}-06$ & $5.641 \mathrm{E}-07$ & $1.329 \mathrm{E}-06$ & $1.645 \mathrm{E}-06$ & $1.154 \mathrm{E}-06$ & $3.854 \mathrm{E}-06$ \\
\hline $\mathrm{SrO}$ & $3.632 \mathrm{E}-03$ & $4.118 \mathrm{E}-03$ & $1.185 \mathrm{E}-03$ & $5.293 \mathrm{E}-03$ & $2.434 \mathrm{E}-02$ & $1.476 \mathrm{E}-02$ & $5.208 \mathrm{E}-03$ \\
\hline $\mathrm{Ta}_{2} \mathrm{O}_{5}$ & $6.495 \mathrm{E}-09$ & 7.997E-08 & $1.997 \mathrm{E}-06$ & $5.408 \mathrm{E}-08$ & $1.904 \mathrm{E}-07$ & $3.579 \mathrm{E}-07$ & $1.257 \mathrm{E}-06$ \\
\hline $\mathrm{Tc}_{2} \mathrm{O}_{7}$ & $3.056 \mathrm{E}-05$ & 5.794E-05 & $2.836 \mathrm{E}-05$ & $4.318 \mathrm{E}-05$ & $3.353 \mathrm{E}-05$ & $4.569 \mathrm{E}-05$ & 4.942E-05 \\
\hline $\mathrm{TeO}_{2}$ & $1.252 \mathrm{E}-07$ & $1.432 \mathrm{E}-06$ & $2.588 \mathrm{E}-04$ & $9.689 \mathrm{E}-07$ & $3.001 \mathrm{E}-06$ & $2.470 \mathrm{E}-05$ & $1.646 \mathrm{E}-05$ \\
\hline $\mathrm{ThO}_{2}$ & $2.562 \mathrm{E}-03$ & $6.321 \mathrm{E}-03$ & $1.974 \mathrm{E}-02$ & $2.219 \mathrm{E}-03$ & $3.844 \mathrm{E}-03$ & $4.434 \mathrm{E}-03$ & $3.204 \mathrm{E}-04$ \\
\hline $\mathrm{TiO}_{2}$ & $2.175 \mathrm{E}-04$ & $1.485 \mathrm{E}-04$ & $4.568 \mathrm{E}-04$ & $2.108 \mathrm{E}-04$ & $1.951 \mathrm{E}-04$ & $1.799 \mathrm{E}-04$ & $1.467 \mathrm{E}-04$ \\
\hline
\end{tabular}




\begin{tabular}{|c|c|c|c|c|c|c|c|}
\hline Cluster \# & $\mathbf{8}$ & $\mathbf{9}$ & $\mathbf{1 0}$ & $\mathbf{1 1}$ & $\mathbf{1 2}$ & $\mathbf{1 3}$ & $\mathbf{1 4}$ \\
\hline $\mathrm{Tl}_{2} \mathrm{O}$ & $2.786 \mathrm{E}-04$ & $1.323 \mathrm{E}-03$ & $8.650 \mathrm{E}-05$ & $3.508 \mathrm{E}-04$ & $7.299 \mathrm{E}-05$ & $6.515 \mathrm{E}-04$ & $7.680 \mathrm{E}-04$ \\
\hline $\mathbf{U O}_{3}$ & $7.863 \mathrm{E}-02$ & $3.510 \mathrm{E}-02$ & $7.591 \mathrm{E}-02$ & $3.462 \mathrm{E}-02$ & $7.299 \mathrm{E}-02$ & $8.037 \mathrm{E}-02$ & $3.581 \mathrm{E}-02$ \\
\hline $\mathrm{V}_{2} \mathrm{O}_{5}$ & $5.918 \mathrm{E}-04$ & $5.951 \mathrm{E}-04$ & $1.925 \mathrm{E}-04$ & $5.806 \mathrm{E}-04$ & $3.676 \mathrm{E}-04$ & $3.252 \mathrm{E}-04$ & $4.361 \mathrm{E}-04$ \\
\hline $\mathrm{WO}_{3}$ & $1.214 \mathrm{E}-07$ & $2.125 \mathrm{E}-07$ & $8.826 \mathrm{E}-04$ & $5.783 \mathrm{E}-06$ & $3.242 \mathrm{E}-06$ & $6.023 \mathrm{E}-05$ & $1.877 \mathrm{E}-04$ \\
\hline $\mathrm{Y}_{2} \mathrm{O}_{3}$ & $8.329 \mathrm{E}-06$ & $2.149 \mathrm{E}-06$ & $2.802 \mathrm{E}-04$ & $3.596 \mathrm{E}-05$ & $1.292 \mathrm{E}-05$ & $2.712 \mathrm{E}-05$ & $4.174 \mathrm{E}-05$ \\
\hline $\mathrm{ZnO}$ & $5.645 \mathrm{E}-04$ & $1.031 \mathrm{E}-03$ & $9.655 \mathrm{E}-04$ & $5.562 \mathrm{E}-04$ & $6.448 \mathrm{E}-04$ & $5.424 \mathrm{E}-04$ & $5.363 \mathrm{E}-04$ \\
\hline $\mathbf{Z r O}$ & $2.122 \mathrm{E}-03$ & $5.230 \mathrm{E}-03$ & $4.399 \mathrm{E}-02$ & $6.245 \mathrm{E}-03$ & $1.301 \mathrm{E}-02$ & $6.116 \mathrm{E}-03$ & $1.361 \mathrm{E}-02$ \\
\hline $\mathrm{SUM}$ & 1 & 1 & 1 & 1 & 1 & 1 & 1 \\
\hline $\begin{array}{c}\text { Oxide } \\
\text { mass (MT) }\end{array}$ & $1,183.119$ & 143.796 & 733.959 & 533.009 & 275.181 & 209.397 & 173.318 \\
\hline
\end{tabular}


Table A.1. (Continued)

\begin{tabular}{|c|c|c|c|c|c|c|}
\hline Cluster \# & 15 & 16 & 17 & 18 & 19 & 20 \\
\hline $\mathrm{Ac}_{2} \mathrm{O}_{3}$ & $2.139 \mathrm{E}-12$ & $9.739 \mathrm{E}-13$ & $2.146 \mathrm{E}-12$ & $9.947 \mathrm{E}-12$ & $2.254 \mathrm{E}-11$ & $5.200 \mathrm{E}-12$ \\
\hline $\mathrm{Ag}_{2} \mathrm{O}$ & $2.797 \mathrm{E}-04$ & $1.143 \mathrm{E}-04$ & $1.348 \mathrm{E}-04$ & $1.165 \mathrm{E}-03$ & $3.112 \mathrm{E}-04$ & $2.698 \mathrm{E}-04$ \\
\hline $\mathrm{Al}_{2} \mathrm{O}_{3}$ & $1.303 \mathrm{E}-01$ & $5.719 \mathrm{E}-01$ & $1.836 \mathrm{E}-01$ & $2.009 \mathrm{E}-01$ & $2.846 \mathrm{E}-01$ & $2.337 \mathrm{E}-01$ \\
\hline $\mathrm{Am}_{2} \mathrm{O}_{3}$ & $3.183 \mathrm{E}-06$ & $9.039 \mathrm{E}-07$ & $1.703 \mathrm{E}-05$ & $5.199 \mathrm{E}-05$ & $1.401 \mathrm{E}-05$ & $2.036 \mathrm{E}-06$ \\
\hline $\mathrm{As}_{2} \mathrm{O}_{5}$ & $2.667 \mathrm{E}-04$ & $3.762 \mathrm{E}-04$ & $5.786 \mathrm{E}-04$ & $3.522 \mathrm{E}-04$ & $2.148 \mathrm{E}-04$ & $5.230 \mathrm{E}-04$ \\
\hline $\mathrm{B}_{2} \mathrm{O}_{3}$ & $1.983 \mathrm{E}-03$ & $2.101 \mathrm{E}-03$ & $1.420 \mathrm{E}-03$ & $2.679 \mathrm{E}-03$ & $1.116 \mathrm{E}-03$ & $3.681 \mathrm{E}-03$ \\
\hline $\mathrm{BaO}$ & $5.001 \mathrm{E}-04$ & $2.210 \mathrm{E}-04$ & $6.212 \mathrm{E}-04$ & $1.455 \mathrm{E}-03$ & $1.173 \mathrm{E}-03$ & $9.286 \mathrm{E}-04$ \\
\hline $\mathrm{BeO}$ & $2.271 \mathrm{E}-05$ & $5.245 \mathrm{E}-05$ & $7.351 \mathrm{E}-05$ & $1.027 \mathrm{E}-04$ & $6.692 \mathrm{E}-05$ & $1.250 \mathrm{E}-04$ \\
\hline $\mathbf{B i}_{2} \mathbf{O}_{3}$ & $5.763 \mathrm{E}-02$ & $1.445 \mathrm{E}-02$ & $1.225 \mathrm{E}-02$ & $3.356 \mathrm{E}-03$ & $8.542 \mathrm{E}-03$ & $4.975 \mathrm{E}-02$ \\
\hline $\mathrm{CaO}$ & $5.348 \mathrm{E}-02$ & $8.628 \mathrm{E}-03$ & $8.891 \mathrm{E}-02$ & $2.214 \mathrm{E}-02$ & $4.009 \mathrm{E}-02$ & $3.954 \mathrm{E}-02$ \\
\hline $\mathrm{CdO}$ & $1.682 \mathrm{E}-04$ & $4.284 \mathrm{E}-05$ & $3.601 \mathrm{E}-03$ & $3.224 \mathrm{E}-02$ & $2.288 \mathrm{E}-03$ & $2.705 \mathrm{E}-04$ \\
\hline $\mathrm{Ce}_{2} \mathrm{O}_{3}$ & $9.392 \mathrm{E}-04$ & $3.228 \mathrm{E}-04$ & $1.574 \mathrm{E}-03$ & $2.348 \mathrm{E}-03$ & $1.009 \mathrm{E}-03$ & $4.756 \mathrm{E}-04$ \\
\hline $\mathrm{Cl}$ & $2.442 \mathrm{E}-03$ & $1.447 \mathrm{E}-03$ & $2.447 \mathrm{E}-03$ & $2.249 \mathrm{E}-03$ & $1.817 \mathrm{E}-03$ & $1.439 \mathrm{E}-03$ \\
\hline $\mathrm{Cm}_{2} \mathrm{O}_{3}$ & $1.483 \mathrm{E}-10$ & $1.240 \mathrm{E}-11$ & $5.312 \mathrm{E}-10$ & $2.982 \mathrm{E}-09$ & $3.500 \mathrm{E}-10$ & $2.591 \mathrm{E}-11$ \\
\hline $\mathrm{CoO}$ & 4.997E-05 & $6.620 \mathrm{E}-05$ & $6.841 \mathrm{E}-05$ & $1.206 \mathrm{E}-04$ & $4.845 \mathrm{E}-05$ & $2.144 \mathrm{E}-04$ \\
\hline $\mathrm{Cr}_{2} \mathrm{O}_{3}$ & $3.810 \mathrm{E}-03$ & $2.023 \mathrm{E}-02$ & $1.458 \mathrm{E}-02$ & $6.172 \mathrm{E}-03$ & $1.179 \mathrm{E}-02$ & $1.847 \mathrm{E}-02$ \\
\hline $\mathrm{Cs}_{2} \mathrm{O}$ & $3.419 \mathrm{E}-04$ & $7.815 \mathrm{E}-05$ & $3.951 \mathrm{E}-04$ & $3.256 \mathrm{E}-04$ & $2.991 \mathrm{E}-04$ & $7.742 \mathrm{E}-05$ \\
\hline $\mathrm{CuO}$ & $3.949 \mathrm{E}-04$ & $1.800 \mathrm{E}-04$ & $3.101 \mathrm{E}-04$ & $4.761 \mathrm{E}-04$ & $3.344 \mathrm{E}-04$ & $3.290 \mathrm{E}-04$ \\
\hline $\mathrm{Eu}_{2} \mathrm{O}_{3}$ & $1.116 \mathrm{E}-08$ & $4.573 \mathrm{E}-10$ & $2.976 \mathrm{E}-08$ & $7.300 \mathrm{E}-08$ & $2.044 \mathrm{E}-08$ & $1.245 \mathrm{E}-09$ \\
\hline $\mathbf{F}$ & $1.230 \mathrm{E}-02$ & $2.574 \mathrm{E}-03$ & $2.545 \mathrm{E}-03$ & $1.180 \mathrm{E}-03$ & $1.657 \mathrm{E}-03$ & $2.258 \mathrm{E}-02$ \\
\hline $\mathrm{Fe}_{2} \mathrm{O}_{3}$ & $2.359 \mathrm{E}-01$ & $5.475 \mathrm{E}-02$ & $1.382 \mathrm{E}-01$ & $3.483 \mathrm{E}-01$ & $1.699 \mathrm{E}-01$ & $1.432 \mathrm{E}-01$ \\
\hline $\mathrm{HgO}$ & $1.809 \mathrm{E}-04$ & $1.000 \mathrm{E}-04$ & $5.899 \mathrm{E}-05$ & $6.659 \mathrm{E}-05$ & $9.738 \mathrm{E}-05$ & $1.867 \mathrm{E}-04$ \\
\hline I & $6.106 \mathrm{E}-07$ & $7.522 \mathrm{E}-07$ & $3.508 \mathrm{E}-06$ & $1.183 \mathrm{E}-06$ & $3.212 \mathrm{E}-06$ & $9.656 \mathrm{E}-07$ \\
\hline $\mathrm{K}_{2} \mathrm{O}$ & $2.133 \mathrm{E}-02$ & $2.170 \mathrm{E}-03$ & 9.914E-03 & $9.598 \mathrm{E}-03$ & $4.801 \mathrm{E}-03$ & $4.238 \mathrm{E}-03$ \\
\hline $\mathrm{La}_{2} \mathrm{O}_{3}$ & $3.262 \mathrm{E}-04$ & $9.503 \mathrm{E}-04$ & $2.169 \mathrm{E}-03$ & $8.420 \mathrm{E}-03$ & $1.821 \mathrm{E}-03$ & $3.198 \mathrm{E}-03$ \\
\hline $\mathrm{Li}_{2} \mathrm{O}$ & $1.672 \mathrm{E}-04$ & $2.228 \mathrm{E}-04$ & $6.235 \mathrm{E}-04$ & $4.301 \mathrm{E}-04$ & $3.230 \mathrm{E}-04$ & $3.880 \mathrm{E}-04$ \\
\hline $\mathrm{MgO}$ & $1.950 \mathrm{E}-03$ & $1.929 \mathrm{E}-03$ & $1.120 \mathrm{E}-03$ & $2.580 \mathrm{E}-03$ & $2.336 \mathrm{E}-03$ & $5.601 \mathrm{E}-03$ \\
\hline MnO & $2.420 \mathrm{E}-02$ & $1.381 \mathrm{E}-02$ & $1.617 \mathrm{E}-02$ & $1.234 \mathrm{E}-02$ & $1.317 \mathrm{E}-02$ & $1.349 \mathrm{E}-02$ \\
\hline $\mathrm{MoO}_{3}$ & $2.299 \mathrm{E}-04$ & $3.248 \mathrm{E}-04$ & $6.089 \mathrm{E}-04$ & $2.615 \mathrm{E}-04$ & $2.231 \mathrm{E}-04$ & $6.952 \mathrm{E}-04$ \\
\hline $\mathrm{Na}_{2} \mathrm{O}$ & $1.284 \mathrm{E}-01$ & $1.622 \mathrm{E}-01$ & $3.709 \mathrm{E}-01$ & $9.553 \mathrm{E}-02$ & $2.018 \mathrm{E}-01$ & $1.504 \mathrm{E}-01$ \\
\hline $\mathrm{Nb}_{2} \mathrm{O}_{5}$ & $6.318 \mathrm{E}-10$ & $7.285 \mathrm{E}-10$ & $8.671 \mathrm{E}-10$ & $3.634 \mathrm{E}-10$ & $5.412 \mathrm{E}-10$ & $7.542 \mathrm{E}-10$ \\
\hline $\mathrm{Nd}_{2} \mathrm{O}_{3}$ & 3.741E-04 & $7.518 \mathrm{E}-04$ & $3.310 \mathrm{E}-03$ & $6.412 \mathrm{E}-03$ & $1.927 \mathrm{E}-03$ & 6.076E-04 \\
\hline NiO & $3.074 \mathrm{E}-02$ & $3.573 \mathrm{E}-03$ & $5.730 \mathrm{E}-03$ & $2.733 \mathrm{E}-02$ & $1.924 \mathrm{E}-02$ & $1.542 \mathrm{E}-02$ \\
\hline $\mathrm{NpO}_{2}$ & $5.805 \mathrm{E}-06$ & $5.993 \mathrm{E}-06$ & $3.955 \mathrm{E}-05$ & $1.761 \mathrm{E}-04$ & $3.137 \mathrm{E}-05$ & $6.276 \mathrm{E}-06$ \\
\hline $\mathbf{P}_{2} \mathbf{O}_{5}$ & $5.597 \mathrm{E}-02$ & $1.393 \mathrm{E}-02$ & $3.158 \mathrm{E}-02$ & $9.674 \mathrm{E}-03$ & $1.302 \mathrm{E}-02$ & $3.289 \mathrm{E}-02$ \\
\hline $\mathrm{Pa}_{2} \mathrm{O}_{5}$ & $2.724 \mathrm{E}-09$ & $2.149 \mathrm{E}-09$ & $5.604 \mathrm{E}-09$ & $3.075 \mathrm{E}-09$ & $6.252 \mathrm{E}-09$ & $1.043 \mathrm{E}-08$ \\
\hline $\mathrm{PbO}$ & $1.226 \mathrm{E}-02$ & $2.596 \mathrm{E}-03$ & $3.122 \mathrm{E}-03$ & $6.782 \mathrm{E}-03$ & $6.942 \mathrm{E}-03$ & $8.197 \mathrm{E}-03$ \\
\hline $\mathrm{PdO}$ & $8.634 \mathrm{E}-07$ & $2.429 \mathrm{E}-08$ & $1.925 \mathrm{E}-04$ & $3.397 \mathrm{E}-05$ & $2.086 \mathrm{E}-04$ & $1.205 \mathrm{E}-07$ \\
\hline $\mathrm{Pr}_{2} \mathrm{O}_{3}$ & $5.671 \mathrm{E}-05$ & $7.297 \mathrm{E}-07$ & $2.405 \mathrm{E}-04$ & $5.419 \mathrm{E}-05$ & $2.903 \mathrm{E}-04$ & $3.995 \mathrm{E}-07$ \\
\hline $\mathrm{PuO}_{2}$ & $9.458 \mathrm{E}-05$ & $4.249 \mathrm{E}-05$ & $7.171 \mathrm{E}-05$ & $2.139 \mathrm{E}-04$ & $1.777 \mathrm{E}-04$ & $5.540 \mathrm{E}-05$ \\
\hline $\mathrm{RaO}$ & $3.581 \mathrm{E}-12$ & $5.831 \mathrm{E}-13$ & $1.627 \mathrm{E}-12$ & $8.658 \mathrm{E}-12$ & $1.115 \mathrm{E}-11$ & $1.833 \mathrm{E}-12$ \\
\hline $\mathrm{Rb}_{2} \mathrm{O}$ & $1.579 \mathrm{E}-05$ & $1.237 \mathrm{E}-07$ & $1.038 \mathrm{E}-04$ & $8.812 \mathrm{E}-05$ & $1.349 \mathrm{E}-04$ & $1.199 \mathrm{E}-07$ \\
\hline $\mathrm{Rh}_{2} \mathrm{O}_{3}$ & $2.017 \mathrm{E}-05$ & $1.790 \mathrm{E}-07$ & $2.093 \mathrm{E}-04$ & $5.439 \mathrm{E}-05$ & $1.228 \mathrm{E}-04$ & $1.984 \mathrm{E}-07$ \\
\hline $\mathrm{RuO}_{2}$ & $3.512 \mathrm{E}-04$ & $2.681 \mathrm{E}-06$ & $4.444 \mathrm{E}-04$ & $1.492 \mathrm{E}-04$ & $9.436 \mathrm{E}-04$ & $1.203 \mathrm{E}-06$ \\
\hline $\mathrm{SO}_{3}$ & $1.538 \mathrm{E}-03$ & $4.985 \mathrm{E}-03$ & $4.485 \mathrm{E}-03$ & $1.837 \mathrm{E}-03$ & $2.623 \mathrm{E}-03$ & $9.767 \mathrm{E}-03$ \\
\hline $\mathrm{Sb}_{2} \mathrm{O}_{3}$ & $1.675 \mathrm{E}-04$ & $1.708 \mathrm{E}-04$ & $2.067 \mathrm{E}-04$ & $1.293 \mathrm{E}-04$ & $7.047 \mathrm{E}-05$ & $1.824 \mathrm{E}-04$ \\
\hline $\mathrm{SeO}_{2}$ & $2.242 \mathrm{E}-05$ & $1.679 \mathrm{E}-05$ & $5.667 \mathrm{E}-05$ & $3.124 \mathrm{E}-05$ & $1.669 \mathrm{E}-05$ & $2.633 \mathrm{E}-05$ \\
\hline $\mathrm{SiO}_{2}$ & $1.405 \mathrm{E}-01$ & $6.917 \mathrm{E}-02$ & $2.406 \mathrm{E}-02$ & $3.159 \mathrm{E}-02$ & $8.062 \mathrm{E}-02$ & $1.283 \mathrm{E}-01$ \\
\hline $\mathrm{Sm}_{2} \mathrm{O}_{3}$ & $1.115 \mathrm{E}-05$ & $4.548 \mathrm{E}-06$ & $1.067 \mathrm{E}-05$ & $4.864 \mathrm{E}-05$ & $1.598 \mathrm{E}-05$ & $1.222 \mathrm{E}-05$ \\
\hline $\mathrm{SnO}_{2}$ & $1.076 \mathrm{E}-06$ & $1.129 \mathrm{E}-06$ & $1.320 \mathrm{E}-06$ & $5.881 \mathrm{E}-07$ & $4.925 \mathrm{E}-07$ & $1.072 \mathrm{E}-06$ \\
\hline $\mathrm{SrO}$ & $1.555 \mathrm{E}-03$ & $1.651 \mathrm{E}-03$ & $2.981 \mathrm{E}-02$ & $6.831 \mathrm{E}-04$ & $1.976 \mathrm{E}-02$ & $1.017 \mathrm{E}-02$ \\
\hline $\mathrm{Ta}_{2} \mathrm{O}_{5}$ & 4.062E-07 & $1.338 \mathrm{E}-08$ & $4.228 \mathrm{E}-06$ & 7.798E-07 & $2.823 \mathrm{E}-06$ & 1.014E-08 \\
\hline $\mathrm{Tc}_{2} \mathrm{O}_{7}$ & $4.231 \mathrm{E}-05$ & $1.980 \mathrm{E}-05$ & $4.351 \mathrm{E}-05$ & $3.384 \mathrm{E}-05$ & $1.672 \mathrm{E}-05$ & $3.936 \mathrm{E}-05$ \\
\hline $\mathrm{TeO}_{2}$ & $4.291 \mathrm{E}-05$ & $2.484 \mathrm{E}-07$ & $9.086 \mathrm{E}-05$ & $2.710 \mathrm{E}-05$ & $1.632 \mathrm{E}-04$ & $1.776 \mathrm{E}-07$ \\
\hline $\mathrm{ThO}_{2}$ & $2.919 \mathrm{E}-03$ & $4.815 \mathrm{E}-04$ & $1.420 \mathrm{E}-03$ & $1.709 \mathrm{E}-02$ & $2.362 \mathrm{E}-02$ & $2.909 \mathrm{E}-03$ \\
\hline $\mathrm{TiO}_{2}$ & $1.325 \mathrm{E}-04$ & $1.294 \mathrm{E}-04$ & $1.341 \mathrm{E}-04$ & $3.350 \mathrm{E}-04$ & $1.613 \mathrm{E}-04$ & $2.368 \mathrm{E}-04$ \\
\hline
\end{tabular}




\begin{tabular}{|c|c|c|c|c|c|c|}
\hline Cluster \# & $\mathbf{1 5}$ & $\mathbf{1 6}$ & $\mathbf{1 7}$ & $\mathbf{1 8}$ & $\mathbf{1 9}$ & $\mathbf{2 0}$ \\
\hline $\mathrm{Tl}_{2} \mathrm{O}$ & $4.002 \mathrm{E}-04$ & $1.742 \mathrm{E}-03$ & $6.497 \mathrm{E}-04$ & $5.162 \mathrm{E}-05$ & $2.056 \mathrm{E}-04$ & $8.883 \mathrm{E}-04$ \\
\hline $\mathbf{U O}_{3}$ & $5.014 \mathrm{E}-02$ & $3.894 \mathrm{E}-02$ & $2.563 \mathrm{E}-02$ & $7.475 \mathrm{E}-02$ & $4.912 \mathrm{E}-02$ & $9.276 \mathrm{E}-02$ \\
\hline $\mathrm{V}_{2} \mathrm{O}_{5}$ & $8.533 \mathrm{E}-05$ & $2.716 \mathrm{E}-04$ & $2.467 \mathrm{E}-04$ & $9.854 \mathrm{E}-05$ & $1.070 \mathrm{E}-04$ & $3.700 \mathrm{E}-04$ \\
\hline $\mathrm{WO}_{3}$ & $9.984 \mathrm{E}-05$ & $1.651 \mathrm{E}-06$ & $4.022 \mathrm{E}-04$ & $5.502 \mathrm{E}-06$ & $3.272 \mathrm{E}-04$ & $2.023 \mathrm{E}-06$ \\
\hline $\mathrm{Y}_{2} \mathrm{O}_{3}$ & $4.026 \mathrm{E}-05$ & $3.720 \mathrm{E}-06$ & $2.450 \mathrm{E}-04$ & $2.378 \mathrm{E}-04$ & $1.646 \mathrm{E}-04$ & $9.097 \mathrm{E}-06$ \\
\hline $\mathrm{ZnO}$ & $9.099 \mathrm{E}-04$ & $3.935 \mathrm{E}-04$ & $7.566 \mathrm{E}-04$ & $1.295 \mathrm{E}-03$ & $4.254 \mathrm{E}-04$ & $6.876 \mathrm{E}-04$ \\
\hline $\mathbf{Z r O}$ & $2.396 \mathrm{E}-02$ & $1.808 \mathrm{E}-03$ & $1.391 \mathrm{E}-02$ & $6.593 \mathrm{E}-02$ & $2.967 \mathrm{E}-02$ & $2.747 \mathrm{E}-03$ \\
\hline $\mathrm{SUM}$ & 1 & 1 & 1 & 1 & 1 & 1 \\
\hline $\begin{array}{c}\text { Oxide mass } \\
(\mathrm{MT})\end{array}$ & 327.203 & $1,453.789$ & 164.666 & 123.884 & 249.230 & $1,350.527$ \\
\hline
\end{tabular}


Table A.2. Composition of 20 Clusters in Terms of 41 "Oxide" Components that Are Tracked in 2009 Glass Models (Vienna et al. 2009) (components in bold represent the 15 components used in cluster analysis)

\begin{tabular}{|c|c|c|c|c|c|c|c|}
\hline Cluster \# & 1 & 2 & 3 & 4 & $\begin{array}{l}5 \\
\end{array}$ & 6 & 7 \\
\hline $\mathrm{Ag}_{2} \mathrm{O}$ & $1.331 \mathrm{E}-03$ & $1.441 \mathrm{E}-04$ & $1.524 \mathrm{E}-03$ & $2.014 \mathrm{E}-04$ & $2.374 \mathrm{E}-04$ & $5.609 \mathrm{E}-04$ & $9.114 \mathrm{E}-05$ \\
\hline $\mathrm{Al}_{2} \mathrm{O}_{3}$ & $1.396 \mathrm{E}-01$ & $2.047 \mathrm{E}-01$ & $1.373 \mathrm{E}-01$ & $3.732 \mathrm{E}-01$ & $4.706 \mathrm{E}-01$ & $2.792 \mathrm{E}-01$ & $4.494 \mathrm{E}-01$ \\
\hline $\mathrm{B}_{2} \mathrm{O}_{3}$ & $2.452 \mathrm{E}-03$ & $2.132 \mathrm{E}-03$ & $8.329 \mathrm{E}-03$ & $1.312 \mathrm{E}-03$ & $2.359 \mathrm{E}-03$ & $4.287 \mathrm{E}-03$ & $1.384 \mathrm{E}-03$ \\
\hline $\mathrm{BaO}$ & $1.593 \mathrm{E}-03$ & $4.272 \mathrm{E}-04$ & $6.923 \mathrm{E}-04$ & $6.330 \mathrm{E}-04$ & $2.341 \mathrm{E}-04$ & $1.360 \mathrm{E}-03$ & $8.476 \mathrm{E}-04$ \\
\hline $\mathrm{Bi}_{2} \mathrm{O}_{3}$ & $6.674 \mathrm{E}-03$ & $7.259 \mathrm{E}-02$ & $2.474 \mathrm{E}-02$ & $9.771 \mathrm{E}-03$ & $1.860 \mathrm{E}-02$ & $3.811 \mathrm{E}-02$ & $5.555 \mathrm{E}-02$ \\
\hline $\mathrm{CaO}$ & $2.466 \mathrm{E}-02$ & $5.625 \mathrm{E}-02$ & $3.875 \mathrm{E}-02$ & $2.624 \mathrm{E}-02$ & $1.560 \mathrm{E}-02$ & $2.003 \mathrm{E}-02$ & $2.443 \mathrm{E}-02$ \\
\hline $\mathrm{CdO}$ & $8.557 \mathrm{E}-04$ & $4.809 \mathrm{E}-04$ & $4.728 \mathrm{E}-03$ & $5.184 \mathrm{E}-03$ & $1.655 \mathrm{E}-04$ & $5.792 \mathrm{E}-04$ & $4.747 \mathrm{E}-05$ \\
\hline $\mathrm{Ce}_{2} \mathrm{O}_{3}$ & $2.690 \mathrm{E}-03$ & $8.393 \mathrm{E}-04$ & $6.909 \mathrm{E}-04$ & $8.705 \mathrm{E}-04$ & $2.447 \mathrm{E}-04$ & $9.537 \mathrm{E}-04$ & $2.682 \mathrm{E}-04$ \\
\hline $\mathrm{Cl}$ & $1.721 \mathrm{E}-03$ & $1.734 \mathrm{E}-03$ & $2.014 \mathrm{E}-03$ & $2.454 \mathrm{E}-03$ & $2.152 \mathrm{E}-03$ & $1.623 \mathrm{E}-03$ & $1.707 \mathrm{E}-03$ \\
\hline $\mathrm{CoO}$ & $1.014 \mathrm{E}-04$ & $1.022 \mathrm{E}-04$ & $1.024 \mathrm{E}-04$ & $1.295 \mathrm{E}-04$ & 7.149E-05 & $2.026 \mathrm{E}-04$ & $8.900 \mathrm{E}-05$ \\
\hline $\mathrm{Cr}_{2} \mathrm{O}_{3}$ & $8.171 \mathrm{E}-03$ & $1.385 \mathrm{E}-02$ & $1.239 \mathrm{E}-02$ & $1.310 \mathrm{E}-02$ & $2.278 \mathrm{E}-02$ & $2.950 \mathrm{E}-02$ & $1.852 \mathrm{E}-02$ \\
\hline $\mathrm{Cs}_{2} \mathrm{O}$ & $9.659 \mathrm{E}-05$ & $1.551 \mathrm{E}-04$ & $2.175 \mathrm{E}-04$ & $3.545 \mathrm{E}-04$ & $3.317 \mathrm{E}-04$ & $1.864 \mathrm{E}-04$ & $1.297 \mathrm{E}-04$ \\
\hline $\mathrm{CuO}$ & $7.177 \mathrm{E}-04$ & $1.671 \mathrm{E}-04$ & $3.613 \mathrm{E}-04$ & $2.307 \mathrm{E}-04$ & $1.699 \mathrm{E}-04$ & $3.550 \mathrm{E}-04$ & $6.243 \mathrm{E}-05$ \\
\hline $\mathbf{F}$ & $1.514 \mathrm{E}-03$ & $2.829 \mathrm{E}-02$ & $1.615 \mathrm{E}-03$ & $1.252 \mathrm{E}-03$ & $1.425 \mathrm{E}-02$ & $5.538 \mathrm{E}-03$ & $5.318 \mathrm{E}-03$ \\
\hline $\mathrm{Fe}_{2} \mathrm{O}_{3}$ & $3.355 \mathrm{E}-01$ & $1.141 \mathrm{E}-01$ & $1.884 \mathrm{E}-01$ & $1.475 \mathrm{E}-01$ & $5.826 \mathrm{E}-02$ & $1.486 \mathrm{E}-01$ & $1.089 \mathrm{E}-01$ \\
\hline $\mathrm{K}_{2} \mathrm{O}$ & $7.953 \mathrm{E}-03$ & $4.906 \mathrm{E}-03$ & $1.037 \mathrm{E}-02$ & $5.407 \mathrm{E}-03$ & $5.862 \mathrm{E}-03$ & $7.509 \mathrm{E}-03$ & $4.540 \mathrm{E}-03$ \\
\hline $\mathrm{La}_{2} \mathrm{O}_{3}$ & $1.851 \mathrm{E}-03$ & $4.413 \mathrm{E}-04$ & $6.736 \mathrm{E}-03$ & $2.683 \mathrm{E}-03$ & $2.117 \mathrm{E}-03$ & $9.713 \mathrm{E}-03$ & $9.901 \mathrm{E}-04$ \\
\hline $\mathrm{Li}_{2} \mathrm{O}$ & $1.977 \mathrm{E}-04$ & $4.101 \mathrm{E}-04$ & $2.460 \mathrm{E}-04$ & $3.422 \mathrm{E}-04$ & $3.871 \mathrm{E}-04$ & $8.235 \mathrm{E}-04$ & $2.126 \mathrm{E}-04$ \\
\hline $\mathrm{MgO}$ & $3.464 \mathrm{E}-03$ & $1.650 \mathrm{E}-03$ & $4.086 \mathrm{E}-03$ & $1.337 \mathrm{E}-03$ & $1.830 \mathrm{E}-03$ & $6.146 \mathrm{E}-03$ & $1.032 \mathrm{E}-03$ \\
\hline MnO & $4.799 \mathrm{E}-02$ & $5.790 \mathrm{E}-03$ & $2.894 \mathrm{E}-02$ & $9.733 \mathrm{E}-03$ & $1.188 \mathrm{E}-02$ & $3.041 \mathrm{E}-02$ & $9.480 \mathrm{E}-03$ \\
\hline $\mathrm{MoO}_{3}$ & $1.155 \mathrm{E}-04$ & $3.740 \mathrm{E}-04$ & $3.220 \mathrm{E}-04$ & $2.239 \mathrm{E}-04$ & $2.758 \mathrm{E}-04$ & $5.394 \mathrm{E}-04$ & $2.715 \mathrm{E}-04$ \\
\hline $\mathrm{Na}_{2} \mathrm{O}$ & $2.061 \mathrm{E}-01$ & $2.481 \mathrm{E}-01$ & $1.268 \mathrm{E}-01$ & $1.214 \mathrm{E}-01$ & $1.484 \mathrm{E}-01$ & $1.683 \mathrm{E}-01$ & $1.283 \mathrm{E}-01$ \\
\hline $\mathrm{Nd}_{2} \mathrm{O}_{3}$ & $3.170 \mathrm{E}-03$ & $7.537 \mathrm{E}-04$ & $1.079 \mathrm{E}-03$ & $1.923 \mathrm{E}-03$ & $3.533 \mathrm{E}-04$ & $1.169 \mathrm{E}-03$ & $2.865 \mathrm{E}-04$ \\
\hline $\mathrm{NiO}$ & $1.672 \mathrm{E}-02$ & 7.794E-03 & $4.184 \mathrm{E}-02$ & $2.467 \mathrm{E}-02$ & $1.291 \mathrm{E}-02$ & $3.080 \mathrm{E}-02$ & $6.917 \mathrm{E}-03$ \\
\hline $\mathbf{P}_{2} \mathbf{O}_{5}$ & $1.738 \mathrm{E}-02$ & $6.754 \mathrm{E}-02$ & $4.281 \mathrm{E}-02$ & $1.163 \mathrm{E}-02$ & $4.528 \mathrm{E}-02$ & $4.359 \mathrm{E}-02$ & $3.581 \mathrm{E}-02$ \\
\hline $\mathrm{PbO}$ & $1.312 \mathrm{E}-02$ & $6.288 \mathrm{E}-03$ & $6.305 \mathrm{E}-03$ & $5.784 \mathrm{E}-03$ & $2.474 \mathrm{E}-03$ & $7.434 \mathrm{E}-03$ & $4.204 \mathrm{E}-03$ \\
\hline $\mathrm{PdO}$ & $2.474 \mathrm{E}-05$ & $1.972 \mathrm{E}-05$ & $1.297 \mathrm{E}-06$ & $2.566 \mathrm{E}-04$ & $4.549 \mathrm{E}-06$ & $3.045 \mathrm{E}-06$ & $1.027 \mathrm{E}-07$ \\
\hline $\mathrm{Re}_{2} \mathrm{O}_{7}$ & $1.628 \mathrm{E}-05$ & $2.920 \mathrm{E}-05$ & $3.551 \mathrm{E}-05$ & $3.090 \mathrm{E}-05$ & $3.338 \mathrm{E}-05$ & $5.726 \mathrm{E}-05$ & $3.371 \mathrm{E}-05$ \\
\hline $\mathrm{Rh}_{2} \mathrm{O}_{3}$ & $1.179 \mathrm{E}-04$ & $2.024 \mathrm{E}-05$ & $2.014 \mathrm{E}-04$ & $6.279 \mathrm{E}-05$ & $6.226 \mathrm{E}-06$ & $5.587 \mathrm{E}-05$ & $5.631 \mathrm{E}-07$ \\
\hline $\mathrm{RuO}_{2}$ & $1.462 \mathrm{E}-03$ & $8.669 \mathrm{E}-05$ & $6.325 \mathrm{E}-05$ & $6.397 \mathrm{E}-04$ & $1.884 \mathrm{E}-05$ & $4.539 \mathrm{E}-04$ & $3.062 \mathrm{E}-06$ \\
\hline $\mathrm{SiO}_{2}$ & $6.381 \mathrm{E}-02$ & $9.362 \mathrm{E}-02$ & $4.126 \mathrm{E}-02$ & $1.046 \mathrm{E}-01$ & $3.430 \mathrm{E}-02$ & $5.085 \mathrm{E}-02$ & $7.496 \mathrm{E}-02$ \\
\hline $\mathrm{SO}_{3}$ & $4.435 \mathrm{E}-03$ & $9.069 \mathrm{E}-03$ & $6.740 \mathrm{E}-03$ & $2.699 \mathrm{E}-03$ & $1.221 \mathrm{E}-02$ & $1.411 \mathrm{E}-02$ & $8.639 \mathrm{E}-03$ \\
\hline $\mathrm{SnO}_{2}$ & $3.378 \mathrm{E}-06$ & $9.762 \mathrm{E}-07$ & $7.324 \mathrm{E}-07$ & $7.285 \mathrm{E}-07$ & $1.491 \mathrm{E}-06$ & $2.496 \mathrm{E}-06$ & $1.368 \mathrm{E}-06$ \\
\hline $\mathrm{SrO}$ & $7.598 \mathrm{E}-04$ & $9.799 \mathrm{E}-03$ & $1.296 \mathrm{E}-03$ & $2.222 \mathrm{E}-03$ & $7.351 \mathrm{E}-03$ & $3.842 \mathrm{E}-03$ & $1.780 \mathrm{E}-03$ \\
\hline $\mathrm{ThO}_{2}$ & $1.604 \mathrm{E}-02$ & $3.756 \mathrm{E}-03$ & $5.055 \mathrm{E}-02$ & $3.060 \mathrm{E}-02$ & $5.835 \mathrm{E}-04$ & $8.141 \mathrm{E}-03$ & $2.548 \mathrm{E}-04$ \\
\hline $\mathrm{TiO}_{2}$ & $6.081 \mathrm{E}-04$ & $1.510 \mathrm{E}-04$ & $3.804 \mathrm{E}-04$ & $1.225 \mathrm{E}-04$ & $2.319 \mathrm{E}-04$ & $2.772 \mathrm{E}-04$ & $6.735 \mathrm{E}-05$ \\
\hline $\mathrm{UO}_{3}$ & $3.276 \mathrm{E}-02$ & $3.926 \mathrm{E}-02$ & $9.487 \mathrm{E}-02$ & $5.724 \mathrm{E}-02$ & $5.338 \mathrm{E}-02$ & $5.497 \mathrm{E}-02$ & $5.316 \mathrm{E}-02$ \\
\hline $\mathrm{V}_{2} \mathrm{O}_{5}$ & $9.357 \mathrm{E}-05$ & $3.517 \mathrm{E}-04$ & $2.565 \mathrm{E}-04$ & $1.566 \mathrm{E}-04$ & $2.393 \mathrm{E}-04$ & $4.590 \mathrm{E}-04$ & $2.242 \mathrm{E}-04$ \\
\hline $\mathrm{Y}_{2} \mathrm{O}_{3}$ & $3.208 \mathrm{E}-04$ & $3.221 \mathrm{E}-05$ & $6.191 \mathrm{E}-05$ & $1.008 \mathrm{E}-04$ & $1.621 \mathrm{E}-05$ & $8.752 \mathrm{E}-05$ & $6.018 \mathrm{E}-06$ \\
\hline $\mathrm{ZnO}$ & $8.631 \mathrm{E}-04$ & $3.647 \mathrm{E}-04$ & $1.426 \mathrm{E}-03$ & $2.869 \mathrm{E}-04$ & $9.498 \mathrm{E}-04$ & $8.217 \mathrm{E}-04$ & $2.022 \mathrm{E}-04$ \\
\hline $\mathrm{ZrO}_{2}$ & $3.300 \mathrm{E}-02$ & $3.390 \mathrm{E}-03$ & $1.115 \mathrm{E}-01$ & $3.339 \mathrm{E}-02$ & $5.290 \mathrm{E}-02$ & $2.835 \mathrm{E}-02$ & $1.878 \mathrm{E}-03$ \\
\hline SUM & 1 & 1 & 1 & 1 & 1 & 1 & 1 \\
\hline $\begin{array}{l}\text { Oxide mass } \\
\text { (MT) }\end{array}$ & 405.155 & 338.933 & 266.291 & 220.917 & 719.021 & 364.147 & $1,839.578$ \\
\hline
\end{tabular}


Table A.2. (Continued)

\begin{tabular}{|c|c|c|c|c|c|c|c|}
\hline Cluster \# & 8 & 9 & 10 & 11 & 12 & 13 & 14 \\
\hline $\mathrm{Ag}_{2} \mathrm{O}$ & $2.831 \mathrm{E}-04$ & $4.452 \mathrm{E}-04$ & $1.193 \mathrm{E}-03$ & $1.790 \mathrm{E}-04$ & $2.611 \mathrm{E}-04$ & $1.909 \mathrm{E}-04$ & $1.902 \mathrm{E}-04$ \\
\hline $\mathrm{Al}_{2} \mathrm{O}_{3}$ & $4.175 \mathrm{E}-01$ & $9.350 \mathrm{E}-02$ & $1.894 \mathrm{E}-01$ & $2.837 \mathrm{E}-01$ & $1.640 \mathrm{E}-01$ & $2.268 \mathrm{E}-01$ & $3.232 \mathrm{E}-01$ \\
\hline $\mathrm{B}_{2} \mathrm{O}_{3}$ & $6.369 \mathrm{E}-03$ & $5.366 \mathrm{E}-03$ & $3.114 \mathrm{E}-03$ & $2.152 \mathrm{E}-03$ & $2.140 \mathrm{E}-03$ & $2.368 \mathrm{E}-03$ & $3.157 \mathrm{E}-03$ \\
\hline $\mathrm{BaO}$ & $8.530 \mathrm{E}-04$ & $6.116 \mathrm{E}-04$ & $3.722 \mathrm{E}-03$ & $7.194 \mathrm{E}-04$ & $4.853 \mathrm{E}-04$ & $5.208 \mathrm{E}-04$ & $3.294 \mathrm{E}-04$ \\
\hline $\mathbf{B i}_{2} \mathbf{O}_{3}$ & $1.852 \mathrm{E}-02$ & $1.311 \mathrm{E}-02$ & $1.707 \mathrm{E}-02$ & $5.733 \mathrm{E}-02$ & $3.414 \mathrm{E}-02$ & $2.470 \mathrm{E}-02$ & $1.767 \mathrm{E}-02$ \\
\hline $\mathrm{CaO}$ & $2.472 \mathrm{E}-02$ & $2.582 \mathrm{E}-02$ & $2.417 \mathrm{E}-02$ & $2.486 \mathrm{E}-02$ & $3.015 \mathrm{E}-02$ & $2.487 \mathrm{E}-02$ & $2.167 \mathrm{E}-02$ \\
\hline $\mathrm{CdO}$ & $2.326 \mathrm{E}-04$ & $4.130 \mathrm{E}-04$ & $7.716 \mathrm{E}-04$ & $3.190 \mathrm{E}-04$ & $2.408 \mathrm{E}-04$ & $4.542 \mathrm{E}-04$ & $7.948 \mathrm{E}-04$ \\
\hline $\mathrm{Ce}_{2} \mathrm{O}_{3}$ & $8.586 \mathrm{E}-04$ & $8.050 \mathrm{E}-04$ & $1.625 \mathrm{E}-03$ & $3.970 \mathrm{E}-04$ & $2.185 \mathrm{E}-04$ & $3.301 \mathrm{E}-04$ & $7.644 \mathrm{E}-04$ \\
\hline $\mathrm{Cl}$ & $1.140 \mathrm{E}-03$ & $1.733 \mathrm{E}-03$ & $2.360 \mathrm{E}-03$ & $2.320 \mathrm{E}-03$ & $2.013 \mathrm{E}-03$ & $2.539 \mathrm{E}-03$ & $2.331 \mathrm{E}-03$ \\
\hline $\mathrm{CoO}$ & $1.875 \mathrm{E}-04$ & $1.640 \mathrm{E}-04$ & $1.120 \mathrm{E}-04$ & $2.954 \mathrm{E}-04$ & $1.199 \mathrm{E}-04$ & $1.265 \mathrm{E}-04$ & $1.452 \mathrm{E}-04$ \\
\hline $\mathrm{Cr}_{2} \mathrm{O}_{3}$ & $1.999 \mathrm{E}-02$ & $2.742 \mathrm{E}-02$ & $6.683 \mathrm{E}-03$ & $2.220 \mathrm{E}-02$ & $7.714 \mathrm{E}-02$ & $2.906 \mathrm{E}-02$ & $7.420 \mathrm{E}-02$ \\
\hline $\mathrm{Cs}_{2} \mathrm{O}$ & $7.801 \mathrm{E}-05$ & $1.806 \mathrm{E}-04$ & $4.827 \mathrm{E}-04$ & $1.567 \mathrm{E}-04$ & $1.584 \mathrm{E}-04$ & $2.635 \mathrm{E}-04$ & $3.110 \mathrm{E}-04$ \\
\hline $\mathrm{CuO}$ & $2.136 \mathrm{E}-04$ & $1.848 \mathrm{E}-04$ & $7.883 \mathrm{E}-04$ & $1.456 \mathrm{E}-04$ & $9.767 \mathrm{E}-05$ & $2.633 \mathrm{E}-04$ & $1.435 \mathrm{E}-04$ \\
\hline $\mathbf{F}$ & $1.086 \mathrm{E}-02$ & $7.012 \mathrm{E}-03$ & $4.486 \mathrm{E}-03$ & $6.083 \mathrm{E}-02$ & $5.010 \mathrm{E}-02$ & $2.290 \mathrm{E}-02$ & $4.400 \mathrm{E}-03$ \\
\hline $\mathrm{Fe}_{2} \mathrm{O}_{3}$ & $1.074 \mathrm{E}-01$ & $6.697 \mathrm{E}-02$ & $2.996 \mathrm{E}-01$ & $9.569 \mathrm{E}-02$ & $1.225 \mathrm{E}-01$ & $1.015 \mathrm{E}-01$ & $8.518 \mathrm{E}-02$ \\
\hline $\mathrm{K}_{2} \mathrm{O}$ & $3.650 \mathrm{E}-03$ & $2.535 \mathrm{E}-02$ & $6.474 \mathrm{E}-03$ & $5.584 \mathrm{E}-03$ & $1.050 \mathrm{E}-02$ & $4.629 \mathrm{E}-03$ & 7.277E-03 \\
\hline $\mathrm{La}_{2} \mathrm{O}_{3}$ & $6.669 \mathrm{E}-04$ & $1.853 \mathrm{E}-04$ & $2.497 \mathrm{E}-03$ & $3.474 \mathrm{E}-04$ & $4.817 \mathrm{E}-03$ & $1.846 \mathrm{E}-03$ & $7.628 \mathrm{E}-04$ \\
\hline $\mathrm{Li}_{2} \mathrm{O}$ & $4.125 \mathrm{E}-04$ & $6.245 \mathrm{E}-04$ & $4.407 \mathrm{E}-04$ & $9.188 \mathrm{E}-04$ & $3.231 \mathrm{E}-04$ & $3.465 \mathrm{E}-04$ & $9.097 \mathrm{E}-04$ \\
\hline $\mathrm{MgO}$ & $3.365 \mathrm{E}-03$ & $3.927 \mathrm{E}-03$ & $7.990 \mathrm{E}-03$ & $1.432 \mathrm{E}-03$ & $2.049 \mathrm{E}-03$ & $2.378 \mathrm{E}-03$ & $1.180 \mathrm{E}-03$ \\
\hline MnO & $1.825 \mathrm{E}-02$ & $5.869 \mathrm{E}-03$ & $2.173 \mathrm{E}-02$ & $5.301 \mathrm{E}-03$ & $1.229 \mathrm{E}-02$ & $8.802 \mathrm{E}-03$ & $2.037 \mathrm{E}-02$ \\
\hline $\mathrm{MoO}_{3}$ & $7.854 \mathrm{E}-04$ & $1.262 \mathrm{E}-03$ & $2.637 \mathrm{E}-04$ & $5.621 \mathrm{E}-04$ & $4.166 \mathrm{E}-04$ & $3.902 \mathrm{E}-04$ & $5.543 \mathrm{E}-04$ \\
\hline $\mathrm{Na}_{2} \mathrm{O}$ & $1.186 \mathrm{E}-01$ & $5.416 \mathrm{E}-01$ & $1.339 \mathrm{E}-01$ & $1.236 \mathrm{E}-01$ & $1.427 \mathrm{E}-01$ & $2.281 \mathrm{E}-01$ & $1.937 \mathrm{E}-01$ \\
\hline $\mathrm{Nd}_{2} \mathrm{O}_{3}$ & $9.836 \mathrm{E}-04$ & $7.893 \mathrm{E}-04$ & $2.043 \mathrm{E}-03$ & $2.886 \mathrm{E}-04$ & $2.006 \mathrm{E}-04$ & $4.698 \mathrm{E}-04$ & $1.063 \mathrm{E}-03$ \\
\hline $\mathrm{NiO}$ & $6.394 \mathrm{E}-03$ & $4.872 \mathrm{E}-03$ & $2.045 \mathrm{E}-02$ & $7.783 \mathrm{E}-03$ & $3.138 \mathrm{E}-02$ & $1.547 \mathrm{E}-02$ & $3.877 \mathrm{E}-03$ \\
\hline $\mathbf{P}_{2} \mathbf{O}_{5}$ & $2.160 \mathrm{E}-02$ & $2.440 \mathrm{E}-02$ & $1.661 \mathrm{E}-02$ & $4.428 \mathrm{E}-02$ & $1.114 \mathrm{E}-01$ & $1.167 \mathrm{E}-01$ & $1.118 \mathrm{E}-01$ \\
\hline $\mathrm{PbO}$ & $8.001 \mathrm{E}-03$ & $5.850 \mathrm{E}-03$ & $1.580 \mathrm{E}-02$ & $2.800 \mathrm{E}-03$ & $3.960 \mathrm{E}-03$ & $4.137 \mathrm{E}-03$ & $4.198 \mathrm{E}-03$ \\
\hline $\mathrm{PdO}$ & $3.301 \mathrm{E}-08$ & $1.179 \mathrm{E}-07$ & $1.506 \mathrm{E}-07$ & $7.017 \mathrm{E}-07$ & $1.505 \mathrm{E}-06$ & $2.350 \mathrm{E}-05$ & $2.619 \mathrm{E}-05$ \\
\hline $\mathrm{Re}_{2} \mathrm{O}_{7}$ & $3.062 \mathrm{E}-05$ & $5.812 \mathrm{E}-05$ & $2.843 \mathrm{E}-05$ & $4.328 \mathrm{E}-05$ & $3.356 \mathrm{E}-05$ & $4.578 \mathrm{E}-05$ & $4.959 \mathrm{E}-05$ \\
\hline $\mathrm{Rh}_{2} \mathrm{O}_{3}$ & $5.112 \mathrm{E}-07$ & $6.543 \mathrm{E}-06$ & $1.487 \mathrm{E}-04$ & $1.111 \mathrm{E}-06$ & $1.638 \mathrm{E}-05$ & $1.193 \mathrm{E}-05$ & $3.264 \mathrm{E}-05$ \\
\hline $\mathrm{RuO}_{2}$ & $5.054 \mathrm{E}-07$ & $3.728 \mathrm{E}-06$ & $1.581 \mathrm{E}-03$ & $6.464 \mathrm{E}-06$ & 7.066E-06 & $1.801 \mathrm{E}-04$ & $1.468 \mathrm{E}-04$ \\
\hline $\mathrm{SiO}_{2}$ & $1.108 \mathrm{E}-01$ & $8.527 \mathrm{E}-02$ & $6.701 \mathrm{E}-02$ & $1.844 \mathrm{E}-01$ & $5.868 \mathrm{E}-02$ & $6.157 \mathrm{E}-02$ & $4.329 \mathrm{E}-02$ \\
\hline $\mathrm{SO}_{3}$ & $8.628 \mathrm{E}-03$ & $3.509 \mathrm{E}-03$ & $4.391 \mathrm{E}-03$ & $2.145 \mathrm{E}-02$ & $2.196 \mathrm{E}-02$ & $1.098 \mathrm{E}-02$ & $1.990 \mathrm{E}-02$ \\
\hline $\mathrm{SnO}_{2}$ & $1.673 \mathrm{E}-06$ & $1.779 \mathrm{E}-06$ & $5.656 \mathrm{E}-07$ & $1.332 \mathrm{E}-06$ & $1.646 \mathrm{E}-06$ & $1.156 \mathrm{E}-06$ & $3.867 \mathrm{E}-06$ \\
\hline $\mathrm{SrO}$ & $3.639 \mathrm{E}-03$ & $4.131 \mathrm{E}-03$ & $1.188 \mathrm{E}-03$ & $5.305 \mathrm{E}-03$ & $2.436 \mathrm{E}-02$ & $1.479 \mathrm{E}-02$ & $5.226 \mathrm{E}-03$ \\
\hline $\mathrm{ThO}_{2}$ & $2.567 \mathrm{E}-03$ & $6.342 \mathrm{E}-03$ & $1.979 \mathrm{E}-02$ & $2.224 \mathrm{E}-03$ & $3.847 \mathrm{E}-03$ & $4.442 \mathrm{E}-03$ & $3.215 \mathrm{E}-04$ \\
\hline $\mathrm{TiO}_{2}$ & $2.179 \mathrm{E}-04$ & $1.490 \mathrm{E}-04$ & $4.580 \mathrm{E}-04$ & $2.113 \mathrm{E}-04$ & $1.953 \mathrm{E}-04$ & $1.803 \mathrm{E}-04$ & $1.472 \mathrm{E}-04$ \\
\hline $\mathrm{UO}_{3}$ & $7.879 \mathrm{E}-02$ & $3.521 \mathrm{E}-02$ & $7.610 \mathrm{E}-02$ & $3.470 \mathrm{E}-02$ & $7.306 \mathrm{E}-02$ & $8.052 \mathrm{E}-02$ & $3.593 \mathrm{E}-02$ \\
\hline $\mathrm{V}_{2} \mathrm{O}_{5}$ & $5.930 \mathrm{E}-04$ & $5.970 \mathrm{E}-04$ & $1.930 \mathrm{E}-04$ & $5.819 \mathrm{E}-04$ & $3.679 \mathrm{E}-04$ & $3.258 \mathrm{E}-04$ & $4.375 \mathrm{E}-04$ \\
\hline $\mathrm{Y}_{2} \mathrm{O}_{3}$ & $8.345 \mathrm{E}-06$ & $2.156 \mathrm{E}-06$ & $2.809 \mathrm{E}-04$ & $3.604 \mathrm{E}-05$ & $1.293 \mathrm{E}-05$ & $2.717 \mathrm{E}-05$ & $4.189 \mathrm{E}-05$ \\
\hline $\mathrm{ZnO}$ & $5.656 \mathrm{E}-04$ & $1.034 \mathrm{E}-03$ & $9.680 \mathrm{E}-04$ & $5.575 \mathrm{E}-04$ & $6.453 \mathrm{E}-04$ & $5.434 \mathrm{E}-04$ & $5.381 \mathrm{E}-04$ \\
\hline $\mathrm{ZrO}_{2}$ & $2.126 \mathrm{E}-03$ & $5.247 \mathrm{E}-03$ & $4.410 \mathrm{E}-02$ & $6.259 \mathrm{E}-03$ & $1.302 \mathrm{E}-02$ & $6.128 \mathrm{E}-03$ & $1.366 \mathrm{E}-02$ \\
\hline SUM & 1 & 1 & 1 & 1 & 1 & 1 & 1 \\
\hline $\begin{array}{l}\text { Oxide mass } \\
\text { (MT) }\end{array}$ & $1,183.119$ & 143.796 & 733.959 & 533.009 & 275.181 & 209.397 & 173.318 \\
\hline
\end{tabular}


Table A.2. (Continued)

\begin{tabular}{|c|c|c|c|c|c|c|}
\hline Cluster \# & 15 & 16 & 17 & 18 & 19 & 20 \\
\hline $\mathrm{Ag}_{2} \mathrm{O}$ & $2.800 \mathrm{E}-04$ & $1.146 \mathrm{E}-04$ & $1.352 \mathrm{E}-04$ & $1.167 \mathrm{E}-03$ & $3.118 \mathrm{E}-04$ & $2.704 \mathrm{E}-04$ \\
\hline $\mathrm{Al}_{2} \mathrm{O}_{3}$ & $1.305 \mathrm{E}-01$ & $5.734 \mathrm{E}-01$ & $1.840 \mathrm{E}-01$ & $2.012 \mathrm{E}-01$ & $2.851 \mathrm{E}-01$ & $2.341 \mathrm{E}-01$ \\
\hline $\mathrm{B}_{2} \mathrm{O}_{3}$ & $1.986 \mathrm{E}-03$ & $2.107 \mathrm{E}-03$ & $1.424 \mathrm{E}-03$ & $2.682 \mathrm{E}-03$ & $1.118 \mathrm{E}-03$ & $3.688 \mathrm{E}-03$ \\
\hline $\mathrm{BaO}$ & $5.008 \mathrm{E}-04$ & $2.215 \mathrm{E}-04$ & $6.229 \mathrm{E}-04$ & $1.457 \mathrm{E}-03$ & $1.176 \mathrm{E}-03$ & $9.305 \mathrm{E}-04$ \\
\hline $\mathbf{B i}_{2} \mathbf{O}_{3}$ & $5.771 \mathrm{E}-02$ & $1.449 \mathrm{E}-02$ & $1.228 \mathrm{E}-02$ & $3.360 \mathrm{E}-03$ & $8.557 \mathrm{E}-03$ & $4.985 \mathrm{E}-02$ \\
\hline $\mathrm{CaO}$ & $5.356 \mathrm{E}-02$ & $8.650 \mathrm{E}-03$ & $8.914 \mathrm{E}-02$ & $2.217 \mathrm{E}-02$ & $4.017 \mathrm{E}-02$ & $3.962 \mathrm{E}-02$ \\
\hline $\mathrm{CdO}$ & $1.684 \mathrm{E}-04$ & $4.295 \mathrm{E}-05$ & $3.611 \mathrm{E}-03$ & $3.228 \mathrm{E}-02$ & $2.292 \mathrm{E}-03$ & $2.710 \mathrm{E}-04$ \\
\hline $\mathrm{Ce}_{2} \mathrm{O}_{3}$ & $9.405 \mathrm{E}-04$ & $3.236 \mathrm{E}-04$ & $1.578 \mathrm{E}-03$ & $2.351 \mathrm{E}-03$ & $1.010 \mathrm{E}-03$ & $4.766 \mathrm{E}-04$ \\
\hline $\mathrm{Cl}$ & $2.445 \mathrm{E}-03$ & $1.450 \mathrm{E}-03$ & $2.454 \mathrm{E}-03$ & $2.252 \mathrm{E}-03$ & $1.820 \mathrm{E}-03$ & $1.442 \mathrm{E}-03$ \\
\hline $\mathrm{CoO}$ & $5.004 \mathrm{E}-05$ & $6.637 \mathrm{E}-05$ & $6.859 \mathrm{E}-05$ & $1.208 \mathrm{E}-04$ & $4.854 \mathrm{E}-05$ & $2.148 \mathrm{E}-04$ \\
\hline $\mathrm{Cr}_{2} \mathrm{O}_{3}$ & $3.815 \mathrm{E}-03$ & $2.029 \mathrm{E}-02$ & $1.462 \mathrm{E}-02$ & $6.181 \mathrm{E}-03$ & $1.181 \mathrm{E}-02$ & $1.851 \mathrm{E}-02$ \\
\hline $\mathrm{Cs}_{2} \mathrm{O}$ & $3.424 \mathrm{E}-04$ & $7.834 \mathrm{E}-05$ & $3.961 \mathrm{E}-04$ & $3.261 \mathrm{E}-04$ & $2.996 \mathrm{E}-04$ & $7.757 \mathrm{E}-05$ \\
\hline $\mathrm{CuO}$ & $3.955 \mathrm{E}-04$ & $1.805 \mathrm{E}-04$ & $3.109 \mathrm{E}-04$ & $4.768 \mathrm{E}-04$ & $3.350 \mathrm{E}-04$ & $3.297 \mathrm{E}-04$ \\
\hline$F$ & $1.232 \mathrm{E}-02$ & $2.581 \mathrm{E}-03$ & $2.552 \mathrm{E}-03$ & $1.182 \mathrm{E}-03$ & $1.660 \mathrm{E}-03$ & $2.263 \mathrm{E}-02$ \\
\hline $\mathrm{Fe}_{2} \mathrm{O}_{3}$ & $2.362 \mathrm{E}-01$ & $5.489 \mathrm{E}-02$ & $1.386 \mathrm{E}-01$ & $3.488 \mathrm{E}-01$ & $1.702 \mathrm{E}-01$ & $1.435 \mathrm{E}-01$ \\
\hline $\mathrm{K}_{2} \mathrm{O}$ & $2.136 \mathrm{E}-02$ & $2.175 \mathrm{E}-03$ & $9.940 \mathrm{E}-03$ & $9.612 \mathrm{E}-03$ & $4.810 \mathrm{E}-03$ & $4.246 \mathrm{E}-03$ \\
\hline $\mathrm{La}_{2} \mathrm{O}_{3}$ & $3.267 \mathrm{E}-04$ & $9.527 \mathrm{E}-04$ & $2.174 \mathrm{E}-03$ & $8.432 \mathrm{E}-03$ & $1.824 \mathrm{E}-03$ & $3.205 \mathrm{E}-03$ \\
\hline $\mathrm{Li}_{2} \mathrm{O}$ & $1.674 \mathrm{E}-04$ & $2.234 \mathrm{E}-04$ & $6.251 \mathrm{E}-04$ & $4.307 \mathrm{E}-04$ & $3.236 \mathrm{E}-04$ & $3.888 \mathrm{E}-04$ \\
\hline $\mathrm{MgO}$ & $1.953 \mathrm{E}-03$ & $1.934 \mathrm{E}-03$ & $1.123 \mathrm{E}-03$ & $2.584 \mathrm{E}-03$ & $2.340 \mathrm{E}-03$ & $5.612 \mathrm{E}-03$ \\
\hline MnO & $2.424 \mathrm{E}-02$ & 1.384E-02 & $1.621 \mathrm{E}-02$ & $1.236 \mathrm{E}-02$ & $1.319 \mathrm{E}-02$ & $1.352 \mathrm{E}-02$ \\
\hline $\mathrm{MoO}_{3}$ & $2.302 \mathrm{E}-04$ & $3.256 \mathrm{E}-04$ & $6.105 \mathrm{E}-04$ & $2.619 \mathrm{E}-04$ & $2.235 \mathrm{E}-04$ & $6.966 \mathrm{E}-04$ \\
\hline $\mathrm{Na}_{2} \mathrm{O}$ & $1.286 \mathrm{E}-01$ & $1.627 \mathrm{E}-01$ & $3.718 \mathrm{E}-01$ & $9.567 \mathrm{E}-02$ & $2.022 \mathrm{E}-01$ & $1.508 \mathrm{E}-01$ \\
\hline $\mathrm{Nd}_{2} \mathrm{O}_{3}$ & $3.746 \mathrm{E}-04$ & $7.537 \mathrm{E}-04$ & $3.319 \mathrm{E}-03$ & $6.421 \mathrm{E}-03$ & $1.930 \mathrm{E}-03$ & $6.088 \mathrm{E}-04$ \\
\hline $\mathrm{NiO}$ & $3.078 \mathrm{E}-02$ & $3.582 \mathrm{E}-03$ & $5.745 \mathrm{E}-03$ & $2.737 \mathrm{E}-02$ & $1.928 \mathrm{E}-02$ & $1.545 \mathrm{E}-02$ \\
\hline $\mathbf{P}_{2} \mathbf{O}_{5}$ & $5.605 \mathrm{E}-02$ & $1.397 \mathrm{E}-02$ & $3.166 \mathrm{E}-02$ & $9.687 \mathrm{E}-03$ & $1.304 \mathrm{E}-02$ & $3.295 \mathrm{E}-02$ \\
\hline $\mathrm{PbO}$ & $1.227 \mathrm{E}-02$ & $2.603 \mathrm{E}-03$ & $3.130 \mathrm{E}-03$ & $6.791 \mathrm{E}-03$ & $6.954 \mathrm{E}-03$ & $8.213 \mathrm{E}-03$ \\
\hline $\mathrm{PdO}$ & $8.646 \mathrm{E}-07$ & $2.435 \mathrm{E}-08$ & $1.930 \mathrm{E}-04$ & $3.402 \mathrm{E}-05$ & $2.090 \mathrm{E}-04$ & $1.208 \mathrm{E}-07$ \\
\hline $\mathrm{Re}_{2} \mathrm{O}_{7}$ & $4.237 \mathrm{E}-05$ & $1.985 \mathrm{E}-05$ & $4.362 \mathrm{E}-05$ & $3.389 \mathrm{E}-05$ & $1.675 \mathrm{E}-05$ & 3.944E-05 \\
\hline $\mathrm{Rh}_{2} \mathrm{O}_{3}$ & $2.020 \mathrm{E}-05$ & $1.795 \mathrm{E}-07$ & $2.099 \mathrm{E}-04$ & $5.446 \mathrm{E}-05$ & $1.230 \mathrm{E}-04$ & $1.988 \mathrm{E}-07$ \\
\hline $\mathrm{RuO}_{2}$ & $3.517 \mathrm{E}-04$ & $2.688 \mathrm{E}-06$ & $4.456 \mathrm{E}-04$ & 1.494E-04 & $9.453 \mathrm{E}-04$ & $1.205 \mathrm{E}-06$ \\
\hline $\mathrm{SiO}_{2}$ & $1.406 \mathrm{E}-01$ & $6.934 \mathrm{E}-02$ & $2.412 \mathrm{E}-02$ & $3.164 \mathrm{E}-02$ & $8.077 \mathrm{E}-02$ & $1.285 \mathrm{E}-01$ \\
\hline $\mathrm{SO}_{3}$ & $1.540 \mathrm{E}-03$ & $4.998 \mathrm{E}-03$ & $4.496 \mathrm{E}-03$ & $1.839 \mathrm{E}-03$ & $2.628 \mathrm{E}-03$ & $9.786 \mathrm{E}-03$ \\
\hline $\mathrm{SnO}_{2}$ & $1.078 \mathrm{E}-06$ & $1.132 \mathrm{E}-06$ & $1.324 \mathrm{E}-06$ & $5.890 \mathrm{E}-07$ & $4.934 \mathrm{E}-07$ & $1.075 \mathrm{E}-06$ \\
\hline $\mathrm{SrO}$ & $1.557 \mathrm{E}-03$ & $1.655 \mathrm{E}-03$ & $2.989 \mathrm{E}-02$ & $6.840 \mathrm{E}-04$ & $1.980 \mathrm{E}-02$ & $1.019 \mathrm{E}-02$ \\
\hline $\mathrm{ThO}_{2}$ & $2.923 \mathrm{E}-03$ & $4.827 \mathrm{E}-04$ & $1.424 \mathrm{E}-03$ & $1.711 \mathrm{E}-02$ & $2.366 \mathrm{E}-02$ & $2.915 \mathrm{E}-03$ \\
\hline $\mathrm{TiO}_{2}$ & $1.327 \mathrm{E}-04$ & $1.297 \mathrm{E}-04$ & $1.345 \mathrm{E}-04$ & $3.355 \mathrm{E}-04$ & $1.616 \mathrm{E}-04$ & $2.373 \mathrm{E}-04$ \\
\hline $\mathrm{UO}_{3}$ & $5.021 \mathrm{E}-02$ & $3.904 \mathrm{E}-02$ & $2.569 \mathrm{E}-02$ & $7.485 \mathrm{E}-02$ & $4.921 \mathrm{E}-02$ & $9.295 \mathrm{E}-02$ \\
\hline $\mathrm{V}_{2} \mathrm{O}_{5}$ & $8.545 \mathrm{E}-05$ & $2.723 \mathrm{E}-04$ & $2.473 \mathrm{E}-04$ & $9.868 \mathrm{E}-05$ & $1.072 \mathrm{E}-04$ & $3.707 \mathrm{E}-04$ \\
\hline $\mathrm{Y}_{2} \mathrm{O}_{3}$ & $4.032 \mathrm{E}-05$ & $3.729 \mathrm{E}-06$ & $2.456 \mathrm{E}-04$ & $2.381 \mathrm{E}-04$ & $1.649 \mathrm{E}-04$ & $9.115 \mathrm{E}-06$ \\
\hline $\mathrm{ZnO}$ & $9.112 \mathrm{E}-04$ & $3.945 \mathrm{E}-04$ & $7.586 \mathrm{E}-04$ & $1.297 \mathrm{E}-03$ & $4.262 \mathrm{E}-04$ & $6.890 \mathrm{E}-04$ \\
\hline $\mathrm{ZrO}_{2}$ & $2.400 \mathrm{E}-02$ & $1.813 \mathrm{E}-03$ & $1.395 \mathrm{E}-02$ & $6.602 \mathrm{E}-02$ & $2.972 \mathrm{E}-02$ & $2.752 \mathrm{E}-03$ \\
\hline SUM & 1 & 1 & 1 & 1 & 1 & 1 \\
\hline $\begin{array}{l}\text { Oxide mass } \\
\text { (MT) }\end{array}$ & 327.203 & $1,453.789$ & 164.666 & 123.884 & 249.230 & $1,350.527$ \\
\hline
\end{tabular}



Appendix B

LAW Glasses Used for Preliminary VHT Model Development 



\section{Appendix B: LAW Glasses Used for Preliminary VHT Model Development}

Table B.1. Composition and VHT Alteration Rate of Glasses Used for Preliminary VHT Model Development

\begin{tabular}{|c|c|c|c|c|c|c|c|c|c|c|c|c|}
\hline \multirow[b]{2}{*}{ Glass ID } & \multicolumn{12}{|c|}{ WTP Glasses } \\
\hline & LAWA44R10 & LAWA53 & LAWA56 & LAWA88 & LAWA102R1 & LAWA126 & LAWA128 & LAWA130 & LAWM10 & LAWM15 & LAWM17 & LAWM20 \\
\hline $\mathrm{Al}_{2} \mathrm{O}_{3}$ & $6.202 \mathrm{E}-02$ & $6.092 \mathrm{E}-02$ & $6.092 \mathrm{E}-02$ & $6.081 \mathrm{E}-02$ & $5.928 \mathrm{E}-02$ & $5.635 \mathrm{E}-02$ & $6.024 \mathrm{E}-02$ & $6.024 \mathrm{E}-02$ & $9.000 \mathrm{E}-02$ & $9.000 \mathrm{E}-02$ & $5.000 \mathrm{E}-02$ & $5.000 \mathrm{E}-02$ \\
\hline $\mathrm{B}_{2} \mathrm{O}_{3}$ & $8.904 \mathrm{E}-02$ & $6.112 \mathrm{E}-02$ & $1.193 \mathrm{E}-01$ & $9.701 \mathrm{E}-02$ & $9.783 \mathrm{E}-02$ & $9.811 \mathrm{E}-02$ & $7.063 \mathrm{E}-02$ & $8.941 \mathrm{E}-02$ & $1.300 \mathrm{E}-01$ & $9.360 \mathrm{E}-02$ & $1.200 \mathrm{E}-01$ & $7.000 \mathrm{E}-02$ \\
\hline $\mathrm{CaO}$ & $1.991 \mathrm{E}-02$ & $7.772 \mathrm{E}-02$ & $1.951 \mathrm{E}-02$ & $1.990 \mathrm{E}-02$ & $4.960 \mathrm{E}-02$ & $1.988 \mathrm{E}-02$ & $2.078 \mathrm{E}-02$ & $2.078 \mathrm{E}-02$ & $1.000 \mathrm{E}-01$ & & $2.210 \mathrm{E}-02$ & $8.000 \mathrm{E}-02$ \\
\hline $\mathrm{Fe}_{2} \mathrm{O}_{3}$ & $6.983 \mathrm{E}-02$ & $7.402 \mathrm{E}-02$ & $7.402 \mathrm{E}-02$ & $5.531 \mathrm{E}-02$ & $5.293 \mathrm{E}-02$ & $5.535 \mathrm{E}-02$ & $5.784 \mathrm{E}-02$ & $2.857 \mathrm{E}-02$ & & $6.280 \mathrm{E}-02$ & $6.500 \mathrm{E}-02$ & $2.000 \mathrm{E}-02$ \\
\hline $\mathrm{K}_{2} \mathrm{O}$ & $5.002 \mathrm{E}-03$ & $4.901 \mathrm{E}-03$ & $4.901 \mathrm{E}-03$ & $2.580 \mathrm{E}-02$ & $2.544 \mathrm{E}-03$ & $3.877 \mathrm{E}-02$ & $3.876 \mathrm{E}-02$ & $3.876 \mathrm{E}-02$ & & & $2.000 \mathrm{E}-02$ & $2.000 \mathrm{E}-02$ \\
\hline $\mathrm{Li}_{2} \mathrm{O}$ & & & & & $2.446 \mathrm{E}-02$ & & & & $4.500 \mathrm{E}-02$ & & $5.000 \mathrm{E}-03$ & $2.260 \mathrm{E}-02$ \\
\hline $\mathrm{MgO}$ & $1.991 \mathrm{E}-02$ & $1.460 \mathrm{E}-02$ & $1.460 \mathrm{E}-02$ & $1.470 \mathrm{E}-02$ & $1.467 \mathrm{E}-02$ & $1.479 \mathrm{E}-02$ & $1.179 \mathrm{E}-02$ & $1.179 \mathrm{E}-02$ & & $3.720 \mathrm{E}-02$ & $3.500 \mathrm{E}-02$ & $3.500 \mathrm{E}-02$ \\
\hline $\mathrm{Na}_{2} \mathrm{O}$ & $2.001 \mathrm{E}-01$ & $1.973 \mathrm{E}-01$ & $1.973 \mathrm{E}-01$ & $2.000 \mathrm{E}-01$ & $1.418 \mathrm{E}-01$ & $1.844 \mathrm{E}-01$ & $1.844 \mathrm{E}-01$ & $1.844 \mathrm{E}-01$ & $1.307 \mathrm{E}-01$ & $2.200 \mathrm{E}-01$ & $1.700 \mathrm{E}-01$ & $1.700 \mathrm{E}-01$ \\
\hline $\mathrm{SiO}_{2}$ & $4.457 \mathrm{E}-01$ & $4.167 \mathrm{E}-01$ & $4.167 \mathrm{E}-01$ & $4.399 \mathrm{E}-01$ & $4.559 \mathrm{E}-01$ & $4.408 \mathrm{E}-01$ & $4.604 \mathrm{E}-01$ & $4.604 \mathrm{E}-01$ & $4.015 \mathrm{E}-01$ & $4.348 \mathrm{E}-01$ & $4.200 \mathrm{E}-01$ & $4.200 \mathrm{E}-01$ \\
\hline $\mathrm{SnO}_{2}$ & & & & & & & & & & & & \\
\hline $\mathrm{SO}_{3}$ & $1.000 \mathrm{E}-03$ & $1.480 \mathrm{E}-02$ & $1.480 \mathrm{E}-02$ & $2.100 \mathrm{E}-03$ & $2.446 \mathrm{E}-02$ & $3.497 \mathrm{E}-03$ & $3.497 \mathrm{E}-03$ & $3.497 \mathrm{E}-03$ & $2.800 \mathrm{E}-03$ & $1.600 \mathrm{E}-03$ & $2.400 \mathrm{E}-03$ & $2.400 \mathrm{E}-03$ \\
\hline $\mathrm{TiO}_{2}$ & $1.991 \mathrm{E}-02$ & $1.090 \mathrm{E}-02$ & $1.090 \mathrm{E}-02$ & $1.990 \mathrm{E}-02$ & $1.115 \mathrm{E}-02$ & $1.998 \mathrm{E}-02$ & $2.088 \mathrm{E}-02$ & $2.088 \mathrm{E}-02$ & $3.000 \mathrm{E}-02$ & $3.000 \mathrm{E}-02$ & $5.000 \mathrm{E}-03$ & $5.000 \mathrm{E}-03$ \\
\hline $\mathrm{ZnO}$ & $2.961 \mathrm{E}-02$ & $2.951 \mathrm{E}-02$ & $2.951 \mathrm{E}-02$ & $2.950 \mathrm{E}-02$ & $2.994 \mathrm{E}-02$ & $2.957 \mathrm{E}-02$ & $3.087 \mathrm{E}-02$ & $4.136 \mathrm{E}-02$ & $1.000 \mathrm{E}-02$ & $1.000 \mathrm{E}-02$ & $5.000 \mathrm{E}-02$ & $5.000 \mathrm{E}-02$ \\
\hline $\mathrm{ZrO}_{2}$ & $2.991 \mathrm{E}-02$ & $2.951 \mathrm{E}-02$ & $2.951 \mathrm{E}-02$ & $2.990 \mathrm{E}-02$ & $2.954 \mathrm{E}-02$ & $2.987 \mathrm{E}-02$ & $3.127 \mathrm{E}-02$ & $3.127 \mathrm{E}-02$ & $4.000 \mathrm{E}-02$ & & $3.500 \mathrm{E}-02$ & $3.500 \mathrm{E}-02$ \\
\hline $\mathrm{BaO}$ & & & & & & & & & $1.000 \mathrm{E}-04$ & $1.000 \mathrm{E}-04$ & $2.500 \mathrm{E}-06$ & $1.000 \mathrm{E}-04$ \\
\hline $\mathrm{Br}$ & & & & & & & & & & & & \\
\hline $\mathrm{CdO}$ & & & & & & & & & $1.000 \mathrm{E}-04$ & $1.000 \mathrm{E}-04$ & $2.500 \mathrm{E}-06$ & $1.000 \mathrm{E}-04$ \\
\hline $\mathrm{Ce}_{2} \mathrm{O}_{3}$ & & & & & & & & & & & & \\
\hline $\mathrm{Cl}$ & $6.503 \mathrm{E}-03$ & $6.402 \mathrm{E}-03$ & $6.402 \mathrm{E}-03$ & $3.300 \mathrm{E}-03$ & $3.228 \mathrm{E}-03$ & $1.998 \mathrm{E}-03$ & $1.998 \mathrm{E}-03$ & $1.998 \mathrm{E}-03$ & $8.002 \mathrm{E}-03$ & $8.002 \mathrm{E}-03$ & $2.001 \mathrm{E}-04$ & $8.002 \mathrm{E}-03$ \\
\hline $\mathrm{Cr}_{2} \mathrm{O}_{3}$ & $2.001 \mathrm{E}-04$ & $2.001 \mathrm{E}-04$ & $2.001 \mathrm{E}-04$ & $1.000 \mathrm{E}-04$ & $1.957 \mathrm{E}-04$ & $1.998 \mathrm{E}-04$ & $1.998 \mathrm{E}-04$ & $1.998 \mathrm{E}-04$ & $3.214 \mathrm{E}-03$ & $3.214 \mathrm{E}-03$ & $8.035 \mathrm{E}-05$ & $3.214 \mathrm{E}-03$ \\
\hline $\mathrm{Cs}_{2} \mathrm{O}$ & & & & & & $1.599 \mathrm{E}-03$ & $1.598 \mathrm{E}-03$ & $1.598 \mathrm{E}-03$ & & & & \\
\hline $\mathrm{F}$ & $1.000 \mathrm{E}-04$ & $1.000 \mathrm{E}-04$ & $1.000 \mathrm{E}-04$ & & $2.935 \mathrm{E}-04$ & $2.997 \mathrm{E}-03$ & $2.997 \mathrm{E}-03$ & $2.997 \mathrm{E}-03$ & $2.994 \mathrm{E}-03$ & $2.994 \mathrm{E}-03$ & $7.485 \mathrm{E}-05$ & $2.994 \mathrm{E}-03$ \\
\hline I & & & & & & & & & & & & \\
\hline $\mathrm{La}_{2} \mathrm{O}_{3}$ & & & & & & & & & & & & \\
\hline $\mathrm{MnO}$ & & & & & & & & & & & & \\
\hline $\mathrm{MoO}_{3}$ & & & & & & & & & & & & \\
\hline $\mathrm{NiO}$ & & & & & & & & & $3.000 \mathrm{E}-04$ & $3.000 \mathrm{E}-04$ & $7.500 \mathrm{E}-06$ & $3.000 \mathrm{E}-04$ \\
\hline $\mathrm{P}_{2} \mathrm{O}_{5}$ & $3.001 \mathrm{E}-04$ & $3.001 \mathrm{E}-04$ & $3.001 \mathrm{E}-04$ & $7.001 \mathrm{E}-04$ & $1.272 \mathrm{E}-03$ & 7.993E-04 & $7.992 \mathrm{E}-04$ & 7.992E-04 & $4.990 \mathrm{E}-03$ & $4.990 \mathrm{E}-03$ & $1.248 \mathrm{E}-04$ & $4.990 \mathrm{E}-03$ \\
\hline $\mathrm{PbO}$ & & & & & & & & & $3.000 \mathrm{E}-04$ & $3.000 \mathrm{E}-04$ & $7.500 \mathrm{E}-06$ & $3.000 \mathrm{E}-04$ \\
\hline $\mathrm{Re}_{2} \mathrm{O}_{7}$ & $1.000 \mathrm{E}-03$ & $1.000 \mathrm{E}-03$ & $1.000 \mathrm{E}-03$ & $1.000 \mathrm{E}-03$ & $9.783 \mathrm{E}-04$ & $9.991 \mathrm{E}-04$ & $9.990 \mathrm{E}-04$ & $9.990 \mathrm{E}-04$ & & & & \\
\hline $\mathrm{SrO}$ & & & & & & & & & & & & \\
\hline $\mathrm{V}_{2} \mathrm{O}_{5}$ & & & & & & & & & & & & \\
\hline SUM & 1 & 1 & 1 & 1 & 1 & 1 & 1 & 1 & 1 & 1 & 1 & 1 \\
\hline$r_{\text {alt }}\left(\mathrm{g} / \mathrm{m}^{2} / \mathrm{d}\right)$ & 1.00 & 0.80 & 1.70 & 1.40 & 3.70 & 2.50 & 0.90 & 0.70 & 12.60 & 95.10 & 0.30 & 13.70 \\
\hline$\frac{\ln \left(r_{a l t}\right)}{4}$ & 0.00 & -0.22 & 0.53 & 0.34 & 1.31 & 0.92 & -0.11 & -0.36 & 2.53 & 4.55 & -1.20 & 2.62 \\
\hline
\end{tabular}

Empty cells represent zero concentration 
Table B.1. (Continued)

\begin{tabular}{|c|c|c|c|c|c|c|c|c|c|c|c|c|}
\hline \multirow[b]{2}{*}{ Glass ID } & \multicolumn{12}{|c|}{ WTP Glasses } \\
\hline & LAWM22 & LAWM24 & LAWM30 & LAWM31 & LAWM33 & LAWM34 & LAWM35 & LAWM38 & LAWM39 & LAWM42 & LAWM45 & $\begin{array}{c}\text { LAWM52 } \\
\text { (LAWA88) }\end{array}$ \\
\hline $\mathrm{Al}_{2} \mathrm{O}_{3}$ & $8.000 \mathrm{E}-02$ & $8.000 \mathrm{E}-02$ & $8.000 \mathrm{E}-02$ & $5.000 \mathrm{E}-02$ & $5.000 \mathrm{E}-02$ & $5.000 \mathrm{E}-02$ & $5.000 \mathrm{E}-02$ & $7.000 \mathrm{E}-02$ & $7.000 \mathrm{E}-02$ & $6.000 \mathrm{E}-02$ & $7.000 \mathrm{E}-02$ & $6.080 \mathrm{E}-02$ \\
\hline $\mathrm{B}_{2} \mathrm{O}_{3}$ & $7.000 \mathrm{E}-02$ & $1.200 \mathrm{E}-01$ & $1.200 \mathrm{E}-01$ & $7.000 \mathrm{E}-02$ & $1.200 \mathrm{E}-01$ & $8.350 \mathrm{E}-02$ & $1.200 \mathrm{E}-01$ & $8.000 \mathrm{E}-02$ & $9.050 \mathrm{E}-02$ & $8.000 \mathrm{E}-02$ & $8.000 \mathrm{E}-02$ & $9.700 \mathrm{E}-02$ \\
\hline $\mathrm{Fe}_{2} \mathrm{O}_{3}$ & $6.500 \mathrm{E}-02$ & $6.500 \mathrm{E}-02$ & $6.500 \mathrm{E}-02$ & $6.500 \mathrm{E}-02$ & $6.500 \mathrm{E}-02$ & $6.290 \mathrm{E}-02$ & $4.410 \mathrm{E}-02$ & $3.000 \mathrm{E}-02$ & $3.000 \mathrm{E}-02$ & $4.030 \mathrm{E}-02$ & $5.000 \mathrm{E}-02$ & $5.530 \mathrm{E}-02$ \\
\hline $\mathrm{K}_{2} \mathrm{O}$ & $2.000 \mathrm{E}-02$ & $2.000 \mathrm{E}-02$ & $1.000 \mathrm{E}-03$ & $1.000 \mathrm{E}-03$ & $1.720 \mathrm{E}-02$ & $2.000 \mathrm{E}-02$ & $1.000 \mathrm{E}-03$ & $1.500 \mathrm{E}-03$ & $1.000 \mathrm{E}-03$ & $1.000 \mathrm{E}-03$ & $3.000 \mathrm{E}-03$ & $2.580 \mathrm{E}-02$ \\
\hline $\mathrm{Li}_{2} \mathrm{O}$ & $5.000 \mathrm{E}-03$ & $6.400 \mathrm{E}-03$ & $2.020 \mathrm{E}-02$ & $3.000 \mathrm{E}-02$ & $9.000 \mathrm{E}-03$ & $3.000 \mathrm{E}-02$ & $5.000 \mathrm{E}-03$ & $2.500 \mathrm{E}-02$ & $2.500 \mathrm{E}-02$ & $2.500 \mathrm{E}-02$ & $1.420 \mathrm{E}-02$ & \\
\hline $\mathrm{MgO}$ & $3.500 \mathrm{E}-02$ & $1.000 \mathrm{E}-02$ & $1.000 \mathrm{E}-02$ & $1.000 \mathrm{E}-02$ & $1.000 \mathrm{E}-02$ & $1.000 \mathrm{E}-02$ & $3.500 \mathrm{E}-02$ & $1.500 \mathrm{E}-02$ & $2.500 \mathrm{E}-02$ & $1.500 \mathrm{E}-02$ & $1.500 \mathrm{E}-02$ & $1.470 \mathrm{E}-02$ \\
\hline $\mathrm{Na}_{2} \mathrm{O}$ & $1.700 \mathrm{E}-01$ & $1.700 \mathrm{E}-01$ & $1.700 \mathrm{E}-01$ & $1.675 \mathrm{E}-01$ & $1.700 \mathrm{E}-01$ & $1.700 \mathrm{E}-01$ & $1.700 \mathrm{E}-01$ & $1.400 \mathrm{E}-01$ & $1.400 \mathrm{E}-01$ & $1.400 \mathrm{E}-01$ & $1.400 \mathrm{E}-01$ & $2.000 \mathrm{E}-01$ \\
\hline $\mathrm{SiO}_{2}$ & $4.200 \mathrm{E}-01$ & $4.707 \mathrm{E}-01$ & $4.200 \mathrm{E}-01$ & $4.231 \mathrm{E}-01$ & $4.200 \mathrm{E}-01$ & $4.200 \mathrm{E}-01$ & $4.200 \mathrm{E}-01$ & $4.800 \mathrm{E}-01$ & $4.800 \mathrm{E}-01$ & $4.800 \mathrm{E}-01$ & $4.800 \mathrm{E}-01$ & 4.399E-01 \\
\hline \multicolumn{13}{|l|}{$\mathrm{SnO}_{2}$} \\
\hline $\mathrm{SO}_{3}$ & $3.300 \mathrm{E}-03$ & $2.400 \mathrm{E}-03$ & $2.400 \mathrm{E}-03$ & $3.400 \mathrm{E}-03$ & $3.300 \mathrm{E}-03$ & $3.300 \mathrm{E}-03$ & $2.400 \mathrm{E}-03$ & $3.500 \mathrm{E}-03$ & $3.500 \mathrm{E}-03$ & $3.700 \mathrm{E}-03$ & $3.500 \mathrm{E}-03$ & $2.100 \mathrm{E}-03$ \\
\hline $\mathrm{TiO}_{2}$ & $6.700 \mathrm{E}-03$ & $5.000 \mathrm{E}-03$ & $5.900 \mathrm{E}-03$ & $2.500 \mathrm{E}-02$ & $2.500 \mathrm{E}-02$ & $1.480 \mathrm{E}-02$ & $2.500 \mathrm{E}-02$ & $1.000 \mathrm{E}-02$ & $1.000 \mathrm{E}-02$ & $2.000 \mathrm{E}-02$ & $2.000 \mathrm{E}-02$ & $1.990 \mathrm{E}-02$ \\
\hline $\mathrm{ZnO}$ & $5.000 \mathrm{E}-02$ & $2.000 \mathrm{E}-02$ & $5.000 \mathrm{E}-02$ & $2.000 \mathrm{E}-02$ & $2.000 \mathrm{E}-02$ & $2.000 \mathrm{E}-02$ & $2.000 \mathrm{E}-02$ & $3.500 \mathrm{E}-02$ & $3.500 \mathrm{E}-02$ & $3.500 \mathrm{E}-02$ & $4.600 \mathrm{E}-02$ & $2.950 \mathrm{E}-02$ \\
\hline $\mathrm{ZrO}_{2}$ & $3.500 \mathrm{E}-02$ & $1.000 \mathrm{E}-02$ & $3.500 \mathrm{E}-02$ & $3.500 \mathrm{E}-02$ & $1.000 \mathrm{E}-02$ & $3.500 \mathrm{E}-02$ & $2.570 \mathrm{E}-02$ & $2.000 \mathrm{E}-02$ & $2.000 \mathrm{E}-02$ & $3.000 \mathrm{E}-02$ & $2.000 \mathrm{E}-02$ & $2.990 \mathrm{E}-02$ \\
\hline $\mathrm{BaO}$ & $1.000 \mathrm{E}-04$ & $2.500 \mathrm{E}-06$ & $2.500 \mathrm{E}-06$ & $1.000 \mathrm{E}-04$ & $2.500 \mathrm{E}-06$ & $2.500 \mathrm{E}-06$ & $1.000 \mathrm{E}-04$ & $1.000 \mathrm{E}-04$ & $1.000 \mathrm{E}-04$ & $1.000 \mathrm{E}-04$ & $2.500 \mathrm{E}-06$ & $2.600 \mathrm{E}-05$ \\
\hline \multicolumn{13}{|l|}{$\mathrm{Br}$} \\
\hline $\mathrm{CdO}$ & $1.000 \mathrm{E}-04$ & $2.500 \mathrm{E}-06$ & $2.500 \mathrm{E}-06$ & $1.000 \mathrm{E}-04$ & $2.500 \mathrm{E}-06$ & $2.500 \mathrm{E}-06$ & $1.000 \mathrm{E}-04$ & $1.000 \mathrm{E}-04$ & $1.000 \mathrm{E}-04$ & $1.000 \mathrm{E}-04$ & $2.500 \mathrm{E}-06$ & $2.600 \mathrm{E}-05$ \\
\hline \multicolumn{13}{|l|}{$\mathrm{Ce}_{2} \mathrm{O}_{3}$} \\
\hline \multicolumn{13}{|l|}{$\mathrm{Cs}_{2} \mathrm{O}$} \\
\hline $\mathrm{F}$ & $2.994 \mathrm{E}-03$ & $7.485 \mathrm{E}-05$ & $7.485 \mathrm{E}-05$ & $2.994 \mathrm{E}-03$ & $7.485 \mathrm{E}-05$ & $7.485 \mathrm{E}-05$ & $2.994 \mathrm{E}-03$ & $2.994 \mathrm{E}-03$ & $2.994 \mathrm{E}-03$ & $2.994 \mathrm{E}-03$ & $7.485 \mathrm{E}-05$ & 7.784E-04 \\
\hline \multicolumn{13}{|l|}{ I } \\
\hline \multicolumn{13}{|l|}{$\mathrm{La}_{2} \mathrm{O}_{3}$} \\
\hline \multicolumn{13}{|l|}{$\mathrm{MnO}$} \\
\hline \multicolumn{13}{|l|}{$\mathrm{MoO}_{3}$} \\
\hline $\mathrm{NiO}$ & $3.000 \mathrm{E}-04$ & $7.500 \mathrm{E}-06$ & $7.500 \mathrm{E}-06$ & $3.000 \mathrm{E}-04$ & 7.500E-06 & 7.500E-06 & $3.000 \mathrm{E}-04$ & $3.000 \mathrm{E}-04$ & $3.000 \mathrm{E}-04$ & $3.000 \mathrm{E}-04$ & $7.500 \mathrm{E}-06$ & $7.800 \mathrm{E}-05$ \\
\hline $\mathrm{P}_{2} \mathrm{O}_{5}$ & $4.990 \mathrm{E}-03$ & $1.248 \mathrm{E}-04$ & $1.248 \mathrm{E}-04$ & $4.990 \mathrm{E}-03$ & $1.248 \mathrm{E}-04$ & $1.248 \mathrm{E}-04$ & $4.990 \mathrm{E}-03$ & $4.990 \mathrm{E}-03$ & $4.990 \mathrm{E}-03$ & $4.990 \mathrm{E}-03$ & $1.248 \mathrm{E}-04$ & $1.297 \mathrm{E}-03$ \\
\hline $\mathrm{PbO}$ & $3.000 \mathrm{E}-04$ & $7.500 \mathrm{E}-06$ & $7.500 \mathrm{E}-06$ & $3.000 \mathrm{E}-04$ & $7.500 \mathrm{E}-06$ & $7.500 \mathrm{E}-06$ & $3.000 \mathrm{E}-04$ & $3.000 \mathrm{E}-04$ & $3.000 \mathrm{E}-04$ & $3.000 \mathrm{E}-04$ & $7.500 \mathrm{E}-06$ & $7.800 \mathrm{E}-05$ \\
\hline \multicolumn{13}{|l|}{$\mathrm{Re}_{2} \mathrm{O}_{7}$} \\
\hline \multicolumn{13}{|l|}{$\mathrm{SrO}$} \\
\hline \multicolumn{13}{|l|}{$\mathrm{V}_{2} \mathrm{O}_{5}$} \\
\hline SUM & 1 & 1 & 1 & 1 & 1 & 1 & 1 & 1 & 1 & 1 & 1 & 1 \\
\hline$r_{\text {alt }}\left(\mathrm{g} / \mathrm{m}^{2} / \mathrm{d}\right)$ & 0.20 & 13.70 & 21.30 & 5.50 & 3.80 & 48.70 & 1.00 & 19.70 & 12.40 & 0.80 & 5.00 & 3.10 \\
\hline $\ln \left(r_{a l t}\right)$ & -1.61 & 2.62 & 3.06 & 1.70 & 1.34 & 3.89 & 0.00 & 2.98 & 2.52 & -0.22 & 1.61 & 1.13 \\
\hline
\end{tabular}


Table B.1. (Continued)

\begin{tabular}{|c|c|c|c|c|c|c|c|c|c|c|c|c|}
\hline \multirow[b]{2}{*}{ Glass ID } & \multicolumn{12}{|c|}{ WTP Glasses } \\
\hline & $\begin{array}{c}\text { LAWM56 } \\
\text { (LAWM35) }\end{array}$ & LAWM57 & LAWM58 & LAWM59 & LAWM60 & LAWM61 & LAWM62 & LAWM63 & LAWM64 & LAWM65 & LAWM66 & LAWM67 \\
\hline $\mathrm{Al}_{2} \mathrm{O}_{3}$ & $5.000 \mathrm{E}-02$ & $6.999 \mathrm{E}-02$ & $6.999 \mathrm{E}-02$ & $6.839 \mathrm{E}-02$ & $5.000 \mathrm{E}-02$ & $5.000 \mathrm{E}-02$ & $5.000 \mathrm{E}-02$ & $6.999 \mathrm{E}-02$ & $6.989 \mathrm{E}-02$ & $5.000 \mathrm{E}-02$ & $7.589 \mathrm{E}-02$ & $7.998 \mathrm{E}-02$ \\
\hline $\mathrm{B}_{2} \mathrm{O}_{3}$ & $1.200 \mathrm{E}-01$ & $1.100 \mathrm{E}-01$ & $9.289 \mathrm{E}-02$ & $9.009 \mathrm{E}-02$ & $1.100 \mathrm{E}-01$ & $1.100 \mathrm{E}-01$ & $8.999 \mathrm{E}-02$ & $9.398 \mathrm{E}-02$ & $1.098 \mathrm{E}-01$ & $9.000 \mathrm{E}-02$ & $1.063 \mathrm{E}-01$ & $1.060 \mathrm{E}-01$ \\
\hline $\mathrm{CaO}$ & $6.180 \mathrm{E}-02$ & $2.999 \mathrm{E}-02$ & $1.030 \mathrm{E}-02$ & $2.960 \mathrm{E}-02$ & $1.710 \mathrm{E}-02$ & $9.999 \mathrm{E}-03$ & $9.999 \mathrm{E}-03$ & $1.040 \mathrm{E}-02$ & $3.000 \mathrm{E}-02$ & $2.960 \mathrm{E}-02$ & $9.999 \mathrm{E}-03$ & $1.550 \mathrm{E}-02$ \\
\hline $\mathrm{Fe}_{2} \mathrm{O}_{3}$ & $4.410 \mathrm{E}-02$ & $4.659 \mathrm{E}-02$ & $6.499 \mathrm{E}-02$ & $6.489 \mathrm{E}-02$ & $4.500 \mathrm{E}-02$ & $4.500 \mathrm{E}-02$ & $6.499 \mathrm{E}-02$ & $4.699 \mathrm{E}-02$ & $6.499 \mathrm{E}-02$ & $4.500 \mathrm{E}-02$ & $6.309 \mathrm{E}-02$ & $4.599 \mathrm{E}-02$ \\
\hline $\mathrm{K}_{2} \mathrm{O}$ & $1.000 \mathrm{E}-03$ & $3.799 \mathrm{E}-02$ & $3.800 \mathrm{E}-02$ & $2.000 \mathrm{E}-02$ & $2.000 \mathrm{E}-02$ & $3.290 \mathrm{E}-02$ & $3.380 \mathrm{E}-02$ & $2.060 \mathrm{E}-02$ & $2.000 \mathrm{E}-02$ & $2.000 \mathrm{E}-02$ & $4.800 \mathrm{E}-03$ & $5.399 \mathrm{E}-02$ \\
\hline $\mathrm{Li}_{2} \mathrm{O}$ & $5.000 \mathrm{E}-03$ & & & & & & & & & & & \\
\hline $\mathrm{MgO}$ & $3.500 \mathrm{E}-02$ & $1.440 \mathrm{E}-02$ & $1.440 \mathrm{E}-02$ & $1.440 \mathrm{E}-02$ & $1.440 \mathrm{E}-02$ & $1.440 \mathrm{E}-02$ & $1.440 \mathrm{E}-02$ & $1.440 \mathrm{E}-02$ & $1.440 \mathrm{E}-02$ & $1.440 \mathrm{E}-02$ & $1.440 \mathrm{E}-02$ & $1.440 \mathrm{E}-02$ \\
\hline $\mathrm{Na}_{2} \mathrm{O}$ & $1.700 \mathrm{E}-01$ & $2.061 \mathrm{E}-01$ & $2.053 \mathrm{E}-01$ & $2.000 \mathrm{E}-01$ & $2.001 \mathrm{E}-01$ & $2.000 \mathrm{E}-01$ & $2.000 \mathrm{E}-01$ & $2.300 \mathrm{E}-01$ & 2.004E-01 & $2.279 \mathrm{E}-01$ & $2.299 \mathrm{E}-01$ & $2.013 \mathrm{E}-01$ \\
\hline $\mathrm{SiO}_{2}$ & $4.200 \mathrm{E}-01$ & $3.925 \mathrm{E}-01$ & $4.164 \mathrm{E}-01$ & $4.454 \mathrm{E}-01$ & $4.533 \mathrm{E}-01$ & $4.505 \mathrm{E}-01$ & $4.433 \mathrm{E}-01$ & 4.259E-01 & $3.836 \mathrm{E}-01$ & $4.359 \mathrm{E}-01$ & $3.835 \mathrm{E}-01$ & $3.835 \mathrm{E}-01$ \\
\hline \multicolumn{13}{|l|}{$\mathrm{SnO}_{2}$} \\
\hline $\mathrm{SO}_{3}$ & $2.400 \mathrm{E}-03$ & $3.499 \mathrm{E}-03$ & $3.500 \mathrm{E}-03$ & $3.500 \mathrm{E}-03$ & $3.500 \mathrm{E}-03$ & $3.500 \mathrm{E}-03$ & $3.500 \mathrm{E}-03$ & $3.499 \mathrm{E}-03$ & $3.500 \mathrm{E}-03$ & $3.500 \mathrm{E}-03$ & $3.500 \mathrm{E}-03$ & 3.499E-03 \\
\hline $\mathrm{TiO}_{2}$ & $2.500 \mathrm{E}-02$ & $1.370 \mathrm{E}-02$ & $1.370 \mathrm{E}-02$ & $1.370 \mathrm{E}-02$ & $1.370 \mathrm{E}-02$ & $1.370 \mathrm{E}-02$ & $1.370 \mathrm{E}-02$ & $1.370 \mathrm{E}-02$ & $1.370 \mathrm{E}-02$ & $1.370 \mathrm{E}-02$ & $1.370 \mathrm{E}-02$ & $1.370 \mathrm{E}-02$ \\
\hline $\mathrm{ZnO}$ & $2.000 \mathrm{E}-02$ & $3.029 \mathrm{E}-02$ & $2.560 \mathrm{E}-02$ & $2.510 \mathrm{E}-02$ & $2.800 \mathrm{E}-02$ & $4.500 \mathrm{E}-02$ & $3.840 \mathrm{E}-02$ & $4.499 \mathrm{E}-02$ & $4.490 \mathrm{E}-02$ & $2.500 \mathrm{E}-02$ & $4.500 \mathrm{E}-02$ & $2.719 \mathrm{E}-02$ \\
\hline $\mathrm{ZrO}_{2}$ & $2.570 \mathrm{E}-02$ & $3.999 \mathrm{E}-02$ & $4.000 \mathrm{E}-02$ & $2.000 \mathrm{E}-02$ & $4.000 \mathrm{E}-02$ & $2.010 \mathrm{E}-02$ & $3.300 \mathrm{E}-02$ & $2.060 \mathrm{E}-02$ & $3.990 \mathrm{E}-02$ & $4.000 \mathrm{E}-02$ & $4.500 \mathrm{E}-02$ & $4.999 \mathrm{E}-02$ \\
\hline $\mathrm{BaO}$ & $1.000 \mathrm{E}-04$ & & & & & & & & & & & \\
\hline \multicolumn{13}{|l|}{$\mathrm{Br}$} \\
\hline $\mathrm{CdO}$ & $1.000 \mathrm{E}-04$ & & & & & & & & & & & \\
\hline \multicolumn{13}{|l|}{$\mathrm{Ce}_{2} \mathrm{O}_{3}$} \\
\hline \multicolumn{13}{|l|}{$\mathrm{Cs}_{2} \mathrm{O}$} \\
\hline $\mathrm{F}$ & $2.994 \mathrm{E}-03$ & $7.998 \mathrm{E}-04$ & $7.999 \mathrm{E}-04$ & $7.999 \mathrm{E}-04$ & 7.999E-04 & $7.999 \mathrm{E}-04$ & $7.999 \mathrm{E}-04$ & $7.998 \mathrm{E}-04$ & $7.999 \mathrm{E}-04$ & $8.000 \mathrm{E}-04$ & $7.999 \mathrm{E}-04$ & $7.998 \mathrm{E}-04$ \\
\hline \multicolumn{13}{|l|}{ I } \\
\hline \multicolumn{13}{|l|}{$\mathrm{La}_{2} \mathrm{O}_{3}$} \\
\hline \multicolumn{13}{|l|}{$\mathrm{MnO}$} \\
\hline \multicolumn{13}{|l|}{$\mathrm{MoO}_{3}$} \\
\hline $\mathrm{NiO}$ & $3.000 \mathrm{E}-04$ & $9.998 \mathrm{E}-05$ & $9.999 \mathrm{E}-05$ & 9.999E-05 & $9.999 \mathrm{E}-05$ & $9.999 \mathrm{E}-05$ & $9.999 \mathrm{E}-05$ & $9.998 \mathrm{E}-05$ & $9.999 \mathrm{E}-05$ & $1.000 \mathrm{E}-04$ & $9.999 \mathrm{E}-05$ & $9.998 \mathrm{E}-05$ \\
\hline $\mathrm{P}_{2} \mathrm{O}_{5}$ & $4.990 \mathrm{E}-03$ & $1.200 \mathrm{E}-03$ & $1.200 \mathrm{E}-03$ & $1.200 \mathrm{E}-03$ & $1.200 \mathrm{E}-03$ & $1.200 \mathrm{E}-03$ & $1.200 \mathrm{E}-03$ & $1.200 \mathrm{E}-03$ & $1.200 \mathrm{E}-03$ & $1.200 \mathrm{E}-03$ & $1.200 \mathrm{E}-03$ & $1.200 \mathrm{E}-03$ \\
\hline $\mathrm{PbO}$ & $3.000 \mathrm{E}-04$ & $9.998 \mathrm{E}-05$ & 9.999E-05 & 9.999E-05 & $9.999 \mathrm{E}-05$ & $9.999 \mathrm{E}-05$ & $9.999 \mathrm{E}-05$ & $9.998 \mathrm{E}-05$ & $9.999 \mathrm{E}-05$ & $1.000 \mathrm{E}-04$ & $9.999 \mathrm{E}-05$ & $9.998 \mathrm{E}-05$ \\
\hline \multicolumn{13}{|l|}{$\mathrm{Re}_{2} \mathrm{O}_{7}$} \\
\hline \multicolumn{13}{|l|}{$\mathrm{SrO}$} \\
\hline \multicolumn{13}{|l|}{$\mathrm{V}_{2} \mathrm{O}_{5}$} \\
\hline SUM & 1 & 1 & 1 & 1 & 1 & 1 & 1 & 1 & 1 & 1 & 1 & 1 \\
\hline$r_{a l t}\left(\mathrm{~g} / \mathrm{m}^{2} / \mathrm{d}\right)$ & 0.70 & 15.70 & 17.30 & 14.80 & 3.30 & 39.90 & 12.70 & 72.30 & 3.00 & 57.60 & 49.10 & 28.70 \\
\hline $\ln \left(r_{a l t}\right)$ & -0.36 & 2.75 & 2.85 & 2.69 & 1.19 & 3.69 & 2.54 & 4.28 & 1.10 & 4.05 & 3.89 & 3.36 \\
\hline
\end{tabular}


Table B.1. (Continued)

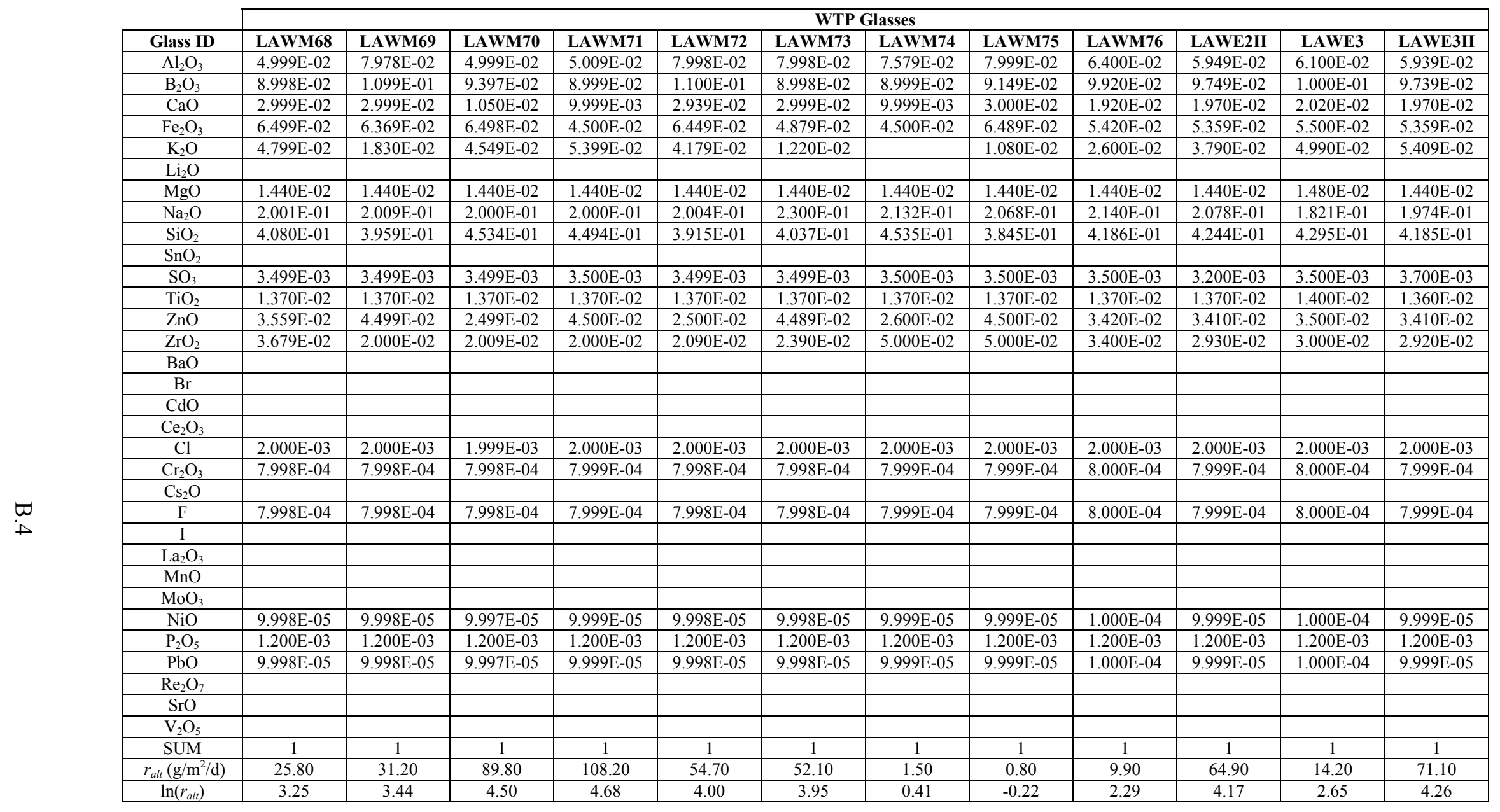


Table B.1. (Continued)

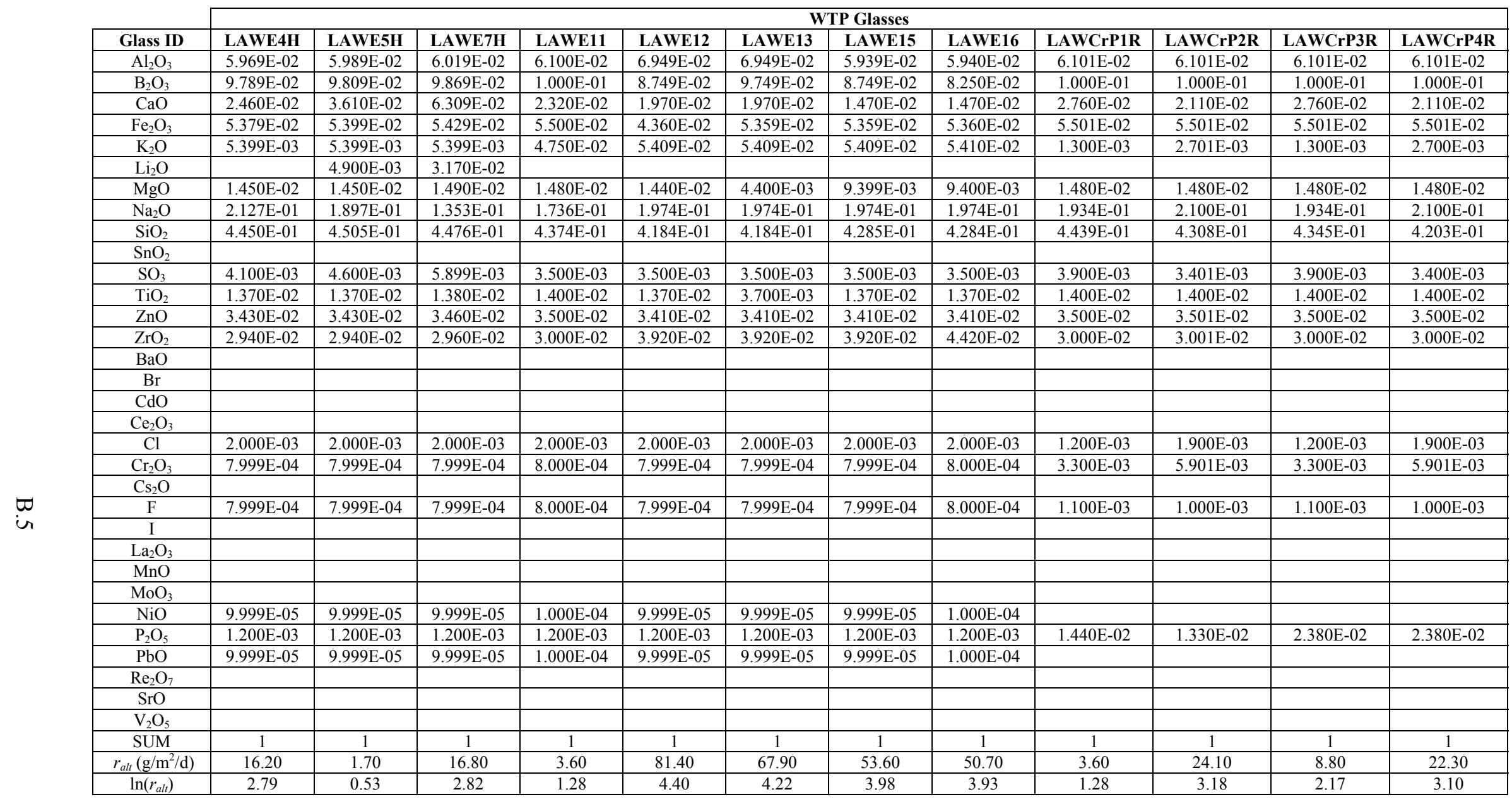


Table B.1. (Continued)

\begin{tabular}{|c|c|c|c|c|c|c|c|c|c|c|c|c|}
\hline & \multicolumn{12}{|c|}{ WTP Glasses } \\
\hline Glass ID & LAWCrP5 & LAWA49 & LAWA51 & LAWA52 & LAWA60 & LAWA104 & LAWA105 & LAWA125 & LAWA133 & LAWA134 & LAWA135 & LAWA136 \\
\hline $\mathrm{Al}_{2} \mathrm{O}_{3}$ & $6.099 \mathrm{E}-02$ & $6.201 \mathrm{E}-02$ & $6.199 \mathrm{E}-02$ & $6.180 \mathrm{E}-02$ & $8.532 \mathrm{E}-02$ & $6.611 \mathrm{E}-02$ & $7.031 \mathrm{E}-02$ & $5.633 \mathrm{E}-02$ & $6.203 \mathrm{E}-02$ & $5.644 \mathrm{E}-02$ & $5.653 \mathrm{E}-02$ & $5.653 \mathrm{E}-02$ \\
\hline $\mathrm{B}_{2} \mathrm{O}_{3}$ & $9.998 \mathrm{E}-02$ & $8.901 \mathrm{E}-02$ & $1.197 \mathrm{E}-01$ & $6.190 \mathrm{E}-02$ & $1.123 \mathrm{E}-01$ & $8.592 \mathrm{E}-02$ & $8.282 \mathrm{E}-02$ & $9.539 \mathrm{E}-02$ & $8.899 \mathrm{E}-02$ & $9.959 \mathrm{E}-02$ & $1.009 \mathrm{E}-01$ & $1.009 \mathrm{E}-01$ \\
\hline $\mathrm{CaO}$ & $5.809 \mathrm{E}-02$ & & & $7.880 \mathrm{E}-02$ & $4.321 \mathrm{E}-02$ & $1.920 \mathrm{E}-02$ & $1.850 \mathrm{E}-02$ & $1.938 \mathrm{E}-02$ & $5.483 \mathrm{E}-02$ & $2.018 \mathrm{E}-02$ & $2.047 \mathrm{E}-02$ & $3.046 \mathrm{E}-02$ \\
\hline $\mathrm{K}_{2} \mathrm{O}$ & $8.998 \mathrm{E}-04$ & $5.001 \mathrm{E}-03$ & $4.500 \mathrm{E}-03$ & $5.000 \mathrm{E}-03$ & $5.001 \mathrm{E}-03$ & $5.501 \mathrm{E}-03$ & $6.001 \mathrm{E}-03$ & $4.205 \mathrm{E}-02$ & $4.295 \mathrm{E}-03$ & $3.726 \mathrm{E}-02$ & $3.575 \mathrm{E}-02$ & $3.575 \mathrm{E}-02$ \\
\hline $\mathrm{Li}_{2} \mathrm{O}$ & $2.639 \mathrm{E}-02$ & & & & & & & & & & & \\
\hline $\mathrm{MgO}$ & $1.490 \mathrm{E}-02$ & $1.480 \mathrm{E}-02$ & $1.480 \mathrm{E}-02$ & $1.480 \mathrm{E}-02$ & $1.990 \mathrm{E}-02$ & $1.920 \mathrm{E}-02$ & $1.850 \mathrm{E}-02$ & $1.438 \mathrm{E}-02$ & $1.998 \mathrm{E}-02$ & $1.498 \mathrm{E}-02$ & $1.518 \mathrm{E}-02$ & $1.518 \mathrm{E}-02$ \\
\hline $\mathrm{Na}_{2} \mathrm{O}$ & $1.438 \mathrm{E}-01$ & $2.000 \mathrm{E}-01$ & $1.800 \mathrm{E}-01$ & $2.000 \mathrm{E}-01$ & $2.000 \mathrm{E}-01$ & $2.200 \mathrm{E}-01$ & $2.400 \mathrm{E}-01$ & $1.998 \mathrm{E}-01$ & $1.998 \mathrm{E}-01$ & $1.772 \mathrm{E}-01$ & $1.701 \mathrm{E}-01$ & $1.701 \mathrm{E}-01$ \\
\hline $\mathrm{SiO}_{2}$ & 4.344E-01 & $4.455 \mathrm{E}-01$ & $4.657 \mathrm{E}-01$ & $4.225 \mathrm{E}-01$ & $4.456 \mathrm{E}-01$ & $4.300 \mathrm{E}-01$ & 4.143E-01 & $4.286 \mathrm{E}-01$ & $4.453 \mathrm{E}-01$ & $4.473 \mathrm{E}-01$ & $4.528 \mathrm{E}-01$ & $4.428 \mathrm{E}-01$ \\
\hline \multicolumn{13}{|l|}{$\mathrm{SnO}_{2}$} \\
\hline $\mathrm{SO}_{3}$ & $5.099 \mathrm{E}-03$ & $1.000 \mathrm{E}-03$ & 8.999E-04 & $1.000 \mathrm{E}-03$ & $1.000 \mathrm{E}-03$ & $1.000 \mathrm{E}-03$ & $1.100 \mathrm{E}-03$ & $3.795 \mathrm{E}-03$ & $2.197 \mathrm{E}-03$ & $3.296 \mathrm{E}-03$ & $3.196 \mathrm{E}-03$ & $3.196 \mathrm{E}-03$ \\
\hline $\mathrm{TiO}_{2}$ & $1.400 \mathrm{E}-02$ & $1.990 \mathrm{E}-02$ & $2.000 \mathrm{E}-02$ & $1.110 \mathrm{E}-02$ & $1.990 \mathrm{E}-02$ & $1.920 \mathrm{E}-02$ & $1.850 \mathrm{E}-02$ & $1.938 \mathrm{E}-02$ & $1.998 \mathrm{E}-02$ & $2.028 \mathrm{E}-02$ & $2.047 \mathrm{E}-02$ & $2.047 \mathrm{E}-02$ \\
\hline $\mathrm{ZnO}$ & $3.499 \mathrm{E}-02$ & $2.480 \mathrm{E}-02$ & $2.490 \mathrm{E}-02$ & $2.990 \mathrm{E}-02$ & $2.961 \mathrm{E}-02$ & $2.861 \mathrm{E}-02$ & $2.761 \mathrm{E}-02$ & $2.877 \mathrm{E}-02$ & $2.966 \mathrm{E}-02$ & $2.997 \mathrm{E}-02$ & $3.036 \mathrm{E}-02$ & $3.036 \mathrm{E}-02$ \\
\hline $\mathrm{ZrO}_{2}$ & $2.999 \mathrm{E}-02$ & $2.990 \mathrm{E}-02$ & $3.000 \mathrm{E}-02$ & $2.990 \mathrm{E}-02$ & $2.991 \mathrm{E}-02$ & $2.891 \mathrm{E}-02$ & $2.781 \mathrm{E}-02$ & $2.907 \mathrm{E}-02$ & $2.996 \mathrm{E}-02$ & $3.037 \mathrm{E}-02$ & $3.076 \mathrm{E}-02$ & $3.076 \mathrm{E}-02$ \\
\hline \multicolumn{13}{|l|}{$\mathrm{BaO}$} \\
\hline \multirow{2}{*}{\multicolumn{13}{|c|}{$\begin{array}{c}\mathrm{Br} \\
\mathrm{CdO}\end{array}$}} \\
\hline \multirow{2}{*}{\multicolumn{13}{|c|}{$\begin{array}{c}\mathrm{CdO} \\
\mathrm{Ce}_{2} \mathrm{O}_{3}\end{array}$}} \\
\hline & & & & & & & & & & & & \\
\hline $\mathrm{Cl}$ & $1.400 \mathrm{E}-03$ & $6.501 \mathrm{E}-03$ & $5.899 \mathrm{E}-03$ & $6.500 \mathrm{E}-03$ & $6.501 \mathrm{E}-03$ & $7.201 \mathrm{E}-03$ & $7.802 \mathrm{E}-03$ & $2.197 \mathrm{E}-03$ & $5.593 \mathrm{E}-03$ & $1.998 \mathrm{E}-03$ & $1.898 \mathrm{E}-03$ & $1.898 \mathrm{E}-03$ \\
\hline $\mathrm{Cs}_{2} \mathrm{O}$ & & & & & & & & $1.798 \mathrm{E}-03$ & & & & \\
\hline $\mathrm{F}$ & $6.999 \mathrm{E}-04$ & $1.000 \mathrm{E}-04$ & $9.999 \mathrm{E}-05$ & $1.000 \mathrm{E}-04$ & $1.000 \mathrm{E}-04$ & $1.000 \mathrm{E}-04$ & $1.000 \mathrm{E}-04$ & $3.196 \mathrm{E}-03$ & $3.995 \mathrm{E}-04$ & $2.897 \mathrm{E}-03$ & $2.796 \mathrm{E}-03$ & $2.796 \mathrm{E}-03$ \\
\hline \multicolumn{13}{|l|}{ I } \\
\hline \multirow{2}{*}{\multicolumn{13}{|c|}{$\frac{\mathrm{La}_{2} \mathrm{O}_{3}}{\mathrm{MnO}}$}} \\
\hline & & & & & & & & & & & & \\
\hline $\mathrm{MoO}_{3}$ & & $1.000 \mathrm{E}-04$ & $9.999 \mathrm{E}-05$ & $1.000 \mathrm{E}-04$ & $1.000 \mathrm{E}-04$ & $1.000 \mathrm{E}-04$ & $1.000 \mathrm{E}-04$ & & & & & \\
\hline $\mathrm{NiO}$ & $9.998 \mathrm{E}-05$ & & & & & & & & & & & \\
\hline $\mathrm{P}_{2} \mathrm{O}_{5}$ & $1.330 \mathrm{E}-02$ & $3.000 \mathrm{E}-04$ & $3.000 \mathrm{E}-04$ & $3.000 \mathrm{E}-04$ & $3.001 \mathrm{E}-04$ & $4.001 \mathrm{E}-04$ & $4.001 \mathrm{E}-04$ & $8.989 \mathrm{E}-04$ & $9.988 \mathrm{E}-04$ & $7.991 \mathrm{E}-04$ & $6.991 \mathrm{E}-04$ & $6.991 \mathrm{E}-04$ \\
\hline $\mathrm{PbO}$ & $9.998 \mathrm{E}-05$ & & & & & & & & & & & \\
\hline $\mathrm{Re}_{2} \mathrm{O}_{7}$ & & $1.000 \mathrm{E}-03$ & $9.999 \mathrm{E}-04$ & $1.000 \mathrm{E}-03$ & $1.000 \mathrm{E}-03$ & $1.000 \mathrm{E}-03$ & $1.000 \mathrm{E}-03$ & $9.988 \mathrm{E}-04$ & $9.988 \mathrm{E}-04$ & $9.989 \mathrm{E}-04$ & $9.987 \mathrm{E}-04$ & $9.987 \mathrm{E}-04$ \\
\hline \multicolumn{13}{|l|}{$\mathrm{SrO}$} \\
\hline \multicolumn{13}{|l|}{$\mathrm{V}_{2} \mathrm{O}_{5}$} \\
\hline SUM & 1 & 1 & 1 & 1 & 1 & 1 & 1 & 1 & 1 & 1 & 1 & 1 \\
\hline$r_{\text {alt }}\left(\mathrm{g} / \mathrm{m}^{2} / \mathrm{d}\right)$ & 0.88 & 3.40 & 0.60 & 7.60 & 6.20 & 6.50 & 39.60 & 37.90 & 0.60 & 0.20 & 0.30 & 0.30 \\
\hline $\ln \left(r_{a l t}\right)$ & -0.12 & 1.22 & -0.51 & 2.03 & 1.82 & 1.87 & 3.68 & 3.63 & $\begin{array}{l}-0.51 \\
\end{array}$ & $\begin{array}{l}-1.61 \\
\end{array}$ & -1.20 & -1.20 \\
\hline
\end{tabular}


Table B.1. (Continued)

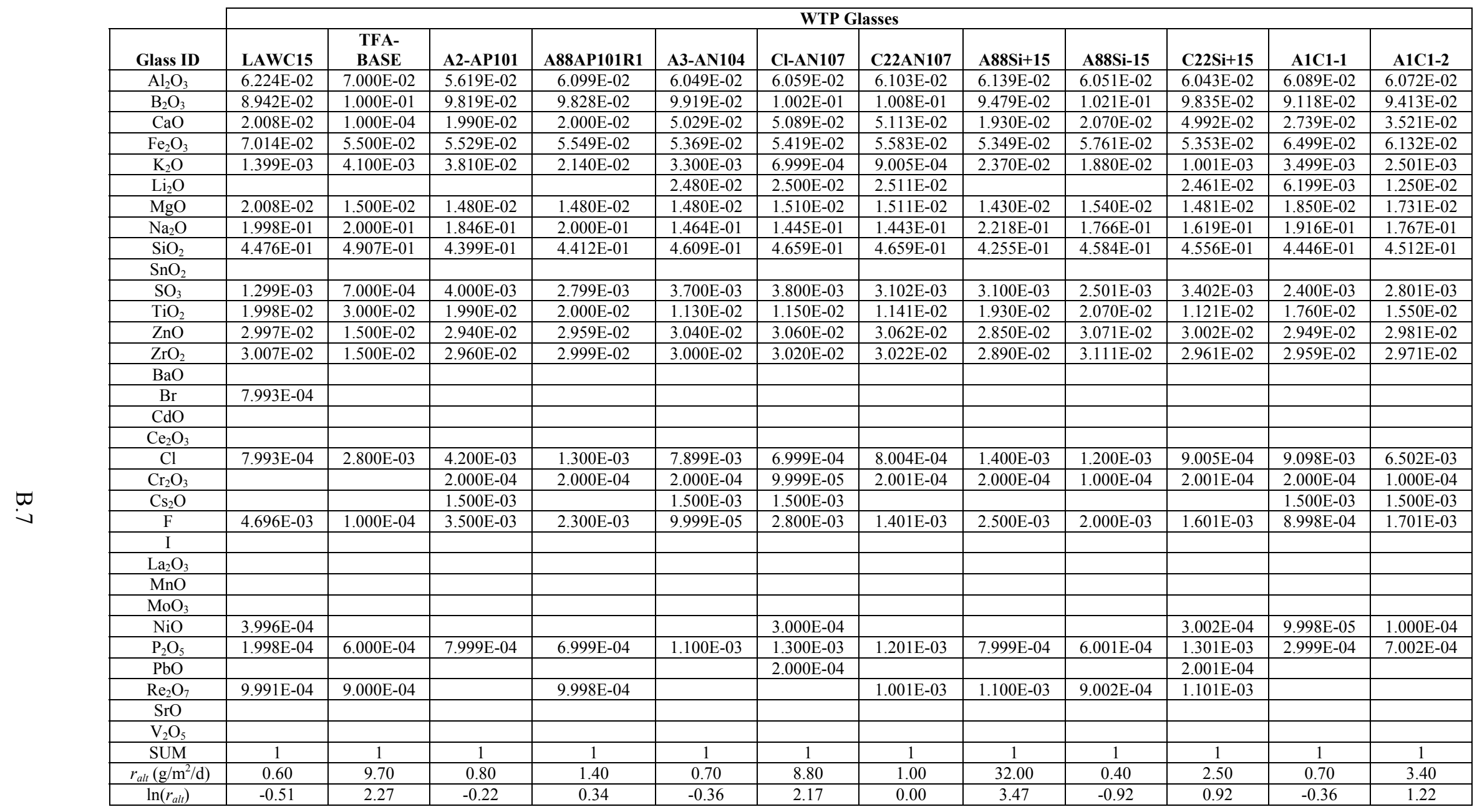


Table B.1. (Continued)

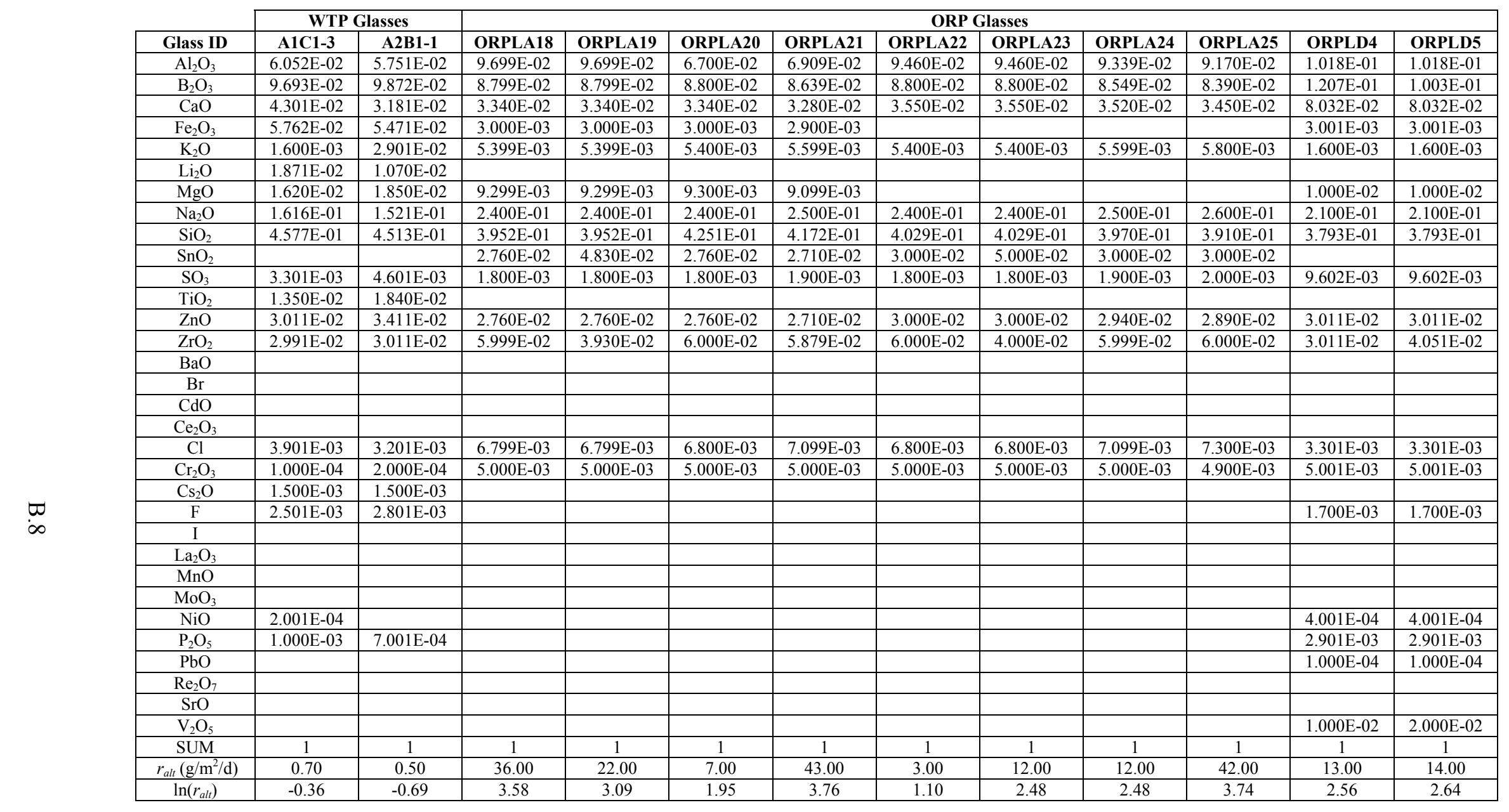


Table B.1. (Continued)

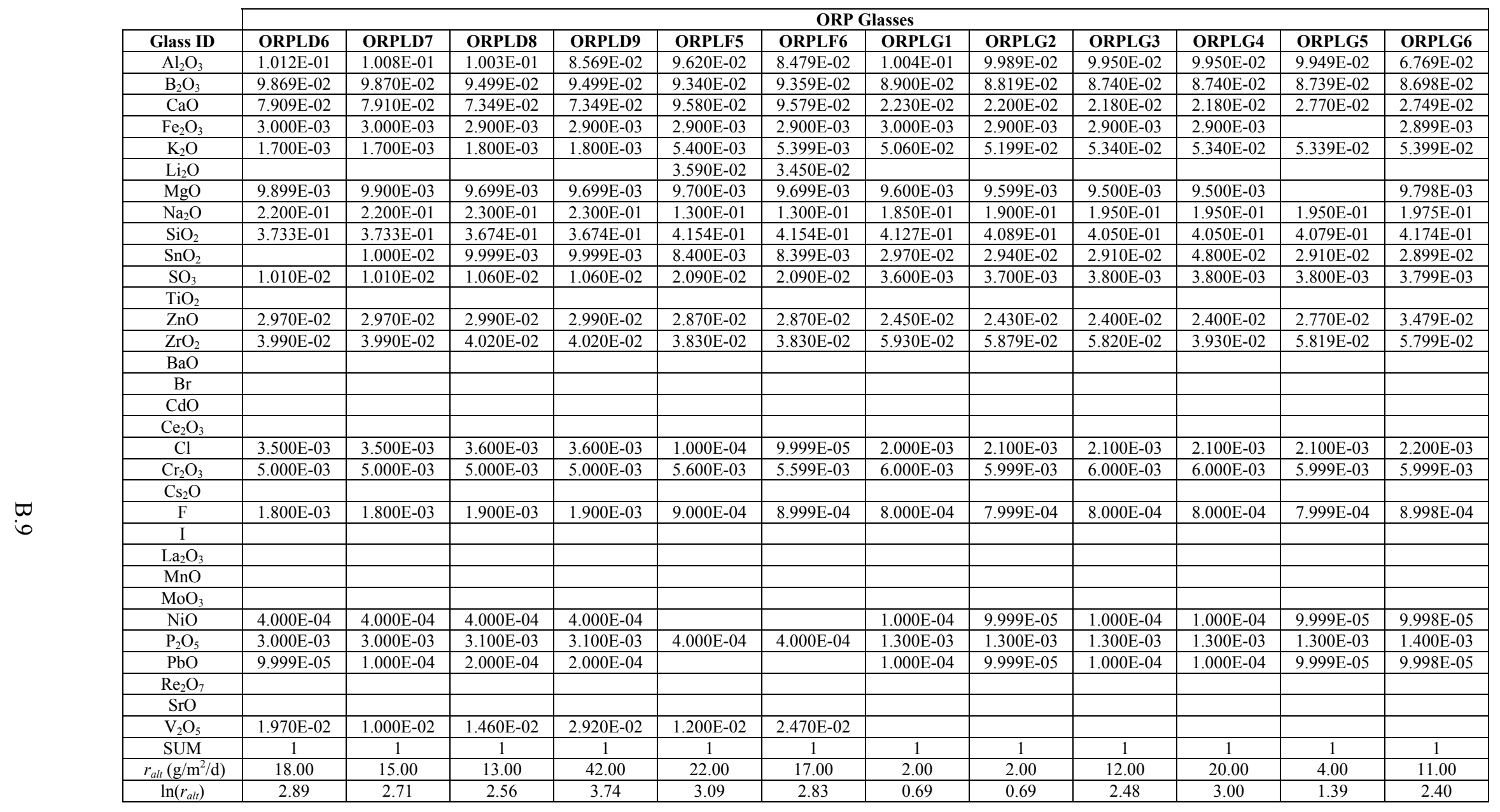


Table B.1. (Continued)

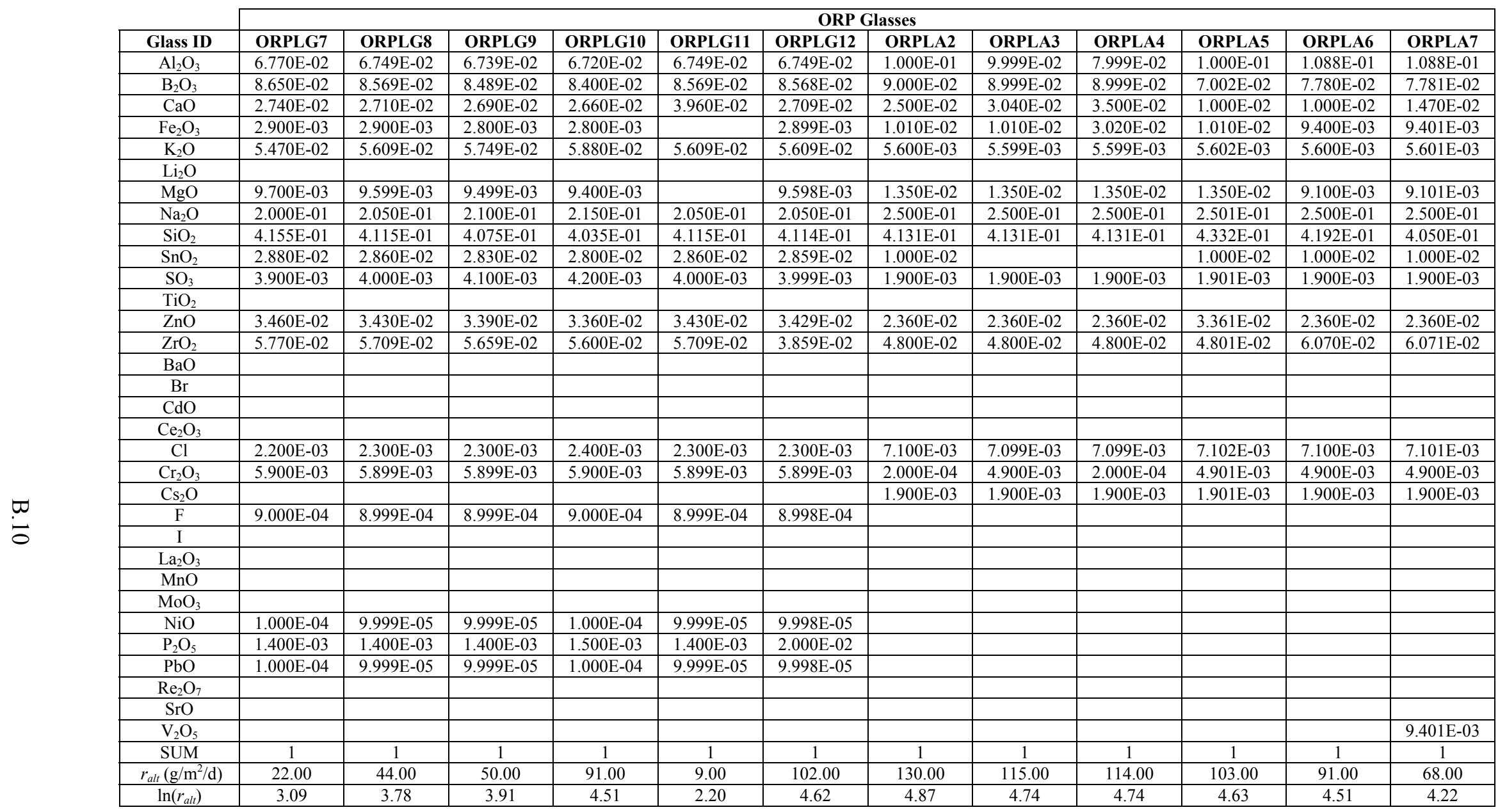


Table B.1. (Continued)

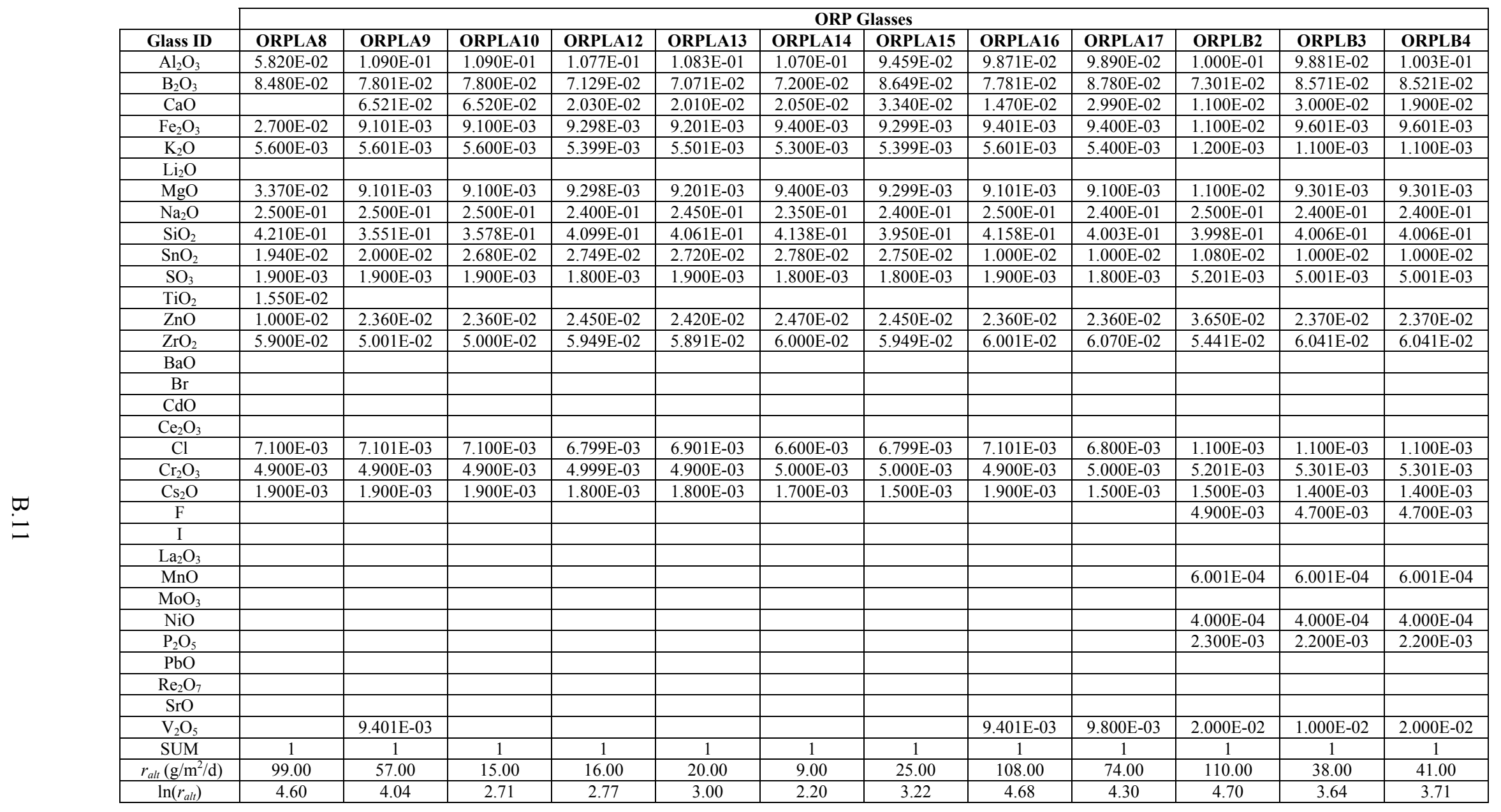


Table B.1. (Continued)

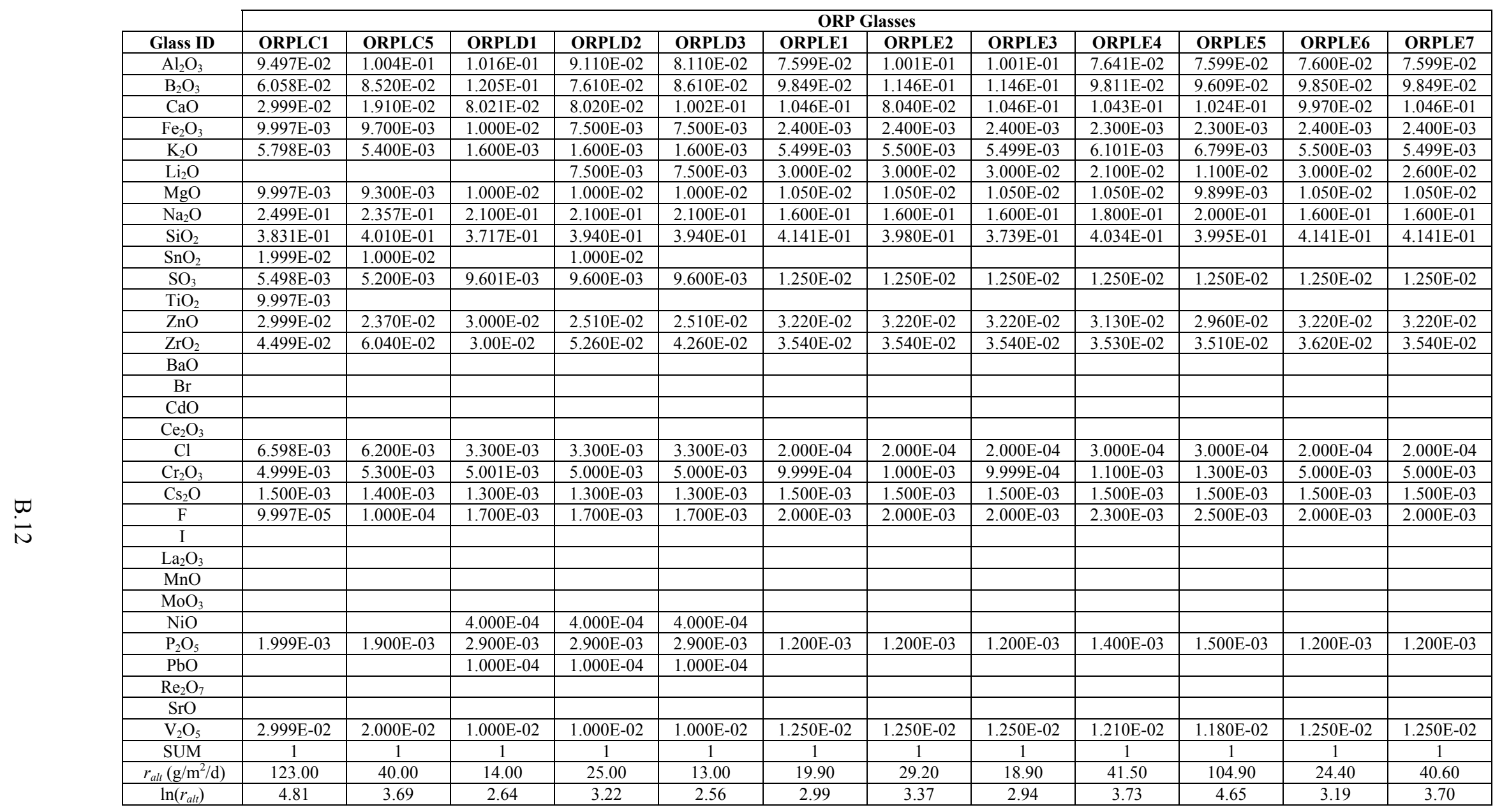


Table B.1. (Continued)

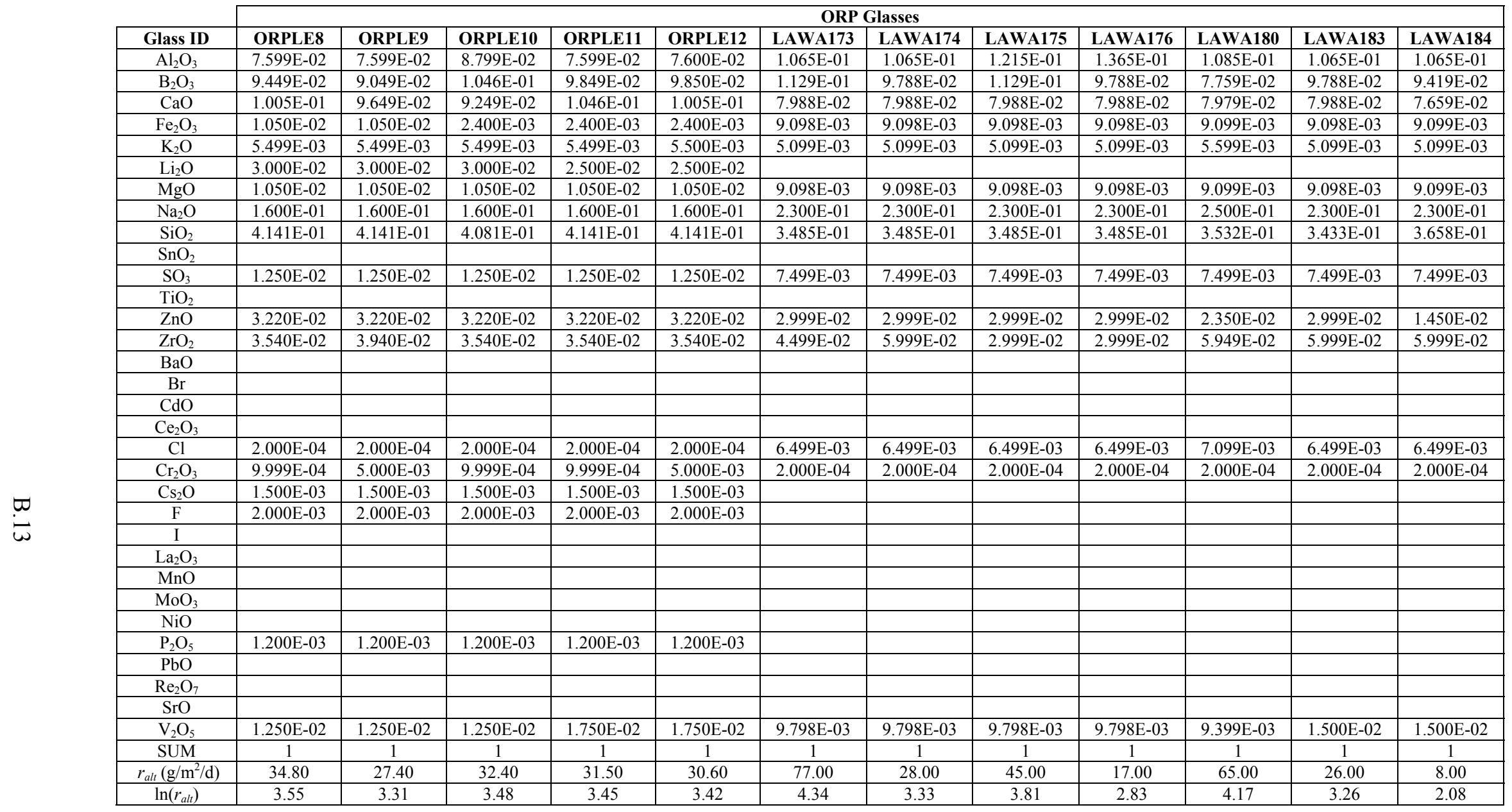


Table B.1. (Continued)

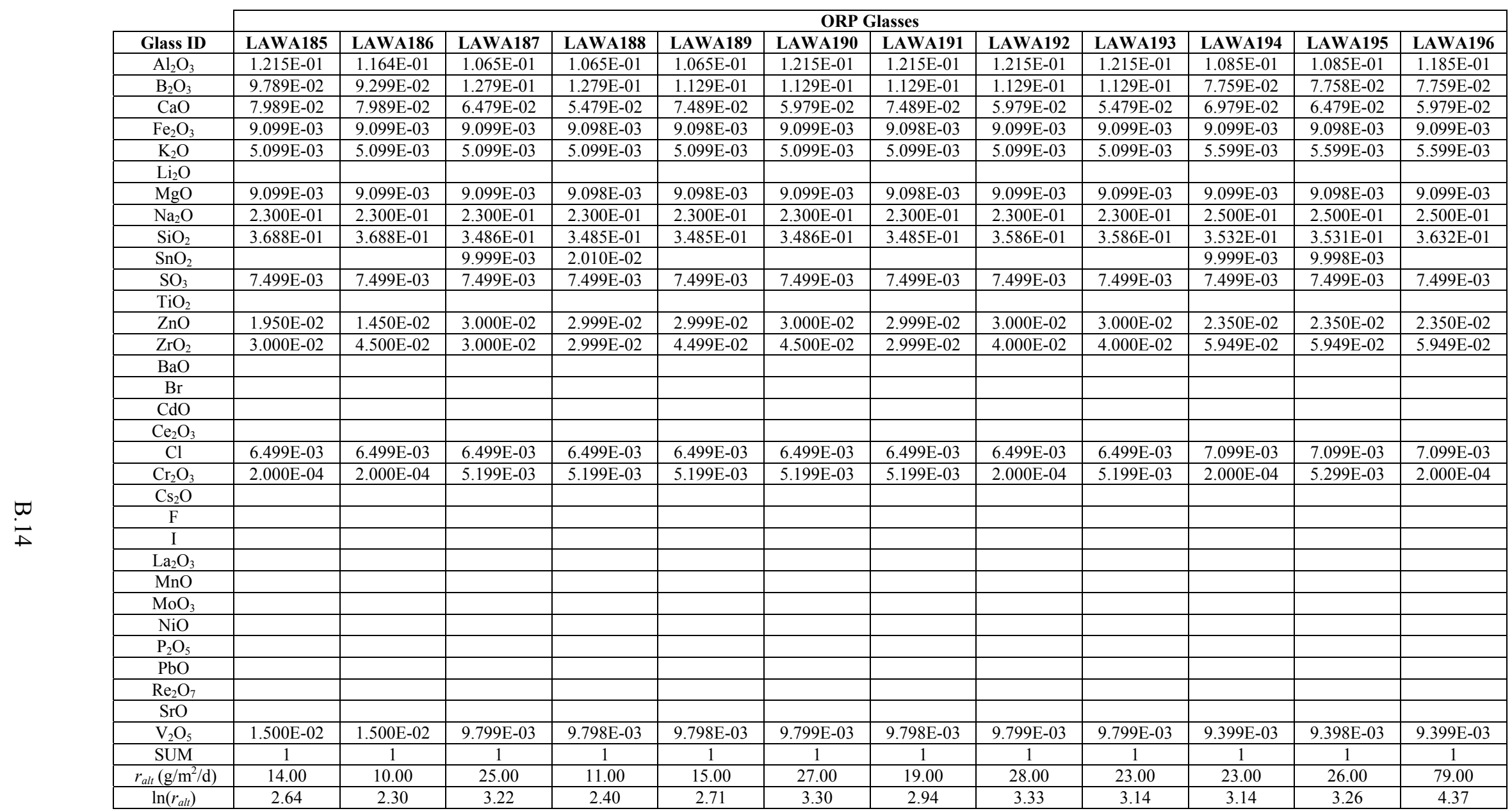


Table B.1. (Continued)

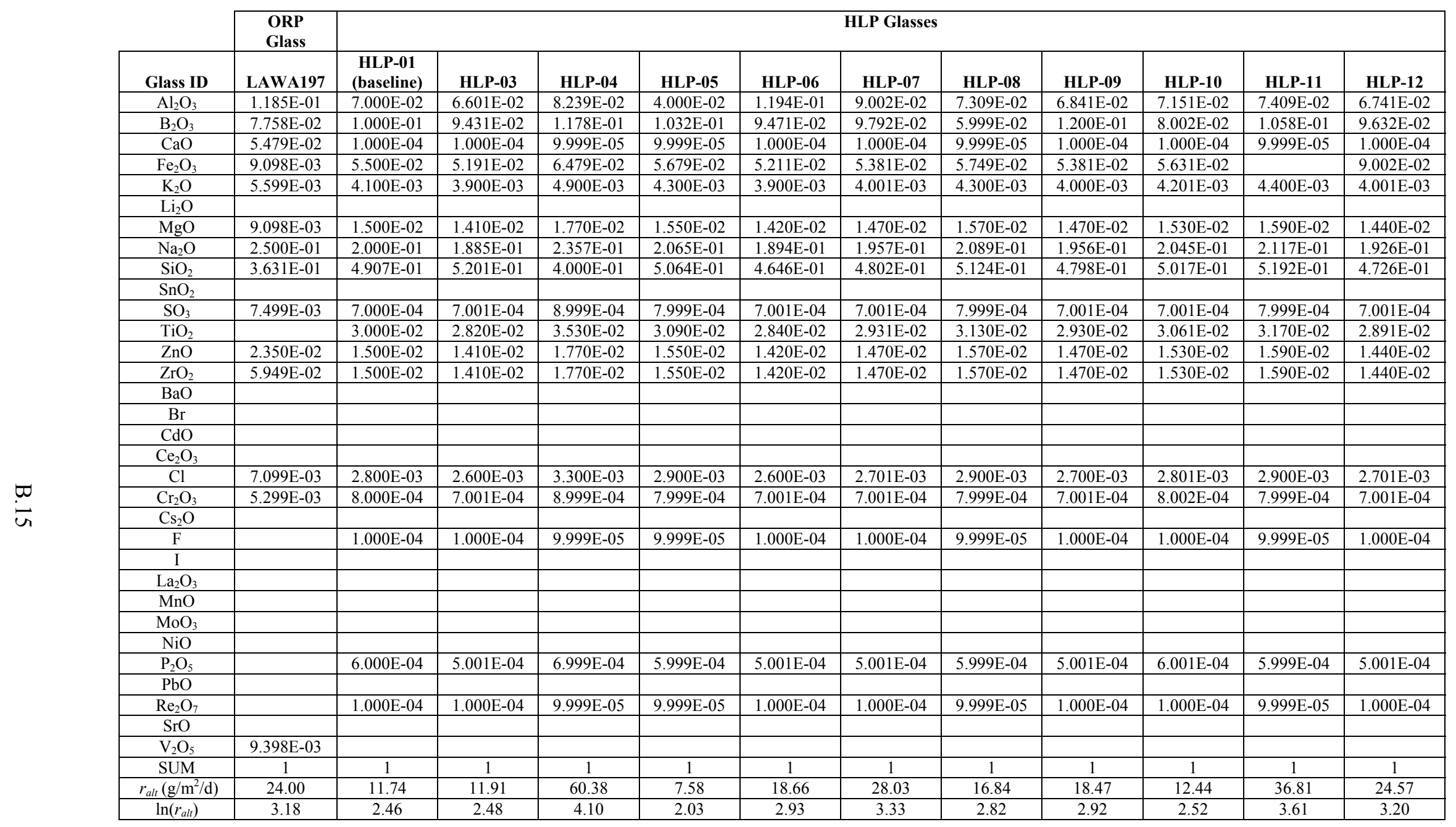


Table B.1. (Continued)

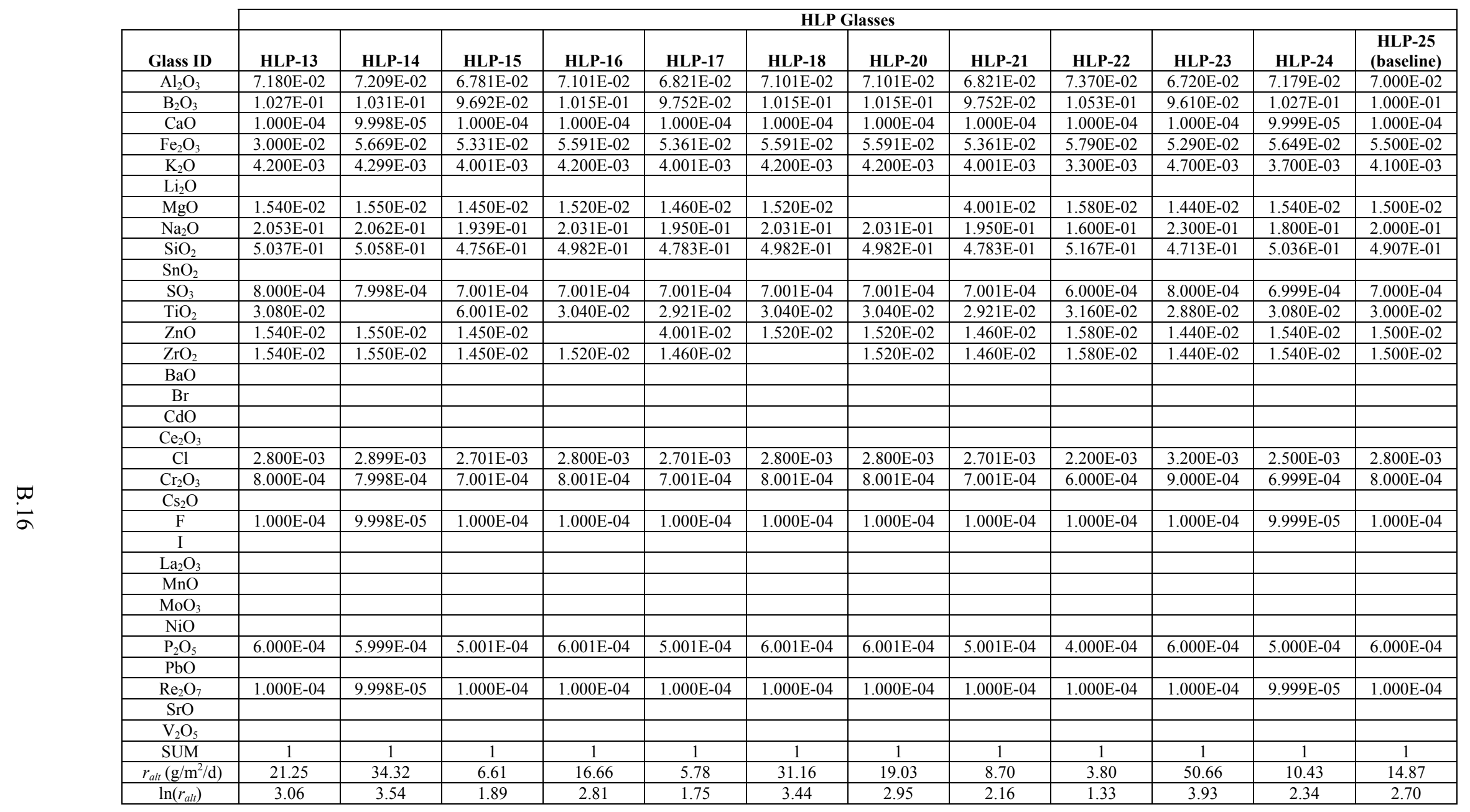


Table B.1. (Continued)

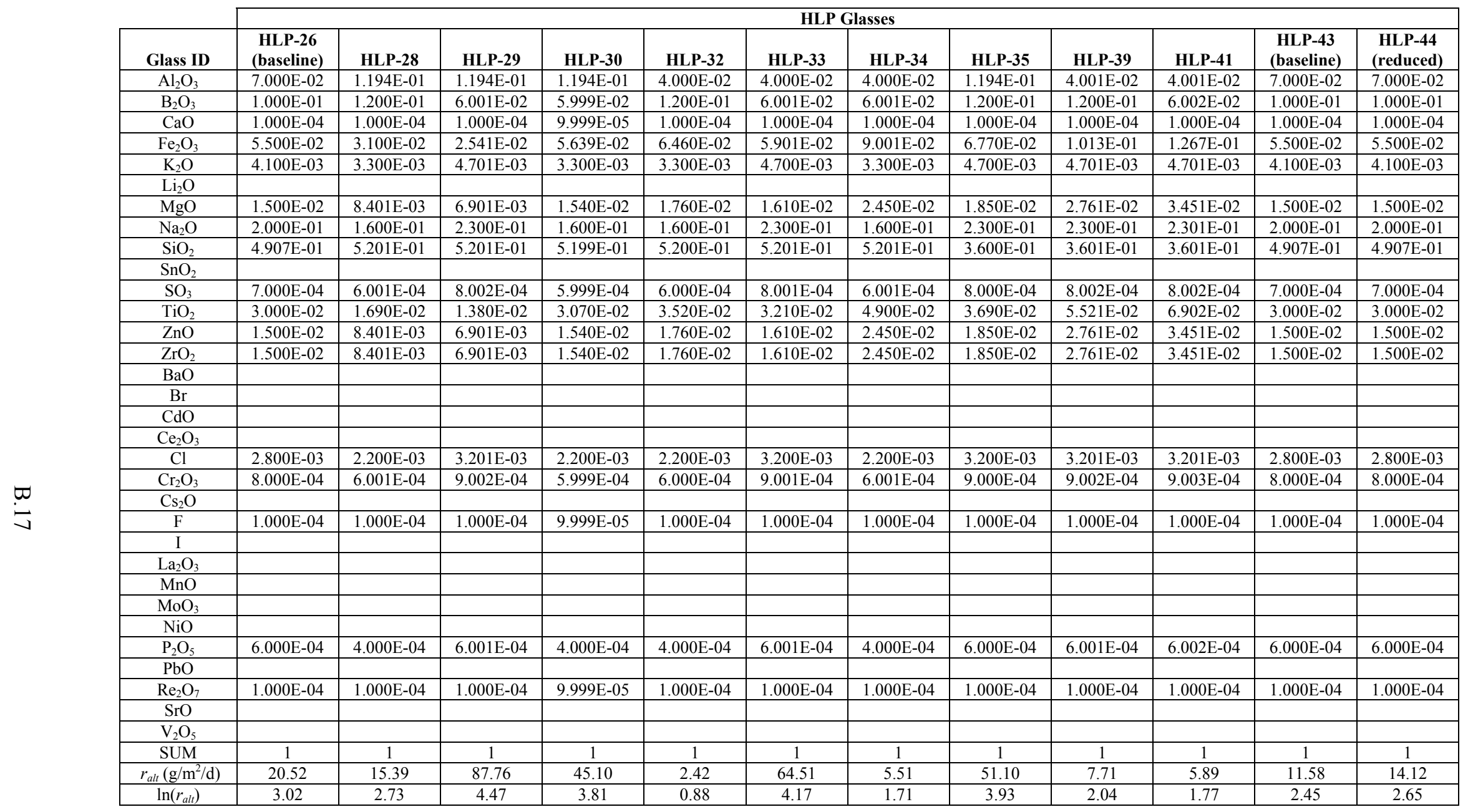


Table B.1. (Continued)

\begin{tabular}{|c|c|c|c|c|c|c|c|c|c|c|c|c|}
\hline \multirow{3}{*}{\begin{tabular}{|c|} 
Glass ID \\
$\mathrm{Al}_{2} \mathrm{O}_{3}$
\end{tabular}} & \multicolumn{12}{|c|}{ HLP Glasses } \\
\hline & $\begin{array}{c}\text { HLP-45 } \\
\text { (reduced) }\end{array}$ & $\begin{array}{c}\text { HLP-47 } \\
\text { (LRM) }\end{array}$ & $\begin{array}{c}\text { HLP-48 } \\
\text { (LAW- } \\
\text { A33) }\end{array}$ & $\begin{array}{l}\text { HLP-51 } \\
\text { (LAW- } \\
\text { ABP1) }\end{array}$ & $\begin{array}{c}\text { HLP-54 } \\
\text { (L4-912) }\end{array}$ & $\begin{array}{c}\text { HLP-55 } \\
\text { (L4-99) }\end{array}$ & $\begin{array}{c}\text { HLP-56 } \\
\text { (LAW- } \\
\text { A44) }\end{array}$ & HLP-58 & HLP-59 & HLP-61 & HLP-62 & HLP-64 \\
\hline & $7.000 \mathrm{E}-02$ & $1.001 \mathrm{E}-01$ & $1.197 \mathrm{E}-01$ & $1.000 \mathrm{E}-01$ & $1.200 \mathrm{E}-01$ & $9.003 \mathrm{E}-02$ & $6.202 \mathrm{E}-02$ & $6.861 \mathrm{E}-02$ & $6.648 \mathrm{E}-02$ & $4.000 \mathrm{E}-02$ & $4.000 \mathrm{E}-02$ & $4.000 \mathrm{E}-02$ \\
\hline \begin{tabular}{c|c|}
$\mathrm{B}_{2} \mathrm{O}_{3}$ \\
\end{tabular} & $1.000 \mathrm{E}-01$ & $8.009 \mathrm{E}-02$ & $8.850 \mathrm{E}-02$ & $9.250 \mathrm{E}-02$ & $9.003 \mathrm{E}-02$ & $9.003 \mathrm{E}-02$ & $8.903 \mathrm{E}-02$ & $9.801 \mathrm{E}-02$ & $9.497 \mathrm{E}-02$ & $1.257 \mathrm{E}-01$ & $1.257 \mathrm{E}-01$ & $6.000 \mathrm{E}-02$ \\
\hline \multirow{33}{*}{$\infty$} & $1.000 \mathrm{E}-04$ & $5.006 \mathrm{E}-03$ & & & & & $1.991 \mathrm{E}-02$ & $2.000 \mathrm{E}-02$ & $4.999 \mathrm{E}-02$ & $5.000 \mathrm{E}-02$ & $5.000 \mathrm{E}-02$ & $1.000 \mathrm{E}-04$ \\
\hline & $5.500 \mathrm{E}-02$ & $1.001 \mathrm{E}-02$ & $5.770 \mathrm{E}-02$ & $2.500 \mathrm{E}-02$ & & & $6.982 \mathrm{E}-02$ & $5.391 \mathrm{E}-02$ & $5.228 \mathrm{E}-02$ & & & \\
\hline & $4.100 \mathrm{E}-03$ & $1.502 \mathrm{E}-02$ & $3.100 \mathrm{E}-02$ & $2.200 \mathrm{E}-02$ & $3.301 \mathrm{E}-03$ & $3.301 \mathrm{E}-03$ & $5.002 \mathrm{E}-03$ & $4.000 \mathrm{E}-03$ & $3.899 \mathrm{E}-03$ & $5.000 \mathrm{E}-02$ & $3.300 \mathrm{E}-03$ & $5.000 \mathrm{E}-02$ \\
\hline & & $1.001 \mathrm{E}-03$ & & & & & & & & & & \\
\hline & $1.500 \mathrm{E}-02$ & $1.001 \mathrm{E}-03$ & $1.990 \mathrm{E}-02$ & $1.000 \mathrm{E}-02$ & & & $1.991 \mathrm{E}-02$ & $1.470 \mathrm{E}-02$ & $1.430 \mathrm{E}-02$ & $4.300 \mathrm{E}-02$ & & $4.300 \mathrm{E}-02$ \\
\hline & $2.000 \mathrm{E}-01$ & $2.002 \mathrm{E}-01$ & $2.000 \mathrm{E}-01$ & $2.000 \mathrm{E}-01$ & $2.001 \mathrm{E}-01$ & $2.001 \mathrm{E}-01$ & $2.001 \mathrm{E}-01$ & $1.960 \mathrm{E}-01$ & $1.899 \mathrm{E}-01$ & $1.600 \mathrm{E}-01$ & $1.600 \mathrm{E}-01$ & $1.600 \mathrm{E}-01$ \\
\hline & 4.907E-01 & $5.443 \mathrm{E}-01$ & $3.825 \mathrm{E}-01$ & 4.189E-01 & $5.680 \mathrm{E}-01$ & $5.980 \mathrm{E}-01$ & $4.456 \mathrm{E}-01$ & 4.809E-01 & 4.661E-01 & $3.965 \mathrm{E}-01$ & 4.692E-01 & $5.200 \mathrm{E}-01$ \\
\hline & & & & & & & & & & & & \\
\hline & $7.000 \mathrm{E}-04$ & $2.002 \mathrm{E}-03$ & $1.000 \mathrm{E}-03$ & $1.000 \mathrm{E}-03$ & $3.201 \mathrm{E}-03$ & $3.201 \mathrm{E}-03$ & $1.000 \mathrm{E}-03$ & 7.001E-04 & $6.998 \mathrm{E}-04$ & $9.000 \mathrm{E}-04$ & $9.000 \mathrm{E}-04$ & $9.000 \mathrm{E}-04$ \\
\hline & $3.000 \mathrm{E}-02$ & $1.001 \mathrm{E}-03$ & $2.490 \mathrm{E}-02$ & $2.490 \mathrm{E}-02$ & & & $1.991 \mathrm{E}-02$ & $2.940 \mathrm{E}-02$ & $2.849 \mathrm{E}-02$ & $8.590 \mathrm{E}-02$ & $8.590 \mathrm{E}-02$ & \\
\hline & $1.500 \mathrm{E}-02$ & & $4.270 \mathrm{E}-02$ & $2.600 \mathrm{E}-02$ & & & $2.961 \mathrm{E}-02$ & $1.470 \mathrm{E}-02$ & $1.430 \mathrm{E}-02$ & $4.300 \mathrm{E}-02$ & & $4.140 \mathrm{E}-02$ \\
\hline & $1.500 \mathrm{E}-02$ & $1.001 \mathrm{E}-02$ & $2.490 \mathrm{E}-02$ & $5.250 \mathrm{E}-02$ & & & 2.991E-02 & $1.470 \mathrm{E}-02$ & $1.430 \mathrm{E}-02$ & & $6.000 \mathrm{E}-02$ & $6.000 \mathrm{E}-02$ \\
\hline & & $5.006 \mathrm{E}-05$ & & & & & & & & & & \\
\hline & & & & & & & & & & & & \\
\hline & & $2.002 \mathrm{E}-03$ & & & & & & & & & & \\
\hline & & & & & & & & & & & & \\
\hline & $2.800 \mathrm{E}-03$ & $8.009 \mathrm{E}-03$ & $5.800 \mathrm{E}-03$ & $5.800 \mathrm{E}-03$ & $9.003 \mathrm{E}-04$ & $9.003 \mathrm{E}-04$ & $6.502 \mathrm{E}-03$ & $2.700 \mathrm{E}-03$ & $2.699 \mathrm{E}-03$ & $3.500 \mathrm{E}-03$ & $3.500 \mathrm{E}-03$ & $3.500 \mathrm{E}-03$ \\
\hline & $8.000 \mathrm{E}-04$ & $2.002 \mathrm{E}-03$ & $2.000 \mathrm{E}-04$ & $2.000 \mathrm{E}-04$ & $4.001 \mathrm{E}-04$ & $4.001 \mathrm{E}-04$ & $2.001 \mathrm{E}-04$ & $8.001 \mathrm{E}-04$ & $7.998 \mathrm{E}-04$ & $9.000 \mathrm{E}-04$ & $9.000 \mathrm{E}-04$ & $9.000 \mathrm{E}-04$ \\
\hline & & & & & & & & & & & & \\
\hline & $1.000 \mathrm{E}-04$ & $1.001 \mathrm{E}-02$ & $4.000 \mathrm{E}-04$ & $4.000 \mathrm{E}-04$ & $2.101 \mathrm{E}-03$ & $2.101 \mathrm{E}-03$ & $1.000 \mathrm{E}-04$ & $1.000 \mathrm{E}-04$ & $9.997 \mathrm{E}-05$ & $1.000 \mathrm{E}-04$ & $1.000 \mathrm{E}-04$ & $1.000 \mathrm{E}-04$ \\
\hline & & $2.002 \mathrm{E}-05$ & & & & & & & & & & \\
\hline & & $1.001 \mathrm{E}-04$ & & $2.000 \mathrm{E}-02$ & $1.000 \mathrm{E}-04$ & $1.000 \mathrm{E}-04$ & & & & & & \\
\hline & & $1.001 \mathrm{E}-03$ & & & & & & & & & & \\
\hline & & & & & & & $1.000 \mathrm{E}-04$ & & & & & \\
\hline & & $1.001 \mathrm{E}-03$ & & & & & & & & & & \\
\hline & $6.000 \mathrm{E}-04$ & $5.006 \mathrm{E}-03$ & $8.000 \mathrm{E}-04$ & $8.000 \mathrm{E}-04$ & $1.190 \mathrm{E}-02$ & $1.190 \mathrm{E}-02$ & $3.001 \mathrm{E}-04$ & $6.001 \mathrm{E}-04$ & $5.998 \mathrm{E}-04$ & $4.000 \mathrm{E}-04$ & $4.000 \mathrm{E}-04$ & $2.000 \mathrm{E}-02$ \\
\hline & & $1.001 \mathrm{E}-03$ & & & & & & & & & & \\
\hline & $1.000 \mathrm{E}-04$ & & & & & & $1.000 \mathrm{E}-03$ & $1.000 \mathrm{E}-04$ & $9.997 \mathrm{E}-05$ & $1.000 \mathrm{E}-04$ & $1.000 \mathrm{E}-04$ & $1.000 \mathrm{E}-04$ \\
\hline & & & & & & & & & & & & \\
\hline & & & & & & & & & & & & \\
\hline & 1 & 1 & 1 & 1 & 1 & 1 & 1 & 1 & 1 & 1 & 1 & 1 \\
\hline & 18.16 & 72.61 & 73.88 & 21.69 & 53.70 & 69.32 & 0.71 & 2.68 & 3.07 & 6.98 & 0.37 & 7.08 \\
\hline & 2.90 & 4.29 & 4.30 & 3.08 & 3.98 & 4.24 & $\begin{array}{l}-0.34 \\
\end{array}$ & 0.98 & 1.12 & 1.94 & -1.00 & 1.96 \\
\hline
\end{tabular}


Table B.1. (Continued)

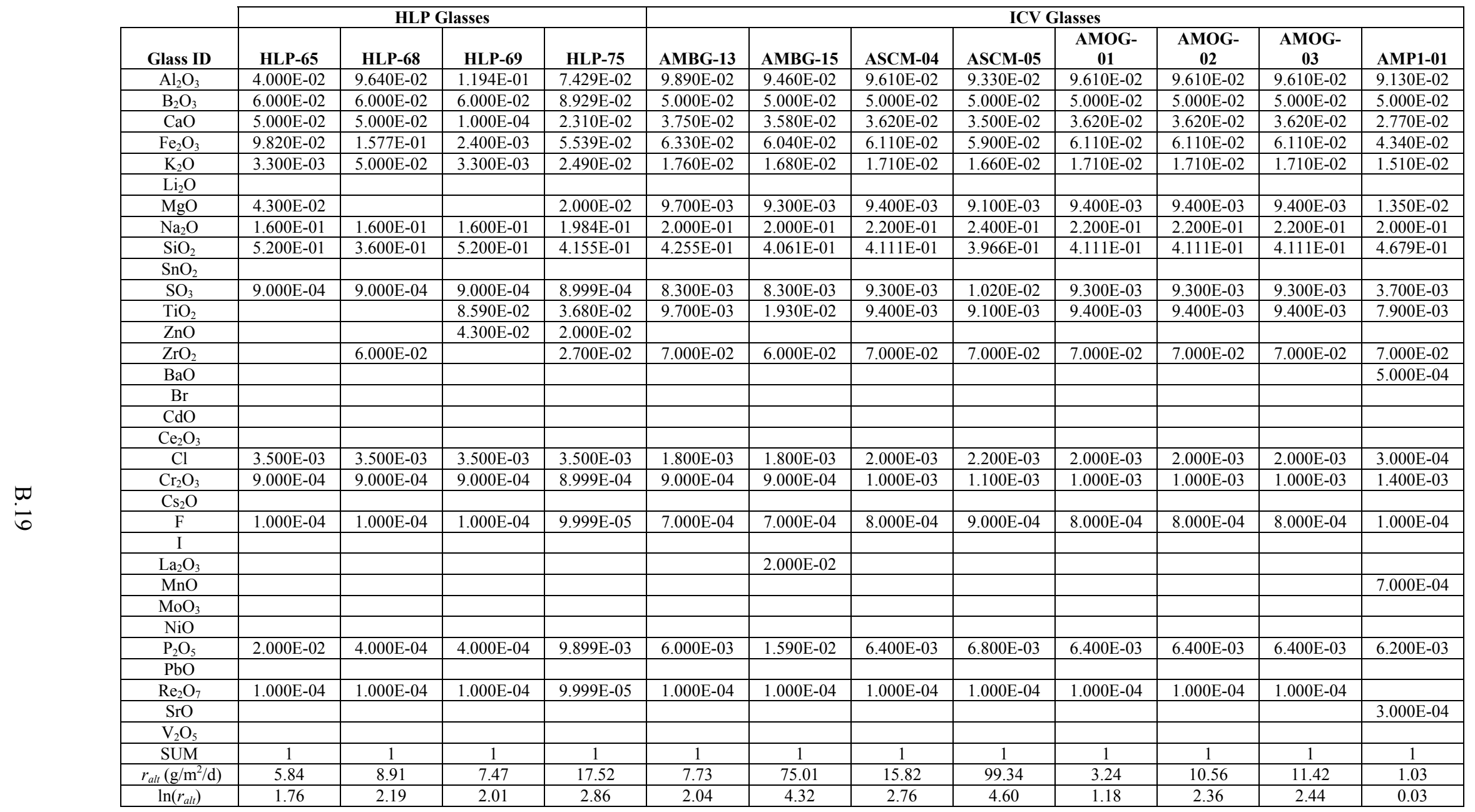


Table B.1. (Continued)

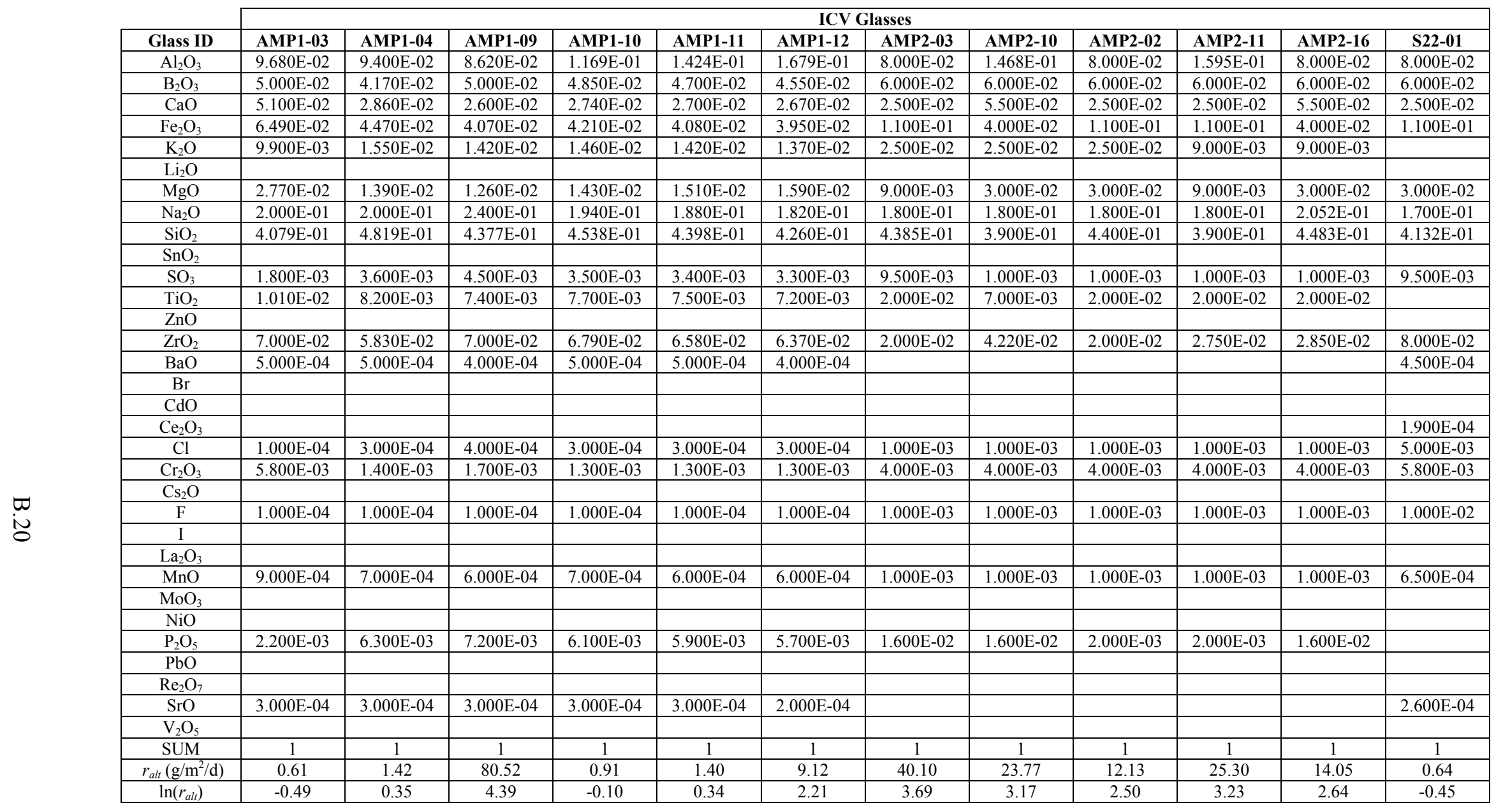


Table B.1. (Continued)

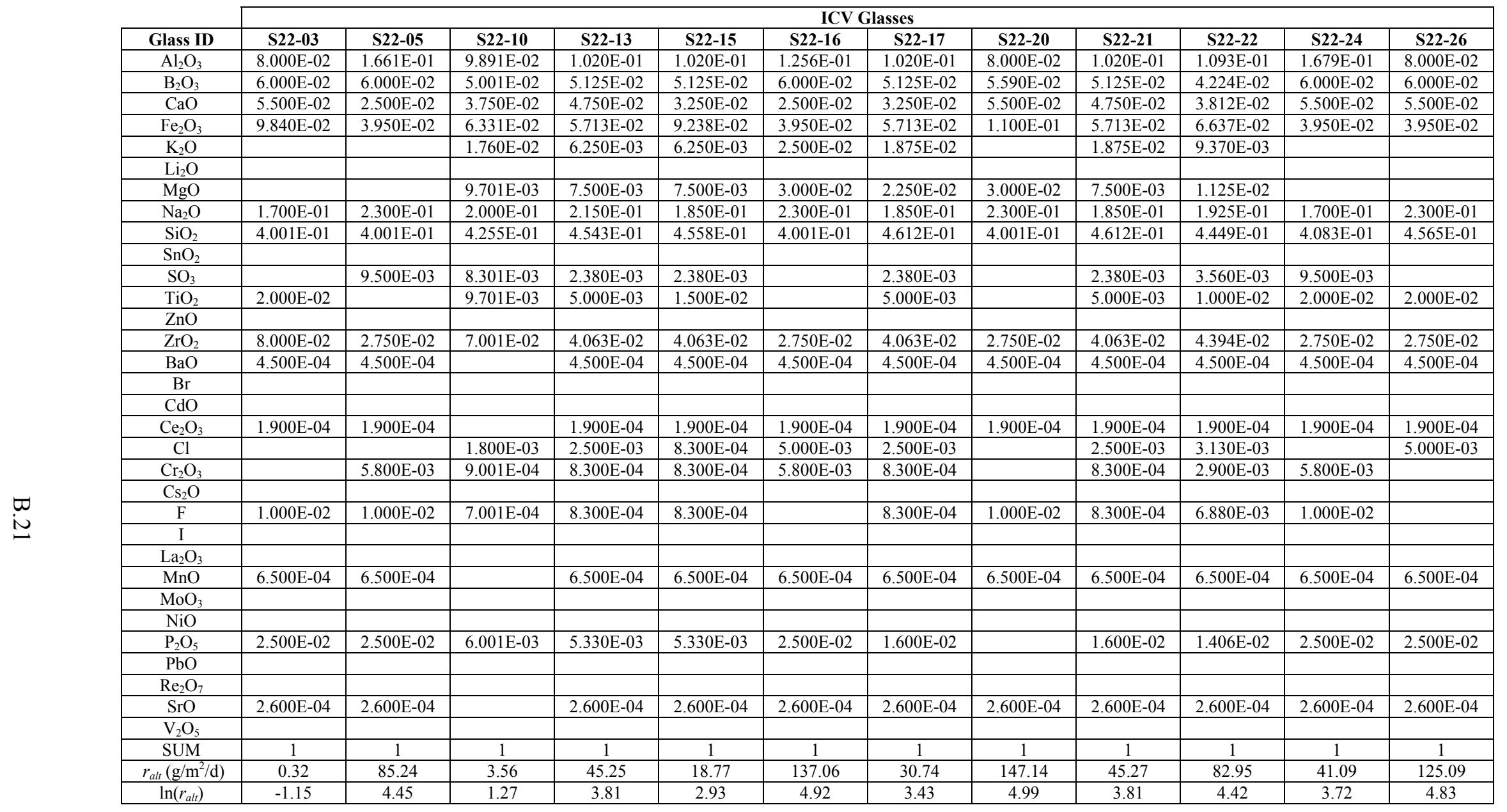


Table B.1. (Continued)

\begin{tabular}{|c|c|c|c|c|c|}
\hline & \multicolumn{5}{|c|}{ ICV Glasses } \\
\hline Glass ID & S22-31 & S22-32 & S22-36 & S22-38 & S22-40 \\
\hline $\mathrm{Al}_{2} \mathrm{O}_{3}$ & $8.000 \mathrm{E}-02$ & $1.093 \mathrm{E}-01$ & $1.020 \mathrm{E}-01$ & $1.263 \mathrm{E}-01$ & $1.020 \mathrm{E}-01$ \\
\hline $\mathrm{B}_{2} \mathrm{O}_{3}$ & $6.000 \mathrm{E}-02$ & $3.988 \mathrm{E}-02$ & $5.125 \mathrm{E}-02$ & $5.125 \mathrm{E}-02$ & $5.125 \mathrm{E}-02$ \\
\hline $\mathrm{CaO}$ & $5.500 \mathrm{E}-02$ & $3.775 \mathrm{E}-02$ & $3.250 \mathrm{E}-02$ & $3.250 \mathrm{E}-02$ & $3.250 \mathrm{E}-02$ \\
\hline $\mathrm{Fe}_{2} \mathrm{O}_{3}$ & $3.950 \mathrm{E}-02$ & $6.770 \mathrm{E}-02$ & $5.713 \mathrm{E}-02$ & 5.713E-02 & $5.713 \mathrm{E}-02$ \\
\hline $\mathrm{K}_{2} \mathrm{O}$ & $2.500 \mathrm{E}-02$ & $8.130 \mathrm{E}-03$ & $1.875 \mathrm{E}-02$ & $6.250 \mathrm{E}-03$ & $6.250 \mathrm{E}-03$ \\
\hline \multicolumn{6}{|l|}{$\mathrm{Li}_{2} \mathrm{O}$} \\
\hline $\mathrm{MgO}$ & & $1.275 \mathrm{E}-02$ & $2.250 \mathrm{E}-02$ & $2.250 \mathrm{E}-02$ & $7.500 \mathrm{E}-03$ \\
\hline $\mathrm{Na}_{2} \mathrm{O}$ & $1.700 \mathrm{E}-01$ & $1.895 \mathrm{E}-01$ & $1.850 \mathrm{E}-01$ & $1.850 \mathrm{E}-01$ & $1.850 \mathrm{E}-01$ \\
\hline $\mathrm{SiO}_{2}$ & $4.387 \mathrm{E}-01$ & $4.613 \mathrm{E}-01$ & $4.564 \mathrm{E}-01$ & $4.500 \mathrm{E}-01$ & $5.010 \mathrm{E}-01$ \\
\hline \multicolumn{6}{|l|}{$\mathrm{SnO}_{2}$} \\
\hline $\mathrm{SO}_{3}$ & $9.500 \mathrm{E}-03$ & $4.040 \mathrm{E}-03$ & $7.130 \mathrm{E}-03$ & $2.380 \mathrm{E}-03$ & $2.380 \mathrm{E}-03$ \\
\hline $\mathrm{TiO}_{2}$ & $2.000 \mathrm{E}-02$ & $8.000 \mathrm{E}-03$ & $5.000 \mathrm{E}-03$ & $1.500 \mathrm{E}-02$ & $5.000 \mathrm{E}-03$ \\
\hline \multicolumn{6}{|l|}{$\mathrm{ZnO}$} \\
\hline $\mathrm{ZrO}_{2}$ & $8.000 \mathrm{E}-02$ & $4.586 \mathrm{E}-02$ & $4.063 \mathrm{E}-02$ & $4.063 \mathrm{E}-02$ & $4.063 \mathrm{E}-02$ \\
\hline $\mathrm{BaO}$ & $4.500 \mathrm{E}-04$ & $4.500 \mathrm{E}-04$ & $4.500 \mathrm{E}-04$ & $4.500 \mathrm{E}-04$ & $4.500 \mathrm{E}-04$ \\
\hline \multicolumn{6}{|l|}{$\mathrm{Br}$} \\
\hline \multicolumn{6}{|l|}{$\mathrm{CdO}$} \\
\hline $\mathrm{Ce}_{2} \mathrm{O}_{3}$ & $1.900 \mathrm{E}-04$ & $1.900 \mathrm{E}-04$ & $1.900 \mathrm{E}-04$ & $1.900 \mathrm{E}-04$ & $1.900 \mathrm{E}-04$ \\
\hline $\mathrm{Cl}$ & $5.000 \mathrm{E}-03$ & $1.670 \mathrm{E}-03$ & $2.500 \mathrm{E}-03$ & $2.500 \mathrm{E}-03$ & $8.300 \mathrm{E}-04$ \\
\hline $\mathrm{Cr}_{2} \mathrm{O}_{3}$ & $5.800 \mathrm{E}-03$ & $9.200 \mathrm{E}-04$ & $8.300 \mathrm{E}-04$ & $8.300 \mathrm{E}-04$ & $8.300 \mathrm{E}-04$ \\
\hline \multicolumn{6}{|l|}{$\mathrm{Cs}_{2} \mathrm{O}$} \\
\hline $\mathrm{F}$ & $1.000 \mathrm{E}-02$ & $1.000 \mathrm{E}-03$ & $8.300 \mathrm{E}-04$ & $8.300 \mathrm{E}-04$ & $8.300 \mathrm{E}-04$ \\
\hline \multicolumn{6}{|l|}{ I } \\
\hline \multicolumn{6}{|l|}{$\mathrm{La}_{2} \mathrm{O}_{3}$} \\
\hline $\mathrm{MnO}$ & $6.500 \mathrm{E}-04$ & $6.500 \mathrm{E}-04$ & $6.500 \mathrm{E}-04$ & $6.500 \mathrm{E}-04$ & $6.500 \mathrm{E}-04$ \\
\hline \multicolumn{6}{|l|}{$\mathrm{MoO}_{3}$} \\
\hline \multicolumn{6}{|l|}{$\mathrm{NiO}$} \\
\hline $\mathrm{P}_{2} \mathrm{O}_{5}$ & & $1.067 \mathrm{E}-02$ & $1.600 \mathrm{E}-02$ & $5.330 \mathrm{E}-03$ & $5.330 \mathrm{E}-03$ \\
\hline \multicolumn{6}{|l|}{$\mathrm{PbO}$} \\
\hline \multicolumn{6}{|l|}{$\mathrm{Re}_{2} \mathrm{O}_{7}$} \\
\hline $\mathrm{SrO}$ & $2.600 \mathrm{E}-04$ & $2.600 \mathrm{E}-04$ & $2.600 \mathrm{E}-04$ & $2.600 \mathrm{E}-04$ & $2.600 \mathrm{E}-04$ \\
\hline \multicolumn{6}{|l|}{$\mathrm{V}_{2} \mathrm{O}_{5}$} \\
\hline SUM & 1 & 1 & 1 & 1 & 1 \\
\hline$r_{\text {alt }}\left(\mathrm{g} / \mathrm{m}^{2} / \mathrm{d}\right)$ & 0.62 & 17.75 & 40.35 & 16.99 & 4.35 \\
\hline $\ln \left(r_{a l t}\right)$ & -0.48 & 2.88 & 3.70 & 2.83 & 1.47 \\
\hline
\end{tabular}


Appendix C

\section{SEM Micrographs of VHT Samples of CCIM-AN Glasses}





\section{Appendix C: SEM Micrographs of VHT Samples of CCIM-AN Glasses}

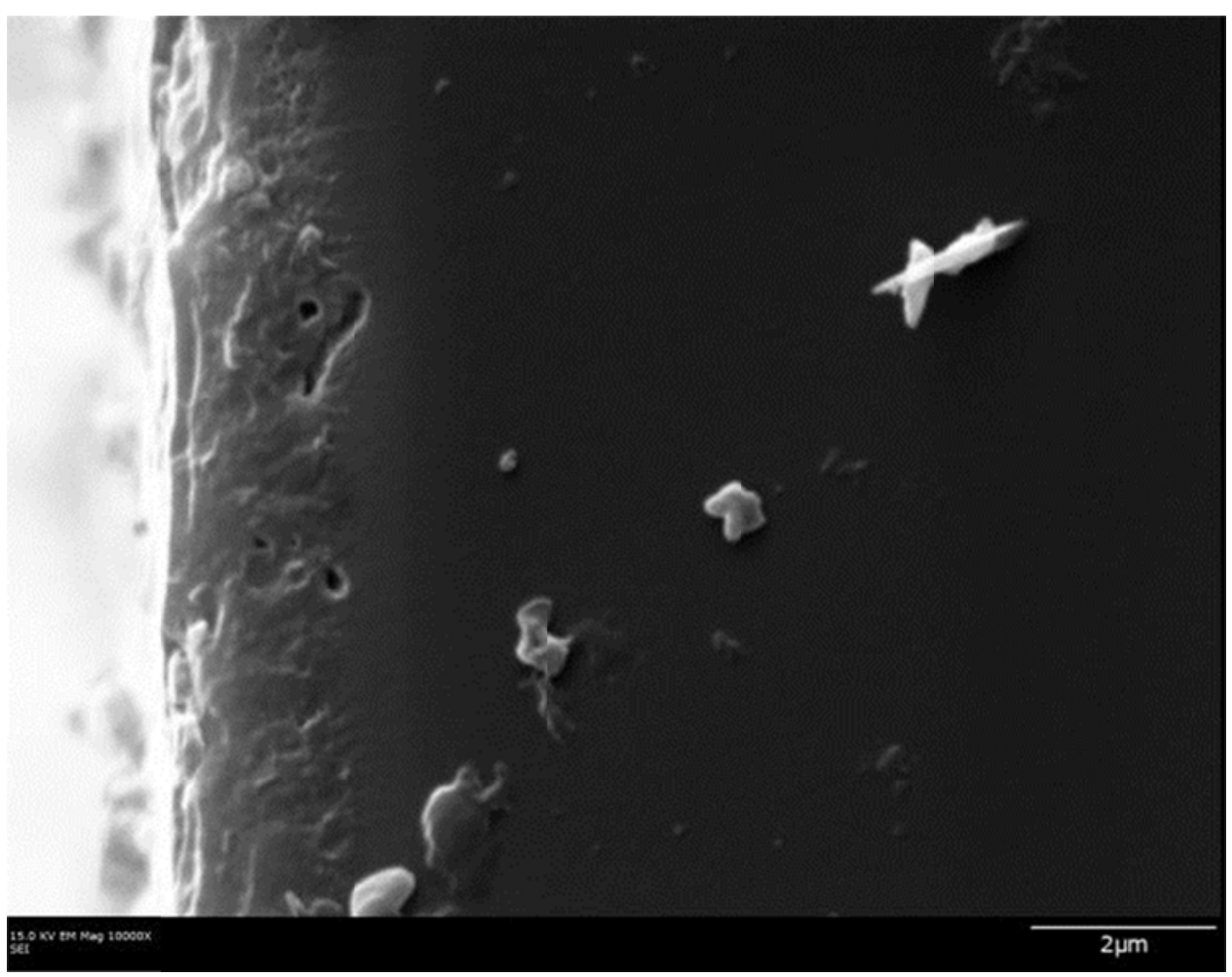

CCIM-AN-02Q 

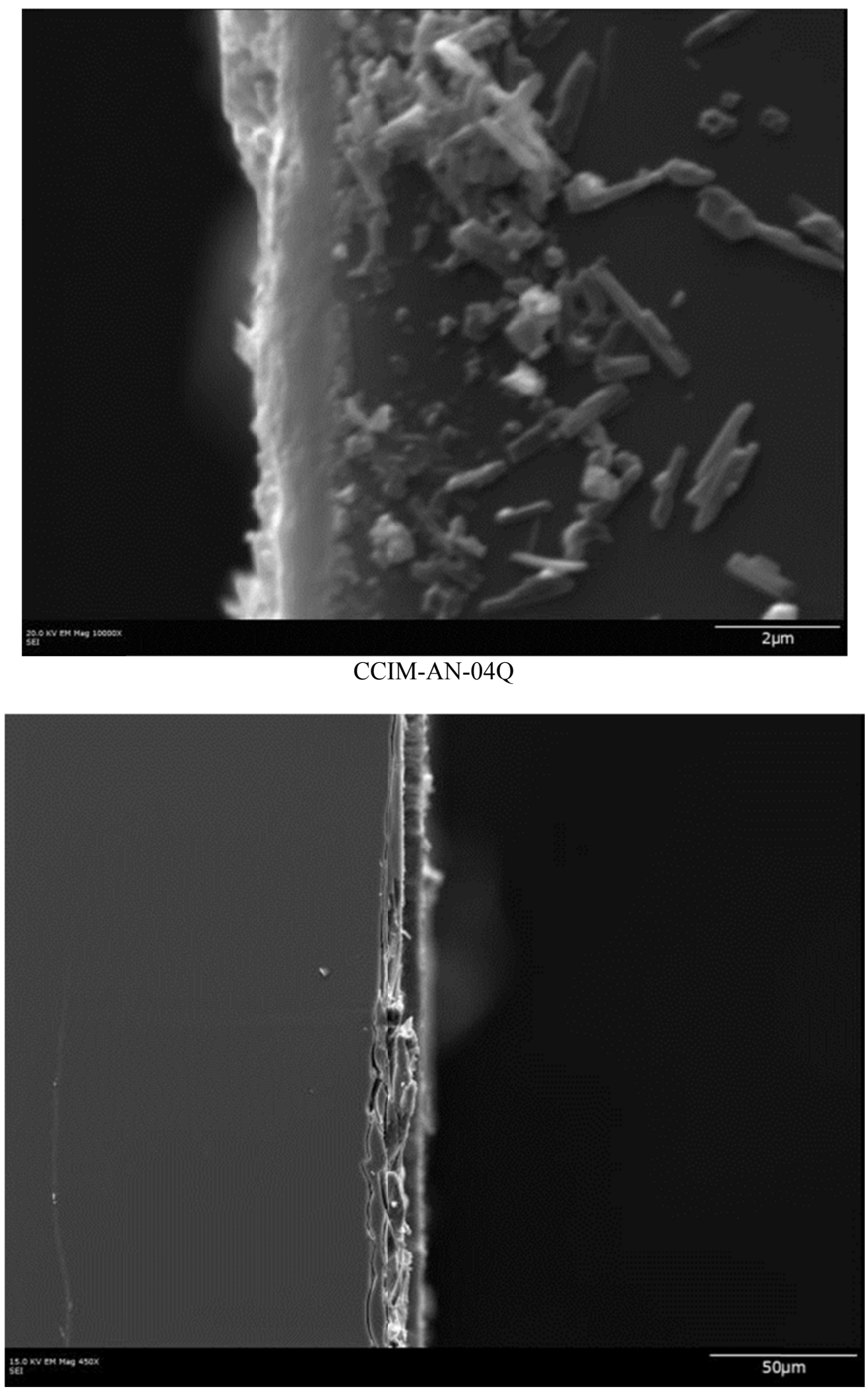

CCIM-AN-09Q

C.2 


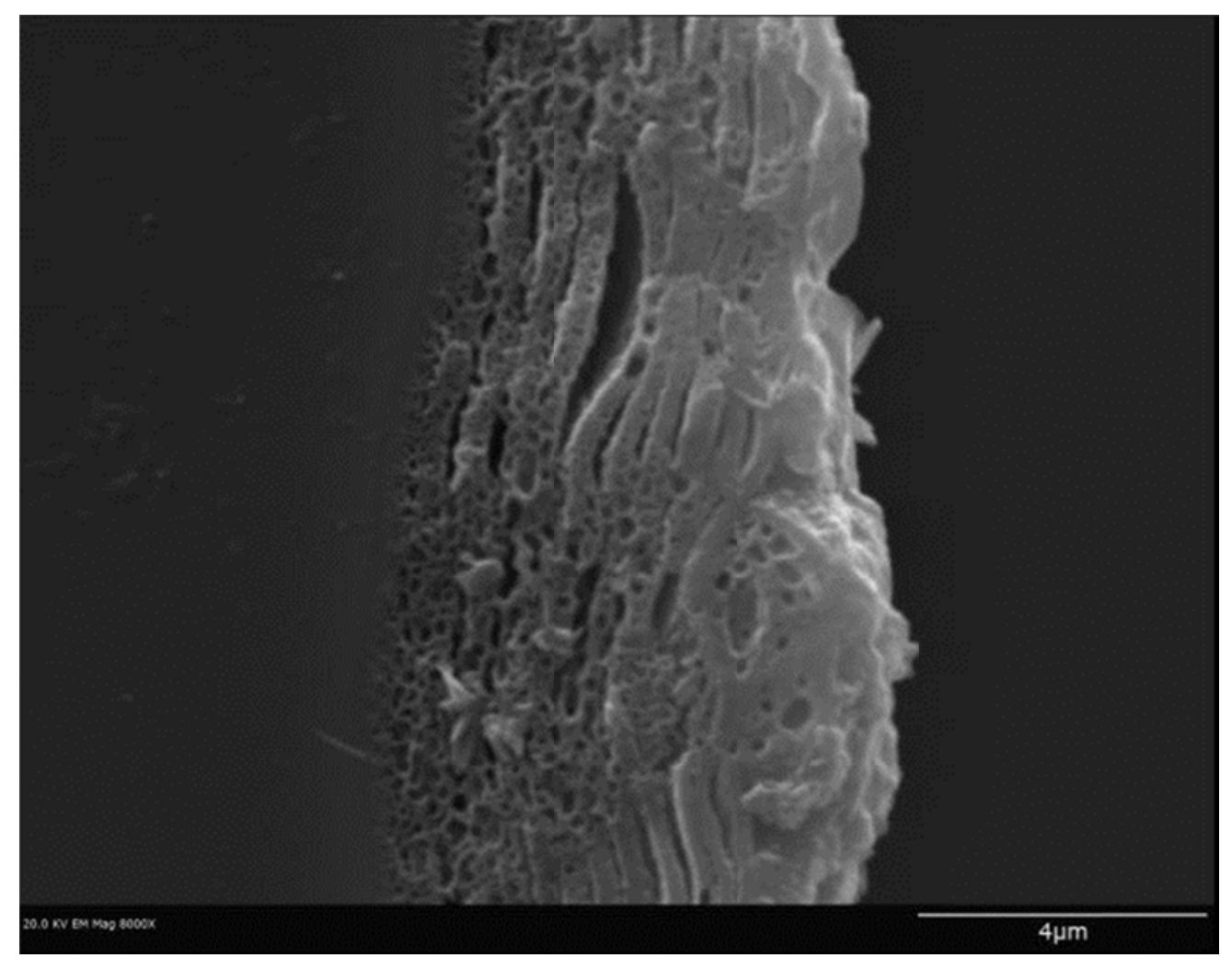

CCIM-AN-11Q

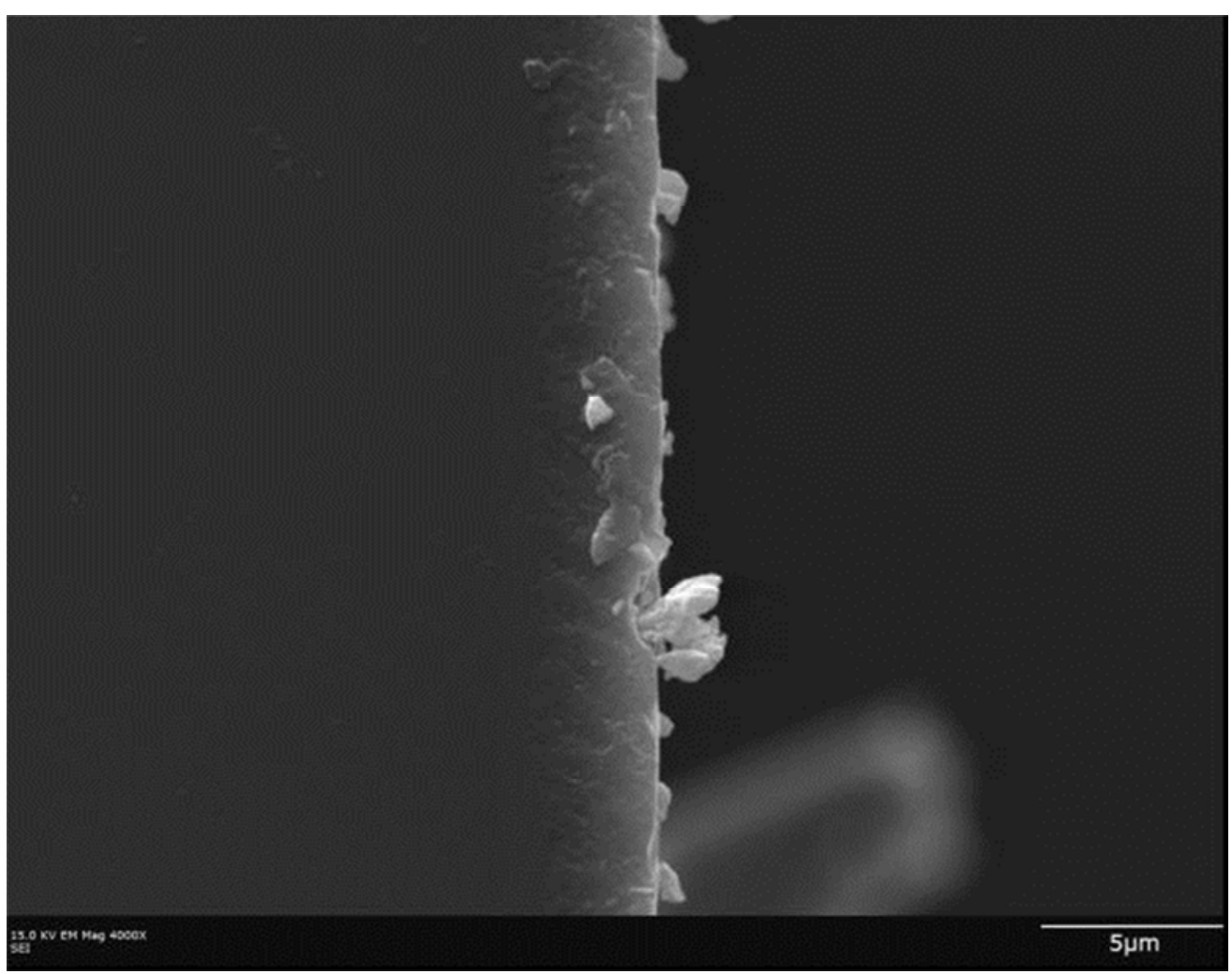

CCIM-AN-18Q

C. 3 


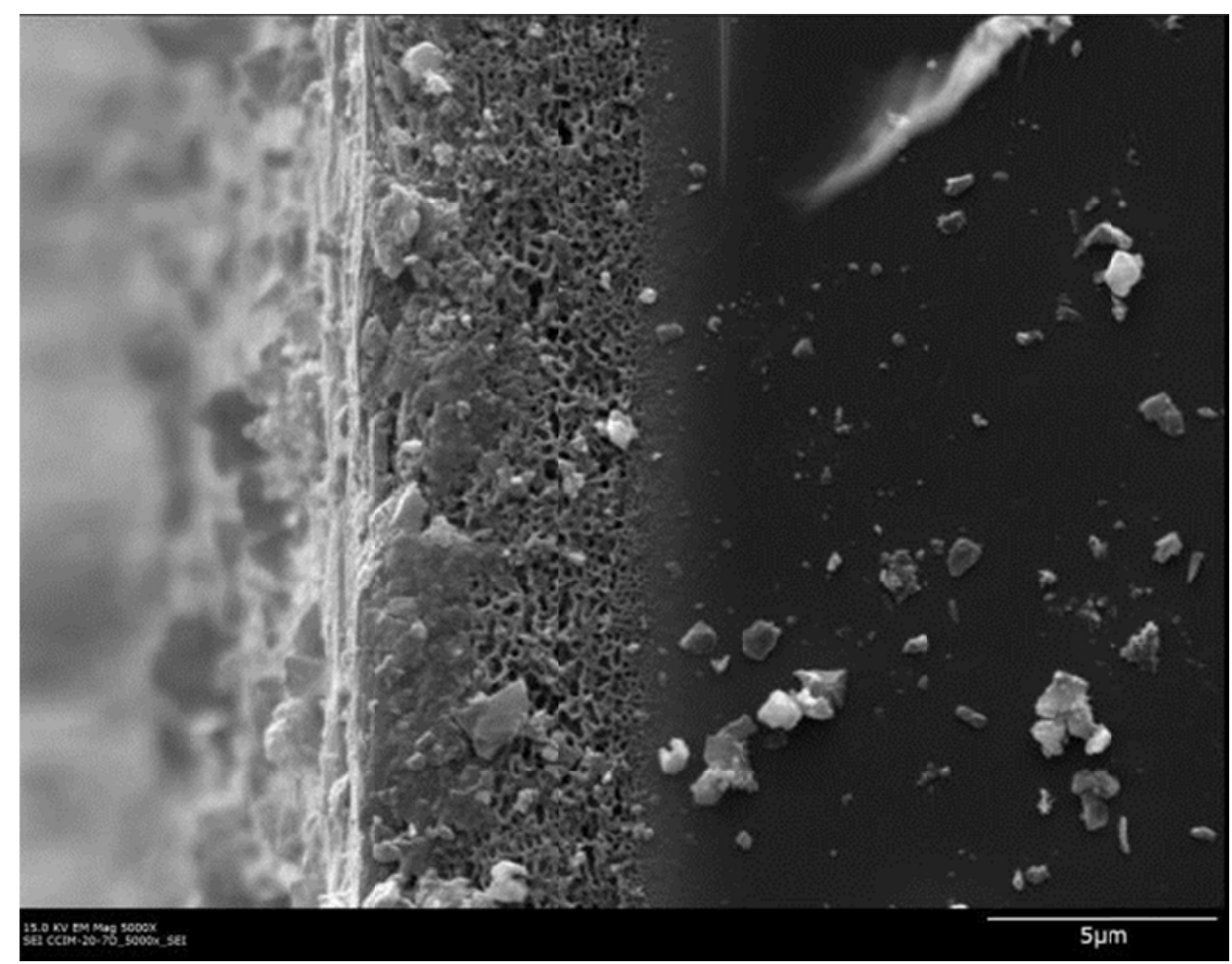

CCIM-AN-20Q

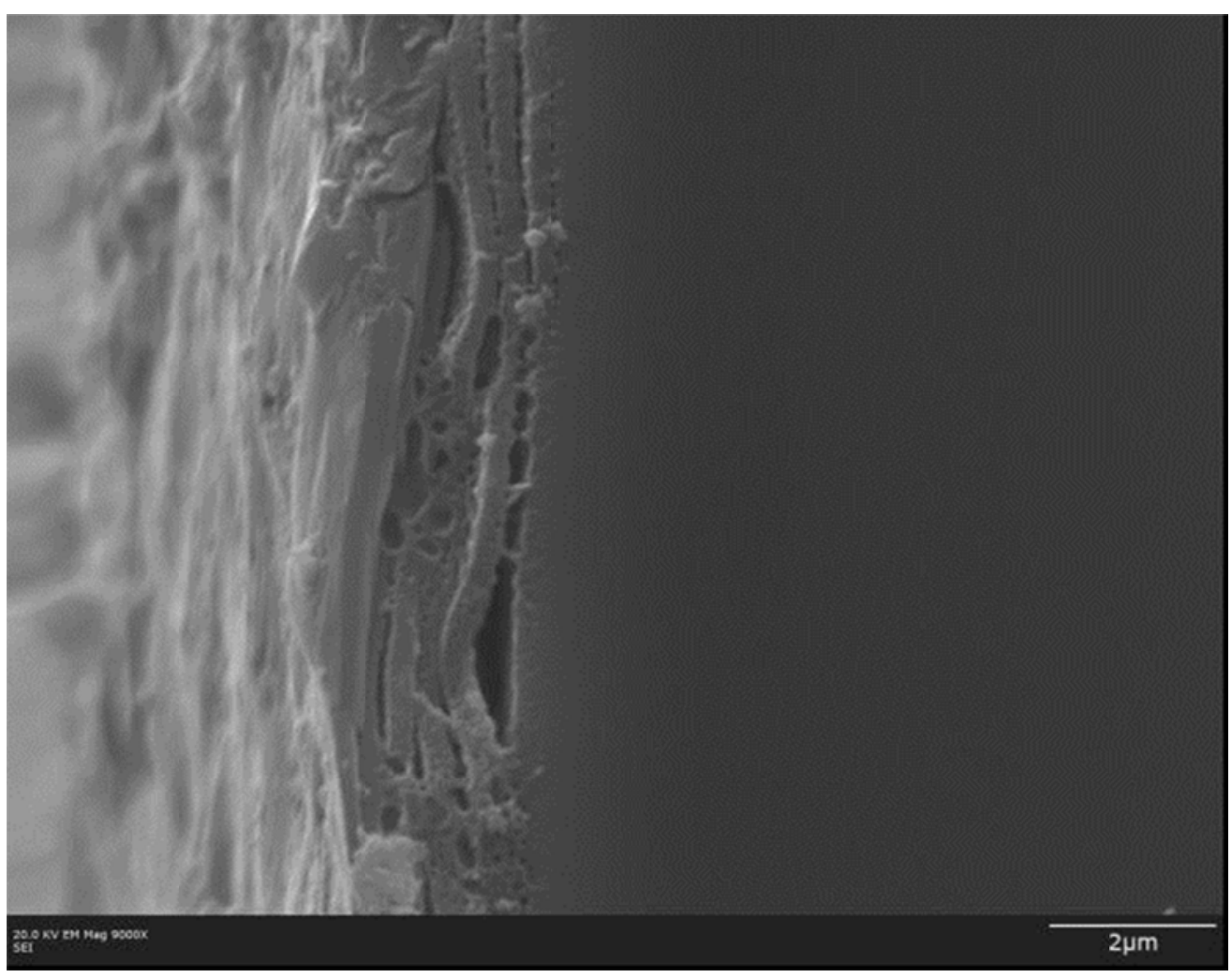

CCIM-AN-02CCC 


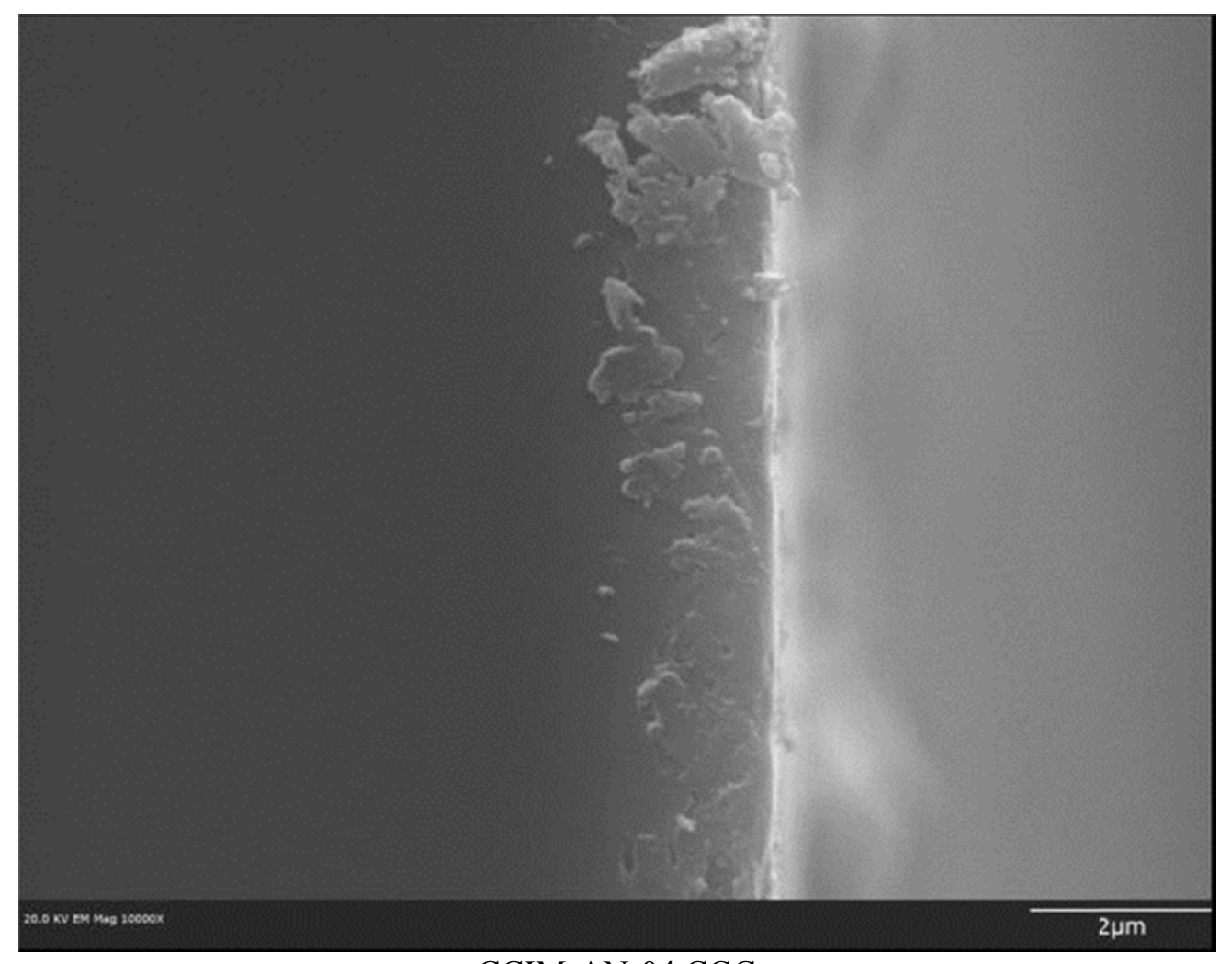

CCIM-AN-04 CCC

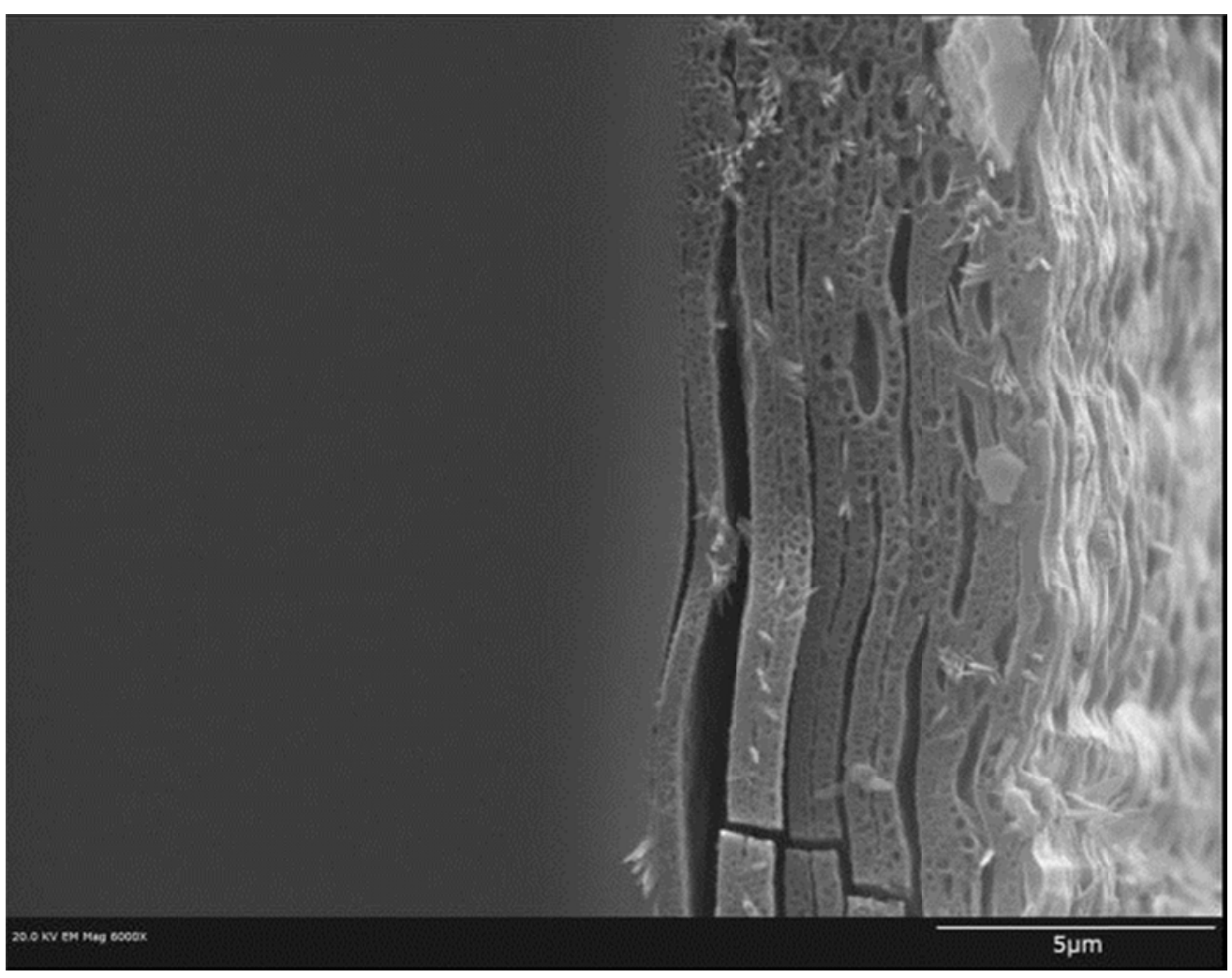

CCIM-AN-09 CCC

C. 5 


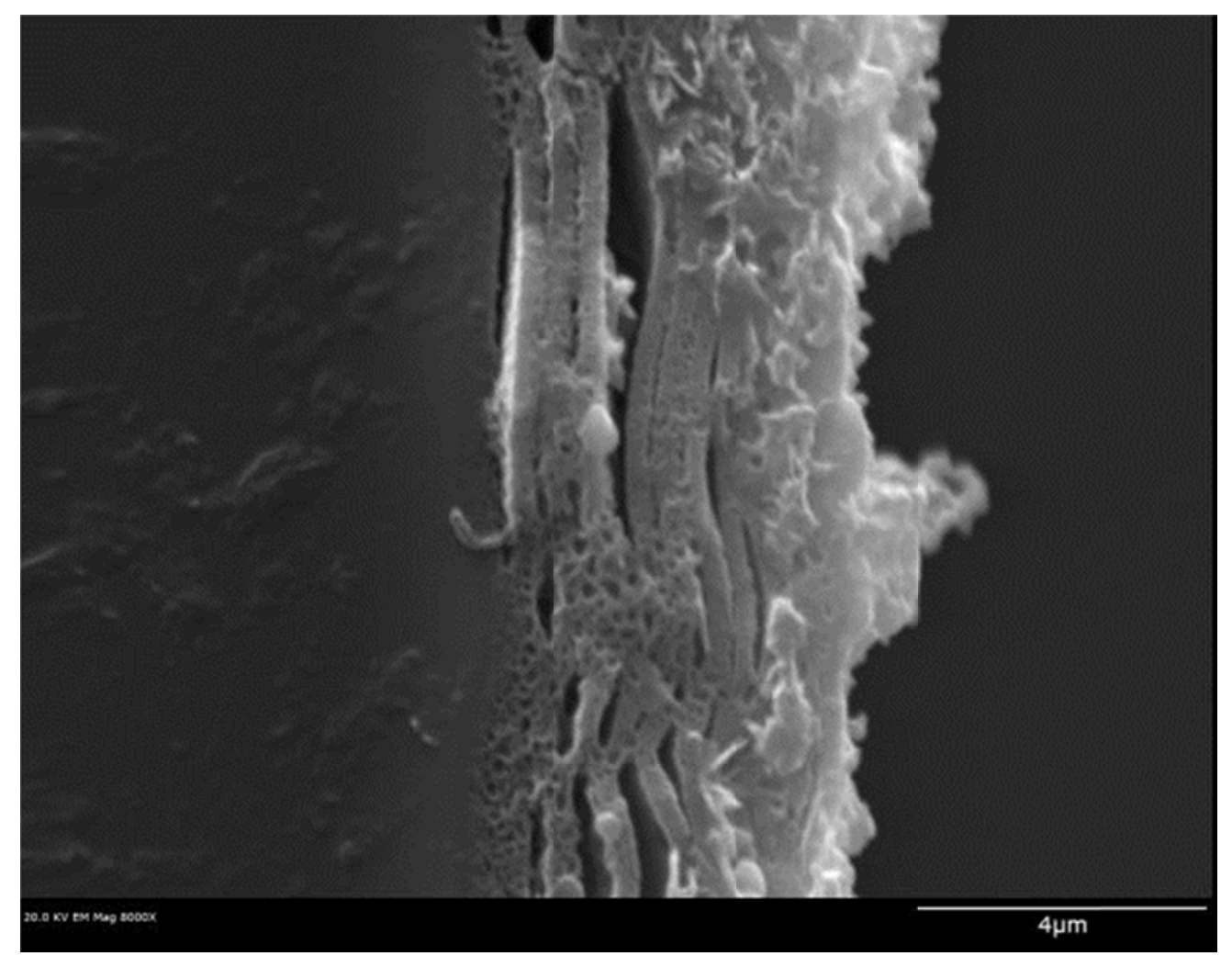

CCIM-AN-11 CCC

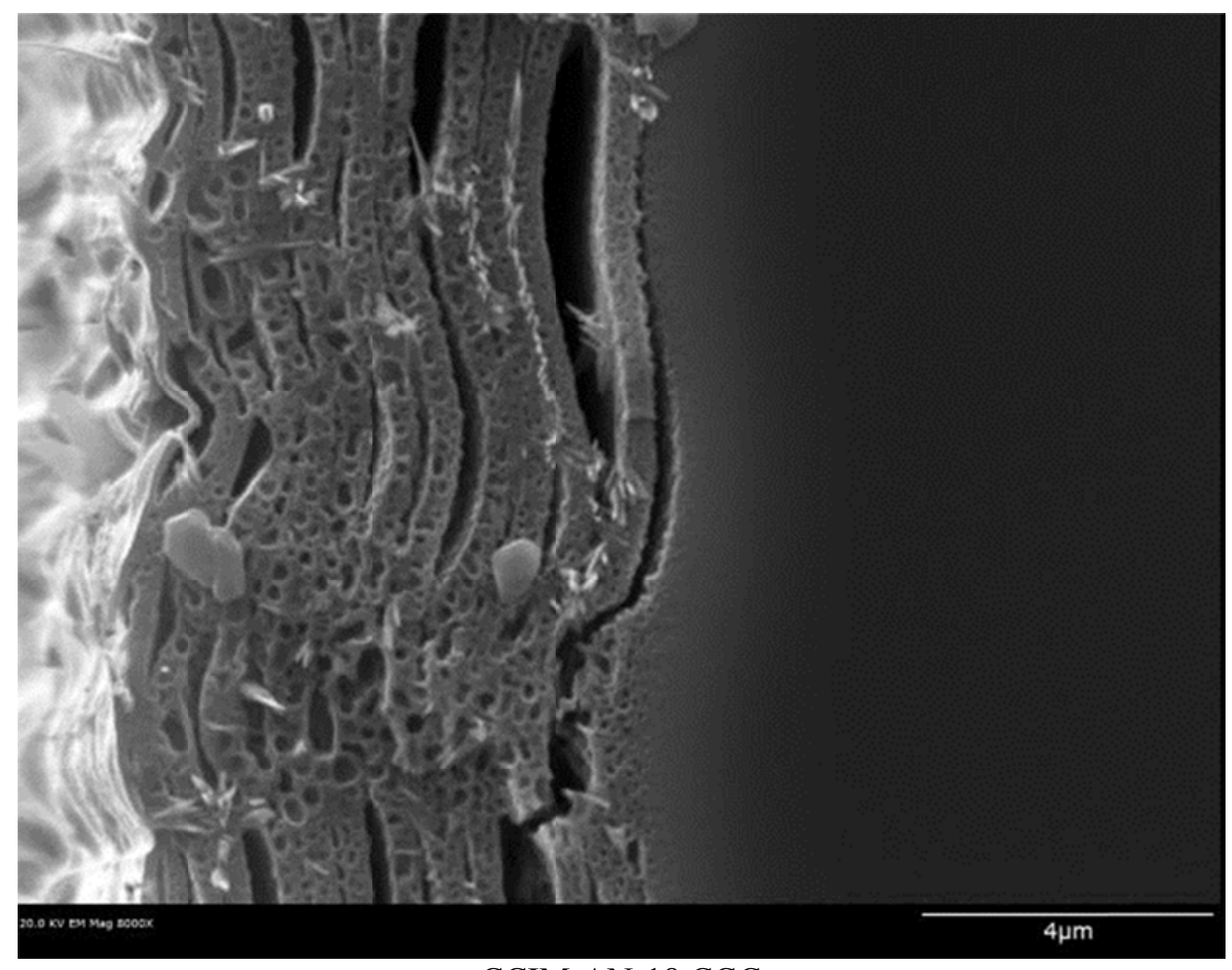

CCIM-AN-18 CCC 


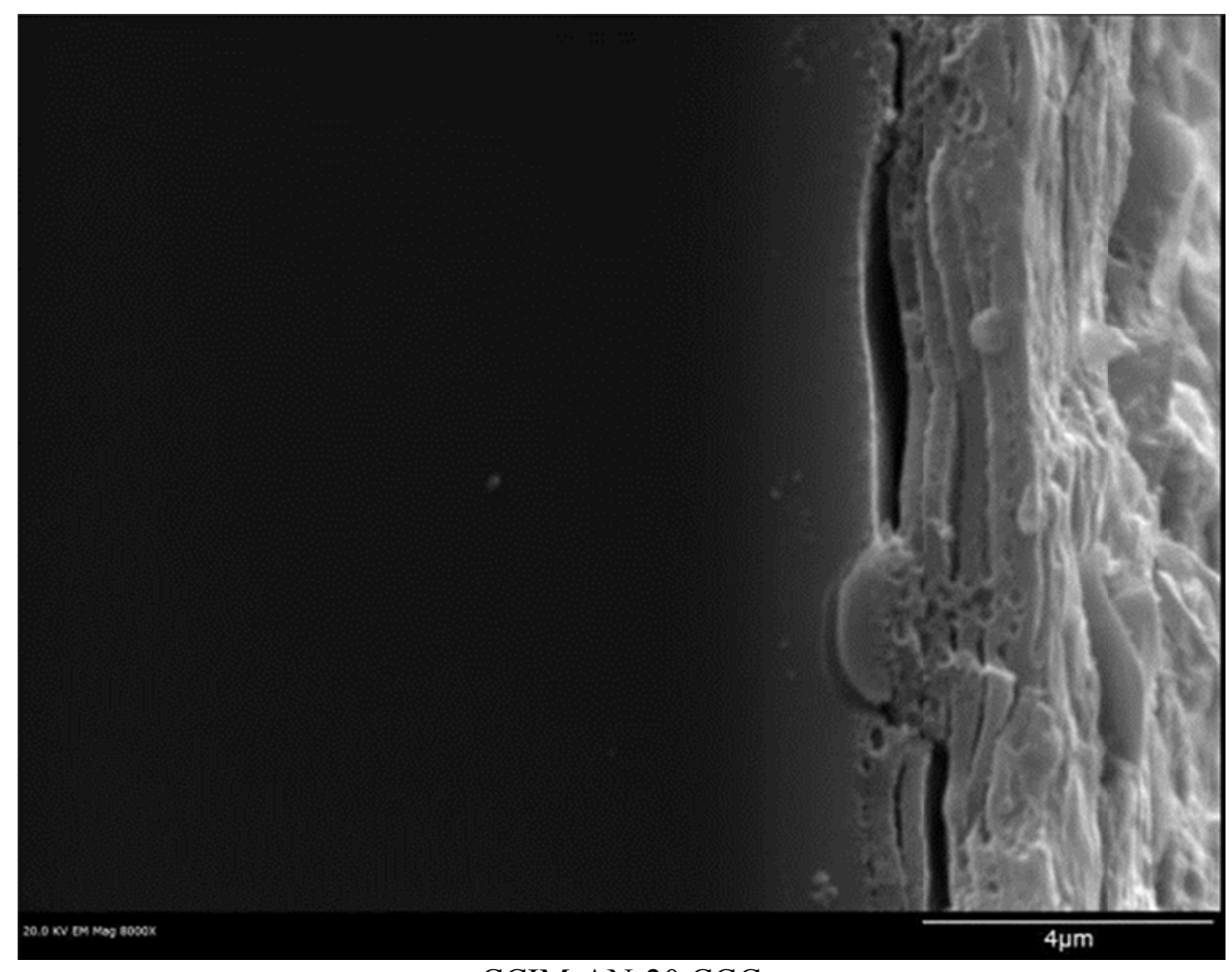

CCIM-AN-20 CCC

C. 7 

Appendix D

\section{Candidate Matrix Glasses}





\section{Appendix D: Candidate Matrix Glasses}

Table D.1. Composition and Predicted Properties of 51 Candidate Matrix Glasses

\begin{tabular}{|c|c|c|c|c|c|c|c|c|c|}
\hline Comp. & 1 & 2 & 3 & 4 & 5 & 6 & 7 & 8 & 9 \\
\hline $\mathrm{Al}_{2} \mathrm{O}_{3}$ & 0.20297 & 0.18032 & 0.22537 & 0.19789 & 0.18136 & 0.19367 & 0.18392 & 0.22464 & 0.18969 \\
\hline $\mathrm{B}_{2} \mathrm{O}_{3}$ & 0.15964 & 0.20737 & 0.17553 & 0.14580 & 0.14241 & 0.21385 & 0.20329 & 0.14905 & 0.17301 \\
\hline $\mathrm{Bi}_{2} \mathrm{O}_{3}$ & 0.02818 & 0.00434 & 0.02972 & 0.01046 & 0.01932 & 0.02111 & 0.00497 & 0.01287 & 0.00419 \\
\hline $\mathrm{CaO}$ & 0.03409 & 0.09341 & 0.08263 & 0.05825 & 0.07286 & 0.01180 & 0.01083 & 0.02710 & 0.08416 \\
\hline $\mathrm{CdO}$ & 0.00178 & 0.00112 & 0.00183 & 0.00199 & 0.00242 & 0.00102 & 0.00267 & 0.00230 & 0.00131 \\
\hline $\mathrm{Cr}_{2} \mathrm{O}_{3}$ & 0.00949 & 0.00783 & 0.00878 & 0.00441 & 0.00583 & 0.01206 & 0.00461 & 0.00334 & 0.00779 \\
\hline $\mathrm{F}$ & 0.00167 & 0.00372 & 0.00524 & 0.00439 & 0.00966 & 0.00353 & 0.00724 & 0.00481 & 0.00985 \\
\hline $\mathrm{Fe}_{2} \mathrm{O}_{3}$ & 0.04666 & 0.04736 & 0.03465 & 0.02316 & 0.02644 & 0.03043 & 0.04174 & 0.04712 & 0.04938 \\
\hline $\mathrm{K}_{2} \mathrm{O}$ & 0.02488 & 0.03570 & 0.00006 & 0.02855 & 0.01360 & 0.00433 & 0.01283 & 0.03106 & 0.02501 \\
\hline $\mathrm{La}_{2} \mathrm{O}_{3}$ & 0.00905 & 0.00728 & 0.00182 & 0.00270 & 0.00543 & 0.00200 & 0.00221 & 0.00593 & 0.00139 \\
\hline $\mathrm{Li}_{2} \mathrm{O}$ & 0.02355 & 0.05417 & 0.02655 & 0.01344 & 0.04822 & 0.01322 & 0.04986 & 0.04672 & 0.05272 \\
\hline $\mathrm{MgO}$ & 0.00972 & 0.00222 & 0.00174 & 0.00955 & 0.00465 & 0.00917 & 0.00583 & 0.00455 & 0.00900 \\
\hline $\mathrm{MnO}$ & 0.00185 & 0.00390 & 0.00638 & 0.01184 & 0.00949 & 0.00589 & 0.00343 & 0.01163 & 0.01432 \\
\hline $\mathrm{Na}_{2} \mathrm{O}$ & 0.08590 & 0.07087 & 0.07714 & 0.08455 & 0.09204 & 0.11495 & 0.05159 & 0.11546 & 0.05268 \\
\hline $\mathrm{Nd}_{2} \mathrm{O}_{3}$ & 0.00139 & 0.00189 & 0.00177 & 0.00130 & 0.00151 & 0.00109 & 0.00183 & 0.00197 & 0.00178 \\
\hline $\mathrm{NiO}$ & 0.00129 & 0.00389 & 0.00402 & 0.00118 & 0.00477 & 0.00695 & 0.00393 & 0.00706 & 0.00525 \\
\hline $\mathrm{P}_{2} \mathrm{O}_{5}$ & 0.00653 & 0.01154 & 0.02146 & 0.00544 & 0.01928 & 0.02142 & 0.01828 & 0.01478 & 0.00653 \\
\hline $\mathrm{PbO}$ & 0.00352 & 0.00494 & 0.00520 & 0.00108 & 0.00839 & 0.00576 & 0.00158 & 0.00104 & 0.00521 \\
\hline $\mathrm{RuO}_{2}$ & 0.00002 & 0.00004 & 0.00003 & 0.00001 & 0.00002 & 0.00004 & 0.00005 & 0.00001 & 0.00003 \\
\hline $\mathrm{SiO}_{2}$ & 0.32913 & 0.23220 & 0.27130 & 0.35733 & 0.27966 & 0.27634 & 0.35169 & 0.27677 & 0.27566 \\
\hline $\mathrm{SO}_{3}$ & 0.00592 & 0.00396 & 0.00693 & 0.00433 & 0.00690 & 0.00516 & 0.00221 & 0.00170 & 0.00389 \\
\hline $\mathrm{SrO}$ & 0.00294 & 0.00409 & 0.00876 & 0.00291 & 0.00880 & 0.00738 & 0.00899 & 0.00371 & 0.00358 \\
\hline $\mathrm{ZrO}_{2}$ & 0.00985 & 0.01783 & 0.00307 & 0.02944 & 0.03693 & 0.03884 & 0.02641 & 0.00637 & 0.02356 \\
\hline Total & 1 & 1 & 1 & 1 & 1 & 1 & 1 & 1 & 1 \\
\hline \multicolumn{10}{|c|}{ Multicomponent constraints } \\
\hline $\mathrm{Al}_{2} \mathrm{O}_{3}+\mathrm{Fe}_{2} \mathrm{O}_{3}+\mathrm{ZrO}_{2}$ & 0.25948 & 0.24552 & 0.26309 & 0.25049 & 0.24473 & 0.26294 & 0.25208 & 0.27813 & 0.26263 \\
\hline $\mathrm{Al}_{2} \mathrm{O}_{3}+\mathrm{Fe}_{2} \mathrm{O}_{3}$ & 0.24963 & 0.22768 & 0.26003 & 0.22105 & 0.20780 & 0.22410 & 0.22566 & 0.27176 & 0.23907 \\
\hline $\mathrm{Al}_{2} \mathrm{O}_{3}+\mathrm{ZrO}_{2}$ & 0.21282 & 0.19815 & 0.22844 & 0.22733 & 0.21829 & 0.23251 & 0.21033 & 0.23101 & 0.21325 \\
\hline $\mathrm{Fe}_{2} \mathrm{O}_{3}+\mathrm{ZrO}_{2}$ & 0.05651 & 0.06520 & 0.03772 & 0.05260 & 0.06337 & 0.06926 & 0.06816 & 0.05349 & 0.07294 \\
\hline \multicolumn{10}{|c|}{ Predicted properties (Vienna et al. 2009) } \\
\hline$\eta_{1150}$, Pa.s & 8.06 & 0.54 & 3.90 & 14.06 & 1.25 & 6.38 & 6.27 & 2.27 & 1.22 \\
\hline$T$ at 5 Pas, ${ }^{\circ} \mathrm{C}$ & 1204.3 & 925.7 & 1122.0 & 1268.5 & 1008.1 & 1174.0 & 1175.2 & 1047.0 & 1000.9 \\
\hline$T_{1 \%}-\mathrm{Sp},{ }^{\circ} \mathrm{C}$ & 1014.3 & 917.4 & 1065.5 & 940.3 & 940.5 & 1047.8 & 919.7 & 992.8 & 1064.7 \\
\hline$\varepsilon_{1150}, \mathrm{~S} / \mathrm{m}$ & 16.4 & 35.7 & 16.4 & 11.4 & 33.4 & 19.4 & 22.9 & 38.9 & 26.6 \\
\hline \multicolumn{10}{|c|}{ Nepheline formation criteria } \\
\hline$N_{S i}$ & 0.533 & 0.480 & 0.473 & 0.559 & 0.506 & 0.472 & 0.599 & 0.449 & 0.532 \\
\hline $\mathrm{OB}$ & 0.570 & 0.587 & 0.570 & 0.572 & 0.594 & 0.556 & 0.542 & 0.592 & 0.585 \\
\hline
\end{tabular}

D. 1 
Table D.1. (Continued)

\begin{tabular}{|c|c|c|c|c|c|c|c|c|c|}
\hline Comp. & 10 & 11 & 12 & 13 & 14 & 15 & 16 & 17 & 18 \\
\hline $\mathrm{Al}_{2} \mathrm{O}_{3}$ & 0.23499 & 0.19171 & 0.20149 & 0.21108 & 0.22020 & 0.24868 & 0.22532 & 0.23021 & 0.22028 \\
\hline $\mathrm{B}_{2} \mathrm{O}_{3}$ & 0.15461 & 0.14234 & 0.17230 & 0.21673 & 0.17137 & 0.16750 & 0.14907 & 0.14291 & 0.16149 \\
\hline $\mathrm{Bi}_{2} \mathrm{O}_{3}$ & 0.02037 & 0.01789 & 0.00427 & 0.00756 & 0.00555 & 0.01494 & 0.00179 & 0.01832 & 0.00230 \\
\hline $\mathrm{CaO}$ & 0.03888 & 0.08265 & 0.09341 & 0.03618 & 0.01980 & 0.09086 & 0.07290 & 0.03119 & 0.06603 \\
\hline $\mathrm{CdO}$ & 0.00228 & 0.00166 & 0.00145 & 0.00109 & 0.00220 & 0.00250 & 0.00247 & 0.00280 & 0.00221 \\
\hline $\mathrm{Cr}_{2} \mathrm{O}_{3}$ & 0.01261 & 0.01269 & 0.00899 & 0.00254 & 0.00402 & 0.00145 & 0.01025 & 0.00249 & 0.00879 \\
\hline $\mathrm{F}$ & 0.00889 & 0.00900 & 0.00777 & 0.00693 & 0.00183 & 0.00438 & 0.00373 & 0.00412 & 0.00373 \\
\hline $\mathrm{Fe}_{2} \mathrm{O}_{3}$ & 0.01012 & 0.04468 & 0.05142 & 0.06467 & 0.04040 & 0.01824 & 0.02590 & 0.02279 & 0.04041 \\
\hline $\mathrm{K}_{2} \mathrm{O}$ & 0.01394 & 0.02792 & 0.03371 & 0.01755 & 0.03761 & 0.03933 & 0.01023 & 0.00208 & 0.03567 \\
\hline $\mathrm{La}_{2} \mathrm{O}_{3}$ & 0.00454 & 0.00764 & 0.00548 & 0.00352 & 0.00559 & 0.00946 & 0.00150 & 0.00315 & 0.00660 \\
\hline $\mathrm{Li}_{2} \mathrm{O}$ & 0.03145 & 0.05455 & 0.04188 & 0.05106 & 0.04265 & 0.01622 & 0.05085 & 0.02545 & 0.03787 \\
\hline $\mathrm{MgO}$ & 0.00816 & 0.00787 & 0.00838 & 0.00428 & 0.00419 & 0.00422 & 0.00639 & 0.00990 & 0.00919 \\
\hline $\mathrm{MnO}$ & 0.00420 & 0.00541 & 0.01193 & 0.00397 & 0.00884 & 0.00443 & 0.00276 & 0.00704 & 0.00717 \\
\hline $\mathrm{Na}_{2} \mathrm{O}$ & 0.05440 & 0.06146 & 0.08187 & 0.08884 & 0.07626 & 0.11700 & 0.09681 & 0.11996 & 0.10801 \\
\hline $\mathrm{Nd}_{2} \mathrm{O}_{3}$ & 0.00154 & 0.00160 & 0.00176 & 0.00140 & 0.00163 & 0.00107 & 0.00109 & 0.00130 & 0.00169 \\
\hline $\mathrm{NiO}$ & 0.00279 & 0.00649 & 0.00572 & 0.00788 & 0.00826 & 0.00461 & 0.00143 & 0.00308 & 0.00176 \\
\hline $\mathrm{P}_{2} \mathrm{O}_{5}$ & 0.00888 & 0.01412 & 0.01120 & 0.01132 & 0.00704 & 0.01070 & 0.02140 & 0.01515 & 0.02357 \\
\hline $\mathrm{PbO}$ & 0.00934 & 0.00405 & 0.00366 & 0.00515 & 0.00716 & 0.00852 & 0.00845 & 0.00816 & 0.00414 \\
\hline $\mathrm{RuO}_{2}$ & 0.00003 & 0.00005 & 0.00002 & 0.00004 & 0.00003 & 0.00003 & 0.00003 & 0.00002 & 0.00003 \\
\hline $\mathrm{SiO}_{2}$ & 0.36647 & 0.29425 & 0.23356 & 0.24027 & 0.29802 & 0.21230 & 0.26677 & 0.31257 & 0.24329 \\
\hline $\mathrm{SO}_{3}$ & 0.00537 & 0.00578 & 0.00482 & 0.00384 & 0.00194 & 0.00428 & 0.00486 & 0.00556 & 0.00619 \\
\hline $\mathrm{SrO}$ & 0.00110 & 0.00254 & 0.00797 & 0.00743 & 0.00884 & 0.00869 & 0.00671 & 0.00411 & 0.00226 \\
\hline $\mathrm{ZrO}_{2}$ & 0.00504 & 0.00366 & 0.00692 & 0.00666 & 0.02658 & 0.01061 & 0.02929 & 0.02762 & 0.00734 \\
\hline Total & 1 & 1 & 1 & 1 & 1 & 1 & 1 & 1 & 1 \\
\hline \multicolumn{10}{|c|}{ Multicomponent constraints } \\
\hline $\mathrm{Al}_{2} \mathrm{O}_{3}+\mathrm{Fe}_{2} \mathrm{O}_{3}+\mathrm{ZrO}_{2}$ & 0.25015 & 0.24004 & 0.25983 & 0.28241 & 0.28717 & 0.27753 & 0.28052 & 0.28062 & 0.26803 \\
\hline $\mathrm{Al}_{2} \mathrm{O}_{3}+\mathrm{Fe}_{2} \mathrm{O}_{3}$ & 0.24511 & 0.23639 & 0.25291 & 0.27576 & 0.26059 & 0.26692 & 0.25122 & 0.25300 & 0.26069 \\
\hline $\mathrm{Al}_{2} \mathrm{O}_{3}+\mathrm{ZrO}_{2}$ & 0.24003 & 0.19536 & 0.20841 & 0.21774 & 0.24677 & 0.25929 & 0.25462 & 0.25783 & 0.22762 \\
\hline $\mathrm{Fe}_{2} \mathrm{O}_{3}+\mathrm{ZrO}_{2}$ & 0.01516 & 0.04834 & 0.05834 & 0.07133 & 0.06697 & 0.02885 & 0.05519 & 0.05041 & 0.04775 \\
\hline \multicolumn{10}{|c|}{ Predicted properties (Vienna et al. 2009) } \\
\hline$\eta_{1150}$, Pa.s & 13.86 & 1.37 & 0.84 & 1.13 & 4.25 & 2.15 & 1.75 & 7.94 & 1.55 \\
\hline$T$ at 5 Pas, ${ }^{\circ} \mathrm{C}$ & 1263.7 & 1005.2 & 958.7 & 970.0 & 1131.8 & 1055.0 & 1034.5 & 1197.2 & 1008.5 \\
\hline$T_{1 \%}-\mathrm{Sp},{ }^{\circ} \mathrm{C}$ & 1074.3 & 1088.6 & 1063.4 & 989.6 & 1031.8 & 943.9 & 1021.2 & 973.5 & 996.5 \\
\hline$\varepsilon_{1150}, \mathrm{~S} / \mathrm{m}$ & 12.5 & 29.7 & 27.6 & 37.0 & 23.8 & 20.9 & 34.9 & 23.1 & 31.5 \\
\hline \multicolumn{10}{|c|}{ Nepheline formation criteria } \\
\hline$N_{S i}$ & 0.559 & 0.538 & 0.452 & 0.445 & 0.501 & 0.367 & 0.453 & 0.472 & 0.426 \\
\hline $\mathrm{OB}$ & 0.553 & 0.591 & 0.599 & 0.571 & 0.574 & 0.603 & 0.591 & 0.577 & 0.594 \\
\hline
\end{tabular}


Table D.1. (Continued)

\begin{tabular}{|c|c|c|c|c|c|c|c|c|c|}
\hline Comp. & 19 & 20 & 21 & 22 & 23 & 24 & 25 & 26 & 27 \\
\hline $\mathrm{Al}_{2} \mathrm{O}_{3}$ & 0.24206 & 0.22837 & 0.20813 & 0.25557 & 0.18659 & 0.20646 & 0.23783 & 0.21598 & 0.20497 \\
\hline $\mathrm{B}_{2} \mathrm{O}_{3}$ & 0.17465 & 0.20640 & 0.14247 & 0.21281 & $\begin{array}{l}0.19479 \\
\end{array}$ & 0.19927 & 0.21524 & 0.17618 & 0.20347 \\
\hline $\mathrm{Bi}_{2} \mathrm{O}_{3}$ & 0.02755 & 0.01096 & 0.01392 & 0.00686 & 0.01902 & 0.00254 & 0.02269 & 0.02731 & 0.02837 \\
\hline $\mathrm{CaO}$ & 0.03461 & 0.01669 & 0.03505 & 0.00173 & 0.09811 & 0.01140 & 0.01549 & 0.02327 & 0.01530 \\
\hline $\mathrm{CdO}$ & 0.00165 & 0.00231 & 0.00259 & 0.00236 & 0.00235 & 0.00207 & 0.00150 & 0.00290 & 0.00180 \\
\hline $\mathrm{Cr}_{2} \mathrm{O}_{3}$ & 0.00423 & 0.00279 & 0.01237 & 0.00385 & 0.00917 & 0.00532 & 0.00402 & 0.00332 & 0.00125 \\
\hline $\mathrm{F}$ & 0.00557 & 0.00622 & 0.00635 & 0.00509 & 0.00188 & 0.00330 & 0.00769 & 0.00166 & 0.00845 \\
\hline $\mathrm{Fe}_{2} \mathrm{O}_{3}$ & 0.05764 & 0.01911 & 0.06137 & 0.05954 & 0.04985 & 0.01206 & 0.04794 & 0.04081 & 0.02729 \\
\hline $\mathrm{K}_{2} \mathrm{O}$ & 0.01185 & 0.00552 & 0.00431 & 0.03777 & 0.03454 & 0.03972 & 0.01975 & 0.00898 & 0.02475 \\
\hline $\mathrm{LL}_{2} \mathrm{O}_{3}$ & 0.00316 & 0.00542 & 0.00808 & 0.00881 & 0.00891 & 0.00849 & 0.00871 & 0.00711 & 0.00202 \\
\hline $\mathrm{Li}_{2} \mathrm{O}$ & 0.04209 & 0.04925 & 0.02879 & 0.03047 & 0.03567 & 0.05421 & 0.01723 & 0.05977 & 0.04780 \\
\hline $\mathrm{MgO}$ & 0.00860 & 0.00225 & 0.00771 & 0.00549 & 0.00327 & 0.00885 & 0.00221 & 0.00508 & 0.00968 \\
\hline $\mathrm{MnO}$ & 0.01337 & 0.00679 & 0.01341 & 0.00370 & 0.00167 & 0.00705 & 0.00570 & 0.00517 & 0.01439 \\
\hline $\mathrm{Na}_{2} \mathrm{O}$ & 0.09796 & 0.07708 & 0.07374 & 0.10953 & 0.08743 & 0.09176 & 0.09241 & 0.05072 & 0.06660 \\
\hline $\mathrm{Nd}_{2} \mathrm{O}_{3}$ & 0.00199 & 0.00154 & 0.00161 & 0.00116 & 0.00103 & 0.00181 & 0.00168 & 0.00138 & 0.00126 \\
\hline $\mathrm{NiO}$ & 0.00261 & 0.00203 & 0.00227 & 0.00221 & 0.00273 & 0.00619 & 0.00930 & 0.00159 & 0.00876 \\
\hline $\mathrm{P}_{2} \mathrm{O}_{5}$ & 0.01827 & 0.00888 & 0.02476 & 0.01312 & 0.01055 & 0.02045 & 0.01940 & 0.00998 & 0.01272 \\
\hline $\mathrm{PbO}$ & 0.00288 & 0.00626 & 0.00374 & 0.00609 & 0.00400 & 0.00288 & 0.00489 & 0.00788 & 0.00860 \\
\hline $\mathrm{RuO}_{2}$ & 0.00002 & 0.00005 & 0.00003 & 0.00002 & 0.00002 & 0.00005 & 0.00004 & 0.00001 & 0.00002 \\
\hline $\mathrm{SiO}_{2}$ & 0.22925 & 0.31536 & 0.32813 & 0.20843 & 0.22176 & 0.28230 & 0.22645 & 0.32795 & 0.26310 \\
\hline $\mathrm{SO}_{3}$ & 0.00314 & 0.00138 & 0.00561 & 0.00572 & 0.00418 & 0.00113 & 0.00565 & 0.00142 & 0.00302 \\
\hline $\mathrm{SrO}$ & 0.00559 & 0.00576 & 0.00742 & 0.00142 & 0.00497 & 0.00330 & 0.00990 & 0.00386 & 0.00951 \\
\hline $\mathrm{ZrO}_{2}$ & 0.01125 & 0.01958 & 0.00814 & 0.01825 & 0.01752 & 0.02941 & 0.02426 & 0.01767 & 0.03688 \\
\hline Total & 1 & 1 & 1 & 1 & 1 & 1 & 1 & 1 & 1 \\
\hline \multicolumn{10}{|c|}{ Multicomponent constraints } \\
\hline $\mathrm{Al}_{2} \mathrm{O}_{3}+\mathrm{Fe}_{2} \mathrm{O}_{3}+\mathrm{ZrO}$ & 0.31094 & 0.26705 & 0.27765 & 0.33336 & 0.25395 & 0.24792 & 0.31003 & 0.27447 & 0.26914 \\
\hline $\mathrm{Al}_{2} \mathrm{O}_{3}+\mathrm{Fe}_{2} \mathrm{O}_{3}$ & 0.29970 & 0.24748 & 0.26951 & 0.31511 & 0.23644 & 0.21851 & 0.28577 & 0.25680 & 0.23225 \\
\hline $\mathrm{Al}_{2} \mathrm{O}_{3}+\mathrm{ZrO}_{2}$ & 0.25330 & 0.24794 & 0.21628 & 0.27382 & 0.20410 & 0.23586 & 0.26209 & 0.23365 & 0.24185 \\
\hline $\mathrm{Fe}_{2} \mathrm{O}_{3}+\mathrm{ZrO}_{2}$ & 0.06889 & 0.03869 & 0.06952 & 0.07779 & 0.06737 & 0.04147 & 0.07220 & 0.05848 & 0.06417 \\
\hline \multicolumn{10}{|c|}{ Predicted properties (Vienna et al. 2009) } \\
\hline$\eta_{1150}$, Pa.s & 2.22 & 4.51 & 8.53 & 3.25 & 0.84 & 2.11 & 5.93 & 4.07 & 2.31 \\
\hline$T$ at 5 Pas, ${ }^{\circ} \mathrm{C}$ & 1055.0 & 1138.6 & 1210.8 & 1098.1 & 965.0 & 1046.2 & 1167.9 & 1128.4 & 1070.8 \\
\hline$T_{1 \%}-\mathrm{Sp},{ }^{\circ} \mathrm{C}$ & 1084.0 & 880.2 & 1169.9 & 1031.3 & 957.5 & 875.2 & 1100.3 & 958.8 & 980.9 \\
\hline$\varepsilon_{1150}, \mathrm{~S} / \mathrm{m}$ & 32.0 & 27.5 & 16.4 & 28.8 & 26.4 & 38.1 & 16.9 & 29.9 & 27.3 \\
\hline \multicolumn{10}{|c|}{ Nepheline formation criteria } \\
\hline$N_{S i}$ & 0.403 & 0.508 & 0.538 & 0.363 & 0.447 & 0.486 & 0.407 & 0.552 & 0.492 \\
\hline $\mathrm{OB}$ & 0.585 & 0.551 & 0.567 & 0.573 & 0.595 & 0.569 & 0.561 & 0.560 & 0.566 \\
\hline
\end{tabular}


Table D.1. (Continued)

\begin{tabular}{|c|c|c|c|c|c|c|c|c|c|}
\hline Comp. & 28 & 29 & 30 & 31 & 32 & 33 & 34 & 35 & 36 \\
\hline $\mathrm{Al}_{2} \mathrm{O}_{3}$ & 0.25920 & 0.22360 & 0.23863 & 0.21606 & 0.19754 & 0.21111 & 0.21611 & 0.25384 & 0.21796 \\
\hline $\mathrm{B}_{2} \mathrm{O}_{3}$ & 0.17329 & 0.14351 & 0.14714 & 0.15590 & 0.18371 & 0.16801 & 0.16620 & 0.18840 & 0.17580 \\
\hline $\mathrm{Bi}_{2} \mathrm{O}_{3}$ & 0.02311 & 0.01774 & 0.00609 & 0.02455 & 0.01686 & 0.01339 & 0.00846 & 0.02508 & 0.01766 \\
\hline $\mathrm{CaO}$ & 0.04830 & 0.08156 & 0.07082 & 0.02767 & 0.07407 & 0.07644 & 0.01839 & 0.02794 & 0.00531 \\
\hline $\mathrm{CdO}$ & 0.00134 & 0.00203 & 0.00154 & 0.00155 & 0.00190 & 0.00168 & 0.00257 & 0.00202 & 0.00131 \\
\hline $\mathrm{Cr}_{2} \mathrm{O}_{3}$ & 0.00250 & 0.00141 & 0.01190 & 0.00903 & 0.00581 & 0.01052 & 0.00918 & 0.00394 & 0.00851 \\
\hline $\mathrm{F}$ & 0.00483 & 0.00140 & 0.00156 & 0.00411 & 0.00723 & 0.00301 & 0.00141 & 0.00217 & 0.00742 \\
\hline $\mathrm{Fe}_{2} \mathrm{O}_{3}$ & 0.04805 & 0.05170 & 0.05481 & 0.05238 & 0.02006 & 0.01819 & 0.05547 & 0.03159 & 0.04866 \\
\hline $\mathrm{K}_{2} \mathrm{O}$ & 0.03015 & 0.01435 & 0.01171 & 0.00269 & 0.01799 & 0.03126 & 0.00868 & 0.01369 & 0.02548 \\
\hline $\mathrm{La}_{2} \mathrm{O}_{3}$ & 0.00563 & 0.00935 & 0.00466 & 0.00183 & 0.00599 & 0.00275 & 0.00462 & 0.00693 & 0.00900 \\
\hline $\mathrm{Li}_{2} \mathrm{O}$ & 0.02536 & 0.01570 & 0.04754 & 0.05354 & 0.03318 & 0.02375 & 0.02504 & 0.03347 & 0.01054 \\
\hline $\mathrm{MgO}$ & 0.00824 & 0.00517 & 0.00167 & 0.00209 & 0.00771 & 0.00336 & 0.00141 & 0.00242 & 0.00516 \\
\hline $\mathrm{MnO}$ & 0.00622 & 0.01193 & 0.00559 & 0.00119 & 0.00915 & 0.00614 & 0.01152 & 0.00130 & 0.01499 \\
\hline $\mathrm{Na}_{2} \mathrm{O}$ & 0.08094 & 0.05236 & 0.08746 & 0.08545 & 0.11334 & 0.11921 & 0.07690 & 0.10604 & 0.08536 \\
\hline $\mathrm{Nd}_{2} \mathrm{O}_{3}$ & 0.00114 & 0.00133 & 0.00132 & 0.00178 & 0.00135 & 0.00113 & 0.00126 & 0.00132 & 0.00103 \\
\hline $\mathrm{NiO}$ & 0.00635 & 0.00921 & 0.00341 & 0.00242 & 0.00106 & 0.00989 & 0.00309 & 0.00311 & 0.00631 \\
\hline $\mathrm{P}_{2} \mathrm{O}_{5}$ & 0.00867 & 0.02067 & 0.02124 & 0.02222 & 0.02144 & 0.02044 & 0.02124 & 0.01457 & 0.02484 \\
\hline $\mathrm{PbO}$ & 0.00531 & 0.00382 & 0.00366 & 0.00121 & 0.00371 & 0.00716 & 0.00351 & 0.00420 & 0.00562 \\
\hline $\mathrm{RuO}_{2}$ & 0.00002 & 0.00005 & 0.00002 & 0.00001 & 0.00004 & 0.00002 & 0.00003 & 0.00004 & 0.00004 \\
\hline $\mathrm{SiO}_{2}$ & 0.24242 & 0.30693 & 0.25890 & 0.31479 & 0.25504 & 0.25946 & 0.33312 & 0.24743 & 0.31408 \\
\hline $\mathrm{SO}_{3}$ & 0.00219 & 0.00146 & 0.00413 & 0.00154 & 0.00254 & 0.00433 & 0.00414 & 0.00402 & 0.00209 \\
\hline $\mathrm{SrO}$ & 0.00321 & 0.00659 & 0.00482 & 0.00985 & 0.00304 & 0.00164 & 0.00722 & 0.00125 & 0.00614 \\
\hline $\mathrm{ZrO}_{2}$ & 0.01353 & 0.01815 & 0.01138 & 0.00814 & 0.01726 & 0.00713 & 0.02043 & 0.02524 & 0.00671 \\
\hline Total & 1 & 1 & 1 & 1 & 1 & 1 & 1 & 1 & 1 \\
\hline \multicolumn{10}{|c|}{ Multicomponent constraints } \\
\hline $\mathrm{Al}_{2} \mathrm{O}_{3}+\mathrm{Fe}_{2} \mathrm{O}_{3}+\mathrm{ZrO}_{2}$ & 0.32077 & 0.29345 & 0.30482 & 0.27658 & 0.23486 & 0.23643 & 0.29201 & 0.31066 & 0.27333 \\
\hline $\mathrm{Al}_{2} \mathrm{O}_{3}+\mathrm{Fe}_{2} \mathrm{O}_{3}$ & 0.30724 & 0.27530 & 0.29343 & 0.26844 & 0.21760 & 0.22930 & 0.27158 & 0.28543 & 0.26662 \\
\hline $\mathrm{Al}_{2} \mathrm{O}_{3}+\mathrm{ZrO}_{2}$ & 0.27273 & 0.24175 & 0.25001 & 0.22420 & 0.21480 & 0.21824 & 0.23654 & 0.27907 & 0.22467 \\
\hline $\mathrm{Fe}_{2} \mathrm{O}_{3}+\mathrm{ZrO}_{2}$ & 0.06158 & 0.06985 & 0.06619 & 0.06052 & 0.03732 & 0.02532 & 0.07590 & 0.05683 & 0.05537 \\
\hline \multicolumn{10}{|c|}{ Predicted properties (Vienna et al. 2009) } \\
\hline$\eta_{1150}$, Pa.s & 5.33 & 12.05 & 2.36 & 3.80 & 1.37 & 2.09 & 13.65 & 4.68 & 14.51 \\
\hline$T$ at 5 Pas, ${ }^{\circ} \mathrm{C}$ & 1157.3 & 1246.3 & 1059.9 & 1117.6 & 1006.4 & 1047.8 & 1260.1 & 1142.5 & 1262.4 \\
\hline$T_{1 \%}-\mathrm{Sp},{ }^{\circ} \mathrm{C}$ & 1131.1 & 1172.4 & 1155.9 & 1023.8 & 858.9 & 1008.6 & 1106.4 & 999.4 & 1110.0 \\
\hline$\varepsilon_{1550}, \mathrm{~S} / \mathrm{m}$ & 16.5 & 8.5 & 30.4 & 34.1 & 29.9 & 24.5 & 15.0 & 26.4 & 12.2 \\
\hline \multicolumn{10}{|c|}{ Nepheline formation criteria } \\
\hline$N_{S i}$ & 0.416 & 0.527 & 0.443 & 0.511 & 0.451 & 0.440 & 0.532 & 0.407 & 0.509 \\
\hline $\mathrm{OB}$ & 0.583 & 0.575 & 0.590 & 0.570 & 0.585 & 0.589 & 0.555 & 0.573 & 0.555 \\
\hline
\end{tabular}


Table D.1. (Continued)

\begin{tabular}{|c|c|c|c|c|c|c|c|c|c|}
\hline Comp. & 37 & 38 & 39 & 40 & 41 & 42 & 43 & 44 & 45 \\
\hline $\mathrm{Al}_{2} \mathrm{O}_{3}$ & 0.18696 & 0.24973 & 0.25923 & 0.19551 & 0.20295 & 0.23550 & 0.23519 & 0.22875 & 0.20433 \\
\hline $\mathrm{B}_{2} \mathrm{O}_{3}$ & 0.19466 & 0.21567 & 0.16126 & 0.17537 & 0.21556 & 0.20962 & 0.21019 & 0.18993 & 0.21262 \\
\hline $\mathrm{Bi}_{2} \mathrm{O}_{3}$ & 0.00888 & 0.02257 & 0.02873 & 0.01883 & 0.02486 & 0.02126 & 0.01473 & 0.00362 & 0.00120 \\
\hline $\mathrm{CaO}$ & 0.05617 & 0.03965 & 0.08985 & 0.01745 & 0.05148 & 0.01806 & 0.05879 & 0.09434 & 0.08060 \\
\hline $\mathrm{CdO}$ & 0.00251 & 0.00216 & 0.00102 & 0.00204 & 0.00286 & 0.00177 & 0.00256 & 0.00178 & 0.00219 \\
\hline $\mathrm{Cr}_{2} \mathrm{O}_{3}$ & 0.00320 & 0.00370 & 0.00897 & 0.00726 & 0.00328 & 0.00885 & 0.01187 & 0.00946 & 0.00279 \\
\hline $\mathrm{F}$ & 0.00980 & 0.00147 & 0.00188 & 0.00957 & 0.00460 & 0.00703 & 0.00627 & 0.00981 & 0.00315 \\
\hline $\mathrm{Fe}_{2} \mathrm{O}_{3}$ & 0.02524 & 0.01244 & 0.01168 & 0.06158 & 0.03107 & 0.01640 & 0.02874 & 0.02764 & 0.03774 \\
\hline $\mathrm{K}_{2} \mathrm{O}$ & 0.01467 & 0.01795 & 0.00203 & 0.03183 & 0.03983 & 0.00657 & 0.00875 & 0.03979 & 0.02951 \\
\hline $\mathrm{La}_{2} \mathrm{O}_{3}$ & 0.00549 & 0.00738 & 0.00854 & 0.00761 & 0.00164 & 0.00637 & 0.00747 & 0.00990 & 0.00875 \\
\hline $\mathrm{Li}_{2} \mathrm{O}$ & 0.02312 & 0.04004 & 0.01320 & 0.00348 & 0.04628 & 0.03773 & 0.02887 & 0.02464 & 0.03715 \\
\hline $\mathrm{MgO}$ & 0.00182 & 0.00913 & 0.00890 & 0.00275 & 0.00259 & 0.00797 & 0.00322 & 0.00465 & 0.00619 \\
\hline $\mathrm{MnO}$ & 0.01071 & 0.00605 & 0.00776 & 0.01301 & 0.00187 & 0.01127 & 0.00418 & 0.01484 & 0.01187 \\
\hline $\mathrm{Na}_{2} \mathrm{O}$ & 0.06551 & 0.11328 & 0.10069 & 0.09427 & 0.06020 & 0.10591 & 0.07605 & 0.05154 & 0.07742 \\
\hline $\mathrm{Nd}_{2} \mathrm{O}_{3}$ & 0.00170 & 0.00197 & 0.00193 & 0.00193 & 0.00146 & 0.00125 & 0.00174 & 0.00183 & 0.00160 \\
\hline $\mathrm{NiO}$ & 0.00229 & 0.00729 & 0.00297 & 0.00189 & 0.00998 & 0.00756 & 0.00313 & 0.00422 & 0.00800 \\
\hline $\mathrm{P}_{2} \mathrm{O}_{5}$ & 0.00758 & 0.01995 & 0.01314 & 0.01682 & 0.01568 & 0.01872 & 0.01519 & 0.00575 & 0.01459 \\
\hline $\mathrm{PbO}$ & 0.00484 & 0.00259 & 0.00601 & 0.00222 & 0.00825 & 0.00278 & 0.00816 & 0.00334 & 0.00280 \\
\hline $\mathrm{RuO}_{2}$ & 0.00004 & 0.00001 & 0.00002 & 0.00004 & 0.00003 & 0.00003 & 0.00001 & 0.00002 & 0.00005 \\
\hline $\mathrm{SiO}_{2}$ & 0.34072 & 0.21303 & 0.25942 & 0.31453 & 0.26192 & 0.24223 & 0.26364 & 0.25280 & 0.20954 \\
\hline $\mathrm{SO}_{3}$ & 0.00165 & 0.00604 & 0.00688 & 0.00195 & 0.00568 & 0.00395 & 0.00232 & 0.00126 & 0.00475 \\
\hline $\mathrm{SrO}$ & 0.00896 & 0.00270 & 0.00213 & 0.00506 & 0.00412 & 0.00607 & 0.00755 & 0.00963 & 0.00452 \\
\hline $\mathrm{ZrO}_{2}$ & 0.02348 & 0.00520 & 0.00377 & 0.01501 & 0.00382 & 0.02312 & 0.00138 & 0.01046 & 0.03866 \\
\hline Total & 1 & 1 & 1 & 1 & 1 & 1 & 1 & 1 & 1 \\
\hline \multicolumn{10}{|c|}{ Multicomponent constraints } \\
\hline $\mathrm{Al}_{2} \mathrm{O}_{3}+\mathrm{Fe}_{2} \mathrm{O}_{3}+\mathrm{ZrO}_{2}$ & 0.23568 & 0.26736 & 0.27468 & 0.27209 & 0.23784 & 0.27502 & 0.26531 & 0.26685 & 0.28073 \\
\hline $\mathrm{Al}_{2} \mathrm{O}_{3}+\mathrm{Fe}_{2} \mathrm{O}_{3}$ & 0.21220 & 0.26217 & 0.27091 & 0.25708 & 0.23402 & 0.25190 & 0.26393 & 0.25639 & 0.24207 \\
\hline $\mathrm{Al}_{2} \mathrm{O}_{3}+\mathrm{ZrO}_{2}$ & 0.21045 & 0.25493 & 0.26300 & 0.21052 & 0.20677 & 0.25862 & 0.23657 & 0.23921 & 0.24299 \\
\hline $\mathrm{Fe}_{2} \mathrm{O}_{3}+\mathrm{ZrO}_{2}$ & 0.04872 & 0.01763 & 0.01545 & 0.07659 & 0.03489 & 0.03952 & 0.03012 & 0.03810 & 0.07640 \\
\hline \multicolumn{10}{|c|}{ Predicted properties (Vienna et al. 2009) } \\
\hline$\eta_{1150}$, Pa.s & 6.95 & 1.72 & 6.21 & 12.89 & 1.69 & 2.88 & 3.67 & 3.09 & 1.25 \\
\hline$T$ at $5 \mathrm{Pas},{ }^{\circ} \mathrm{C}$ & 1185.2 & 1016.6 & 1175.3 & 1252.2 & 1027.3 & 1085.7 & 1114.6 & 1092.6 & 1005.0 \\
\hline$T_{1 \%} \mathrm{Sp},{ }^{\circ} \mathrm{C}$ & 874.1 & 950.8 & 1095.9 & 1021.7 & 923.3 & 1045.1 & 1053.9 & 1085.0 & 1007.0 \\
\hline$\varepsilon_{1150}, \mathrm{~S} / \mathrm{m}$ & 12.5 & 34.3 & 14.4 & 12.1 & 25.0 & 29.8 & 17.4 & 12.0 & 23.6 \\
\hline \multicolumn{10}{|c|}{ Nepheline formation criteria } \\
\hline$N_{S i}$ & 0.574 & 0.370 & 0.419 & 0.520 & 0.499 & 0.415 & 0.459 & 0.474 & 0.427 \\
\hline $\mathrm{OB}$ & 0.553 & 0.574 & 0.582 & 0.562 & 0.563 & 0.566 & 0.560 & 0.580 & 0.584 \\
\hline
\end{tabular}


Table D.1. (Continued)

\begin{tabular}{|c|c|c|c|c|c|c|c|c|}
\hline Comp. & 46 & 47 & 48 & 49 & 50 & Centroid & Min & Max \\
\hline $\mathrm{Al}_{2} \mathrm{O}_{3}$ & 0.23901 & 0.22314 & 0.21019 & 0.24000 & 0.23315 & 0.22000 & 0.18032 & 0.25923 \\
\hline $\mathrm{B}_{2} \mathrm{O}_{3}$ & 0.20708 & 0.21072 & 0.20103 & 0.16638 & 0.17948 & 0.18000 & 0.14234 & 0.21673 \\
\hline $\mathrm{Bi}_{2} \mathrm{O}_{3}$ & 0.01926 & 0.00628 & 0.00773 & 0.02974 & 0.00419 & 0.01550 & 0.00120 & 0.02974 \\
\hline $\mathrm{CaO}$ & 0.00733 & 0.07134 & 0.04770 & 0.09639 & 0.01832 & 0.05000 & 0.00173 & 0.09811 \\
\hline $\mathrm{CdO}$ & 0.00198 & 0.00267 & 0.00229 & 0.00127 & 0.00220 & 0.00200 & 0.00102 & 0.00290 \\
\hline $\mathrm{Cr}_{2} \mathrm{O}_{3}$ & 0.01071 & 0.00572 & 0.01119 & 0.00144 & 0.00697 & 0.00700 & 0.00125 & 0.01269 \\
\hline $\mathrm{F}$ & 0.00173 & 0.00272 & 0.00841 & 0.00853 & 0.00120 & 0.00550 & 0.00120 & 0.00985 \\
\hline $\mathrm{Fe}_{2} \mathrm{O}_{3}$ & 0.06817 & 0.02998 & 0.01140 & 0.03177 & 0.01732 & 0.04000 & 0.01012 & 0.06817 \\
\hline $\mathrm{K}_{2} \mathrm{O}$ & 0.02445 & 0.03183 & 0.01091 & 0.02879 & 0.02906 & 0.02000 & 0.00006 & 0.03983 \\
\hline $\mathrm{La}_{2} \mathrm{O}_{3}$ & 0.00512 & 0.00227 & 0.00365 & 0.00266 & 0.00810 & 0.00550 & 0.00139 & 0.00990 \\
\hline $\mathrm{Li}_{2} \mathrm{O}$ & 0.03556 & 0.00803 & 0.04206 & 0.04598 & 0.03927 & 0.03000 & 0.00348 & 0.05977 \\
\hline $\mathrm{MgO}$ & 0.00158 & 0.00472 & 0.00842 & 0.00825 & 0.00781 & 0.00550 & 0.00141 & 0.00990 \\
\hline $\mathrm{MnO}$ & 0.00525 & 0.00491 & 0.01114 & 0.00786 & 0.00992 & 0.00800 & 0.00119 & 0.01499 \\
\hline $\mathrm{Na}_{2} \mathrm{O}$ & 0.11187 & 0.09668 & 0.10029 & 0.07741 & 0.05257 & 0.08500 & 0.05072 & 0.11996 \\
\hline $\mathrm{Nd}_{2} \mathrm{O}_{3}$ & 0.00165 & 0.00198 & 0.00103 & 0.00167 & 0.00147 & 0.00150 & 0.00103 & 0.00199 \\
\hline $\mathrm{NiO}$ & 0.00483 & 0.00172 & 0.00294 & 0.00905 & 0.00643 & 0.00550 & 0.00106 & 0.00998 \\
\hline $\mathrm{P}_{2} \mathrm{O}_{5}$ & 0.01985 & 0.00902 & 0.02250 & 0.00564 & 0.01955 & 0.01500 & 0.00544 & 0.02484 \\
\hline $\mathrm{PbO}$ & 0.00497 & 0.00183 & 0.00109 & 0.00897 & 0.00279 & 0.00550 & 0.00104 & 0.00934 \\
\hline $\mathrm{RuO}_{2}$ & 0.00002 & 0.00004 & 0.00005 & 0.00002 & 0.00002 & 0.00003 & 0.00001 & 0.00005 \\
\hline $\mathrm{SiO}_{2}$ & 0.21784 & 0.23658 & 0.25727 & 0.20686 & 0.31925 & 0.26897 & 0.20686 & 0.36647 \\
\hline $\mathrm{SO}_{3}$ & 0.00245 & 0.00660 & 0.00501 & 0.00344 & 0.00499 & 0.00400 & 0.00113 & 0.00693 \\
\hline $\mathrm{SrO}$ & 0.00921 & 0.00888 & 0.00141 & 0.00781 & 0.00608 & 0.00550 & 0.00110 & 0.00990 \\
\hline $\mathrm{ZrO}_{2}$ & 0.00008 & 0.03235 & 0.03230 & 0.01006 & 0.02986 & 0.02000 & 0.00008 & 0.03884 \\
\hline Total & 1 & 1 & 1 & 1 & 1 & 1 & 1 & 1 \\
\hline \multicolumn{9}{|c|}{ Multicomponent constraints } \\
\hline $\mathrm{Al}_{2} \mathrm{O}_{3}+\mathrm{Fe}_{2} \mathrm{O}_{3}+\mathrm{ZrO}_{2}$ & 0.30727 & 0.28547 & 0.25388 & 0.28183 & 0.28032 & 0.28000 & 0.23486 & 0.33336 \\
\hline $\mathrm{Al}_{2} \mathrm{O}_{3}+\mathrm{Fe}_{2} \mathrm{O}_{3}$ & 0.30718 & 0.25312 & 0.22159 & 0.27177 & 0.25046 & 0.26000 & 0.20780 & 0.31511 \\
\hline $\mathrm{Al}_{2} \mathrm{O}_{3}+\mathrm{ZrO}_{2}$ & 0.23909 & 0.25549 & 0.24249 & 0.25006 & 0.26301 & 0.24000 & 0.19536 & 0.27907 \\
\hline $\mathrm{Fe}_{2} \mathrm{O}_{3}+\mathrm{ZrO}_{2}$ & 0.06826 & 0.06233 & 0.04369 & 0.04184 & 0.04717 & 0.06000 & 0.01516 & 0.07779 \\
\hline \multicolumn{9}{|c|}{ Predicted properties (Vienna et al. 2009) } \\
\hline$\eta_{1150}, \mathrm{~Pa} . \mathrm{s}$ & 2.28 & 5.16 & 1.99 & 0.84 & 10.68 & 3.72 & 0.54 & 14.51 \\
\hline$T$ at 5 Pas, ${ }^{\circ} \mathrm{C}$ & 1048.8 & 1153.5 & 1043.8 & 964.7 & 1237.4 & 1117.1 & 925.7 & 1268.5 \\
\hline$T_{1 \%}-\mathrm{Sp},{ }^{\circ} \mathrm{C}$ & 1101.7 & 969.2 & 968.8 & 1057.6 & 1066.5 & 1057.3 & 858.9 & 1172.4 \\
\hline$\varepsilon_{1150}, \mathrm{~S} / \mathrm{m}$ & 33.8 & 13.7 & 31.2 & 28.0 & 16.4 & 19.7 & 8.5 & 38.9 \\
\hline \multicolumn{9}{|c|}{ Nepheline formation criteria } \\
\hline$N_{S i}$ & 0.383 & 0.425 & 0.453 & 0.395 & 0.528 & 0.469 & 0.363 & 0.599 \\
\hline OB & 0.574 & 0.573 & 0.570 & 0.606 & 0.555 & 0.574 & 0.542 & 0.606 \\
\hline
\end{tabular}


PNNL-20774

\section{Distribution*}

U.S. Department of Energy Office of Environmental Management Kurt Gerdes

Steve Schneider

Gary Smith

\section{U.S. Department of Energy}

Office of River Protection

Rob Gilbert

Albert Kruger

Billie Mauss

Idaho National Laboratory

Nick Soelberg

Savannah River National Laboratory

Fabienne Johnson

Jim Marra

David Peeler

Vitreous State Laboratory

Wing Kot

Ian Pegg

Washington River Protection Solutions

Paul Certa

Gene Ramsey

Terry Sams

\section{Waste Treatment and Immobilization}

Plant

Steve Barnes

Ernie Lee

Jim Nelson

Larry Petkus

\section{AREVA Federal Services}

Eric Tchemitcheff

Catherine Veyer
Pacific Northwest National Laboratory

Paul Bredt

Jim Buelt

Jaehun Chun

Jarrod Crum

Ashutosh Goel

Pavel Hrma

Brad Johnson

Gary Josephson

Jesse Lang

Will Lepry

Dongsang Kim

Pepa Matyas

John McCloy

Reid Peterson

Loni Peurrung

Greg Piepel

Brian Riley

Carmen Rodriguez

Joseph Ryan

Mike Schweiger

Dan Skorski

John Vienna

Joseph Westsik, Jr.

*Distribution will be made electronically 


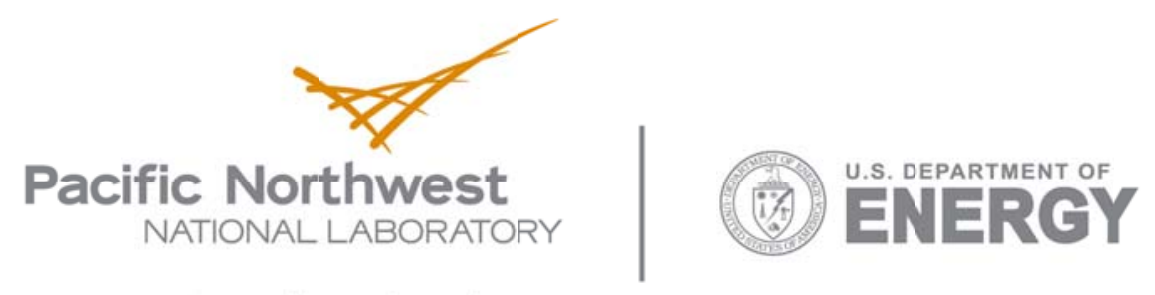

902 Battelle Boulevard

P.O. Box 999

Richland, WA 99352

1-888-375-FNNL (7665)

www.pnl.gov 